UNIVERSIDADE DE SÃO PAULO

FACULDADE DE ARQUITETURA E URBANISMO

\title{
Zoneamento e Urbanização: Trechos da Rod. Raposo Tavares (SP270) - 1950 a 2017
}

\section{Sandra Yukari Shirata Lanças}

\author{
EXEMPLAR REVISADO E ALTERADO EM \\ RELAÇÃO À VERSÃO ORIGINAL, SOB \\ RESPONSABILIDADE DA ORIENTADORA. \\ A versão original, em formato digital, ficará \\ arquivada na Biblioteca da Faculdade. \\ São Paulo, 21 de junho de 2018.
}

SÃO PAULO 
Autorizo a reprodução e divulgação total ou parcial deste trabalho, por qualquer meio convencional ou eletrônico, para fins de estudo e pesquisa, desde que citada a fonte.

Catalogação na Publicação

Serviço Técnico de Biblioteca

Faculdade de Arquitetura e Urbanismo da Universidade de São Paulo

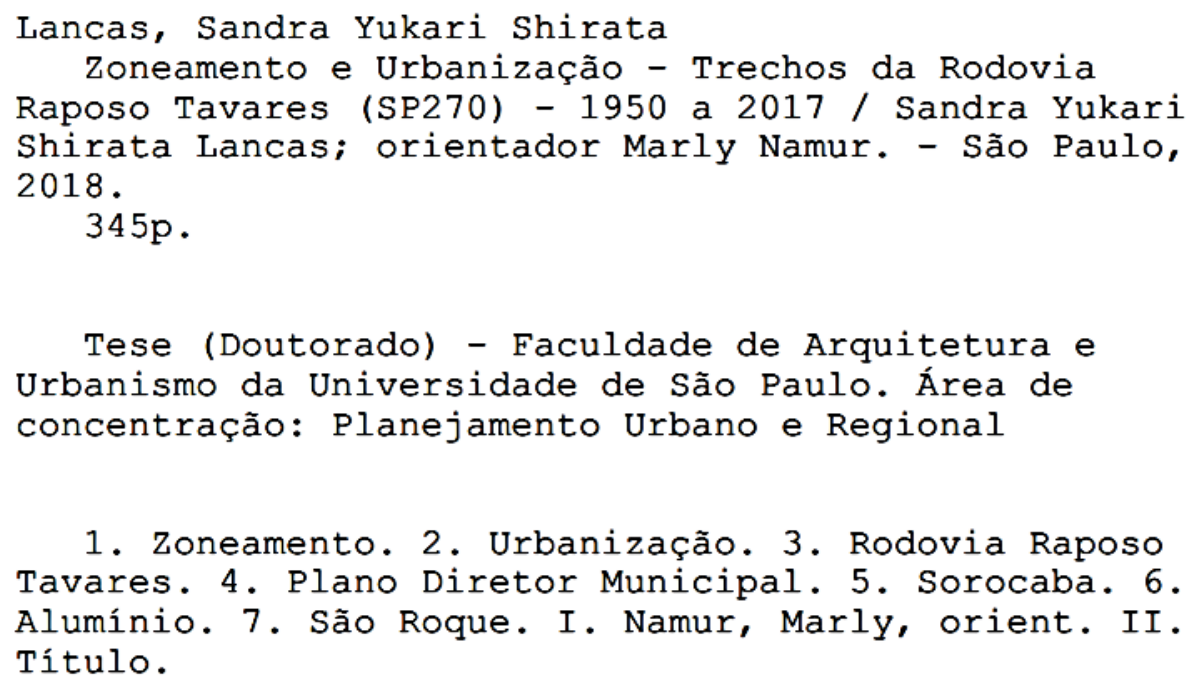

1. Zoneamento. 2. Urbanização. 3. Rodovia Raposo Tavares. 4. Plano Diretor Municipal. 5. Sorocaba. 6. Alumínio. 7. São Roque. I. Namur, Marly, orient. II. Título. 


\section{Zoneamento e Urbanização: Trechos da Rod. Raposo Tavares (SP270) - 1950 a 2017}

Tese de doutorado apresentada a Faculdade de Arquitetura e Urbanismo da Universidade de São Paulo, para obtenção do título de Doutora em Arquitetura e Urbanismo, na área de concentração: Planejamento Urbano e Regional.

Orientadora: Profa. Dra. Marly Namur 
Universidade de São Paulo

ATA DE DEFESA

Aluno: 16139 - 3758665 - 3 / Página 1 de 1

Ata de defesa pública de Tese do(a) Senhor(a) Sandra Yukari Shirata Lanças no Programa: Arquitetura e Urbanismo, do(a) Faculdade de Arquitetura e Urbanismo da Universidade de São Paulo.

Aos 22 dias do mês de maio de 2018, no(a) sala no 803 realizou-se a Defesa da Tese do(a) Senhor(a) Sandra Yukari Shirata Lanças, apresentada para a obtenção do título de Doutora intitulada:

"Zoneamento e Urbanização - Trechos da Rodovia Raposo Tavares (SP270) - 1950 a 2017"

Após declarada aberta a sessão, o(a) Sr(a) Presidente passa a palavra ao candidato para exposição e a seguir aos examinadores para as devidas arguições que se desenvolvem nos termos regimentais. Em seguida, a Comissão Julgadora proclama o resultado:

\begin{tabular}{|c|c|c|c|}
\hline Nome dos Participantes da Banca & Função & Sigla da CPG & Resultado \\
\hline Marly Namur & Presidente & FAU - USP & APRDVADA \\
\hline Maria de Assunçao Ribeiro Franco & Titular & FAU - USP & APROIIADA \\
\hline Angélica Aparecida Tanus Benatti Alvim & Titular & UPM - Externo & APROVADA \\
\hline Valter Luís Caldana Junior & Titular & UPM - Externo & $\triangle P R O V \triangle P O$ \\
\hline Eunice Helena Sguizzardi Abascal & Suplente & UPM - Externo & ApreNADA \\
\hline
\end{tabular}

Resultado Final: A PRQUAOA

\section{Parecer da Comissão Julgadora *}

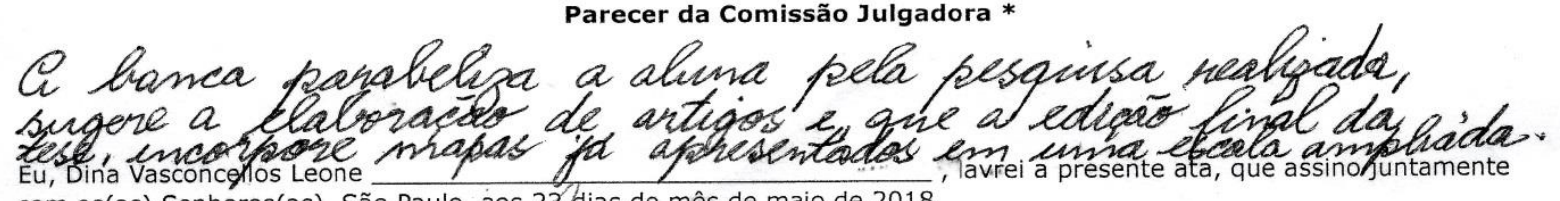
com os(as) Senhores(as), São Paulo, àos 22 dias do mês de maio de 2018.

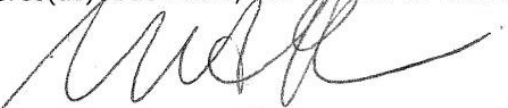

Maria de Assunçao Ribeirö Franco

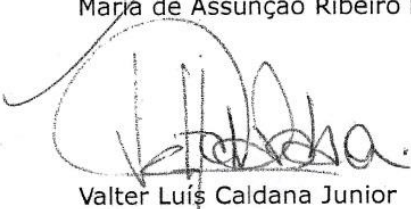

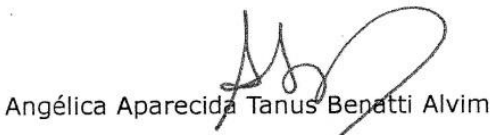

Angélica Aparecida Tanus Benatti Alvim

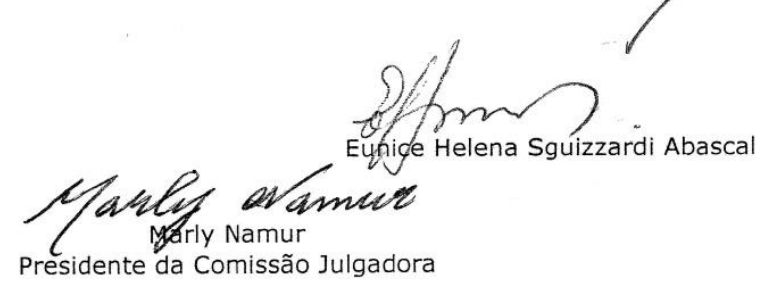

* Obs: Se o candidato for reprovado por algum dos membros, o preenchimento do parecer é obrigatório.

A defesa foi homologada pela Comissão de Pós-Graduação em e, portanto, o(a) aluno(a) faz jus ao título de Doutora em Ciências obtido no Programa Arquitetura e Urbanismo - Área de concentração: Planejamento Urbano e Regional.

\begin{tabular}{|c|c|}
\hline \multirow{3}{*}{ Presidente da Comissão de Pós-Graduação } & \multirow[b]{2}{*}{$\begin{array}{l}\text { UNIVERSIDADE DE SÃO PAULO } \\
\text { FACULOHDE DE ARQUITETURA E URBANISMO } \\
\text { GUUMISSÃO OE POS-GRADUAÇÃO }\end{array}$} \\
\hline & \\
\hline & Sāo Paulo $22 / 05 / \frac{\pi}{8}$ \\
\hline
\end{tabular}


Dedico este trabalho

Ao meu marido, pelo exemplo de conduta, fruto de sua educação familiar e de seu caráter, e aos meus filhos; e à população, às nascentes, cursos d'água e fragmentos vegetais das áreas lindeiras da Rod. Raposo Tavares. Que o bom Deus nos proteja e ajude-nos, ao nosso povo e nossos governantes a produzirem melhores cidades e vidas para todos. 



\section{AGRADECIMENTOS}

À querida professora Dra. Marly Namur, um exemplo formidável da docência, que fez diferença no passado, faz a diferença no presente e assim, para as futuras gerações.

À minha querida madrinha Tia Ana, exemplo de amor incondicional. Às minhas queridas tias, Alzira e Alice (in memorian). À toda minha querida família, sempre unida na alegria e na tristeza... À minha querida amiga Maria José Ramos (in memorian), a assistente social que conseguia ajudar a todos que a conhecem. A todos eles dediquei nesses anos menos tempo do que gostaria e mereciam.

Ao meu orientador na área de Paisagem e Ambiente, prof. Dr. Paulo Renato Mesquita Pellegrino. Nunca me faltou, mesmo quando eu não era mais sua orientanda, quando busquei seu conhecimento para nossa cidade, assim como a querida profa. Maria Assunção Ribeiro Franco, responsável pelo convite à pós-graduação na FAU-USP, que me proporcionou um novo mundo.

Aos professores da FAU-USP que colaboraram na compreensão da área de Paisagem e Ambiente: Profa. Miranda Magnoli (in memorian), Catarina, Fábio, Euler, Vladimir, Eugenio, Sílvio. Também são mais que especiais o prof. Cândido Malta Campos Filho, a profa. Andreína Nigriello, o prof. Nilton Ricoy, o prof. Nestor Goulart Reis, dentre os vários outros notáveis professores. Aos funcionários da FAU-USP, principalmente os da secretaria da pós-graduação e da biblioteca, na Cid. Universitária e na Rua Maranhão, que me serviu de abrigo, desde minha formatura em 2001. Sempre exemplos do melhor tipo de funcionalismo público: sempre dispostos a ajudar.

Aos meus professores da FAU-Mackenzie, em especial ao meu antigo orientador, Arq. Fábio Canteiro, e aos prof.s Paks, Sunao, Maria Tereza Stockler, Hoover Sampaio, Carlos Leite, Mário Figueroa, Paulo Martins, Eleana Patta Flain, Eunice S. e Angélica Alvim, pelos ensinamentos e exemplos.

À minha querida amiga e irmã italiana, a Arquiteta Claudia Crivelaro, que com seu apoio e de sua maravilhosa família, pude terminar de cursar a graduação em São Paulo.

$\mathrm{Na}$ vida, para começar e principalmente para terminar um estudo acadêmico, precisamos de tanta ajuda desinteressada: meu amigo Alexandre Proença Leite, que me proporcionou a alegria de projetar meu primeiro edifício, uma cozinha comunitária; ao prof. Dr. Engo. Sergio Aranha, por me encorajar nos primeiros passos no estudo acadêmico, ao seus emprestar livros raros; a Arq. Zuremar Basso Maia, por me mostrar o trabalho do IAB local; o engenheiro civil Ricardo Gutierrez, que com sua esposa Valentina veio do Chile e com sua empresa de serviços me proporcionou a alegria de realizar meu primeiro projeto paisagístico profissional, do Jardim interno e externo do Centro de Visitantes da Floresta Nacional de Ipanema; o engenheiro de estruturas e doutorando em Artes Visuais, Ismar 
Curi, que me proporcionou a alegria de realizar minha primeira consultoria em uso e ocupação do solo, no plano diretor de Piracaia, SP; e com quem muito aprendi; ao arquiteto e urbanista José Luiz Porta, com quem trabalhei em Campinas, no Cambuí, e me proporcionou a alegria de coordenar as equipes técnicas de estudantes da graduação e da pós-graduação da Unicamp, nos planos diretores locais e municipais sob sua coordenação geral.

Ao prof. Dr. Marcos Marins, da UFSCAR (in memorian). Outro professor notável, que também fez muita diferença para a população de São Carlos e Sorocaba; à exemplo da profa. Neide Gutiyama, da ETEC de Piedade, que continua fazendo a diferença para muitos, embora muitos não tenham noção e nem a devida gratidão aos professores... À jovem professora Natália Suzuki, e aos maravilhosos alunos de lá. Ao Prof. Dr. Daniel, e ao prof. Dr. Claudio Leandro da Fatec de Indaiatuba, outros dois exemplos maravilhosos de abnegação da docência, e da decência. Ao prof. Dr. Marcos Garcia, Márcio Rosa e Luís Rosa, pelo precioso apoio no início da minha carreira acadêmica, na Fatec de Sorocaba.

Aos professores Ludwig Plata, Aurílio Caiado, Flaviano Lima, Francisco Ribeiro, Luís Leite e Henrique Frey, por trazerem à discussão os aspectos econômicos da cidade e região, desde os tempos do GT da metropolização de Sorocaba, nas discussões na Uniso, e na Prefeitura de Sorocaba, e depois nas discussões do PDUI da RMS.

À Dra. Maria Helena Scavone, um exemplo de combatente digna, que me honrou com a confiança de elaboração dos meus primeiros projetos de parques públicos municipais, e que até hoje me honra com outros projetos institucionais; mas principalmente por sua amizade. Ao Engo. Elétrico e Químico Dr. Valter Idargo, e sua esposa Débora, pela confiança e amizade. Ao Engo. José Carlos Carneiro, pelo companheirismo nos Think Tank da Associação dos Engenheiros e Arquitetos de Sorocaba, bem como no Instituto Defenda Sorocaba.

Ao prof. Dr. Walter Barrela, por suas contribuições acadêmicas e suas alunas, as futuras biólogas Tatiane e Bianca, pelas colaborações nos levantamentos de campo. Aos prof. Dr. Denilson Mirim, e Prof. Heiton Gomes, do grupo de pesquisa em robótica aplicada (GERA) do Instituto Federal SP, núcleo Sorocaba, pela disposição em ajudar nas fotos aéreas com drones, para os levantamentos ao longo da RRT. A combinação dos dois times de biólogos e da robótica aplicada foi importante para a verificação in loco e aérea da urbanização ao longo da RRT nos trechos escolhidos.

À Arq. Lila, atual presidente do IAB-Sorocaba, e à Arq. Luciana Valsechi, presidente anterior do querido IAB Sorocaba, junto à Arquiteta Zuremar Basso e outros memoráveis, batalhando pela nossa profissão e pelos que nela estão, combatendo o bom combate, inclusive nas conferências da Cidade... 
Ao biólogo e botânico Demis Lima, pela disposição à vida, sempre ferrenha dos biólogos, principalmente para as árvores, jardins e rios de Sorocaba. Aos arquitetos e urbanistas Fellipe Abreu e Lima, da Secretaria de Planejamento de Araçoiaba da Serra e Marco Hagen, do Conselho de Arquitetura e Urbanismo - Núcleo Sorocaba, outros exemplos do bom profissionalismo.

Aos funcionários das prefeituras de Sorocaba, São Roque, Alumínio e Votorantim, Piracaia, Bragança Paulista, Cabreúva, Jundiaí e Campinas e das Câmaras municipais destas cidades e em outras. Sempre fui bem atendida, e a colaboração dos funcionários públicos na partilha de dados e do seu tempo não tem preço. E aos funcionários do IGC e da EMPLASA, pelo provimento de informações essenciais.

Aos meus ex-alunos e orientandos, pela honra de poder participar deste período tão precioso de suas vidas, e pela ajuda com que este projeto pôde se tornar realidade: Fernanda Hellen, Laís Granado, Lívia Gomes, e especialmente à Amanda Prado Dias, pelo empenho, competência e dedicação.

Ao pessoal das plotagens e copiadoras, na pessoa da Nilce, fundamental para a materialização do trabalho escrito, e no tempo adequado. Meticulosidade, paciência e compaixão para as entregas dos volumes ficarem prontos a um custo acessível.

Ao sr. Sergio Reze, exemplo de cidadania e de civismo; e à todos do Instituto Defenda Sorocaba, pelos bons exemplos, pela confiança. À Arq. e artista plástica Caterina Rosa Reze, pela cessão temporária do lindo espaço para funcionamento do meu escritório em sua galeria de arte. Ao incansável sr. Paulo Dirceu Dias, pelo acolhimento, amizade e exemplo de vida e trabalho.

A minha então colaboradora no lar, Carmelita Bina, exemplo da trabalhadora brasileira, guerreira pelos filhos.

A possibilidade do trabalho acadêmico, especialmente no País, depende principalmente da compreensão de nossa família: aos meus filhos Sean, Diana e Serena, meu esposo Vande, amigo e companheiro de uma vida.

E aos meus queridos pai Hideo Shirata, e saudosa mãe Sueko Henna (in memorian).

À todos, minha sincera gratidão.

Sandra Y. S. Lanças 


\section{RESUMO}

LANÇAS, Sandra Yukari Shirata. Zoneamento e Urbanização - Trechos da Rodovia Raposo Tavares (SP 270) - (1950-2017). 2018. 345p. Tese (Doutorado) - Faculdade de Arquitetura e Urbanismo da Universidade de São Paulo. Área de concentração: Planejamento Urbano e Regional. São Paulo, 2018.

As rodovias têm papel estruturante na produção do espaço urbano regional e metropolitano; por elas trafegam as pessoas e as cargas que movimentam a economia local e regional, metropolitana e por vezes até global. Este trabalho é sobre a urbanização ocorrida e o zoneamento municipal das áreas lindeiras de quatro trechos escolhidos da rod. Raposo Tavares (SP 270), analisados desde 1950 a 2017, em três municípios diferentes (São Roque, Alumínio e Sorocaba), que tem como características o início da ocupação no período colonial, a implantação da linha férrea no final do séc. XIX; o uso da terra para fins agrícolas, a industrialização no séc. $\mathrm{XX}$, e a ocupação pelos mais pobres de áreas de preservação permanente, áreas de risco, áreas verdes nos três primeiros trechos. No último trecho, diferentemente dos anteriores, ocorreu a passagem do uso rural para o residencial de bom desenho urbano, utilizando-se o exemplo dos bairros jardins paulistanos e ingleses, com uso comercial e a verticalização residencial de nível predatório, que ensejou questionamentos jurídicos (2015) e intervenção do Ministério Público federal (2017), ainda não resolvidos nas políticas públicas municipais sintetizadas no Plano Diretor Municipal, aprovado na madrugada de 16/12/2014. São comparadas as legislações de zoneamento de vários planos diretores que vão se modificando ao longo de mais de sessenta anos, antes e depois do Estatuto da Cidade (2001), e do Estatuto da Metrópole (2015); e as urbanizações que resultaram ao longo das décadas, e do uso e ocupação do solo levantado em imagens de satélite LandSat e in loco para a tese e utilizadas as informações do uso e ocupação do solo pela EMPLASA (2017); comparadas com fotos de satélite de diversos anos anteriores. Foram elaborados mapas dos zoneamentos municipais quando não existentes, para fins analíticos. Os trechos escolhidos para análise seguiram três critérios para sua determinação: 1) padrão sócio-econômico, 2) territorial e 3) ambiental. Os resultados aqui colocados evidenciam a questão da urbanização versus a legislação municipal dos planos diretores - especialmente o de zoneamento municipal, e espera colaborar para o planejamento urbano e regional da utilização destas áreas lindeiras às rodovias metropolitanas, cuja ocupação é estratégica para o desenvolvimento sustentável de nossas populações, tão necessitadas da boa aplicação de políticas públicas, principalmente municipais.

Palavras-chave: Zoneamento. Urbanização. Plano Diretor. Rodovia Raposo Tavares. Região Metropolitana. Sorocaba. 


\begin{abstract}
LANÇAS, Sandra Yukari Shirata. Zoning and Urbanization: stretches of Raposo Tavares Road (SP 270) - (1950-2017). 2018. 345p. Tese (Doutorado) - Faculdade de Arquitetura e Urbanismo da Universidade de São Paulo. Área de concentração: Planejamento Urbano e Regional. São Paulo, 2018.

The highways have a structuring role in the production of the regional and metropolitan urban space; by which they travel the people and the burdens that move the local and regional economy, metropolitan and sometimes even global. This work is about the urbanization that occurred and the municipal zoning of the border areas of four selected stretches of the rod. Raposo Tavares (SP 270), analyzed from 1950 to 2017, in three different municipalities (São Roque, Alumínio and Sorocaba), whose characteristics are the beginning of the occupation in the colonial period, the implantation of the railway line at the end of the century. XIX; the use of land for agricultural purposes, industrialization in the century. $\mathrm{XX}$, and the occupation by the poorest of permanent preservation areas, risk areas, green areas; and in the last section, unlike previous ones, from the passage from rural to urban design, using the example of the Garden-neighborhoods of São Paulo and English, commercial use and residential verticalization at the predatory level, which led to legal questions ( 2015) and intervention of the Federal Public Ministry (2017), still not resolved of the municipal public policies synthesized in the Municipal Master Plan, approved in the dawn of 12/16/2014. The zoning legislations of several master plans are being compared and are changing over more than sixty years, before and after the City Statute (2001), and the Metropolis Statute (2015); and the urbanization that resulted over the decades, and the use and occupation of the land raised in LandSat satellite images and in loco for the thesis and the information of the use and occupation of the soil by EMPLASA (2017); compared to satellite photos of several previous years and elaborated maps of municipal zoning where none exist for analytical purposes. The sections chosen for analysis followed three criteria for their determination: 1) socio-economic, 2) territorial and 3) environmental. The results presented here highlight the issue of urbanization versus the municipal legislation of the master plans - especially the municipal zoning, and hopes to collaborate in the urban and regional planning of the use of these border areas to the metropolitan highways, whose occupation is strategic for the sustainable development of our populations that are so in need of the proper application of public policies, especially municipal ones.
\end{abstract}

Keywords: Zoning. Urbanization. Master Plan. Raposo Tavares Road. Metropolitan Region. Sorocaba. 


\section{LISTA DE FIGURAS}

Figura 1 - Região Metropolitana de Sorocaba (em destaque) e a Macrometrópole de São Paulo...... 56

Figura 2 - Região Metropolitana de Sorocaba, com as divisões sub-regionais.................................. 57

Figura 3 - Representação da localização dos pontos mais altos da Região Metropolitana de Sorocaba.

Figura 4 - Corte ilustrativo da Região Metropolitana de Sorocaba, sem escala................................... 58

Figura 5 - Ilustração da localização das principais represas da RM Sorocaba. (s/E). ........................ 59

Figura 6 - Os 27 Municípios e as Unidades de Conservação da Região Metropolitana de Sorocaba,

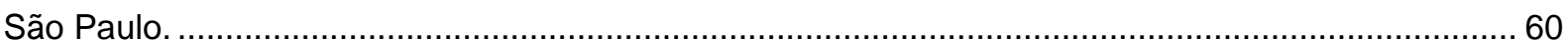

Figura 7 - População Região Metropolitana de Sorocaba (2000-2014) ........................................... 61

Figura 8 - PIB da Região Metropolitana de Sorocaba (2009-2011) ................................................ 62

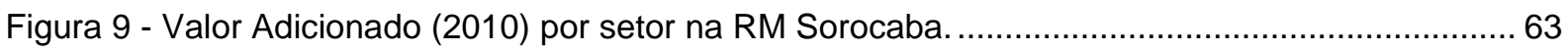

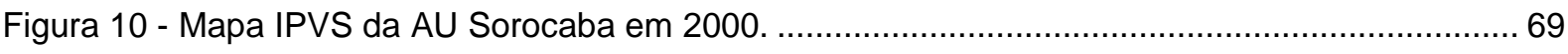

Figura 11- Sorocaba na RMS: pólo regional, 19 municípios em conurbação direta e indireta............. 71

Figura 12 - Principais atividades econômicas agrupadas dos municípios da Região Metropolitana de

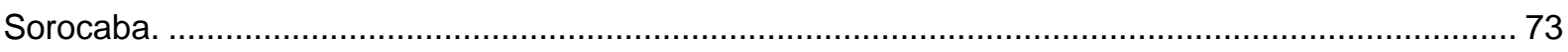

Figura 13 - Classificação de total de empregos RAIS 2014 por UIT para o Município de Sorocaba... 75

Figura 14 - Mapa do ramal da Estrada de Ferro Sorocabana (linha em verde e ampliação em

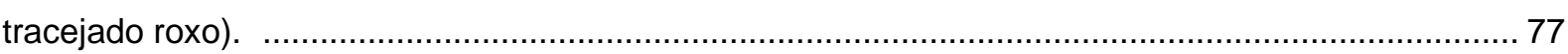

Figura 15 - Traçado inicial Proposta do Trem Regional Sorocaba - São Paulo. ................................. 79

Figura 16 - Rede Proposta e Demanda - Carregamento - Horizonte 2020 ...................................... 79

Figura 17 - Sistema Urbano da RM Sorocaba e principais rodovias. .................................................. 81

Figura 18 - Ligações rodoviárias entre Regiões Metropolitanas do Estado de São Paulo (destaque para o Sistema Castelo Branco - Raposo Tavares, ligando a RMSP a RMS). ................................. 82

Figura 19 - Vetor Sorocaba, no Eixo Sorocaba- São Paulo.............................................................. 83

Figura 20 - Mapa viário Sistema Castelo Branco - Raposo Tavares. ……...................................... 84

Figura 21 - Sistema Castelo Branco - Raposo Tavares e interligações, no Município de Sorocaba, SP.

Figura 22 - Trecho da Rod. Raposo Tavares, no Município de São Paulo. .......................................... 86

Figura 23 - Principais fluxos pendulares na MMP (2010). ............................................................ 88

Figura 24 - Principais Movimentos Pendulares Intermunicipais a Trabalho e Estudo na RMS............ 89

Figura 25 - Fluxo Pendular Intermunicipal, segundo municípios de origem: Deslocamentos por motivo de trabalho e estudo.

Figura 26 - Fluxo Pendular Intermunicipal, segundo municípios de origem selecionados:

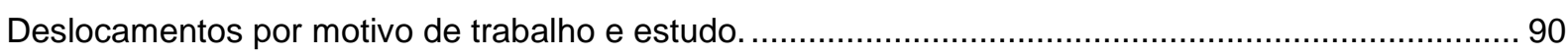

Figura 27 - Velocidade média $(\mathrm{km} / \mathrm{h})$ no horário de pico da manhã paulista....................................... 93

Figura 28 - Mapa da RRT no Estado de São Paulo, destacada em linha vermelha. .......................... 97

Figura 29 - Foto da RRT antes da conclusão de sua pavimentação em 1951................................... 99 
Figura 30 - Trecho inicial (Butantã, Capital) da RRT e Figura 31 - Trecho final, entre Itapetininga (SP) e Ourinhos

Figura 32 - Uso do Solo, Estrutura Urbana e Conexões na RMS, com destaque para o trecho da RRT escolhido 102

Figura 33 - Densidade de empregos na RMS (2014), com destaque para o trecho da RRT escolhido.

Figura 34 - Densidade de empregos na RMS (2014), com destaque para os trechos escolhidos na RRT.

Figura 35 - Delimitação do polígono de estudo, do acesso a Araçoiaba da Serra a São Roque, SP, passando por Sorocaba, Mairinque, Alumínio.

Figura 36 - Localização dos trechos de estudo da Raposo Tavares, na Região Metropolitana de

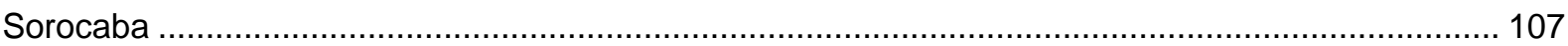

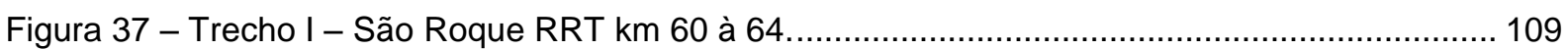

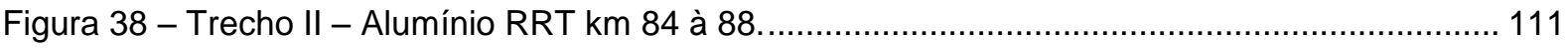

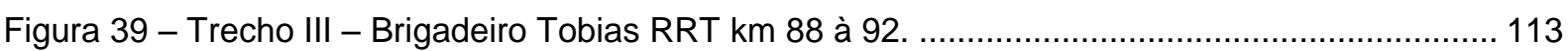

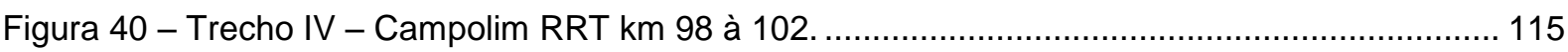

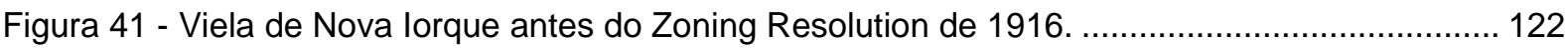

Figura 42 - Mapa de indústrias de Nova lorque em 1922, após o Zoning Resolution de 1916.......... 124

Figura 43 - Divisão do perímetro urbano de Sorocaba em zonas (lei n.119/1914). .......................... 131

Figura 44 - Imposto Predial Rústico (lei n.115/1914)................................................................ 131

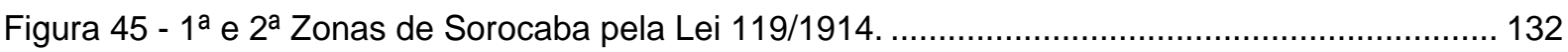

Figura 46 - Localização do bairro do Rio Acima em mapa atual (2018) ........................................... 132

Figura 47 - Imagem aérea da RRT km 64 no trecho de São Roque, SP. ...................................... 141

Figura 48 - Mapa de São Roque em 1932 (antiga, antes dos desdobramentos do séc. XX). .......... 142

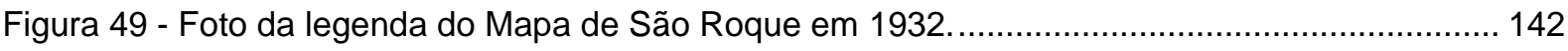

Figura 50 - Indicação da área atual do Município de São Roque (em amarelo). ............................... 143

Figura 51 - Vista aérea de abril de 2017, com destaque no círculo vermelho para o empreendimento

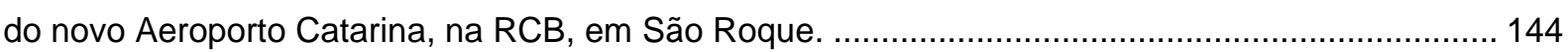

Figura 52 - Mapa de Zoneamento do PD 1972 no Trecho I do Município de São Roque .................. 147

Figura 53- Detalhe (Trecho 1) do mapa de Macrozoneamento Ambiental I, do PD de 2006, lei complementar no. 40/2006.

Figura 54 - Detalhe do mapa de Macrozoneamento Ambiental II (específico para) Sede do Município de São Roque (Trecho 1 anotado), do PD de 2006, lei complementar no. 40/2006

Figura 55 - Detalhe (Trecho 1) da Carta III - Macrozonas de Uso e Ocupação - Perímetros Urbanos e

Rural do PD de 2006, lei complementar no. 40/2006. 152

Figura 56 - Detalhe (Trecho 1) da Carta IV - Perímetro São Roque - Zonas Urbanas. Macrozonas de Consolidação Urbana - PD de 2006, lei complementar no. 40/2006. 153

Figura 57 - Macrozonas de Consolidação Urbana do PD 2006 no Trecho I do Município de São Roque 
Figura 58 - Detalhe (Trecho 1) da Carta VIII - AEIAs, AEIUs e AEIS de São Roque - PD de 2006, lei complementar no. 40/2006

Figura 59 - Mapa de AEIA, AEUI, AEI, do PD 2006 no Trecho I do Município de São Roque.......... 165

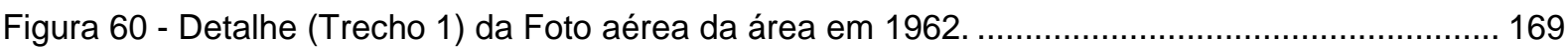

Figura 61 - Detalhe (Trecho 1) da Foto aérea da área em 1972................................................... 169

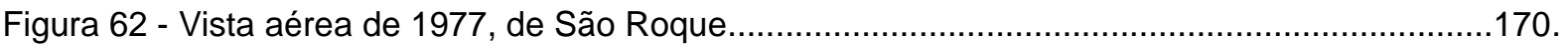

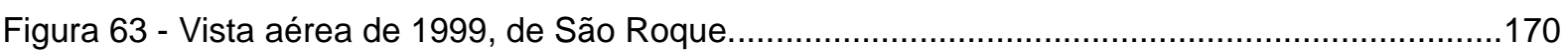

Figura 64 - Traçado antigo da RRT passando pela Rua Santa Cruz no centro de São Roque (em

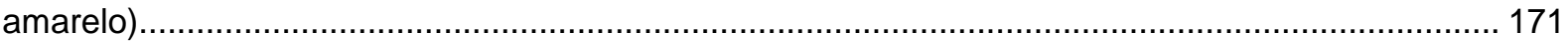

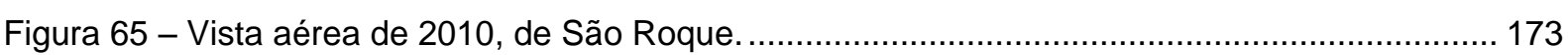

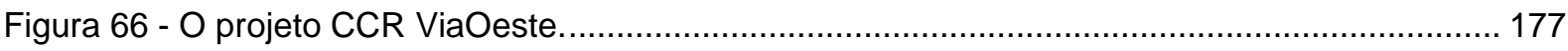

Figura 67 - Foto do Novo Contorno RRT km 61 RRT São Roque, abril de 2016 .............................. 177

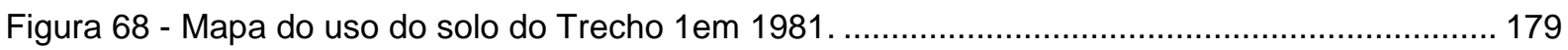

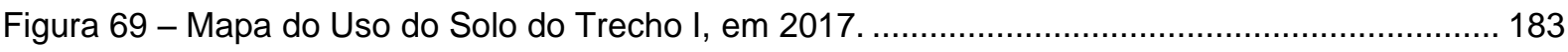

Figura 70 - Vista da área da CBA em Alumínio, (SP), lado sul da RRT no km 77. ............................ 187

Figura 71 - Vista de satélite da área do território municipal de Alumínio, (SP). ............................... 188

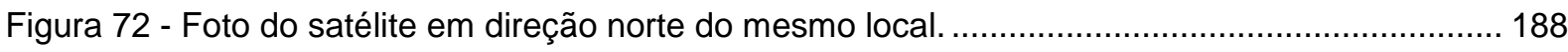

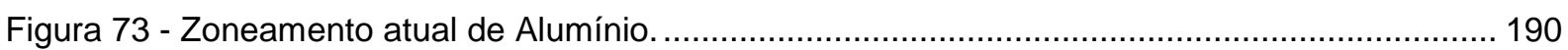

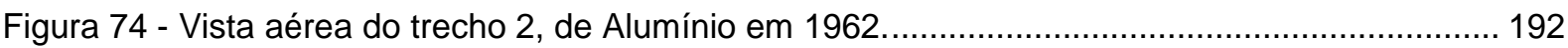

Figura 75 - Vista aérea do trecho 2, de Alumínio em 1978.......................................................... 193

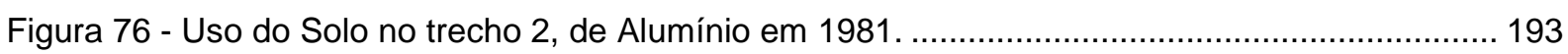

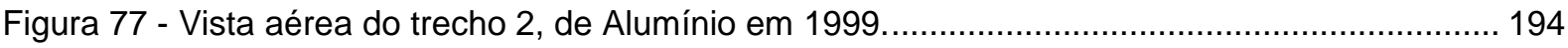

Figura 78 - Vista aérea em direção a oeste do trecho 2 em Alumínio............................................... 195

Figura 79 - Vista aérea do Trecho II, de Alumínio em 2010 .......................................................... 197

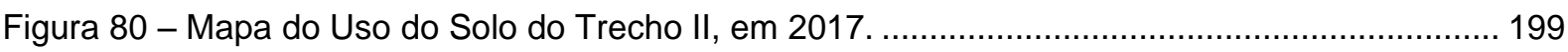

Figura 81 - Vista aérea de Brigadeiro Tobias em direção a leste da RRT (km 88).......................... 203

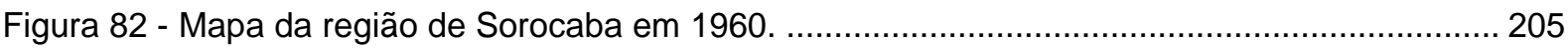

Figura 83 - Um dia na história - 06/06/1953: 24 ônibus diários para São Paulo. ................................ 206

Figura 84 - DER define projeto do contorno de Brigadeiro Tobias na RRT...................................... 207

Figura 85 - Mapa de Brigadeiro Tobias com o novo contorno RRT a partir de 2007; (antigo traçado

RRT: av. Bandeirantes), arruamento e principais nascentes e cursos de água................................. 208

Figura 86 - Mapa de Brigadeiro Tobias e principais ruas em 1963. (Lei municipal no. 1071/63)....... 211

Figura 87 - Mapa de Macrozoneamento Ambiental do PD de 2004, com a localização do trecho 3 de

Brigadeiro Tobias.

Figura 88 - Trecho RRT Brig. Tobias, detalhe do Mapa 01 de Macrozoneamento Ambiental do PD de

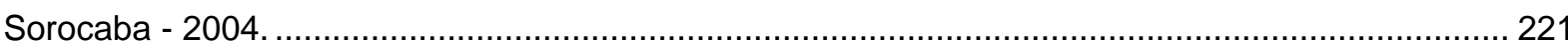

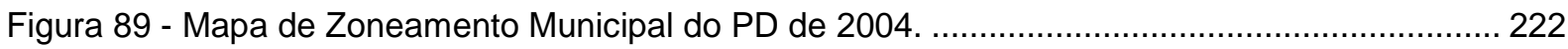

Figura 90 - Detalhe do trecho 3 no Mapa de Zoneamento Municipal do PD de 2004 ....................... 222

Figura 91 - Mapa de Zoneamento Municipal do Trecho III, de Brigadeiro Tobias em 2004.............. 227 
Figura 92 - Macrozoneamento Ambiental, Plano Diretor Ambiental de Sorocaba (2007), detalhe do trecho RRT de Brigadeiro Tobias. À direita:- Macrozoneamento Ambiental, Plano Diretor Desenvolvimento Físico Territorial de Sorocaba (2014), detalhe do trecho RRT de Brigadeiro Tobias.

Figura 93 - Mapa de Zoneamento Municipal do Trecho III, de Brigadeiro Tobias em 2007. 233

Figura 94 - Á esquerda: Zoneamento Municipal, PD de Sorocaba (2007), detalhe do trecho RRT de BT. À direita - Proposta Zoneamento Municipal, PD de Sorocaba (março/2013), detalhe do trecho RRT de Brigadeiro Tobias.

Figura 95 - Outra proposta (SAAE) de Zoneamento Municipal, PD de Sorocaba (março/2013), detalhe do trecho RRT de Brigadeiro Tobias.

Figura 96 - Zoneamento Municipal, PD de Sorocaba (dez/2015), detalhe do trecho RRT de Brigadeiro Tobias. 238

Figura 97 - Mapa de zoneamento municipal de Votorantim (lado inferior esquerdo) x o zoneamento municipal de Sorocaba (PD 2014), com anotações de APP',s Projetos MCMV, e loteamentos aprovados e em estudo.

Figura 98 - Mapa de Zoneamento Municipal do Trecho III, de Brigadeiro Tobias em 2014.

Figura 99 - Vista aérea do trecho do entorno do Casarão de Brigadeiro Tobias e trecho RRT, em 2015.

Figura 100 - Detalhe da Carta Base da Bacia do Ribeirão Pirajibu-Mirim.

Figura 101 - Detalhe da foto aérea da RRT no trecho estudado: Arredores de Brigadeiro Tobias (ao sul da estrada de rodagem São Paulo-Curitiba). 249

Figura 102 - Arredores de Brigadeiro Tobias 250

Figura 103 - Paisagem urbana de Brigadeiro Tobias - Núcleo linear ao longo da rodovia São PauloCuritiba. 251

Figura 104 - Detalhe do folheto distribuído pela ViaOeste/GESP no dia da inauguração da rod. Celso Charuri, em 28/06/2003. 256

Figura 105 - Vista aérea do Trecho 3, de Brigadeiro Tobias em 1962. 258

Figura 106 - Vista aérea do Trecho 3, de Brigadeiro Tobias em 1972. 258

Figura 107 - Vista aérea do Trecho 3, de Brigadeiro Tobias em 1978. 259

Figura 108 - Mapa do Uso do Solo do Trecho 3, de Brigadeiro Tobias em 1981............................. 259

Figura 109 - Vista aérea do Trecho III, de Brigadeiro Tobias em 2010. 261

Figura 110 - Fotos da visita do vereador Geraldo Reis, à vila São João, distrito de Brig. Tobias, ocupação do lado direito da RRT... 266

Figura 111 - Mapa parcial com os grupos de IPVS por setor censitário do Trecho Brig. Tobias ....... 268

Figura 112 - Localização e Vista aérea do trecho 3 - Brigadeiro Tobias km 88 a 92 RRT. 270

Figura 113 - Foto de entrada de "loteamento fechado" no km 91 da RRT, final do trecho estudado. 271 Figura 114 - Anúncio de empreendimento de 18 torres MCMV na Vila Astúrias, Brig. Tobias no canto inferior esquerdo, a RRT. 271

Figura 115 - Vista aérea da ocupação da várzea do Ribeirão Pirajibu, em Brig. Tobias; em segundo plano, o trecho d a RRT. 
Figura 116 - Mapa de Uso do Solo do Trecho III, de Brigadeiro Tobias em 2017........................... 275

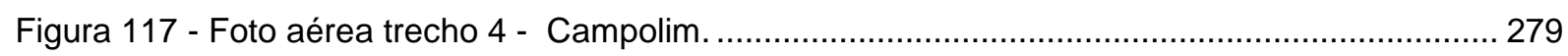

Figura 118 - Tráfego de veículos ficou lento na pista sentido interior. ............................................. 279

Figura 119 - Trecho 4 - Estradas e mancha urbana do trecho 4 em 1973, do Rio Sorocaba até confluência da Av. Armando Pannunzio, Bairro Pq. Campolim....................................................... 281

Figura 120 - Áreas Verdes e APP's do Campolim. ..................................................................... 282

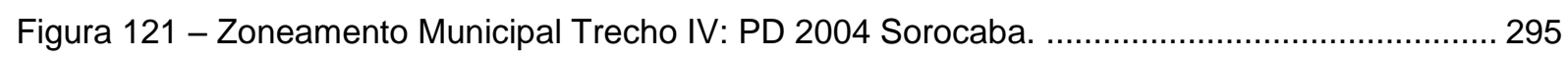

Figura 122 - Zoneamento Municipal Trecho IV: PD Sorocaba 2007 e Votorantim PD 2009............ 297

Figura 123 - Zoneamento Municipal Sorocaba 2014 e Votorantim 2015........................................ 299

Figura 124 - Parque Campolim visto em direção à Votorantim. ........................................................ 302

Figura 125 - Vista aérea do Trecho IV, Parque Campolim em 1962. ............................................... 305

Figura 126 - Trecho 4 - Estradas e mancha urbana do trecho 4 em 1973, do Rio Sorocaba até confluência da Av. Armando Pannunzio, Bairro Pq. Campolim...................................................... 307

Figura 127 - Vista aérea do Trecho 4, Campolim em 1978. .......................................................... 308

Figura 128 - Mapa do Uso do Solo do Trecho 4, Campolim em 1981 .............................................. 309

Figura 129 - Foto aérea do trecho 4 em 1994. .......................................................................... 310

Figura 130 - Foto da intensa verticalização na parte sul do Parque Campolim, em sua fase 3, após o

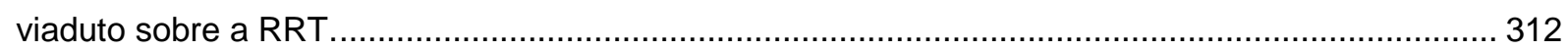

Figura 131 - Análise espacial da distribuição e expansão das manchas urbanas do Município de

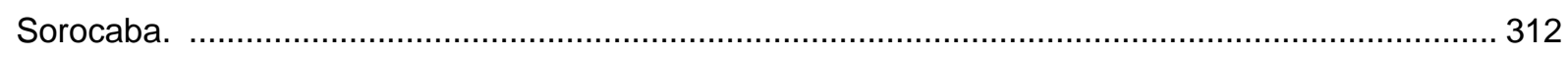

Figura 132 - Panorama da região do Campolim. À direita, a Av. A.C. Comitre de Sorocaba a

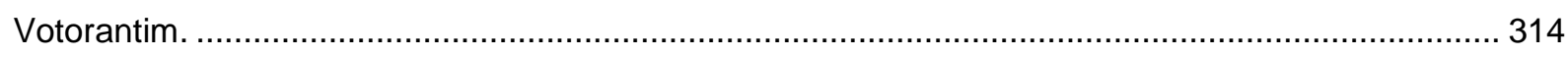

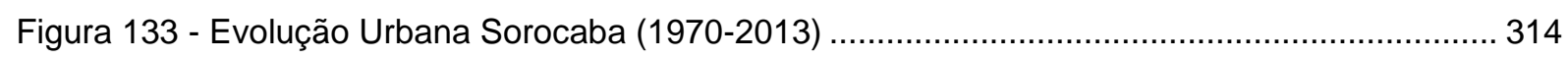

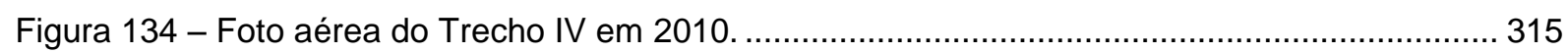

Figura 135 - Panorama do trecho 4 RRT vista ao Sul (em direção a Votorantim), hipermercados,

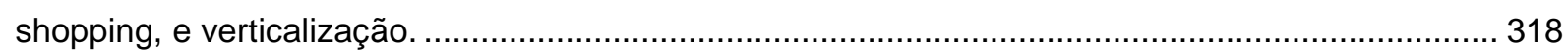

Figura 136 - Foto empreendimento imobiliário......................................................................... 318

Figura 137 - Fotos de empreendimentos imobiliários. ................................................................ 318

Figura 138 - Densidade Demográfica e Distribuição de Densidade de Emprego por Região............ 319

Figura 139 - Publicidade Parque Salamanca - Campolim - Sorocaba........................................... 320

Figura 140 - Publicidade Parque Salamanca - Campolim - Sorocaba............................................ 320

Figura 141 - Mapa do Uso do Solo do Trecho IV, Campolim em 2017. .......................................... 323

Figura 142 - Rodovia Raposo Tavares no ponto em que a mesma "corta" o Campolim. .................. 333

Figura 143 - Uso e ocupação do solo no trecho do Campolim em Votorantim. .................................. 334

Figura 144 - Uso e Ocupação do Solo de todos os trechos analisados na RRT, em 2017.............. 337

Figura 145 - Quadro resumo de Leis municipais que alteraram o zoneamento municipal proposto pela Lei $1541 / 1968$. 358 


\section{LISTA DE TABELAS}

Tabela 1 - Campo de lutas sociais na produção do espaço urbano: ações esperadas do Estado e demais atores sociais.

Tabela 2 - Campo de lutas sociais na produção do espaço urbano: ações esperadas dos Proprietários Fundiários e demais atores sociais.

Tabela 3 - Campo de lutas sociais na produção do espaço urbano: ações esperadas dos Proprietários dos meios de produção e demais atores sociais.

Tabela 4 - Campo de lutas sociais na produção do espaço urbano: ações esperadas dos Promotores imobiliários e demais atores sociais.

Tabela 5 - Campo de lutas sociais na produção do espaço urbano: ações esperadas dos grupos

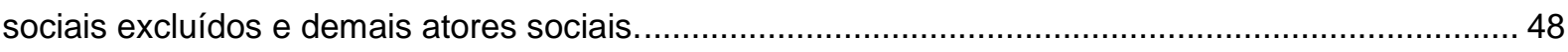

Tabela 6 - Indicadores dos municípios da RMS.

Tabela 7 - Principais atividades econômicas dos municípios da Região Metropolitana de Sorocaba. 66

Tabela 8 - Indicadores sociais Municípios RM Sorocaba (2010) ................................................... 70

Tabela 9 - Unidades Territoriais por Eixo Rodoviário da RM Sorocaba. .............................................. 85

Tabela 10 - Localização das praças de pedágios na RRT no território da RMS. ............................... 100

Tabela 11 - Quadro resumo de Leis municipais que alteraram o zoneamento municipal proposto pela Lei $1541 / 1968$. 136

Tabela 12 - Detalhe da tabela de zoneamento do trecho 1 - Município de São Roque pelo PD de 1972

Tabela 13 - Tabela de coeficientes do PD de 2006 de São Roque. ............................................... 157

Tabela 14 - Quadro de parâmetros uso e ocupação do solo PD 2006.............................................. 158

Tabela 15 - Quadro de parâmetros Usos admitidos por zona PD 2006 .......................................... 159

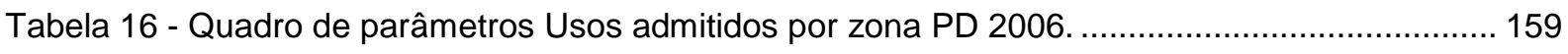

Tabela 17 - Quadro de parâmetros de Recuos por zona PD 2006 .................................................. 160

Tabela 18 - Tabela de índices relativos ao zoneamento municipal do Trecho 3 no PD de 2004....... 223

Tabela 19 - Alterações dos perímetros urbanos do Município de Sorocaba no PD de 2004............. 229

Tabela 20 - Usos permitidos Zonas ZR1 e ZR2 - PD Sorocaba de 2007 ........................................ 230

Tabela 21 - Parâmetros de ocupação por zona PD 2007. Sorocaba (tabela parcial). ....................... 230

Tabela 22 - Parâmetros de ocupação do Município de Sorocaba no PD de 2014 ............................ 243

Tabela 23 - Dimensões mínimas de lotes do Município de Sorocaba no PD de 2014 ....................... 244

Tabela 24 - Taxas geométricas de crescimento populacional Município de Sorocaba, SP (1960 -

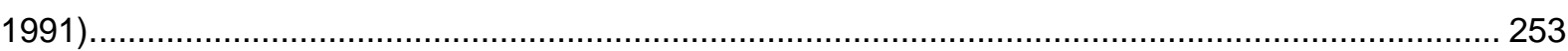

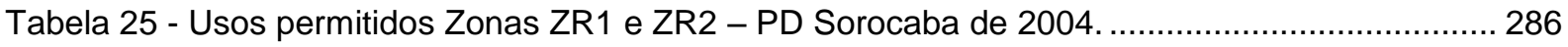

Tabela 26 - Parâmetros de ocupação por zona PD 2004 Sorocaba ............................................... 287

Tabela 27 - Usos permitidos Zonas ZR1, ZR2 e CS1 - PD Sorocaba de 2007................................. 289

Tabela 28 - Parâmetros de ocupação por zona PD 2007 Sorocaba (tabela parcial). ......................... 289

Tabela 29 - Usos permitidos Zonas ZR1 e ZR2 - PD Sorocaba de 2014 ........................................ 291

Tabela 30 - Parâmetros de ocupação por zona PD 2014 Sorocaba (tabela parcial). ......................... 292 


\section{LISTA DE SIGLAS}

\begin{tabular}{|c|c|}
\hline ADIN & Ação Direta de Inconstitucionalidade \\
\hline AEIAs & Área de Especial Interesse Ambiental \\
\hline AEIS & Área Especial de Interesse Social \\
\hline AEIUs & Áreas de especial Interesse Urbanístico \\
\hline ALESP & Assembléia Legislativa do Estado de São Paulo \\
\hline ALLMS & América Latina Logística - Malha Sul S/A \\
\hline AMBEU & Associação de Moradores dos Bairros Elton Ville, Uirapuru e Adjacências \\
\hline ANAC & Agência Nacional de Aviação Civil \\
\hline APA & Área de Preservação Ambiental \\
\hline APP & Area de Preservação Permanente \\
\hline$A U$ & Aglomeração Urbana \\
\hline AUP & Departamento de Projeto \\
\hline BANESPA & Banco do Estado de São Paulo \\
\hline BB & Banco do Brasil \\
\hline BID & Banco Interamericano de Desenvolvimento \\
\hline BRT & Bus Rapid Transit \\
\hline $\mathrm{CA}$ & Coeficiente de Aproveitamento \\
\hline CBA & Companhia Brasileira de Alumínio \\
\hline CEF & Caixa Econômica Federal \\
\hline CF & Constituição Federal \\
\hline CMA & Câmara Municipal de Alumínio \\
\hline CMS & Câmara Municipal de Sorocaba \\
\hline CMV & Câmara Municipal de Votorantim \\
\hline CP1 & Centro principal 1 \\
\hline CMSR & Câmara Municipal de São Roque \\
\hline СРТМ & Companhia Paulista de Trens Metropolitanos \\
\hline CS1 & Centro de Serviços 1 \\
\hline CSI & Usos Comerciais, de Serviços e Industriais de Pequeno Porte \\
\hline DER & Departamento de Estradas de Rodagem \\
\hline EFS & Estrada de Ferro Sorocabana \\
\hline EIA & Estudos de Impacto Ambiental \\
\hline EIV & Estudos de Impacto de Vizinhança \\
\hline EMG & Estado de Minas Gerais \\
\hline EMPLASA & Empresa Metropolitana de Planejamento S. A. \\
\hline ESP & Estado de São Paulo \\
\hline FATEC & Faculdade de Tecnologia do Estado de São Paulo \\
\hline FAU & Faculdade de Arquitetura e Urbanismo \\
\hline FAUUSP & Faculdade de Arquitetura e Urbanismo da Universidade de São Paulo \\
\hline FDA & Fundação Dom Aguirre \\
\hline FEPASA & Ferrovia Paulista S.A. \\
\hline FERROBAN & Ferrovias Bandeirantes \\
\hline FESPSP & Fundação Escola de Sociologia e Política de São Paulo \\
\hline
\end{tabular}




\begin{tabular}{|c|c|}
\hline FFLCH & Faculdade de Filosofia, Linguas, Ciencias e História \\
\hline FIRJAN & Federação das Indústrias do Estado do Rio de Janeiro \\
\hline FJP & Fundação João Pinheiro \\
\hline GESP & Governo do Estado de São Paulo \\
\hline GRD & Usos Geradores de Ruído Diurno \\
\hline GRN & Usos Geradores de Ruído Noturno \\
\hline GT & Grupo de Trabalho \\
\hline HIS & Habitação de Interesse Social \\
\hline IBGE & Instituto Brasileiro de Geografia e Estatística \\
\hline IDFM & Indice de Desenvolvimento Financeiro Municipal \\
\hline IDH & Indice de Desenvolvimento Humano \\
\hline IGC & Instituto Geográfico e Cartográfico do Estado de São Paulo \\
\hline IPEA & Instituto de Pesquisas Econômicas Aplicadas \\
\hline IPRS & Indice Paulista de Responsabilidade Social \\
\hline IPVS & Indice Paulista de Vulnerabilidade Social \\
\hline JCS & Jornal Cruzeiro do Sul \\
\hline LANDSAT & Land Remote Sensing Satellite \\
\hline LOGIT & Empresa LOGIT Engenharia Consultiva LTDA \\
\hline MBB & Mercedes Bens do Brasil \\
\hline MCMV & Minha Casa Minha Vida \\
\hline MMP & Macro-Metropole Paulista \\
\hline NASA & National Agency of Spacial \\
\hline NYCP & New York City Planning \\
\hline ONG & Organização Não Governamental \\
\hline OUC & Operações Urbanas Consorciadas \\
\hline PAM & Plano de Ação da Macrometrópole Paulista \\
\hline PD & Plano Diretor \\
\hline PDDI & Plano Diretor de Desenvolvimento Integrado \\
\hline PDUI & Plano de Desenvolvimento Urbano Integrado \\
\hline PDTUM & Plano Diretor de Transporte Urbano e Mobilidade \\
\hline PEA & População Economicamente Ativa \\
\hline PGT & Polos Geradores de Tráfego \\
\hline PIB & Produto Interno Bruto \\
\hline PMS & Prefeitura Municipal de Sorocaba \\
\hline PMSR & Prefeitura Municipal de São Roque \\
\hline PMV & Prefeitura Municipal de Votorantim \\
\hline PSDB & Partido da Social Democracia Brasileira \\
\hline PT & Partido dos Trabalhadores \\
\hline PUC & Pontificie Universidade Católica \\
\hline RA & Região Administrativa \\
\hline $\mathrm{RCB}$ & Rodovia Castelo Branco (SP 280) \\
\hline RFFSA & Rede Ferroviária Federal \\
\hline$R G$ & Uso Residencial em Glebas \\
\hline $\mathrm{RL}$ & Uso Residencial em Lotes \\
\hline $\mathrm{RMBH}$ & Região Metropolitana de Belo Horizonte \\
\hline
\end{tabular}




\begin{tabular}{|c|c|}
\hline $\mathrm{RMC}$ & Região Metropolitana de Campinas \\
\hline RMRJ & Região Metropolitana do Rio de Janeiro \\
\hline RMS & Região Metropolitana de Sorocaba \\
\hline RMSP & Região Metropolitana de São Paulo \\
\hline RMSTS & Região Metropolitana de Santos e \\
\hline RMVP & Região Metropolitana do Vale do Paraíba \\
\hline $\mathrm{RRT}$ & Rodovia Raposo Tavares (SP 270) \\
\hline $\mathrm{RSI}$ & Uso Residencial com Serviços Internos ou Privativos \\
\hline RT & Uso Residencial com Apoio Terapêutico \\
\hline RUMO & Antiga América Latina Logística - Malha Sul S/A \\
\hline SEADE & Fundação Sistema Estadual de Análise de Dados \\
\hline SECOVI & Sindicato dos Construtores e Vendedores de Imóveis \\
\hline SESI & Serviço Social da Indústria \\
\hline SINDUSCON & Sindicato da Indústria de Construção Civil \\
\hline SM & Salário mínimo \\
\hline SP & São Paulo \\
\hline SP-RJ & São Paulo - Rio de Janeiro \\
\hline STM & Secretaria dos Transportes Metropolitanos \\
\hline TAC & Termo de Ajustamento de Conduta \\
\hline TDC & Transferência do Direito de Construir \\
\hline TJSP & Tribunal de Justiça de São Paulo \\
\hline TO & Taxa de Ocupação \\
\hline TP & Taxa de Permeabilidade \\
\hline UE & Usos Especiais \\
\hline UFSCAR & Universidade Federal de São Carlos \\
\hline UIT & Unidade de informação Territorial \\
\hline UNESP & Universidade Estadual Paulista \\
\hline UNIP & Universidade Palista \\
\hline UNISO & Universidade de Sorocaba \\
\hline ZCA & Zona de Conservação Ambiental \\
\hline $\mathrm{ZCH}$ & Zona de chácara urbana \\
\hline ZEIS & Zona Especial de Interesse Social \\
\hline ZR & Zona rural \\
\hline ZR1,2,3 & Zona Residencial Tipo 1, 2 e 3 \\
\hline ZUC & Zona Urbana Central \\
\hline ZUE & Zona de Urbanização Específica \\
\hline ZUI & Zona Urbana Industrial \\
\hline ZUPA & Zona Urbana de Preservação Ambiental \\
\hline ZUR-ad & Zona Urbana Residencial de Alta Densidade \\
\hline ZUR-bd & Zona Urbana Residencial de Baixa Densidade \\
\hline ZUR-md & Zona Urbana Residencial de Média Densidade \\
\hline
\end{tabular}




\section{SUMÁRIO}

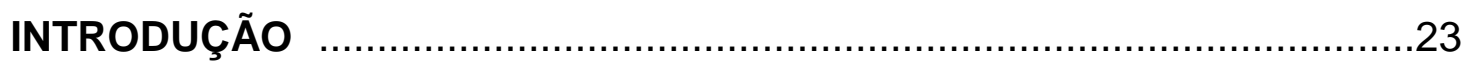

I CAPÍTULO I-CONCEITOS

II CAPÍTULO II - CARACTERÍSTICAS RRT NA RMS, SP .........................53

2.1 Dados territoriais, populacionais e sócios econômicos da RMS, SP ..............55

2.2 Prevalência de Sorocaba como município-pólo da RMS ..............................71

2.3 Mobilidade urbana na RMS / RRT ........................................................

III CAPÍTULO III - TRECHOS ESCOLHIDOS DA ROD. RAPOSO TAVARES

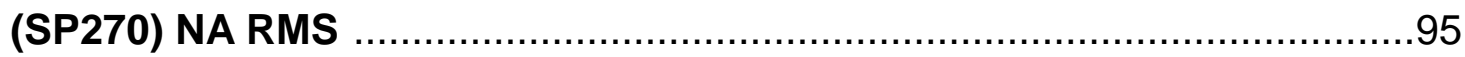

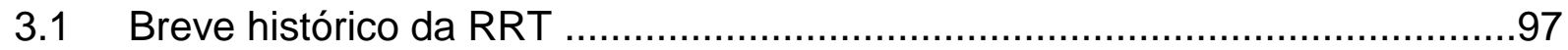

3.2 Escolha dos trechos estudados ........................................................101

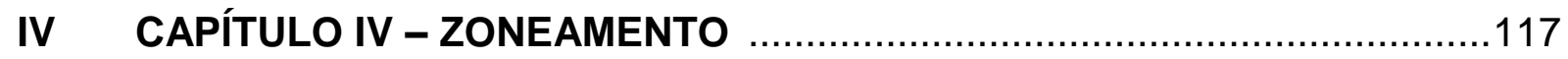

4.1 Breve histórico do Zoneamento na Europa e nos EUA …….....................119

4.2 Breve histórico do início do Zoneamento no Brasil .....................................125

4.3 Zoneamento do Município de Sorocaba, SP ..........................................130

V. CAPÍTULO V - URBANIZAÇÃO x LEGISLAÇÃO de ZONEAMENTO -

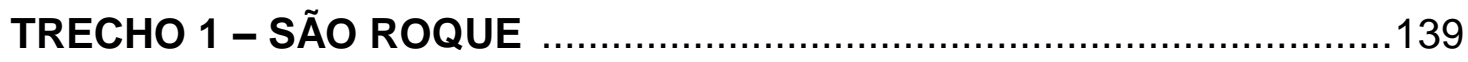

5.1 Breve histórico do Município de São Roque, SP .......................................141

5.2 Legislação urbana no Trecho $1(1972$ - 2006) ......................................145

5.3 Ocupação urbana $x$ Zoneamento Trecho $1(1962$ - 2017) ….......................167

VI CAPÍTULO VI - URBANIZAÇÃO x LEGISLAÇÃO de ZONEAMENTO -

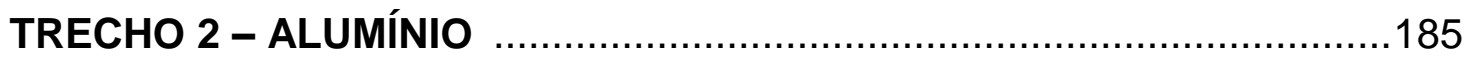

6.1 Breve histórico do Município de Alumínio, SP ......................................187

6.2 Legislação urbana no Trecho $2(1942$ - 1999) ..........................................189

6.3 Ocupação urbana x Zoneamento Trecho $2(1962-2017)$...........................191 
VII CAPÍTULO VII - URBANIZAÇÃO x LEGISLAÇÃO de ZONEAMENTO -

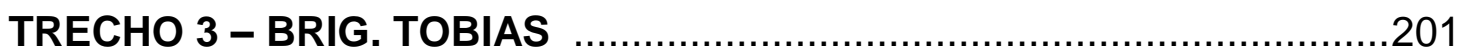

7.1 Breve histórico do Distrito de Brigadeiro Tobias, Sorocaba, SP ................203

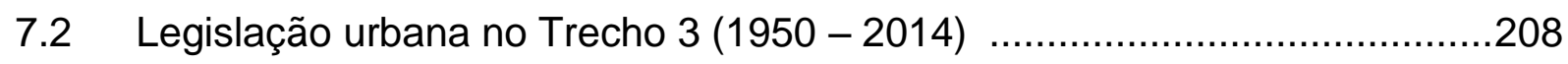

7.3 Ocupação urbana $x$ Zoneamento Trecho $3(1962$ - 2017) .........................246

VIII CAPÍTULO VIII - URBANIZAÇÃO x LEGISLAÇÃO de ZONEAMENTO -

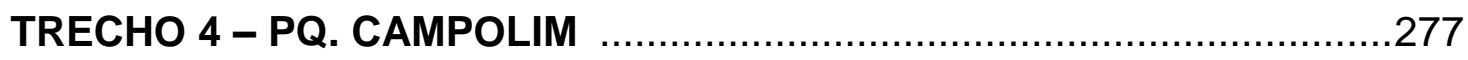

8.1 Breve histórico do Bairro Parque Campolim, Sorocaba, SP .......................280

8.2 Legislação urbana no Trecho $4(1950-2014)$..........................................284

8.3 Ocupação urbana $x$ Zoneamento Trecho $4(1962-2017)$..........................301

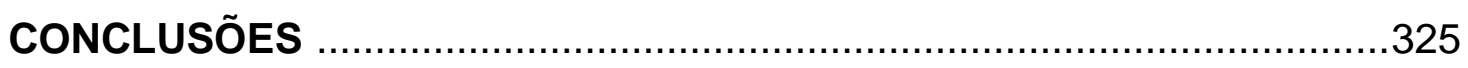

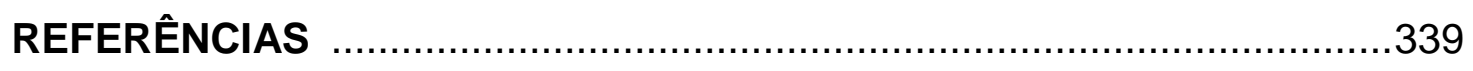

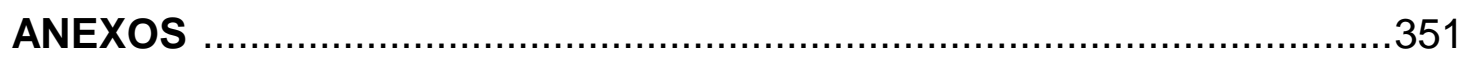

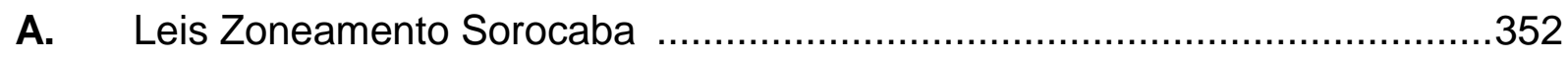

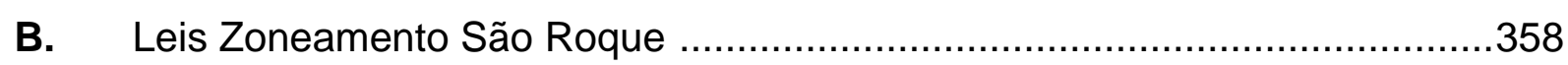

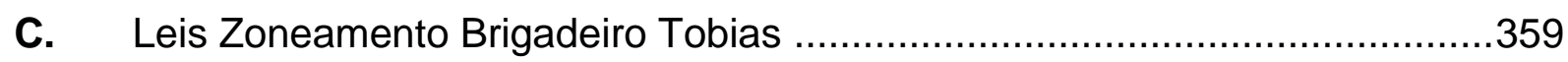

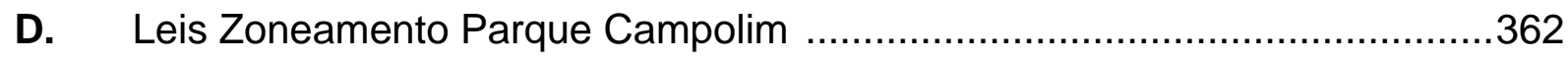

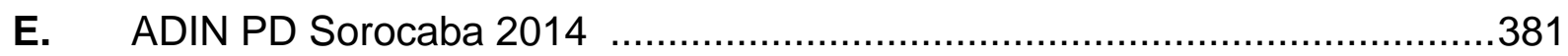

F. Corregedoria Geral do Município …………........................................382 


\section{INTRODUÇÃO}

Desde adolescente viajo à capital, São Paulo, para estudar. Por várias vezes viajei pela Rod. Castelo Branco, em um "Cometa". Viajei inclusive para São Paulo por trem, creio que em uma das últimas viagens realizadas com passageiros. Embora de menor custo, esta viagem não era viável: 0 trem chegou muito depois do horário estipulado. Também viajei muito pela Rod. Raposo Tavares, pelo Rodoanel trecho oeste, sul e leste, já com meu carro. Vi as transformações que ocorreram nas áreas lindeiras às estas rodovias nas últimas décadas, e sempre me fascinou como estas transformações urbanas ocorriam: às vezes em locais distantes menos de cinco quilômetros entre elas, na mesma rodovia havia mundos completamente diferentes em termos do tipo de ocupação, de atividades, de renda, de aproveitamento do potencial local, e principalmente do resultado da ocupação urbana, que em alguns locais é rapidamente mutante; em outros parecia que o tempo parou. Também depois vi outras estradas, rodovias, highways, em alguns países e vi muitas transformações, até aqui próximo de casa (moro próximo ao km 100 da Rod. Raposo Tavares). Percebi o quanto o dinamismo de uma cidade, Estado, nação, depende delas.

"Pode-se planejar a paisagem?1" Este título instigante que vi em um jornal local referente ao planejamento de intervenções em áreas na região em que morava ficava pairando na minha mente, enquanto eu me deslocava pelas rodovias para ir e voltar à São Paulo, no tempo dos estudos da graduação e depois da pós-graduação. Vi os pinheiros desaparecerem na entrada de Alphaville, próximo ao Rio Pinheiros, e do outro lado da rodovia Castelo Branco, aparecer um dia um enorme lago de contenção de água que depois descobri havia sido feito para contemplar uma questão energética, pela consultoria de um antigo professor da minha faculdade de projetos tecnológicos para a antiga Eletropaulo e o BID; para depois ver inúmeros prédios com mais de vinte andares serem construídos exatamente onde antes esteve o lago.

E me indagava, quem planejava estas modificações agora em áreas urbanas? Quem as aprovava, o município ou o governo do Estado de SP? Ou ambos? Haveria um planejamento urbano e regional de curto, médio prazo? Haveria um sentido de atendimento à demanda da sociedade como um todo, ou seria simplesmente para atendimento da especulação imobiliária, como no caso do outro lado da rodovia? Por que demoraram anos para duplicar as marginais da Rod. Castelo Branco? A resposta que descobri mais tarde evidencia o tipo de planejamento urbano que se tem no País.

Até hoje pergunto, por que não existe oferta de transporte público na Rod. Castelo Branco, onde a intelligentsia do Estado e até do País passam longas horas na ida e na volta, sacrificando horas

\footnotetext{
${ }^{1}$ PELLEGRINO, 2000. Revista Paisagem e Ambiente, ensaios no. 13 p. 159 a 179 - dez. 2000.
} 
de sono, saúde e tempo familiar? Porque eles se conformam com isto anos a fio? Que tipo de sociedade é esta? Poderia haver transporte público do tipo trem metropolitano, suburbano no sentido do que se tem na Europa, Estados Unidos e Japão, entre as cidades satélites e a metrópole? Por que não foi feito, se havia a fábrica da MBB para eixos em Osasco? Valeria a pena ser feito? Se foi para privilegiar um modal, será que não seria hora de começar a pensar em outras soluções mais contemporâneas pelo planejamento urbano e regional de uma sociedade que está envelhecendo, mas que não tem banheiros nos ônibus intermunicipais? Para algumas indagações hoje sei a resposta, outras ainda preciso descobrir. E o planejamento regional e urbano para uma nova região metropolitana, com áreas lindeiras às rodovias que a cruzam, ainda não urbanizadas, como deveria ou poderia ser feito? Por que para o Brasil, a resposta poderia ser proveitosa; temos muitas estradas ainda rurais, temos que proteger as nascentes e cursos de água, podemos ocupar as áreas lindeiras para comércio e indústrias - mas será que no séc. XXI, da produção robotizada e globalizada devemos reservar espaços para indústrias se instalarem? E que tipo de indústrias podem se instalar nestas áreas? De transformação, de logística, de montagem? Será que vale a pena reservar estas áreas para estas atividades, ou é melhor deixar a indústria civil construir vários prédios com vários andares e vários apartamentos sem uma política de transporte público rodoviário? É melhor colocar então um equipamento de BRT nos moldes de Curitiba no bairro do Pinheirinho? Tantas questões...

Este trabalho de doutoramento surgiu desse questionamento interno, do porque em alguns lugares destas áreas lindeiras existe desenvolvimento econômico e o valor do preço da terra ou do solo urbano, pode ser alto, e muitos querem morar neste trecho; e em outros, as vezes com cinco quilômetros de distância, é ocupado irregularmente, o casario é precário, na maioria das vezes em áreas de risco, e estão lá há décadas. São tão próximas entre si quando as percebo viajando no alto do banco do Cometa, passando por várias localidades em que mudavam significantemente as paisagens e as populações. Para escrever sobre este trabalho de doutorado, devo mencionar que por feliz coincidência o meu primeiro trabalho na pós-graduação foi o projeto de uma estrada: a Estrada de Santa Inês, para a disciplina Desenho Ambiental, com a profa. Maria Assunção. Assunto totalmente diferente do que havia estudado na graduação; nos estudos da pós-graduação tive noção mais clara do que, como arquiteta e urbanista, poderia estar contribuindo profissionalmente com meu tempo e trabalho.

Por este estudo de caso conheci a importância técnica do acesso à Represa Paiva Castro; da Sabesp Cantareira para o abastecimento da população de São Paulo; do Rodoanel Mario Covas antes de sua implantação e a luta de algumas ONG's para a preservação da Serra da Cantareira, na zona norte de São Paulo, além de também organizar após a entrega dos trabalhos da turma, minha primeira exposição na FAU-Maranhão, junto a uma colega, dos trabalhos finais desta disciplina. Ao fim desta 
disciplina na pós-graduação da FAUUSP fui contratada por uma empresa de consultoria em Campinas para fazer diagnósticos de uso e ocupação do solo, para planos diretores municipais, planos locais de gestão, planos locais de habitação de interesse social e afins. Enfim, viajar e trabalhar com Planejamento Urbano e Regional, vendo pela prática da profissão a realidade das comunidades estudadas, além de suas legislações urbanísticas e tentar contribuir para a melhora de suas vidas pela proposição de novas.

Para fazer o projeto de doutoramento nesta (para mim) nova área de Planejamento urbano e regional, escolhi a disciplina AUP 5858 - Teoria do Planejamento e do Desenvolvimento, dos professores Cândido Malta e Marly Namur. Oferecia a base teórica para o entendimento de uma outra área na pós-graduação da FAU-USP, mas o mais importante, oferecia um direcionamento de planejamento para o desenvolvimento sustentável de maneira socialmente aplicada; algo que sempre considerei imprescindível para o bem-estar de uma sociedade que se devote a oferecer uma melhoria da qualidade de vida para uma população que, em sua maioria, muito necessita disso. Nas minhas viagens para elaboração de diagnósticos de uso e ocupação do solo, percebi o quanto ainda temos que avançar no oferecimento de condições básicas de moradia e cidadania para grande parte da população.

Neste estudo de caso específico, partiu-se de um sistema rodoviário complexo, pois a RRT (rodovia escolhida) pertence a um sistema (Castelo-Raposo) que conecta uma região metropolitana do interior à uma Macro-metrópole e à várias outras, na medida em que a rodovia estudada conecta regiões metropolitanas importantes do Estado de São Paulo; está localizada no extremo oeste da Macro Metrópole Paulista, que por sua vez pertence à Mega-Região de SP-RJ, portanto tem importância nacional (64\% PIB do País).

As áreas lindeiras às rodovias metropolitanas são áreas estratégicas ao deslocamento, à urbanização e ao desenvolvimento sócio-econômico positivo para suas populações. Suas ocupações devem, na medida do possível, ser planejadas e gestadas pelo poder público e sociedade técnica para oferecer às populações das regiões perpassadas pelas rodovias, condições para que a sua ocupação seja a melhor possível, considerando-se que nestas áreas podem estar a chave do abastecimento hídrico, da produção e comercialização de bens e serviços, dos deslocamentos eficientes em relação inclusive à moradia dos trabalhadores; enfim, do almejado bem-estar social.

Para o processo de conhecimento da realidade em si, definido o espaço de aplicação, que passou por um contínuo processo de ampliação e redução até abarcar o sistema urbano que tem em suas pontas Sorocaba e São Roque, e seus espaços intersticiais; passamos à sua análise, dividindo os subsistemas natural e antrópico em seus componentes relevantes para a identificação das 
especificidades espaciais, enquanto condicionantes, como restrições e potencialidades, às tensões impostas pelas ações humanas.

O objetivo principal desta tese foi de verificar, através da comparação da urbanização ocorrida e da legislação urbana vigente (sobre o uso do solo permitido pelo zoneamento municipal), desde a criação da rodovia Raposo Tavares (1954) até atualmente (2017); se a urbanização verificada seguiu a legislação urbana vigente ou não nos trechos escolhidos; e se a legislação de zoneamento municipal não foi seguida, como e porque não o foi.

A hipótese da tese, considerando as seguintes premissas:

- Entre os km 45 e 92 da Rod. Raposo Tavares (SP 270), houve em média, 64\% de aumento das áreas urbanizadas, constatado em levantamentos realizados entre 2014 e 2015 (CAMARGO, LANÇAS, 2015);

- Há necessidade de conservação de recursos hídricos e fragmentos vegetais remanescentes, próximos dos principais eixos rodoviários da região, principalmente para abastecimento hídrico das populações e suas atividades econômicas e de outras naturezas (cultural, esportiva, de lazer, etc) no entôrno;

- É preciso identificar uma maneira de conciliar a ocupação do território pela população com a preservação de recursos naturais essenciais às atividades vitais, de moradia e do desenvolvimento econômico das populações, e comum às várias municipalidades dos eixos rodoviários mais utilizados.

E dos seguintes questionamentos:

- Existem ocupações irregulares para fins de moradia ou não nas áreas lindeiras de uma rodovia?

- As leis reguladoras da produção do espaço urbano de uso do solo foram obedecidas pela ocupação urbana nas áreas lindeiras de uma rodovia?

- Qual é o papel do zoneamento municipal pelo uso do solo permitido na produção do espaço urbano?

\section{A. HIPÓTESE:}

$>$ Existe ocupação irregular para fins de moradia, em áreas de risco das áreas lindeiras à uma rodovia. A produção de espaço urbano nas áreas lindeiras de uma rodovia não é decorrente do respectivo zoneamento municipal, pois ele não é obedecido quanto ao uso do solo permitido; 
A legislação do zoneamento municipal nas áreas lindeiras à uma rodovia, quanto ao uso do solo, é mais permissiva para outros usos do que para a ocupação industrial e comercial; permitindo-se nelas a produção de espaço urbano para fins de moradia unifamiliar e multi-familiar;

As diretrizes de zoneamento municipal para ocupação destas áreas lindeiras às rodovias de alto tráfego não levam em conta a priorização da ocupação industrial e comercial de grande porte em relação à ocupação habitacional dos tipos unifamiliar e multi-familiar.

\section{B. METODOLOGIA UTILIZADA}

Para a realização da tese aqui apresentada, seguiram-se as seguintes ações:

\section{Revisão Bibliográfica e Cartográfica:}

- Revisão bibliográfica e cartográfica, da área de estudo nos trechos da Rodovia Raposo Tavares, para os municípios de São Roque, Mairinque, Alumínio e Sorocaba. Definição do critério de escolha dos trechos. (o final foi eventualmente ajustado para o km 102), e a determinação de uma área lindeira à RRT limitada a $500 \mathrm{~m}$ do eixo longitudinal da rodovia, para ambos os lados.

- A revisão bibliográfica e cartográfica sobre a RRT na RMS foi realizada em fontes primárias e secundárias confiáveis, como o IBGE, EMPLASA, Google Scholar, Google Maps, a biblioteca da FAU-Maranhão e FAU-USP, bem como outras fontes locais institucionais e públicas.

2. Fotos aéreas IGC e fotos de satélite LandSat/NASA e INPE e fotos in loco por drone (2017) e in loco (rés-do-chão):

- Foram buscadas fotos aéreas do IGC dos trechos escolhidos dos períodos de 1954 em diante;

- E fotos de satélite do início do séc. XXI (2000 a 2010) disponibilizadas pelo site da NASA para o satélite Landsat 5, 6, 7 e 8 para compará-las com as fotos de satélite de 2014/15, também pinçadas para se determinar em quais trechos houve o maior aumento de área urbanizada, utilizando o programa de desenho auxiliado por computador AutoCad, para elaboração de polígonos de áreas e mensuração destas áreas urbanizadas. Estas informações foram sistematizadas para se obter os resultados em quantidades do aumento de área urbanizada para a escolha dos trechos a serem estudados. Após esta sistematização, foram verificados os QUATRO trechos que mais tiveram aumento de área urbanizada, de preferência em municípios diferentes.

- Paralelamente, também fomos a campo para fotografar in loco, o grau de urbanização, a tipologia do uso e ocupação do solo nestes trechos. Foi também feita uma sistematização das 
fotos destes trechos, para se ter uma idéia da realidade urbana de cada trecho. Os resultados deste primeiro levantamento foram a quantificação das áreas mais urbanizadas e suas unidades de paisagem destes trechos. (CAMARGO, LANÇAS, 2016)

- A determinação dos trechos levou em conta os resultados sistematizados com os resultados de três critérios: dos trechos mais urbanizados levantados no estudo preliminar, quais trechos detinham as mais diferentes tipologias sócio-econômicas de mancha urbana; estavam dentro da RMS e de diferentes municípios, (São Roque, Alumínio e Sorocaba, excluindo-se os municípios de Mairinque e Votorantim); e também tivesse a questão ambiental e paisagística importante para o contexto da legislação urbana, pois a partir da aprovação do Estatuto da Cidade (2001), as APP's e áreas de risco eram importantes para levar-se em conta as ocupações/soluções das populações de baixa e baixíssima renda para sua moradia.

\section{Pesquisas realizadas nas prefeituras municipais e câmaras municipais de São Roque,}

Alumínio e Sorocaba, sobre as legislações urbanísticas pertinentes:

Determinados os quatro trechos a serem analisados, buscou-se, nas prefeituras municipais das cidades escolhidas, informações quanto à legislação urbana existente desde 1950 (época da criação da Rod. Raposo Tavares) até 2016: portanto em São Roque, Alumínio, Sorocaba e Votorantim (visto que este município em determinada época pertenceu como distrito ao Município de Sorocaba). Também foram pesquisados, nas Câmaras municipais destes locais, as legislações pertinentes ao período e locais estudados, os quatro trechos escolhidos da RRT. Estas leis foram lidas e relidas, para se separar os trechos realmente pertinentes ao zoneamento dos trechos escolhidos, e separados em anexo para eventual consulta do leitor mais interessado.

\section{Complementação de fotos dos trechos escolhidos:}

Além das fotos de satélite e fotos in loco, procurou-se tomar, com apoio do grupo de pesquisa em robótica do Instituto Federal de São Paulo - núcleo Sorocaba, fotos por drones a cerca de 200 metros de altura, para se fotografar aereamente mais proximamente, e com maior visibilidade aérea, os trechos as áreas lindeiras à RRT (2017).

\section{Outras informações:}

À todas estas informações foram somadas as informações de Unidades de Informações Territorializadas (UIT) da EMPLASA (2017), pesquisadas desde 2014 no território da RMS e liberadas para utilização para fins da produção do PDUI da RMS 'por representantes da sociedade civil organizada no $2^{\circ}$ semestre de 2017.

\section{Mapeamentos:}

Foram então elaborados vários mapas-síntese dos zoneamentos municipais por trecho e por mudanças significativas na legislação urbanísticas destes quatro trechos, e da transposição dos dados 
de uso e ocupação do solo disponibilizados pela EMPLASA em 2017 para cada trecho, totalizando 19 mapas-síntese.

\section{Análises:}

Os mapas-síntese e as leis de zoneamentos foram analisados com os mapas de uso e ocupação do solo, fotos in loco, rés-do-chão e a 200 metros de altura dos drones, com as fotos de satélite antigas (a partir de 1986) para se chegar a conclusões pertinentes a cada trecho sobre a questão da urbanização e zoneamento.

\section{Conclusões:}

Todas estas informações citadas anteriormente foram utilizadas para se verificar os padrões de uso e ocupação do solo e fazer as análises comparativas entre a legislação urbanística e sua aplicação ou não, seu seguimento ou não, e os resultados das análises foram colocados em quatro capítulos, em seus respectivos trechos. Por fim, foram elaboradas as conclusões finais do conjunto dos trechos analisados, e colocam-se algumas observações que poderão ser utilizadas nas diretrizes de ocupação de áreas lindeiras as rodovias metropolitanas.

A tese aqui apresentada foi dividida em oito capítulos, aqui descritos:

O Capítulo I: coloca os conceitos teóricos que fundamentaram o trabalho. São trabalhados a partir de autores escolhidos dos estudados nas disciplinas cursadas no período de aprendizado no programa de pós-graduação, e de pesquisas em diversas fontes e discussões com a orientação, para as palavras-chaves e suas conceituações: espaço, espaço urbano, localização, localização urbana, atuação do Estado na produção do espaço urbano.

O CAPITULO II: neste capítulo procurou-se caracterizar a RMS para que o leitor possa ter uma idéia-síntese da região, com dados da mobilidade urbana da RMS do séc. XIX até o presente, passando pela implantação da via férrea (EFS), dados do carregmento para o horizonte de 2020 no sistema viário regional e uma proposta de ligação São Paulo-Sorocaba pela CPTM, através de um ramal regional. Completando as informações da mobilidade urbana na região da RRT na RMS, estão colocados os dados do Sistema Castelo-Raposo, operado pela concessionária ViaOeste, que fazem a conexão com a RMSP, RMC, já considerando-se também o PDUI atualmente sendo desenvolvido para a RMS.

Finaliza-se a caracterização da RMS com os dados do Sistema Castelo-Raposo, com a denominação do Eixo Urbano-Industrial da Rod. Castelo Branco e sub-eixo Rod. Santos Dumont e o Eixo Verde Rod. Raposo Tavares, via de acesso à APA de Jurupará e Represa de Itupararanga, na RMSO CAPITULO III: trata da escolha dos trechos da RRT analisados. Iniciamos com um breve histórico da Rod. Raposo Tavares, operacionalizado atualmente pela concessionaria ViaOeste, através 
de pedágios localizados nas praças de São Roque, no sentido interior, e Alumínio, no sentido da capital (dentre os trechos estudados).

Para fins de análise das áreas lindeiras, adotou-se um limite de $500 \mathrm{~m}$ do eixo longitudinal da rodovia, para ambos os lados. Os critérios de escolha dos trechos a serem analisados levaram em conta três critérios: 1) padrão sócio econômico, (determinados pelos quesitos grau de urbanização, tipologia das edificações, quantidade de emprego existente); 2) recorte territorial, uma vez que os trechos deveriam estar no território da RMS; e 3) ambiental, os trechos que estivessem em áreas urbanizadas mas também houvesse a ocorrência de nascentes ou cursos d'água de maneira significativa, além de fragmentos remanescentes de vegetação, que pudessem configurar necessidade de preservação; elemento de patrimônio paisagístico e ou também patrimônio histórico.

Desta maneira foram isolados quatro trechos da Rod. Raposo Tavares, segundo os três critérios mencionados:

$\checkmark$ Trecho 1: São Roque, do km 60 a 64;

$\checkmark$ Trecho 2: Alumínio, do km 75 a 79;

$\checkmark$ Trecho 3: Brigadeiro Tobias, do $\mathrm{km} 88$ a 92;

$\checkmark$ Trecho 4: Parque Campolim, do km 98 a 102.

As análises de cada trecho foram colocadas em capítulos separados:

O Trecho 1 de São Roque caracteriza-se por ter uso residencial, comercial e industrial; também há o interesse turístico e paisagístico, caracterizado pelo Morro do Cruzeiro; e em 2017 recebeu novo contorno da RRT, desviado do núcleo urbano central.

O Trecho 2 de Alumínio ainda tem seu traçado passando por área urbanizada, com a questão da tipologia mais pobre, de ocupação e de auto-construção, nos morros que ladeiam a estrada no trecho urbana de Alumínio. Tem também em seu trecho a planta da CBA, e é o trecho de aspecto mais verde devido a existência de plantações de eucaliptos.

0 Trecho 3, do distrito de Brigadeiro Tobias e suas áreas lindeiras à Rod. Raposo Tavares segue a lógica cronológica da implantação da fazenda na era colonial, seguida pela implantação da estação ferroviária na época da EFS e utilização rural até os anos 50; depois ocupada pela migração da população do interior dos estados do Paraná e de Minas gerais nos anos 70 que ocorreu na região de Sorocaba e Votorantim.

O Trecho 4 foi escolhido principalmente pelo quesito do grau de urbanização e do padrão sócioeconômico; tem também a questão ambiental, devido à bacia de retenção que forma o Parque Campolim. Este bairro teve origem rural, e depois seu principal loteamento teve o desenho urbano baseado nos bairros jardins dos bairros homônimos de São Paulo. Tem grande atividade comercial e 
de serviços, e verticalização pontual às margens da rodovia no trecho analisado e nas bordas do bairro principal. O potencial construtivo também foi e é motivo de disputas imobiliárias entre residentes antigos e novos, bem como das forças do mercado imobiliário de grau nacional, levando à mediação do ministério público para a resolução de questões de impacto de vizinhança, mobilidade urbana, e insegurança jurídica quanto ao zoneamento municipal.

O CAPITULO IV procura aprofundar o conceito do zoneamento urbano, e descreve sua breve história desde as antigas leis do séc. XII; a construção do zoneamento de Frankfurt, na Alemanha do séc. XIX, em Londres no início do séc. XX, e do Zoning Resolution de Nova lorque de 1916. Também do zoneamento brasileiro têm-se uma breve história, para se concentrar no zoneamento vigente para Sorocaba, pois neste município estão dois dos quatro trechos analisados da RRT. O estudo do zoneamento municipal de Sorocaba cobre o período de 1914 a 2003, do centro para a periferia, onde estão os trechos 3 (distrito de Brigadeiro Tobias, na zona leste) e trecho 4 (Parque Campolim, na zona sul).

No Capítulo V estão as análises do zoneamento versus a ocupação para o Trecho 1 - São Roque. Nele estão levantadas as informações a partir da criação da Rod. Raposo Tavares (1954), do Plano Diretor de 1972 e ocupação verificada em fotos aéreas; o então novo PD de 2006 e ocupação verificada por fotos aéreas e in loco, que introduz questões mais complexas relativas ao uso dos corredores de tráfego mais intenso e tendências de urbanização, para determinar novos usos e gabaritos de altura para colaborar na visibilidade de elementos da paisagem para ajudar a fomentar a atividade turística, uma das principais fontes de renda municipais. Em 2017 o trecho da RRT recebeu novo traçado, contornando a área central paralelamente à linha férrea, que deverão ensejar nova revisão do PD.

No Capítulo VI estão as análises do zoneamento versus a ocupação para o Trecho 2 - Alumínio; contando a emancipação de Alumínio de Mairinque, por sua vez também desdobrada de São Roque. Por isto sua legislação de zoneamento começa a valer a partir do início da década de 90 , mas seu plano diretor desde então não foi atualizado, embora esteja sendo refeito atualmente. 0 zoneamento atual do municipal de Alumínio é composto de apenas dois itens: a zona urbana e a zona rural. Não discrimina um zoneamento especifico para a zona industrial; o zoneamento da área urbana não evitou ocupações nas áreas lindeiras à rodovia, na entrada do município, e na divisa entre Alumínio e Sorocaba também há ocupações, estas fora da visibilidade da beira da rodovia. $O$ interessante é notar que o Município de Alumínio tem a mais alta renda per capita de todos os municípios da RMS, mas a urbanização verificada no trecho é de baixa tipologia, em certo ponto de travessia até com insegurança para a população, embora em Alumínio esteja a praça de pedágio da concessionária ViaOeste no sentido interior-capital. 
No Capítulo VII estão as análises do zoneamento versus a ocupação para o Trecho 3 Brigadeiro Tobias. Neste trecho estão elencadas as transformações das áreas lindeiras do trecho desde sua ocupação inicial para uma fazenda de uma rica família no tempo colonial, a implantação da estação de Brigadeiro Tobias, a urbanização do entorno da estação, em área de várzea do rio PirajibuMirim, a questão ambiental das nascentes e cursos d'água, numerosos devido à topografia da Serra de Inhayba; bem como a questão do zoneamento rural, que foi transformado em macrozona de grande restrição à urbanização, e as modificações nos planos diretores de 1968 a 2014, com grande detrimento à questão ambiental, mas que não solucionou a questão da ocupação irregular que se verifica em suas áreas de várzeas e colinas. Investidas no zoneamento municipal consideradas ilegais pela população e pelo ministério público federal resultaram em ação de inconstitucionalidade, e itens relativos ao zoneamento da área está sob júdice.

No Capítulo VIII estão as análises do zoneamento versus a ocupação para o Trecho 4 - Parque Campolim, o trecho mais rico e verticalizado dos quatro trechos estudados. Explica as origens rurais do bairro que foi transformado a partir da implantação de um novo loteamento no final dos anos 70, com desenho urbano inspirado nos bairros jardins paulistanos; e que, com a implantação de dois shoppings no trecho, recebeu urbanização célere, que culminou em verticalização e utilização fora do respeito à lei de zoneamento municipal do tipo ZR1 e necessidade de intervenção municipal, estadual e federal para um acordo de atendimento às necessidades de vários atores do capital imobiliário, empresarial, comercial, população do entorno e de proprietários de novos empreendimentos imobiliários.

Finalmente, as conclusões dispõem os resultados das análises dos zoneamentos versus ocupação urbana ao longo dos trechos analisados, no período estudado. 


\section{CAP. I - CONCEITOS}

"As cidades também acreditam ser obra da mente ou do acaso, mas nem um nem o outro bastam para sustentar as suas muralhas. De uma cidade, não aproveitamos as suas sete ou setenta e sete maravilhas, mas a resposta que dá às nossas perguntas". (CALVINO, 1972) 


\title{
CAP. I - CONCEITOS
}

Como se dá a ocupação, nos espaços das áreas lindeiras às rodovias metropolitanas, dos homens e de suas atividades, e especificamente no nosso caso, como poderia ser possível atender a necessidade da moradia e ainda conservar e preservar os corpos d'água necessários ao abastecimento das populações? Passaria pela questão da legislação urbanística do zoneamento municipal?

Neste capítulo mencionamos 0 instrumental teórico que embasa o presente trabalho. Foi construído da seguinte forma: conceitos básicos inerentes a compreensão do objeto investigado para 0 projeto de doutoramento (localização, zoneamento municipal e urbanização de áreas lindeiras a uma rodovia metropolitana). Isto implicou na busca dos conceitos de localização, localização urbana, espaço, espaço urbano, produção do espaço urbano, atuação do Estado para a produção do espaço urbano e habitações de interesse social.

Iniciamos neste capítulo o instrumental teórico pelo conceito do espaço; e no quarto capítulo do presente trabalho, sobre o instrumento urbanístico de zoneamento municipal, sendo o uso do solo 0 principal instrumento analisado nos trechos escolhidos da Rod. Raposo Tavares (SP 270).

Sobre o espaço, Henri Lefèbvre mencionou Marx (1844) em relação à questão da realidade espacial, a consideração do espaço já como conceito em seus discursos, sobre a Natureza como premissa:

\begin{abstract}
"Para nós, o espírito tem a natureza como sua premissa, sendo a verdade da natureza e, por conseguinte, seu primus absoluto. Nessa verdade, a natureza desapareceu e 0 espírito capitulou como a idéia que alcançou ser-por-si, cujo objeto, assim como o sujeito, é o conceito. Essa identidade e negativamente absoluta, pois enquanto na natureza o conceito encontra sua perfeita objetividade exterior, aqui sua alienação foi revogada e o conceito identificou-se a si mesmo. Ele é essa identidade somente na medida em que é um retorno da natureza." (loc. cit., pág. 392.) (MARX, 1844)².
\end{abstract}

E Lefèbvre continua sobre o conceito do espaço:

"Pode-se elaborar uma semântica dos discursos sobre o espaço. (...) Todo espaço é significante? Em caso positivo, de quê? Mais precisamente, todo espaço ou fragmento de espaço não seria um texto social, ele próprio contexto de textos específicos, isto é, escritos: inscrições, anúncios, etc? de sorte que é preciso ou reencontrar ou construir os códigos dessas diversas mensagens para decifrá-las. Nessa perspectiva, a relação da teoria com a prática não é a de uma abstração transcendente a uma imediataridade ou a um "concreto" anterior. A abstração teórica já está no concreto. É preciso aí revela-la. No seio do espaço percebido e concebido já se encontra o espaço teórico e a teoria do espaço." (LEFEBVRE, 2008, p. 38).

\footnotetext{
${ }^{2}$ In: https://www.marxists.org/portugues/marx/1844/manuscritos/cap07.htm, acesso em janeiro/2017.
} 
Para Lefèbvre, se o espaço desempenhar um papel ou uma função decisiva no estabelecimento de uma totalidade, de uma lógica, de um sistema (caso em que acreditamos), não se pode tirá-lo deste sistema, ou lógica, ou totalidade, mas mostrar sua função nesta perspectiva, pela prática e estratégica. Ele levanta algumas hipóteses sobre o que é o espaço: em $1^{0}$ lugar, que o espaço é uma forma pura, a transparência, a inteligibilidade, (desembaraçada de todo conteúdo sensível, material, vivido, prático, ideológico, interpretativo, o não-saber; é uma essência, uma idéia absoluta como o número platônico. Nesta versão, o espaço é configurado como coerência e modelo de coerência, articulando o social, e o mental; o teórico e o prático, o ideal e o real; em $2^{\circ}$., que o Espaço é um produto da sociedade, constatável e dependente (da constatação); portanto da descrição empírica antes de qualquer teorização; neste caso, o espaço é resultante do trabalho e de sua divisão: ele é o lugar geral dos objetos produzidos; o conjunto das coisas e dos subconjuntos, portanto "funcional"; em $3^{0}$ lugar, que o Espaço não é um ponto de partida (hipótese filosófica mental e social) nem um ponto de chegada (produto do trabalho social ou lugar os produtos), mas um intermediário: um modo, um instrumento, um meio e uma mediação.

Neste caso, o espaço é um instrumento político intencionalmente manipulado - tendo haver com o poder: decretos e idéias (de um Estado, ou de uma classe dominante - por exemplo: a burguesia), mas de grupo que pode ter várias escalas e objetivos (por exemplo os tecnocratas); esse espaço é ideológico (porque político) e do saber (pois deve colocar representações elaboradas): é o espaço racional-funcional-estratégico, e desta maneira é o espaço do meio e do modo do trabalho produtivo e do consumo dirigido; e por último, que o Espaço não seria um produto qualquer, ou uma soma de coisas: o espaço estaria essencialmente ligado à reprodução das relações sociais de produção: neste caso, um passo mais avançado da hipótese anterior (por exemplo: o espaço na pintura, na escultura, na arquitetura, nas novas cidades, no "saber": um espaço homogêneo e desarticulado: aí encontra-se o espaço urbano, os espaços de lazeres, os espaços educativos, do cotidiano, do mobiliário, do design, etc) (LEFEBVRE, 2008, p. 39).

Nesta última hipótese o autor se debruçou mais para enunciar que este é o Espaço (homogêneo e desarticulado), produtivo no sentido mais amplo: nele coexistem a produção de relações sociais e reprodução de determinadas relações (por exemplo, através do cotidiano, dos lazeres, da cultura, das escolas e das universidades; através do espaço inteiro) como as enumeradas acima; mas também é o Espaço onde a conexão coercitiva à sociedade existe por meio de um sistema de acessos às partes deslocadas: portanto o Espaço é o informe, duro e constrangedor das periferias e subúrbios, cortiços, favelas, a cidade das urgências que complementam as áreas residenciais. E nesse caso, um suporte de inerências na dissociação, de inclusão na separação; ou seja, o Espaço como um todo. 
Assim, "o Espaço inteiro torna-se o lugar da reprodução das relações de produção". (LEFEBVRE, 2008, p. 41-49). Este conceito aplica-se inteiramente a produção do espaço nas áreas estudadas, pois as relações de produção manifestaram-se desde a instalação das fazendas no período colonial, prosseguindo pelo início das atividades industriais no final do séc. XIX, que motivaram a implantação da linha ferroviária e suas estações, permanecendo até hoje:

"Em todos os momentos da história da humanidade, cada revolução socioeconômica traduziu-se em modificações nos relacionamentos humanos e na natureza do espaço produzido. O espaço é uma instância social. (...)" (SOUZA, 1988, p. 55).

Para Doreen Massey, o Espaço é um produto de inter-relações em todas as escalas, construídas e negociáveis relacionalmente. Além disso, nele (Espaço) existe a possibilidade da multiplicidade, e de sempre estar em construção, sem término: aberto em sentido amplo, e que pode ter resultados imprevisíveis e de ligações ausentes:

$1^{\circ} \mathrm{O}$ Espaço é produto de inter-relações, sendo constituído através de interações, desde a imensidão do global até o intimamente pequeno. (...) Nenhum lugar/espaço é uma autenticidade coerente e contínua, pois as identidades espaciais são também construídas relacionalmente e negociadas internamente;

$2^{\circ}$ O espaço é a esfera da possibilidade da existência da multiplicidade, no sentido da pluralidade contemporânea, como a esfera na qual distintas trajetórias e a heterogeneidade coexistem. Multiplicidade e espaço são desse modo co-constitutivos. (...)

$3^{\circ}$ O Espaço está sempre em construção, no processo de fazer-se como produto de relações que estão necessariamente embutidas em práticas materiais que devem ser efetivadas. O espaço nunca está fechado, ele é uma simultaneidade de estórias-até-agora.

Sob o ponto de vista político, essa proposição diz respeito à radical abertura do futuro, como escape à inexorabilidade das grandes narrativas da modernidade (Progresso, Desenvolvimento e Modernização). Não apenas a história, mas também o espaço é aberto. Ele jamais é uma simultaneidade completa. Ele não é nem um recipiente para identidades sempre-já constituídas, tampouco um holismo completamente fechado. É assim um espaço de resultados imprevisíveis e de ligações ausentes." (MASSEY, 2012).

Enuncia o geógrafo e professor Milton Santos: "o Espaço é um acúmulo de tempos. (...) 0 espaço é formado por um conjunto indissociável, solidário e também contraditório, de sistemas de objetos e sistemas de ações - não considerados isoladamente, mas como o quadro único no qual a história se dá". Portanto, para Milton Santos, o espaço é resultado de um acúmulo de ações nos tempos (SANTOS, 2004, p.63).

Sobre o espaço urbano, agregando-se à definição do Espaço de Lefebvre, Maria Adélia Souza, Doreen Massey, e a de Milton Santos de que o espaço é um elemento sistêmico complexo, colocaremos a seguir outros conceitos, conforme salientado no início deste capítulo. Sobre o espaço urbano:

"No começo era a Natureza selvagem, formada por objetos naturais, que ao longo da história vão sendo substituídos por objetos fabricados, objetos técnicos, mecanizados e, depois, cibernéticos, fazendo com que a natureza artificial tenda a funcionar como uma máquina. Através da presença desses objetos técnicos: hidroelétricas, fábricas, fazendas modernas, 
portos, estradas de rodagem, estradas de ferro, cidades, o espaço é marcado por esses acréscimos, que lhes dão conteúdo extremamente técnico" (SANTOS, 2004, p.63).

Santos aponta que após a $2^{\mathrm{a}}$ guerra mundial, a ciência e a técnica unem-se sobre a égide do mercado, que então torna-se global; que a produção e localização geram informação; o que é na verdade, a energia principal de seus funcionamentos: da produção, da utilização e do funcionamento do espaço; e que tende a ser seu substrato, no que ele chamou de um novo meio: técnico-científico e informacional, e face da globalização. "Os espaços assim requalificados atendem sobretudo aos interesses dos atores hegemônicos da economia, da cultura e da política, e são incorporados plenamente às novas correntes mundiais" (SANTOS, 2004, p. 338 e 339).

O espaço urbano sempre foi alvo de questionamentos e interpretações de teóricos do urbanismo. Para Roberto Lobato Corrêa: "Este complexo conjunto de usos da terra é, na realidade, a organização espacial da cidade, ou simplesmente, o espaço urbano que aparece assim como espaço fragmentado" (CORRÊA, 1995, p.7).

Em 1997 Borja e Castells expressaram a tendência da idéia de cidade:

"Um mundo organizado em torno de grandes aglomerações difusas de funções econômicas e assentamentos humanos disseminados ao largo de vias de transportes, com zonas semi rurais intersticiais, áreas periurbanas sem controle e serviços desigualmente repartidos em uma infra-estrutura descontínua". (BORJA; CASTELLS, 1997, 13, apud LENCIONI, 2014).

Para Topalov o espaço urbano está diretamente ligado à diferenciação dos espaços, à formação de custos e preços dos imóveis, e assim, às rendas urbanas. Ele mencionou a divisão social do espaço por três correntes distintas de vários estudiosos: 1) a ecologia urbana; 2) a economia neoclássica e 3) a sociologia culturalista; mas ele acreditava que estas correntes eram limitadas conceitualmente na distribuição espacial das residências, pois não levavam em conta a situação da classe social dos habitantes e suas relações com o espaço urbano (TOPALOV, 1984, P. 141 apud FERREIRA, 1987, p. 31).

Detalhando melhor a $1^{\text {a }}$. corrente, tinha como princípio característico os modelos descritivos naturalistas da Escola de Chicago que desenvolveram a econometria dos fatores de valoração do solo, algo que Topalov pensou limitado por que não explicava o modus operandi das regularidades ou legislação observadas, pois "constatar uma regularidade não implica constatar simultaneamente as causas dessa regularidade, e portanto, a eficácia explicativa desse modelo descritivo é nula": no modelo de zonas concêntricas de Burgess, as cidades se compõem de cinco zonas concêntricas: 1) área central (centro de negócios composto do comércio varejista, edifícios de escritórios, serviços; 2) em sua zona periférica, uma zona de comércio atacadista; 3) uma zona de transição (alternância de residências degradadas e indústrias); 4) zona residencial das categorias médias e altas da população; 
5) zona periférica, moradia de migrantes e da população mais pobre da cidade. Essas cinco zonas, cada qual empurrando a subsequente, repetidamente, seria a expansão e desenvolvimento da cidade. Este modelo não nos serviria, pois não considera mais aprofundadamente a questão do sistema viário periférico à cidade no século XX e XXI. Agora um modelo clássico, o modelo de Burgess foi criticado por muitos, mas teve o mérito fomentar novos modelos conceituais (REIS, 2016, p. 23).

O próximo modelo mencionado por Topalov (1984, apud FERREIRA, 1987, p. 3) é modelo dos setores desenvolvido por Homer Hoyt (1934), que considera os eixos viários, aplicando uma alternativa empírica à análise de Burgess, pois para ele a cidade se organiza não em círculos concêntricos, mas em círculos núcleados; continua atrelado aos preços das habitações, que se distribuiriam por setores radiais ao longo dos eixos viários; neste caso Hoyt supunha que os preços distribuíriam-se pela cidade em um gradiente regular. Mais tarde (1944), junto Erna Herrey e Constantin Pertzoff, Hoyt propôs um novo modelo baseado em unidades de vizinhança, poli-nucleado, para integração dos centros secundários ao principal, visando a que todos se sentissem uma comunidade integrada. Reis observa que embora com a boa intenção dos teóricos, pela característica conservadora da sociedade americana da época, poderia inclusive favorecer a característica de segregação de comunidades menos favorecidas, inclusive racistas. (REIS, 2016, p. 23)

Topalov considerava que o maior problema epistemológico nestes dois modelos clássicos da ecologia urbana americana, pois as discussões dos processos reais que determinavam as localizações dos núcleos urbanos nunca foram abordados. $O$ preço da terra era sempre considerado como o único operador da diferenciação urbana (TOPALOV, 1984, apud FERREIRA, 1987, p. 33).

A $2^{\mathrm{a}}$. corrente de análise da divisão social do espaço está ligada aos "modelos teóricos racionalistas: a economia clássica da localização", caracterizada pela análise à lógica da decisão econômica racional, deduzindo leis de comportamento; neste modelo teórico os agentes econômicos têm um papel ativo na sua adaptação ao espaço, guiados pela flutuação/dinamização de custos. Isto daria especial ênfase à acessibilidade, a única propriedade espacial capaz de definir um custo; e a localização das residências seriam definidas por sua distancia ao centro de negócios, desconsiderando sub-centros, pólos de empregos, etc.

$\mathrm{Na}$ avaliação de Topalov, os consumidores são tratados nesta teoria como apenas sujeitos pelo enfoque econômico: do "trabalhar e consumir; o espaço é apenas a distância em onde estes dois fatos acontecem". Ele ainda concedia à teoria a questão do tempo de deslocamento, que tem um custo e cada família pode atribuir um preço ao tempo despendido em seus deslocamentos; neste caso os preços seriam fixados pelas famílias de maiores rendimentos, pois podem atribuir um valor maior ao seu tempo: estes quadros definiriam as densidades e preços na aglomeração urbana. Quanto mais 
próximo ao centro, maior o preço da terra, maior a densidade. (TOPALOV, 1984, apud FERREIRA, 1987. p. 33 e 34).

Embora a questão da acessibilidade e o custo dos deslocamentos influenciem no oferecimento de novos espaços urbanos, atualmente a abordagem com relação a apenas trabalhar e consumir está superada; primeiro porque pode-se trabalhar sem sair de casa, com o advento da internet, pode-se consumir entretenimento em casa (antes dela também se podia) e mesmo antes do advento da internet e do celular o homem não só fazia o trajeto casa-trabalho-consumo-casa; e sobre o preço, atualmente dependendo das condições de uso e oferecimento de serviços nas áreas centrais de muitas cidades, não são mais o lugar mais cobiçado para se viver. Dependendo da acessibilidade, áreas distantes do centro tem o atrativo do bucólico, (sem mencionar que muitas áreas centrais atualmente estão decadentes e ainda não receberam ações de revitalização e requalificação de seus espaços), muito mais buscado hoje em dia, haja vista a proliferação de loteamentos "fechados" apreciados e comprados desde a classe mais alta à classe média baixa, com seus gramados, jardins, quintais, e áreas de preservação permanente disponibilizados desde os folhetos de vendas iniciais, até a implantação de áreas de lazer esportivo com faixas para caminhadas, ciclovias, etc nas bordas dessas APP's enclausuradas nos loteamentos e condomínios fechados comuns agora na maioria dos municípios brasileiros.

Já Smolka (1983) questiona a relação entre elevação de preço do m2 do lote e adensamento, classificando-a de nebulosa (SMOLKA, 1983, p. 143, apud FERREIRA, p. 34). Ele leva em consideração três modelos de estudo analisados desta $2^{a}$ corrente de pensamento analisada por Topalov: A) de Wingo, de 1961 em que o custo do solo e custo de transporte são complementares e custo e quantidade do solo utilizado são inversamente proporcionais; assim sendo, o modelo estabelece o preço do solo e a densidade residencial em cada ponto da aglomeração; B) a de Alonso (1964), que introduz uma função de satisfação que pode substituir a quantidade de solo consumida, ou das distancias percorridas; C) a de Muth (1969), que acrescenta à função de satisfação um estudo sobre os benefícios de venda da moradia: neste caso, o solo não é analisado apenas pela sua função (útil), mas como fator de produção (produto) (TOPALOV, 1984, p. 146, apud FERREIRA, 1987, p. 34).

Neste breve resumo, cada pesquisador citado por Topalov da década de 60 do séc. XX acrescenta uma função válida de análise da produção de espaços urbanos, fruto do crescente crescimento da população, das cidades e da disponibilidade de automóveis para os deslocamentos entre casa e trabalho, (naquela época muito separados em espaço e funções). Hoje na realidade da utilização da rede mundial (internet) e de novos arranjos produtivos para a produção industrial, 0 binômio casa-trabalho foi muito modificado: o foco é a montagem da produção ao menor custo, ainda que a produção seja pulverizada a nível mundial; ainda mais: o preço final ao consumidor supõe outras 
soluções logísticas. Com isto, a implantação dos centros de produção, são determinados e desinstalados pelas corporações ao sabor das menores taxas e impostos e demais vantagens oferecidas por municípios, estados e países.

Portanto, habitação, trabalho e consumo realmente agregam os quesitos satisfação no momento presente e a posteriori; (se e quando houver venda da moradia); neste caso, localização e acessibilidade eram naquela época e ainda são fatores de valorização para a aquisição de edificação urbana.

A $3^{\mathrm{a}}$. corrente teórica abordada por Topalov e lembrada por Reis $(1967,2016)$ e Ferreira $(1987)$ foi denominada por ele de "abordagem culturalista". Nela, os "valores sociais não só conferem ao espaço suas características, como também as explicam". Foi esboçada por Halbwachs no início do séc. $X X$, que propôs uma interpretação da produção do espaço urbano pelas relações sociais. Halbwachs pregava que "o valor do terreno é essencialmente um valor de opinião" (HALBWACHS, apud TOPALOV, 1984, p. 152, apud FERREIRA, 1987, p. 35).

Corroborando a hipótese culturalista de Halbwachs, uma atualização para o momento: no séc. $X X I$, para a geração $X$, habitação, trabalho e consumo ainda são fatores valorizados; para a geração $Y$, nem tanto. Devido a fatores da constituição da realidade histórica atual, os millenials preferem o não comprometimento de tanta renda pessoal na aquisição de terreno, construção e manutenção da unidade comprada; privilegiam a maior facilidade de mobilidade: o quesito subjetivo mais valorizado é a satisfação pessoal, predominantemente no consumo de entretenimento e viagens. A possibilidade de deslocamentos é mais valorizada sem o peso da propriedade urbana. Mesmo quando realizam a compra de unidades habitacionais, são unidades cada vez menores em metragem; e os mais jovens neste caso privilegiam a acessibilidade/localização, e o tipo de acabamento do empreendimento além dos itens do clube oferecido no "pacote" (salão de festas, quadra de esportes, piscina, etc - não são itens primordiais, pois geram manutenção contínua em termos de recursos financeiros), e preferem bares e restaurantes externos aos comunitários internos.

Naturalmente, isto varia de grau dependendo da classe social, idade e estado nupcial. O IBGE liberou um novo estudo sobre população e envelhecimento de agora (2018) para 2050, e espera-se cada vez mais menos casamentos, filhos, e o envelhecimento paulatino da população. As unidades habitacionais, que na década de 50 eram para mais de 5 pessoas, na de 80 eram para 3, em 2010 para 3,2 e projetadas para 2030 estão unidades habitacionais para 2,47 pessoas (IBGE, 2018) o que fatalmente acarretará em reconfiguração das plantas arquitetônicas de edificações do tipo habitacionais em termos de unidades oferecidas, e o uso do solo principalmente nas metrópoles, como já vem 
ocorrendo paulatinamente no oferecimento do número de quartos, conforme relatório do SECOVI (2015).

Tratando da ocupação urbana das áreas lindeiras de trechos da RRT, colocamos este enunciado de características do espaço urbano que moldam as condições de deslocamento, condição importante para utilização de uma rodovia metropolitana.

Segundo Nigriello (2013), o espaço urbano tem determinadas características que moldam as condições de deslocamento da população urbana. São descritas a seguir. Ele é: 1) Fragmentado: é um conjunto de áreas destinadas às diferentes funções urbanas: habitação, comércio, serviços, lazer, indústria, usos institucionais, distribuídas sobre um território seccionado por barreiras naturais e artificiais, que podem ser utilizadas como limites de espaços segregados; 2) Articulado: é um conjunto de redes de circulação e comunicação para realizar as relações espaciais de natureza econômica e social; 3) Reflexo Da Sociedade: é um espaço desigual e segregado. O processo de produção do espaço urbano promove concentração de renda e ampliação das condições de desigualdade e segregação. Neste caso, caberia ao Estado, com investimentos públicos em infra-estrutura e equipamentos urbanos, reduzir a desigualdade e a segregação. (Segregação: organização espacial em "áreas de forte homogeneidade social interna e de forte disparidade entre elas". (CASTELLS, 2000, apud NIGRIELLO, 2013); 4) Condicionante dos Processos de Produção: o espaço urbano oferece economias de aglomeração e de urbanização que ampliam a acumulação do capital proveniente da produção de mercadorias; 5) Condicionante do Processo de Reprodução: o espaço urbano apresenta áreas residenciais segregadas, usadas no processo de reprodução dos diferentes grupos sociais; 6) Simbólico: contém crenças, valores e mitos criados no bojo da sociedade, projetados em monumentos, lugares sagrados, ruas especiais... constituindo seu patrimônio histórico; 7) Mutável: é o acúmulo de formas espaciais de relações do passado com formas espaciais de relações do presente, e é também o produto das diferentes tecnologias empregadas na produção, transporte e comunicação, em cada período o processo de inércia na organização do espaço urbano se justapõe às necessidades, estabelecidas pela racionalidade econômica, de alterações na localização das atividades, ou seja, de reorganização espacial, e também 8) Campo de Lutas Sociais: é o cenário e palco das lutas dos diversos grupos sociais, pelo direito ao uso do espaço urbanizado, para participar do processo de produção e para garantir sua reprodução e crescimento.

Um dos fatores cruciais para que o espaço urbano seja campo de lutas sociais constantemente é a localização urbana, pois: "O Espaço é um atributo material de todos os valores de uso, (...) e o trabalho útil concreto produz valores de uso em determinados lugares" (HARVEY, 1982, p. 375 apud VILLAÇA, 2001, p. 22). Um determinado lugar quando relacionado a um objeto ou conjunto de objetos pode ter um atributo específico: é a localização urbana, quando existem relações deste determinado 
lugar e deslocamentos no espaço e no tempo (portanto prescinde de uma rede de infra-estrutura) de pessoas e cargas. A localização urbana depende, pois, das vias e possibilidades de deslocamentos e comunicações das pessoas; dependendo da necessidade destes deslocamentos - principalmente da moradia para o trabalho (reais e/ou virtuais, no caso das comunicações) terá uma importância como localização urbana ainda maior: dominará a estruturação do espaço-intra urbano:

\begin{abstract}
"A localização é a relação a outros objetos ou conjuntos de objetos e a localização urbana é um tipo específico de localização: aquela na qual as relações não podem existir sem um tipo particular de contato: aquele que envolve deslocamentos dos produtores e dos consumidores entre os locais de moradia e os de produção e consumo. (...)

A localização urbana é determinada por dois atributos: 1) Uma rede de infra-estrutura: vias, redes de água, esgotos, pavimentação de energia, etc; 2) Possibilidades de transporte de produtos de um ponto a outro, de deslocamentos de pessoas e de comunicação. Dentre estas possibilidades, a de deslocamento do ser humano (para os locais de trabalho, de compras, de serviços, de lazer, etc) dominará a estruturação do espaço intra-urbano (...) (VILLAÇA, 2001, p. 23).
\end{abstract}

\title{
Cidade Dual
}

Conceito desenvolvido por Castells (1995), tratado por Sassen (2000) e Hampf (2009), referese à manifestação cada vez mais contemporânea da polarização de uma estrutura urbana social e econômica.

No chamado Global South pós-colonial (VAINER, 2014; PARNELL, OLDFIELD, 2014), este modelo está acentuando-se com sociedades convivendo com dois tipos de populações, em que temos o primeiro e o terceiro mundo dentro de um mesmo Estado: a primeira, determinada por uma cultura de consumo e hedonismo; e a segunda, a cultura da sobrevivência, das necessidades básicas, resultando espacialmente em termos de urbanização, em grandes cidades, com crescimentos dispersos e fragmentados no território; e de tipologias como ilhas/arquipélagos "mono-funcionais" e de guetos residenciais, com divisões sociais, espaciais e temporais entre as populações.

\section{Atuação do Estado na produção do espaço urbano:}

"O Estado, no entanto, nas suas várias escalas e setores de atuação, é sempre o ator protagonista, mesmo que parcelas do grande capital tenham cada vez maior influência e autonomia." (PDDI de RMBH, 2014).

Nádia Somekh questionou se existe no Brasil, realmente leis reguladoras da produção do espaço urbano (FERREIRA, 1987, p. 31). Se existem tais leis que realmente regulem a produção de espaços urbanos brasileiros, como a regulação ou ação do Estado funciona? Que tipo de ocupação urbana pode ser constatada nas áreas lindeiras de uma rodovia metropolitana e que seja decorrente destas leis reguladoras? 
Segundo Topalov (2006), a ocupação (ou não) do lugar está diretamente condicionada à diferenciação dos espaços, à formação dos preços dos solos (regulares ou irregulares), configurando a divisão social do espaço; a forma da cidade ("La ciudad constituye uma forma de la socialización capitalista de las fuerzas productivas") seria decorrente de um sistema especializado de elementos, "resultado de los processos de circulação, de consumo; processos que cuentam com soportes físicos, es decir, objetos materiales incorporados al suelo." (TOPALOV, 2006, p. 9).

Mas historicamente, uma vez na cidade, os trabalhadores também colocaram outras reinvindicações além do pagamento de salários: um reconhecimento social direto de outras necessidades dissociadas:

"Esta exigência es el motor de la aparición de um sistema público de mantenión de la fuerza de trabajo. Este sistema comporta dos componentes. Por uma parte, hay transferência en forma monetária: assignaciones familiares, subsídios de enfermedad, etc Por outra parte, existe el suministro directo de valores de uso: escuelas y hospitales públicos, viviendas y transportes públicos, etc Estos equipamentos constituyen uma forma de satisfaccion socializada no mercantilizada, o, por menos, no capitalista, de necessidades no reconocidas en el salario." (TOPALOV, 2006, 40).

Lembrando que Lefebvre comenta sobre o espaço arquitetônico e urbanístico: concomitantemente dominado pela técnica, mas não apropriado (para e pelo uso); ele é imediato e mediato; ou seja, pertence à uma ordem próxima (vizinhança) e distante (sociedade, Estado); depende de interesses divergentes e de grupos diversos, que vão se encontrar em unidade no Estado.

Segundo Topalov como objeto imóvel urbano, a habitação comporta dois aspectos contraditórios: tem valor de uso e valor de comércio. Por um lado, engendra crises sucessivas na produção imobiliária, e transformações estruturais nela; por outro, contribuiu para as dificuldades do abastecimento da mão de obra nas empresas, e a fixar as condições de sua utilização/exploração.

E o Estado é um jogador com papel ativo nestas transformações estruturais: seria "la organización que se han dado las clases dominantes para defender sus privilégios sociales", (em Marx: Critica del Programa de Gotha); em outros termos: o aparato de direcionamento da sociedade pela classe dominante em seu conjunto. Deste ponto de vista, em determinadas condições, pode prejudicar inclusive certos interesses gerais da classe dominante, desde que os mantenham na essência (TOPALOV, 2006, p. 60).

Flávio Villaça menciona que a lei federal que mais influencia a organização do espaço brasileiro é a lei no. 6766/79, que regula o parcelamento do solo; e que no Brasil, o Estado atua sobre as cidades de várias maneiras: instalando redes de abastecimento de água potável, de saneamento; construindo avenidas, parques, conjuntos habitacionais, delimitado as zonas urbanas, loteamentos, 
edifícios privados e públicos; também realizando ou regulando a oferta de transporte público urbano (VILLAÇA, 1995, p. 171).

Nigriello (2013), prosseguindo a reflexão sobre as políticas do Estado brasileiro, em matéria de equipamentos coletivos urbanos, e concentrando-se especialmente no problema da habitação de interesse social: serão colocadas aqui algumas reflexões pois nos interessa a colocação ou não destes equipamentos do "papel" esperado pela sociedade atendida pelo Estado brasileiro (Tabelas 1, 2, 3, 4 e $5)$.

O Estado brasileiro existiria para a) assegurar a reprodução da força de trabalho; b) implantar a infra-estrutura e demais serviços públicos para viabilizar os custos de produção; c) regular os interesses envolvidos (na produção de mercadorias e serviços; na produção do espaço urbano e na apropriação das vantagens locacionais - impostos); d) assegurar a manutenção da ordem social e e) manter o seu próprio poder em relação à sociedade atendida.

A maioria da sociedade brasileira espera do Estado que: 1) os proprietários dos meios de produção aumentem os salários e a oferta de empregos; 2) com relação aos proprietários fundiários, 0 Estado reduza o estoque do solo nas áreas já urbanizadas com a) taxação dos "vazios urbanos"; b) faça o planejamento do uso e ocupação do solo do espaço urbano. Com relação aos 3) promotores imobiliários, o Estado espera que: construam e vendam unidades a preços reduzidos, destinados aos mercados de menor poder aquisitivo; e quanto aos 4) grupos sociais excluídos do consumo (médio) pela renda (baixa ou baixíssima): reduzam as ocupações irregulares em áreas de risco, fonte de "inconveniências" de custo a serem sanados com ajudas de custo aos municípios e estados, dependendo da localidade. (Tab.1)

A seguir, pode-se verificar os variados interesses e expectativas em relação à sua atuação na sociedade pelos grupos de atores sociais interessados na produção do espaço urbano (Tabelas 1, 2, 3, 4 e 5). 
Tabela 1 - Campo de lutas sociais na produção do espaço urbano: ações esperadas do Estado e demais atores sociais.

\begin{tabular}{|c|c|c|c|c|c|}
\hline $\begin{array}{l}\text { ATORES } \\
\text { SOCIAIS }\end{array}$ & ESTADO & $\begin{array}{l}\text { PROPRIETÁRIOS } \\
\text { DOS MEIOS DE } \\
\text { PRODUÇÄO }\end{array}$ & $\begin{array}{l}\text { PROPRIETÁRIOS } \\
\text { FUNDIÁRIOS }\end{array}$ & \begin{tabular}{|l|} 
PROMOTORES \\
IMOBILIÁRIOS
\end{tabular} & $\begin{array}{l}\text { GRUPOS } \\
\text { SOCIAIS } \\
\text { EXCLUIDOS }\end{array}$ \\
\hline ESTADO & $\begin{array}{l}\text { assegurar a reprodução da força } \\
\text { de trabalho } \\
\text { implantar infraestrutura e demais } \\
\text { serviços públicos para viabilizar } \\
\text { os custos de produção } \\
\text { regular os interesses envolvidos: } \\
\text { •na produção de mercadorias } \\
\text { e serviços } \\
\text { •na produção do espaço } \\
\text { urbano e na apropriação das } \\
\text { vantagens locacionais } \\
\text { assegurar a manutenção da ordem } \\
\text { social } \\
\text { manter o poder }\end{array}$ & $\begin{array}{l}\text { aumentar os } \\
\text { salários e a } \\
\text { oferta de } \\
\text { emprego }\end{array}$ & $\begin{array}{l}\text { reduzir o } \\
\text { estoque de solo } \\
\text { em área } \\
\text { urbanizada: } \\
\text {-taxação dos } \\
\text { "vazios } \\
\text { urbanos" } \\
\text {-planejamento } \\
\text { do uso do solo } \\
\text { e da expansão } \\
\text { do espaço } \\
\text { urbano }\end{array}$ & $\begin{array}{l}\text { construir } \\
\text { habitações a } \\
\text { custos } \\
\text { reduzidos, } \\
\text { destinadas } \\
\text { ao mercado } \\
\text { da população } \\
\text { de menor } \\
\text { renda }\end{array}$ & $\begin{array}{l}\text { reduzir } \\
\text { ocupações } \\
\text { irregulares e } \\
\text { em áreas de } \\
\text { risco }\end{array}$ \\
\hline
\end{tabular}

Fonte: Nigriello, 2013.

Tabela 2 - Campo de lutas sociais na produção do espaço urbano: ações esperadas dos Proprietários Fundiários e demais atores sociais.

\begin{tabular}{|c|c|c|c|c|c|}
\hline \begin{tabular}{|l|} 
ATORES \\
SOCIAIS
\end{tabular} & ESTADO & $\begin{array}{l}\text { PROPRIETÁRIOS } \\
\text { DOS MEIOS DE } \\
\text { PRODUÇÃO }\end{array}$ & $\begin{array}{l}\text { PROPRIETÁRIOS } \\
\text { FUNDIÁRIOS }\end{array}$ & \begin{tabular}{|l|} 
PROMOTORES \\
IMOBILIÁRIOS
\end{tabular} & \begin{tabular}{|l} 
GRUPOS \\
SOCIAIS \\
EXCLUIDOS
\end{tabular} \\
\hline $\begin{array}{l}\text { PROPRIETÁRIOS } \\
\text { FUNDIÁRIOS }\end{array}$ & $\begin{array}{l}\text { reduzir impostos sobre a } \\
\text { propriedade e comercialização } \\
\text { de terrenos e glebas (IPTU, } \\
\text { IPTU progressivo, ITBI, imposto } \\
\text { de renda sobre o lucro } \\
\text { imobiliário...) } \\
\text { dotar de infraestrutura e } \\
\text { demais serviços públicos as } \\
\text { áreas em que se localizam } \\
\text { terrenos e glebas estocadas } \\
\text { reduzir as restrições sobre os } \\
\text { tipos de uso do solo e } \\
\text { aumentar os coeficientes de } \\
\text { aproveitamento do solo } \\
\text { previstos em lei, nas áreas em } \\
\text { que se localizam terrenos e } \\
\text { glebas estocadas } \\
\text { afastar /realocar população de } \\
\text { baixa renda com moradias } \\
\text { próximas a imóveis de sua } \\
\text { propriedade }\end{array}$ & $\begin{array}{l}\text { aumentar os } \\
\text { salários } \\
\end{array}$ & $\begin{array}{l}\text { maximizar a } \\
\text { renda decorrente } \\
\text { da } \\
\text { comercialização } \\
\text { de imóveis } \\
\text { estocar imóveis } \\
\text { aguardando sua } \\
\text { valorização por } \\
\text { escassez de } \\
\text { oferta ou } \\
\text { implantação de } \\
\text { melhorias } \\
\text { urbanas }\end{array}$ & $\begin{array}{l}\text { aumentar o \% do } \\
\text { capital } \\
\text { imobiliário } \\
\text { destinado à } \\
\text { compra do solo } \\
\text { para uso da } \\
\text { industria da } \\
\text { construção civil }\end{array}$ & $\begin{array}{l}\text { evitar invasão } \\
\text { de } \\
\text { propriedades } \\
\text { privadas } \\
\text { reintegrar a } \\
\text { posse de } \\
\text { propriedades } \\
\text { privadas } \\
\text { invadidas }\end{array}$ \\
\hline
\end{tabular}

Fonte: Nigriello, 2013. 
Tabela 3 - Campo de lutas sociais na produção do espaço urbano: ações esperadas dos Proprietários dos meios de produção e demais atores sociais.

\begin{tabular}{|c|c|c|c|c|c|}
\hline $\begin{array}{l}\text { ATORES } \\
\text { SOCIAIS }\end{array}$ & ESTADO & $\begin{array}{l}\text { PROPRIETÁRIOS DOS MEIOS } \\
\text { DE PRODUÇÃO }\end{array}$ & $\begin{array}{l}\text { PROPRIETÁ } \\
\text { RIOS } \\
\text { FUNDIÁRIOS }\end{array}$ & $\begin{array}{l}\text { PROMOTORES } \\
\text { IMOBILIÁRIOS }\end{array}$ & \begin{tabular}{|l} 
GRUPOS \\
SOCIAIS \\
EXCLUIDOS
\end{tabular} \\
\hline $\begin{array}{l}\text { PROPRIETÁRIOS } \\
\text { DOS MEIOS DE } \\
\text { PRODUÇÃO }\end{array}$ & $\begin{array}{l}\text { reduzir impostos } \\
\text { sobre a produção } \\
\text { de mercadorias } \\
\text { reduzir as taxas de } \\
\text { juros das } \\
\text { operações de } \\
\text { capital de giro } \\
\text { implantar a } \\
\text { infraestrutura e } \\
\text { demais serviços } \\
\text { públicos que } \\
\text { promovam } \\
\text { menores custos de } \\
\text { produção } \\
\text { subsidiar moradias } \\
\text { e transporte para a } \\
\text { mão de obra }\end{array}$ & $\begin{array}{l}\text { garantir o ritmo de } \\
\text { produção e } \\
\text { comercialização das } \\
\text { mercadorias } \\
\text { maximizar a taxa de } \\
\text { retorno do capital } \\
\text { aplicado na produção de } \\
\text { mercadorias } \\
\text { buscar vantagens fiscais } \\
\text { e de redução dos custos } \\
\text { de produção associadas à } \\
\text { localização das empresas } \\
\text { (acessibilidade ao } \\
\text { mercado, mão de obra, } \\
\text { matéria prima, } \\
\text { equipamentos, serviços e } \\
\text { equipamentos urbanos) }\end{array}$ & $\begin{array}{l}\text { reduzir os } \\
\text { custos de } \\
\text { moradia }\end{array}$ & $\begin{array}{l}\text { reduzir os } \\
\text { custos de } \\
\text { moradia }\end{array}$ & \\
\hline
\end{tabular}

Fonte: Nigriello, 2013.

Tabela 4 - Campo de lutas sociais na produção do espaço urbano: ações esperadas dos Promotores imobiliários e demais atores sociais.

\begin{tabular}{|c|c|c|c|c|c|}
\hline \begin{tabular}{|l} 
ATORES \\
SOCIAIS
\end{tabular} & ESTADO & $\begin{array}{l}\text { PROPRIETÁRIOS } \\
\text { DOS MEIOS DE } \\
\text { PRODUÇÃO }\end{array}$ & $\begin{array}{l}\text { PROPRIETÁRIOS } \\
\text { FUNDIÁRIOS }\end{array}$ & \begin{tabular}{|l} 
PROMOTORES \\
IMOBILIÁRIOS
\end{tabular} & \begin{tabular}{|l|} 
GRUPOS \\
SOCIAIS \\
EXCLUIDOS
\end{tabular} \\
\hline \begin{tabular}{|} 
PROMOTORES \\
IMOBILIÁRIOS
\end{tabular} & $\begin{array}{l}\text { aumentar a área } \\
\text { urbanizada dotada de } \\
\text { infraestrutura e demais } \\
\text { serviços públicos } \\
\text { reduzir impostos sobre a } \\
\text { produção e a venda de } \\
\text { imóveis } \\
\text { reduzir as restrições sobre } \\
\text { os tipos de uso do solo e } \\
\text { aumentar os coeficientes } \\
\text { de aproveitamento do solo } \\
\text { previstos em lei } \\
\text { criar linhas de } \\
\text { financiamento para } \\
\text { produção e } \\
\text { comercialização de } \\
\text { edificações }\end{array}$ & $\begin{array}{l}\text { aumentar os } \\
\text { salários }\end{array}$ & $\begin{array}{l}\text { colocar à } \\
\text { venda } \\
\text { terrenos e } \\
\text { glebas } \\
\text { estocadas }\end{array}$ & $\begin{array}{l}\text { produzir } \\
\text { edificações para } \\
\text { a demanda } \\
\text { solvável } \\
\text { maximizar a taxa } \\
\text { de lucro do } \\
\text { capital aplicado } \\
\text { na produção e } \\
\text { comercialização } \\
\text { de edificações } \\
\text { garantir o ritmo } \\
\text { de produção e } \\
\text { comercialização } \\
\text { de edificações }\end{array}$ & \begin{tabular}{|l} 
distanciar \\
empreendi \\
mentos \\
imobiliário \\
s de \\
ocupações \\
irregulares
\end{tabular} \\
\hline
\end{tabular}

Fonte: Nigriello, 2013. 
Tabela 5 - Campo de lutas sociais na produção do espaço urbano: ações esperadas dos grupos sociais excluídos e demais atores sociais.

\begin{tabular}{|c|c|c|c|c|c|}
\hline $\begin{array}{l}\text { ATORES } \\
\text { SOCIAIS }\end{array}$ & ESTADO & $\begin{array}{l}\text { PROPRIETÁRIOS } \\
\text { DOS MEIOS DE } \\
\text { PRODUÇÃO }\end{array}$ & $\begin{array}{l}\text { PROPRIETÁRIOS } \\
\text { FUNDIÁRIOS }\end{array}$ & \begin{tabular}{|l} 
PROMOTORES \\
IMOBILIÁRIOS
\end{tabular} & $\begin{array}{l}\text { GRUPOS SOCIAIS } \\
\text { EXCLUIDOS }\end{array}$ \\
\hline $\begin{array}{l}\text { GRUPOS } \\
\text { SOCIAIS } \\
\text { EXCLUIDOS }\end{array}$ & $\begin{array}{l}\text { promover programas } \\
\text { habitacionais e de } \\
\text { implantação de } \\
\text { serviços públicos } \\
\text { para atender grupos } \\
\text { sociais excluidos } \\
\text { realocar população } \\
\text { que ocupa áreas de } \\
\text { risco } \\
\text { legalizar ocupações } \\
\text { de áreas invadidas } \\
\text { para a moradia dos } \\
\text { grupos sociais } \\
\text { excluidos, quando } \\
\text { localizadas em } \\
\text { áreas urbanas livres } \\
\text { de risco }\end{array}$ & & & & $\begin{array}{l}\text { consolidar as invasões } \\
\text { do solo realizadas para } \\
\text { localização da moradia } \\
\text { dos grupos sociais } \\
\text { excluidos } \\
\text { ter direito a moradias } \\
\text { localizadas em áreas } \\
\text { urbanas livres de risco, } \\
\text { dotadas de transporte } \\
\text { e outros serviços } \\
\text { públicos, próximas a } \\
\text { empregos }\end{array}$ \\
\hline
\end{tabular}

Fonte: Nigriello, 2013.

Herança do Brasil colonial e escravocrata, e das políticas públicas de educação básica desde então, os grupos sociais excluídos têm expectativas com relação à ocupação do espaço urbano advindas do Estado. No Brasil, devido à baixa renda observada pela maioria do contingente da população brasileira, a responsabilidade do Estado na promoção de programas habitacionais de interesse social é fundamental para a diminuição de discrepâncias sociais que inclusive são tragédias anunciadas pelo tipo de área normalmente ocupada: áreas de risco, de deslizamentos e alagamentos, normalmente áreas públicas de preservação ambiental (Tabela 5). Com relação à expectativa da sociedade da atuação do Estado, Nigriello (2013) resume que:

"Cabe ao Estado, como agente regulador do processo de desenvolvimento, a criação de linhas de financiamento e implantação de implantação de redes de infraestrutura e equipamentos urbanos, que: 1) promovam a produção de moradias a menores custos, de modo a viabilizar a taxa de lucro do capital privado aplicado na produção e comercialização de edificações, principalmente as destinadas à população de menor renda; 2) garantam economias de localização que possibilitem melhores níveis salariais, sem reduzir a taxa de lucro do capital privado aplicado na produção de mercadorias; 3) viabilizem taxas adequadas de ocupação do solo, que permitam o aumento da oferta de terrenos para a indústria da construção civil e a redução dos custos de moradia (principalmente as destinadas à população menos favorecida em termos econômicos), sem prejuízo da renda do solo; e 4) desestimulem a ocupação irregular do solo, com a ampliação da oferta de áreas urbanas providas de serviços públicos e acessíveis à áreas de emprego." (NIGRIELLO, 2013).

\section{Papel do Estado no processo de produção de habitação de interesse social}

A maioria dos conjuntos habitacionais de interesse social produzidos pelo Estado no País estão (salvaguardadas raras exceções), nas periferias das cidades em que elas foram implantadas. 
Lembrando que Harvey (1980), Gottdiener (1987), Smolka (1992) e Castells (2000) consideram os padrões espaciais urbanos como resultado de sua estrutura social. No caso brasileiro, Villaça (2001) parte da hipótese da "segregação como um processo fundamental para a compreensão da estrutura espacial urbana, segundo o qual diferentes classes sociais tendem a se concentrar cada vez mais em diferentes regiões ou conjuntos de bairros das cidades", sendo o mais conhecido padrão de segregação da metrópole brasileira a do centro x periferia: o primeiro dotado dos serviços urbanos, públicos e privados, ocupado pelas classes de renda mais alta; a segunda: longínqua e sub-equipada, predominantemente ocupada pelos excluídos, sendo o espaço entre eles um mecanismo de exclusão (VILLAÇA, 2001, p. 142 e 143).

Lojkine (1981, p. 167, apud VILLAÇA, 2001, p. 147), discorrendo sobre o preço do solo, distingue três tipos de segregação urbana: $1^{\mathrm{a}}$ ) oposição entre centro (com preços do solo mais altos) versus periferia; $2^{\mathrm{a}}$ ) distâncias espaciais crescentes entre as zonas de moradias de camadas mais ricas das mais pobres; e $3^{a}$ ) esfacelamento e reorganização concentrada das funções urbanas entre regiões geograficamente distintas para uma redistribuição, não excludente de locais para escritórios, para indústrias, para residências, etc.

"Despite the presence of a private real estate market, housing can also be supplied by governamental sponsored programs at all levels of society from the local to the national. Using public funds, these can support the construction and or subsidy of rental housing, based on economic need or addiction, subsidized housing can be constructed and run not only by government but also by unions, coops and housing associations. But government sponsored public housing is never for profit." (GOTTDIENER, BUDD, 2005, p. 59).

Embora atualmente os escritórios possam ser virtuais (atualmente modelo preferido pelo capital e funcionários; pelo acesso instantâneo à rede de internet mundial, por questões de custos do escritório físico e do tempo de deslocamento dos funcionários, dentre outros fatores); no caso brasileiro a questão de zoneamento industrial e residencial permanece, inclusive permeada das questões de classes sociais pela renda, e não pelo preço do solo, pois como lembrou Villaça em 2001: às vezes a elite brasileira mora em terras antes de baixo custo: Alphaville ou Granja Vianna em São Paulo; Recreio dos Bandeirantes, no Rio de Janeiro.

Aliás, esta formula vem sendo utilizada desde então para disseminação do padrão Alphaville no interior brasileiro: terras baratas nas periferias das cidades, mas com cursos de água e áreas verdes, foram urbanizadas pelo padrão do empreendimento, inclusive gerando mais "estoques" preparados para um dia serem ocupados pelas classes mais abastadas desses lugares; na prática tornando mais distante ainda a localização dos conjuntos residenciais de interesse social, pelo preço influenciado da terra urbanizada, cada vez mais acessível por veículos automotivos e menos por 
transportes públicos de tarifas acessíveis, e na maioria das vezes subsidiados pelo Estado. Assim, a profa. Marly Namur (2004) discorre:

"As ações do capital imobiliário especulativo, no processo de produção do espaço urbano, acarretam desequilíbrios intra-urbanos: excessiva verticalização nas áreas centrais (saturadas e congestionadas, (exigindo do Estado a substituição da infra-estrutura por outra com maior capacidade de suporte); e excessiva horizontalização das periferias urbanas, com altos custos de urbanização e ocupação rarefeita, intercaladas de vazios urbanos, ociosamente estocados, na expectativa da valorização imobiliária. (...) a população de baixa renda é excluída das áreas bem atendidas pela infra-estrutura e equipamentos públicos, alojando-se nas periferias, em geral em áreas de risco e insalubres" (...)

"qualquer análise superficial das cidades brasileiras revela relação direta entre moradia pobre e degradação ambiental" e "grande parte das áreas urbanas de proteção ambiental estão ameaçadas pela ocupação com uso habitacional pobre, por absoluta falta de alternativas". (MARICATO, 1996, p. 65-66 apud NAMUR, 2004, p. 58).

Namur (2004) ainda discute o papel do Estado como empreendedor de conjuntos de HIS e desta forma produtor de espaço urbano, e a escolha da localização deste tipo de empreendimento: "a localização de empreendimentos habitacionais é um indutor de desenvolvimento urbano e tem implicações diretas na qualidade de vida urbana do usuário, pelas distâncias que estabelece em relação aos serviços e comércios urbanos" e deveria caracterizar-se como política de desenvolvimento urbano (NAMUR, 2004, p.55):

"Sob esta ótica, a escolha da localização de conjuntos HIS, necessariamente, deve ser embasada em uma análise histórica do desenvolvimento urbano na cidade onde se pretende implantá-los, uma vez que eles poderão acarretar um considerável adensamento populacional, bem como uma excessiva horizontalização das periferias urbanas, desprovidas dos equipamentos e serviços públicos básicos, com reflexos diretos sobre o meio ambiente." (...)

"Essa política deveria adotar como critério básico a ocupação dos vazios urbanos existentes dentro das áreas já urbanizadas, ou das áreas contíguas às mesmas, com acessibilidade em relação aos centros nos quais existe oferta de emprego, comércio e serviços, próximos aos equipamentos sociais existentes, tais como escolas, creches e postos de saúde, e com infraestrutura urbana, incluindo redes de água esgoto e enegia elétrica. Isto possibilitaria a consolidação dos bairros existentes em seu entorno imediato, a mistura de atividades em um mesmo setor da cidade, evitando a geração de áreas dormitórios, com baixa qualidade de vida e a retenção de terrenos para fins especulativos, favorecendo, dessa forma, um desenvolvimento urbano mais equilibrado." (NAMUR, 2004, p. 60).

Conjuntos HIS também necessitam de infra-estrutura viária e transporte coletivo acessível, dentre os outros já mencionados; portanto a escolha de áreas em locais já urbanizados ou muito próximos é de fundamental importância para redução destes custos, melhoria da qualidade de vida e inclusão social de seus moradores; assim, a ação do Estado como empreendedor de conjuntos de HIS pode, na localização dos empreendimentos gerar ou não grandes ganhos especulativos para os proprietários de terras, em detrimento da qualidade de vida de toda a população urbana, pois os custos são socializados. 
Gottdiener e Budd (2005) mencionam que acessibilidade para uma habitação adequada é um item crítico para o pobre urbano; nos países em desenvolvimento Habitação também é justamente um ítem crítico por que não é muitas unidades disponíveis; inclusive cita que o Brasil em 1991 tinha 36 milhões de habitações, mas havia uma falta de 6 milhões de unidades (GOTTDIENER; BUDD, 2005, p. 57 e 58).

No Brasil, a aprovação da nova constituição federal brasileira (CF/1998), influenciou a aprovação do Estatuto da Cidade (2001), a criação do Ministério das Cidades (2003), o Conselho das Cidades (2004) e as Conferências das cidades (atualmente (2018) congelada até 2019 por decreto presidencial); e em 2009, a criação do programa federal Minha Casa Minha Vida (MCMV) proporcionou produção pelo mercado imobiliário formal, mas a demanda habitacional brasileira, formada em parte por domicílios inadequados, mais o crescimento demográfico, era - segundo estudo da Caixa Econômica Federal (2011) - de aproximadamente 7,71 milhões de unidades, concentrada na faixa de 3 a 10 salários mínimos $(\mathrm{SM})^{3}$ (54\% do total), e de cerca de 5,430 milhões de moradias (FJP, 2014) concentrava-se nas faixas de renda situadas abaixo de 3 SM (73,6\%) (FURTADO; LIMA NETO; KRAUSE, 2013), conforme informações do Relatório Brasileiro para a Habitat III de 2016 (IPEA, 2016).

Conclui-se que o problema do HIS no Brasil, uma geração depois do observado em 1991 por Gottdiener, correlacionado à renda per capita, (embora tenha tido uma década (2004-2014) de desenvolvimento econômico positivo), ainda tem muito para ser resolvido.

Gottdiener e Budd (2005) lembram que o problema da Habitação com subsídio público não é apenas de quantidade, mas de qualidade:

\begin{abstract}
"A more serious problem is the quality of existing and new units such as substandard housing and overcrowding. In the developing countries, a very high proportion of housing is substandard, being built on illegally occupied land with temporary materials, no authorization and no real access to basic infrastructure and services. About a quarter of urban housing stock has temporary structures, more than a third have been constructed without compliance with local regulations, and $13 \%$ of urban dwellers are cramped in areas without access to safe water, and $25 \%$ without access to adequate sanitation. (UNCHS, 1999 apud GOTTDIENER, BUDD, 2005).
\end{abstract}

"E são frequentemente construídos sem os equipamentos necessários, apenas com reserva de área para sua implementação, e sua população tem que buscar atendimento em outros bairros, as vezes distantes (...)" (NAMUR, 2004, p. 60).

Infelizmente, mesmo após o advento do Estatuto da Cidade (2001) com possibilidades de aplicação de instrumentos notáveis de urbanismo (Direito de preempção, outorga onerosa, etc) o fator localização de HIS é relevado em muitos dos planos diretores municipais aprovados; e ainda se sabe

\footnotetext{
${ }^{3}$ O salário mínimo, conforme o Decreto no 8.381, de 29 de dezembro de 2014, para 2015 correspondia a R\$788,00. Atualmente, o salário mínimo é de R\$954,00 (2018).
} 
de muitos empreendimentos ${ }^{4}$ de HIS sendo colocados na periferia de grandes cidades. Há alguns exemplos de HIS de boa qualidade, como os executados após a $2^{\mathrm{a}}$ guerra mundial nos países que tiveram suas cidades e grande parte da população necessitando de novas habitações (França, Alemanha; em São Paulo, dentre outros, têm-se o Conjunto Habitacional do Real Parque ${ }^{5}$ (projeto de 2010 a 2012; construção, de 2010 a 2015), na área nobre do Morumbi, na zona sul da capital paulista. O projeto foi desenvolvido de forma conjunta pelo poder público, comunidade e escritório contratado, mantendo as famílias no mesmo local da moradia anterior e com boa qualidade de projeto e execução; e deve-se mencionar que em uma das áreas mais caras da metrópole. Há possibilidade de se desenvolver e executar bons projetos habitacionais de interesse social com direito à cidade, e também ao usufruto da Natureza; para que nossas populações de baixa renda, ainda uma herança do colonialismo, tenham o Direito à vida urbana como proposto pelo marxista Henri Lefèbvre (2001, p, 114, 117 e 118). O que, aliás, conforme o ex-Ministro das Cidades Gilberto Kassab, em 2016 reiterou como "eixo norteador das discussões" (IPEA, 2016, p.10) do relatório oficial brasileiro para o Habitat III, e foi também o mote do ex-Ministro de Estado e das Relações Exteriores:

"Na preparação para a Habitat III, o governo brasileiro tem reafirmado a importância do debate sobre os direitos na cidade - do qual surge, contemporaneamente, a instigante e visionária defesa de um direito à cidade - como eixo norteador das discussões. É em torno desse eixo que se devem articular questões como desenho urbano, finanças e governança, $e$ não o contrário." (IPEA, p. 12, 2016).

Mas há também que se explicitar que "a responsabilidade de exercer a cidadania é também dos profissionais do planejamento urbano, que devem reclamar autonomia intelectual frente aos políticos, elaborar e defender suas propostas, assumir riscos as autoridades e opinião pública, e saber renunciar publicamente, antes de trair suas convicções." (BORJA, 1998 apud NAMUR, 2004, p. 65).

Maricato (2013) lembra que em São Paulo e no Rio de Janeiro, respectivamente o preço dos imóveis aumentou 153\% e 194\%, entre 2009 e 2012.6 "O entendimento comum entre urbanistas é que a gestão da terra urbana continua sendo objeto de pressão do capital imobiliário, verificando-se, em vários casos, a flexibilização ou modificação de leis em seu benefício." (IPEA, 2016).

\footnotetext{
${ }^{4} \mathrm{Na}$ RMS, os maiores exemplos são: (Ex.: 1) Habiteto, na zona norte da cidade de Sorocaba, criado em 1998; onde foram colocadas 10.000 pessoas; e (Ex.: 2) Carandá, idem, inaugurado em 2017, outras 2.560 famílias. No primeiro caso, foram tirados de barracos de áreas verdes para barracos a $16 \mathrm{~km}$ do centro da cidade, tiveram que esperar um ano para mudarem para casas, e mais anos com reinvindicações para terem infra-estrutura urbana; no segundo caso, as famílias foram sorteadas do cadastro de 35 mil famílias para 2560 unidades de apartamentos; também com infra-estrutura faltante ou de má qualidade, inclusive no abastecimento de água, sem creche, escolas, etc A população também reclama que de ônibus, leva-se mais de uma hora para chegar ao centro de Sorocaba (para depois serem redirecionados à outras regiões do município).

5 Este HIS contempla 1.252 unidades habitacionais distribuídas em 11 condomínios; edifício institucional de 2550m2, e creche de $800 \mathrm{~m} 2$.

${ }^{6}$ Para simples comparação, conforme o Banco Central (2014) a valorização imobiliária do período entre 2009 e 2013 foi de 113\% (valorização baseada no Índice de Valores de Garantia de Imóveis Residenciais Financiados - IVG-R).
} 
CAP. II - CARACTERÍSTICAS DA RRT

NA RMS, SP 


\section{CAP. II - CARACTERÍSTICAS DA RRT NA RMS, SP}

Para se configurar as características da RRT na RMS, colocaremos nesta seção alguns dados básicos sobre a RMS: seu território, população, dinâmica sócio-econômica e a mobilidade urbana desde meados do séc. XX, até os planos pertinentes para o futuro.

\subsection{Dados territoriais, populacionais e sócios econômicos da RMS, SP}

A RMS pertence à Mega-Região São Paulo-Rio de Janeiro (LENCIONI, 2014, p.1), estando localizada no extremo oeste da MMP (EMPLASA, 2015), e situa-se à oeste da RMSP, à sudeste da AU Jundiaí e RMC, e ao sul da AU de Piracicaba. Pela RCB, RRT e o Rodo Anel Mário Covas, liga-se também à RM de Santos e à RMVP, e por esta também à RMRJ:

"São Paulo - Rio de Janeiro constituem uma mega-região. Essa mega-região compreende a cidade-região de São Paulo, com 167 municípios, cujo núcleo, a metrópole de São Paulo, se constitui como uma cidade global de segundo nível. Essa cidade-região, também conhecida como Macrometrópole Paulista, contém outras formações espaciais. A primeira a mencionar diz respeito às regiões metropolitanas, que são em número de cinco: a região metropolitana de São Paulo (metrópole: São Paulo) a de Campinas (metrópole: Campinas), a de Sorocaba (metrópole: Sorocaba), a do Vale do Paraíba e Litoral Norte (metrópole: São José dos Campos), e a da Baixada Santista (metrópole: Santos) (...)" (LENCIONI, 2014, p.1).

A proposição de criação da região metropolitana de Sorocaba foi antes estudada pelo grupo de trabalho de metropolização de várias entidades acadêmicas e políticas da região de Sorocaba no início do séc. XXI, e em 2005 foi levada à ALESP pelo então deputado Hamilton Pereira (PT/SP). Após quase uma década da idealização à aprovação, em 8 de maio de 2014 a RMS foi instituída pela Lei Complementar Estadual $n^{0}$ 1.241. Dois anos depois, pela Lei Complementar $n^{0} 1.289$, de 29 de junho de 2016, o Município de Itapetininga foi anexado à RMS (Fig. 1). 
Figura 1 - Região Metropolitana de Sorocaba (em destaque) e a Macrometrópole de São Paulo.

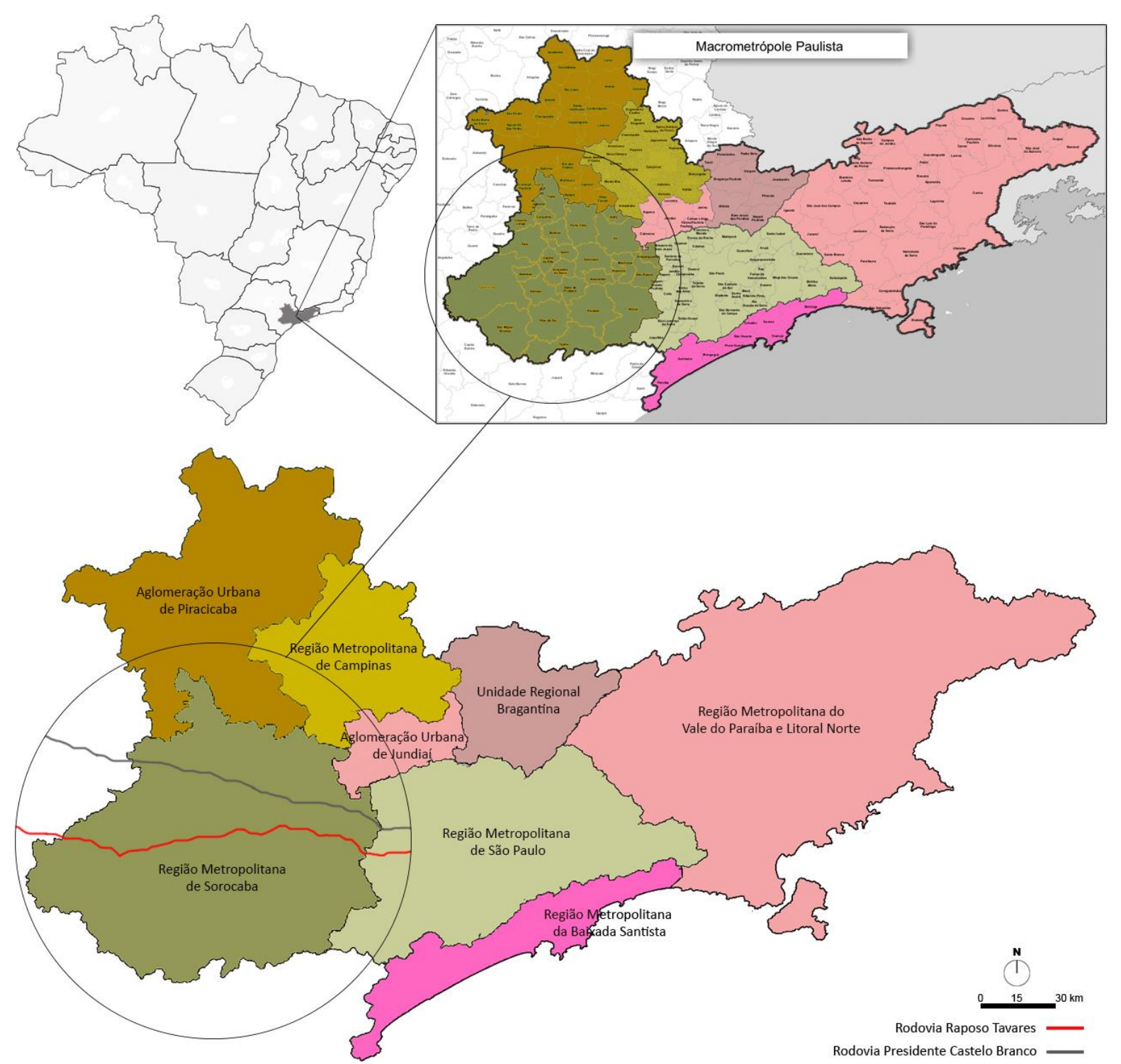

Fonte: EMPLASA, 2017. Retrabalhado por Amanda Dias, 2018.

Integrada atualmente por 27 municípios, com área de 9.821,32km2, a RMS corresponde a 19,18\% do território da Macrometrópole Paulista; 3,69\% do Estado de São Paulo e a 0,12\% da superfície nacional. Está subdividida em três regiões, constituída pelos municípios de: a) Sub-região 1: Alambari, Boituva, Capela do Alto, Cerquilho, Cesário Lange, Jumirim, Sarapuí, Tatuí e Tietê; b) Subregião 2: Alumínio, Araçariguama, Ibiúna, Itu, Mairinque, Porto Feliz, Salto e São Roque; e c) Subregião 3: Araçoiaba da Serra, Iperó, Itapetininga, Piedade, Pilar do Sul, Salto de Pirapora, São Miguel Arcanjo, Sorocaba, Tapiraí e Votorantim (EMPLASA, 2018) (Fig. 2). 
Figura 2 - Região Metropolitana de Sorocaba, com as divisões sub-regionais.

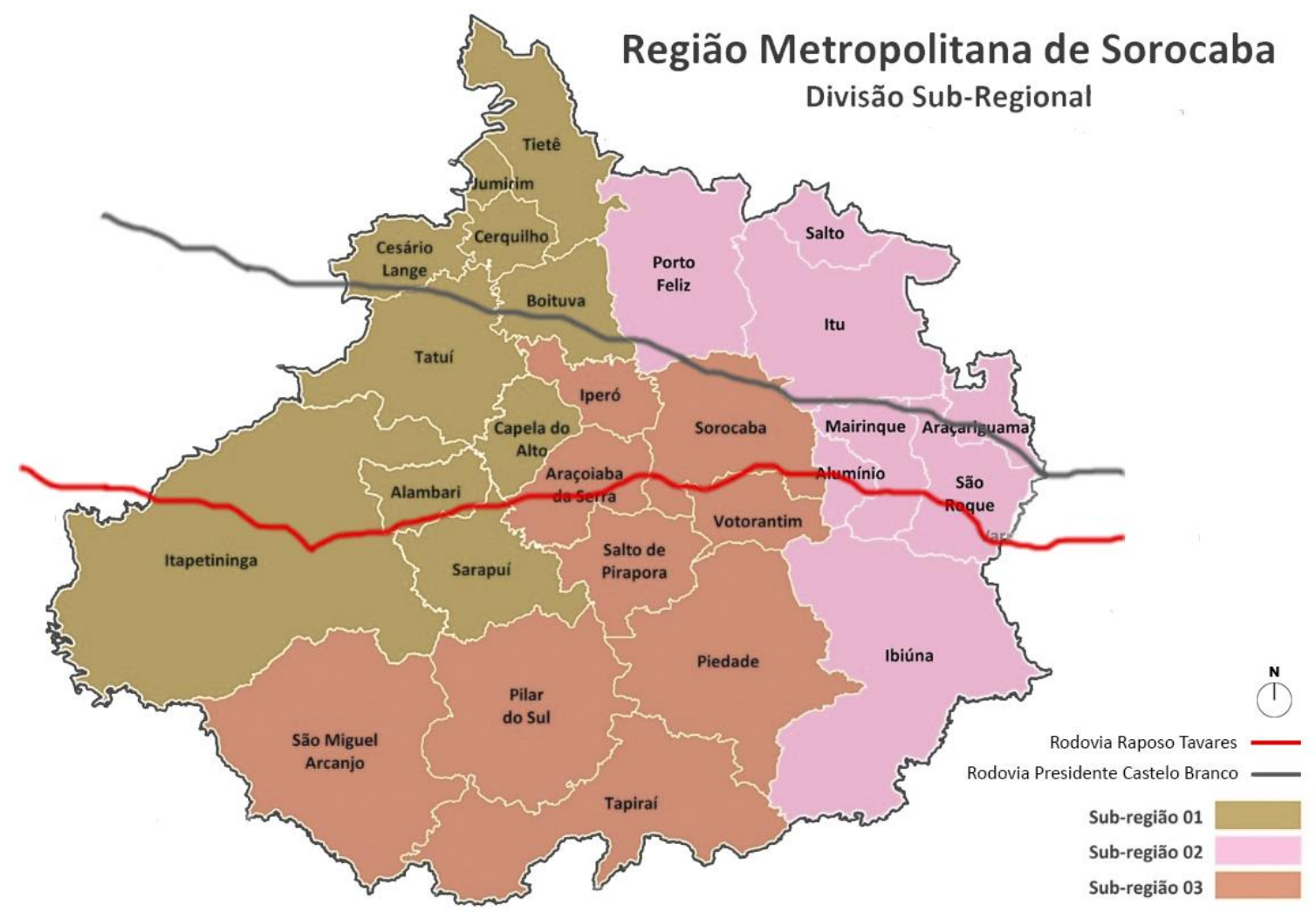

Fonte: EMPLASA, 2018. Retrabalhado por Amanda Dias, 2018.

\section{Base fisiográfica da Região Metropolitana de Sorocaba, SP}

O levantamento de informações referentes à paisagem, ao clima, ao solo, entre outros similares descreve a base fisiográfica de uma região. No caso da RMS, ela está localizada a cerca de 100 km da capital, na parte sudeste do Estado de São Paulo.

Seguindo a topografia típica do Estado, em que há a elevação abrupta próxima ao litoral, no sentido do interior as cotas de nível caem: em Piedade a altitude é de $760 \mathrm{~m}$, em Sorocaba a $600 \mathrm{~m}$, em Porto Feliz a 525m, chegando a 508m em Tietê, (corte esquemático sem escala na figura 4 configurando na RM de Sorocaba (SP) as Serras de: Paranapiacaba, da Queimada, de São Francisco, e do Morro do Ipanema em Iperó (SP) (Fig. 3 e 4). 
Figura 3 - Representação da localização dos pontos mais altos da Região Metropolitana de Sorocaba.
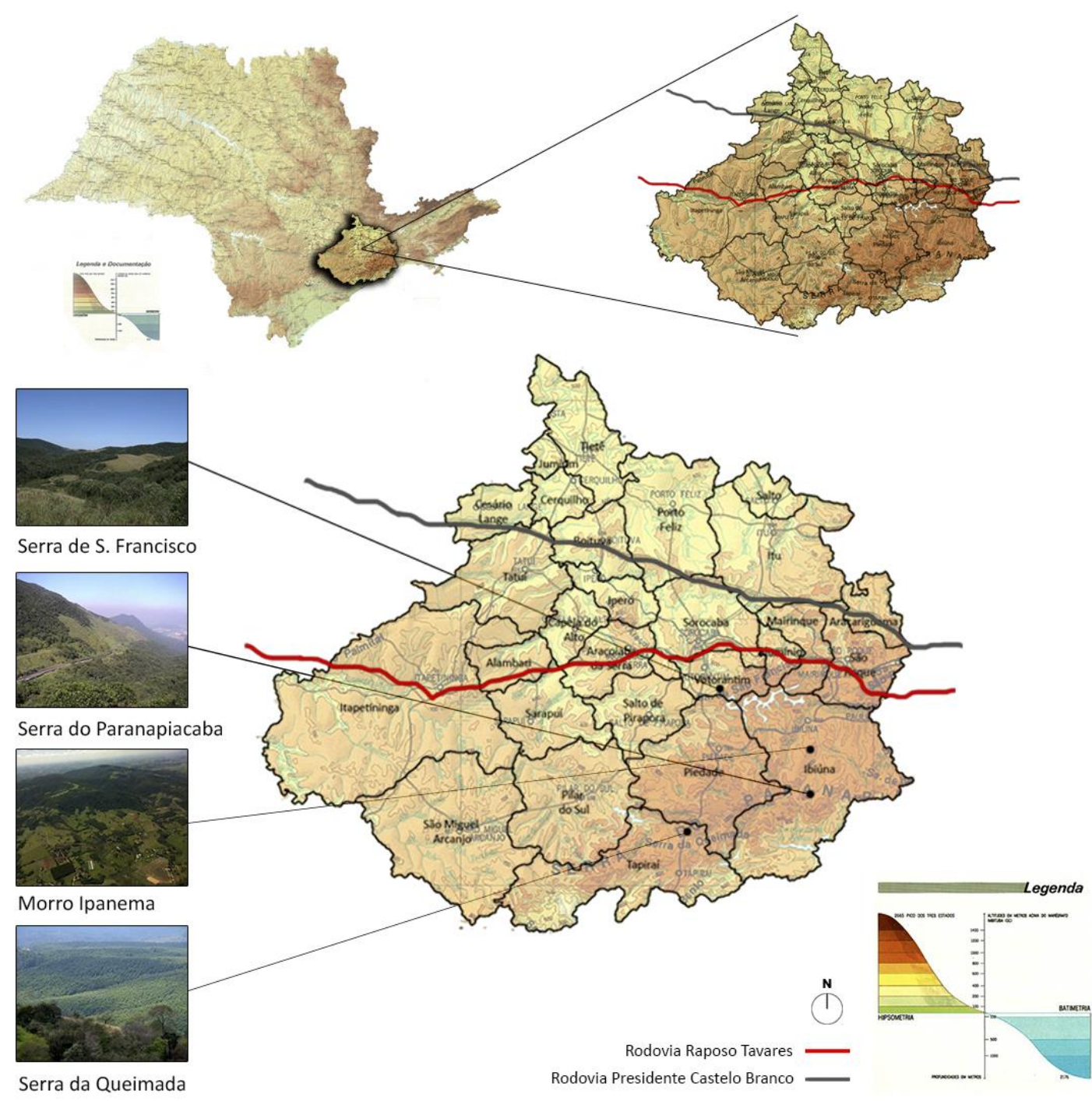

Fonte: IGC, Mapa Hipsométrico, 1982. Fotos: Imagens Google. Retrabalhado por Amanda Dias, 2018.

Figura 4 - Corte ilustrativo da Região Metropolitana de Sorocaba, sem escala.

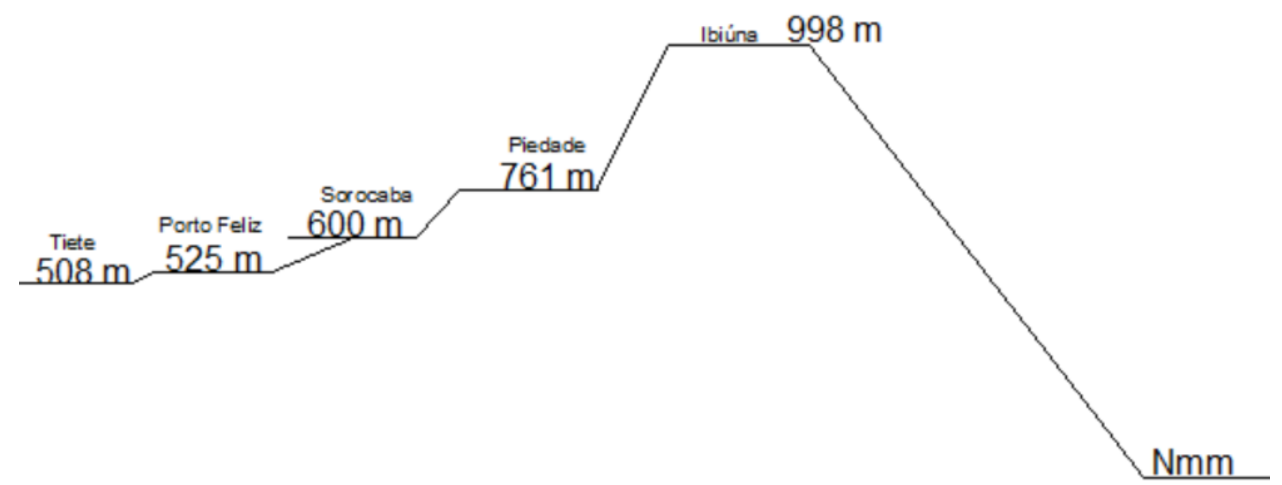

Fonte: IGC, Mapa Hipsométrico, 1982. 


\section{Recursos hídricos da RMS}

A reservação de águas para abastecimento da população residente na RM de Sorocaba é feita principalmente pelo represamento de corpos hídricos, em represas construídas ao longo do século XX, a saber: a Represa de Itupararanga, que abastece a cidade pólo (Sorocaba), a Represa da Barra, a Represa Pedro Beicht, a Represa de Jurupará e a Represa das Paineras (Fig. 5).

Figura 5 - Ilustração da localização das principais represas da RM Sorocaba. (s/E).

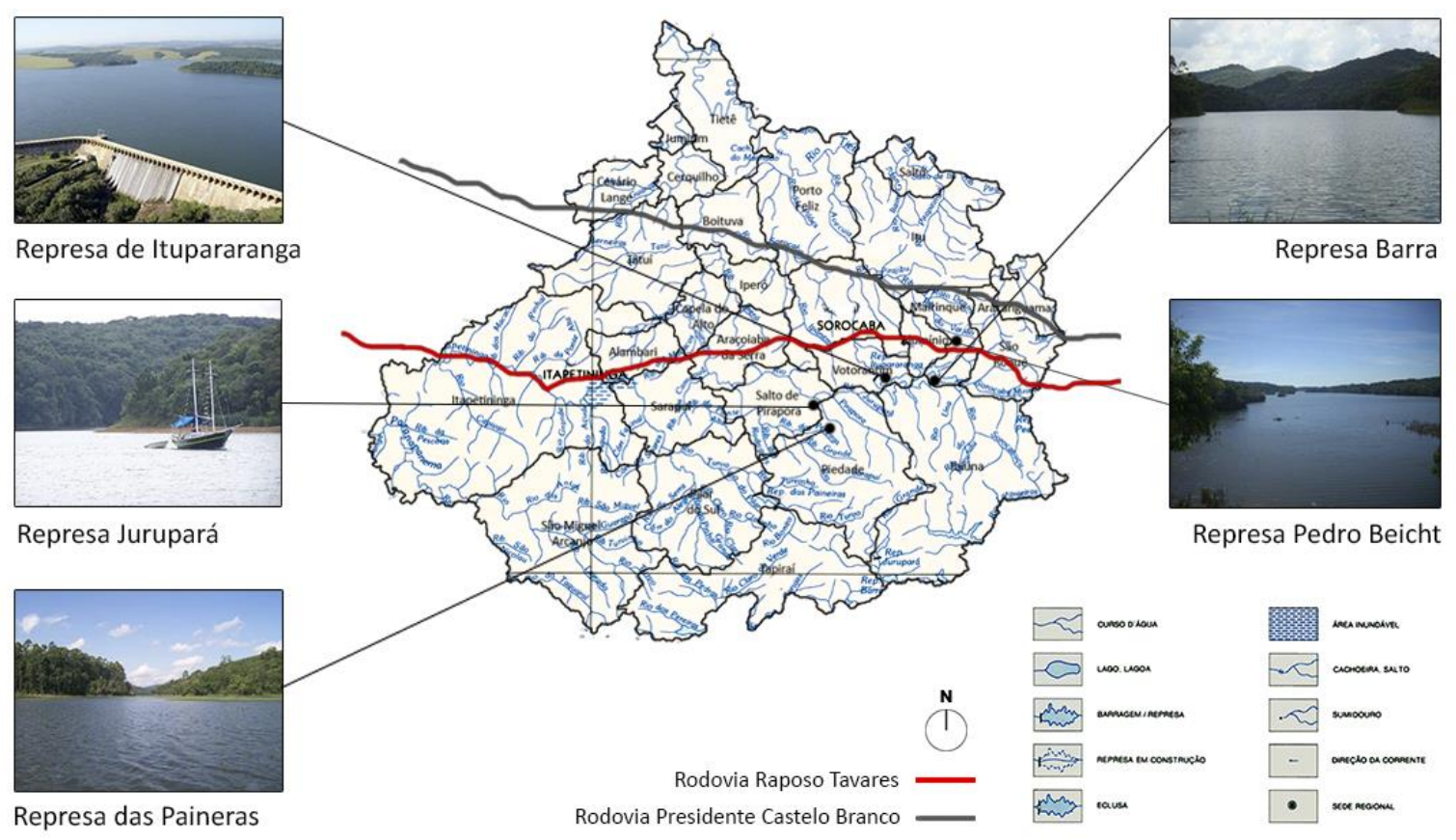

Fonte: IGC, Rede Hidrográfica, 1985. Fotos: Imagens Google. Retrabalhado por Amanda Dias, 2018.

\section{Unidades de conservação na RM Sorocaba}

Atualmente é cada vez maior a importância da existência de Unidades de Conservação em uma região metropolitana, quanto maior for a quantidade da população nela instalada. Na RMS, estão as seguintes Unidades de Conservação: 1) parte do Parque Estadual Carlos Botelho, em São Miguel Arcanjo; 2) Parque Estadual Jurupará, em Ibiúna; 3) APA de Itupararanga (parte em Ibiúna, Piedade, Votorantim, Alumínio, Mairinque e São Roque) e 4) a Unidade de Conservação da Floresta Nacional de Ipanema, no Município de Iperó, SP (Fig. 6). 
Figura 6 - Os 27 Municípios e as Unidades de Conservação da Região Metropolitana de Sorocaba, São Paulo.

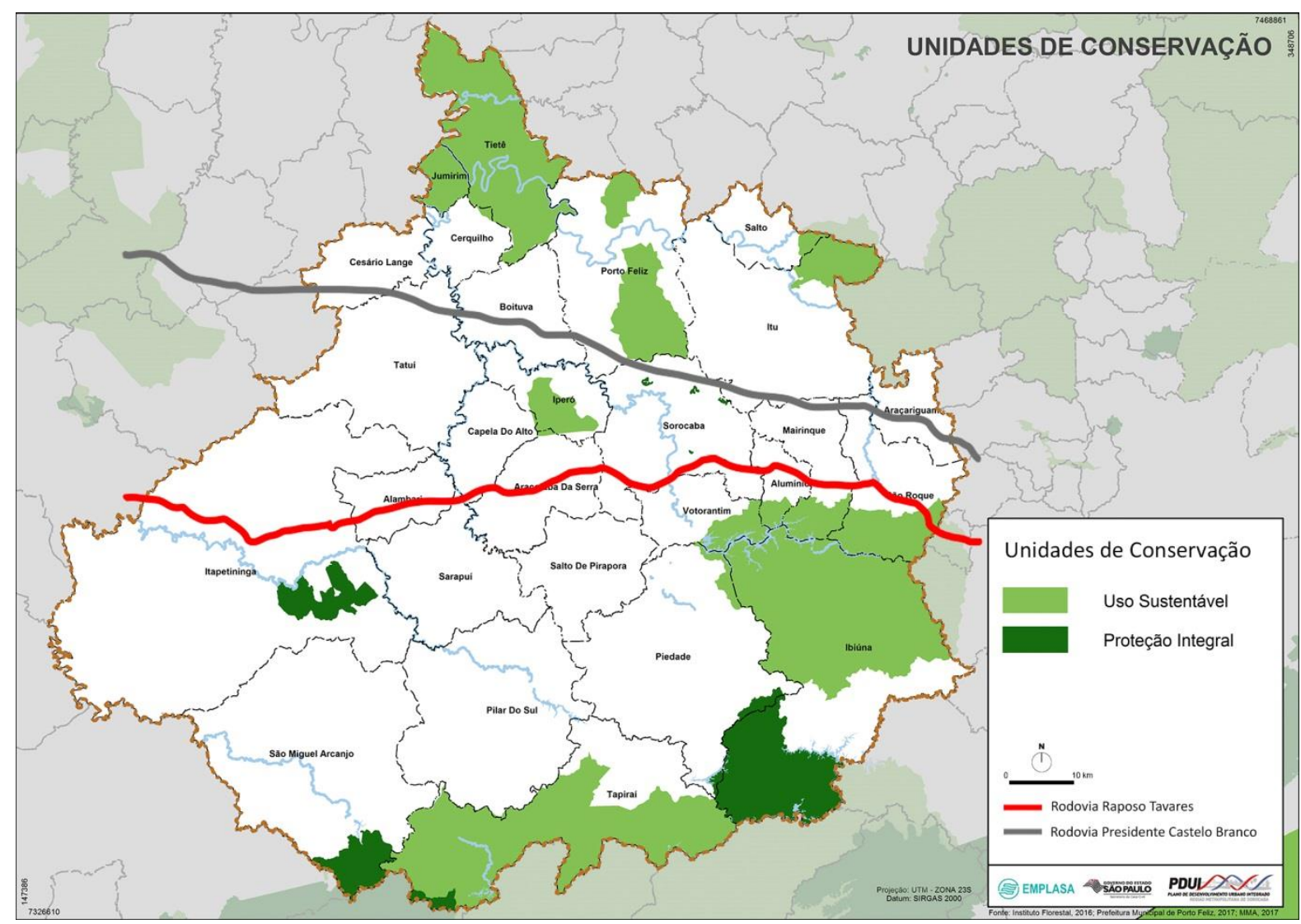

Fonte: EMPLASA, 2017. Retrabalhado por Amanda Dias, 2018.

A população da RMS atualmente é de cerca de dois milhões de habitantes, sendo concentrada no município sede, Sorocaba, com cerca de 660 mil habitantes (IBGE, 2017). Segue tabela com os principais indicadores dos vinte e sete municípios da RMS, divididos por sub-região administrativa: nome dos municípios, área, população, densidade demográfica, e PIB de 2014 (EMPLASA, 2017).

Os habitantes da RMS em 2010 contabilizavam 1.726.785 moradores (IBGE, 2010), com densidade média de 175,82 habitantes por quilometro quadrado. No período 2000/2010 sua taxa de crescimento foi de 1,68\%, terceiro maior índice registrado dentre as unidades da MMP e acima da média estadual de $1,10 \%$.

Este total de habitantes representavam em 2010 4,18\% da população estadual e 0,91\% da população nacional. 0 município mais populoso é Sorocaba, onde residem $34 \%$ do total de habitantes da RM, seguido por Itú com $9 \%$ e Salto, Tatuí e Votorantim com 6\% e São Roque com 5\% (Fig. 7). 
Figura 7 - População Região Metropolitana de Sorocaba (2000-2014).

População

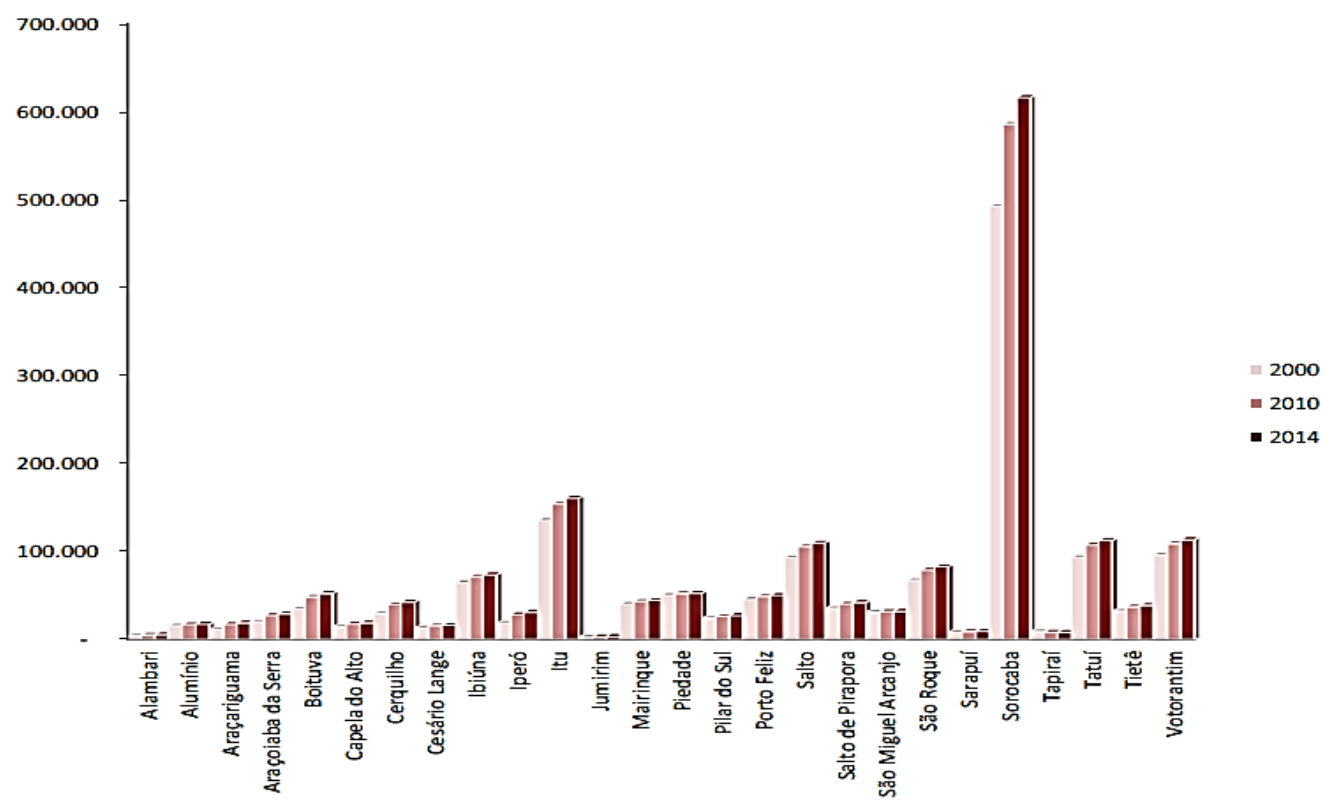

Fonte: FESPSP, 2014.

O Produto interno bruto (PIB) da RM Sorocaba foi de 42,9 bilhões de reais em 2010 e 46,7 bilhões de reais em 2011. O último montante representa 3,46\% do PIB estadual e 1,13\% do nacional. O PIB per capita é de $\mathrm{R} \$ 26.748,14$, sétimo da Macrometrópole paulista (EMPLASA, 2015).

Dos municípios de que é composta a RM, Sorocaba é o que possui o maior PIB, correspondendo a 38\% da região, seguido de Itu. Alumínio apresentou o maior PIB per capita (2011) da RM, cerca de três vezes maior que o índice do Estado de São Paulo. (Alumínio, Araçariguama e Cerquilho possuem PIB per capita superior à média da região). Verifica-se que de 2009 a 2011 todos os municípios da RM Sorocaba tiveram crescimento do PIB, com exceção de Alumínio, Araçariguama e Cerquilho (respectivamente, decréscimo de 13\%, 0.1\% e 17\% no período).

Os maiores crescimentos para o período foram de Sarapuí, Araçoiaba da Serra e Alambari (FESPSP, 2014) (Fig. 8). 
Figura 8 - PIB da Região Metropolitana de Sorocaba (2009-2011).

\section{PIB em milhões de reais correntes}

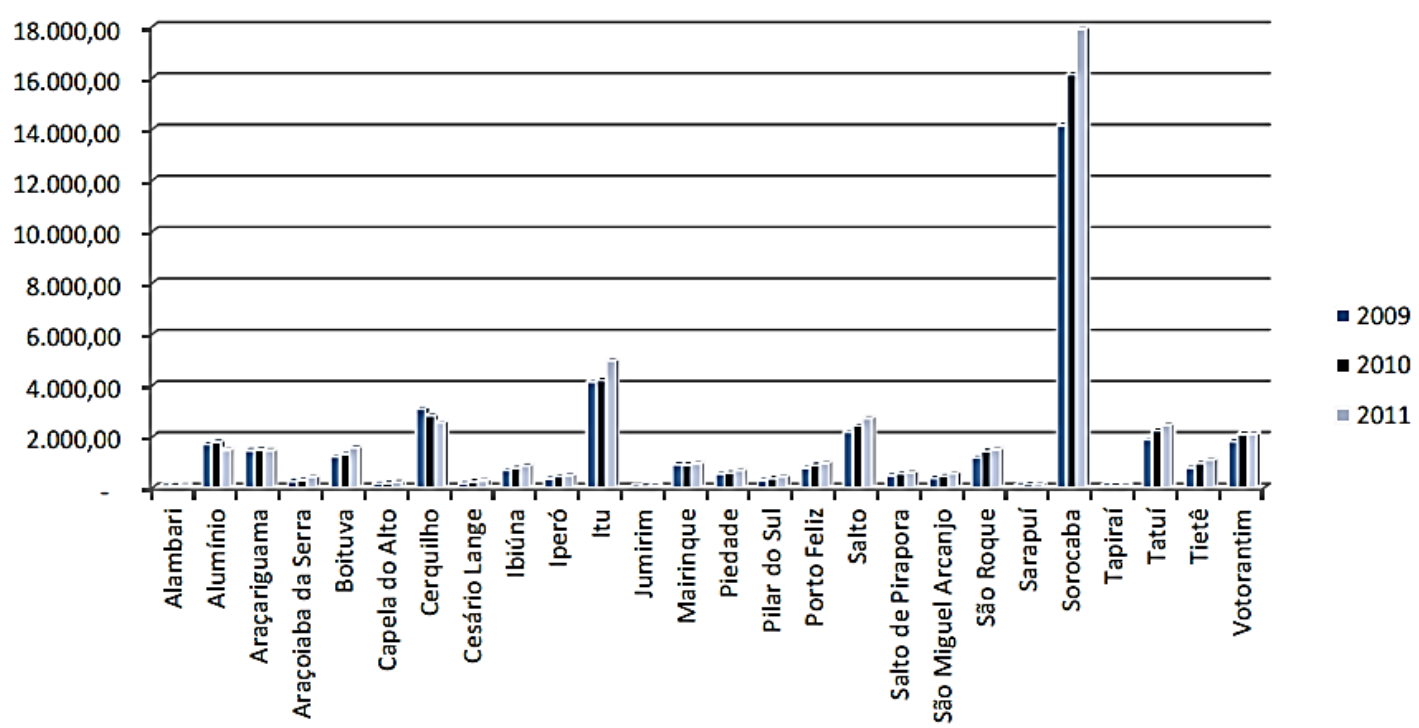

Fonte: FESPSP, 2014.

Com relação a empregos, os setores de Serviços e da Industria são os maiores geradores de emprego (somados, passavam de 340 mil postos de trabalho em 2011 conforme dados do SEADE), com destaque para o primeiro, seguido pela produção industrial e pelo comércio. Por último, e representando um pouco mais de $3 \%$ de um total de 481.308 está o setor agropecuário, fato que indica um alto grau de industrialização e urbanização da Região.

A distribuição do valor adicionado por setor econômico nos municípios da RM Sorocaba (Fig. 9) indica que os segmentos mais relevantes são os de serviços e da indústria, sendo que o primeiro apresenta os maiores indicadores em todos os municípios à exceção de Alumínio, Araçariguama, Boituva, Cerquilho e Itu; nos quais o setor industrial é mais relevante para as economias.

O complexo industrial da Região Metropolitana de Sorocaba é formado por diversos ramos industriais como setor automobilístico, metalurgia, siderurgia, produção de máquinas e equipamentos, de aviões, alumínio, cimento, alimentos, bebidas, artigos eletrônicos, entre outros. 
Figura 9 - Valor Adicionado (2010) por setor na RM Sorocaba.

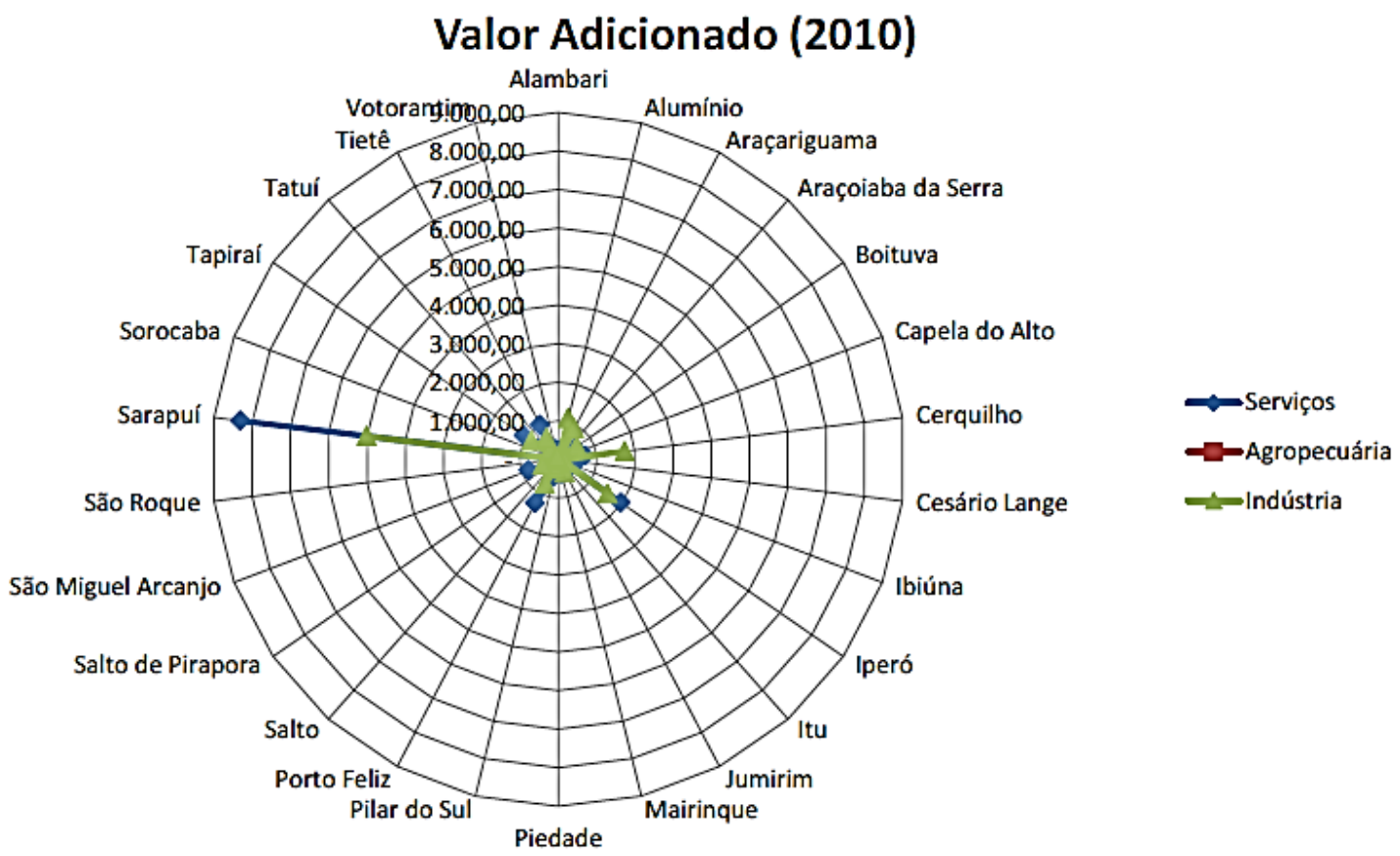

Fonte: FESPSP, 2014.

A Agropecuária representava em 2010 2\% do valor adicionado da RMS. Na Agricultura, a região possui criadores de gado de corte e de leite, bem como culturas de milho, soja e hortifrutigranjeiro.

Entre os municípios de menor porte, predominam a produção rural e atrativos turísticos, seja pela natureza loca, seja por atrativos como um grande parque de pára-quedismo (em Boituva, SP); 0 maior conservatório de música da América Latina (em Tatuí, SP), bem como a arquitetura de construções tombadas como patrimônio ambiental (Unidade de Conservação Floresta Nacional de Ipanema, em Iperó, SP). 
Tabela 6 - Indicadores dos municípios da RMS.

\begin{tabular}{|c|c|c|c|c|c|c|}
\hline Municípios & Área $\left(\mathbf{k m}^{2}\right)^{1}$ & $\begin{array}{l}\text { População } \\
2017^{1}\end{array}$ & $\begin{array}{l}\text { Densidad } \\
\text { e } \\
\text { Demográf } \\
\text { ica } 2017 \\
\left(\mathrm{hab} / \mathrm{km}^{2}\right) \\
1\end{array}$ & $\begin{array}{l}\text { TGC } \\
A \\
2010 \\
/ 201 \\
7 \\
(\%)^{2}\end{array}$ & $\begin{array}{l}\text { PIB } 2014 \\
\text { (mil reais) }^{1}\end{array}$ & $\begin{array}{l}\text { Distância até } \\
\text { São Paulo }(\mathrm{km})^{3}\end{array}$ \\
\hline Alambari & 159,60 & 5.754 & 36,05 & 2,37 & 70.467 & 154 \\
\hline Boituva & 248,97 & 57.910 & 232,60 & 2,62 & 2.587 .854 & 121 \\
\hline Capela do Alto & 169,89 & 20.005 & 117,75 & 1,90 & 248.260 & 136 \\
\hline Cerquilho & 127,80 & 46.733 & 365,66 & 2,39 & 1.571 .087 & 140 \\
\hline Cesário Lange & 190,39 & 17.587 & 92,37 & 1,78 & 311.108 & 150 \\
\hline Itapetininga & $1.789,35$ & 160.070 & 87,71 & 1,48 & 3.935.738 & 172 \\
\hline Jumirim & 56,69 & 3.237 & 57,11 & 2,10 & 70.427 & 152 \\
\hline Sarapuí & 352,53 & 10.034 & 28,46 & 1,52 & 124.870 & 150 \\
\hline Tatuí & 523,75 & 118.939 & 227,09 & 1,48 & 3.417 .706 & 141 \\
\hline Tietê & 404,40 & 41.022 & 101,44 & 1,55 & 1.640 .139 & 143 \\
\hline $\begin{array}{l}\text { Total Sub- } \\
\text { Região } 1\end{array}$ & $4.023,36$ & 481.291 & 119,62 & 1,75 & 13.977 .656 & \\
\hline Alumínio & 83,66 & 18.324 & 219,03 & 1,21 & 1.526 .672 & 79 \\
\hline Araçariguama & 145,20 & 21.038 & 144,89 & 3,02 & 1.494 .020 & 53 \\
\hline lbiúna & $1.058,08$ & 77.566 & 73,31 & 1,23 & 1.438 .503 & 69 \\
\hline
\end{tabular}




\begin{tabular}{|c|c|c|c|c|c|c|}
\hline Itu & 640,72 & 170.157 & 265,57 & 1,42 & 7.551 .445 & 101 \\
\hline Mairinque & 210,15 & 46.567 & 221,59 & 1,07 & 1.540 .245 & 71 \\
\hline Porto Feliz & 556,69 & 52.507 & 94,32 & 1,02 & 1.429 .706 & 118 \\
\hline Salto & 133,06 & 116.191 & 873,24 & 1,39 & 5.695 .364 & 101 \\
\hline São Roque & 306,91 & 88.473 & 288,27 & 1,66 & 2.272 .458 & 66 \\
\hline $\begin{array}{l}\text { Total Sub- } \\
\text { Região } 2\end{array}$ & $3.134,47$ & 590.823 & 188,49 & 1,41 & 22.948 .413 & \\
\hline $\begin{array}{l}\text { Araçoiaba da } \\
\text { Serra }\end{array}$ & 255,33 & 32.495 & 127,27 & 2,52 & 508.944 & 122 \\
\hline Iperó & 170,29 & 34.913 & 205,02 & 3,05 & 438.542 & 126 \\
\hline Piedade & 746,87 & 55.092 & 73,76 & 0,79 & 1.129 .675 & 99 \\
\hline Pilar do Sul & 681,12 & 28.718 & 42,16 & 1,21 & 449.225 & 150 \\
\hline $\begin{array}{l}\text { Salto de } \\
\text { Pirapora }\end{array}$ & 280,70 & 44.397 & 158,17 & 1,45 & 1.383 .574 & 124 \\
\hline $\begin{array}{l}\text { São Miguel } \\
\text { Arcanjo }\end{array}$ & 930,34 & 32.910 & 35,37 & 0,65 & 556.845 & 184 \\
\hline Sorocaba & 450,38 & 659.871 & $1.465,14$ & 1,70 & 32.662 .452 & 99 \\
\hline Tapiraí & 755,10 & 7.973 & 10,56 & $-0,07$ & 144.494 & 135 \\
\hline Votorantim & 183,52 & 119.898 & 653,33 & 1,40 & 4.708 .770 & 105 \\
\hline $\begin{array}{l}\text { Total Sub- } \\
\text { Região } 3\end{array}$ & $4.453,64$ & 1.016 .267 & 228,19 & 1,60 & 41.982 .521 & \\
\hline RMS & $11.611,48$ & 2.088.381 & 179,84 & 1,58 & 78.908 .590 & \\
\hline $\begin{array}{l}\text { Estado de São } \\
\text { Paulo }\end{array}$ & $248.222,00$ & 45.094.866 & 181,67 & 1,28 & 1.858.196.057 & \\
\hline
\end{tabular}

${ }^{1}$ Fonte: IBGE. ${ }^{2}$ Fonte: EMPLASA. ${ }^{3}$ Fonte: DER - Departamento de Estradas de Rodagem. Elaboração: EMPLASA,GIP/CDI, 2017. 
Tabela 7 - Principais atividades econômicas dos municípios da Região Metropolitana de Sorocaba.

\begin{tabular}{|c|c|}
\hline \multicolumn{2}{|c|}{$\begin{array}{l}\text { PRINCIPAIS ATIVIDADES ECONÔMICAS DOS MUNICÍPIOS QUE FORMAM A } \\
\text { REGIÃO METROPOLITANA DE SOROCABA }\end{array}$} \\
\hline Município & Atividade (s) Econômica (s) \\
\hline 2. $\quad$ Alambari & Agropecuária; Comércio por atacado. \\
\hline 3. $\quad$ Alumínio & Metalurgia \\
\hline $\begin{array}{l}\text { 4. Araçariguam } \\
\text { a }\end{array}$ & $\begin{array}{l}\text { Extração de minerais metálicos; Extração de minerais não-metálicos; } \\
\text { Metalurgia; Coleta, tratamento e disposição de resíduo; Recuperação de } \\
\text { materiais; Armazenamento e atividades auxiliares dos transportes. }\end{array}$ \\
\hline $\begin{array}{l}\text { 5. Araçoiaba da } \\
\text { Serra }\end{array}$ & $\begin{array}{l}\text { Produção Florestal; Produtos farma-químicos e farmacêuticos; Pesquisa e } \\
\text { desenvolvimento científico; Atividades ligadas ao patrimônio cultural e } \\
\text { ambiental; Esporte e lazer; Reparação e manutenção de equipamentos de } \\
\text { informática e comunicação e de Objetos pessoais e domésticos. }\end{array}$ \\
\hline Boituva & $\begin{array}{l}\text { Extração de minerais metálicos; Bebidas; Bio-combustível; Produtos de metal, } \\
\text { exceto máquinas e equipamentos; Armazenamento e atividades auxiliares dos } \\
\text { transportes; Atividades de vigilância, segurança e investigação. }\end{array}$ \\
\hline $\begin{array}{l}\text { 7. Capela do } \\
\text { Alto }\end{array}$ & Agropecuária, Extração de minerais não-metálicos; produtos diversos \\
\hline 8. Cerquilho & $\begin{array}{c}\text { Produtos Têxteis, Confecção de Vestuário e Acessórios; Produtos de borracha } \\
\text { e de material plástico; Máquinas, aparelhos e materiais elétricos; }\end{array}$ \\
\hline $\begin{array}{l}\text { 9. Cesário } \\
\text { Lange }\end{array}$ & $\begin{array}{l}\text { Agropecuária; Pesca e Aquicultura; Produtos Químicos; Produtos de minerais } \\
\text { não-metálicos. }\end{array}$ \\
\hline 10. Ibiúna & Agropecuária; Produtos alimentícios; Eletricidade e gás \\
\hline 11. Iperó & $\begin{array}{c}\text { Extração de minerais não-metálicos; Produtos de madeira; Produtos de me } \\
\text { exceto máquinas e equipamentos; Máquinas e Equipamentos; Móveis; Serviços } \\
\text { engenharia e análises técnicas }\end{array}$ \\
\hline 12. Itu & $\begin{array}{l}\text { Bebidas; Produtos de minerais não-metálicos; Máquinas, aparelhos e } \\
\text { materiais elétricos; }\end{array}$ \\
\hline 13. Jumirim & $\begin{array}{l}\text { Produtos alimentícios; Produtos têxteis; Produtos de madeira; Produtos de } \\
\text { minerais não -metálicos; Serviços para edifícios e atividades paisagísticas. }\end{array}$ \\
\hline 14. Mairinque & Produtos Têxteis; \\
\hline
\end{tabular}




\begin{tabular}{|c|c|}
\hline 15. Piedade & $\begin{array}{c}\text { Agropecuária; Produção florestal; Pesca e agricultura; Produtos de madeira; } \\
\text { Equipamentos de informática, produtos eletrônicos e ópticos; Reparação e } \\
\text { manutenção de equipamentos de informática e comunicação e de Objetos } \\
\text { pessoais e domésticos. }\end{array}$ \\
\hline 16. Pilar do Sul & Agropecuária; Produção florestal, Vigilância, segurança e investigação. \\
\hline 17. Porto Feliz & $\begin{array}{l}\text { Agropecuária; Extração de minerais não metálicos; Confecção de vestuário e } \\
\text { acessórios; Celulose e Papel. }\end{array}$ \\
\hline 18. Salto & Produção Florestal; Produtos de madeira; Instituições extraterritoriais. \\
\hline $\begin{array}{l}\text { 19. Salto de } \\
\text { Pirapora }\end{array}$ & $\begin{array}{c}\text { Pesca e Aquicultura; Extração de minerais não-metálicos; Produtos de } \\
\text { madeira; Celulose e papel; Produtos de minerais não-metálicos; Máquinas e } \\
\text { equipamentos. }\end{array}$ \\
\hline $\begin{array}{l}\text { 20. São Miguel } \\
\text { Arcanjo }\end{array}$ & Agropecuária; Produção Florestal; Prestação de serviços de informação. \\
\hline 21. São Roque & Bebidas; Produtos de borracha e de material plástico; Alojamento. \\
\hline 22. Sarapuí & $\begin{array}{c}\text { Agropecuária; Extração de minerais não metálicos; Celulose e papel; Produtos } \\
\text { Químicos; Móveis; Coleta, tratamento e disposição de resíduos e } \\
\text { Recuperação de Materiais. }\end{array}$ \\
\hline 23. Sorocaba & Equipamentos de informática, produtos eletrônicos e ópticos; \\
\hline 24. Tapiraí & $\begin{array}{l}\text { Produção Floresta; Extração de minerais não-metálicos; Produtos de madeira; } \\
\text { Produtos químicos; Eletricidade, gás e outros utilidades. }\end{array}$ \\
\hline 25. Tatuí & $\begin{array}{l}\text { Produtos de minerais não-metálicos; metalurgia; veículos automotores, } \\
\text { reboques e carrocerias; Edição e impressão. }\end{array}$ \\
\hline 26. Tietê & $\begin{array}{l}\text { Extração de minerais não-metálicos; Bebidas; Produtos têxteis; Confecção de } \\
\text { Vestuário e Acessórios; Produtos de Madeira; Alimentação. }\end{array}$ \\
\hline 27. Votorantim & $\begin{array}{l}\text { Confecção de vestuário e acessórios; Produtos de borracha e de material } \\
\text { plástico; Equipamentos de informática, produtos eletrônicos e ópticos; } \\
\text { Captação, tratamento e distribuição de água. }\end{array}$ \\
\hline
\end{tabular}

Fonte: EMPLASA, 2014. 


\section{Vulnerabilidade social na RMS}

Ao longo de sua história, a população do Município de Sorocaba vivenciou experiências sociais dos agentes locais com o Brasil e o exterior, seja fornecendo produtos e serviços, seja consumindo bens de produção para a indústria local. Nas décadas de 1970 e 1980 do século XX, com a descentralização industrial e a reordenação da produção, motivados pela nova forma de acumulação flexível do capitalismo global, o município reforçou seu papel de protagonista central com atrativos regionais e, dialeticamente, na área de execução daquilo que era e ainda é decidido nas grandes metrópoles nacionais e internacionais.

Na área da Saúde, ao contrário dos demais 26 municípios da RMS, o Município de Sorocaba também é servido por uma infra-estrutura com muitos hospitais como o Hospital Santa Lucinda, Conjunto Hospitalar de Sorocaba, Santa Casa de Misericórdia (fundada há mais de duzentos anos), Hospital Evangélico, Hospital Samaritano, Hospital da Unimed, e o Hospital Regional de Sorocaba, sendo os dois últimos mencionados, notadamente de atendimento à população da região metropolitana de Sorocaba.

Para março de 2018 (JCS, 2018) está programada a inauguração de um novo hospital regional estadual, localizado no km 110 da RRT, ali instalado para descentralização do atendimento do hospital regional de Sorocaba, que atualmente está próximo a área central e a uma rodoviária na área urbana, que provoca transtorno ao tráfego local.

Complementando as informações, na RM Sorocaba há a passagem da linha do Gasoduto operado pela Gás Natural Fenosa S/A. Ressalta-se a importância do setor de Educação, com a presença de universidades, tais como a UFSCAR, a UNESP, a FATEC (Centro Paula Souza), UNISO, PUC e a UNIP. A região de Sorocaba, particularmente o Município de Sorocaba, apresentou na última década franco desenvolvimento de vários setores produtivos (indústria, comércio e serviços), todos demandando intrinsecamente melhores condições efetivas de profissionais qualificados para atender a tal demanda.

O Aeroporto de Sorocaba é um dos mais movimentados do estado em termos de pousos e decolagens. Atualmente, é usado por aviões de pequeno porte e praticamente, não são feitos voos comerciais. Dentre os serviços prestados, encontram-se, principalmente, os de transporte de carga. Na nova região metropolitana de Sorocaba também está em construção um novo aeroporto no município de São Roque, com futuro acesso pela Rod. Castelo Branco (SP 280). Para complementar as informações da RMS, colocamos aqui as informações relativas ao índice paulista de vulnerabilidade social, com os principais indicadores sociais da RMS em 2014 (Tabela 8).

Socialmente, os municípios da RMS têm entre si diferenciais em termos de qualidade de vida, 
sendo que apenas 3 municípios (Itu, Salto e Sorocaba) tem IPRS do tipo 1 - correspondendo, em termos municipais, à baixa vulnerabilidade social de sua população; mesmo assim, pode-se notar no início do séc. XX que a vulnerabilidade social (IPVS) do tipo alta ou muito alta vulnerabilidade prevalecia na então AU Sorocaba (Fig. 10.) Nota-se pela figura a seguir que na AU de Sorocaba, em 2000 na maior parte do território ainda existe alta vulnerabilidade social. Com exceção de poucas localidades (pequenas porções de Sorocaba, São Roque, Itu, Salto e Salto de Pirapora), a maior parte da região tem vulnerabilidade alta e muito alta. Novos dados de IPVS da RMS ainda não foram divulgados.

Figura 10 - Mapa IPVS da AU Sorocaba em 2000.

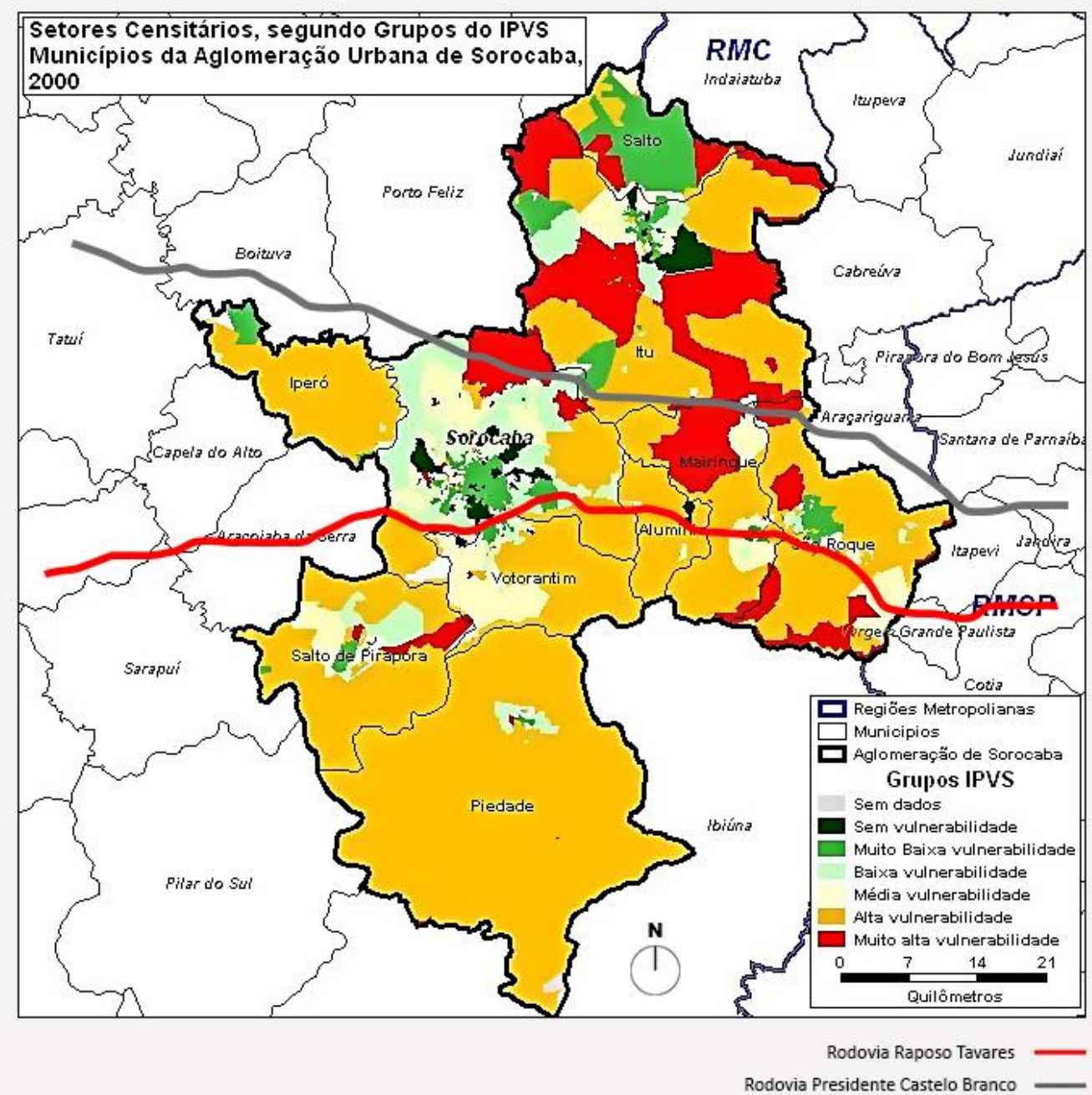

Fonte: Grupo estudos Metropolização Sorocaba, FDA. Retrabalhado por Amanda Dias, 2018.

Pelos indicadores sociais dos municípios da RMS, percebe-se o desequilíbrio de forças sócioeconômicas para sua população desta região metropolitana, o que explica em parte a pendularidade na mobilidade urbana do sistema viário principal da RMS, próximo item a ser observado (Tab. 8). 
Tabela 8 - Indicadores sociais Municípios RM Sorocaba (2010).

\begin{tabular}{|c|c|c|c|c|c|c|c|}
\hline Municipio & Alambari & Aluminio & Araçariguama & $\begin{array}{l}\text { Araçoiaba } \\
\text { da Serra }\end{array}$ & Boituva & \begin{tabular}{|l|} 
Capela do \\
Alto
\end{tabular} & Cerquilho \\
\hline $\begin{array}{l}\text { PIB per Capta } \\
\text { (2010) }\end{array}$ & $19.192,71$ & $106.507,16$ & $88.248,09$ & $11.146,56$ & $27.176,37$ & $10.645,37$ & $71.231,76$ \\
\hline $\begin{array}{l}\text { Taxa de } \\
\text { Mortalidade Infantil } \\
\text { (2010, por mil } \\
\text { nascidos vivos) }\end{array}$ & 0 & 4,13 & 20,76 & 9,76 & 11,22 & 7,87 & 11,54 \\
\hline $\begin{array}{l}\text { Taxa de } \\
\text { analfabetismo da } \\
\text { população de } 15 \\
\text { anos ou mais de } \\
\text { idade (2010) }\end{array}$ & 6,57 & 4,58 & 6,72 & 4,91 & 4,92 & 6,99 & 3,56 \\
\hline IPRS (2010) & 5 & 2 & 2 & 3 & 2 & 4 & 3 \\
\hline IPRS - Riqueza & 30 & 51 & 50 & 31 & 42 & 32 & 38 \\
\hline $\begin{array}{l}\text { IPRS - } \\
\text { Longevidade }\end{array}$ & 59 & 61 & 63 & 66 & 64 & 73 & 71 \\
\hline $\begin{array}{l}\text { IPRS - } \\
\text { Escolaridade }\end{array}$ & 42 & 53 & 44 & 50 & 59 & 46 & 66 \\
\hline Municipio & Cesário Lange & Ibiúna & Iperó & Itu & Jumirim & Mairing & Piedade \\
\hline $\begin{array}{l}\text { PIB per Capta } \\
\text { (2010) }\end{array}$ & $15.445,47$ & $10.834,85$ & $15.635,26$ & $27.252,50$ & $22.918,6$ & $20.785,3$ & $11.324,76$ \\
\hline $\begin{array}{l}\text { Taxa de } \\
\text { Mortalidade Infantil } \\
\text { (2010, por mil } \\
\text { nascidos vivos) }\end{array}$ & 19,23 & 19,4 & 18,42 & 9 & 0 & 10,51 & 21,74 \\
\hline $\begin{array}{l}\text { Taxa de } \\
\text { analfabetismo da } \\
\text { população de } 15 \\
\text { anos ou mais de } \\
\text { idade (2010) }\end{array}$ & 5,45 & 8,7 & 5,04 & 4,44 & 6,6 & 5,41 & 8,62 \\
\hline IPRS (2010) & 4 & 2 & 2 & 1 & 4 & 2 & 4 \\
\hline IPRS - Riqueza & 34 & 47 & 40 & 48 & 35 & 42 & 29 \\
\hline $\begin{array}{l}\text { IPRS - } \\
\text { Longevidade }\end{array}$ & 73 & 61 & 63 & 70 & 61 & 65 & 59 \\
\hline $\begin{array}{l}\text { IPRS- } \\
\text { Escolaridade }\end{array}$ & 41 & 39 & 36 & 50 & 66 & 50 & 50 \\
\hline Municipio & Sorocaba & Tapirai & Tatui & Tietê & \multicolumn{2}{|c|}{ Votorantim } & \\
\hline $\begin{array}{l}\text { PIB per Capta } \\
\text { (2010) }\end{array}$ & $27.527,01$ & $9.731,30$ & $20.739,03$ & $26.559,69$ & \multicolumn{2}{|c|}{\begin{tabular}{|l|}
$19.248,92$ \\
\end{tabular}} & \\
\hline $\begin{array}{l}\text { Taxa de } \\
\text { Mortalidade Infantil } \\
\text { (2010, por mil } \\
\text { nascidos vivos) }\end{array}$ & 13,35 & 27,03 & 9,8 & 2,03 & \multicolumn{2}{|l|}{14,06} & \\
\hline $\begin{array}{l}\text { Taxa de } \\
\text { analfabetismo da } \\
\text { população de } 15 \\
\text { anos ou mais de } \\
\text { idade (2010) }\end{array}$ & 3,1 & 10,95 & 4,25 & 3,69 & \multicolumn{2}{|l|}{3,48} & \\
\hline IPRS (2010) & 1 & 5 & 3 & 3 & \multicolumn{2}{|l|}{2} & \\
\hline IPRS - Riqueza & 45 & 28 & 37 & 38 & \multicolumn{2}{|l|}{40} & \\
\hline $\begin{array}{l}\text { IPRS - } \\
\text { Longevidade }\end{array}$ & 69 & 63 & 68 & 72 & \multicolumn{2}{|l|}{63} & \\
\hline $\begin{array}{l}\text { IPRS - } \\
\text { Escolaridade }\end{array}$ & 56 & 48 & 53 & 54 & \multicolumn{2}{|l|}{55} & \\
\hline
\end{tabular}

Fonte: FESPSP, 2014. 


\subsection{Prevalência de Sorocaba como município-pólo da RMS}

Caracterizada por seu passado e presente industrial, Sorocaba (município sede da RMS), foi marcada pela industrialização no final do século XIX o que forjou tanto as classes operárias como a burguesia - bem como forças produtivas e agentes sociais distintos; e pela forte expansão do setor industrial nas últimas cinco décadas.

O Município de Sorocaba, de aproximadamente 670 mil habitantes (IBGE, 2015), é considerado o pólo centralizador de uma região de mais de dois milhões de habitantes. Tem grande diversidade econômica (indústria, comércio e serviços), e é responsável por $42 \%$ do PIB em sua área de conurbação, onde principalmente sua produção industrial atinge mais de 120 países, gerando um PIB de mais que R\$13,3 bilhões (LOGIT, 2013) (Fig. 11).

Figura 11- Sorocaba na RMS: pólo regional, 19 municípios em conurbação direta e indireta.

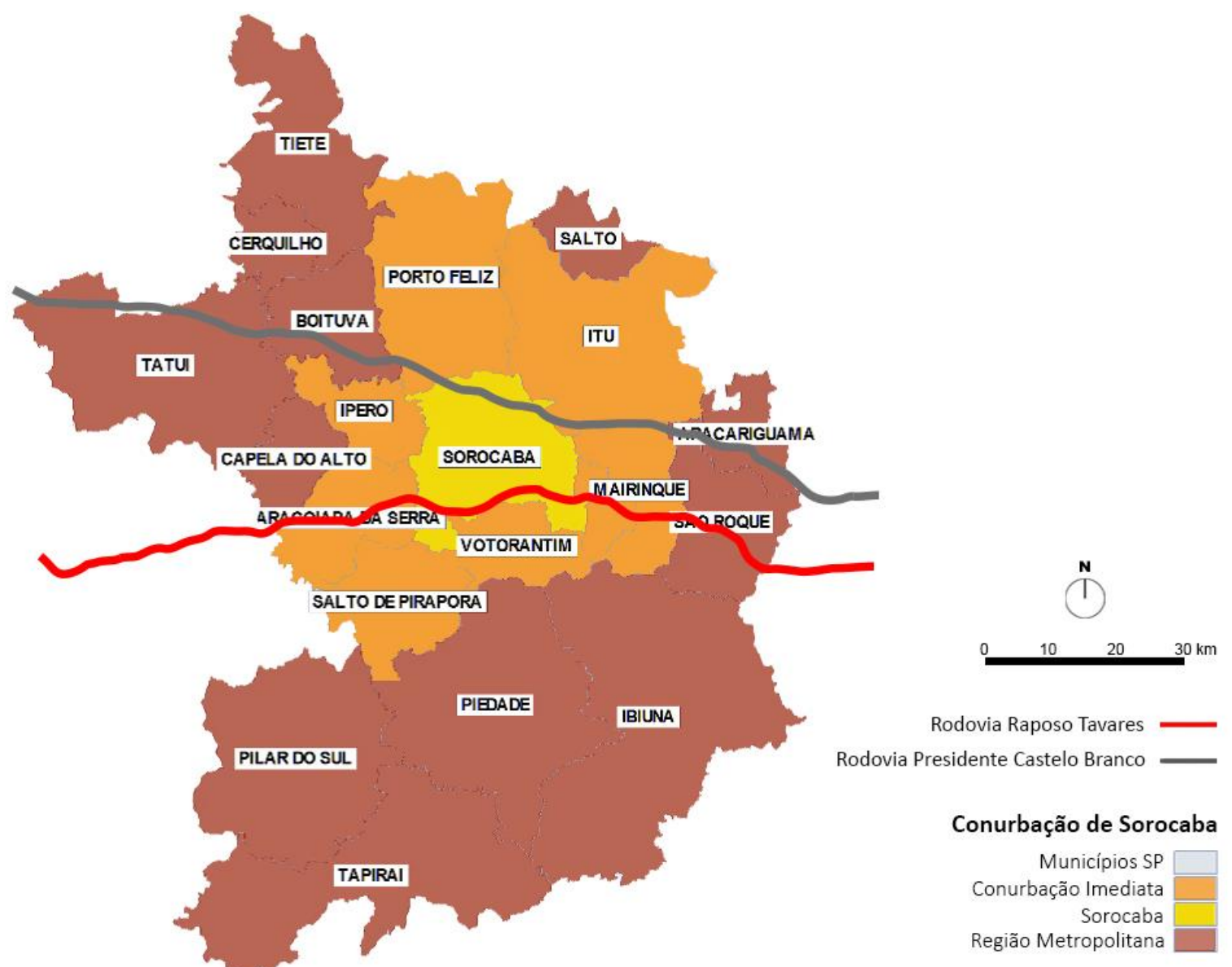

Fonte: LOGIT, 2013. Retrabalhado por Amanda Dias, 2018. 
Sorocaba é a quinta cidade em desenvolvimento econômico do ESP, com investimentos da ordem de 3.500.000.000 de dólares estadunidenses, com 5.000.000.000 de dólares estadunidenses de produto interno bruto (PIB). Suas indústrias exportam para mais de 115 países gerando impostos da ordem de 370.000.000 de dólares estadunidenses por ano. Existem em Sorocaba cerca de 1700 indústrias instaladas, 15.300 pontos de comércio, 9.900 prestadores de serviço e 25.000 trabalhadores autônomos. Sorocaba oferece atrativo adicional às empresas: uma estrutura de qualificação de mão-de-obra que cobre com qualidade o nível operacional devido às escolas técnicas e faculdades de tecnologia e universidades públicas, comunitária e privadas (IBGE, 2013).

É o oitavo município brasileiro e quarto mercado consumidor do Estado fora da RMSP, com um potencial de consumo per capita anual estimado em US\$2400 para a população urbana e US\$ 917 para a população rural (cerca de 7200 pessoas, e a 29a . município brasileiro com maior potencial de consumo). Também é a $4^{\mathrm{a}}$ maior cidade paulista a receber investimentos novos e uma das maiores do País, figurando na lista das trinta maiores cidades que mais geram empregos no Brasil (IBGE, 2013). Segundo o IBGE (2010), o IDH de Sorocaba foi de 0,828, estando, segundo a classificação do PNUD, entre as regiões consideradas de elevado IDH (entre 0,800 e 1).

O PIB do município em 2010 foi de $\mathrm{R} \$ 16.127 .236$ mil reais e o PIB per capita de $\mathrm{R} \$ 27.506,28$ (IBGE, 2010). A capacidade econômica instalada no Município de Sorocaba é evidenciada por dois distritos industriais, na zona leste de Sorocaba, servida pela RCB e RRT; e um parque tecnológico na zona norte da cidade, onde está se configurando o terceiro distrito industrial, pela instalação, nos anos 2010, de uma planta da Toyota e doze sistemistas, na região norte cortada pela RCB.

O Município de Sorocaba, portanto, é considerado o polo centralizador de uma região de mais de dois milhões de habitantes. Tem grande diversidade econômica (indústria, comércio e serviços), e é responsável por $42 \%$ do PIB em suas áreas conturbadas; sua produção industrial atinge atualmente mais de 120 países, gerando um PIB superior a $R \$ 13,3$ bilhões. O forte crescimento de Sorocaba implica em duplo papel local: área de execução, a mando das metrópoles nacionais e internacionais; bem como a de exercício da liderança regional (LOGIT, 2013). 
Figura 12 - Principais atividades econômicas agrupadas dos municípios da Região Metropolitana de Sorocaba.

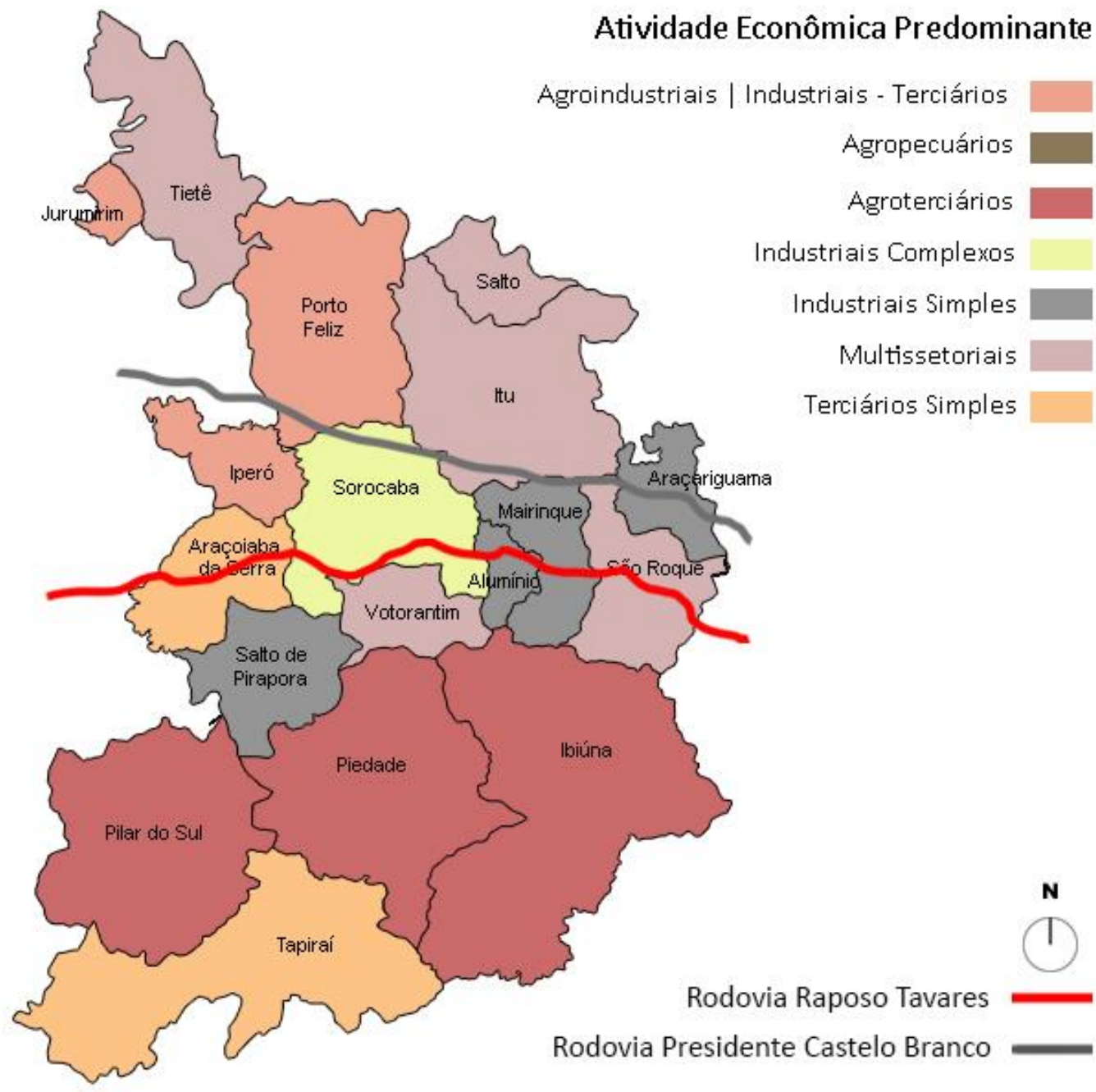

Fonte: EMPLASA, 2014. Retrabalhado por Amanda Dias, 2018.

\section{Dados sócio-econômicos do Município de Sorocaba (2013-2015)}

O território brasileiro nos últimos 30 anos reconfigurou-se por meio de um processo de "concentração desconcentrado": a produção de riqueza encontra-se extremamente concentrada no território nacional - 33\% do PIB brasileiro são produzidos no estado de São Paulo, e 85,2\% deste, no entorno da região metropolitana de São Paulo, incluindo as regiões de Campinas, São José dos Campos, Santos e Sorocaba (SEADE, 2008, apud SOMEKH, 2010). O desenvolvimento econômico que aconteceu na primeira década na região de Sorocaba (2000-2010) embora oscilante, foi positivo e motivou vários investimentos em Sorocaba e região. Lembrando que 0 índice FIRJAN para 0 Município de Sorocaba $\left(0,8516\right.$ em 2013) é um dos mais altos da RMS; é o $85^{\circ}$. do País e $51^{\circ}$. Do 
Estado de São Paulo, atrás do Município de Arujá (SP) e à frente de Limeira (SP). Na composição dos índices, o maior peso é o da educação $(0,9415)$ e o menor o de emprego e renda $(0,7603)$ (FIRJAN, 2014).

Em termos de dados do IBGE, o resumo atualizado seria este: "Em 2015, o SM mensal do Município de Sorocaba era de $3,3 \mathrm{SM}$; a população ocupada era de $35 \%$ em relação à população total; e 31,7\% dos domicilios recebiam rendimentos mensais de $1 / 2$ SM por pessoa. Neste caso, seria 0 município de $300^{a}$. posição dentre as 645 do Estado de SP e na posição de $4353^{a}$. de 5570 dentre as cidades do Brasil" (IBGE, 2018).

Estes números descrevem um cenário de dificuldades financeiras, (em conformidade com a crise econômica ainda vigente) para praticamente dois terços da população total do Município de Sorocaba que não está ocupada economicamente; e que menos de um terço dos domicílios recebiam 1/2 SM por pessoa. Entretanto, o PIB per capita de Sorocaba em 2015 foi de $\mathrm{R} \$ 47.396,33$ e 41,2\% das receitas foram oriundas de fontes externas; o IBGE classifica o Município de Sorocaba em $282^{\circ}$. de 5570 municípios do País e $63^{\circ}$. do Estado de SP, e $05^{\circ}$ município em termos econômicos da sua região (IBGE, 2018).

Com relação à moradia própria, dados de setembro de 2017 de estudo para o quadro em Sorocaba informava que havia um estoque de imóveis a serem ocupados de 4,5 mil unidades, sendo $65 \%$ destes empreendimentos financiados pelo programa federal MCMV. Ao mesmo tempo, o município apresenta cadastro de 30 mil famílias à espera da casa própria.

Os níveis de desemprego atuais tem peso neste processo, pois a falta de recursos financeiros impede acesso à moradia própria, mesmo com a existência de muitos imóveis prontos e vazios (SECOVI, 2017); e a tendência indicada pela fundação $\operatorname{SEADE~(2018,~p.~} 5$ e 6) de que o número médio de moradores por domicílio vem diminuindo sistematicamente desde 1950: de mais de 5 para 4,4 em 1980, 3,2 em 2010, e que deverá atingir 2,47 em 2050; pode ser utilizado para se fazer o planejamento urbano e social para atender a esta população que está sempre na berlinda com relação á moradia própria (FERREIRA; CASTINERAS, 2018).

Segundo projeção da Fundação SEADE para 2050, o número de domicílios ocupados na RA de Sorocaba ${ }^{7}$ em 2010 era de 850.759; em 2030 a projeção é de 1.179.011; e para 2050 será de 1.330.627 habitações ocupadas. Em síntese, é de se esperar que o processo de envelhecimento demográfico continue contribuindo para o aumento da concentração de domicílios com 1 e 2 moradores; e como a população economicamente ativa atualmente é de $35 \%$, é preciso urgentemente

\footnotetext{
7 Fonte: IBGE; Fundação Seade. (1) Neste estudo foi mantida a configuração da RA de Sorocaba de 2010, quando ainda não existia a RA de Itapeva.
} 
reavaliar as políticas públicas de educação e de uso e ocupação do solo, que poderiam observar e sanar os problemas das ocupações das áreas lindeiras das rodovias metropolitanas, normalmente mais distantes das áreas com infra-estrutura urbana consolidada, em áreas de risco de deslizamento e alagamento, que por vezes esperam há décadas soluções do poder público municipal.

Figura 13 - Classificação de total de empregos RAIS 2014 por UIT para o Município de Sorocaba.

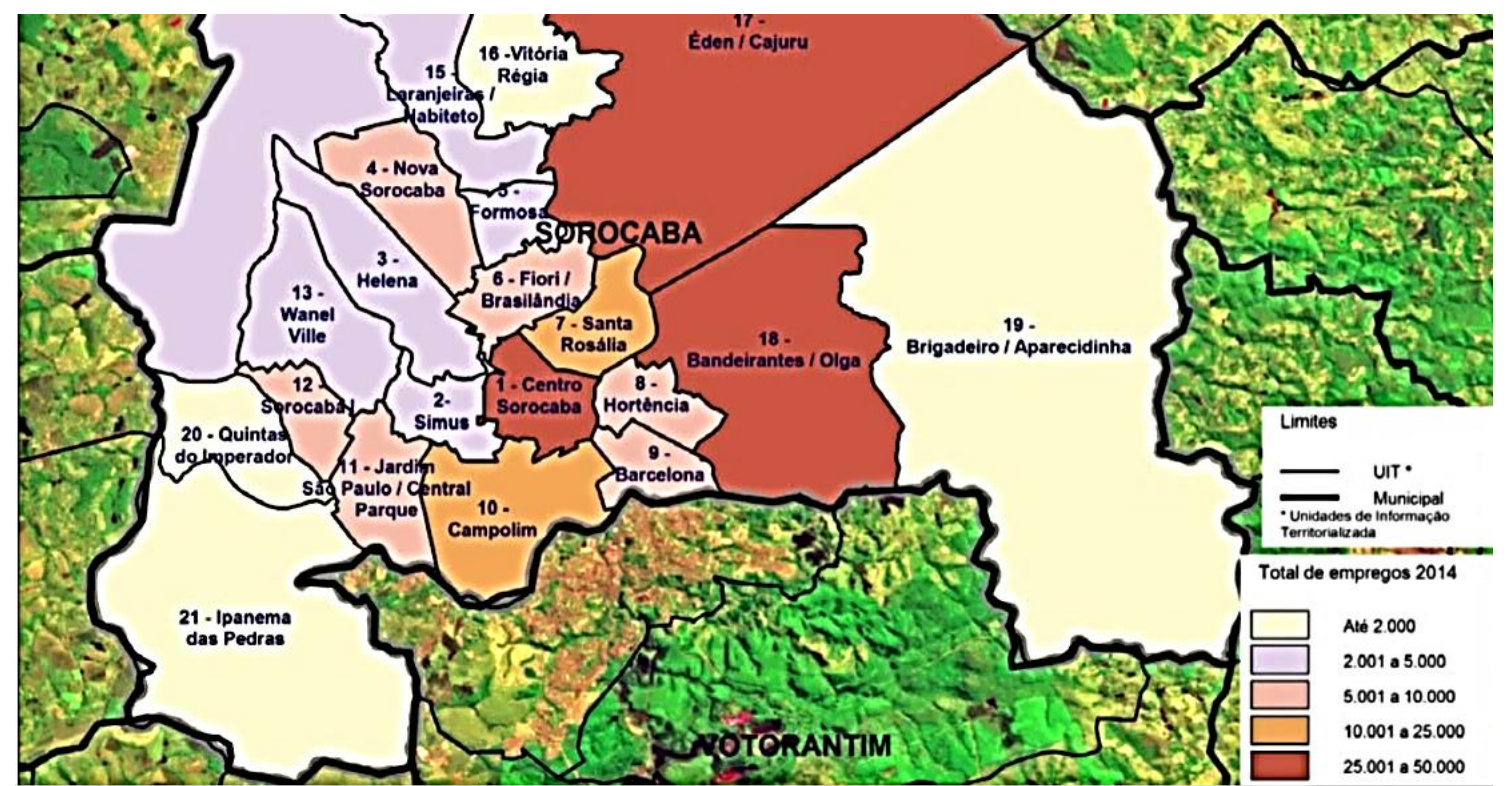

Fonte: EMPLASA, 2017. 


\subsection{Mobilidade urbana na RMS / RRT}

Neste item, trataremos do sistema viário mais utilizado desde o séc. XIX até atualmente, iniciando com: 1) Ferrovia (final do séc. XIX até o presente); 2) Estrada de rodagem São PauloCuritiba (PR), do início do séc. XX até hoje, já transformada em RRT, pertencente ao Sistema CasteloRaposo, e 3) Pendularidade da população PEA da RMS, na última década e 4) Informações complementares às características interessantes ao tema da dinâmica metropolitana da RMS.

\section{Ferrovia - Estrada de Ferro Sorocabana (1872 - até o presente)}

“(...) mas só em 1825 com a invenção da locomotiva de Stephenson, se iniciou 0 desenvolvimento das estradas de ferro, marcando assim decisivamente os decênios seguintes." (BENEVOLO, 1987 apud ABIKO; ALMEIDA; BARREIROS, 1995, p.38).

Finalizando-se o ciclo tropeiro na região sorocabana, e já com indústrias têxteis instaladas, em Sorocaba o interior paulista necessitava de escoar com maior velocidade e maior capacidade de carga os produtos que começam a ser industrializados. A São Paulo Railway não quis estender um ramal até o Município de Sorocaba (pois não havia produção cafeeira volumosa). Na região (principalmente em Sorocaba, Votorantim e Salto de Pirapora) havia produção têxtil e de calcário, cujos empreendedores poderiam se beneficiar das entregas mais rápidas e de maior capacidade de carga que a ferrovia proporcionava, além de outras benesses que poderiam advir deste então novo sistema de transporte:

\footnotetext{
"The decision to build the railway, where lines are fixed in certain locations, is deeply political in the sense of transferring / reshuffling power relationships in the city. It could be done as a top-down intervention (let's call it 'urbs' tradition'), or as an outcome of the participatory planning process ('polis' tradition'). In any case, the decision to build the railway reshuffles local power structure; it benefits some groups of residents by providing better access, by locating stops close to certain businesses, by increasing the value of land." (s/d).
}

Em Sorocaba foi iniciada a construção, no final do século XIX, da Estrada de Ferro Sorocabana (EFS), por Matheus Maylasky e Roberto Dias Baptista, empresário sorocabano (Fig. 14):

"Exatamente às 13 horas do dia 13 de junho de 1872 um grupo de homens munidos de pás e enxadas iniciava, no centro de Sorocaba, à margem do Córrego Supiriri, a construção da Estrada de Ferro Sorocabana (EFS). A ferrovia, projetada e bancada por empresários, teve o trecho entre 
Sorocaba e São Paulo concluído em três anos, um feito até para os dias atuais." (O Estado de São Paulo, 13/6/20028).

Figura 14 - Mapa do ramal da Estrada de Ferro Sorocabana (linha em verde e ampliação em tracejado roxo).

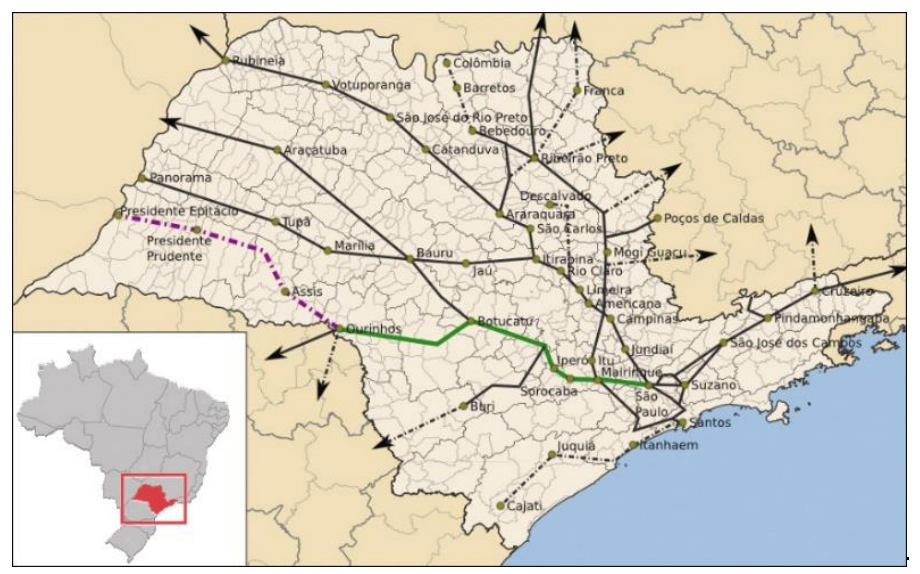

Disponível em:

https://commons.wikimedia.org/wiki/File:Mapa_Sao_Paulo_Sorocabana.png\#/media/File:Mapa_Sao_P aulo_Sorocabana.png, acesso em junho de 2015.

A construção da linha do tronco ferroviário de 110 km de extensão, ligando Sorocaba à São Paulo, teve seu trecho inicial inaugurado em 10/julho/1875, com as seguintes estações: Sorocaba, Piragibu' ${ }^{9}$ Pantojo ${ }^{10}$, São Roque, Baruery, Barra Funda e São Paulo (atual Júlio Prestes). Na estação São Paulo havia armazens de distribuição e uma linha que se conectava à ferrovia São Paulo Railways, escoando os produtos de Sorocaba e região até o Porto de Santos.

A Estrada de Ferro Sorocabana ajudou a interiorizar a população paulista, funcionando como transporte de cargas e de passageiros até seu declínio, devido ao incentivo dado às rodovias e aos veículos automotivos, principalmente após os anos 50 , com a instalação das indústrias automotivas. 0 transporte de passageiros da ferrovia foi utilizado até meados da década de 90, e em 2000, foi desativado. Outra era, a exemplo do tropeirismo, se fora. Os serviços disponibilizados foram diminuindo até só sobrarem os de carga, que depois foram privatizados:

"Em 1998 a FEPASA é transferida para a Rede Ferroviária Federal S.A. R.F.F.S.A., como parte do pagamento de uma enorme dívida do Banco do Estado de São Paulo - BANESPA junto ao governo federal. A seguir a empresa é privatizada, sendo substituída pela Ferrovias Bandeirantes FERROBAN no início de 1999. De imediato a nova empresa suspende toda

\footnotetext{
${ }^{8}$ Memória de ferroviário resgata tempos áureos da Sorocabana - Com trens parados e estações desativadas, linha férrea completa 130 anos de existência. Jornal O Estado de São Paulo, 13/6/2002.

${ }^{9}$ Atual estação de Brigadeiro Tobias.

${ }^{10}$ Atual estação de Mairinque.
} 
a eletrificação nas linhas da FEPASA, inclusive nos trechos da antiga E.F. Sorocabana." (s/d).

Além do modal rodoviário e aeroviário, a mobilidade na RM Sorocaba é complementada pelo modal ferroviário de cargas, operada pela RUMO (antiga ALLMS - América Latina Logística - Malha Sul S/A), importante meio de transporte para o escoamento de minérios e outros produtos no eixo Santos / Paraná / Santa Catarina / Rio Grande do Sul e Mato Grosso do Sul / Santos; e o transporte de cargas no Estado é regionalizado, sendo que cerca de 50\% da demanda de transporte está concentrada na MMP constituída pelo quadrilátero Sorocaba, Campinas, Santos e São José dos Campos (SÃO PAULO, 2009). Não há transporte público ferroviário na RMS.

Atualmente há um projeto mencionado no Plano Diretor de Mobilidade de Sorocaba, (aprovado em 2015), que dispõe sobre uma ligação regional de São Paulo a Sorocaba por um ramal da CPTM, a exemplo do proposto para ligar São Paulo a Jundiaí, Santos e São José dos Campos. Este ramal ferroviário tem previsão de saída da estação da Água Branca, em São Paulo, pararia em São Roque, e em Sorocaba, sendo que está para ser decidido o local de uma nova estação intermodal: poderia ser em Brigadeiro Tobias, distrito de Sorocaba na parte leste do território, cheio de mananciais que abastecem o córrego Pirajibu, afluente do Rio Sorocaba pela margem direita, ou em local da Rodovia Celso Charuri, que interliga a Rod. Castelo Branco à Rod. Raposo Tavares, ou no agora vazio urbano do centro, onde estão as antigas instalações da FEPASA, atual RUMO e antiga EFS.

Para fins de informação quanto ao diagnóstico do modal ferroviário de São Paulo a Sorocaba, como pretende-se utilizar a linha ferroviária já existente da CPTM, de Itapevi a Sorocaba - com a intenção da criação de novas estações em São Roque e em Sorocaba (a ser decidido entre as localidades de Brigadeiro Tobias, Rod. Celso Charuri e o vazio urbano da própria estação ferroviária antiga, no centro de Sorocaba - estão a seguir as ideias oriundas do caderno de propostas do governo do ESP, relativo aos Trens Regionais Paulistas do início do século XXI (Fig. 15).

Embora proposto, não há previsão de inauguração deste ramal da CPTM para Sorocaba-São Paulo nos próximos 2 anos, pois a prioridade do governo do Estado de São Paulo é atender ao ramal de São Paulo-Jundiaí (com expressivo carregamento rodoviário nos sistemas Anhanguera e Bandeirantes, na chegada à capital e retorno a Campinas e Jundiaí) e a Santos, pelas questões de logística ao Porto de Santos. Na figura a seguir, pela previsão de demanda e carregamento para 2020, pode-se perceber que a demanda de maior carregamento é no sistema de mobilidade urbana é entre São Paulo-Jundiaí, no caso prioridade do governo estadual paulista (Fig. 16). 
Figura 15 - Traçado inicial Proposta do Trem Regional Sorocaba - São Paulo.

Trens Regionais | Ligação São Paulo - Sorocaba

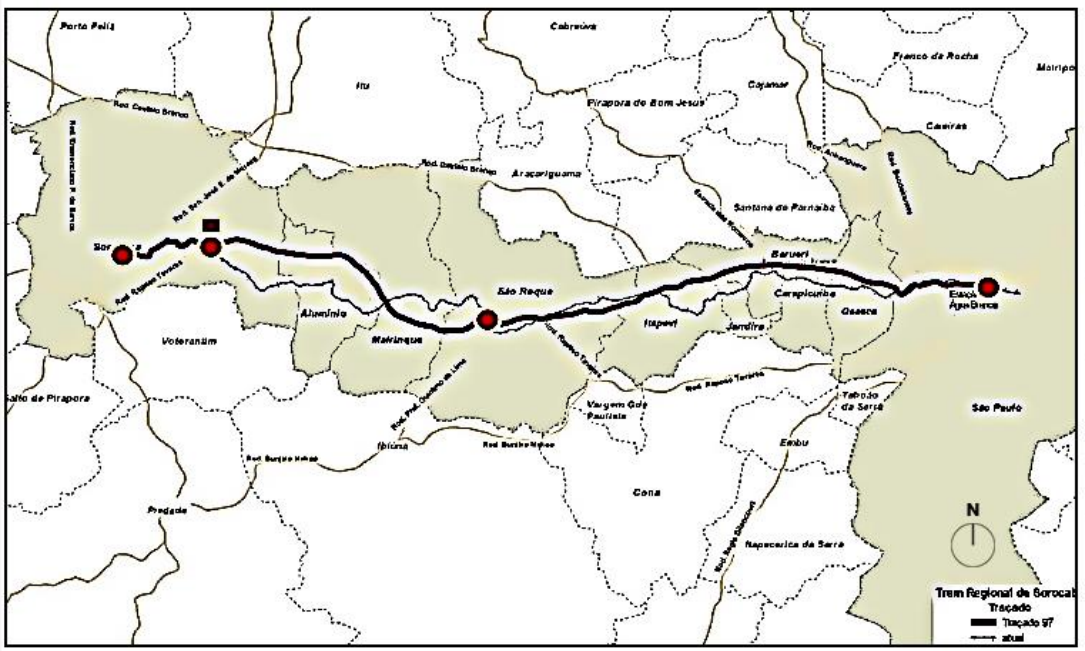

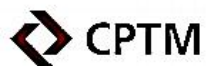

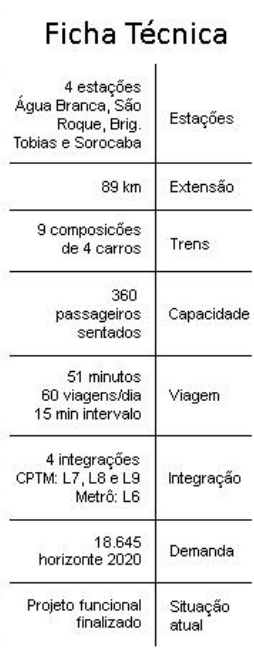

Fonte: CPTM, 2014. Fonte: http://www.stm.sp.gov.br/images/stories/regionais23dez.pdf, acesso em 30 de junho de 2014. Retrabalhado por Amanda Dias, 2018.

Figura 16 - Rede Proposta e Demanda - Carregamento - Horizonte 2020.

Rede proposta e demanda | Carregamento - Horizonte 2020

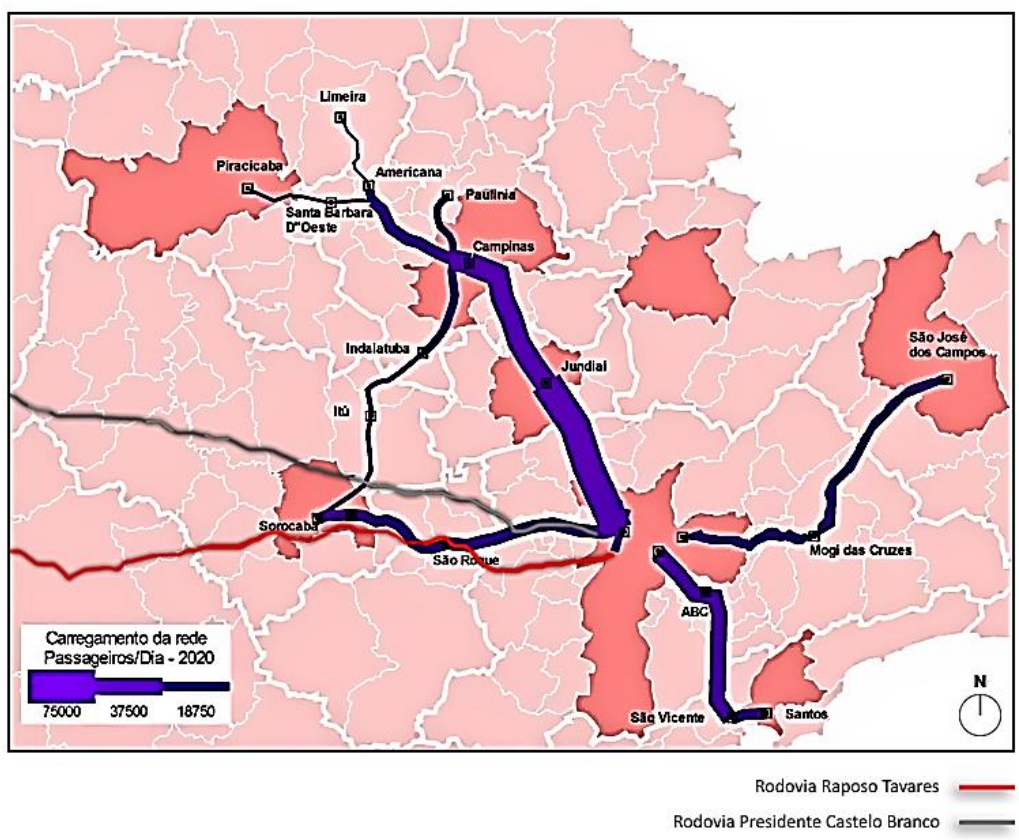

Fonte: http://www.stm.sp.gov.br/images/stories/publicacoes/STM_Trens_Regionais.pdf (STM SP, 2012). Retrabalhado por Amanda Dias, 2018. 


\title{
Sistema viário da RMS
}

\begin{abstract}
Segundo a EMPLASA (2017):
"O sistema viário na RMS é formado por uma malha estruturada por três eixos rodoviários radiais paralelos, muito importantes para a conexão do seu território à Região Metropolitana de São Paulo (RMSP) e à Aglomeração Urbana de Jundiaí (AUJ), no sentido oeste-leste, e com os demais municípios do Estado, no sentido leste-oeste. $01^{\circ}$ eixo é a SP-300, na porção norte da região, que tem início em Jundiaí e segue até a divisa com o Estado do Mato Grasso do Sul. Esta rodovia interliga a RMS ao complexo rodoviário Anhanguera-Bandeirantes. $02^{\circ}$ eixo estruturador, também localizado na parte norte da região, é o da SP280, denominada Rodovia Presidente Castello Branco12, que interliga a RMS à RMSP, no sentido oeste-leste, e aos demais municípios do Estado, no sentido lesteoeste. $03^{\circ}$ eixo é formado pela SP-270, denominada Rodovia Raposo Tavares. Inicia-se na zona oeste do município de São Paulo, sendo uma das vias de ligação entre as regiões metropolitanas de São Paulo e de Sorocaba." (EMPLASA, 2017, p. 52-53).
\end{abstract}

O sistema viário principal da RMS atende atualmente 27 municípios, agrupados em três subregiões. Sobre a RMS, a EMPLASA (2017) menciona:

"Seus mais de 2 milhões de habitantes representam 4,6\% da população estadual. A região gera cerca de $4,25 \%$ do Produto Interno Bruto (PIB) paulista.

Está estrategicamente situada entre duas importantes regiões metropolitanas do País - São Paulo (SP) e Curitiba (PR) -, além de manter limite territorial e processo de conurbação com a Região Metropolitana de Campinas. (...) Doze de seus municípios estão localizados no eixo das Rodovias Castello Branco e/ou Raposo Tavares, com economias baseadas em atividades industriais. Destes, seis apresentam especial relevância na economia paulista: Sorocaba, Itu, Itapetininga, Salto, Cerquilho e Votorantim. É a maior produtora agrícola entre as regiões metropolitanas do Estado de São Paulo, com elevada diversidade. (...)"11 (EMPLASA, 2017).

\footnotetext{
11 In: https://www.emplasa.sp.gov.br/RMS, acesso em setembro de 2017.
} 
Figura 17 - Sistema Urbano da RM Sorocaba e principais rodovias.

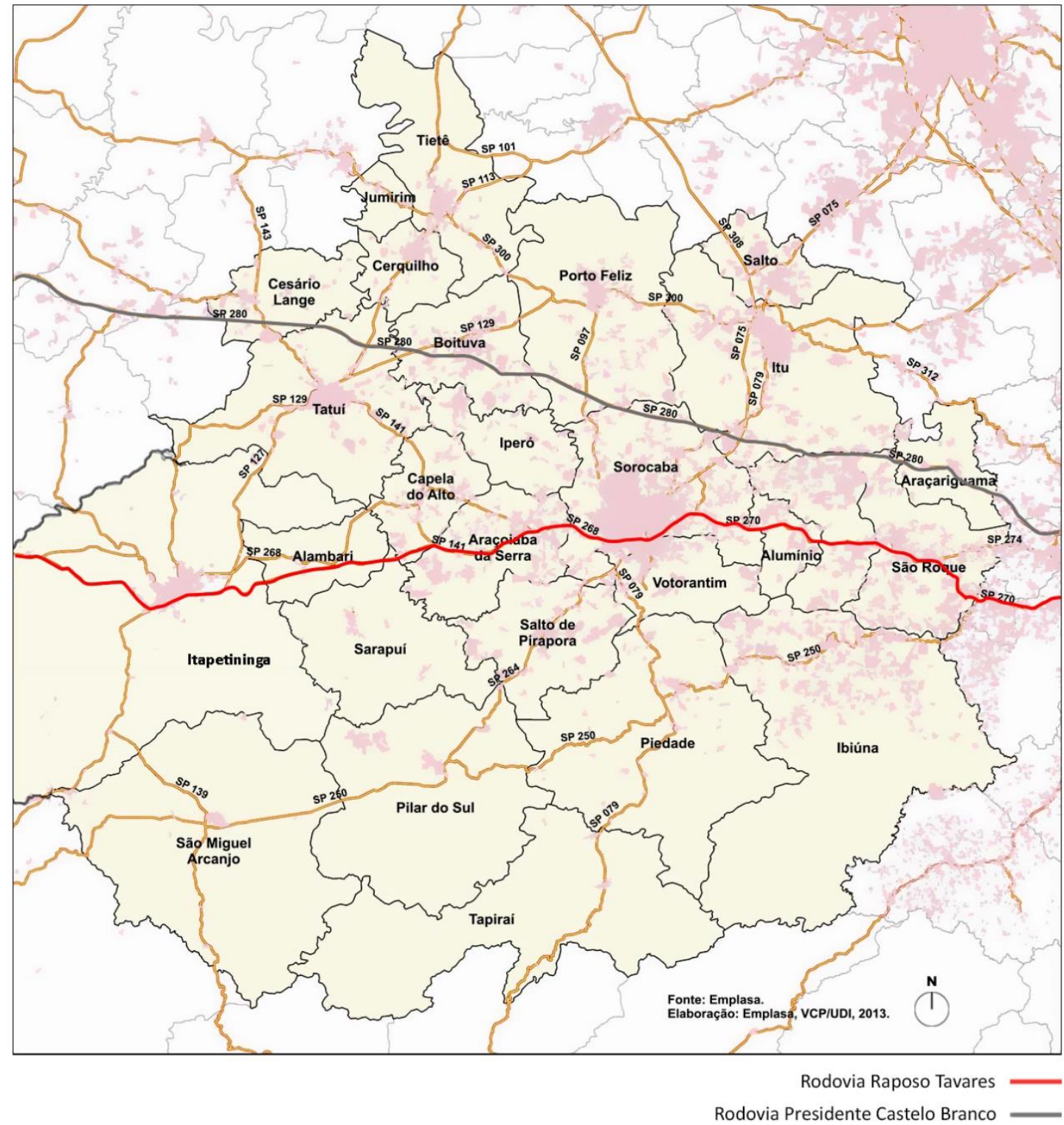

Fonte: EMPLASA, 2013. Retrabalhado por Amanda Dias, 2018.

O sistema viário principal da RMS está interligado mais proximamente ao da RMSP e à da RMC em triangulação, (Fig. 18) formado por uma malha de rodovias estaduais e estradas municipais estruturada por três eixos rodoviários, muito importantes para a conexão do seu território à Região Metropolitana de São Paulo (RMSP), à Aglomeração Urbana de Jundiaí: SP 300 (Marechal Rondon) que a interliga ao complexo Anhanguera-Bandeirantes à RMC; a ao Sistema Castelo-Raposo, pela SP 280 (Castello Branco) e SP 270 (Raposo Tavares) que por sua vez, através da SP 021 (Rodoanel Mário Covas), liga a região da RMS ao complexo rodoviário Anchieta-Imigrantes e ao Porto de Santos.

A figura 18 mapeia os eixos rodoviários que conectam os núcleos urbanos da Região 
Metropolitana de Sorocaba entre si e com as regiões metropolitanas de Campinas e São Paulo além da Aglomeração Urbana de Jundiaí.

Figura 18 - Ligações rodoviárias entre Regiões Metropolitanas do Estado de São Paulo (destaque para o Sistema Castelo Branco - Raposo Tavares, ligando a RMSP a RMS).

Fonte: EMPLASA, 2017.

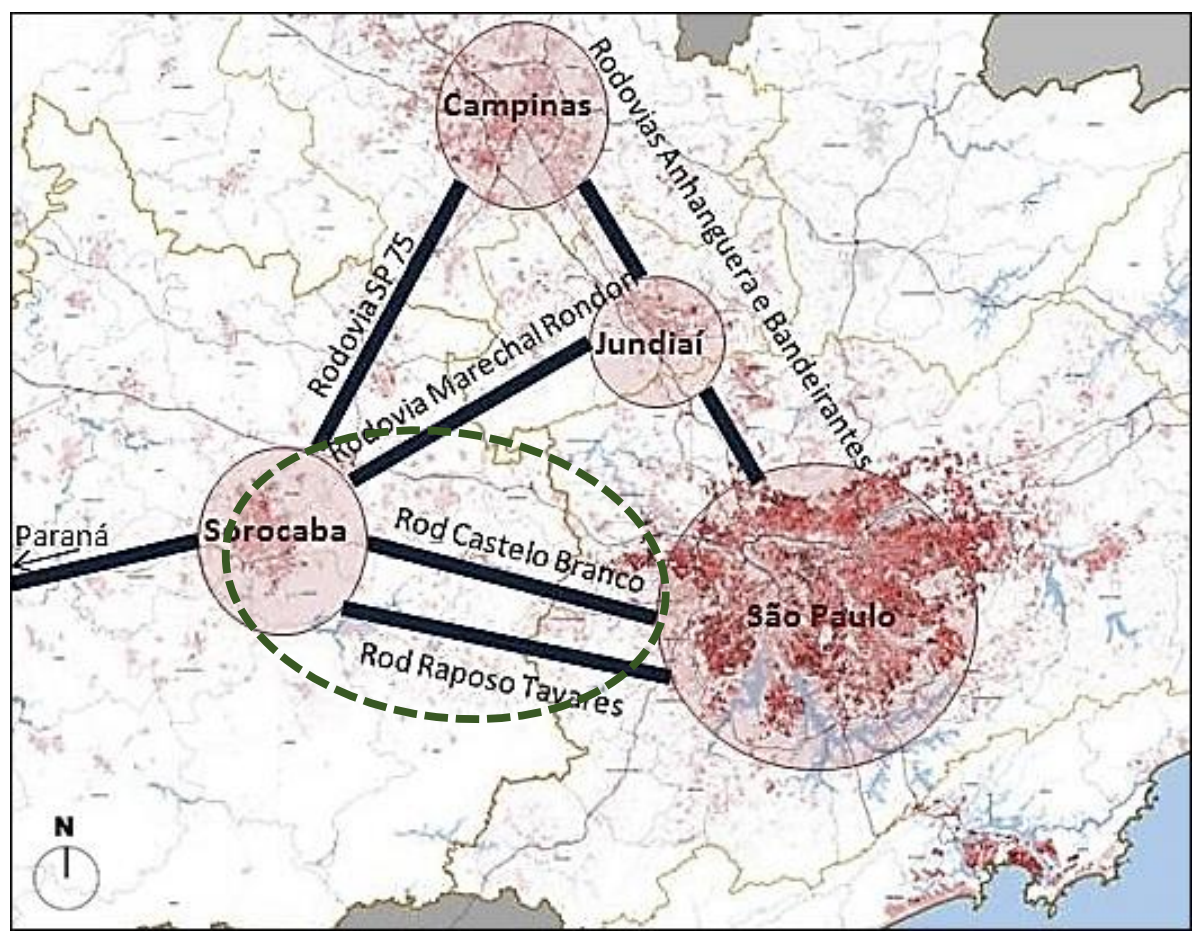

Estas rodovias favorecem o acesso a Sorocaba, município sede da RMS, que passou a ser um polo atrativo para novas empresas ou pátios industriais de empresas com sede na capital paulista, além das populações que migraram de outras localidades para se instalar e morar no município (REIS, 2009, 2010).

As conexões rodoviárias, especialmente as feitas pelas rodovias Castelo Branco e Raposo Tavares (Sistema Castelo-Raposo), fortalecem atualmente a formação de um vetor de desenvolvimento, chamado de Vetor Sorocaba, que foi estudado pelo Plano de Ação da MacroMetrópole Paulista (PAM, 2017), considerando-se a importância econômica da região metropolitana de Sorocaba (Fig. 19). 
Figura 19 - Vetor Sorocaba, no Eixo Sorocaba- São Paulo.

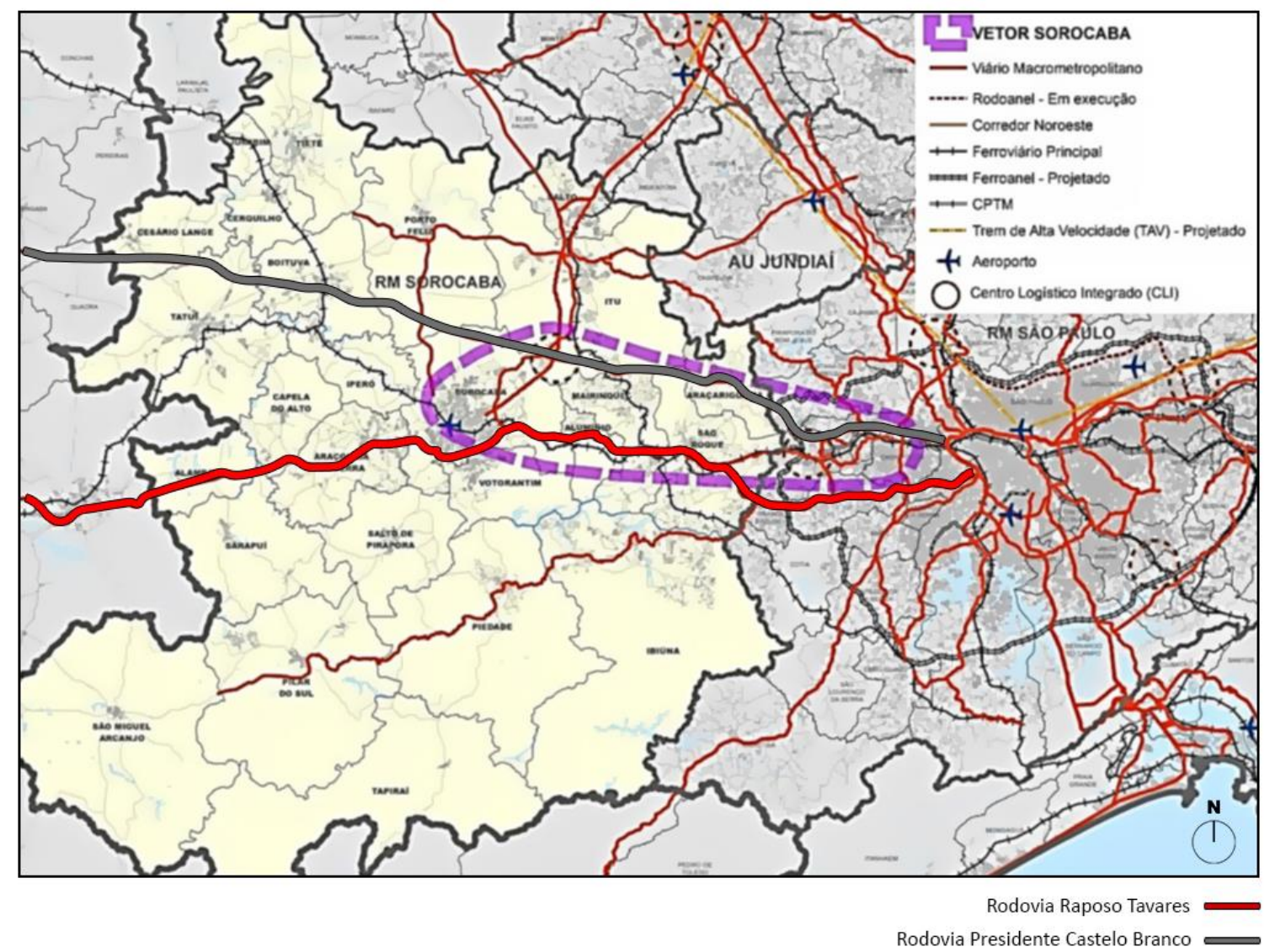

Fonte: PAM, 2014. Retrabalhado por Amanda Dias, 2018.

Sobre o sistema viário da RMS, o panorama enunciado pela EMPLASA para se fazer o PDUI12 da RMS com relação aos eixos estruturantes rodoviários é:

"Os eixos de circulação estão na base do desenvolvimento econômico da região, sendo a porção do território a norte do eixo da Rodovia Raposo Tavares, a que apresenta maior densidade da malha viária, favorecendo a localização das atividades industriais e de logística (armazenamento e transporte) que se estabelecem, preferencialmente, ao longo dos eixos rodoviários, também nos dias atuais.

Na porção sul da região (ao sul do eixo da Rodovia Raposo Tavares) as rodovias SP 079; SP 127; SP 139; SP 250 e SP 254 conectam os municípios da RMS cuja atividade econômica principal é a agricultura, (com exceção de Votorantim); e garantem o escoamento de sua produção, bastante expressiva e diversificada, destinada principalmente às centrais de abastecimento de São Paulo, Campinas e Sorocaba." (EMPLASA, 2017, p. $62)$.

\footnotetext{
12 Os PDUls das RMs seguiram então o calendário do Estatuto da Metrópole, que estabelecia prazo máximo para sua realização em três anos (no caso da RM Sorocaba, até 12/01/2018; o prazo foi estendido, por decreto presidencial, para $31 /$ dez/2021.
} 
Por isto, o próximo tópico do sistema viário principal da RMS é sobre o Sistema CasteloRaposo (Fig. 20).

\section{Sistema Castelo - Raposo}

Atualmente sob concessão operada pela CCR Viaoeste, o sistema Castelo Raposo é um dos mais importantes do ESP, pois liga a RMSP ao oeste do interior de São Paulo; e em conexão, pelo Rodoanel Mario Covas, com outras regiões do País (Fig. 20).

Figura 20 - Mapa viário Sistema Castelo Branco - Raposo Tavares.

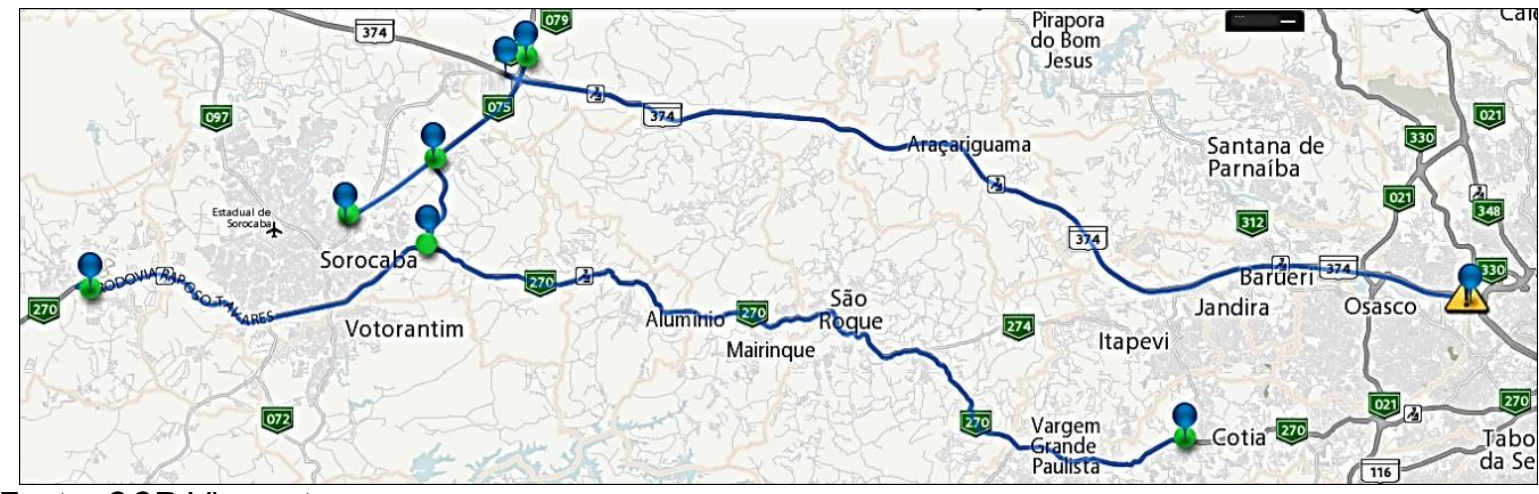

Fonte: CCR Via oeste.

http://www.viaoeste.com.br/resources/files/maps/mapa_viaoeste_rodoanel_2014.pdf, acesso em julho/2017.

Fazem parte do Sistema Castelo Branco - Raposo Tavares as seguintes rodovias:

I. SP-280 - Rodovia Castelo Branco do km 13,7 Osasco ao km 79,38 em Itu;

II. SP-270 - Rodovia Raposo Tavares do km 34,0 em Cotia ao km 115,5 em Araçoiaba da Serra - exceto os perímetros urbanos localizados entre o km 58,5 ao km 53,0 (São Roque) e 0 km 87,2 ao km 89,3 (Brigadeiro Tobias);

III. SP-75 - Rodovia Sen. José Ermírio de Morais, (também conhecida como Castelinho pela população local) do km 0,0 ao km 15,0;

IV. SP-091/270 - Rodovia Dr. Celso Charuri do $\mathrm{km} \mathrm{0,0} \mathrm{ao} \mathrm{km} \mathrm{6,20,} \mathrm{interligando} \mathrm{a} \mathrm{Rodovia}$ Castelo Branco com a Rodovia Raposo Tavares, sendo distribuídos da seguinte maneira no município polo da RMS, Sorocaba (Fig. 21): 
Figura 21 - Sistema Castelo Branco - Raposo Tavares e interligações, no Município de Sorocaba, SP.

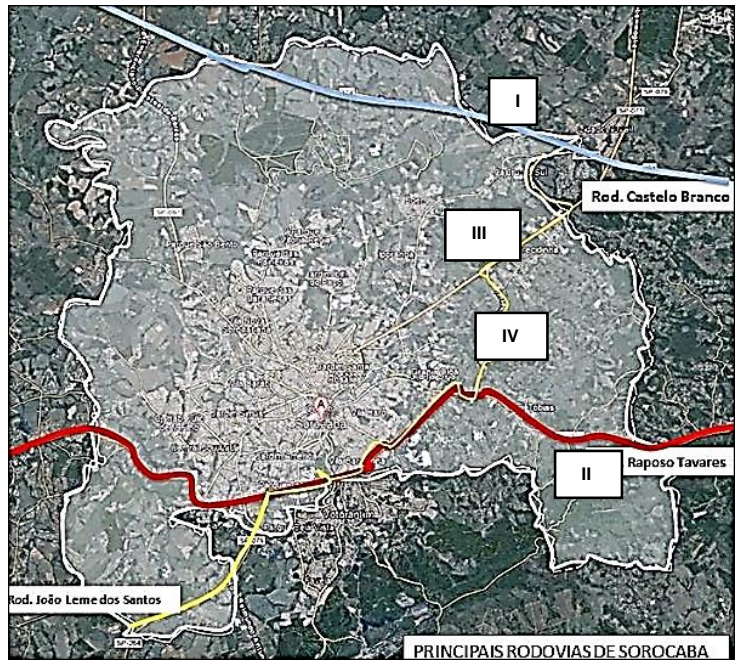

Fonte: CAMARGO, 2015, modificado pela autora (2017).

A Região Metropolitana de Sorocaba apresenta funcionalidades urbanas que se articulam em um território diferenciado por complementaridade e coesão territorial, devido às duas unidades territoriais consideradas a partir de dois eixos urbanos (EMPLASA, 2013). São elas (Tabela 9): a) Eixo Urbano Industrial Castello Branco (e sub-eixo Rod. Santos Dumont): Municípios: Araçariguama, Iperó, Sorocaba, Boituva, Cerquilho, Cesário Lange, Jumirim, Itu, Porto Feliz, Salto, Tatuí e Tietê; b) Eixo Verde Raposo Tavares - APA's Jurupará e Itupararanga: Municípios: Alambari, Alumínio, Araçoiaba da Serra, Capela do Alto, Ibiúna, Mairinque, Piedade, Pilar do Sul, Salto de Pirapora, São Miguel Arcanjo, São Roque, Sarapuí, Tapiraí e Votorantim.

Tabela 9 - Unidades Territoriais por Eixo Rodoviário da RM Sorocaba.

\begin{tabular}{|c|c|c|c|c|c|}
\hline Unidades Territoriais & $\begin{array}{c}\text { Número } \\
\text { de } \\
\text { Municípios }\end{array}$ & $\begin{array}{c}\text { População } \\
2010\end{array}$ & Área $\left(\mathrm{km}^{2}\right)$ & $\begin{array}{c}\text { Densidade } \\
\left(\mathrm{km}^{2}\right)\end{array}$ & $\begin{array}{c}\text { PIB } 2010 \\
\text { (milhöes de } \\
\text { reais) }\end{array}$ \\
\hline \multicolumn{6}{|l|}{ Eixo Raposo Tavares - APAs } \\
\hline $\begin{array}{l}\text { Alambari, Alumínio, Ara çoia ba da Serra, } \\
\text { Capela do Alto, Ibiúna, Mairinque, } \\
\text { Pieda de, Pilar do Sul, Sa Ito de Pira pora, } \\
\text { Sa rapuí, São Miguel Arcanjo, São Roque, } \\
\text { Tapiraí, Votorantim }\end{array}$ & 14 & 535.794 & $6.174,38$ & 86,78 & $9.738,92$ \\
\hline \multicolumn{6}{|l|}{ Eixo Castello Branco - Industrial } \\
\hline $\begin{array}{l}\text { Araça rigua ma, I peró, Soroca ba, Boituva, } \\
\text { Cerquil ho, Cesá rio Lange, Jumi rim, Itu, } \\
\text { Porto Feliz, Sal to, Ta tuí e Tie tê }\end{array}$ & 12 & 1.190 .991 & $3.646,87$ & 326,58 & $33.211,64$ \\
\hline RM de Sorocaba & 26 & $\mathbf{1 . 7 2 6 . 7 8 5}$ & $9.821,25$ & 175,82 & $42.950,56$ \\
\hline
\end{tabular}

Fonte: EMPLASA, 2013. 
Estes dois eixos rodoviários - Rod. Presidente Castello Branco (SP 280), Raposo Tavares (SP270/SP079) - estão em localização estratégica: entre a Região Metropolitana de São Paulo e o Estado do Paraná, interligando importantes sistemas urbanos do País. A importância desses eixos rodoviários é regional, nacional e internacional: faz conexões com a RM de São Paulo - pela Rod. Presidente Castelo Branco - e com a Região Metropolitana de Campinas - Rod. Santos Dumont.

A RM Sorocaba têm, portanto, um padrão demográfico dinâmico - com concentração da população e da riqueza no Eixo da rodovia Castelo Branco e da rodovia Santos Dumont - somando investimentos públicos, privados e transnacionais, caracterizando o Corredor Asiático (Campinas, Itu a Sorocaba- Porto Feliz), pelas Rodovias Santos Dumont e Castelo Branco.

Existem pedágios desde 2008 no sentido Capital-Interior; a cobrança de pedágio é feita nas praças de São Roque, Araçoiaba da Serra e Presidente Bernardes (no trecho RMS). Já no sentido Interior-Capital a cobrança é realizada em Alambari, Araçoiaba da Serra e Alumínio. Nas praças de Itapetininga, Assis e Presidente Prudente, a cobrança é executada nos dois sentidos. Em termos de arrecadação, o trecho da RMS do Sistema Castelo-Raposo é um dos mais rentáveis considerando-se os investimentos realizados pela concessionária. No feriado do Carnaval de 2017, mesmo em cenário de crise econômica nacional, cerca de 720 mil veículos passaram pelo sistema, que é pedagiado.

Figura 22 - Trecho da Rod. Raposo Tavares, no Município de São Paulo.

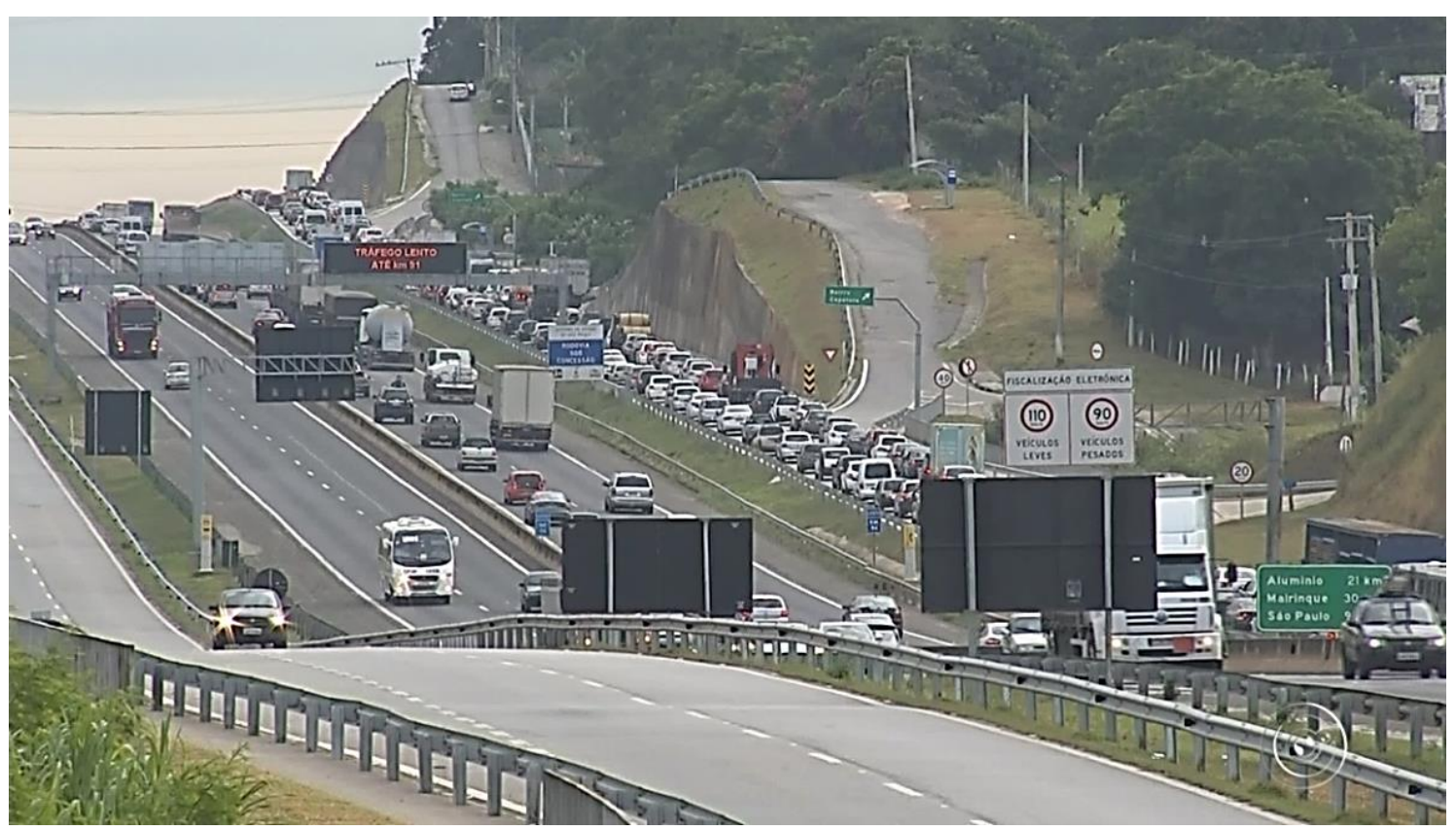

Fonte: GLOBO NEWS, https://s01.video.glbimg.com/x720/6532768.jpg, acesso em 27/02/2018. 


\section{Pendularidade da PEA na RMS a partir do séc. XXI}

A descentralização industrial da Capital para o interior iniciada pelo processo da criação na segunda metade do século XX, das rodovias SP 270- Raposo Tavares em 1954, e SP 280 - Castelo Branco em 1964; (e também das rod. Anhanguera e Bandeirantes) levou ao processo de mudança de parte da população PEA da região metropolitana de São Paulo para algumas cidades do interior, como descrito no processo de dispersão urbana pelo prof. Nestor Reis $(2009,2010)$, que colaboraram em parte para o aumento de área urbanizada, e em alguns municípios para a conurbação urbana entre diversas cidades da RMS (ex.: Sorocaba / Porto Feliz / Itu, Alumínio, Votorantim, Araçoiaba da Serra, Iperó - no destaque em amarelo). Isto reconfigurou o mapa de arranjos populacionais no território paulista.

No início do séc. XXI, políticas públicas de ampliação de crédito ao consumidor final e 0 incentivo a bens de consumo no período do governo petista (2001-2015) através da maior oferta de crédito, possibilitaram a aquisição de inúmeros bens de consumo antes inacessíveis à camada menos abastada da população (IPEA, 2015). Com o aumento da atividade econômica notou-se que a pendularidade da PEA da RMS, aumentou em termos intermunicipais e interestaduais na MMP (EMPLASA, 2010) (Fig. 23), com destaque para a RMS; e também em suas interações com a RMSP, RMC, e demais estados do País. A RMS também ainda vem absorvendo parte da população e dos empregos da Região Metropolitana de São Paulo (EMPLASA, 2017, p.23).

No Estado de São Paulo, na Macrometrópole Paulista, na RMSP e RMS, a RRT e a RCB tem importância fundamental para o deslocamento da população e para o escoamento da produção agrícola e de outros produtos para a capital, e vice-versa; e a partir dela, para outras regiões do Estado e do País. Pela figura 23, pode-se notar que desde 2010 há um fluxo inter-metropolitano de mais de 10 mil pessoas circulando entre a RMSP e RMS, e mais de 10 mil pessoas circulando entre a RMC e a RMS, além desta enviar de 5 a 10 mil para outras cidades do Estado de São Paulo e mais de 10 mil para os outros estados brasileiros.

Segundo o relatório da EMPLASA (2014), no total, aproximadamente 111 mil pessoas em 2010 participavam do movimento pendular na RM Sorocaba:

"Grandes fluxos de pessoas maiores de 15 anos que trabalham ou estudam fora de seu município de residência são decorrentes de processos da estruturação urbana e dos modos de organização social da vida cotidiana; relaciona-se moradia a estas atividades essenciais, como trabalhar e estudar. Tais movimentos estão em sintonia direta com a complexidade e intensidade dos processos de urbanização, crescimeno demográfico e fatores socioeconômicos, que implicam nas relações entre municípios de 
uma região, e consequentemente, no dinamismo intra-regional." (EMPLASA, 2014).

A seguir, ilustrações sobre os dados de pendularidade da PEA na RMS: a) Fluxo pendular intermunicipal, deslocamentos por motivos de trabalho e estudo de seus municípios: Fig. 25 b) Principais Movimentos Pendulares Intermunicipais a Trabalho e Estudo na RMS: Fig. 24; c) Fluxo Pendular Intermunicipal, segundo municípios de origem selecionados: Deslocamentos por motivo de trabalho e estudo: Fig. 26.

Figura 23 - Principais fluxos pendulares na MMP (2010).

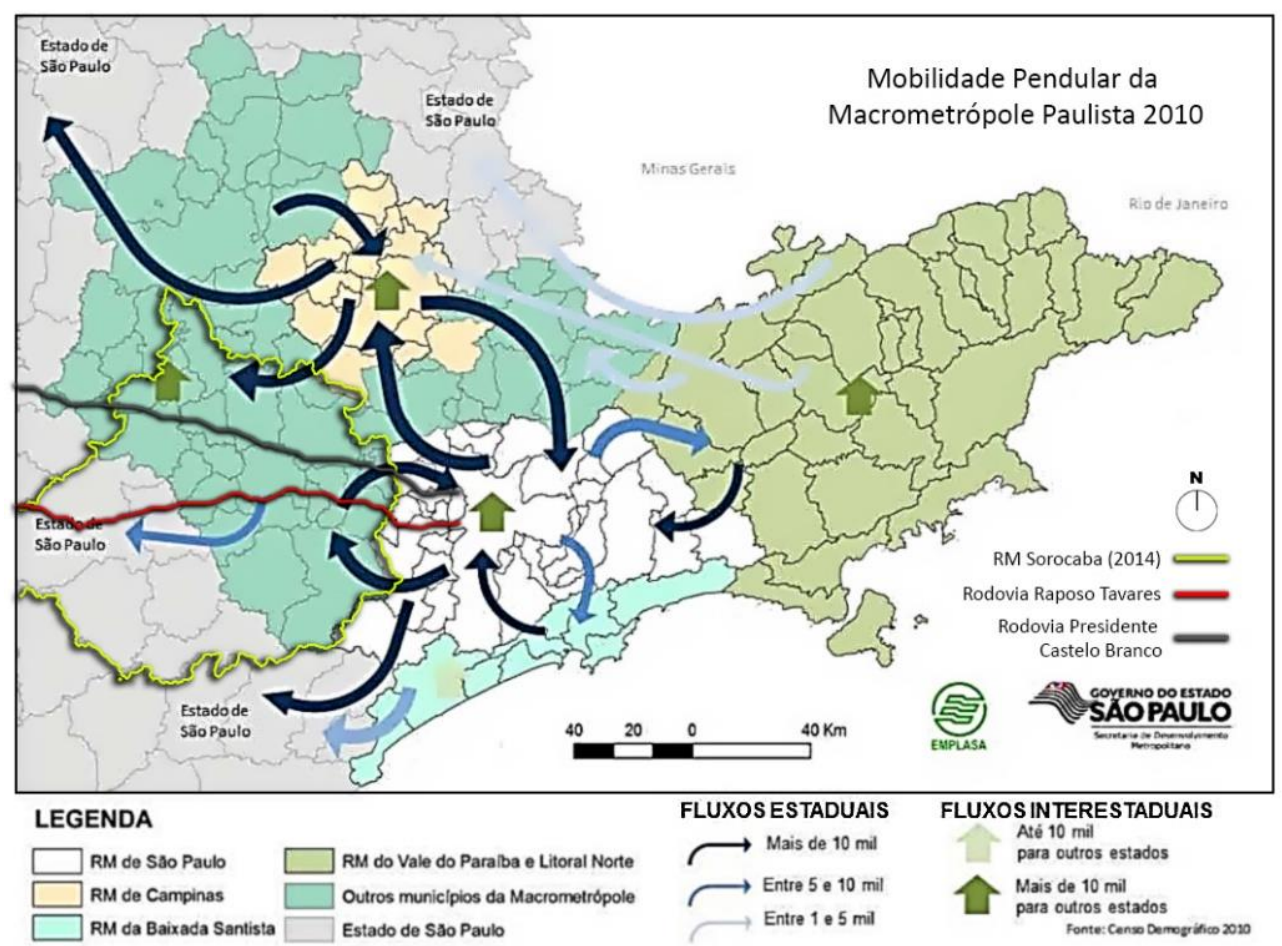

Fonte: https://demografiaunicamp.files.wordpress.com/2013/03/mapa02_jm.jpg, acesso em julho/2017. Retrabalhado por Amanda Dias, 2018. 
Figura 24 - Principais Movimentos Pendulares Intermunicipais a Trabalho e Estudo na RMS.

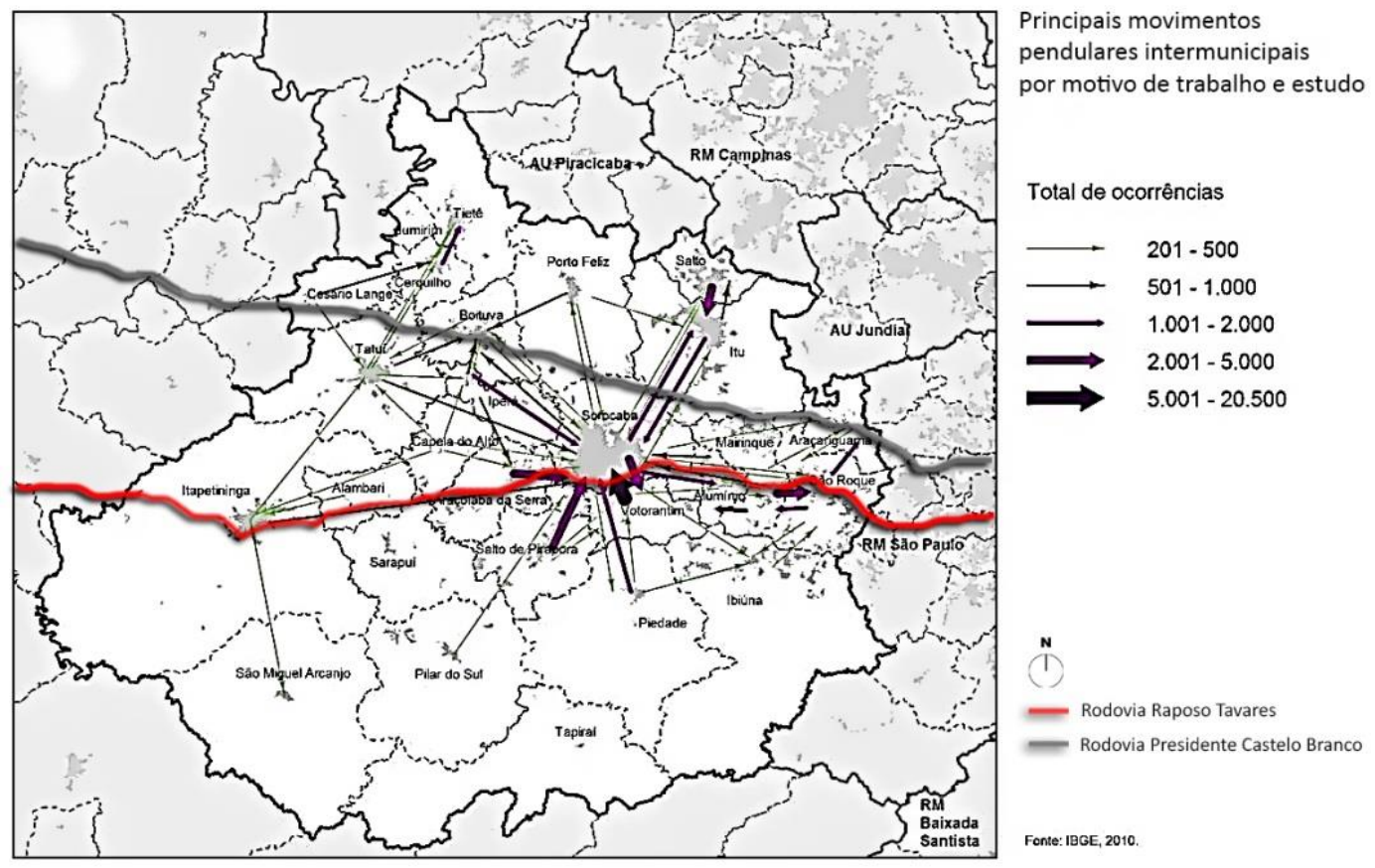

Fonte: EMPLASA, 2017. Retrabalhado por Amanda Dias, 2018.

Figura 25 - Fluxo Pendular Intermunicipal, segundo municípios de origem: Deslocamentos por motivo de trabalho e estudo.

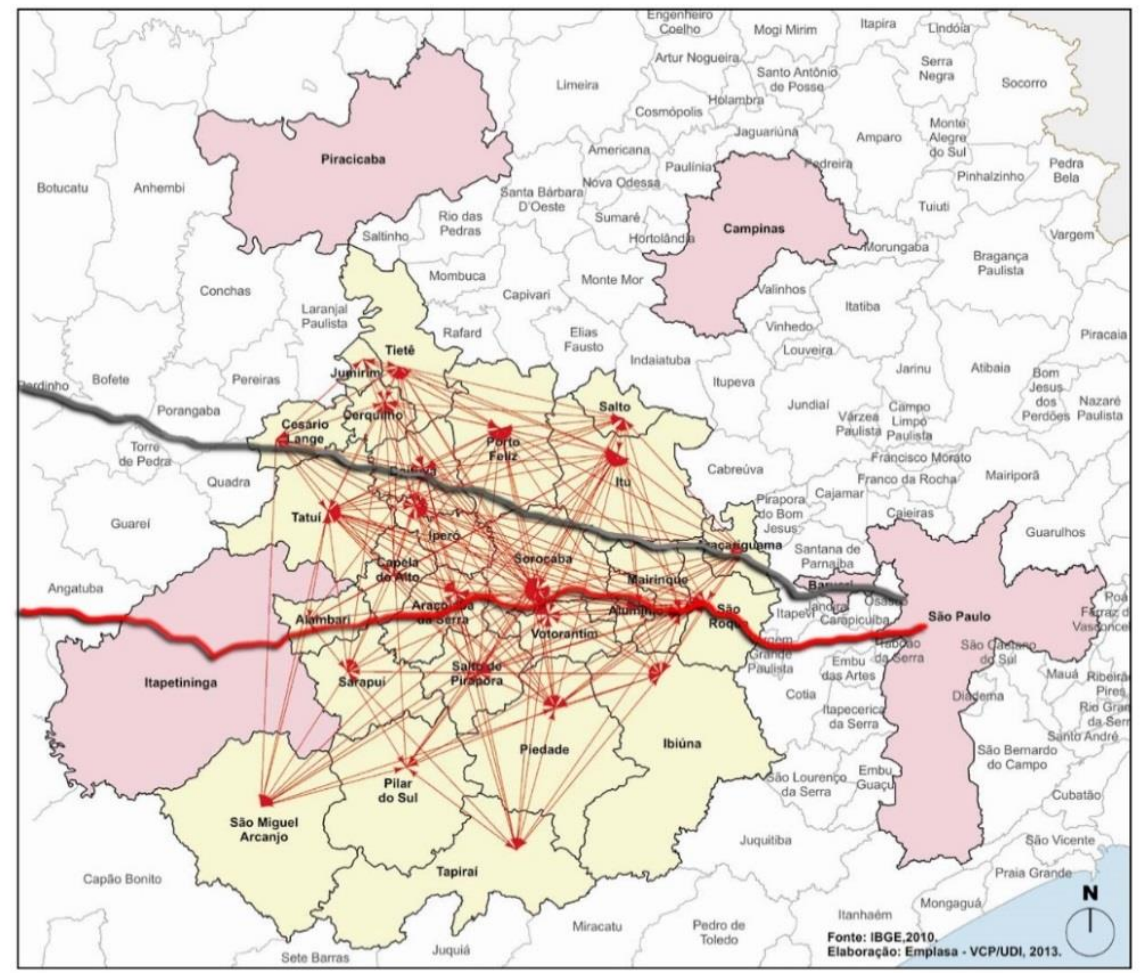

Rodovia Raposo Tavares

Rodovia Presidente Castelo Branco

Fonte: EMPLASA, 2013. Retrabalhado por Amanda Dias, 2018. 
Figura 26 - Fluxo Pendular Intermunicipal, segundo municípios de origem selecionados:

Deslocamentos por motivo de trabalho e estudo.

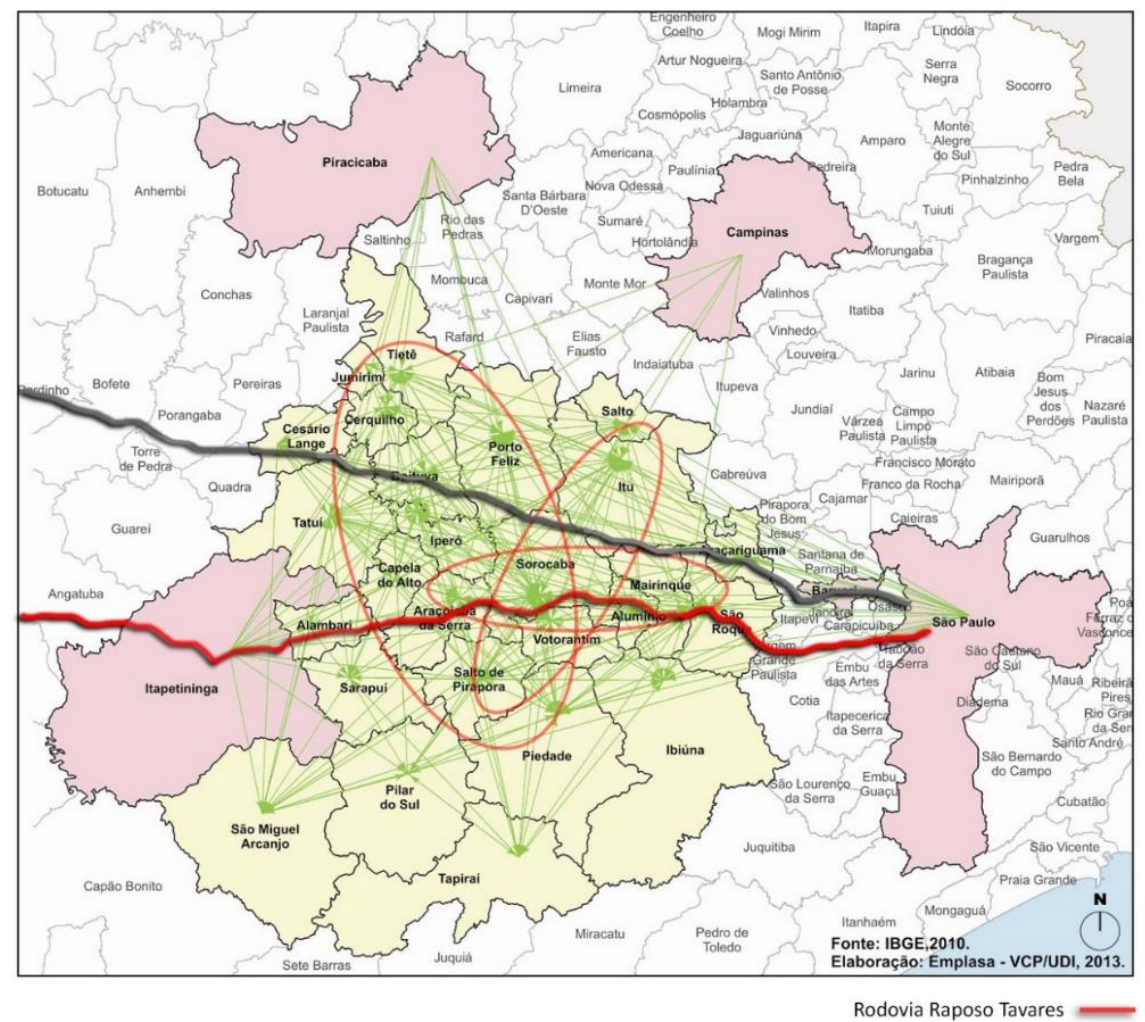

Fonte: EMPLASA, 2013. Retrabalhado por Amanda Dias, 2018.

Além do escoamento da produção agrícola e minérios, provenientes dos municípios de Itapetininga, Piedade, Votorantim e Alumínio (dentre outras), a RRT também é atualmente utilizada diariamente para os movimentos pendulares de trabalho e estudo, principalmente da população dos municípios de Votorantim, Sorocaba, Araçoiaba da Serra, Salto de Pirapora, Piedade, Alumínio, Mairinque, Ibiúna e São Roque (Fig. 24).

A acessibilidade proporcionada pela RRT, bem como os pontos de interesse localizados próximos à RRT em alguns trechos atendem a uma escala regional (VILLAÇA, 2001, p.71): pelo mapa da figura 26 pode-se verificar que um trabalhador ou estudante circula dos municípios de Votorantim ou Salto de Pirapora, ou Araçoiaba da Serra, Piedade, para Sorocaba em movimentos pendulares intermunicipais, dentre outros municípios.

Muitos estabelecimentos comerciais, indústrias e universidades (principalmente as as universidades privadas - estabelecem-se às margens das rodovias para que sua localização seja facilmente acessível aos estudantes dos vinte e seis munícipios do entorno de Sorocaba, além deste, uma vez que detêm 600000 habitantes da estimativa de 2 milhões de habitantes da RMS). Isto faz com que nos horários de pico (principalmente na entrada e saída das fábricas e de entrada e saída de 
escolas, e de funcionamento do comércio), trechos da RRT fiquem congestionados, aumentando o tempo de trajeto entre a residência e o trabalho e/ou escolas, e vice-versa.

"O adquirente de espaço continua a adquirir um valor de uso. Qual? Ele não compra apenas um volume habitável, permutável com outros... $O$ adquirente é detentor de uma distância, aquela que interliga sua habitação a lugares, os centros de comércio, de trabalho, de lazer, de cultura, de decisão. Aqui 0 tempo entra novamente em cena." (LEFEBVRE, 1974, p. 391 apud VILLAÇA, 2001, p. 73).

Além da questão do tempo dos trajetos pendulares, as áreas de domínio das rodovias muitas vezes são ocupadas para usos urbanos ilegais e/ou inadequados. E o traçado rodoviário desrespeita o desenho urbano existente principalmente quando em ocasiões da duplicação dos trechos rodoviários onde a demanda por espaço rodoviário é maior.

O percurso da RRT através de áreas urbanizadas também traz conflitos geralmente relacionados à segregação de bairros pelo traçado da rodovia; da insegurança viária com alto índice de atropelamentos e acidentes automobilísticos graves, de congestionamentos em horários de pico e os decorrentes de atropelamentos e acidentes, limitando a mobilidade urbana de passageiros e de cargas. A percepção é que isto tenha acontecido devido à falta de planejamento compartilhado entre as gestões municipais e estaduais.

Soluções sugeridas para os casos mais críticos prevêem a implantação de anéis viários e/ou rotatórias para separação de fluxos existentes e os que tendem a ter maior carregamento de passageiros e cargas nos próximos anos, casos mais críticos para os municípios de Itu, Salto, Sorocaba, Araçoiaba da Serra, Tatuí, Cerquilho e Tietê (EMPLASA, 2017, p. 64).

\section{Anotações sobre a atual mobilidade urbana da Região Metropolitana de Sorocaba:}

1. Com a desativação da ferrovia paulista no trecho da RMS, e mesmo com o modelo rodoviarista adotado na década de 60 não atende mais à necessidade de deslocamento da maior parte da população economicamente ativa da região metropolitana de Sorocaba. A (con) formação do espaço urbano (principalmente macro-metropolitano) e o papel da acessibilidade estão intimamente relacionados, e a acessibilidade mais universalizada poderia contribuir não só para a qualidade de vida, mas também para um equilíbrio maior da economia urbana e regional;

2. A relação entre a oferta de acessibilidade e o uso do solo no planejamento de transporte ainda é decidida mais em favor da manutenção do modelo econômico vigente - e conhecido do que em prol da maior qualidade de vida e equilíbrio econômico da maioria da população; 
3. As características do espaço urbanizado que moldam as condições de deslocamento da população ainda estão carecendo de intervenções mais eficazes do planejamento urbano e regional;

4. A mobilidade da população e suas condições de deslocamento obedecem à lógica dos meios de produção, ainda baseados em parâmetros do séc. XX: clusters, planos centralizadores, criando polarização em algumas cidades do Estado de São Paulo, e atraindo a maioria dos investimentos públicos e privados;

5. As condições de deslocamento da PEA do estado de São Paulo não serão modificadas a curto e a médio prazo;

6. O planejamento de transporte e a organização do espaço urbano só mudarão com mudanças de paradigmas nos investimentos públicos;

7. As alterações no espaço urbano decorrentes de intervenções no sistema de transporte são atualmente mais propícias aos proprietários fundiários e promotores imobiliários;

8. O papel da acessibilidade na conformação espacial da Região Metropolitana de São Paulo está comprometido, visto que os recursos públicos empenhados em PPP's visam priorizar a cadeia produtiva, mas na prática a indústria paulista opera com grandes custos e baixa produtividade, o que compromete a sustentabilidade a médio e longo prazos dela mesma, uma vez que tem-se como concorrentes a mão de obra chinesa e indiana;

9. As viagens na Região Metropolitana de São Paulo são demoradas (normalmente mais de duas horas para a distancia de 100km entre Sorocaba, o município-polo, e a Barra Funda, e/ou Cidade Universitária da USP), e no sentido em que a população ainda tolera curtos percursos de longa duração (baixa velocidade de deslocamento), o que na prática compromete os produtos em natura, e eleva os custos de distribuição e custo final tanto ao mercado doméstico quanto o internacional;

10. A Política Nacional de Mobilidade Urbana esbarra em muitos itens de gestão política, cultural e de execução.

11. Tais aplicações poderiam reduzir o movimento pendular quando indesejado, diminuindo tempo e custos improdutivos, e proporcionando o equilibrio econômico à população macrometropolitana.

Atualmente, a velocidade média nas principais rodovias da MMP é muito baixa, conforme dados da CPTM de 2013. Com a venda diária de veículos automotivos, os números só pioram. No Sistema Castelo Raposo da RMS, as velocidades máximas em horário de pico são, em alguns trechos: menor do que $40 \mathrm{~km} / \mathrm{hora}$. A pior rodovia para se movimentar em velocidade na RMS é a RRT, no trecho 
entre Alumínio e São Paulo. É justamente por onde passam a maior parte dos produtos agrícolas da RMS a RMSP (CPTM, 2013 apud PDTUM, 2015).

Figura 27 - Velocidade média (km/h) no horário de pico da manhã paulista.

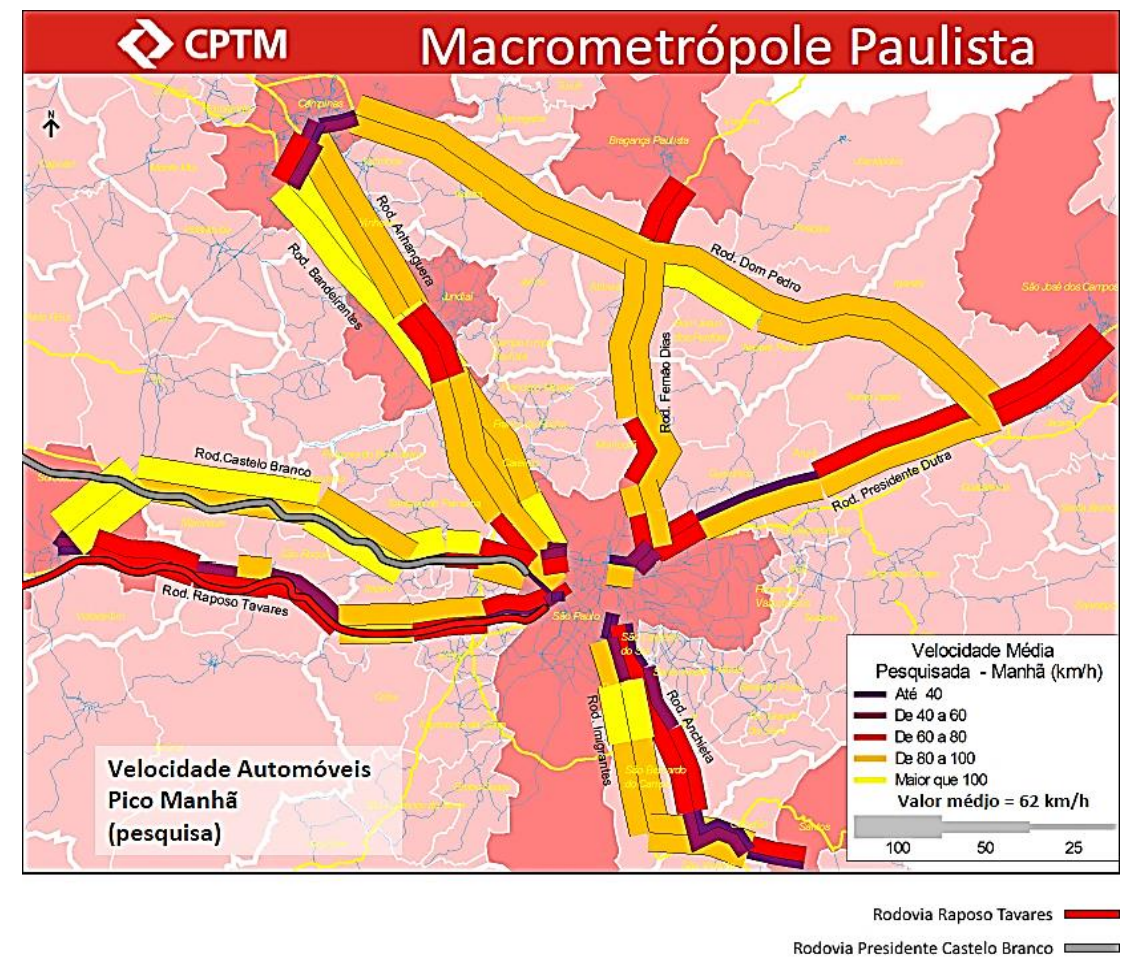

Fonte: CPTM, divulgado no Plano diretor de mobilidade de Sorocaba, SP (2014). Retrabalhado por Amanda Dias, 2018.

Para melhor cumprir a finalidade do estudo do projeto de doutoramento, o recorte do estudo do zoneamento das áreas lindeiras à rodovia foi limitado às do eixo rodoviário: Eixo Verde - Rod. Raposo Tavares (SP 270) no trecho compreendido entre São Roque e Sorocaba - km 60 na Rod. Raposo Tavares (SP 270), trecho RRT no território RMS, mais ocupado e verticalizado. 
CAP. III - TRECHOS ESCOLHIDOS DA ROD. RAPOSO TAVARES (SP 270) NA RMS 


\section{CAP. III - TRECHOS ESCOLHIDOS DA ROD. RAPOSO TAVARES (SP 270) NA RMS}

Figura 28 - Mapa da RRT no Estado de São Paulo, destacada em linha vermelha.

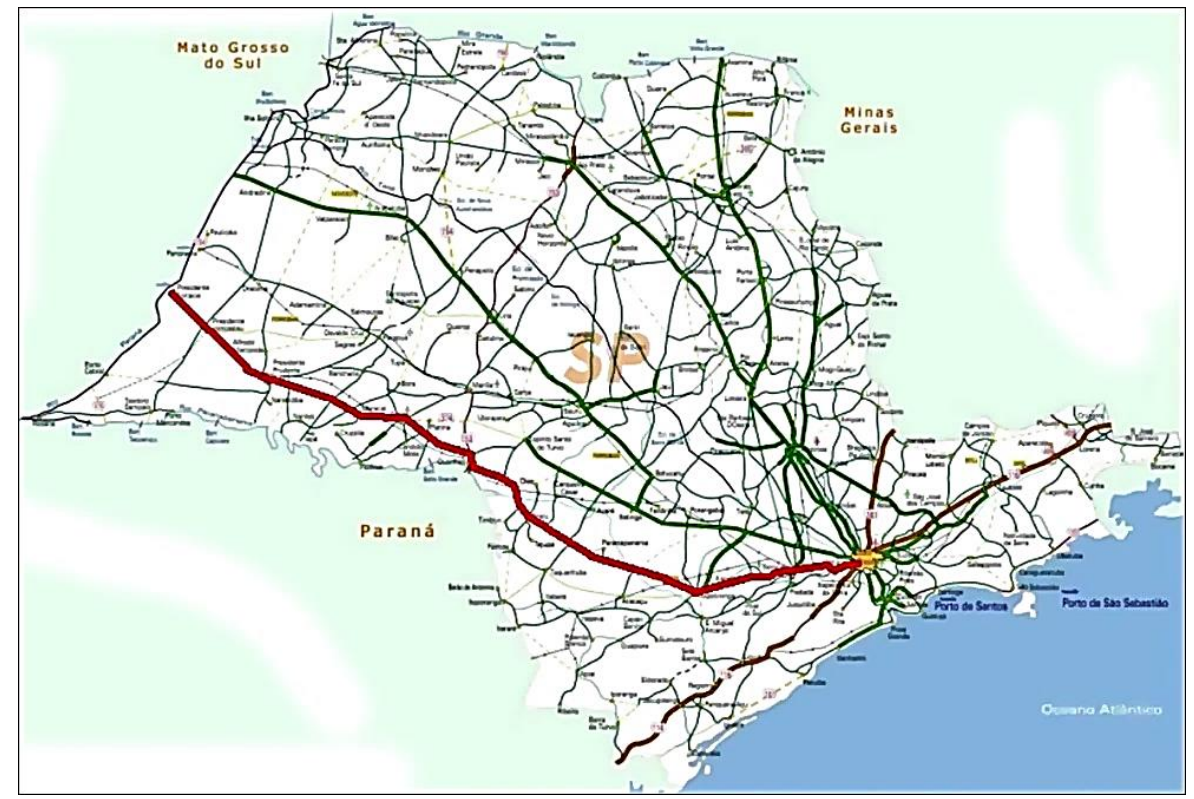

Fonte: DER, acesso em 26/06/2017.

\subsection{Breve histórico da RRT}

"Pierre Monbeig mostrou que, a partir de 1920, as obras rodoviárias possibilitaram uma ampla transformação nas formas de utilização das terras agrícolas do estado. Até então, 0 aproveitamento mais amplo das terras era circunscrito fortemente às áreas com acesso direto às ferrovias, que eram os grandes canais de exportação. (...)

A partir dos anos 20, com a construção das rodovias estaduais, que permitiam o tráfego de veículos em qualquer época do ano, terras até então sub-aproveitadas, por inacessíveis, tiveram seu aproveitamento e seu valor multiplicados, pela facilidade com que tinham acesso às linhas férreas e aos mercados urbanos. (...) A rodovia foi, portanto um fato de melhoria no aproveitamento das terras do Estado, como uma complementação eficiente da malha ferroviária." (REIS, 1995).

Este breve histórico da RRT (na RMS) origina-se com a construção da estrada São Paulo Paraná, iniciada em 1921. Segundo Savioli (2007):

"Enquanto a ferrovia foi se tornando obsoleta, carente de investimentos que a modernizassem, a expansão do município de São Paulo seguia na direção da infra-estrutura viária provinda dos investimentos públicos nas rodovias ${ }^{13}$. Só a partir dos anos 40 o território metropolitano, organizado pelas estradas estabelecidas no período colonial e depois pela malha ferroviária da segunda metade do século 19, "foi submetido a um novo elemento, de enorme repercussão na estruturação metropolitana: um sistema rodoviário de grande abrangência territorial ${ }^{14 "}$ ". Em 1922 foram inauguradas as obras da estrada São Paulo - Cotia

\footnotetext{
${ }^{13}$ MEYER, Regina Maria Prosperi; GROSTEIN, Marta Dora; BIDERMAN, Ciro. São Paulo: Metrópole. 1. ed. São Paulo: Edusp, 2004, p. 41.

14 Ibidem, p. 37.
} 
- São Roque ${ }^{15}$, parte do tronco denominado São Paulo - Paraná no Plano Geral de Viação de Rodagem do Estado de São Paulo. De 1949 a 1951, com seu traçado corrigido e pavimentado, atingiu Sorocaba com o nome de rodovia Raposo Tavares." (SAVIOLI, 2007, p. 113).

Foi inaugurada oficialmente em 26 de agosto de 1922 por Washington Luis, presidente do Estado de São Paulo (como era conhecido o governador na época):

\begin{abstract}
"Com o lema "governar é abrir estradas", ele inaugurou o trecho São Paulo-Cotia-São Roque da estrada denominada 'São Paulo-Paraná. 0 historiador Adilson Cézarir, explica que era um período de crescimento econômico e, por isso, necessário atingir pontos mais distantes. $\mathrm{Na}$ época, São Paulo estava crescendo com a agricultura do café e se expandindo cada vez mais para o oeste, então, a necessidade de ligar a capital com boas estradas. Um marco da inauguração está em uma área verde, discretamente instalado na praça do pedágio em Alumínio (SP). A inscrição na pedra tem o nome de Washington Luiz, do então secretário da agricultura do estado, Heitor Penteado, e as indicações dos caminhos para Sorocaba (SP) e São Roque. (...)" 17 (G1, 2012).
\end{abstract}

Mesmo com a abertura da estrada de rodagem, como era chamado à época, podemos verificar na figura 29 abaixo, em alguns pontos era realmente muito difícil transitar pela estrada São Paulo-Paraná de então, antes da pavimentação. As chuvas, muitas vezes torrenciais, típicas do clima local, deixavam as estradas intransitáveis pelo lamaçal. Havia também o perigo de perdas das cargas e de vidas; atrasos, e dependendo das chuvas não havia como haver cumprimento de horários, a não ser pelos trens de passageiros e de cargas, que faziam o trajeto entre Sorocaba, São Roque e São Paulo e Santos, mas estes tinham horários, capacidades de cargas e trajetos delimitados.

\footnotetext{
${ }^{15}$ REIS, Nestor Goulart. Memória do transporte rodoviário: Desenvolvimento das atividades rodoviárias de São Paulo. São Paulo: CPA Consultoria de Projetos e Artes Ltda. [1998], p. 61.

${ }^{16}$ Presidente do Instituto Histórico, Geográfico e Genealógico de Sorocaba e da Academia de História Militar Terrestre do Brasil de São Paulo "General Bertholdo Klinger", desde 1989, em sua nona gestão. In: https://ihgb.org.br/perfil/userprofile/ACesar.html, acesso em julho/2017.

17 In: Rodovia Raposo Tavares completa 90 anos: Rodovia passa por trinta municípios do Estado de São Paulo. Com 654 $\mathrm{km}$, rodovia foi construída para alavancar crescimento do Estado. Disponível em: http://g1.globo.com/sao-paulo/sorocabajundiai/noticia/2012/11/rodovia-raposo-tavares-completa-90-anos.html, acessado em julho de 2017.
} 
Figura 29 - Foto da RRT antes da conclusão de sua pavimentação em 1951.

Foto-27. Na estrada São Paulo - Sorocaba. Lama e mais Lama ... Apenas $20 \mathrm{Km}$ para conclusão de serviço de pavimentação. A Raposo Tavares em dia de chuva, em alguns pontos era intransitável.

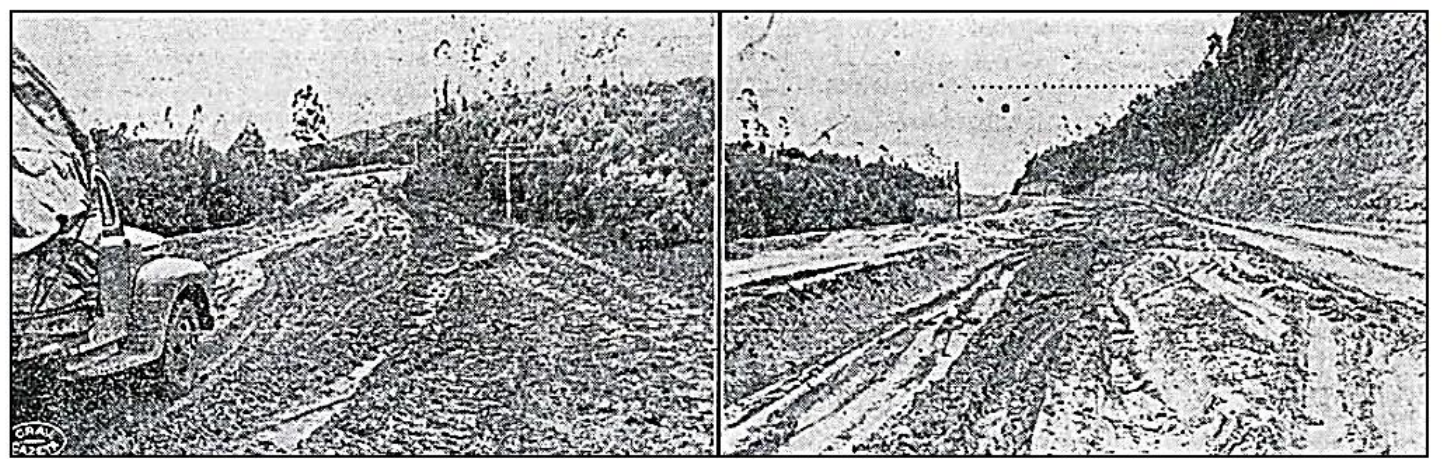

Fonte: Jornal a Gazeta- 28/11/1951.

Fonte: RIBEIRO, 2006.

A pavimentação da RRT e posteriormente da RCB, modificou profundamente, em vários aspectos, o Estado de São Paulo e até o País. O governador Adhemar de Barros, ciente da importância do novo modelo de rodovia pavimentada, rebatizou a então Rodovia São Paulo-Paraná, como Rodovia Raposo Tavares.

"Em 1954, a rodovia recebeu o nome de Raposo Tavares, em homenagem ao bandeirante que desbravou o oeste paulista. Neste mesmo ano, a rodovia - que era de terra - foi asfaltada"18 $(G 1,2012)$.

Como o caminho à oeste do bandeirante percorrido no século XVII, a RRT sai de São Paulo ${ }^{19}$ no bairro do Butantã (Fig. 30) e, dentro do território da RMS segue até entre os municípios de Itapetininga (SP) e Ourinhos (PR) (Fig. 31); continuando seu trajeto até a divisa do estado com o Mato Grosso do Sul, no município de Presidente Epitácio (km 654); a partir daí como rodovia BR-267.

18 Idem à referência anterior.

19 Inicia-se oficialmente ao final da Rua Reação, no distrito do Butantã, zona oeste da cidade de São Paulo - km 9,8. 
Figura 30 - Trecho inicial (Butantã, Capital) da RRT e Figura 31 - Trecho final, entre Itapetininga (SP) e Ourinhos.
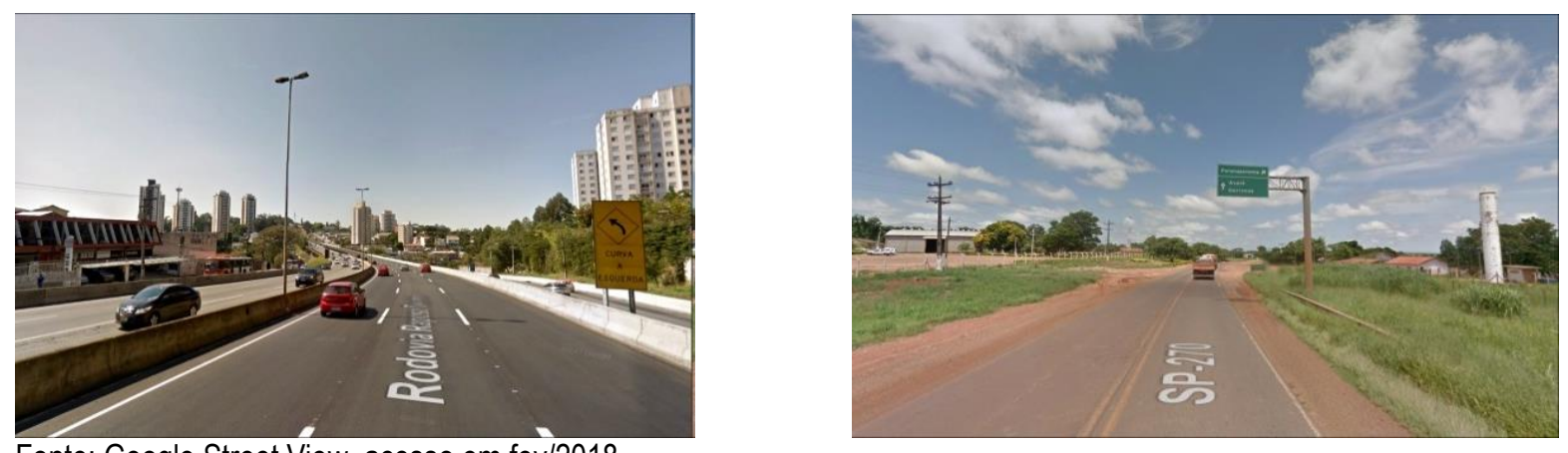

Fonte: Google Street View, acesso em fev/2018.

\section{Dados financeiros da Concessão da RRT no trecho RMS}

O consórcio formado pela Invepar e pela construtora OAS venceu o leilão pela rodovia Raposo Tavares, com uma proposta de pedágio para pista dupla de $\mathrm{R} \$ 0,090525$ por quilômetro, o que representa um deságio de $16,11 \%$ sobre o teto estipulado pelo governo do Estado de São Paulo, de R\$ 0,107910 . A rodovia exigirá também investimentos de $R \$ 1,803$ bilhão durante os 30 anos da concessão. ${ }^{20}$

\section{Localização dos pedágios}

No quadro abaixo está a localização das praças de pedágio da Rodovia Raposo Tavares no trecho da RMS estudado. Sua anotação é importante para se saber se a arrecadação interfere positivamente no bem-estar da população de seu município de instalação.

Tabela 10 - Localização das praças de pedágios na RRT no território da RMS.

\begin{tabular}{|c|c|c|c|c|c|}
\hline Pedágio & km & Sentido & Cidade & Concessionária & Geocoordenadas \\
\hline $1 \mathrm{~A}$ & 46 & Interior & $\underline{\text { São Roque }}$ & Viaoeste & $23^{\circ} 35^{\prime} 58.07^{\prime \prime} \mathrm{S} 47^{\circ} 02^{\prime} 19.73^{\prime \prime W}$ \\
\hline 1B & 79 & Capital & $\underline{\text { Alumínio }}$ & Viaoeste & $23^{\circ} 30^{\prime} 33.78^{\prime \prime S} 47^{\circ} 16^{\prime} 43.37^{\prime \prime W}$ \\
\hline
\end{tabular}

Fonte: g1.com.br, acesso em março/2018.

A ocupação paulatina de suas margens em alguns trechos escolhidos da RMS versus sua legislação urbanística de uso e ocupação do solo é objeto deste estudo, e a seguir serão colocadas as informações referentes à escolha destes trechos analisados.

20 In: http://g1.globo.com/Noticias/Economia Negocios/0,,MUL841252-9356,00CONSORCIO+INVEPAR+OAS+ARREMATA+RODOVIA+RAPOSO+TAVARES.html, acesso em fev/2018. 


\subsection{Escolha dos trechos estudados}

Iniciamos com a constatação de que a Rod. Raposo Tavares (SP-270), conforme o Estudo Técnico "Processo de Criação da Região Metropolitana de Sorocaba", de agosto de 2013, é mencionada pela EMPLASA como Eixo Verde da RMS:

"Eixo Verde Raposo Tavares - APAs Jurupará e Itupararanga (olericultura): Municípios de Alambari, Alumínio, Araçoiaba da Serra, Capela do Alto, Ibiúna, Itapetininga, Mairinque, Piedade, Pilar do Sul, Salto de Pirapora, São Miguel Arcanjo, São Roque, Sarapuí, Tapiraí e Votorantim." (EMPLASA, 2013, 2017, negrito nosso).

\section{Critérios de escolha dos trechos a serem estudados:}

Para a escolha final dos trechos estudados nesta pesquisa foram considerados três critérios:

1) Padrões sócio-econômicos: as tipologias observadas fossem diferentes no uso e ocupação do solo das áreas lindeiras da rodovia;

2) Territorial: trechos urbanizados nas áreas lindeiras à RRT que estivessem contidos em municípios pertencentes à área metropolitana da RMS e

3) Ambiental: trechos que estivessem em áreas urbanizadas com nascentes e cursos d'água relevantes para preservação, conservação e abastecimento hídrico da população da RMS.

Com as análises dos dados recolhidos e relatados por Camargo (2015), no trecho teste, chegou-se à conclusão de que nos trechos lindeiros à RRT entre São Roque e Sorocaba, considerando-se o critério de padrão sócio econômico encontrado in loco versus o critério de densidade de empregos conforme tabulação EMPLASA (2017) (Fig. 33), os trechos que detinham densidade de empregos muito diferentes, conforme os trechos e municípios que a rodovia entrecortava, eram mais numerosos e concentrados na zona sul do Município de Sorocaba, escassos no Município de Alumínio e poucos em São Roque (Fig. 34); coincidentemente com os dados relatados pela EMPLASA em 2017. 
Figura 32 - Uso do Solo, Estrutura Urbana e Conexões na RMS, com destaque para o trecho da RRT escolhido.

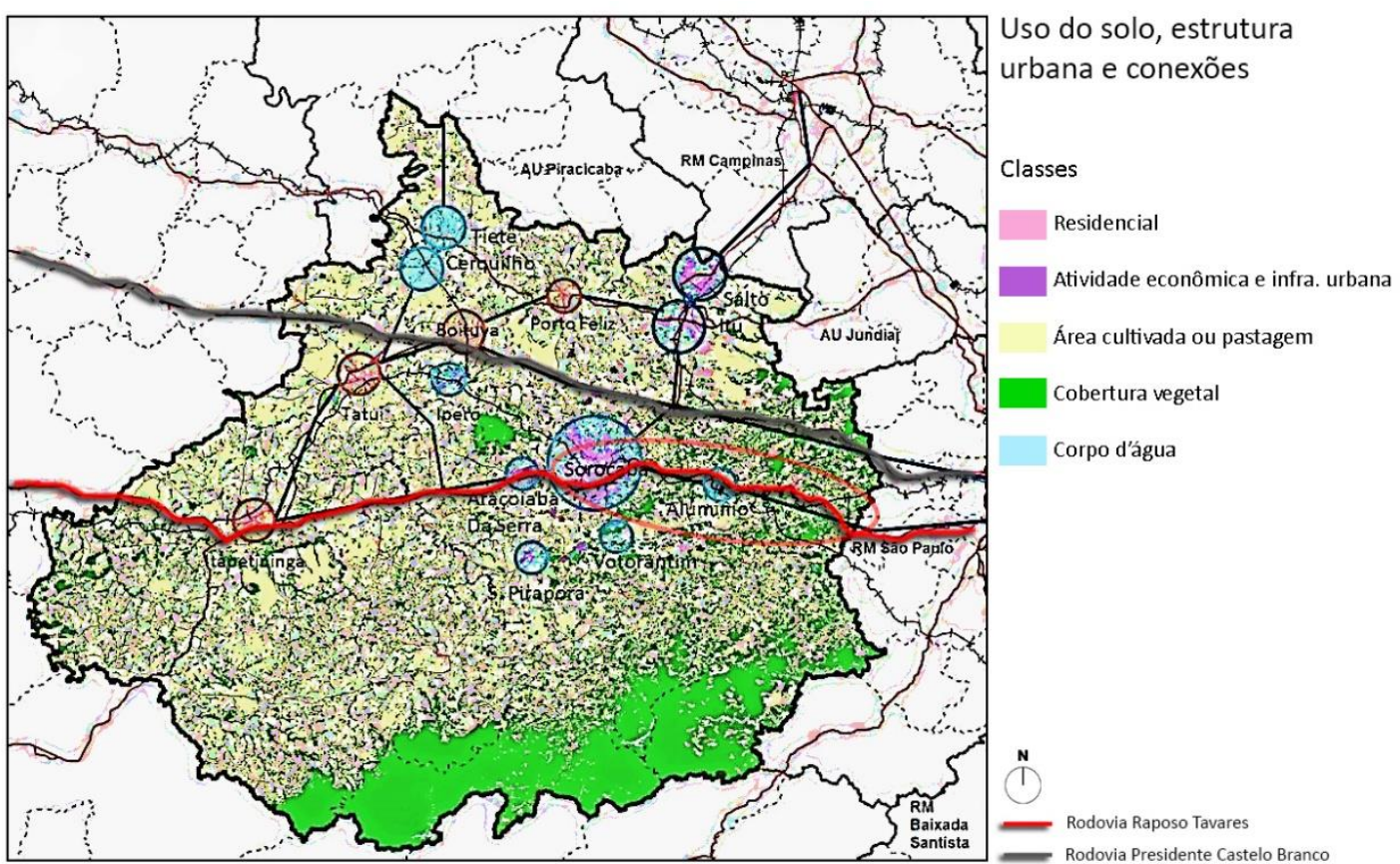

Fonte: EMPLASA, 2016, 2017. Retrabalhado por Amanda Dias, 2018.

Figura 33 - Densidade de empregos na RMS (2014), com destaque para o trecho da RRT escolhido.

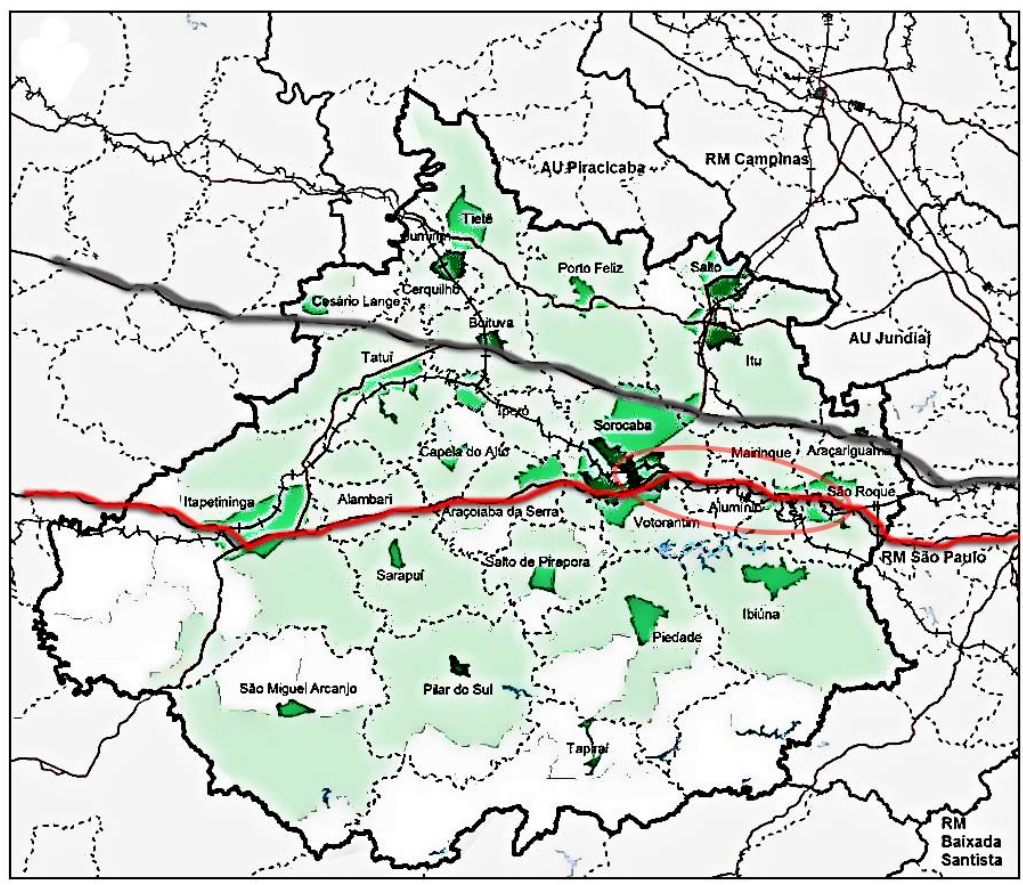

Densidade de empregos Total - 2014

Empregos/ha

Até 1
1 a 5
5 a 20
Acima de 20

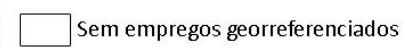

Fonte: EMPLASA, 2017. Retrabalhado por Amanda Dias, 2018. 
Figura 34 - Densidade de empregos na RMS (2014), com destaque para os trechos escolhidos na RRT.

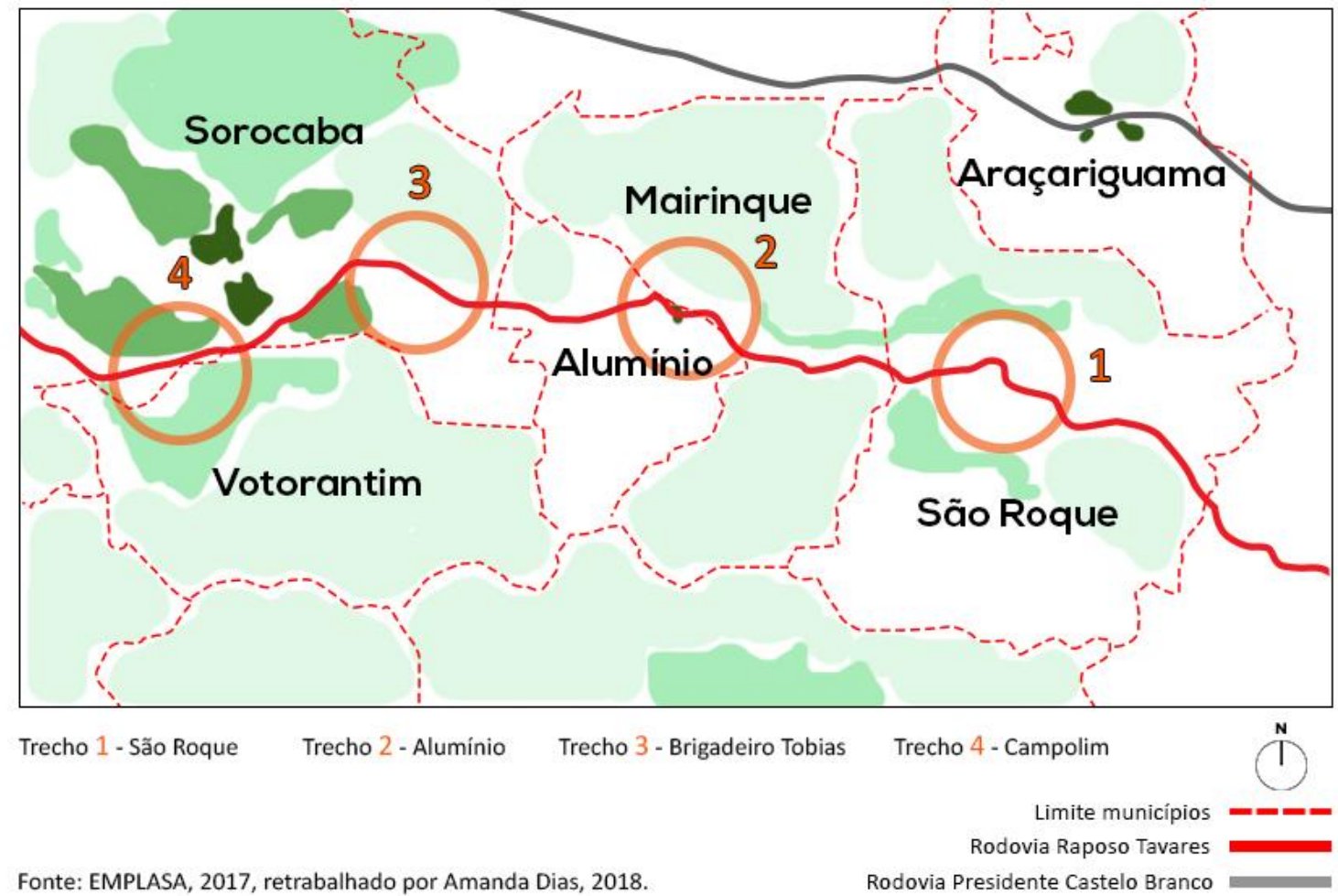

Elipse em laranja, trecho em Sorocaba; Elipse em roxo, trecho em Brigadeiro Tobias; Elipse em vermelho, trecho em Alumínio, e elipse em amarelo, Município de São Roque. Fonte: EMPLASA, 2017. Retrabalhado por Amanda Dias, 2018.

Também referente ao trecho do bairro Parque Campolim na zona sul de Sorocaba, e norte do Município de Votorantim, SP foi constatado neste trecho o Rio Sorocaba, importante recurso hídrico municipal, único afluente da margem esquerda do Rio Tietê, e um córrego que compõe o cenário paisagístico do Parque Campolim, que dá nome ao bairro.

Neste trecho também se verifica o mais alto índice de densidade de empregos e renda da RMS; e o trecho de conurbação urbana, nas áreas lindeiras da RRT detêm alto índice de valorização imobiliária, com vários lançamentos imobiliários nas áreas do entorno da RRT.

Para o primeiro critério da escolha dos trechos a serem estudados, observamos pelos dados da EMPLASA (2017) de que a RRT é um eixo rodoviário verde; e nos trechos considerados, devido à topografia colinosa existem muitas nascentes e vários cursos d'água. Aliás, em todos os trechos em destaque, existem cursos de água relevantes no entorno da área urbanizada e sua população.

Para o segundo critério, na figura 34 nota-se que no trecho da RRT contido no destaque da elipse vermelha, que existem três trechos de pesos diferentes em atividade econômica e infra-estrutura urbana (Sorocaba, Alumínio e São Roque), que pode ser combinado às observações da densidade de empregos por hectare das figuras 33 e 34 . 
O terceiro critério está contemplado na medida em que embora os limites territoriais municipais tenham variação no trecho da RRT, os limites considerados foram os da atual RMS - sem Itapetininga, incluída depois em 2016 (EMPLASA, 2016, 2017).

Os trechos estudados da rod. Raposo Tavares (SP 270) localizam-se do km 45 ao 102, por ser 0 trecho rodoviário metropolitano da RMS. (EMPLASA, 2015). Inicialmente foi elaborada uma planilha com os acessos da rodovia à área urbanizada no trecho inicial ( $\mathrm{km} 54$ a 110), além de um levantamento in loco do trecho inicial ( $\mathrm{km} 45$ a 92). Outro subsídio utilizado foi a ferramenta do site do Google Earth para imagens salvadas e disponibilizadas com acesso livre, que possibilitou verificar imagens do trecho escolhido a partir do ano 2002 até 2017. O trecho foi escolhido devido à maior facilidade de iniciação da pesquisa, pois a área ainda é menos ocupada do que o trecho da rodovia Raposo Tavares (Fig. 35).

A escolha dos trechos a serem estudados com maior profundidade para a pesquisa obedeceu aos critérios de padrões sócio-economicos, conforme estabelecidos pela EMPLASA (2015) e comprovados in loco e por fotos realizadas por drone em 2017. Desta forma, os quatro trechos escolhidos (Fig. 35 e 36) para o estudo das políticas públicas aplicadas pelo Estado através do zoneamento municipal, por suas diferentes características ao longo da RRT foram:

$>$ Trecho 1 - São Roque (km 60 - 64) (Fig. 37);

$>$ Trecho 2 - Alumínio (km 79 - 83) (Fig. 38);

$>$ Trecho 3 - Brigadeiro Tobias (km 88 a 92) (Fig. 39) e

> Trecho 4 - Campolim (km 98 a 102) (Fig.40).

As alterações quando pertinentes aos trechos estudados, serão melhor explicitados nas próximas páginas, separadas por trechos, e dedicados à melhor explanação por trecho.

Os trechos escolhidos estão ilustrados nas páginas que se seguem. 
Figura 35 - Delimitação do polígono de estudo, do acesso a Araçoiaba da Serra a São Roque, SP, passando por Sorocaba, Mairinque, Alumínio.

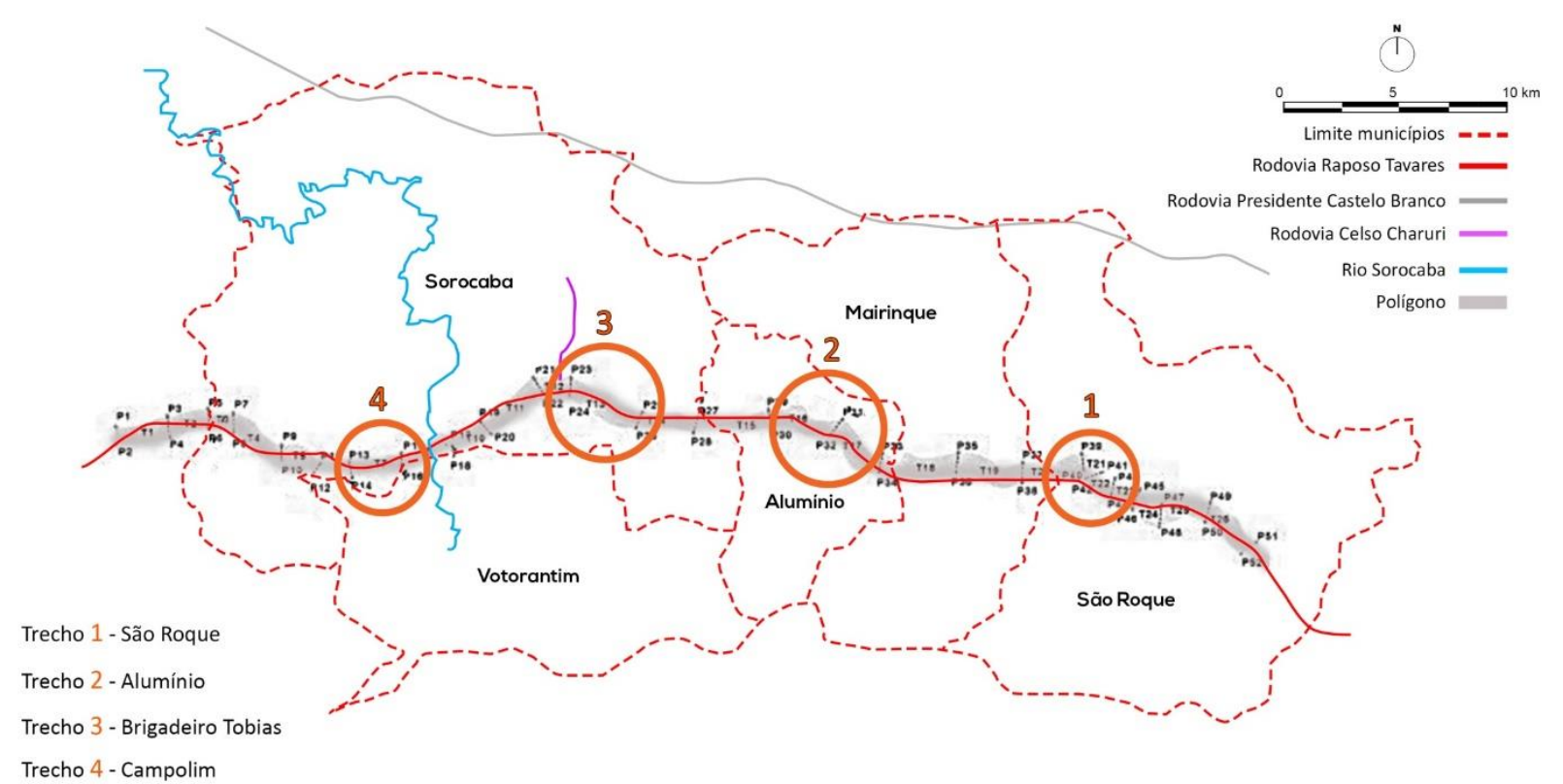

Fonte: Elaborado por Amanda Dias, 2018. 


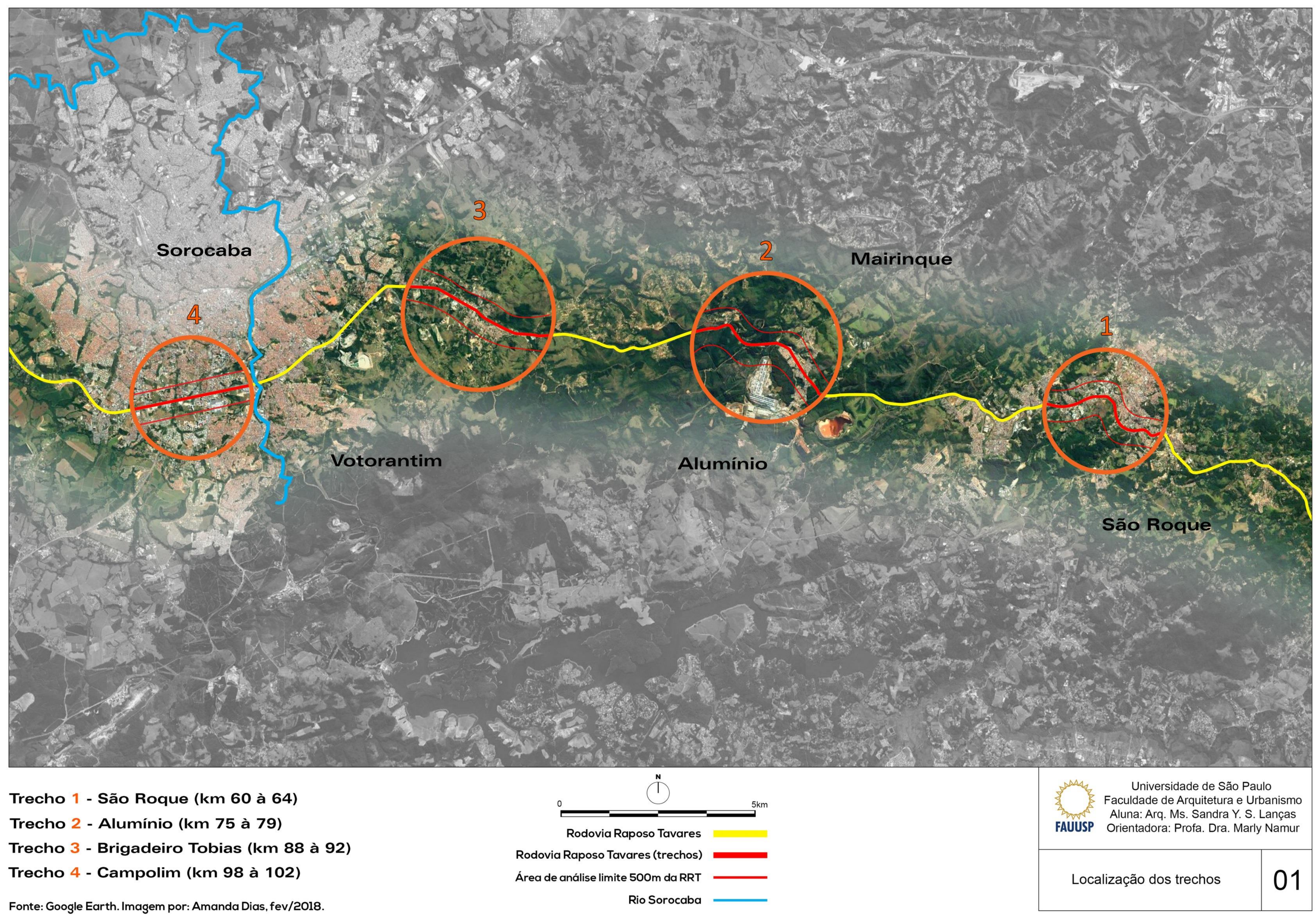




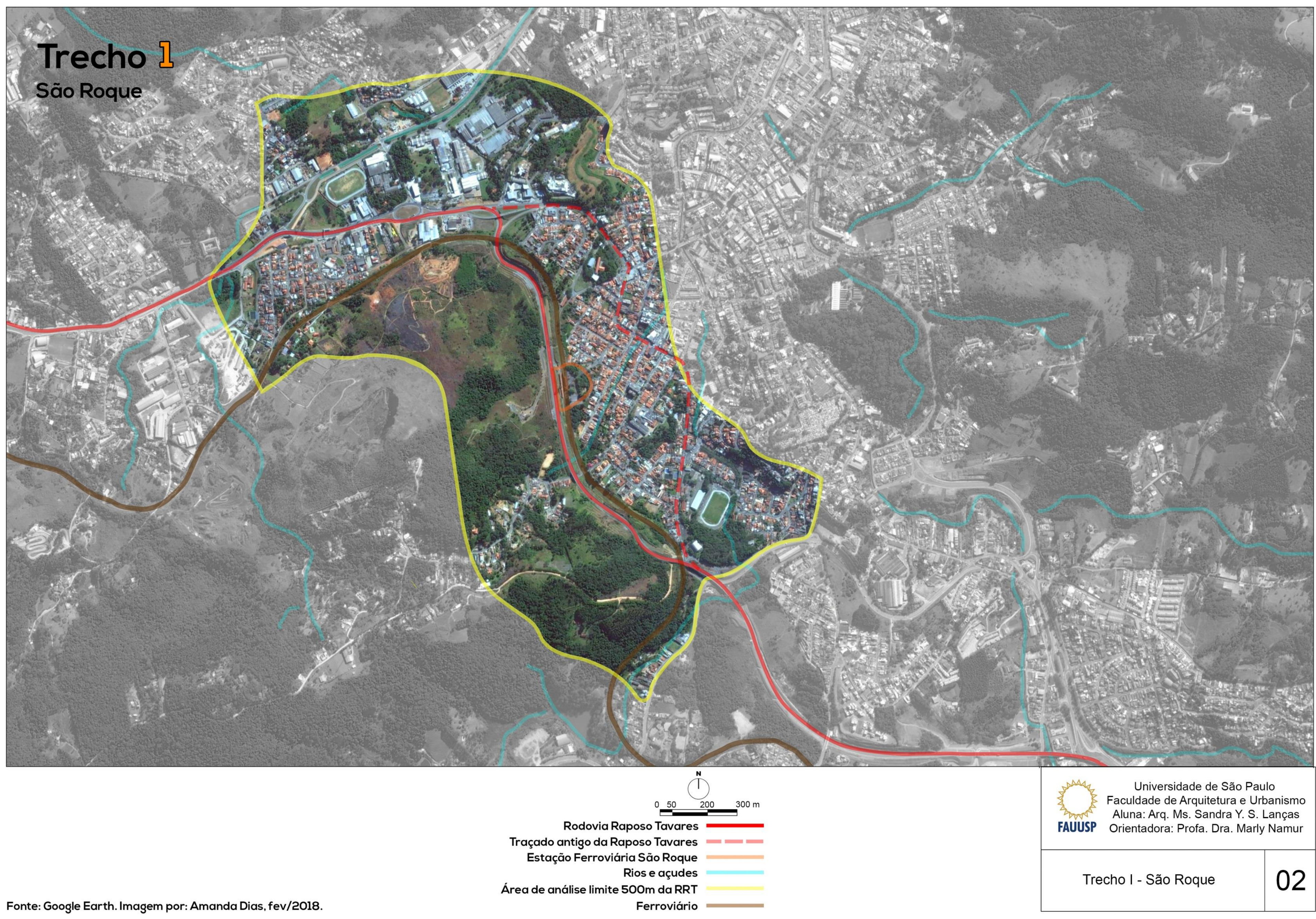




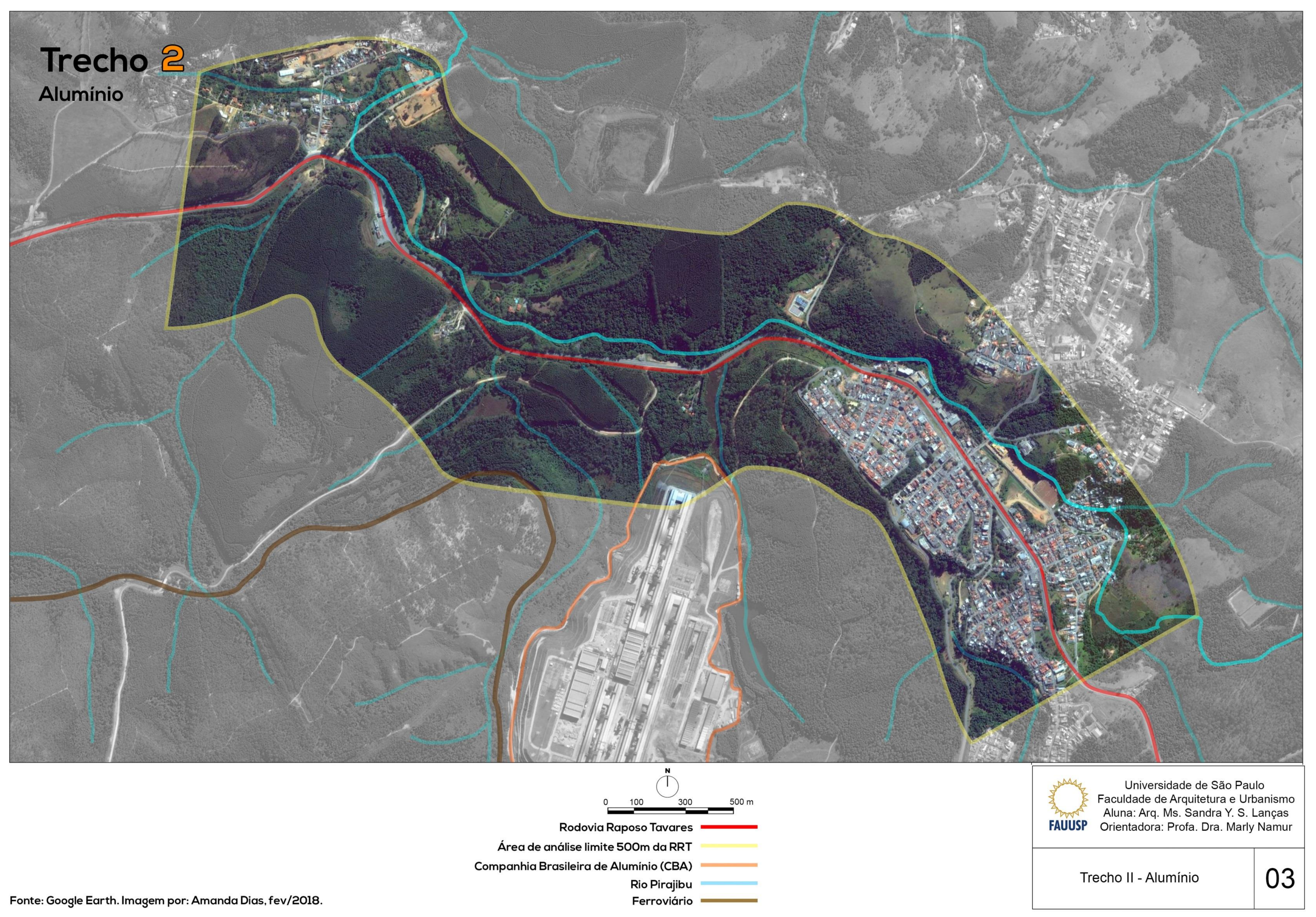




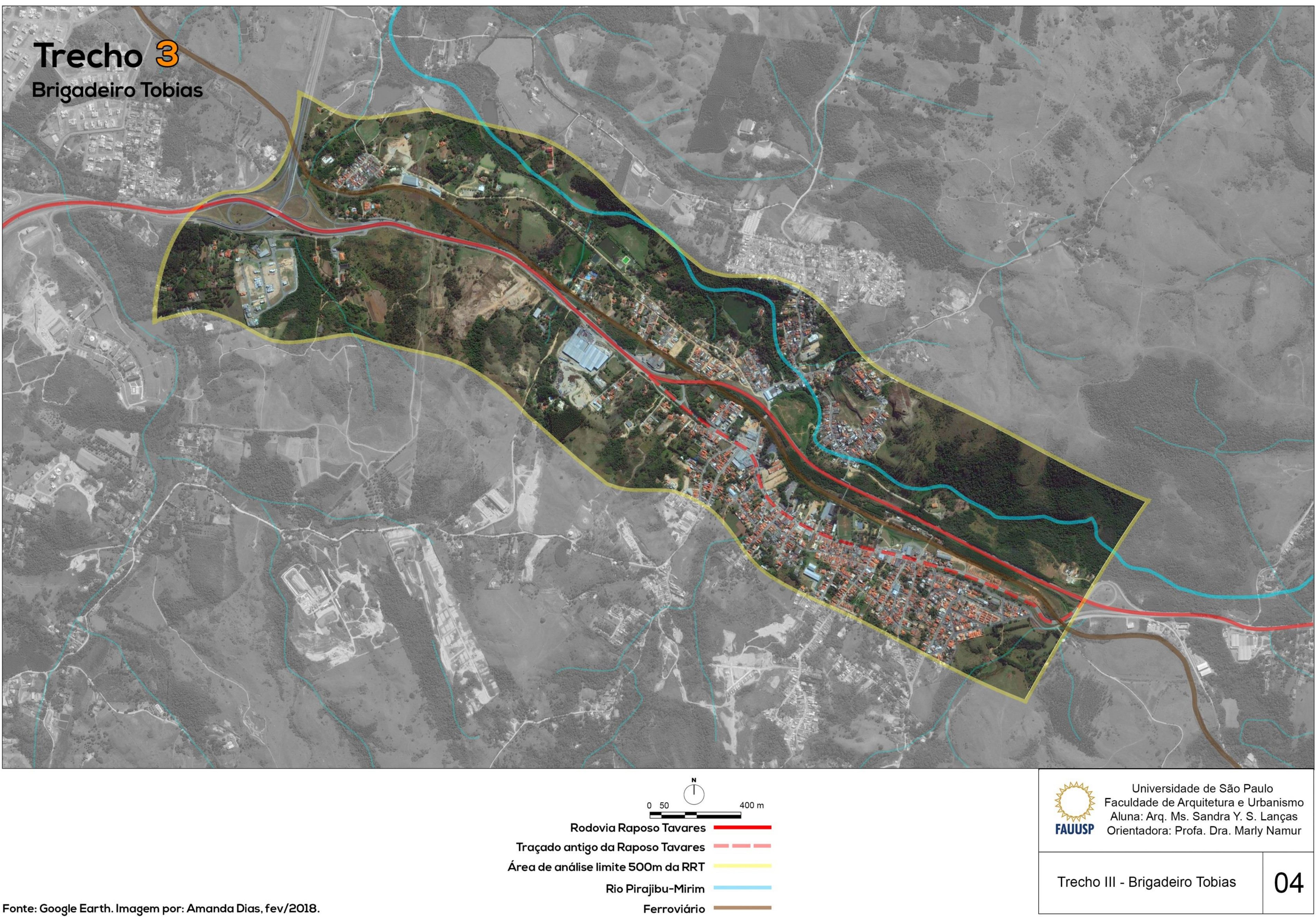




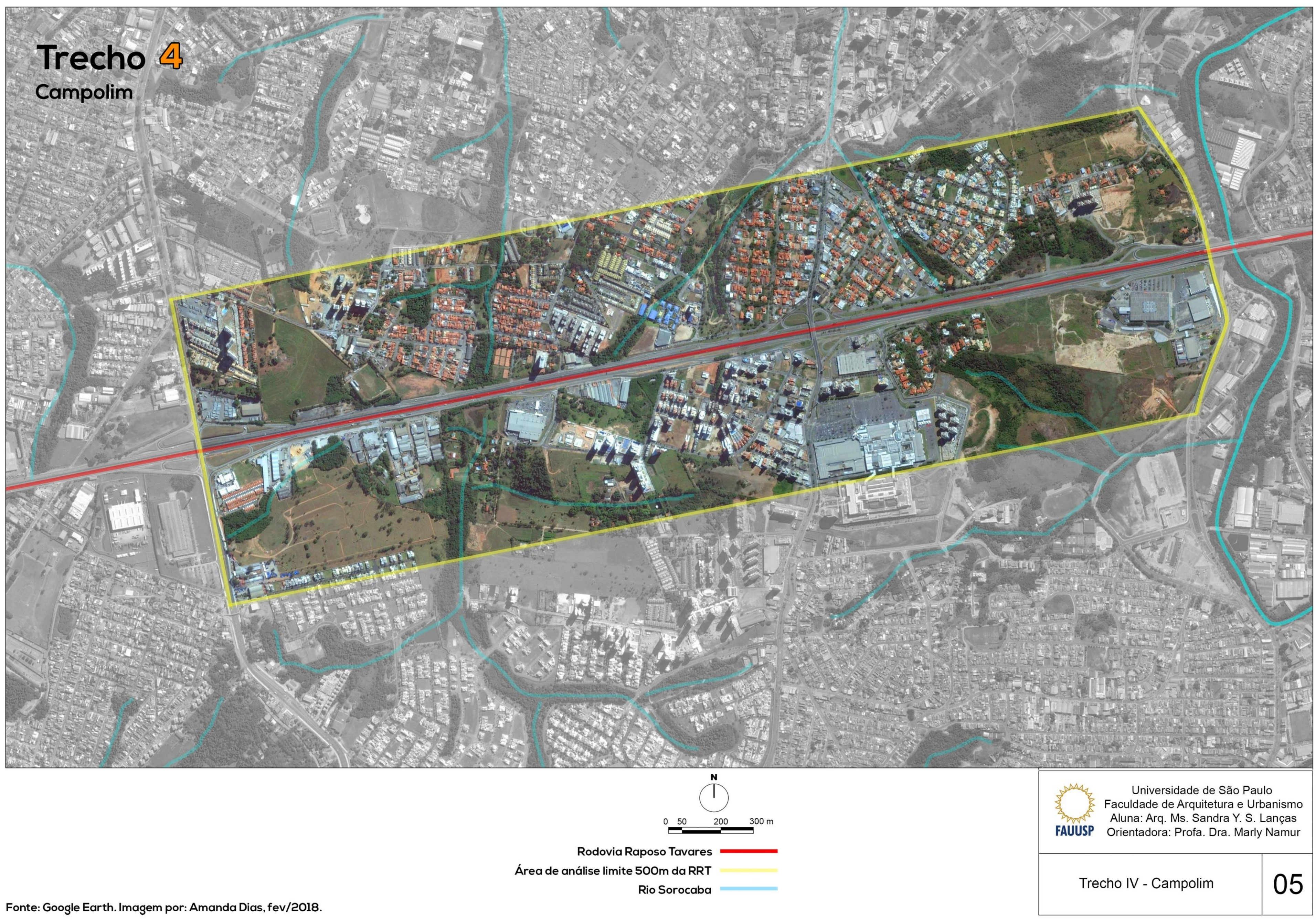




\section{CAP. IV - ZONEAMENTO}

“Organizar o território é questão vital em qualquer sociedade, e sempre o foi. O 'zoneamento' como expressão espacial e territorial dessa organização, é intuitivo. As pessoas organizam - ou zoneiam - os campos que utilizam para plantar, para criar, para preservar. (...) A forma sócio-técnica do zoneamento urbano, entretanto, é coisa recente e própria da racionalidade produtiva que se impôs sobre o espaço social com a revolução industrial.

Nesse sentido o zoneamento, tal como modernamente concebido, é uma imposição de uma ordem externa (produtiva) industrial ao espaço de vida urbano (e rural), o qual é então subordinado à logica industrial produtiva e transformado em espaço abstrato, na maioria das vezes a serviço das várias facetas dessa economia de mercado. (...)" (EMG,2014). 


\section{CAP. IV - ZONEAMENTO}

\subsection{Breve histórico do Zoneamento na Europa e nos EUA}

Williams (1914) e Basset (1922) escreveram que a palavra "zone" é francesa de origem e está ligada à pratica medieval de retirar as muralhas de pedras das cidades francesas e depois substituí-las por "belts" ou "zones" de parques ou boulevares.

Também na escala da cidade, Basset e Williams admiravam as cidades alemãs pelo esforço contínuo de proteção às residencias pelo banimento das indústrias de certas partes da cidade, considerando-se principalmente as especificidades do lugar (ex.: certa indústria não poderia se localizar em determinado lugar se ali fosse instalada pois os ventos dominantes poderiam levar as fumaças para a região central, mais habitada, da cidade).

Leis promulgadas para disciplinar edificações em tamanho, altura, localizações destas e as de usos menos saudáveis ou perigosos vinham sendo estabelecidas desde o século XII: Assize of Buildings em Londres (1189), regras de construções para New Amsterdam (depois New York) em 1625; uso de materiais construtivos e proteção contra incêndios, localização de matadouros, manufaturas de sebos e gorduras em Boston $(1625,1645)$ para limitar e controlar a localização das atividades mais perigosas à saude publica das populações.

O código de leis imperiais da Prússia e Germania disciplinava a localização das indústrias insalubres, pois elas tinham que obter autorizações públicas já na era da revolução industrial (HIRT, 2016, p.297). As cidades alemães, quase desde o início de sua história, foram governadas através de regulamentações que se aplicavam igualmente por toda a cidade, embora tais leis não excluissem as indústrias de áreas habitadas (HIRT, 2016, p.298).

Na primeira metade do séc. XIX, inicia-se na Europa a concentração da população em aglomerações a serviço das indústrias - é a urbanização que em escala nunca antes vista, transformou por completo especialmente algumas cidades (Londres, Paris, etc) e criou outras novas. E:

"A cidade industrial neste período é caracterizada pelo congestionamento e pela insalubridade; sem um sistema de abastecimento de água e esgotamento sanitário e sem coleta de lixo atendendo à população de operários; surgem epidemias difíceis de serem controladas, além de doenças que prejudicam a população como um todo. (...) para controlar e evitar os graves problemas de saúde pública observados, em 1848 é aprovada a primeira lei sanitária, a Public Health Act, em Londres. (...) As leis sanitárias evoluiram para uma legislação especificamente de natureza urbanística. (...) Os regulamentos urbanísticos atualmente existentes, as leis de zoneamento, uso e ocupação do solo e os códigos de edificações, tem como origem esta preocupação sanitarista de se criar um ambiente salubre e adequado." (ABIKO; ALMEIDA; BARREIROS, 1995, p.39-40). 
Em 1876 Reinhard Baumeister, professor da Universidade de Karlsruhe e "o maior planejador teorico" da Alemanha segundo Williams (1914 apud HIRT, 2016), publicou o livro intitulado "Expansão Urbana com respeito à Tecnologia, Código de Construção e Economia", com a melhor análise de compreensão dos problemas urbanos e suas soluções para aquela época.

Baumeister observou que as atividades economicas das cidades industrializadas tendiam a se agrupar como nunca antes aconteceu na história, e propunha que se reforçasse este processo através de um mecanismo municipal legal através do "districting or zoning", através da classificação dos edificios em três tipologias diferentes (atividades industriais, atvidades comerciais e outras atividades de diferentes ocupações às duas primeiras atividades mencionadas):

\begin{abstract}
"When we built a vision of the future... we want to distinguish three sections. The first consist of the large-scale of the industry and the wholesaling... but also de homes of the workers and even the factory owners; the second includes all trading that requires direct contact with the public, and similarly the homes which be united with trade premises; the third includes homes whose owners have no trade and have different occupations (landlords, officials, merchants, factory owners, workers". (Translated from BAUMEISTER, 1876, p. 80 apud HIRT, 2016, p.299).
\end{abstract}

Alex Abiko et ali escreve no texto sobre "Urbanismo: história e desenvolvimento" que na França as preocupações urbanas fez com que o barão Haussman (prefeito de Sena, Paris de 1853 a 1870 sobrepusesse a cidade medieval pré-existente uma nova rede de avenidas e edificações institucionais de tamanho monumental, estrategicamente colocadas; o que se pode conhecer como urbanismo estético viário. Haussman, assim inventou as quadras, e o conceito de lote, antes inexistente.

O prof. Cândido Malta relata: "nascido ao tempo das carrugagens e dos bondes puxados a burro, no final do séc. XIX, será, na primeira metade do séc. XX, extremamente funcional para o surgimento e a implantação plena das cidades contemporâneas, dos veículos automotores: 0 bonde elétrico; os onibus, os caminhoes e os próprios automóveis." (CAMPOS FILHO, 1989, apud ABIKO et ali, 1995, p. 41).

Nádia Somekh escreve em sua tese de doutoramente que o primeiro plano de zoneamento alemão foi aplicado a partir de 1891 no Municipio de Frankfurt, e além de parametros para altura dos edificios, ocupação de cada parcela, o uso do solo foi classificado em industrial, residencial e de atividades mistas. Mas este primeiro plano de zoneamento municipal foi decorrente do acordo realizado entre grupos sociais que tinham interesses antagônicos: a reinvindicação de moradia pela classe trabalhadora, e exigencias dos proprietarios de imoveis e dos empresários industriais, mediados pelo poder público, através do prefeito Franz Adickes, que 
realizou congressos durante o ano de 1890 para debater o uso do solo de Frankfurt, e resultou no zoneamento municipal (SOMEKH, 1997, p. 40).

Planos de zoneamento municipal tambem foram adotados no mesmo ano por Hamburgo, e depois por Berlim, e abriram caminho para a difusão do zoneamento na Alemanha de então. Antes da $1^{\text {a }}$. Guerra muncial as maiores e influentes cidades alemãs já tinham planos de zoneamentos mais complexos. Estes planos foram exportados para os demais paises europeus e até para os Estados Unidos, onde as regras de zoneamento influenciaram largamente as cidades americanas da costa leste e depois as demais no território norteamericano (HIRT, 2016).

Nova lorque é reconhecidamente uma localidade global (SASSEN, 2006) com o solo de metro quadrado dos mais valorizados no mundo. Mas talvez fosse de outra maneira, se houvesse determinado diferentemente ou deixasse transcorrer o que acontecia com a aglomeração da população para atividade industrial na área ocupada inicialmente para a instalação de fábricas. Na metade do século XIX também nela acontecia o processo de industrialização, com a construção desordenada de edifícios na área urbana próxima aos portos da cidade.

Os resultados urbanos extrapolavam o que a população e a elite de então considerava possível de convivência: altos edificios que projetavam sombras, interferindo na iluminação e ventilação dos edificios; além da sensação desagradável de pequenez em relação ao tamanho das edificações; por outro lado, entre os edificios não havia espaço suficiente para passagens adequadas, criando longas vielas e becos escuros e perigosos, além de outros perigos internos às edificações (Fig. 41):

"The development of zoning regulations had much to do with the chaotic and sometimes dangerous living and working conditions that structured everyday life in New York in the 19th to early 20th century. By the mid-19th century, Lower Manhattan was suffering from overcrowding and in many neighborhoods, chaos abounded as families and businesses co-existed in the same spaces. It was not uncommon in the late 19th century, for example, for sweatshops to be run out of the tenement kitchens. These home factories were often unsanitary and posed fire hazards. For children, it also meant living in small factories, and as a result, being exposed to the dangers of the workplace from infancy. (...) By the early 20th century, the growing height of buildings was also raising health and safety concerns for many New York residents. In the Financial District, which at the time had the highest concentration of skyscrapers in the United States, the dark shadows cast by the rising buildings was also negatively impacting rents and real estate values. In 1913, the vacancy rate in buildings south of Chambers Street was over $12 \%$. If tenants were reluctant to rent or buy buildings in the neighborhood, however, it is entirely understandable." (ETHERINGTON, 2016). 
Figura 41 - Viela de Nova lorque antes do Zoning Resolution de 1916.

Fonte: www.cityrealty.com, disponível em:

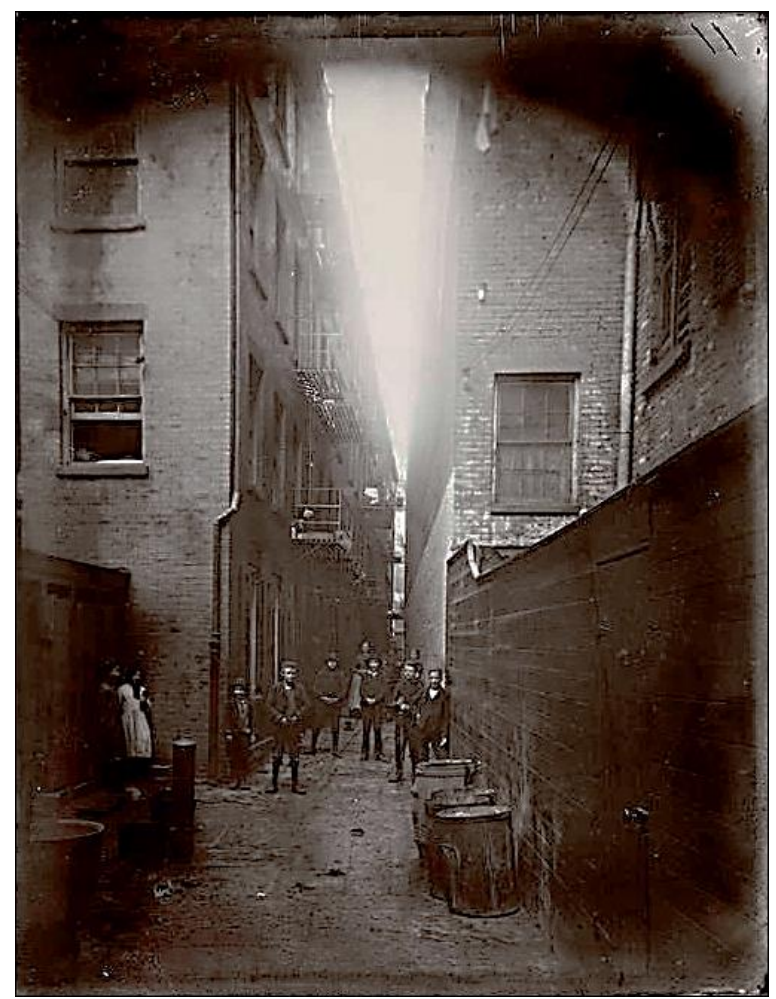

https://ds3.cityrealty.com/img/54cd3c380ebb10d2c1a452ebd01baf0433b5f122+1004++0+60 , acesso em jan/18.

O edifício Equitable, existente até hoje na parte baixa da cidade de Nova lorque, foi 0 catalisador da discussão de construção de novos edifícios no início do séc. XX. Por suas características propostas de ocupação do solo, sem precedentes anteriores: uma enorme área construída, em uma quadra inteira $(4.000 \mathrm{~m} 2)$, com quarenta andares; teria mais de 16.000 apartamentos residenciais a serem alugados. O edifício projetaria uma sombra nos seus arredores de $28.000 \mathrm{~m} 2$, além de manter permanentemente sombreado o Singer Building até 0 270. andar; outro edifício (City Investing Building) até o 240. andar, e tirar completamente a insolação de outros três edifícios com menos de 21 andares. À época, os nova-iorquinos tinham a impressão de que isto tornaria Manhattan em um local escuro e desagradável. Mas não havia o necessário impedimento legal para a construção do edifício.

Para evitar mais problemas, uma comissão foi formada para estudar uma forma de disciplinar a construção de edifícios em Nova lorque. que garantisse a penetração da luz do sol que chegasse ao nível do solo nas ruas da cidade, gerando o que eles chamam de setbacks, ou seja, as construções recuaram em ângulos estabelecidos em relação à sua implantação, para garantir a luz solar e espaços abertos ao seu redor. A comissão formada por cidadãos do poder público e privado elaborou o Zoning Resolution de 1916, que passou então a regular o uso e ocupação do solo para a cidade de Nova lorque desde então (ETHERINGTON, 2016). 
A exemplo das cidades industriais da Alemanha e Inglaterra, que também tiveram sua área urbana zoneada para suas indústrias no final do séc. XIX, o mapa industrial de Nova lorque de 1922 reflete o seguimento das leis de zoneamento promulgadas em 1916. Foi produto da mobilização de sua sociedade contra os resultados perniciosos da instalação de indústrias nos andares dos prédios construídos e da qualidade urbanística resultante dos edifícios construídos à época para a vida comunitária (principalmente quanto ao sentido da saúde pública: saneamento básico, insolação e ventilação). o que impediu e reverteu o processo de desvalorização imobiliária do seu centro financeiro, além de contribuir para a melhoria da eficiencia urbana, incluindo a criação de espaços abertos ao nível do solo para recreação da classe operária e nas alturas de seus edifícios, que garantiram a salubridade e o bom aspecto da urbe no rés-do-chão, o que contribuiu naturalmente para a valorização dos edifícios de Manhattan como locais de trabalho e moradia (Fig. 42).

O Zoning Resolution de 1916 só foi revisado de maneira mais contundente em 1961, para permitir 0 adensamento em bairros mais pobres e permitir a produção de habitação de interesse social para a população local. Durante praticamente cinco décadas modelou o skyline da cidade e o exemplo de zoneamento como instrumento urbanístico legal foi copiado por outras cidades americanas, determinando o planejamento urbano de novos bairros e novas cidades americanas ao longo do séc. XX. 
Figura 42 - Mapa de indústrias de Nova lorque em 1922, após o Zoning Resolution de 1916.

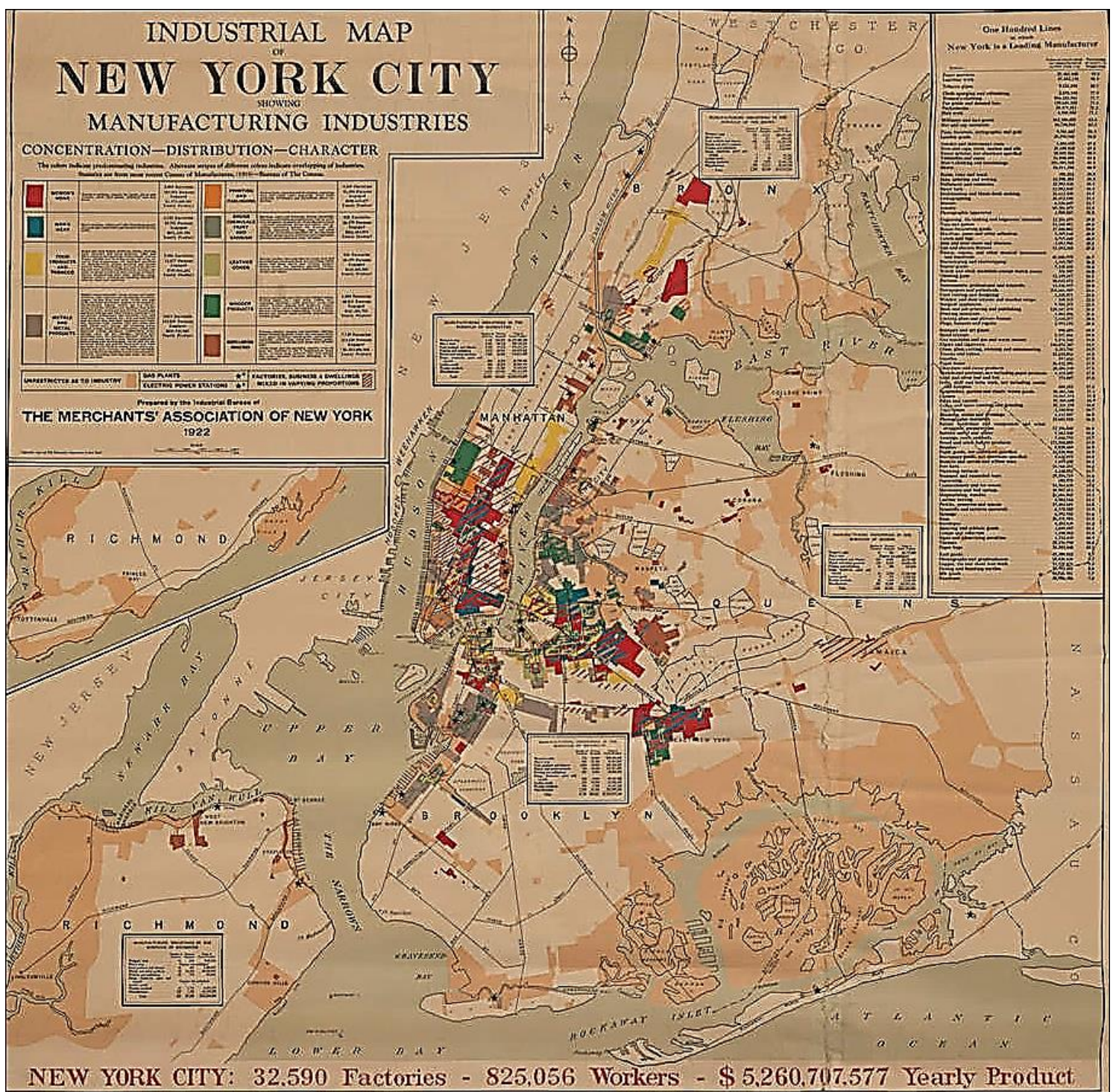

Fonte: www.cityrealty.com, disponivel em:

https://ds3.cityrealty.com/img/1221d8045322f86e39e21b4829d8274e396d08b1+1004++0+60, acesso em jan/18.

Note-se que a industrialização, além de provocar demandas no planejamento urbano com relação ao código sanitário relativo à construção das edificações, também propiciou acesso a recreação através do zoneamento municipal para conseguir a eficiência econômica.

O papel do zoneamento municipal, junto com o poder do Estado em avaliar, taxar e condenar propriedades foi e é a chave para também implementar a política nova irquina de planejamento urbano: "o zoneamento é do Estado, que garante às municipalidades poderes para regular o uso e a ocupação do solo de maneira a promover a saúde e o bem-estar público." (NYCP, 2018).

O atual conselho de planejamento urbano da cidade de Nova lorque, enuncia sua missão publicamente em seu endereço eletrônico: 


\begin{abstract}
"Industrialization across the Americas and Europe spurred a public health focus on planning through housing construction, sanitation improvements, and - most notably - access to recreation and an appropriate way to divide cities through zoning to achieve economy and efficiency. (...) Along with the city's power to budget, tax, and condemn property, zoning is a key tool for implementing planning policy. New York City's power to regulate use, bulk, density of buildings, to promote affordable housing, and to protect places of historical significance through zoning is derived from the state, which grants municipalities the power to regulate land use in a manner designed to promote the public health and welfare." (NY City Planning, 2017).
\end{abstract}

As palavras grifadas, são simples e claras para se compreender a importância do zoneamento municipal atualmente: o zoneamento vem do poder público, é municipal pois a atribuição da lei e sua aplicação é local; mas o objetivo final (promover a saúde e o bem-estar público) muitas vezes como finalidade é permeada pelas prerrogativas de aplicação da legislação urbana às populações.

O zoneamento funciona até hoje nos países desenvolvidos e em desenvolvimento como instrumento de regulação do uso e ocupação do solo urbano. De certa maneira seu funcionamento é fruto inclusive do seu resultado financeiro: os lucros das incorporações podem ser maiores e melhores conforme o que o zoneamento local do empreendimento o permite.

Por outro lado, em algumas localidades o zoneamento municipal pode encarecer ou dificultar os empreendimentos residenciais para os mais pobres:

\footnotetext{
"Zoning has for a century enabled cities to chart their own course. It is a useful and popular institution, enabling homeowners to protect their main investment and provide safe neighborhoods. As home values have soared in recent years, however, this protection has accelerated to the degree that new housing development has become unreasonably difficult and costly." (FISCHEL, 2017).
}

Nos empreendimentos residenciais para as camadas menos favorecidas da população, muitas vezes o proprio Estado os incluem nos planos diretores municipais: zoneamentos de interesse social para determinadas áreas com o fim específico de acomodar prédios residenciais.

Isto é particularlmente necessário em cidades com preço do solo muito valorizados, como Nova lorque; mas ainda maís crítico nas metrópoles dos países em desenvolvimento (GOTTDIENER; BUDD, 2005, p. 57).

\title{
4.2 Breve histórico do início do Zoneamento no Brasil
}

O prof. Flávio Villaça entende por Zoneamento "a legislação urbanística que varia no espaço urbano." (VILLAÇA, 2001, p.177). Mas o zoneamento municipal brasileiro para ele não é considerado como planejamento urbano na forma stricto sensu, embora todo plano diretor brasileiro inclua o zoneamento: 


\begin{abstract}
"O zoneamento - ao contrário do planejamento urbano stricto sensu - surge no Brasil sem qualquer elaboração teórica, sem a participação de intelectuais estudiosos da cidade e sem a influência do pensamento estrangeiro. Recorde-se que no final do século XIX, quando se inicia no Brasil, o zoneamento mal ensaiava os primeiros passos na Alemanha e nos Estados Unidos. 0 que se inicia no Brasil corresponde (e continuará correspondendo) a interesses e soluções específicos das elites brasileiras. Mesmo recentemente, na maioria dos planos diretores brasileiros 0 zoneamento aparece apenas como princípios vagos e não operacionais. Ao contrário, as leis específicas de zoneamento, separadas dos planos diretores são operacionais, aprovadas nas Câmaras Municipais e executadas (evidentemente com os percalços da execução de tantas leis no Brasil).

A história do zoneamento é totalmente distinta da história do planejamento urbano stricto sensu, e até hoje predomina o zoneamento separado do plano diretor (embora no discurso, se afirme que o zoneamento é parte integrante de um plano diretor). Esta é a razão pela qual o zoneamento é a prática de planejamento urbano lato sensu mais difundida no Brasil. Nos seus quase cem anos de existência entre nós, quase que exclusivamente serviu para atender a interesses claros e específicos, particularmente os dos bairros da população de mais alta renda" (VILLAÇA, 2001, p. 178).
\end{abstract}

Os municípios brasileiros levaram muito tempo para terem uma autonomia sobre 0 zoneamento municipal, pois por muitos séculos o planejamento urbano stricto sensu foi vertical no Brasil então colonial: onde se estabelecer a igreja, a câmara municipal, o tamanho do arruamento, o lado da rua de implementação primeira do casario, etc., eram determinados de modo específico por Portugal (LANÇAS, 2007).

Depois, no Brasil Imperial, continuou a seguir-se o modelo português, uma vez que não houve grande ruptura sobre o pensamento colonizador, pela continuidade da casa real, ainda que houvesse a separação legal do Brasil de Portugal. Após a proclamação da República em 1889, com a Constituição da República dos Estados Unidos do Brasil, promulgada em 24 de fevereiro de 1891, Monteiro e Mattos afirmam que os Estados regulamentavam os assuntos municipais de modo a garantir-Ihes autonomia regional, mas a regulamentação dos impostos de propriedades eram responsabilidade estadual (uma vez que na esfera legislativa estadual estavam representadas as famílias detentoras de terras municipais):

\footnotetext{
"Acerca dos assuntos municipais, estabelecia, por exemplo, normatizações que permitiam autonomia regional. Regulamentava, com o Art. 68, uma hierarquização institucional para isso, em que: "Os Estados organizar-se-ão de forma que fique assegurada a autonomia dos Municípios em tudo quanto respeite ao seu peculiar interesse. (...) Exemplo prático dessa hierarquização é encontrado no art. $9^{\circ}$ da Constituição (1891), ao qual estabelecia a regulamentação acerca da taxação de impostos de propriedade - elemento de poder nos municípios - como responsabilidade dos Estados" (MONTEIRO; MATTOS, 2015, p. 1792).
}

Nada havia, portanto, como zoneamento strictu sensu, algo que se relacionasse ao planejamento urbano stricto sensu, antes uma determinação com preocupação apenas para a arrecadação estadual. Em São Paulo, a elite paulista da época de transição do império para a 
primeira república já se preocupava com a autonomia municipal. Alberto Sales, teórico do Partido Republicano Paulista no final do século XIX, escreveu:

"Os municípios, apertados em uma organização acanhada e raquítica, que não lhes
reconhece competência para coisa alguma, ainda mesmo nos assuntos mais triviais
de policiamento das cidades, vivem esmagados completamente pela ferrenha
centralização do império e só se movem a custo dentro de estreitos limites de uma
organização absurda e intolerável, sem nem ao menos possuírem o direito de
organizar por si mesmos os seus orçamentos". (SALES, apud MONTEIRO;
MATTOS, 2015)

Sobre a lei estadual paulista número 1038/1906, que dispõe sobre a organização municipal, novamente relacionado à receita municipal, no artigo 19 , destacam-se, dele, os incisos $2^{\circ}$ e 12:

"Artigo 19. - A receita dos municípios será constituída somente das seguintes verbas: (...) 2..$^{\circ}$ Do imposto de indústrias e profissões, e do imposto predial urbano nas localidades em23 que este couber às municipalidades; 12. Das taxas de viação, comprehendendo calçadas, terrenos em aberto, cercas, guias, e falta de encanamento nos prédios urbanos para aguas pluviais; (...)" (ALESP,1906).

A Lei n. 1.038/1906 previa, no Art. $3^{0}$ das disposições transitórias, que os municípios deveriam se adequar às normatizações estaduais. Para os municipios do interior paulista, este dispositivo jurídico foi importante pois os municípios utilizaram os recursos advindos da arrecadação de rendas municipais para resoluções de suas próprias demandas, sem depender tanto de uma reinvindicação política que muitas vezes significava (quando pleiteada e atendida) uma demora no repasse dos recursos até chegarem ao erario publico municipal. Borges (2007) acrescentou dados importantes ao clarificar legislações em que Monteiro e Matos consideram como referências ao surgimento de leis de zoneamento no País:

\footnotetext{
"Outra referência ao surgimento do zoneamento no Brasil, é a partir do final da década de 1910, quando se deu a utilização dessa normatização urbanística, através da divisão da cidade em zonas diferenciadas quanto ao uso do solo e à volumetria das edificações, categorizadas, de acordo com o ordenamento e a evolução urbana, pelos novos Regulamentos de Construção aprovados para os principais centros brasileiros. (...)

Os regulamentos de construção da década de 1920 possibilitaram a transformação do espaço urbano ao introduzirem em suas determinações o zoneamento urbanístico, onde a cidade foi dividida em áreas (zonas) diferenciadas por sua normalização" (MONTEIRO; MATTOS, 2015, p.1794).
}

Para São Paulo, o municipio mais emblemático em verticalização do País, Sarah Feldman descreveu em sua tese de doutoramento o processo de instituição do planejamento e da construção do zoneamento da capital do ESP, baseado em referências urbanísticas americanas na sua organização administrativa, durante o periodo de 1947 a 1972. Diferentemente da construção do zoneamento alemão, elaborado também junto à classe do proletariado industrial, o zoneamento paulistano foi então um elemento organizador da cidade, 
utilizado para hierarquizar as funções urbanas; elaborado como um código de leis mais protetivo dos valores imobiliários, sendo então um novo código legal para garantir uma velha ordem (FELDMAN, 1996, p.67 a 92).

Quase cem anos após o início da aplicação do zoneamento no Brasil, ele está integrado à legislação urbana na maioria dos municípios que utilizam-se de planos diretores, requeridos oficialmente a partir do Estatuto da Cidade (lei federal no. 10.257/2001) para municipios com população minima de 20.000 habitantes.

Atualmente, outra questão se coloca, com a possibilidade maior de deslocamentos das populações entre municípios e regiões: verifica-se 0 aumento da pendulariade que a população PEA (e até a terceira idade realiza mais deslocamentos intra-urbanos). Devemos notar o que está acontecendo nos deslocamentos das populações, que tem as vezes domicílios registrados em um municipio, mas trabalha em outro; muitas vezes também estuda em outro, e ou também tem relações de afetividade em outro; no caso também o deslocamento é afetado pelos zoneamentos das cidades pertencentes às áreas metropolitanas, uma vez que estes podem determinar a localização de indústrias, comércios, moradias (em loteamentos residenciais ou de $2^{a}$ moradia), etc Tais movimentações podem ter implicações de diversas naturezas na vida cotidiana das pessoas, pois muitas vezes as populações de municípios com menos oferecimento de empregos e atividades de lazer ou mesmo recursos na área de atendimento à questões de saúde fazem trajetos que consomem muitas horas e recursos financeiros para estes deslocamentos, particularmente em regiões metropolitanas bem servidas por rodovias por exemplo (há vários no Brasil) como a RRT e RCB, do Sistema Castelo-Raposo.

Firkowski (2000), coloca a questão do cidadão metropolitano que vive atualmente uma base territorial ampliada, muito além do seu bairro, cidade ou município, e prevê que as possibilidades de soluções de questões metropolitanas estarão, cada vez menos frequentemente, limitadas à esfera da legislação municipal, devendo alguns problemas de recorte metropolitano (quando for o caso) ser resolvido como questão metropolitana:

\footnotetext{
"As cidades são lugares privilegiados, onde tudo se realiza; devemos fazer com que nelas se concretizem também parte dos sonhos de uma sociedade mais justa, onde a população, muitas vezes refém da rigidez dos limites políticos existentes no interior dos espaços aglomerados, possa encontrar mecanismos mais solidários e conciliatórios entre seus dilemas diários de trabalhar em um município e votar em outro; trabalhar em um município e precisar da creche para seus filhos em outro; trabalhar em um município e preocupar-se com a falta de água para suas necessidades básicas em outro.

Faz-se mister que as pessoas passem a assumir sua condição de cidadão metropolitano ou de aglomerados, possam exercer sua cidadania em uma base territorial ampliada, pois seus problemas e as possibilidades de soluções, estarão, cada vez menos, limitadas à esfera municipal." (FIRKOWSKI, 2000, apud BARRETO, 2007, p.50).
} 
No caso das metrópoles brasileiras, o Estatuto das Metrópoles (Lei no. 13.089 de 12/01/2015), estabeleceu há cerca de três anos que o Macrozoneamento deverá compor o Plano de Desenvolvimento Urbano Integrado - PDUI (art. 12, $\S 1^{\circ}$, II) das RMs e AUs.

\footnotetext{
"É possível antever que, se levada a sério, a redistribuição das competências e titularidades para a consecução das FPIC consistirá num dos focos nevrálgicos das negociações políticas. Tomemos o exemplo do parcelamento, uso e ocupação do solo: se já é conflituosa sua normatização dentro de um único município, quem dirá o macrozoneamento que deverá compor o Plano de Desenvolvimento Urbano Integrado - PDUI (art. 12, $\S 1^{\circ}$, II) das RMs e AUs. Até que ponto essa regulação supra municipal colide com a autonomia constitucional dos municípios para 0 ordenamento territorial (art. 30, VIII da CF/88)? Qual o grau aceitável de direcionamento e detalhe de um macrozoneamento metropolitano, agora vinculante para os demais entes?

(...) Controvérsias provavelmente emergirão também na prestação de determinados serviços públicos essenciais. Se é verdade que o transporte coletivo, o saneamento, entre outros, podem ser mais eficientes e inclusivos se planejados e geridos em nível regional ou metropolitano, o novo modelo, em certa medida, coloca em xeque 0 arraigado municipalismo nas políticas setoriais.

Os municípios deverão, pelo art. $10,3^{\circ}$ da Lei $13.089 / 2015$, a compatibilizar seus Planos Diretores com as novas diretrizes dos PDUI. Contudo, olvidou o legislador todos os demais planos (Planos de Saneamento Básico, Planos de Mobilidade Urbana, Planos de Gestão de Resíduos Sólidos, Planos Locais de Habitação de Interesse Social, etc.), os quais não restaram sujeitos à mesma obrigatoriedade." (MOURA; HOSHINO, 2000, p. 4-5).
}

O exíguo prazo e a complexidade dos assuntos municipais e regionais, desde a promulgação do Estatuto da Metrópole não permitiu, em muitos casos (com exceção de poucos, como o PDDI da RMBH) elaborar e terminar a maioria dos PDDUl's das 69 RM existentes no País. $O$ atual presidente do País, Michel Temer assinou a medida provisória $n^{0} 818$, de 11 de janeiro de 2018, prorrogando o prazo de finalização destes até 31/12/2021, o que na prática deve permitir um tempo maior de deliberação entre os municípios e os agentes metropolitanos para a elaboração dos macrozoneamentos metropolitanos que deverão compor estes PDDUl's:

“(...)

a) garantir o cumprimento do disposto no caput do art. 10 no prazo de cinco anos, contado da data da instituição da região metropolitana ou da aglomeração urbana; e b) a elaboração, no âmbito da estrutura de governança interfederativa, e a aprovação pela instância colegiada deliberativa, até 31 de dezembro de 2021, do plano de desenvolvimento urbano integrado das regiões metropolitanas ou das aglomerações urbanas; (...)" (BRASIL, 2018).

Desde 2016 está sendo realizado o PDDUI da RMS, conduzido pela EMPLASA. Dentre várias observações, pode-se evidenciar que nesta RM há uma dificuldade de participação dos elementos da administração pública dos municípios menores, (em população e arrecadação tributária), para as discussões que foram separadas em cinco eixo temáticos (GT de Saúde, GT de Segurança Pública, GT de Desenvolvimento Urbano, GT de Meio Ambiente e GT de Mobilidade Urbana), cujas diretrizes desenvolvidas deverão ser agregadas em um GT de 
Macrozoneamento que deverá apresentar, sob coordenação da EMPLASA a definição das Macrozonas metropolitanas e suas diretrizes (em 09/03/2018).

Como Moura e Hoshino (2000) prevêem, se a lei do Estatuto da Metrópole for levada a sério, a redistribuição das competências e titularidades, que serão os focos nevrálgicos das negociações políticas, principalmente considerando-se o uso e a ocupação do solo, e sua legislação, (normalmente já conflituosa nos interesses internos a um município); entre municípios de diversos graus de desenvolvimento econômico e recursos naturais, partidos políticos e graus de qualidade de vida, dentre os muitos itens que devem ser levados em conta na discussão dos Macrozoneamentos, na realização dos PDDUl's, quando feitos democraticamente. Com esta interrogação para o futuro dos zoneamentos municipais versus os macrozoneamentos metropolitanos, sem pretensão de encerrar as importantes questões pertinentes, finalizamos este breve histórico do zoneamento. Para o caso desta tese, seguimos com o zoneamento do Município de Sorocaba, pois na região analisada é o município mais numeroso em termos de população, e detêm dois dos quatro trechos escolhidos para as análises. Os outros dois trechos terão seus zoneamentos incluídos nos respectivos capítulos das análises.

\subsection{Zoneamento do Município de Sorocaba, SP}

Para este trecho de Brigadeiro Tobias (Trecho 3) e para do Parque Campolim (Trecho 4), será colocado a seguir uma breve história do zoneamento municipal de Sorocaba, que servirá aos dois próximos trechos no período da primeira metade do séc. XX.

Para a região de Sorocaba, estabeleceu-se em 1914, condição nacional inédita a divisão inicial jurídica do espaço urbano em dois tipos de zonas: a primeira, central, delimitada por lei; a outra zona era a que excluísse a área urbana central; a partir daí incidindo impostos prediais na zona central e na zona rústica (MONTEIRO; MATTOS, 2015) (Fig. 43 e 44). Pelos registros da Câmara Municipal acerca da divisão do perímetro urbano em zonas no ano de 1914, e da cobrança de Impostos Prediais e de Viação no ano de 1916 ficou registrado: "É destacável observar, mediante 0 art. $1^{0}$ da lei n.119/1914, a definição do zoneamento urbano sorocabano, delimitando-se o que era a cidade, e, por consequência: o que não era" (Fig. 43) (MONTEIRO; MATTOS, 2015, p.1802). 
Figura 43 - Divisão do perímetro urbano de Sorocaba em zonas (lei n.119/1914).

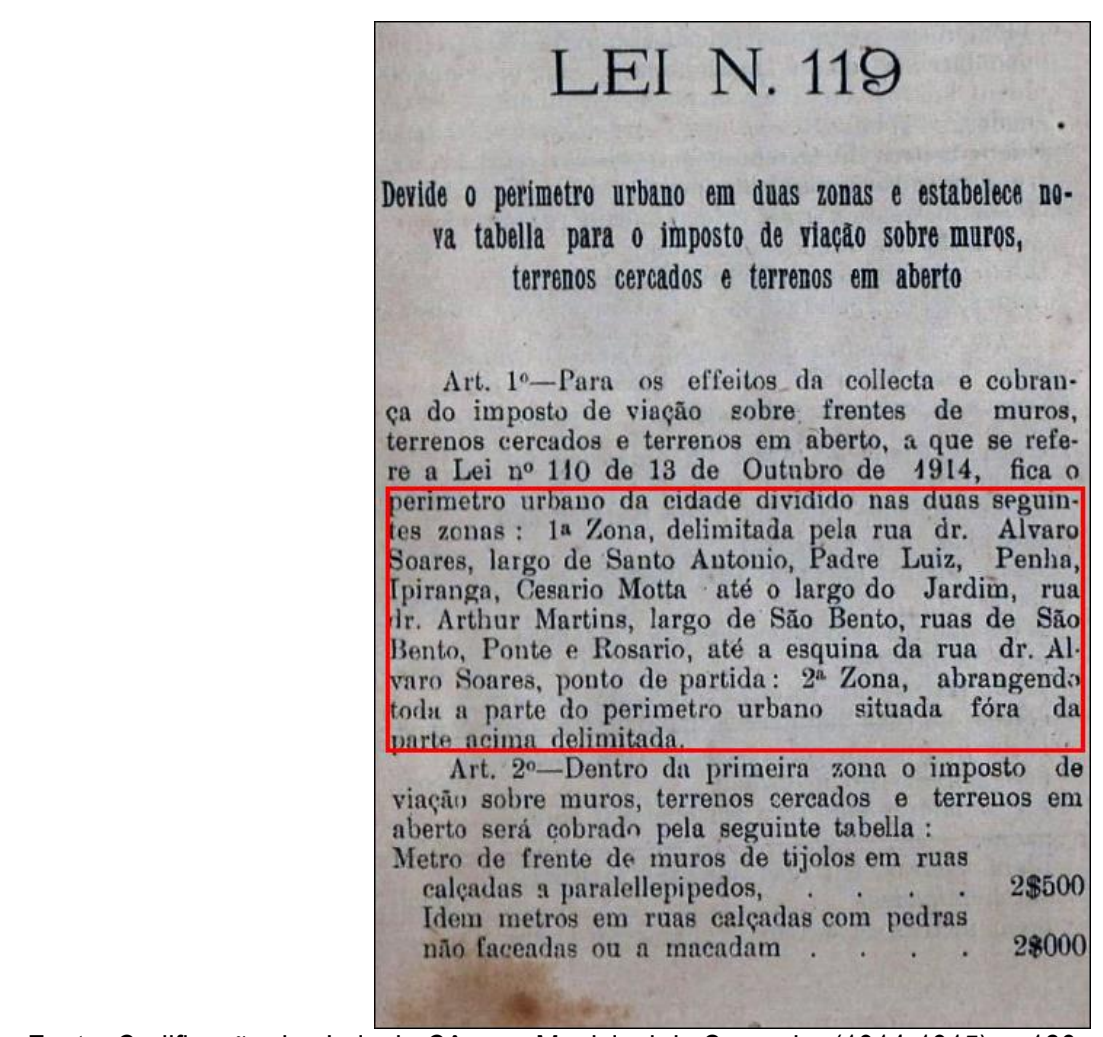

Fonte: Codificação das Leis da Câmara Municipal de Sorocaba (1914-1915), p.126.

Figura 44 - Imposto Predial Rústico (lei n.115/1914).

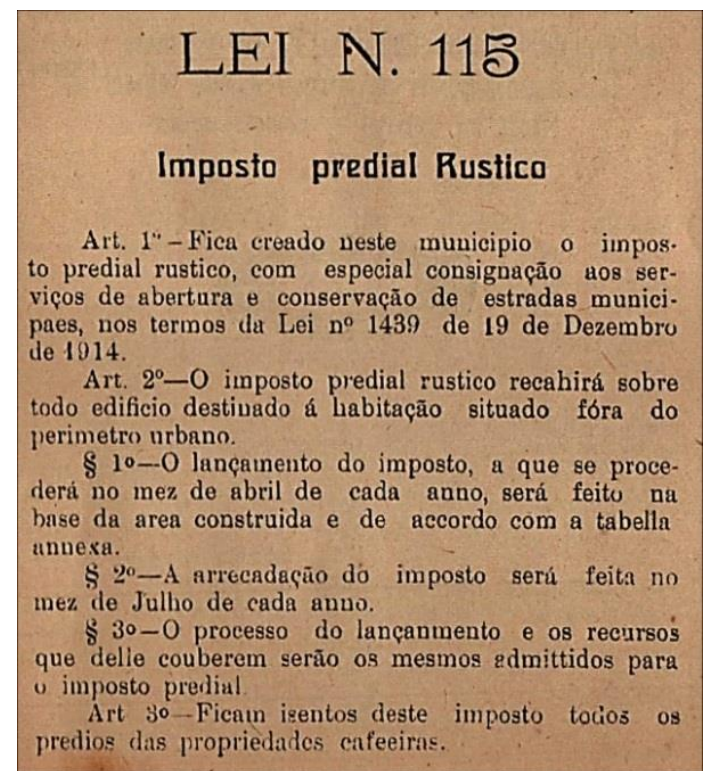

Fonte: Codificação das Leis da Câmara Municipal de Sorocaba (1914-1915), p.126.

Monteiro e Mattos considera que a legislação de zoneamento sorocabana (1914) é pioneira no ambito nacional. A seguir está o mapa da cidade evidenciando o núcleo urbano, estradas de rodagem e ferrovia (E.F.S.), fábricas e corpos d'água em 1909. Note-se também 0 ramal ferroviário, que servia à fábrica para levar os produtos ao ramal da EFS em Sorocaba, 
construído em apenas três anos (1903-1906). Nota-se na figura a seguir o primeiro zoneamento de Sorocaba era delimitado pela linha vermelha para fins de taxação de impostos de viação; no restante era aplicado o imposto predial rústico. Um fato curioso é a indicação do sentido norte está para baixo, evidenciando a percepção de espaços que colabora para a nomeação dos lugares (ex.: Rio Acima, bairro cujo nome permanece desta maneira há mais de cem anos) (Fig. 46).

Figura $45-1^{\mathrm{a}}$ e $2^{\mathrm{a}}$ Zonas de Sorocaba pela Lei 119/1914.

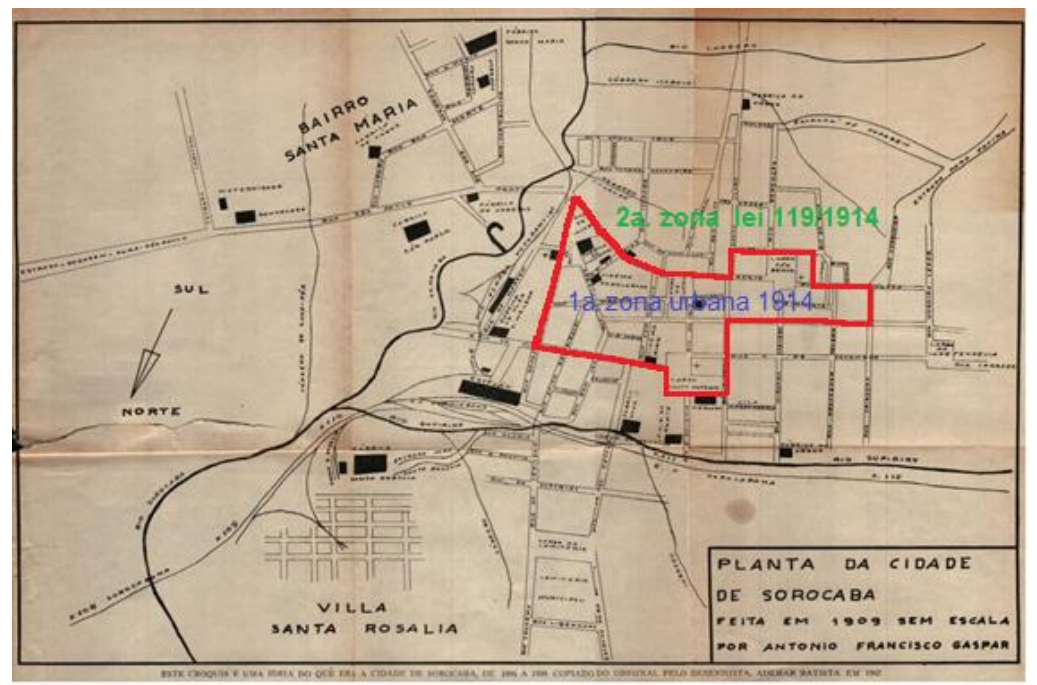

Fonte: Planta da Cidade de Sorocaba em 1909, de Antonio Francisco Gaspar, copiado do original pelo Desenhista Ademar Batista em 1967.

Figura 46 - Localização do bairro do Rio Acima em mapa atual (2018).

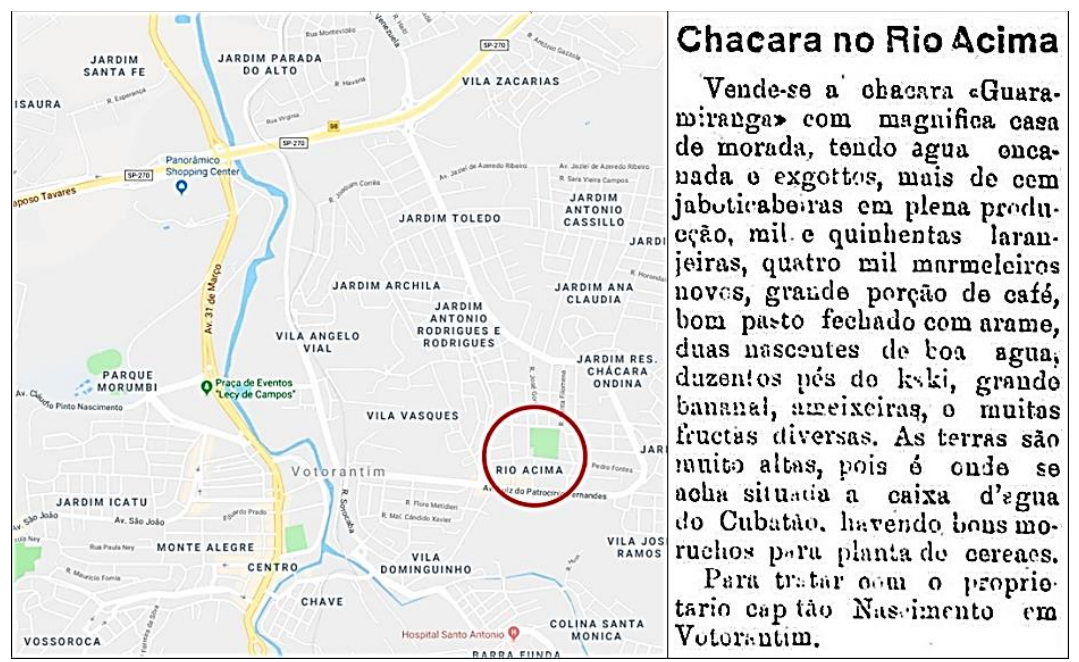

Fonte: Google Maps, acesso em fev/2018. Figura (dir.) - Anúncio de chácara com água encanada em Sorocaba, no bairro do Rio Acima, de 1912. Fonte: (Reprodução) Jornal Cruzeiro do Sul, 28/12/1912, p.3.

Os engenheiros da Light \& Co. já haviam construído a Represa de Itupararanga (1911), ao sul, para servir às indústrias de tecelagem do então incipiente grupo Votorantim. O Distrito de Votorantim foi instalado em 25 de fevereiro de 1912, oficializando a ocupação da área 
denominada Rio Acima, mas ainda continuava sendo área de chácaras, como verificado no anúncio da figura anterior, embora já tendo água encanada e esgoto servindo a casa do exprefeito de Sorocaba de então e antigo proprietário da chácara do anúncio, capitão Augusto Nascimento (BADDINI, 2002).

Na representação de CELLI (2012) da mancha urbana de Sorocaba em 1925, destacase a área do distrito de Votorantim, ainda na chamada Zona Rural de Sorocaba, mas já com 0 Núcleo dos Protestantes e o acesso pelo Cerrado (Estrada do Quiló e futura Av. Antônio Carlos Cômitre, do bairro Campolim) ao bairro de Vossoroca, em Votorantim.

O crescimento da mancha urbana do Município de Sorocaba e do norte do Município de Votorantim de 1925 a 1962, quando os distritos de Aparecidinha, Eden e Cajuru já estão consolidados como mancha urbana, embora ainda considerados como Zona Rural, e o distrito de Votorantim já exibem considerável mancha urbana; embora mesmo com o traçado da "variante" da Via Raposo Tavares, reinaugurada (era a Estrada São Paulo-Paraná) e transformada em via asfaltada em 1954, ainda permaneça as características típicas da zona rural; o mesmo acontecendo com Brigadeiro Tobias, na zona leste de Sorocaba.

Evidenciando a regulamentação estadual quanto ao zoneamento municipal, a Lei número 1 da Assembléia Legislativa do Estado de São Paulo, de 18/setembro/1947, dispunha sobre a organização dos municípios, em seu artigo 16, com destaques para os incisos VIII ao XI do primeiro parágrafo:

\footnotetext{
"VIII - regulamentar as construções de qualquer natureza, loteamentos e arruamentos em terrenos particulares;

IX - dispor sobre 0 uso das áreas urbanas, regulamentando o zoneamento, particularmente quanto à localização de fábricas, oficinas, depósitos e instalações que interessem à saúde, à higiene, ao sossego ao bem-estar e à segurança pública; $X$ - regulamentar a utilização dos logradouros públicos, e em particular o trânsito e a circulação nas vias públicas, bem como o serviço de transporte de passageiros e cargas;

$\mathrm{XI}$ - prover sobre a defesa estética das cidades, regulamentando os estilos e 0 equilíbrio das massas das edificações." (CMS, 1947).
}

Sorocaba, município sede da Região Administrativa do sudeste de São Paulo, seguindo a legislação estadual, e evidenciando o crescimento populacional e a preocupação com possíveis inserções de novas indústrias no território municipal, no âmbito das questões de zoneamento municipal promulga a Lei $n^{0} 162$, de 18 de agosto de 1950. Já tendo sido instalado o distrito de Brigadeiro Tobias, além do já mencionado de Votorantim, que exclui do zoneamento estes distritos, pois terão zoneamento à parte do núcleo urbano principal, e dedica uma parte do Código de Obras do Município (Título II: Zoneamento, Capitulo I, Seção única) para a divisão e sub-divisão das zonas para Sorocaba tem-se esta redação: 


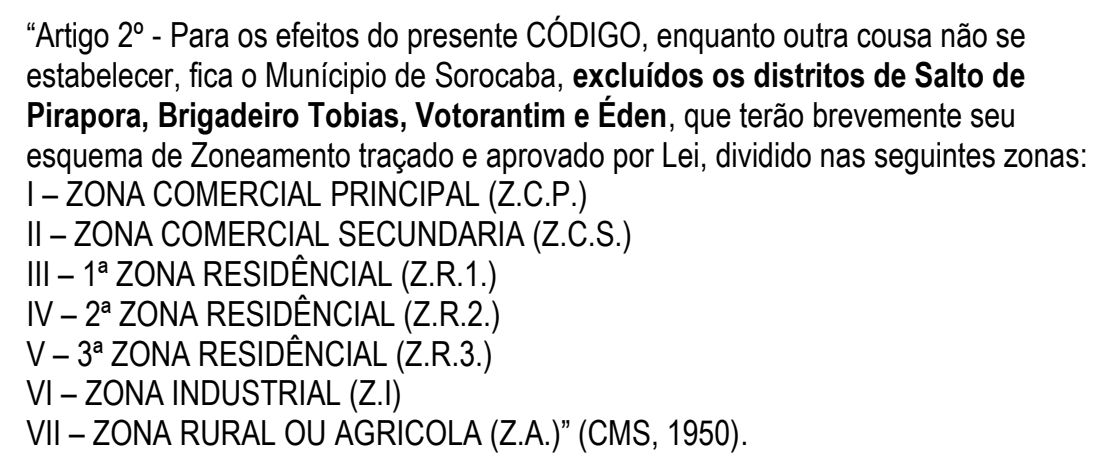

Pela lei no. 1.319, de 17 de maio de 1965, é delimitado novo perímetro urbano da sede do Município de Sorocaba; e pela lei no. 9205, de 28/12/196521, substituindo a lei estadual número 1 de 1947, altera-se novamente a lei orgânica dos municípios pelo seu artigo 52, sobre as normas urbanísticas, instituindo a necessidade de Plano Diretor; portanto como o município já havia preparado, pela Lei $n^{0} 1438$ de 21 de novembro de 1966 foi aprovado o Plano Diretor do Município de Sorocaba, que delimita duas áreas: urbana e rural (para fins de tributação).

Gestado desde 1964, a Câmara Municipal de Sorocaba promulga a lei no. 1541, de 23/12/1968, dispondo sobre uso do solo, já atribuído ao órgão municipal encarregado do planejamento. No artigo $2^{\circ}$ da referida lei o território municipal é dividido em zonas e setores. (veja em anexo). É um plano bem detalhado, que prepara o município para o recebimento de indústrias que seriam recebidas devido à abertura e funcionamento da RCB, tendo obtido êxito nesta política pública, embora as outras considerações referentes à abertura de anéis viários e anel ferroviário só fossem começar a ser realizadas décadas mais tarde.

Devido à emancipação de Votorantim de Sorocaba, pelo plebiscito ocorrido em $1^{0} \mathrm{de}$ dezembro de 1963, o Município de Votorantim foi instituído em 27/03/1965; na sequencia foi delimitado outro perímetro urbano da sede do Município de Sorocaba pela lei no. 1568 de 27/10/1969.

Sobre a próxima década de 70 em Sorocaba, a historiadora Cássia Baddini descreve:

\footnotetext{
"Sorocaba atraia a população pobre de estados vizinhos, como o Paraná e Minas Gerais; o que era visto como risco ao equilíbrio econômico. Este contingente, não especializado, disputava certos setores do mercado de trabalho, como o da construção civil e linhas de produção industrial. Além disso e o que era mais grave, trazia problemas de moradia, transporte, saúde pública, e saneamento básico, arriscando levar a cidade a um colapso de crescimento. (...) A preocupação com tal condição urbana fez o poder municipal por em prática o seu plano diretor na década de 70, elaborado desde 1964." (BADDINI, 2002, p.26).
}

\footnotetext{
21 Disponivel em: http://www.al.sp.gov.br/repositorio/legislacao/lei/1965/lei-9205-28.12.1965.html, acesso em julho de 2017.
} 
Outro trecho citado por Baddini relata que "Embora não exista um prazo para o mesmo ser integralmente executado (...), constituiu-se num planejamento a longo prazo, com previsão para o crescimento da cidade até 0 ano 2000" (BADDINI, 2002, p. 26).

Nota-se através das alterações da Lei municipal 1541/68 (Tabela 11), que houveram preocupações com as questões de habitações populares (lei 1717/73) e adequações quanto ao zoneamento municipal (lei 1882/76, lei 1962/78, lei 2041/79):

As alterações listadas acima denotam a garantia de um lote mínimo de cento e vinte metros quadrados, e acesso pelo morador (se este for possuidor do último lote do fundo do loteamento) de menos de quinhentos metros linearmente à via principal; preocupação de uma outra época em que o veículo automotivo não era tão acessível às famílias como 0 são atualmente.

Durante a década de 80 , a Lei 1541/68 foi ainda várias vezes modificada com vistas às questões de habitação de interesse social (Lei 2041/79; Lei 2102/81) e da proibição de áreas para construção de edifícios multi-familiares (Lei 2821/88); já na década de 90 o zoneamento dos bairros abaixo mencionados (próximos à rodovia Raposo Tavares no início do trecho urbano) é alterado para disciplinar questões industriais e comerciais em bairros-jardins (na prática proíbe-se a atividade industrial nos bairros citados e permite-lhes novos usos comerciais e de serviços, viabilizando o funcionamento mais dinâmico dos bairros jardins e do bairro Parque Campolim, próximo à rod. Raposo Tavares). Também nesta época é disciplinada utilização de aumento do coeficiente de aproveitamento, desde que recolhido os valores determinados pela lei 4554/94 e a serem pagos conforme discriminava a lei.

Em meados da década de 90 , as principais avenidas de Sorocaba são tornadas corredores comerciais, com zoneamento específico; definido o princípio dos corredores comerciais de comercio e serviços, permitem-se a instalação de cafés, bares, restaurantes, e congêneres no principal corredor viário (Av. Antônio Carlos Comitre, no bairro Parque Campolim, com acesso pela saída 100 da rod. Raposo Tavares).

Em junho de 1999, é promulgada pelo então prefeito Renato Amary a Lei $5911^{22}$, sobre a ampliação da Zona Residencial 1 - $2^{\circ}$ setor, antes definida no artigo 24 da Lei $n^{0} 1.541$, de 23 de dezembro de 1968. A partir da lei 6200 de 08/08/2000, nota-se a intervenção pública pontual na ZR1 já expandida. A seguir, um quadro resumo das alterações da lei número 1541 de 23/12/1968 até o ano de 2000:

\footnotetext{
${ }^{22}$ http://www.camarasorocaba.sp.gov.br/sitecamara/proposituras/verpropositura?numero propositura=5911\&tipo pro positura=1, acesso em julho/2017.
} 
Tabela 11 - Quadro resumo de Leis municipais que alteraram o zoneamento municipal proposto pela Lei 1541/1968.

$$
\mathbf{n}^{*}: 1541 \quad \text { Data : } 23 / 12 / 1968
$$

Ementa : Dispõe sôbre o Código de Zoneamento.

Alterada pela Lei

\begin{tabular}{|c|c|c|}
\hline Lei & Data & Ementa \\
\hline$\underline{6200}$ & $08 / 08 / 2000$ & 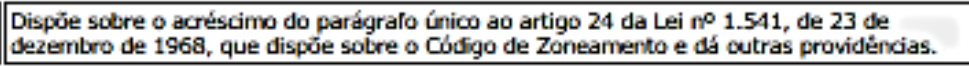 \\
\hline$\underline{5911}$ & 01/06/1999 & $\begin{array}{l}\text { Dispóe sobre a ampliaçäo da Zona Residencial } 1 \text { - } 2^{\circ} \text { setor, definida no artigo } 24 \text { da Lei mo } \\
1.541 \text {, de } 23 \text { de dezembro de } 1968 \text {, que dispüe sobre o Código de Zoneamento e dá outras } \\
\text { providências. }\end{array}$ \\
\hline$\underline{5683}$ & $26 / 05 / 1998$ & \begin{tabular}{|l|} 
Altera o item 7 do Art. 20 , da Lei no 1.541 , de 23 de dezembro de 1968, e dá outras \\
providências.(Dispöe sốbre o Código de Zoneamento)
\end{tabular} \\
\hline 5261 & $25 / 10 / 1996$ & Altera o Avtigo 32 da Lei $n^{0} 1.541$, de 23 de dezembro de 1968. (Código de Zoneamento) \\
\hline 4874 & 06/07/1995 & $\begin{array}{l}\text { Cria os corredores comerciais, as Zonas Comerciais Secundárias Z.C.5, Z.C.6. e Z.C.7, } \\
\text { amplia as Zonas Comerciais } 3 \text { e } 4 \text { e a Zona Residendial } 1-2^{\circ} \text { setor. }\end{array}$ \\
\hline 4555 & $03 / 06 / 1994$ & Condiciona o uso do Artigo $7^{\circ}$ da Lei na 1541. (Código de Zoneamento) \\
\hline$\underline{4554}$ & $03 / 06 / 1994$ & Condiciona o uso do Artigo 15 da Lei ro 1.541. (Cúdigo de Zoneamento) \\
\hline 3519 & $08 / 04 / 1991$ & 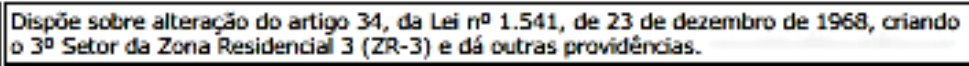 \\
\hline$\underline{3287}$ & $18 / 05 / 1990$ & $\begin{array}{l}\begin{array}{l}\text { Dispöe sobre alteraçäo do Código de Zoneamento, instituindo a Zona Comercial no } 4 \text {, e dé } \\
\text { outras providéndias. }\end{array} \\
\end{array}$ \\
\hline 1985 & $30 / 10 / 1978$ & 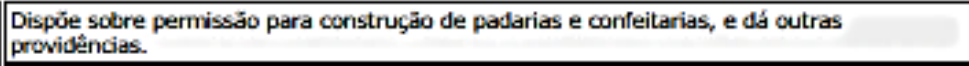 \\
\hline$\underline{1962}$ & $23 / 05 / 1978$ & $\begin{array}{l}\text { Dispö̉e sobre alteraçäo da redaça do artigo 46, da Lei no 1.541, de } 23 \text { de dezembro de } \\
\text { 1968. (Codsigo de Zoneamento) }\end{array}$ \\
\hline$\underline{1882}$ & $05 / 10 / 1976$ & 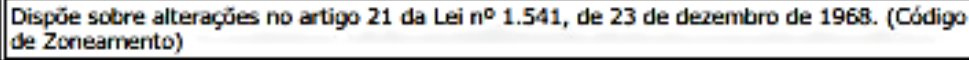 \\
\hline
\end{tabular}

Tem matéria versada na Lei

\begin{tabular}{|c|c|c|}
\hline Lei & Data & Ementa \\
\hline 4594 & $02 / 09 / 1994$ & Dispōe sobre a autorizaç̄o para a construçقo de Apart-Hotés e dá outras providências. \\
\hline$\underline{3457}$ & $18 / 12 / 1990$ & $\begin{array}{l}\text { Dispoue sobre proibiçäo de instalaçües industriais nos Jardins que menciona e define uso } \\
\text { permitido em outros e dá outras providéncias. }\end{array}$ \\
\hline$\underline{3235}$ & $26 / 03 / 1990$ & $\begin{array}{l}\text { Suprime o alargamento para } 25,00 \text { metros da Rua Aparesida, nos termos do parágrafo } \\
\text { únioo, do artigo } 3^{\circ} \text {, da Lei no } 1.438 \text {, de } 21 \text { de Novembro de } 1.966 \text {. }\end{array}$ \\
\hline 2821 & $13 / 09 / 1988$ & Proibe a corstrugạo de edifícios multifamiliares e dá outras providéncias. \\
\hline$\underline{2102}$ & $01 / 04 / 1981$ & $\begin{array}{l}\text { Altera a redaça dos artigos } 1^{\circ} \text { e } 18 \text { da Lei no } 2.042 \text {, de } 29 \text { de outubro de } 1.979 \text { e dá outra } \\
\text { providencia. (arrumento, loteamento e construça de residüncias de interesse social) }\end{array}$ \\
\hline 2042 & $29 / 10 / 1979$ & Dispóe sobre o arruamento, loteamento e construģöo de residências de interesse social. \\
\hline$\underline{1717}$ & $12 / 04 / 1973$ & Concede isençäo de tributos à construgöes populares e dá outras providências. \\
\hline
\end{tabular}

Fonte: Camara Municipal de Sorocaba. Acesso em julho/2017.

Os professores da FAU-USP Paula Santoro, Renato Cymbalista e colaboradora Paula Nakashima resumem a política urbana do Município de Sorocaba desde os anos 60 até o final do século XX:

"A cidade já teve vários planos diretores. Em 1964 elaborou um Plano Diretor, aprovado em 1966 (Lei Municipal no 1.438/66), complementado pelo Código de Obras (Lei Municipal no 1437/66), e Código de Zoneamento (Lei Municipal no 1541/68), com a delimitação de zonas de uso, cada uma delas acompanhada de uma lista de atividades permitidas e com uma considerável Zona de Expansão Urbana. Em 1971, foi aprovado o Plano Diretor de Desenvolvimento Integrado. (...) Em termos territoriais, o município privilegiou, desde seus primeiros planos e zoneamentos a existência de zonas restritas ao uso industrial, ou seja, criou uma reserva de terra para esse uso. Em 1970 foram aprovados os Distritos Industriais, destinados exclusivamente à implantação de indústrias e outros investimentos afins que thes dessem suporte, com uma área inicial de 25 milhões de $\mathrm{m} 2$, hoje desconfigurado em $70 \%$ de seu território em virtude de várias alterações de 
zoneamento feitas em um processo aleatório, visando principalmente a abertura de loteamentos residenciais que disputam com as indústrias." (SANTORO; CYMBALISTA; NAKASHIMA, 2005).

Encerrando o século XX, preparou-se para Sorocaba, município polo da Região Administrativa e de Governo da parte sudeste do Estado de São Paulo, o próximo plano diretor municipal, que será o primeiro sob a égide da lei federal número 10.257 de 10 de julho de 2001, Lei do Estatuto das Cidades. Com a instituição do Estatuto da Cidade, a partir de 2001, o município pólo da atual Região Metropolitana de Sorocaba, então com orçamento municipal crescente, elaborou e instituiu pela Lei № 7.122, o Plano Diretor de Desenvolvimento Físico Territorial do Município de Sorocaba, aprovado em $1^{\circ}$. de junho de 2004. Formalmente, foi 0 primeiro plano de zoneamento municipal elaborado de acordo com a Lei do Estatuto das Cidades, com a convocação da sociedade civil para sua elaboração. Participaram das duas audiências públicas realizadas no auditório do SESI de Sorocaba, cerca de 100 pessoas (em cada audiência), a maioria empresários ligados à empreendimentos imobiliários, técnicos da prefeitura, historiadores, professores e interessados no tema.

Lembrando que a prefeitura de Frankfurt realizou em 1890 congressos com seus munícipes trabalhadores, empresários e proprietários de edificações para a discussão e aprovação do zoneamento municipal de Frankfurt (1891), estamos com mais de 100 anos de atraso neste item de participação comunitária, pois ao fim do séc. XX e início do XXI ainda não se verifica a participação maciça da maior parte da sociedade organizada na aprovação do PD de 2004 de Sorocaba. Aliás, após sua aprovação, rapidamente o Plano Diretor de Sorocaba (2004) começa a receber solicitações de alterações, principalmente de empreendedores imobiliários e arquitetos e engenheiros muito atuantes no mercado imobiliário em diversas partes das cidades de Sorocaba e Votorantim, (municípios já conurbados ao final do séc. XX); donde percebem-se pequenos ajustes pontuais; e uma nova revisão do plano diretor, é aprovada em 2007 (Lei municipal no. 8181, de 05/06/2007), bem antes dos dez anos para a revisão exigida pela lei do Estatuto das Cidades. 
CAP. V - URBANIZAÇÃO X LEGISLAÇÃO Zoneamento Trecho 1 - São Roque: RRT do km 60-64 


\section{CAP. V - URBANIZAÇÃO X LEGISLAÇÃO: Zoneamento Trecho 1 - São Roque: RRT do km 60-64}

\subsection{Breve histórico do Município de São Roque, SP}

Para analisar a atuação do Estado através de sua legislação urbanística nos trechos determinados para a pesquisa, iniciaremos a análise pelo trecho de São Roque, do km 60 a 64 da RRT (Fig. 47).

Figura 47 - Imagem aérea da RRT km 64 no trecho de São Roque, SP.

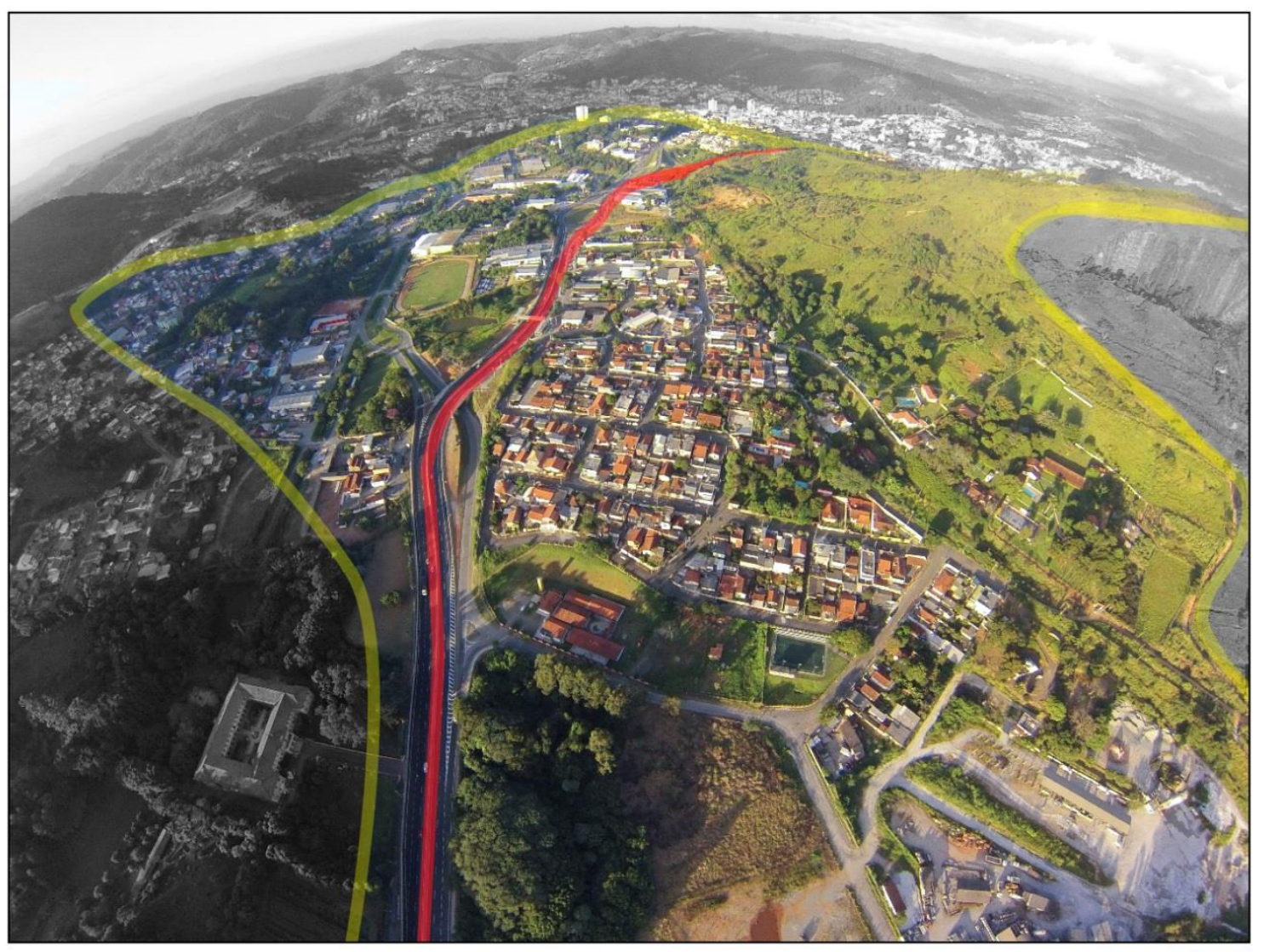

Rodovia Raposo Tavares

Área de análise limite 500m da RRT

Autor: Heiton Gomes, por drone. Data: 11/maio/2017. Retrabalhado por Amanda Dias, 2018.

O Município de São Roque, localizado atualmente na RMS, é oriundo de uma enorme fazenda, fundada na segunda metade do século XVII pelo bandeirante Pedro Vaz de Barros, que ali ergueu uma capela, levantada em devoção a São Roque, onde hoje é a Praça da Matriz, no centro antigo de São Roque. No início do séc. XX São Roque já era atravessado na direção leste-oeste pela então denominada Estrada São Paulo-Paraná, e no sentido sudeste-noroeste 
pela linha férrea Sorocabana; ambos percursos existentes até hoje. As duas rotas (EFS e a antiga Estrada de Rodagem São Paulo - Paraná, hoje parte da RRT) cruzavam-se onde hoje está a estação ferroviária de Mairinque, atualmente próximas ao novo contorno da RRT na região, pois o traçado antigo foi desviado em 2017 para fora do núcleo central. Segundo pesquisado no arquivo municipal de São Roque, o mapa mais antigo encontrado foi o do Município de São Roque em 1932 (Fig. 48 e 49) denotando que este então fazia limite com os municípios de Araçariguama, Itu, Sorocaba e Ibiúna.

Figura 48 - Mapa de São Roque em 1932 (antiga, antes dos desdobramentos do séc. XX).

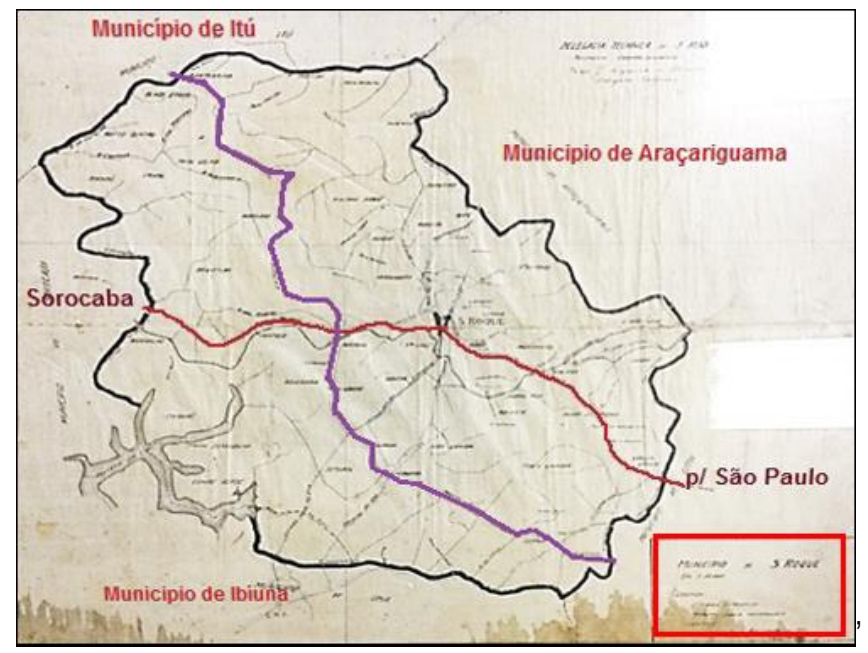

Retrabalhado pela autora. Em vermelho, a linha que indica a Estrada São Paulo - Paraná (BR-34). Em lilás, a linha da ferrovia. No retângulo vermelho, a legenda do mapa. Fonte: Prefeitura Municipal de São Roque, setembro de 2017.

Figura 49 - Foto da legenda do Mapa de São Roque em 1932.

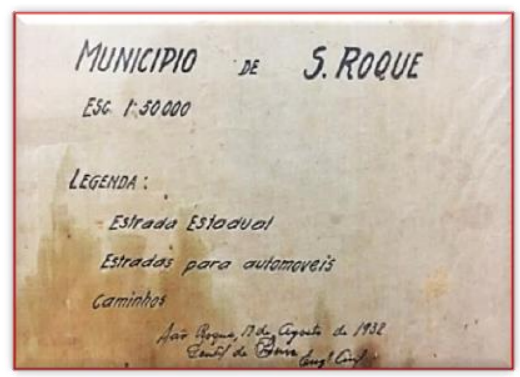

Destaque do retângulo em vermelho, da foto anterior, retrabalhada pela autora. Fonte: Prefeitura Municipal de São Roque.

O território de São Roque diminuiu depois de 1932, pois após décadas foram emancipados os municípios de Araçariguama, Mairinque e Alumínio, e seu limite territorial atual pode ser verificado no mapa a seguir (Fig. 50). 
Figura 50 - Indicação da área atual do Município de São Roque (em amarelo).

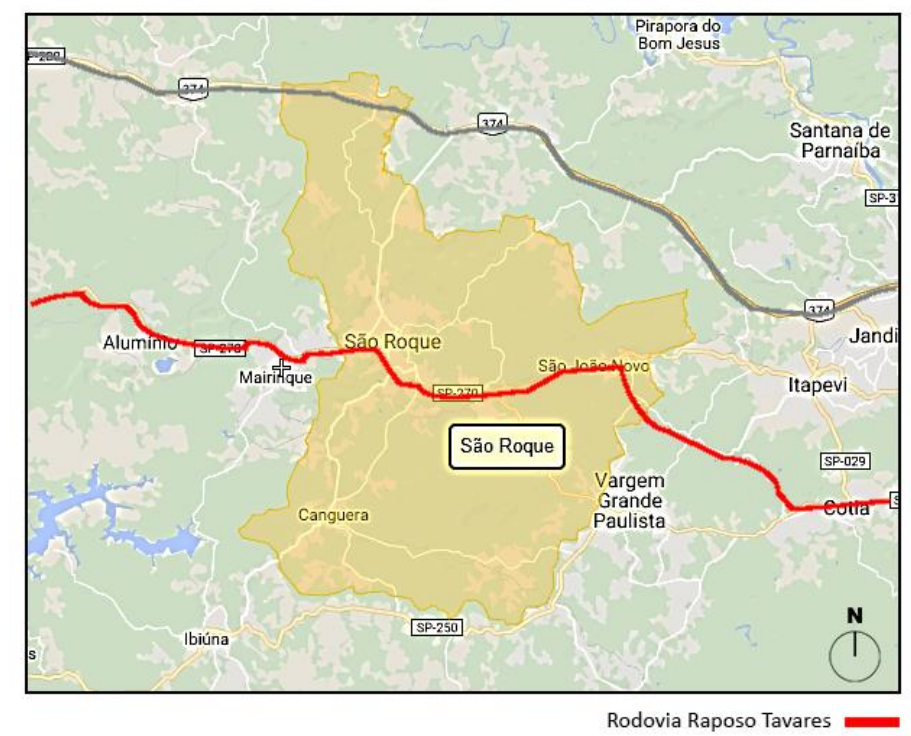

Rodovia Presidente Castelo Branco

Fonte: Google Maps. Acesso em setembro de 2017. Retrabalhado por Amanda Dias, 2018.

O município também gerou suas próprias centralidades, desenvolvidas desde 0 séc. XVII: a industrialização pela imigração italiana e também pelo incentivo dado pela lei municipal no. 407 de 20/10/1960 (que proporcionou incentivos fiscais às indústrias que instalassem no município, possibilitada também pela pavimentação da RRT); e mais recentemente com a atividade turística, oriunda das visitas de turistas às plantações das vinhas, pousadas, restaurantes e da proximidade com São Paulo (c. $50 \mathrm{~km}$ ). São Roque é um dos 29 municípios paulistas considerados estâncias turísticas pelo ESP; este título proporciona aporte de verba por parte do Estado para a promoção do turismo regional. "O turismo "bate volta" é muito importante para a cidade: pessoas da região no raio aproximado de $100 \mathrm{~km}$ visitam a cidade semanalmente, onde usufruem dos variados restaurantes e dos vinhos, licores, destilados, alcachofra e doces produzidos na cidade" (PMSR, 2018). As festas tradicionais, o Sky Mountain Park e também o centro de compras Catarina, instalado no km 60 da RCB, no território são-roquense, contribuem dentre atividades, para a arrecadação municipal.

Atualmente o território municipal de São Roque é atravessado em sua porção norte pela RCB (desde 1962) e na porção sul pela RRT. Com estas duas importantes rodovias estaduais, São Roque tem suas terras valorizadas para compra e venda de empreendimentos imobiliários; se já havia existência de sítios e chácaras de lazer de propriedade de paulistanos ao final do séc. XX, na década passada houve o crescimento de lotes vendidos em residenciais "fechados" que fazem com que muitas famílias morem em São Roque e alguns de seus membros trabalhem 
em outros municípios próximos pelo uso do automóvel, como Araçariguama, São Paulo, Sorocaba, etc., com a utilização da RRT e RCB.

O próximo equipamento a ser instalado no território de São Roque, na RCB, do lado oposto ao Shopping Catarina, com obras já em andamento, será o novo Aeroporto Internacional Executivo Metropolitano de São Paulo, no bairro Catarina (Termo de autorização para exploração do aeródromo civil público da ANAC, de 29/10/2014, pela JHSF Incorporações Ltda., com aditivo de transferência em 04/05/2015 para JHSF Administradora do Catarina Aeroporto Executivo S.A.).

Este empreendimento se obtiver êxito comercial, deverá afetar profundamente sua área de influência direta e indireta, não só no Município de São Roque, mas nos vizinhos municípios de Itu, Araçariguama, Mairinque, Alumínio, Sorocaba e Porto Feliz (Fig. 51).

Figura 51 - Vista aérea de abril de 2017, com destaque no círculo vermelho para o empreendimento do novo Aeroporto Catarina, na RCB, em São Roque.

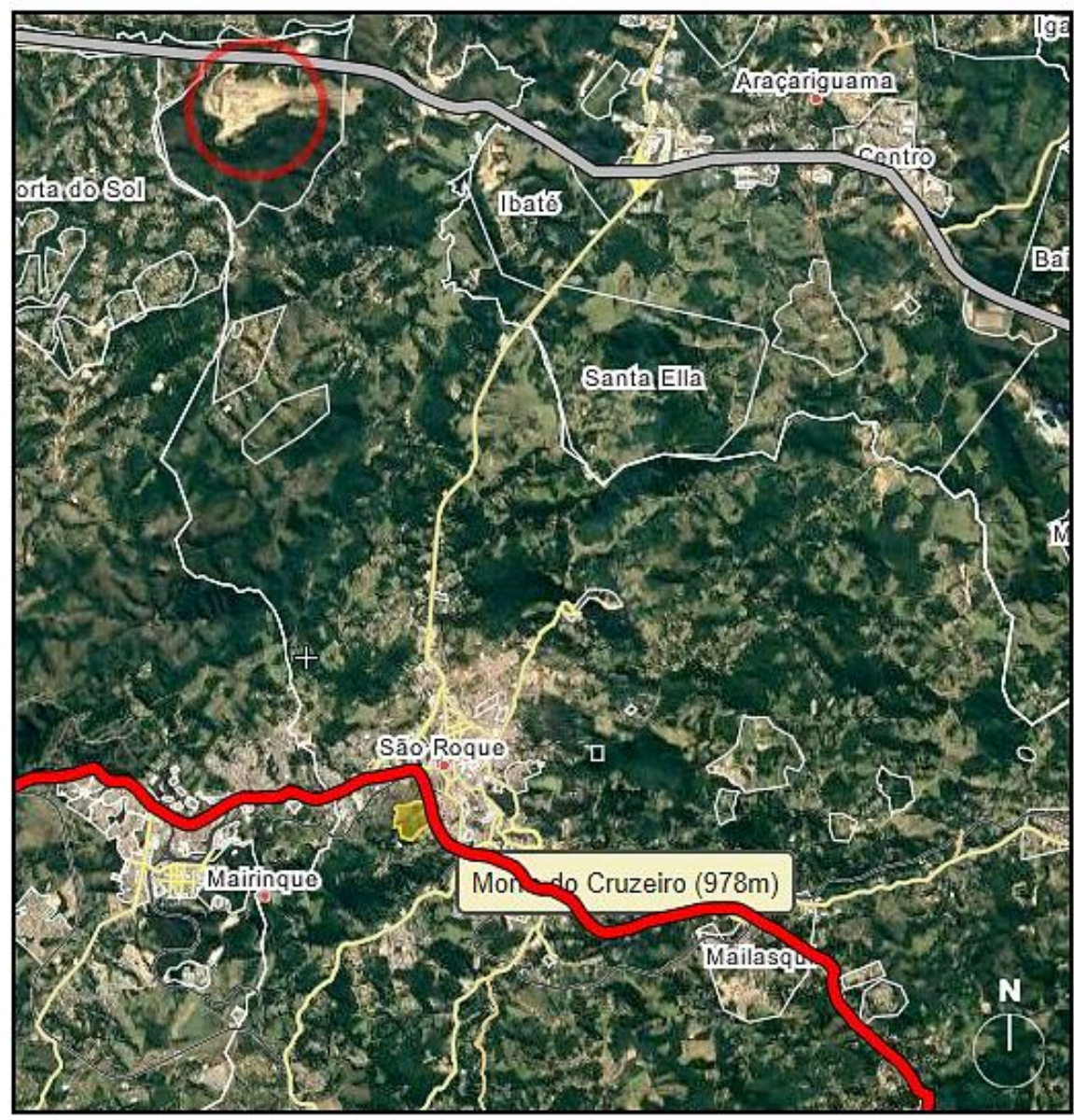

Rodovia Raposo Tavares

Rodovia Presidente Castelo Branco

Ao sul, o morro do Cruzeiro, próximo ao trecho RRT em São Roque. Fonte: Wikimapia/Google Maps, acesso em janeiro de 2018. Retrabalhado por Amanda Dias, 2018. 


\subsection{Legislação urbana no Trecho 1 (1972 - 2006)}

Sobre 0 zoneamento municipal de São Roque, há várias menções à modificação dos limites territoriais na legislação municipal de São Roque e Araçariguama, pois a fazenda que originou o município esteve subordinada ao Município de Araçariguama na época de sua fundação, no período colonial; e ao longo dos anos, os limites territoriais foram várias vezes reajustados entre Araçariguama e São Roque. Para efeito mais assertivo da análise da legislação urbanística do trecho 1 , focaremos primeiramente 0 antigo distrito do Ribeirão Marmeleiro, próximo à antiga estrada de rodagem São-Paulo-Paraná, depois transformada em 1954 na RRT (SP270).

No distrito aqui analisado, percebe-se a conformação da área industrial do Município de São Roque, já nos idos de 1960, pela lei no. 407/1960 de 20/10/1960, que visava incentivar a instalação de indústrias nas áreas lindeiras à RRT em São Roque. Pelas leis municipais nos. 501 e 502/1963, são desapropriados amigavelmente os terrenos para a instalação de uma via marginal à área urbana de então, que daria acesso à área industrial, ligada à RRT neste trecho. A lei municipal no. 837 de 30/12/1969 estabeleceu o perímetro urbano do Município de São Roque nos distritos: 1) Marmeleiro, Araçariguama, São João Novo, Canguera e Mailasqui. 0 Trecho 1 da RRT aqui analisado se encontra no antigo distrito do Ribeirão do Marmeleiro.

\section{O PD de 1972 - Lei 953/72}

Todo plano diretor estabelece seus objetivos prioritários, reflexo de seu tempo e estilo da administração pública que o preparou. Este, de 115 páginas datilografadas, colocou especificamente os seguintes objetivos:

I - Fixar a divisão territorial e zoneamento do município de forma a possibilitar 0 planejamento e a facilitar a execução dos melhoramentos públicos a cargo da Prefeitura;

II - Assegurar o crescimento racional e estético da cidade;

III - Organizar o sistema de estradas municipais e o sistema viário urbano;

IV - Proporcionar, a localização adequada dos serviços básicos, sociais e administrativos;

V- Garantir as áreas verdes de recreação e lazer necessárias à população.

Consideraremos então a legislação urbana que instituiu as normas referentes ao Plano Diretor Físico do Município de São Roque, Lei 953/18 de dezembro de 1972 (ver mapa no. 06) 
em diante. Pela legislação urbanística do PD de 1972, no trecho analisado, próximo ao km 60 estava 0 antigo traçado ${ }^{23}$ da RRT, que passava na área central de São Roque.

Esta área no início do trecho RRT (km 60) tinha parâmetros de zoneamento municipal anotados do artigo 26 ao 29; e na área central (por onde passava a RRT então), o zoneamento era então denominado para o Centro Principal 1 (CP1), com TO de 75\%, CA=5,0; taxa de permeabilização permitida: $100 \%$, com os seguintes usos permitidos: residencial, plurihabitacional, cultural (salvo escolas), recreativo, prestação de serviços à residências, comércio varejista, serviços públicos, (salvo quartéis e cadeias) e bancários. Como se pode verificar, o zoneamento permitia os usos característico das áreas centrais antigas das cidades do interior paulista, visto que a ocupação urbana do núcleo central já estava consolidada; mas não permitia o funcionamento de estabelecimentos industrias, usos incompatíveis com residências; e atividades incomodas, perigosas ou nocivas a higiene e ao conforto público.

Havia também o zoneamento do CS1 (Centro Secundário 1) estabelecido para a região do Marmeleiro. No círculo em laranja de raio de 110m, estava o limite da área do CS1, cujo raio se localiza no cruzamento da RRT com a via de acesso ao loteamento Vila Nova São Roque, que tinha como parâmetros de zoneamento TO de 50\% e CA igual a 1,0 (um); de uso residencial, cultural, recreativo e assistencial (ambulatórios, posto de saúde e congêneres). 0 artigo 34 especifica que as edificações destes serviços permitidos poderão ser edificados em vias de serviços, e nunca às margens da RRT.

Sobre o zoneamento industrial (em roxo): é considerada industrial pelo Cap. VII, artigo 53, a área situada no setor Marmeleiro e limitada pela EFS, pelos loteamentos Vila Nova São Roque, Vila São Rafael e Vila Brasília, pela via projetada VL9 e pela linha divisória que acompanha a cota 780, a partir da RRT até a rua Santa Quitéria. A ressalva do parágrafo único é que caberia ao Grupo Executivo de Planejamento, localizar e dimensionar a área industrial, que tinha como uso específico o industrial, e além disso permitira-se postos de abastecimento de veículos, depósitos e serviços de reparação em geral. A critério deste grupo, poderiam ser localizados loteamentos residenciais na área industrial desde estes não ficassem sujeitos a poluição, ruídos, poeiras, etc.; mas os trechos marginais à RRT e à VL9, seriam reservados exclusivamente para a instalação de indústrias (inciso $2^{\circ}$ do artigo 55 do PD 1972), e nesta área industrial TO e CA seriam estabelecidos pelo Grupo Executivo de Planejamento, através de regulação especial, em atenção a particularidades de cada caso. (São Roque, Lei 953/72, p. 18).

\footnotetext{
${ }^{23}$ Até o início de 2017.
} 


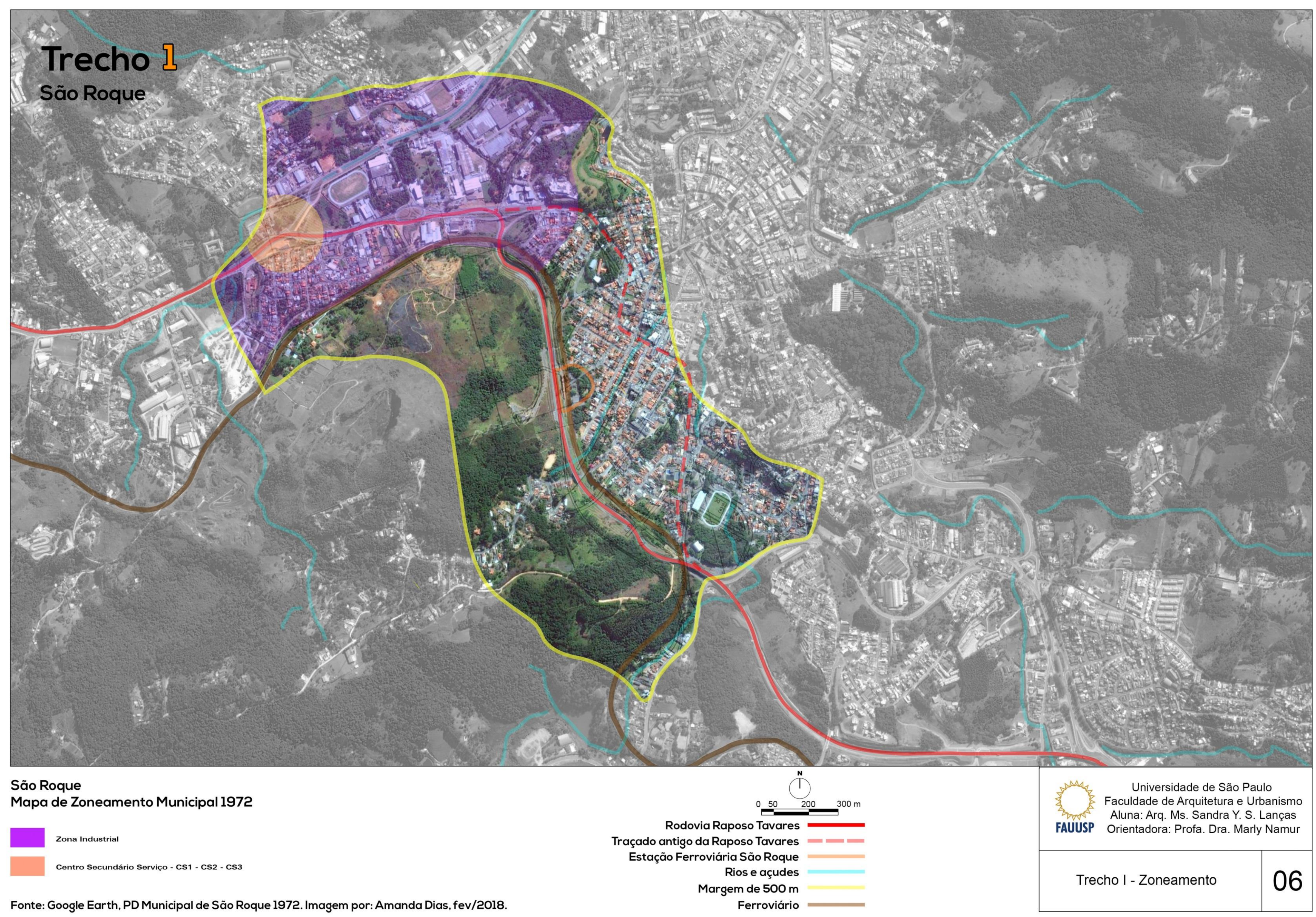


Segue tabela do mapa de zoneamento do PD de 1972: (Tab. 12)

Tabela 12 - Detalhe da tabela de zoneamento do trecho 1 - Município de São Roque pelo PD de 1972.

\begin{tabular}{|c|c|c|c|c|}
\hline ZONA & LOCAL & $\begin{array}{l}\text { TAXA } \\
\text { OCUPAÇÃO }\end{array}$ & $\begin{array}{l}\text { COEF. } \\
\text { APROVEITAVo }\end{array}$ & USOS PERMITIDOS \\
\hline CP1 & $\begin{array}{l}\text { NÚCLEO } \\
\text { CENTRAL }\end{array}$ & $\begin{array}{l}\text { TÉRREO }=100 \% \\
\text { DEMAIS PAV. }=75 \%\end{array}$ & 5 & $\begin{array}{l}\text { RESIDENCIAL PLURI-HABITACIONAL } \\
\text { CULTURAL SALVO ESCOLAS } \\
\text { RECREATIVO } \\
\text { PRESTAÇÃO SERVIÇOS À RESIDÊNCIAS } \\
\text { COMÉRCIO VAREJISTA } \\
\text { SERVIÇOS PÚBLICOS, SALVO QUARTÉIS E CADEIAS } \\
\text { BANCÁRIO }\end{array}$ \\
\hline $\mathrm{CP} 2$ & $\begin{array}{l}\text { EXPANSÃO } \\
\text { CENTRAL }\end{array}$ & $\begin{array}{l}\text { ED. RESID. }=60 \% \\
\text { RESID. } \\
\text { TER } / \text { SOBR }=50 \% \\
\text { N RESID. }=70 \%\end{array}$ & $\begin{array}{c}2.4 \\
1 \\
2.4\end{array}$ & $\begin{array}{l}\text { RESIDENCIAL } \\
\text { CULTURAL } \\
\text { RECREATIVO } \\
\text { ASSISTENCIAL (AMBULATÓRIOS/ POSTO } \\
\quad \text { SAÚDE/ CONGENERES) } \\
\text { SERVIÇOS PÚBLICOS } \\
\text { PRESTAÇÃO SERVIÇOS À RESIDÊNCIAS } \\
\text { COMÉRCIO VAREJISTA } \\
\text { BANCÁRIO }\end{array}$ \\
\hline CS1 & MARMELEIRO & $50 \%$ & 1 & \multirow{2}{*}{\begin{tabular}{l} 
RESIDENCIAL \\
CULTURAL \\
RECREATIVO \\
ASSISTENCIAL (AMBULATÓRIOS/ POSTO \\
\multicolumn{1}{c}{ SAÚDE/ CONGENERES) } \\
SERVIÇOS PÚBLICOS \\
PRESTAÇÃO SERVIÇOS À RESIDÊNCIAS \\
COMÉRCIO VAREJISTA \\
BANCÁRIO \\
CENTRO ESPORTIVO
\end{tabular}} \\
\hline $\operatorname{cs} 3$ & $\begin{array}{l}\text { TABOÃO } \\
\text { SANTA } \\
\text { QUITÉRIA }\end{array}$ & $\begin{array}{l}50 \% \\
50 \%\end{array}$ & $\begin{array}{l}2.4 \\
2.4\end{array}$ & \\
\hline $\mathrm{AH}$ & $\begin{array}{l}\text { TODAS AS ÁREAS } \\
\text { INSERIDAS NO PE- } \\
\text { RIMETRO URBANO } \\
\text { E SEM USO ESPE- } \\
\text { CIFICO DETERMI- } \\
\text { NADO POR ESSA } \\
\text { LEI }\end{array}$ & $\begin{array}{l}\text { SER. } L O C A L=60 \% \\
\text { RESID. } \\
\text { TER/SOBR }=50 \% \\
\text { EDIF. RES. C/ }+ \\
3 \text { AND }=25 \%\end{array}$ & $\begin{array}{c}1.4 \\
1 \\
0.4 \\
0.5 \text { LOTES } \\
\text { CONTÍGUOS }\end{array}$ & \\
\hline $\mathrm{Al}$ & & $\begin{array}{l}\text { A SER ESTABELE- } \\
\text { CIDO PELO DPMA }\end{array}$ & & \\
\hline AR & & & & RESIDENCIAL ÁREA $10.000,00 \mathrm{M} 2$ \\
\hline $\mathrm{AE}$ & & & & \\
\hline
\end{tabular}

Fonte: PMSR, 1972. Retrabalhado por Amanda Dias, 2018.

A lei orgânica do Município de São Roque, que rege a questão da aprovação do Plano Diretor municipal pela Câmara Municipal de vereadores de São Roque foi depois estabelecida pela lei ordinária nº 1801, de 5/04/1990.

\section{PD 2006 - Lei complementar $n^{0}$ 39, de 8/11/2006}

Já o PD de 2006 foi realizado através de lei complementar e além dos objetivos já citados na lei anterior, destacam-se as questões de acessibilidade universal (no sentido da mobilidade urbana atual), o macrozoneamento ambiental e de consolidação urbana na definição de áreas de especial interesse municipal para desenvolvimento de programas específicos e controle da questão ambiental de abastecimento de água e resíduos, bem como de suas unidades de conservação ambiental: 
“(...) Art. $4^{\circ}$ São objetivos estratégicos do Plano Diretor do Município da Estância Turística de São Roque, visando o bem-estar individual e coletivo do Munícipe:

I - promover o desenvolvimento econômico local, de forma social e ambientalmente sustentável; II - garantir o direito universal à moradia digna, democratizando o acesso à terra e aos serviços públicos de qualidade; III - garantir a acessibilidade universal, entendida como 0 acesso de todos e todas a qualquer ponto do território, por intermédio da rede viária e do sistema de transporte público; IV - ampliar as oportunidades para os segmentos da população, ora excluídos do acesso ao emprego e a participação nas decisões das instituições públicas de poder; $\mathrm{V}$ - definir as Áreas de Especial Interesse no território municipal estabelecendo os programas específicos para cada área; VI - organizar um sistema local de Unidades de Conservação Ambiental; VII - promover a gestão compartilhada sobre os serviços de água e esgoto e resíduos sólidos." (CMSR, 2006).

Com a lei do PD de 2006 já vigente, foi também promulgada a lei complementar $n^{\circ} 40$, de 8/11/2006 que disciplinou o uso, ocupação, parcelamento e regularização do solo, nos termos do que dispõe o Plano Diretor do Município da Estância Turística de São Roque, e dividiu a área urbana em duas Macrozonas: a $1^{\text {a }}$ de Consolidação urbana e a $2^{\mathrm{a}}$ de Urbanização específica: "(...) Art. $2^{\circ}$ Para efeito da ordenação de parcelamento, uso e ocupação do solo, a área urbana do território do Município da Estância Turística de São Roque é dividida em Macrozona de Consolidação Urbana e Macrozona de Urbanização Específica" (CMSR, 2006). Pelo Mapa de Macrozoneamento Ambiental Carta I, com detalhe na figura 53, verificamos pela representação no diagrama que 0 Trecho 1 está na Área adequada à ocupação urbana com medidas de proteção ao sistema de drenagem, com o agora Córrego do Marmeleiro e outros; ferrovia, a RRT, arruamento e por cima está a mancha da área urbana, conforme legenda. À parte ao sul da linha férrea, que contorna o Morro do Cruzeiro, foi estabelecida como área com severas restrições à ocupação. 
Figura 53- Detalhe (Trecho 1) do mapa de Macrozoneamento Ambiental I, do PD de 2006, lei complementar no. $40 / 2006$.

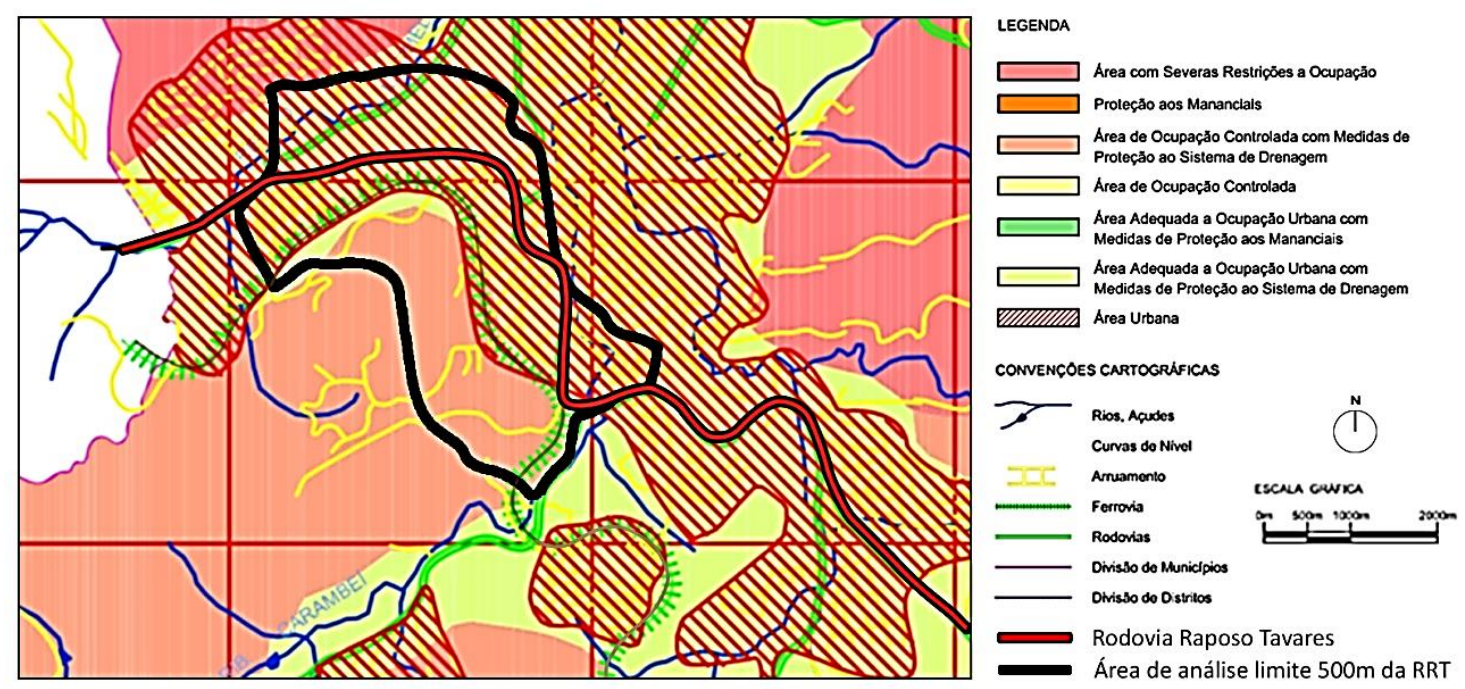

Fonte: CMSR, anexo Carta I. Data: 2006.

O próximo mapa (Mapa II - Macrozoneamento ambiental - Sede do município) (detalhe do trecho 1 na Fig. 54) da mesma lei complementar no. 039/2006 especifica na porção sul do trecho (em verde claro) que esta seria uma área adequada à ocupação urbana com cuidados técnicos especiais. Por este mapa verifica-se que a legislação do macrozoneamento sobrepõe as áreas urbanizadas às áreas não ocupáveis e áreas adequadas à ocupação urbana com cuidados técnicos especiais e outras com ainda mais restrições quanto à água subterrânea e obras de drenagem, denotando conflitos de ocupação quanto às obras de drenagem e restrições à água subterrâneas (Fig. 54). 
Figura 54 - Detalhe do mapa de Macrozoneamento Ambiental II (específico para) Sede do Município de São Roque (Trecho 1 anotado), do PD de 2006, lei complementar no. 40/2006.
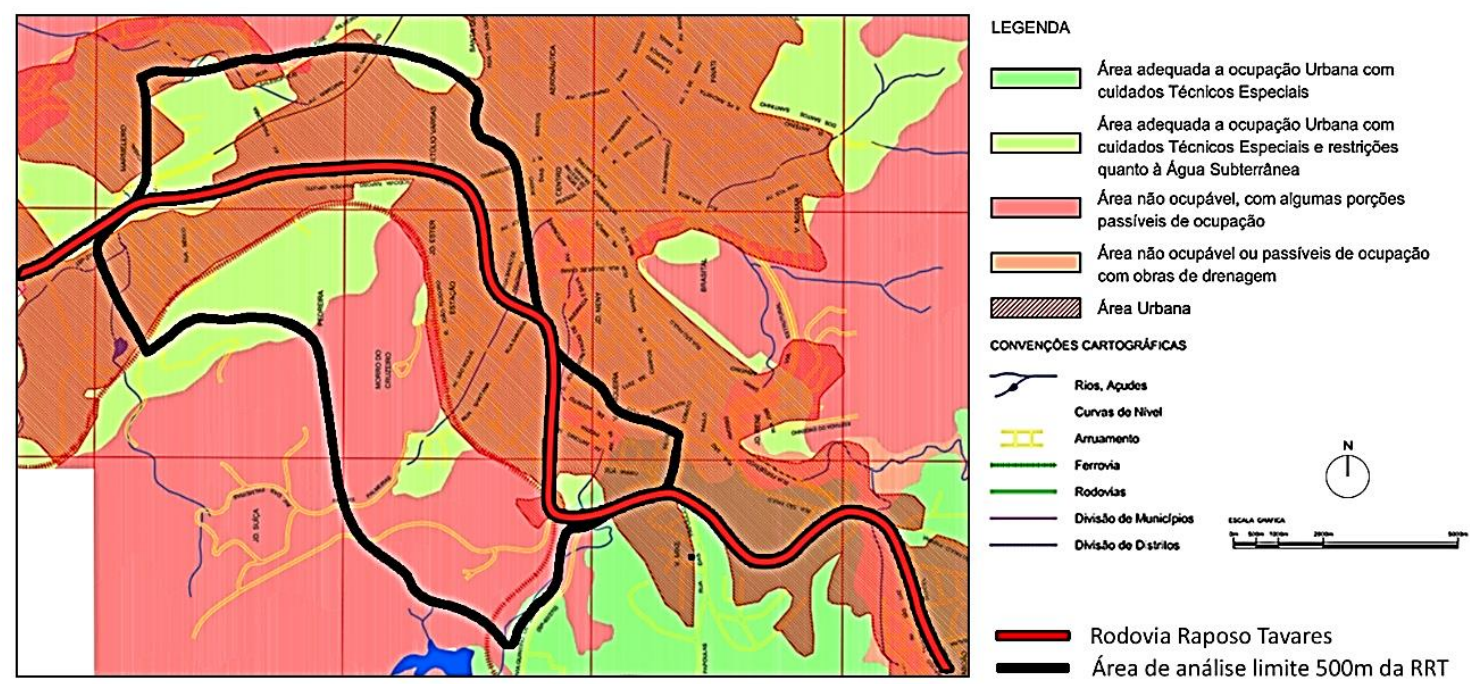

Fonte: CMSR, anexo Carta II. Data: 2006.

Este conflito é aparentemente resolvido com a determinação do perímetro urbano e rural especificado no Mapa III da mesma lei complementar no. 39/2006 em que se verifica que 0 Trecho 1 estudado pertence à Macrozona de Consolidação Urbana de São Roque, e na Zona de Urbanização Específica (ZUE) - de Desenvolvimento Econômico (Fig. 55).

Figura 55 - Detalhe (Trecho 1) da Carta III - Macrozonas de Uso e Ocupação - Perímetros Urbanos e Rural do PD de 2006, lei complementar no. 40/2006.
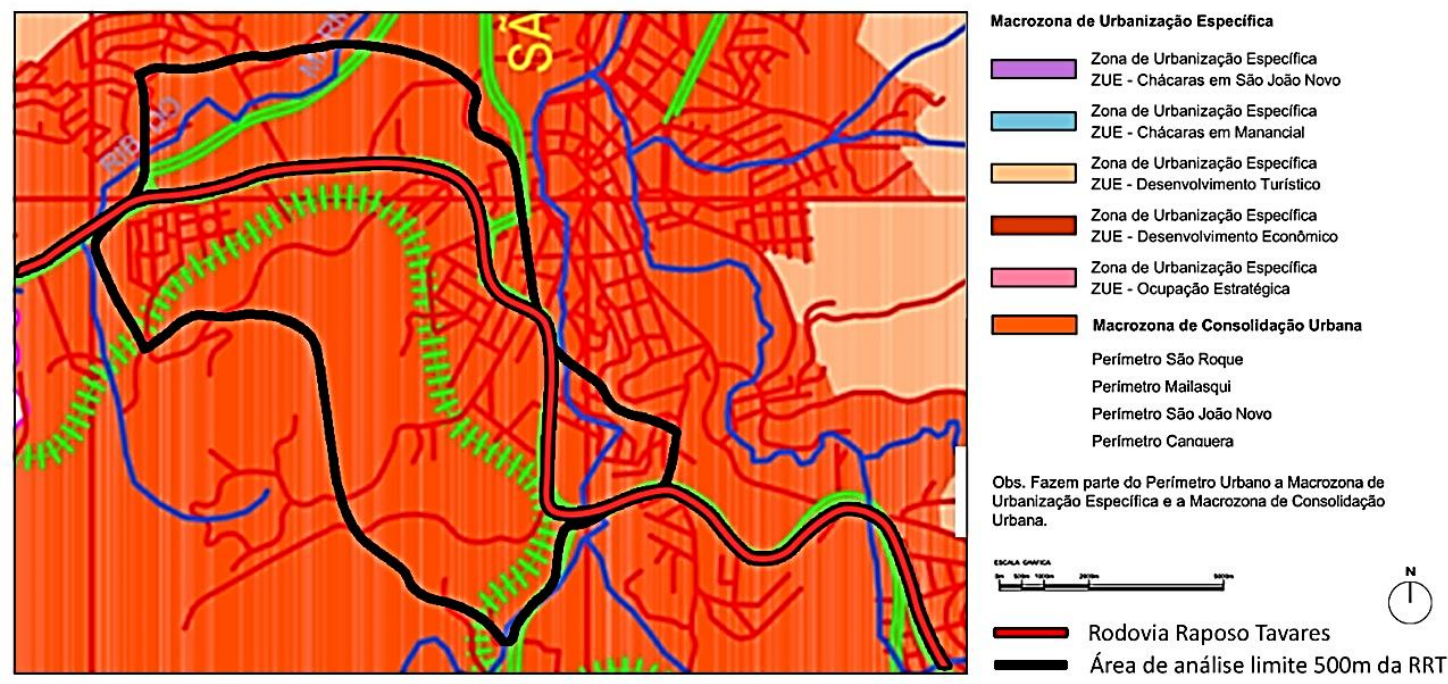

Fonte: CMSR, anexo Carta I. Data: 2006.

Desta forma, a próxima Carta IV da lei complementar no. 39/2006 versa sobre 0 macrozoneamento de uso e ocupação, demarcando os perímetros das zonas urbanas de São 
Roque, estabelecendo Macrozonas de consolidação urbana (Fig. 56), que foi o embrião do zoneamento municipal final do PD de 2006.

Figura 56 - Detalhe (Trecho 1) da Carta IV - Perímetro São Roque - Zonas Urbanas. Macrozonas de Consolidação Urbana - PD de 2006, lei complementar no. 40/2006.
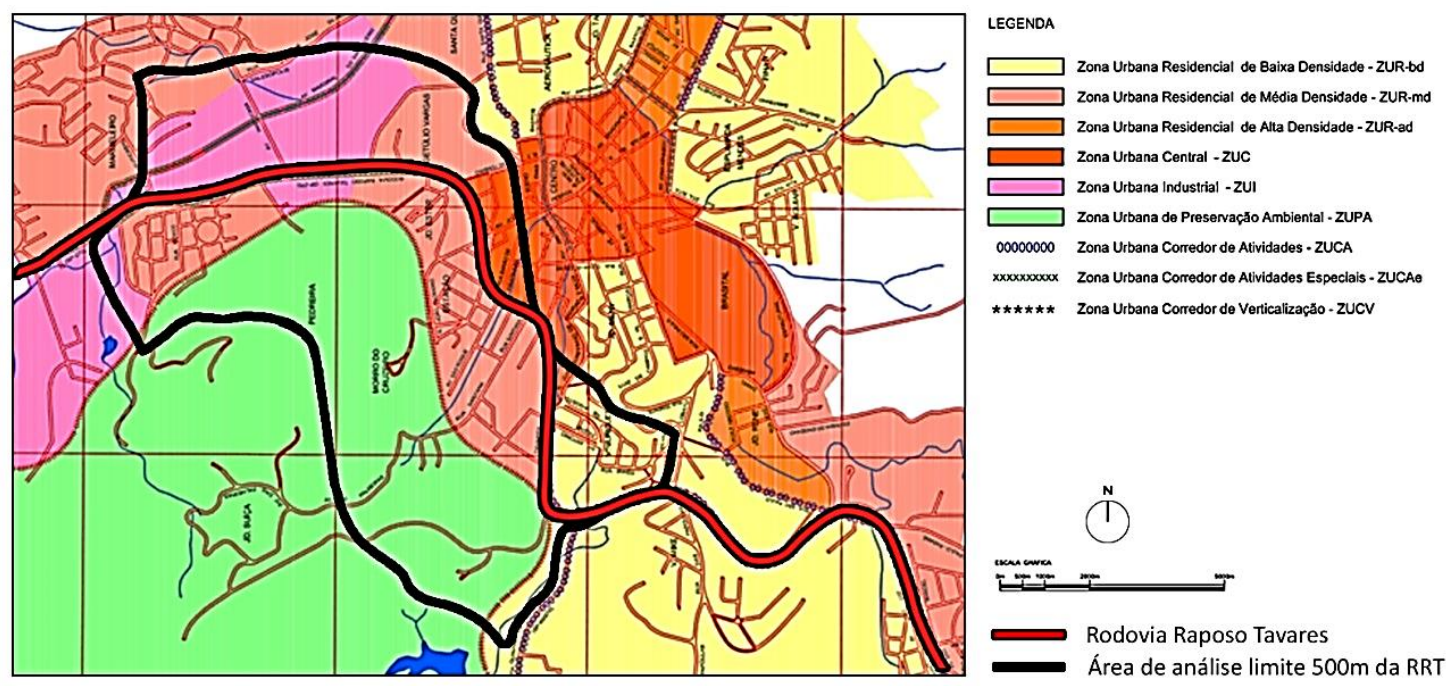

Fonte: CMSR, anexo Carta I. Data: 2006.

Na figura no. 57, (de Macrozonas do PD de 2006), podemos verificar como ficou 0 zoneamento para o Trecho 1, que agora passa a ter seis zonas municipais distintas: ZUC, ZURbd; ZUR-md, ZUI e ZUPA, desta maneira especificando mais detalhadamente os parâmetros de ocupação neste trecho (Tabela 13). Seguindo suas vocações mais consolidadas desde a década de 90 e adequando-o às diretrizes definidas pelo Estatuto da Cidade (2001) com relação à preocupação ambiental e turística, ligada à questão da arrecadação municipal, pois este trecho analisado é vizinho ao setor de maior vocação turístico do município, Canguera.

Neste trecho 1, o Centro Principal 1 (CP1) do zoneamento anterior com TO=75\% e $C A=1,0$ foi dividido em quatro setores (ZURbd, ZUR md, ZUR ad) respectivamente zona urbana residencial de baixa, média e alta densidade, com diminuição de TO (respectivamente 60, 70 e 60\% para lotes e 50, 60 e 50\% para glebas), embora aumentando o CA de 1,0 até 2,4 no caso da ZUR ad (ver as diferenças na tabela 13). Pelo PD de 2006 no trecho 1 aqui analisado, é introduzido o conceito de limitação ao gabarito de altura das novas edificações. Ficando limitado então a 8 (oito) metros na zona residencial de média densidade (ZUR-md), 13 (treze) metros na zona central (ZUC) e 15 (quinze) metros na zona industrial (ZUI). Outro zoneamento introduzido foi a ZUPA (Zona urbana de Proteção Ambiental) para a área do Morro do Cruzeiro, pois ele é uma atração turística de área pouco ocupada devido à sua topografia e altitude $(938 \mathrm{~m})$, onde está o Cruzeiro, com um mirante para a região. Os parâmetros para a ocupação desta área 
estão mais limitados: $\mathrm{TO}=10 \%, \mathrm{CA}=0,2$; Taxa de permeabilidade mínima de $70 \%$ mas não foi estabelecido nenhum limite ao gabarito de altura.

Outro fator alterado no novo zoneamento do PD de 2006 (ver mapa no. 07) foi a utilização dos corredores de tráfego de maior intensidade (rodovias) para aproveitamento de suas áreas lindeiras, permitindo-se implantação de comercio e serviços independentemente de porte e grau de incomodicidade, bem como de industrias de pequeno porte; depósitos e garagens e em duas avenidas especificas que ligam o Centro principal 1 ao Centro principal 2, a verticalização para usos não específicos.

Foram colocados também parâmetros específicos para a ocupação dos principais corredores de maior intensidade de tráfego (rodovias), inclusive no trecho aqui analisado; no caso deste PD, visando às áreas lindeiras com 60 metros de profundidade para corredores logísticos (depósitos e garagens); o que aumentaria ainda mais o fluxo de circulação de mercadorias, e dificultará a travessia dos pedestres que habitam nas áreas lindeiras à estas rodovias. 


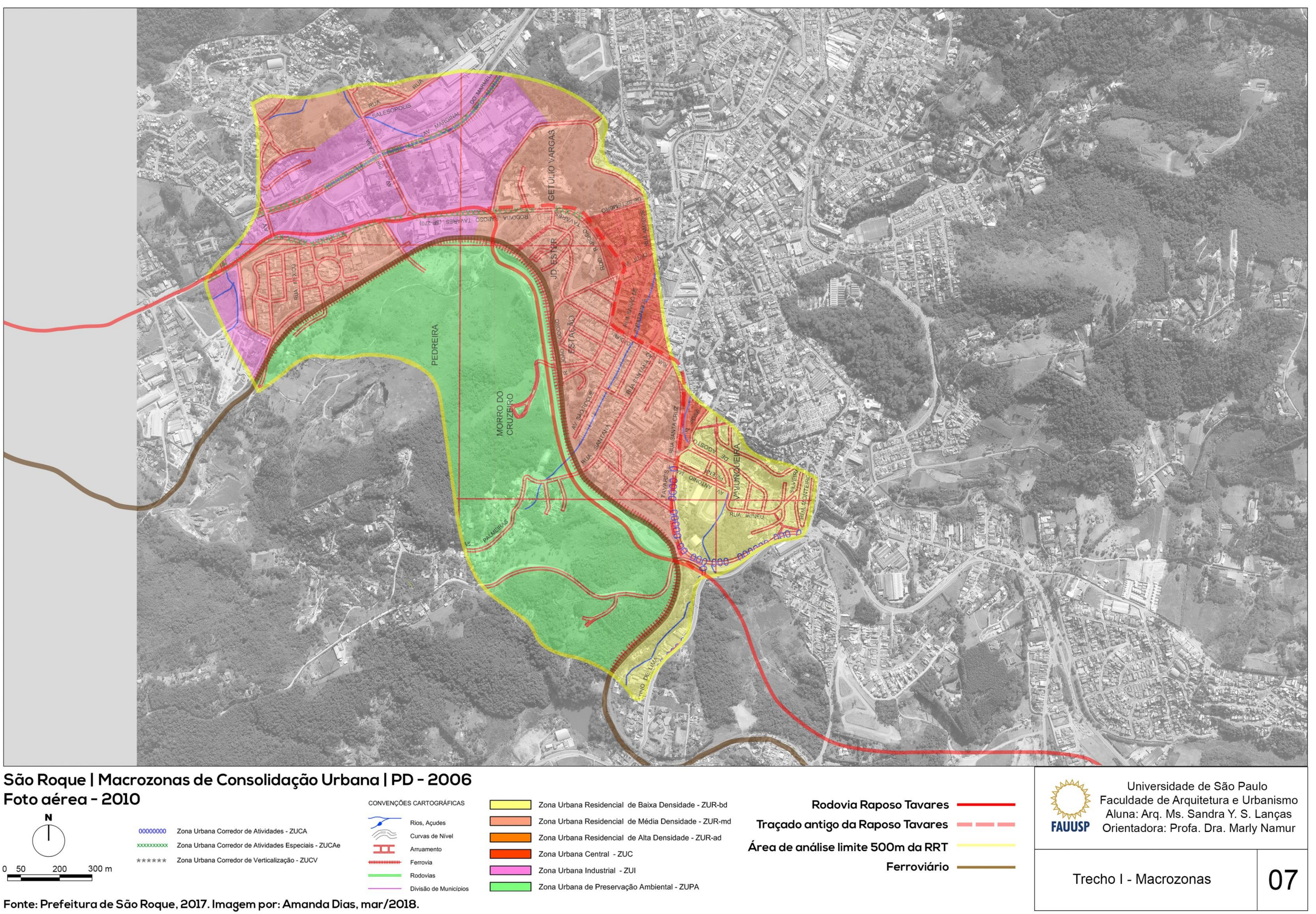


Tabela 13 - Tabela de coeficientes do PD de 2006 de São Roque.

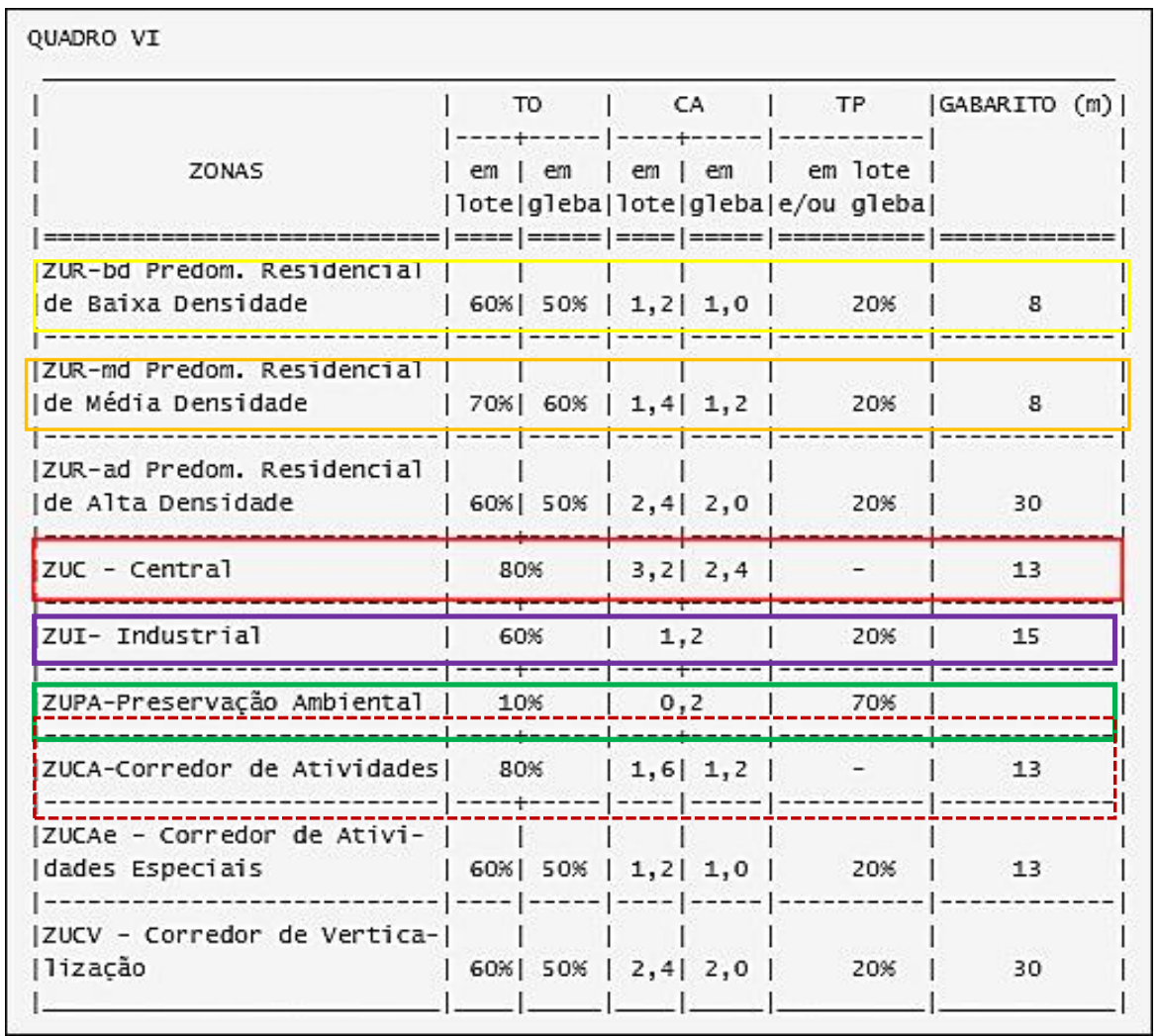

Note-se o aumento de TO e 0 acréscimo do critério de gabarito, limitando o número de andares, devido à questão paisagística. Fonte: CMRS, 2006.

Para isto prepara-se a ocupação legal, na profundidade de 60 metros do alinhamento das vias de maior tráfego em suas áreas lindeiras para, conforme o caso, se permitir a ocupação lindeira dos corredores, nos seguintes artigos do PD de 2006:

"Artigo 63: Zona Urbana de Corredor de Atividades (ZUCA): corresponde aos imóveis lindeiros as vias de maior intensidade de tráfego, e destina-se predominantemente a implantação de comércio e serviços independentemente de porte e grau de incomodo e de industrias de pequeno porte;

Artigo 64: Zona Urbana de Corredor de Atividades Especiais (ZUCAe): corresponde a estradas e rodovias em seus trechos mais próximas as áreas urbanas, e destinamse predominantemente a implantação de comércio e serviços de grande porte, como depósitos e garagens;

Artigo 65: Zona Urbana de Corredor de Verticalização (ZUCV), correspondente aos imóveis lindeiros a Av. Antonino Dias Batista e Av. John Kennedy, destinando estas áreas predominantemente à implantação de construções verticalizadas destinadas a diferentes usos." (CMSR, 2006).

E regras de ocupação do solo nas zonas acima apontadas estão sintetizadas foram ligeiramente alteradas quanto ao gabarito de altura nas ZUR bd e ZUR md no mesmo ano da promulgação do PD de 2006, pela lei complementar no. 40, de 08/11/2006 (Tabela 14). 
Tabela 14 - Quadro de parâmetros uso e ocupação do solo PD 2006.

Quadro VI-

PD 2006 SRQ

\begin{tabular}{|c|c|c|c|c|c|c|c|}
\hline \multirow[t]{2}{*}{ Zonas } & \multicolumn{2}{|l|}{ To } & \multicolumn{2}{|l|}{$\mathrm{CA}$} & \multirow[t]{2}{*}{ TP } & \multirow[t]{2}{*}{$\begin{array}{l}\text { Gabarito } \\
\text { Lei comp. } \\
\text { No. 40/06 }\end{array}$} & \multirow[t]{2}{*}{$\begin{array}{l}\text { Gabarito } \\
\text { Anterior } \\
\text { Lei 39/2006 }\end{array}$} \\
\hline & Em lote & Em gleba & Em lote & Em gleba & & & \\
\hline $\begin{array}{l}\text { ZUR - bd Predom. } \\
\text { Residencial de } \\
\text { Baixa Densidade }\end{array}$ & $60 \%$ & $50 \%$ & 1,2 & 1 & 9 & 9 & 8 \\
\hline $\begin{array}{l}\text { ZUR - md Predom. } \\
\text { Residencial de } \\
\text { Média Densidade }\end{array}$ & $70 \%$ & $60 \%$ & 1,4 & 1,2 & 12 & 12 & 8 \\
\hline $\begin{array}{l}\text { ZUR - ad Predom. } \\
\text { Residencial de Alta } \\
\text { Densidade }\end{array}$ & $60 \%$ & $50 \%$ & 2,4 & 2 & 30 & 30 & $=$ \\
\hline ZUC - Central & $80 \%$ & & 3,2 & 2,4 & - & 13 & $=$ \\
\hline ZUI - Industrial & $60 \%$ & & 1,2 & & $20 \%$ & 15 & $=$ \\
\hline $\begin{array}{l}\text { ZUPA - } \\
\text { Preservação } \\
\text { Ambiental }\end{array}$ & $10 \%$ & & 0,2 & & $70 \%$ & slespec. & $=$ \\
\hline $\begin{array}{l}\text { ZUCA - Corredor } \\
\text { de Atividades }\end{array}$ & $80 \%$ & & 1,6 & 1,2 & - & $13 \%$ & $=$ \\
\hline $\begin{array}{l}\text { ZUCAe - Corredor } \\
\text { de Atividades } \\
\text { Especiais }\end{array}$ & $60 \%$ & $50 \%$ & 1,2 & 1 & 13 & 13 & $=$ \\
\hline $\begin{array}{l}\text { ZUCV - Corredor } \\
\text { de Verticalização }\end{array}$ & $60 \%$ & $50 \%$ & 2,4 & 2 & 30 & 30 & $=$ \\
\hline
\end{tabular}

Fonte: CMSR, 2006. (Lei complementar no. 40/06).

Os usos admitidos para cada zona são alterados especificamente para acomodar principalmente os polos geradores de tráfego e de uso geradores de ruídos diurnos e noturnos, regramento mais específicos aos novos tempos de maior movimentação da população e cargas no território, no início do séc. XXI, quando o volume de movimentação começa a aumentar devido ao aumento da atividade econômica e da política de incentivo ao consumo (principalmente voltado aos veículos automotivos) e também com a ativação do programa federal 
MCMV; além da adequação de uma lei do plano diretor de mais de três décadas passadas (PD 1972) (Tabela 15).

Tabela 15 - Quadro de parâmetros Usos admitidos por zona PD 2006.

\begin{tabular}{|l|l|}
\hline & Usos Admitidos \\
\hline Zonas & \\
\hline $\begin{array}{l}\text { ZUR-bd Predom. Residencial de } \\
\text { Baixa Densidade }\end{array}$ & RL e RG (RU e RM), CS \\
\hline $\begin{array}{l}\text { ZUR-md Predom. Residencial de } \\
\text { Média Densidade }\end{array}$ & I, RL E RG (RU e RM), CS \\
\hline ZUC - Central & RL e RG (RU e RM), CS, TL, PGTI, GRN, GRD \\
\hline ZUI- Industrial & I, PGTP, PGTI, GRN, GRD \\
\hline ZUPA - Preservação Ambiental & TL, UES (est. Rádio-transferência), RL, RG (RU e RM) e IT \\
\hline ZUCA - Corredor de Atividades & I, RL e RG (RU e RM), CS, TL, PGTI, GRN, GRD \\
\hline $\begin{array}{l}\text { ZUCAe - Corredor de Atividades } \\
\text { Especiais }\end{array}$ & I, RL e RG (RU e RM), CS, TL, PGTP, PGTI, GRN, GRD \\
\hline ZUCV - Corredor de Verticalização & RL e RG (RU e RM), CS, TL, PGTI \\
\hline
\end{tabular}

Fonte: CMSR, 2006. (Lei complementar no. 40/06).

Também aumentam os pedidos de parcelamento de glebas para residenciais horizontais e verticais no município; estes recebem regulação quanto ao mínimo de áreas para o sistema viário, áreas verdes, áreas institucionais, tamanho de lote mínimo e também contemplou uma área para lotes populares (mínimo de 10\%), mas infelizmente, só para a zona urbana de proteção ambienta (ZUPA) (Tabela 16). Os recuos mínimos também são estabelecidos da maneira minimamente possível, principalmente para a zona urbana industrial, e nas ZUCA e ZUCAe (Tabela 17).

Tabela 16 - Quadro de parâmetros Usos admitidos por zona PD 2006.

Quadro VIII

\begin{tabular}{|l|l|l|l|l|l|}
\hline Zonas & $\begin{array}{l}\text { Sistema } \\
\text { Viário }(\%)\end{array}$ & $\begin{array}{l}\text { Área Verde } \\
(\%)\end{array}$ & $\begin{array}{l}\text { Área } \\
\text { Institucional }(\%)\end{array}$ & $\begin{array}{l}\text { Área para } \\
\text { lotes } \\
\text { populares } \\
(\%)\end{array}$ & Lote mínimo $\left(\mathrm{m}^{2}\right)$ \\
\hline $\begin{array}{l}\text { ZUR - bd Predom. Residencial de } \\
\text { Baixa Densidade }\end{array}$ & Min. 20\% & Min. 10\% & Min. 5\% & - & 250 \\
\hline
\end{tabular}




\begin{tabular}{|l|l|l|l|l|l|}
\hline $\begin{array}{l}\text { ZUR-md Predom. Residencial de } \\
\text { Média Densidade }\end{array}$ & Min. 20\% & Min. 10\% & Min. 5\% & - & 250 \\
\hline $\begin{array}{l}\text { ZUR-ad Predom. Residencial de Alta } \\
\text { Densidade }\end{array}$ & Min. 20\% & Min. 10\% & Min. 5\% & - & 250 \\
\hline ZUC - Central & - & - & Min. 5\% & - & 250 \\
\hline ZUI - Industrial & Max. 12\% & Min. 10\% & - & - & 250 \\
\hline ZUPA - Preservação Ambiental & - & Min. 15\% & - & Min. 10\% & 1.000 \\
\hline ZUCA - Corredor de Atividade & - & - & Min. 15\% & - & 2.000 \\
\hline $\begin{array}{l}\text { ZUCAe - Corredor de Atividades } \\
\text { Especiais }\end{array}$ & - & - & Min. 15\% & - & 250 \\
\hline ZUCV - Corredor de Verticalização & Min. 20\% & Min. 10\% & Min. 5\% & & 250 \\
\hline
\end{tabular}

Fonte: CMSR, 2006. (Lei complementar no. 40/06).

Tabela 17 - Quadro de parâmetros de Recuos por zona PD 2006.

\section{Quadro IX}

\begin{tabular}{|l|l|l|l|}
\hline Zona/Recuo & Frente & Lateral & Fundos \\
\hline $\begin{array}{l}\text { ZUR - bd Predom. Residencial de Baixa } \\
\text { Densidade }\end{array}$ & 5 & 1,5 & 3 \\
\hline $\begin{array}{l}\text { ZUR-md Predom. Residencial de Média } \\
\text { Densidade }\end{array}$ & 5 & 1,5 & 3 \\
\hline $\begin{array}{l}\text { ZUR-ad Predom. Residencial de Alta } \\
\text { Densidade }\end{array}$ & 5 & 1,5 & 3 \\
\hline ZUC - Central & - & - & - \\
\hline ZUI - Industrial & 10 & 3 & 5 \\
\hline ZUCA - Corredor de Atividade & 6 & 1,5 & 3 \\
\hline $\begin{array}{l}\text { ZUCAe - Corredor de Atividades } \\
\text { Especiais }\end{array}$ & 10 & 2 & 3 \\
\hline ZUCV - Corredor de Verticalização & 5 & 3 & 3 \\
\hline
\end{tabular}

Fonte: CMSR, 2006. (Lei complementar no. 40/06).

Nos trechos ainda verdes, este PD procura estabelecer regras de compactação de áreas verdes para a formação de parques municipais, como por exemplo no $\mathrm{km} 60$, onde espara-se forma um Horto Florestal, o que colaboraria para a questão paisagística e turística, dessa maneira contribuindo para a questão paisagística, e em consequência para a atividade turística, necessária à sustentabilidade de maioria da população de São Roque. Resta saber se será aplicada e o Horto Florestal ali estabelecido. 
A última alteração a ser anotada do PD de 2006 é relativa à Carta VIII, das Áreas de Especial Interesse Ambiental, que complementa as informações de zoneamento do PD de 2006 para o trecho estudado. Foi estabelecido a AEIA-5 para o Morro do Cruzeiro, pelos artigos $69 \mathrm{e}$ 74 , com o objetivo principal da consolidação de um parque público na área delimitada, com as áreas verdes resultantes de parcelamentos nas ZUI, ZUE Interesse Turístico e ZUE Desenvolvimento econômico (Fig. 58 e 59).

Figura 58 - Detalhe (Trecho 1) da Carta VIII - AEIAs, AEIUs e AEIS de São Roque - PD de 2006, lei complementar no. 40/2006.

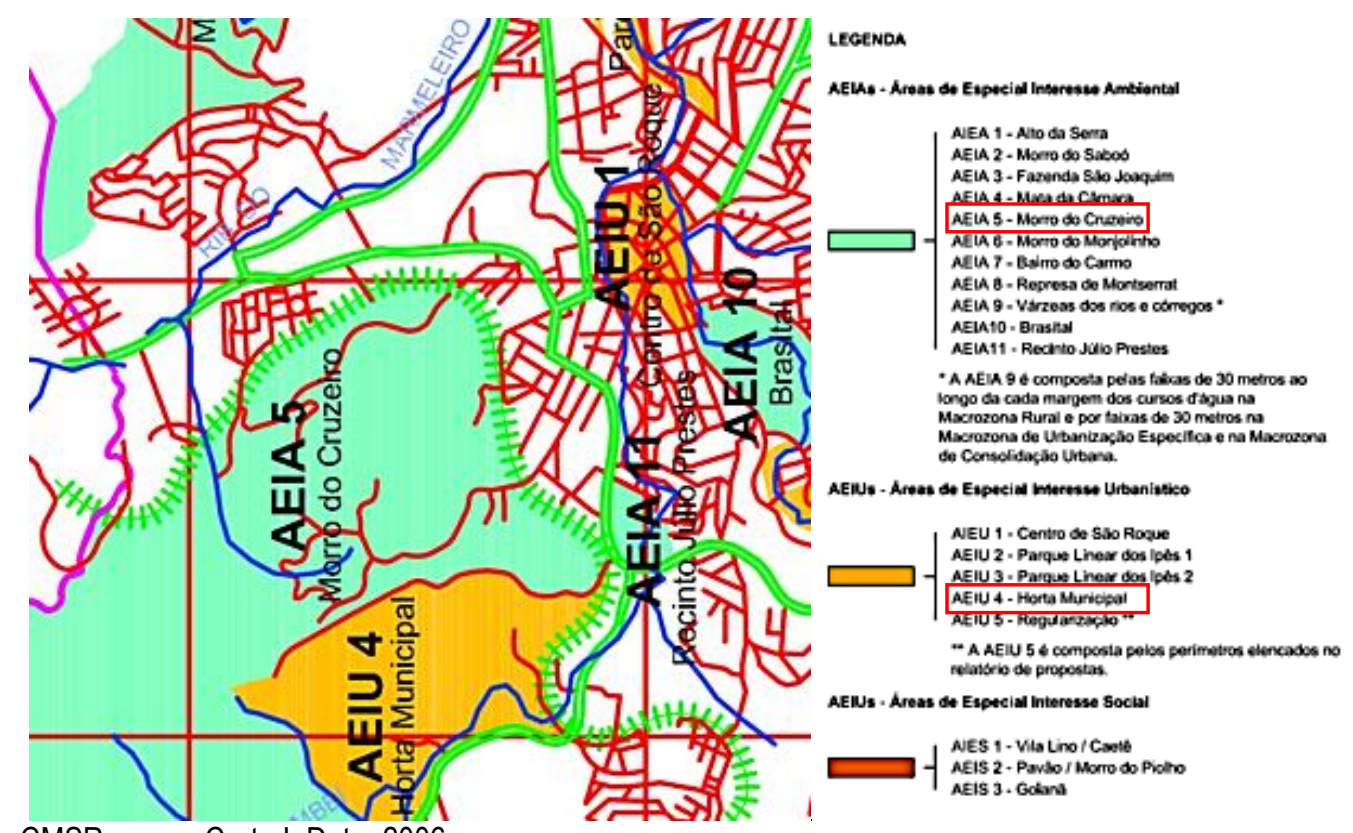

Fonte: CMSR, anexo Carta I. Data: 2006.

A lei complementar $n^{0} 48$, de 8/08/2008 estabeleceu o Plano de Urbanização, específico da zona de ocupação estratégica (ZUE) na área lindeira à RCB em sua porção sul, próximo ao km 60. Embora não esteja dentro do trecho 1 analisado, esta ZUE permite autorizar, a critério do órgão público municipal competente, a transferência da cota de área verde imposta pela lei de parcelamento de glebas para áreas de especial interesse paisagístico (AEIA) do Morro do Cruzeiro (Artigo 15, 10. Inciso) (CMSR, 2008). Esta lei prepara a ocupação da porção das áreas lindeiras à RCB no território são-roquense, para a implantação do futuro aeroporto executivo Catarina, na medida que determina coeficientes e diretrizes específicas para o uso e ocupação do solo incluindo o fim de utilização para aeródromos e loteamentos nesta área. Foi complementara pela lei complementar $n^{0} 79$, de 3/9/14, que dispõe sobre a criação do Programa de Desenvolvimento do Setor Aeroportuário (PRODESA) na Zona de Urbanização Especifica de Desenvolvimento Econômico (ZUE - DE) e na Zona de Urbanização Específica de Ocupação 
Estratégica (ZUE-OE). É interessante anotar que a implantação do aeroporto Catarina em São Roque vem sendo preparada há pelo menos uma década.

Outra anotação que podemos tirar da carta VIII seria que havia a delimitação de três áreas de especial interesse social, no PD de 2006, nenhuma delas no trecho estudado. Uma década após a aprovação deste plano diretor, novamente por legislação complementar, devido a presença de vários núcleos habitacionais que necessitavam de regularização fundiária, foram relacionados pela Lei Complementar $n^{0}$ 82, de 3/02/15, dando sequência ao processo da legalização fundiária plena nas áreas especiais de interesse social em São Roque:

"Art. $1^{\circ}$ Esta Lei dispõe sobre o processo de legalização dos núcleos habitacionais
nas áreas especiais de interesse social de que trata a Lei Complementar n⿳0 39 , fixando
normas e procedimentos específicos para regularização fundiária plena.
Parágrafo único. Entende-se por regularização fundiária plena a regularização
urbanística, jurídico-administrativa e socioambiental dos núcleos situados nas áreas
especiais de interesse social, no âmbito do Município, de modo a integrá-las a
estrutura urbana da cidade" (CMSR, 2015).

E depois houve alteração pela lei complementar $n^{0} 84$, de 15 de junho de 2015 , que deu nova redação ao art. $6^{\circ}$-A. Esta lei estabeleceu mais de 20 novas AEIS, sendo que no Trecho 1 temos a Vila Nova São Roque, denotando a existência de ocupação habitacional em terreno antes não utilizado para fins industriais (no caso da área lindeira à RRT neste trecho 1):

"Art. 6-A. Ficam incluídas como AEIS (Área Especial de Interesse Social) os seguintes bairros
do Município: Vila Lino, Guilhermina, Coopertec, Jardim Santa Vitória, Vila dos Crentes, Bairro
do Goianã, Alpes do Guaçu, Jardim Ponta Porá, Vale dos Pássaros, Vinhedos I, II e III, São
João Velho, São Julião, Vila Vinhas, Gabriel Piza, Floradas do Sino, Chácara Vale das Flores,
Mirante da Serra, Cascavel, Vila Nova São Roque e Sítio Capela São João Novo IV." (CMSR,
2015, negrito nosso).

Esta lei também ajustou trechos residenciais que antes estavam em área de zoneamento industrial; e desta forma permanecem até hoje. 0 mérito desta lei é a inserção de parâmetros de gabarito de altura e proteção a áreas de especial interesse ambiental, pois São Roque deve proteger sua vocação turística, e para isto precisa da manutenção de seus recursos naturais e das visadas da paisagem do entorno dos morros, ainda que já parcialmente ocupados.

A lei em referência também colocou, para novos empreendimentos imobiliários, a necessidade do EIA e EIV, o que em tese seria ótimo; mas apenas para terrenos acima de 50 hectares - dimensão muito grande - quais empreendimentos que ocupam terrenos maiores do que esta área? Na prática, desonera dos empreendimentos menores a necessidade de EIA e EIV, pois poucos empreendimentos imobiliários têm esta dimensão na totalidade de suas áreas.

Na redação da lei do PD de 2006 também foram colocados os instrumentos notáveis de urbanização para utilização pelo PD (direito de preempção, outorga onerosa, transferência do 
direito de construir, operações consorciadas urbanas e regularização fundiária), podendo-se então viabilizar vários tipos de operações urbanísticas.

O PD de 2006 deveria ter sido revisado no prazo máximo de 10 anos, conforme estabelece a lei do Estatuto da Cidade, para se fazer as atualizações pela participação popular, que se fizessem necessárias; não o foi até atualmente. Segundo apurado, a Secretaria de Planejamento de São Roque pretende realizá-lo neste ano (2018). 


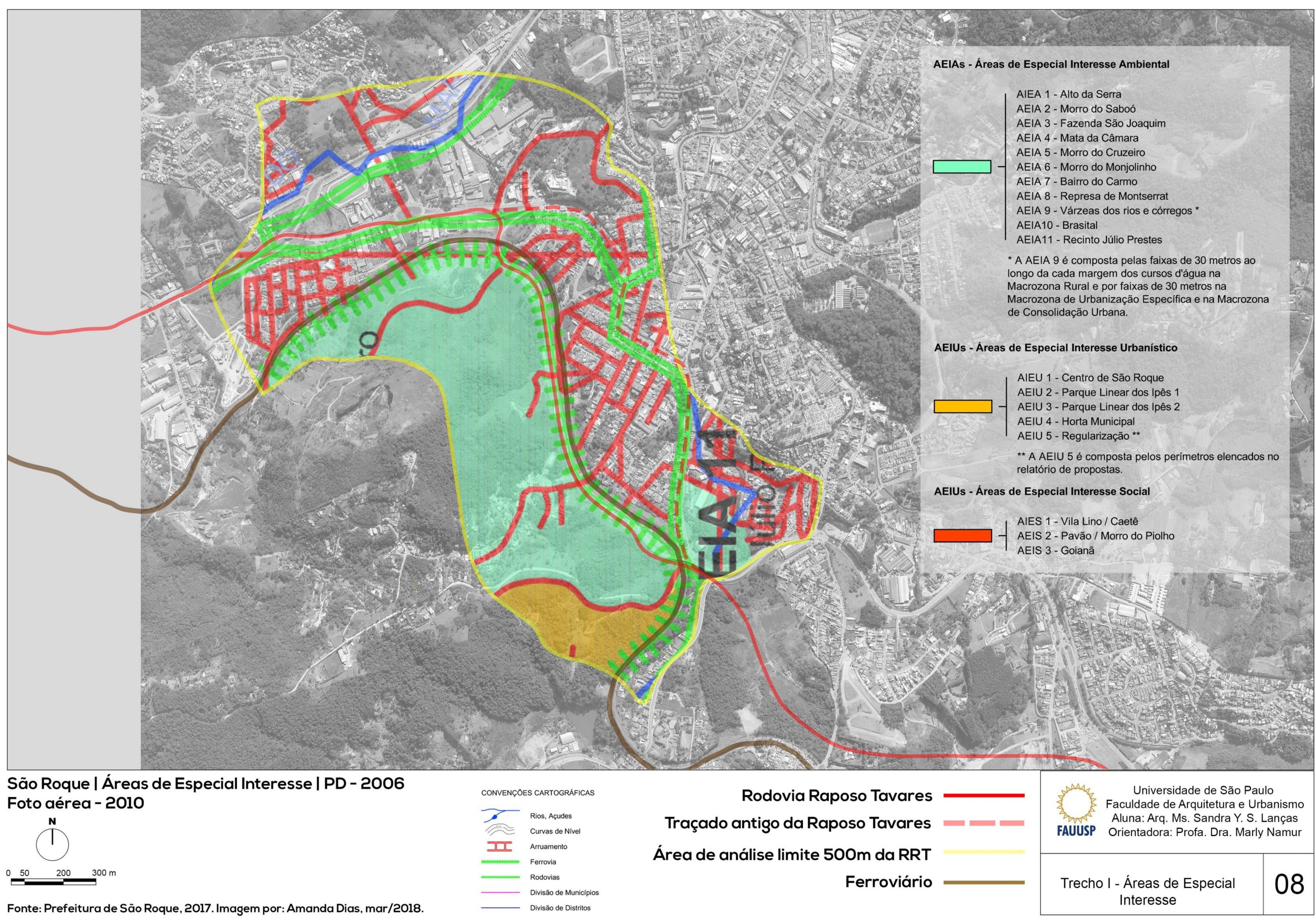




\subsection{Ocupação urbana x Zoneamento Trecho 1 (1962 - 2017)}

Antes local de fundação da fazenda pelo bandeirante que a batizou em devoção a São Roque, a praça da Matriz foi o local inicial do processo de urbanização do trecho 1 estudado. A ocupação urbana se consolidou com a implantação da linha férrea e da estação ferroviária próxima ao núcleo urbano, em área plana contornando o Morro do Cruzeiro.

Para resgatar a urbanização ocorrida no trecho no período de 1954 a 2016, nas próximas páginas estão fotos aéreas do trecho 1 de 1962 a 2016, pesquisadas no IGC e EMPLASA.

Na primeira foto aérea tirada em 1962, pode-se verificar que à esquerda da linha férrea a ocupação é rarefeita, e de uso rural e agrícola, embora com ligação com o núcleo urbano passando pela linha férrea. A expansão da área central foi limitada pela linha férrea e a topografia mais íngreme do morro do Cruzeiro. Fora do núcleo urbano central, as áreas lindeiras à RRT neste trecho ainda tinham em sua maior parte uso rural e agrícola (Fig. 60).

Pela foto aérea de 1972 verificamos o início da ocupação do caminho à esquerda na porção sul do Morro do Cruzeiro, com sítios e chácaras. O núcleo central está mais adensado, e pode-se perceber a ocupação residencial no trecho à esquerda do traçado antigo da RRT, na saída do núcleo urbano; e já entre os km 62 e 63 verifica-se a instalação de galpões industriais. Ao final do trecho 1, próximo ao km 64, verifica-se a instalação do loteamento Vila São Rafael, do lado esquerdo da RRT (Fig. 61). Ainda na foto aérea de 1972 percebe-se o aumento da ocupação na porção sul do Morro do Cruzeiro, ainda com sítios e chácaras, e o contínuo adensamento no núcleo urbano central e a expansão da mancha urbana na saída do traçado antigo da RRT da área central e da Vila São Rafael, no final do trecho 1. A área industrial já está se consolidando, como pode ser percebida na foto de 1977 (Fig. 62).

Com a desapropriação das áreas rurais promovida pela prefeitura municipal de São Roque nos anos 60 para a abertura da av. marginal do córrego do Marmeleiro, foi executada a av. Prefeito Bernardino de Lima, projetada para dar acesso à área industrial da RRT. Esta avenida também permitiu a interligação da RRT com a RCB, o que facilitou ainda mais a instalação de galpões industriais entre na área intersticial da Av. Pref. Bernardino de Lima e a RRT, e influenciou o maior adensamento e aumento da área física à direita da Vila São Rafael, como pode ser vista na foto aérea de 1999.

Na porção sul do trecho, no Morro do Cruzeiro o sistema viário estendido possibilitou a ocupação desta parte do Morro, e verificou-se a instalação de mais sítios e chácaras (Fig. 63). 
De 1972 a 1999, verifica-se a ocupação e aumento da mancha urbana na porção do final da área central do lado esquerdo da RRT, antes do km 62, de ocupação residencial. Embora pelo zoneamento de 1972 esta área tenha sido estabelecida como de zoneamento industrial, pois é lindeira à RRT no traçado antigo, a área foi ocupada para o uso residencial, embora de menor densidade, quando comparada à mancha urbana do lado direito da RRT, já mais próximo do centro principal 3, de maior densidade, do lado direito da RRT. 
Figura 60 - Detalhe (Trecho 1) da Foto aérea da área em 1962.

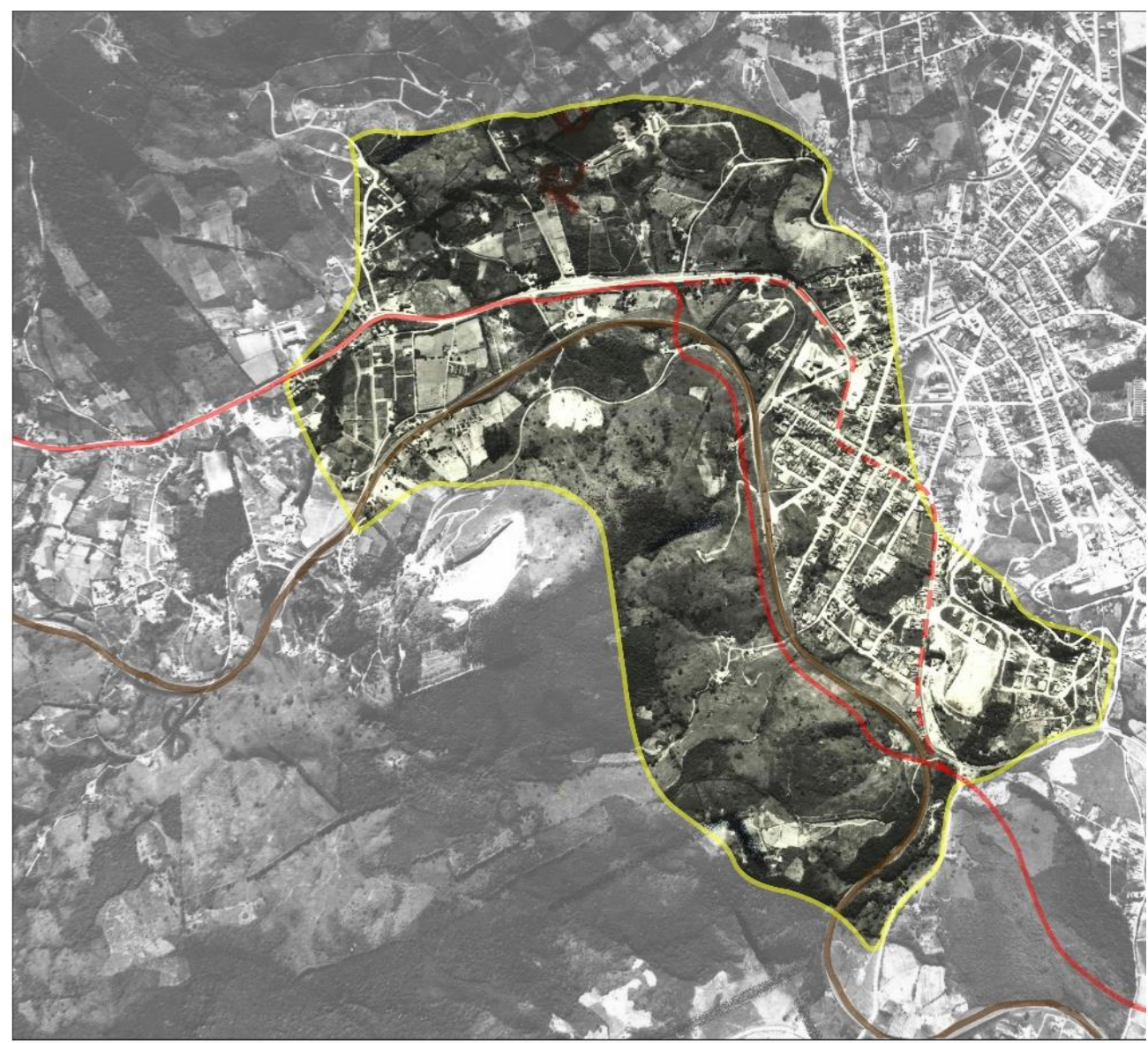

São Roque - 1962

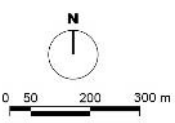

Fonte: IGC. Imagem por: Amanda Dias, mar/2018.
Figura 61 - Detalhe (Trecho 1) da Foto aérea da área em 1972.

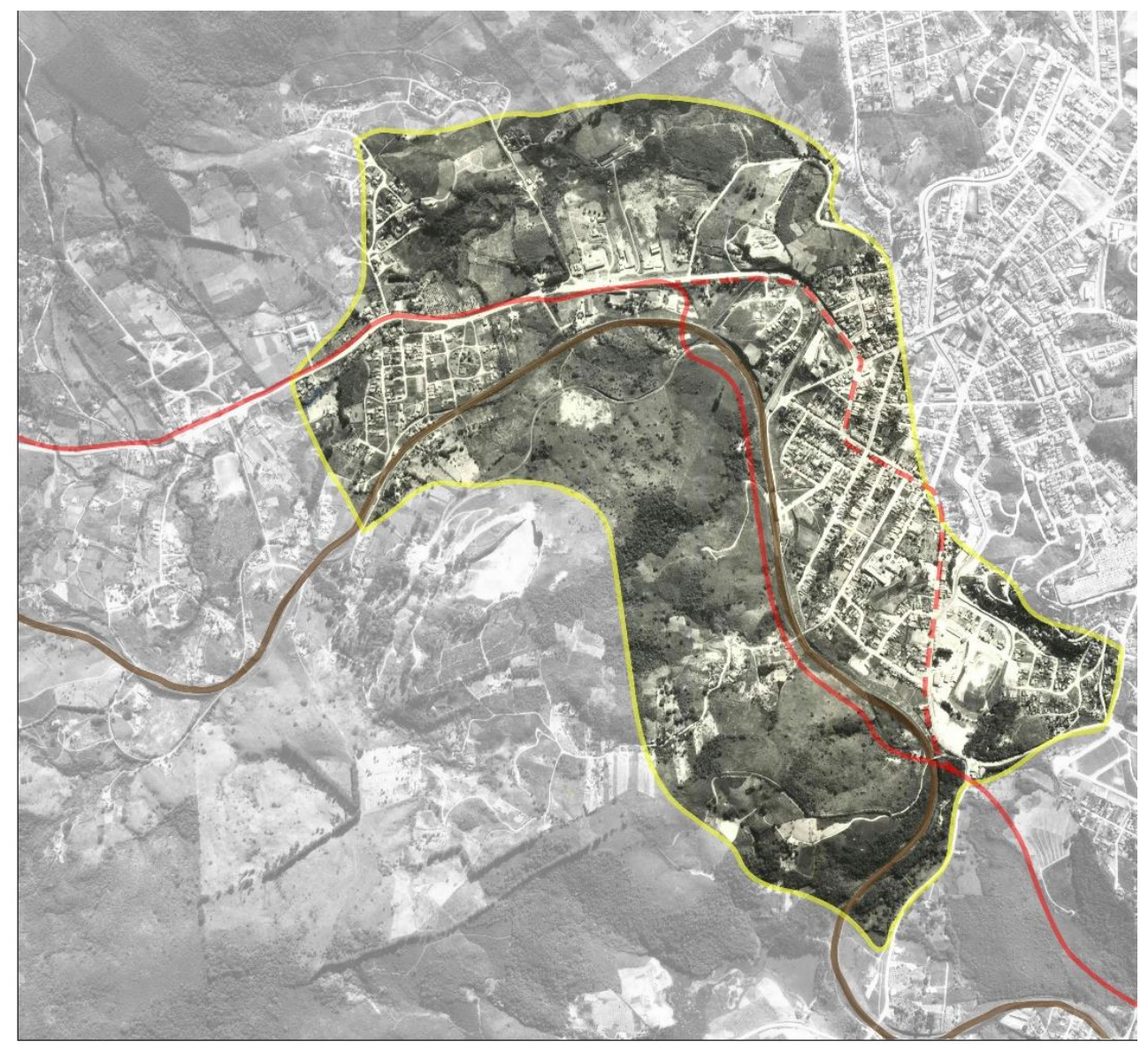

São Roque - 1972

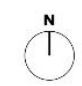

Foto não encontrada no acervo

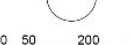

Fonte: IGC. Imagem por: Amanda Dias, mar/2018 


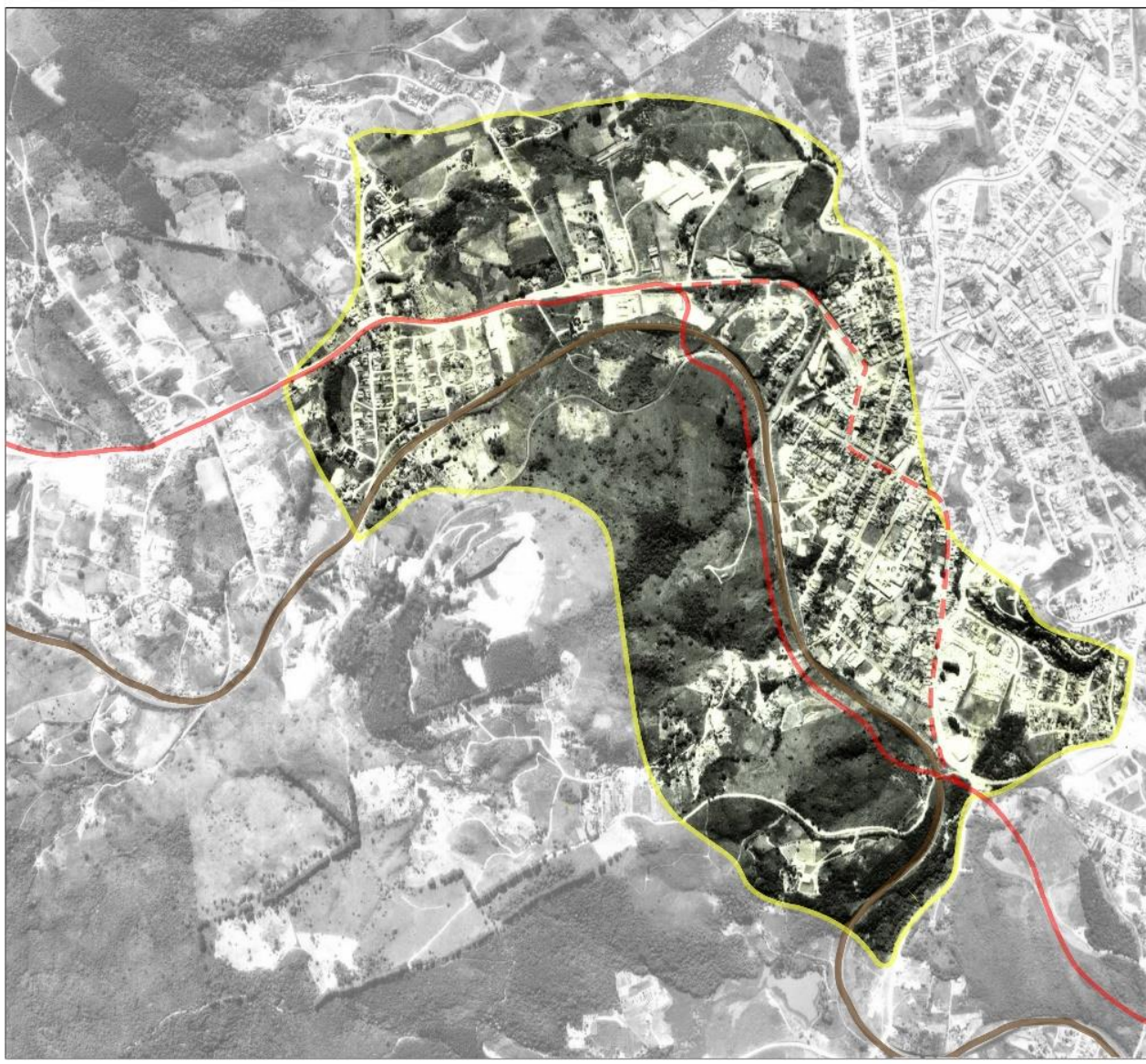

São Roque - 1977

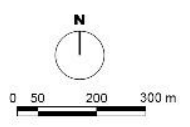

Fonte: IGC. Imagem por: Amanda Dias, mar/2018.

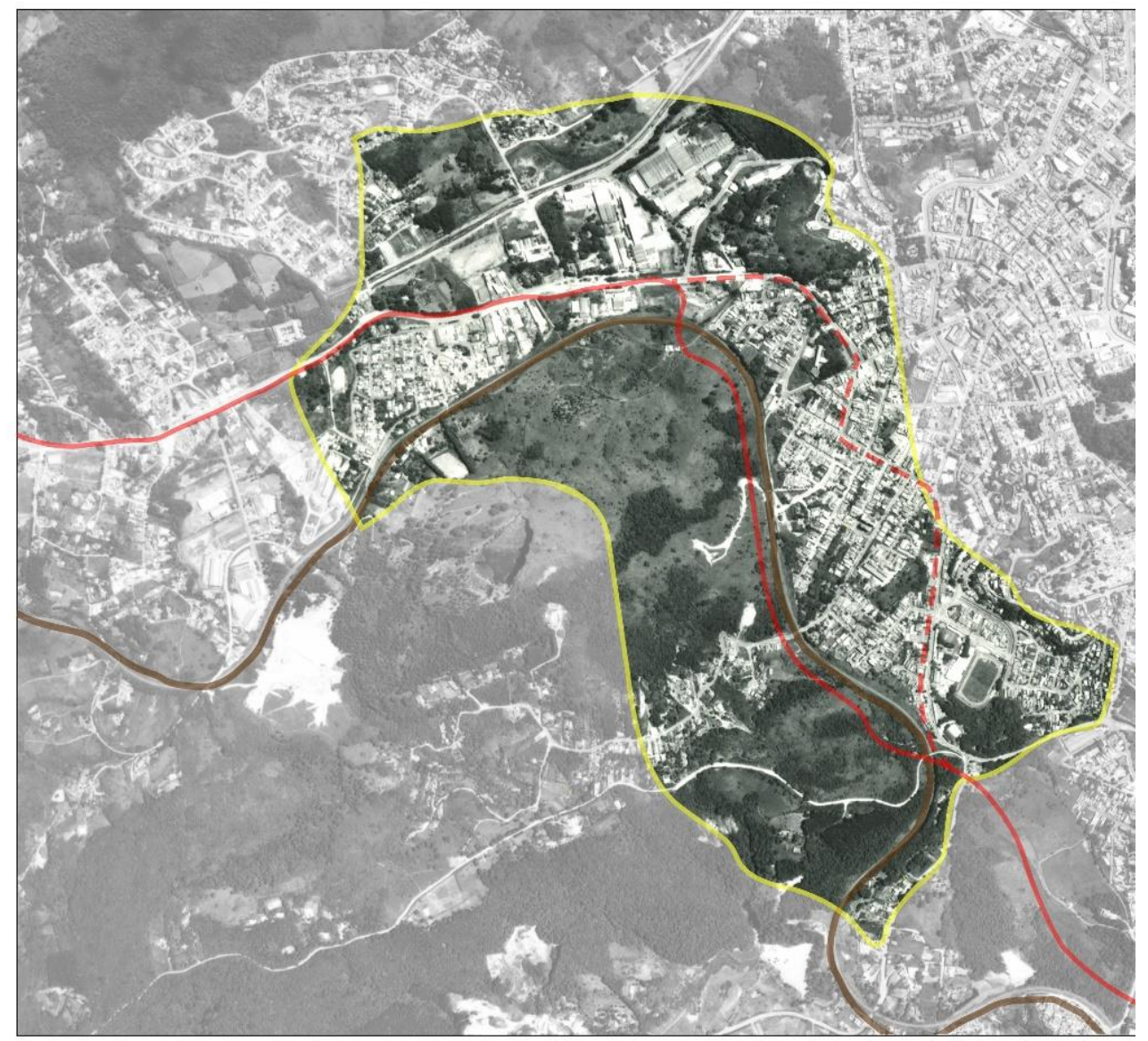

São Roque - 1999

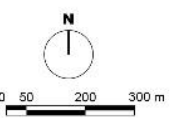

Fonte: IGC. Imagem por: Amanda Dias. mar/2018. 


\section{Trecho 1 RRT: Novo Contorno x urbanização existente}

A passagem da RRT na área central, efetivamente trazia mais transações comerciais, mas também transtornos, pois o núcleo central tinha ruas estreitas, e a velocidade principalmente dos caminhões de cargas atrapalhava o tráfego local; além das questões de segurança quanto a atropelamentos e transportes de cargas perigosas.

Em 2003, já havia diretriz para o novo contorno da RRT, deixando de passar a rodovia pela área central principal 1 de São Roque, e do bairro da Estação ferroviária e do Jd. Ester. A proposta foi, entretanto, melhor adequada posteriormente, pois o traçado proposto passaria pelo meio da Vila São Rafael e nova Brasília, núcleos urbanos existentes do lado esquerdo da RRT, próximos ao km 63 e 64 (Fig. 64).

Figura 64 - Traçado antigo da RRT passando pela Rua Santa Cruz no centro de São Roque (em amarelo).

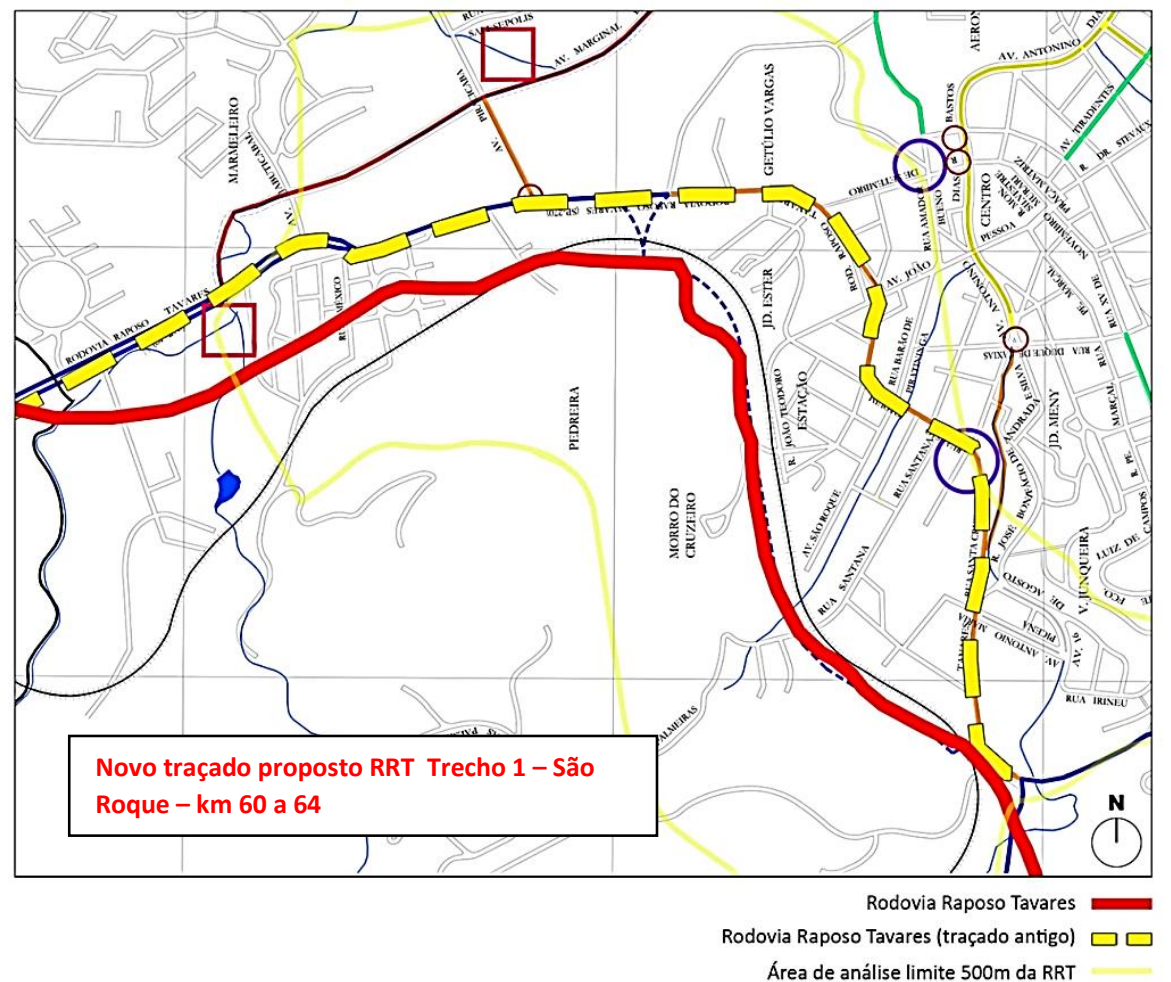

Detalhe do Mapa de Zoneamento da Cidade (PD 2006 lei no. 39/2006). Fonte: Departamento de Planejamento e Meio Ambiente, Prefeitura da Estancia Turística de São Roque. Data: maio/2003. Retrabalhado por Amanda Dias, 2018. 


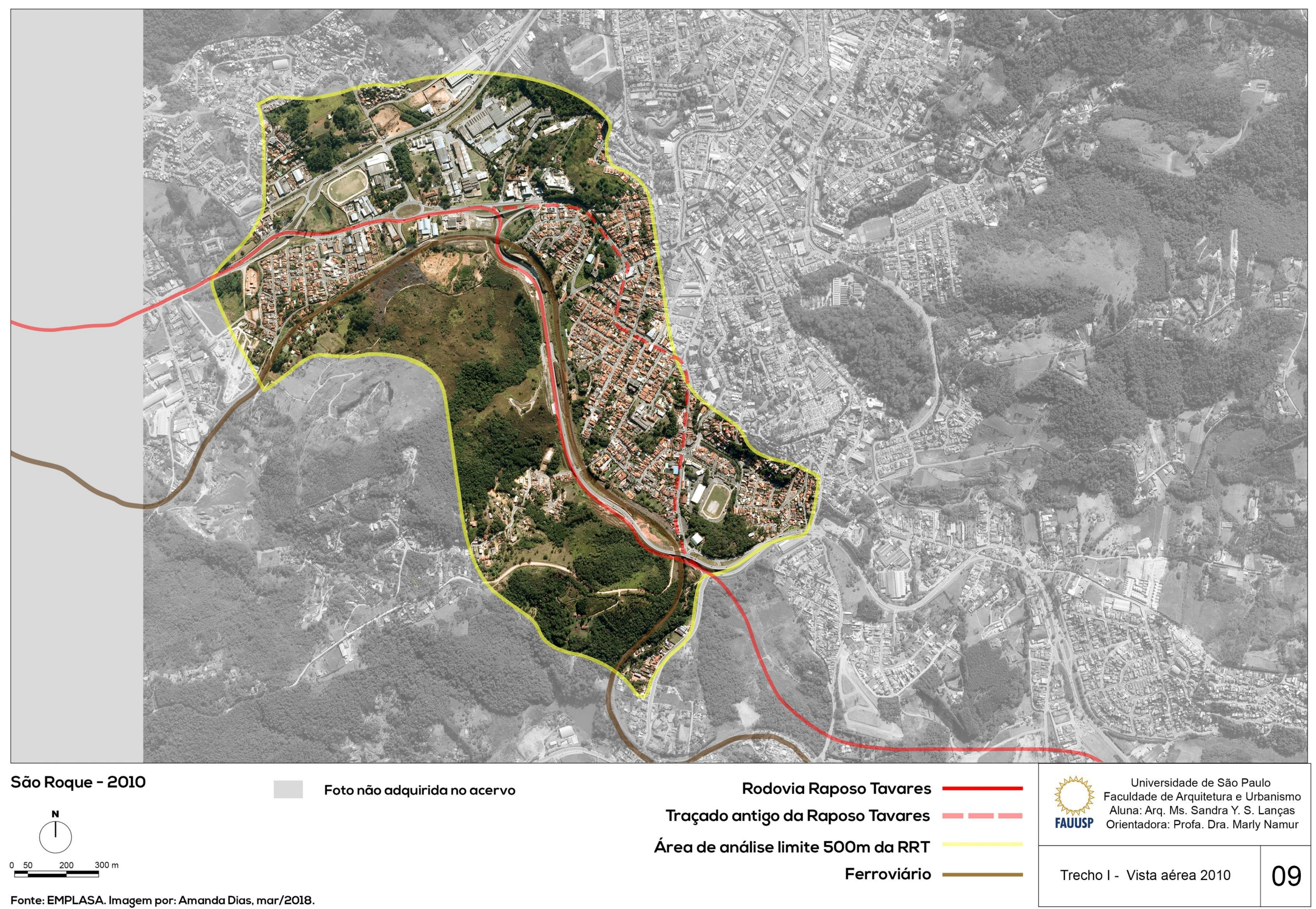


Cerca de uma década depois do lançamento da diretriz do novo contorno no PD de 2006 de São Roque, em maio de 2014, o Gov. Geraldo Alckmin (PSDB) assinou o decreto de desapropriação de áreas para o novo contorno da RRT em São Roque. A ARTESP aprovou 0 projeto do novo contorno em junho de 2014. Foram desapropriadas doze áreas para a execução da obra. O novo contorno RRT de São Roque foi inaugurado em 06/05/2016, e teve investimento de aproximadamente $\mathrm{R} \$ 84,6$ milhões ${ }^{24}$.

"Em 19 de maio deste ano, o Governador Geraldo Alckmin, assinou o decreto No
60.470 , que declara de utilidade pública, para fins de desapropriação pela
Concessionária de Rodovias do Oeste de São Paulo - VIAOESTE S.A, imóveis
necessários às obras de prolongamento do contorno alternativo de São Roque na
Rodovia Raposo Tavares. No documento estão previstas 12 áreas a serem
desapropriadas (...) A princípio, o investimento nas obras de contorno é de R\$ 68
milhões e de acordo com o projeto, os trabalhos teriam início ainda em 2014 com o
término para 2015. Se isso não ocorrer o objetivo é entregar o novo traçado em
2016" (JEONLINE. 26/06/2014)

Sobre a questão da RRT na ocasião de seu novo contorno em São Roque: embora o novo contorno esteja passando na parte menos habitada da área entre a linha férrea e o Morro do Cruzeiro, os representantes dos bairros existentes nas áreas lindeiras ao trecho RRT não foram chamados para poderem opinar quanto as questões do novo traçado e como resultado algumas passagens foram fechadas, e o acesso por pedestres para a transposição da RRT ficou mais limitado e demorado, gerando protestos das populações lindeiras (Jornal Globo/TV tem, 2017).

Comentários de pessoas sobre a falta de acesso do contorno aos bairros: "Infelizmente, ninguém pensou nos moradores da região, que por sinal, foram os únicos prejudicados com a obra, e não tiveram nenhum benefício, pois se precisarem, não terão, como utilizarem a nova Raposo, sem ter que andarem mais de $3 \mathrm{~km}$ para fazerem um retorno corretamente"; e "Como podem realizar uma obra dessa magnitude e não prever algo tão banal como isso? Aí ao invés de facilitar e melhorar a vida do cidadão, só piora!"26 (JEONLINE, 2016). Cerca de um mês depois da inauguração deste novo contorno, a concessionária teve que colocar proteção contra conversões:

\footnotetext{
"Motoristas da cidade, que por algum motivo acessam o início do contorno, do outro lado do município, no km 61, próximo à entrada da Vila Nova, sentido São Paulo, não tem ao longo do contorno, até o Jardim Villaça, no km 58, uma opção de saída.

Desta forma, ao entrarem no contorno, os motoristas sairão somente no Jardim Villaça, após $3 \mathrm{~km}$ de novo trajeto. Como no Villaça também não há uma alça de

${ }^{24}$ https://jeonline.com.br/noticia/7661/governador-inaugura-novo-contorno-da-raposo-tavares-em-sao-roque , acesso em setembro/2016. ${ }^{25} \mathrm{http}: / / j$ jeonline.com.br/noticia/1868/artesp-aprova-projeto-de-sequencia-do-contorno-da-raposo-tavares-em-saoroque, acesso em setembro/2016.

${ }^{26} \mathrm{http}: / /$ www.saoroquenoticias.com.br/noticia.asp?idnoticia=16038, acesso em setembro/2016.
} 
retorno, os motoristas passaram a realizar cruzamentos proibidos no meio da rodovia. As conversões perigosas, feitas por motoristas que saem do contorno sentido São Paulo, são realizadas em diversos trechos da rodovia no Villaça, no meio da pista." (São Roque Notícias, 03/06/2016)27.

Este é um problema que tem sido recorrente quando da duplicação ou execução dos novos contornos de trechos da RRT na RMS: de modo geral, a concessionária não faz audiências públicas para ouvir a população dos bairros atravessados, visto que isto pode significar atrasos nos cronogramas das obras, pois quando liberadas para execução, o prazo de entrega é curto; e cada dia a mais trabalhado nas obras também aumenta o custo e diminuiu 0 lucro possível de ser auferido. Mas o ideal seria que a urbanização que ocorresse nas áreas consideradas para a passagem de novos contornos ou trajetos, ou da duplicação de rodovias, a opinião da população fosse levada em conta, pois ainda que algumas áreas ainda não tenham sido passíveis da regularização fundiária pelo poder municipal, as pessoas estão lá e seria mais assertivo quanto à mobilidade urbana e em questões de segurança levar em conta a realidade existente. Também para os motoristas da rodovia há acréscimos de trajeto e muitos fazem conversões perigosas nos trechos, para diminuir os novos trajetos impostos.

Estes são alguns aspectos da urbanização nas áreas lindeiras da RRT no trecho de São Roque que poderiam ser levados em conta: embora o novo contorno saindo da área urbana do núcleo antigo tenha sido um ganho quanto ao tempo de tráfego e segurança para a população de uma área de boa densidade populacional, para os habitantes das periferias, muitas vezes instalados já precariamente, sem acessos executados para os pedestres nos novos traçados, e inclusive também o acesso direto aos bairros pelos veículos automotivos.

Neste caso aumenta-se a segregação dos habitantes dessas áreas lindeiras, pois nos $4 \mathrm{~km}$ deste trecho foi instalado apenas a passarela do km 64 para o cruzamento da via por pedestres. Também é o ponto de maior adensamento da população das áreas lindeiras do trecho 1 de São Roque, desconsiderando-se a área central (Fig. 66 e 67).

\footnotetext{
27 In: http://www.saoroquenoticias.com.br/noticia.asp?idnoticia=16038. Acesso em setembro/2016.
} 
Figura 66 - 0 projeto CCR ViaOeste.

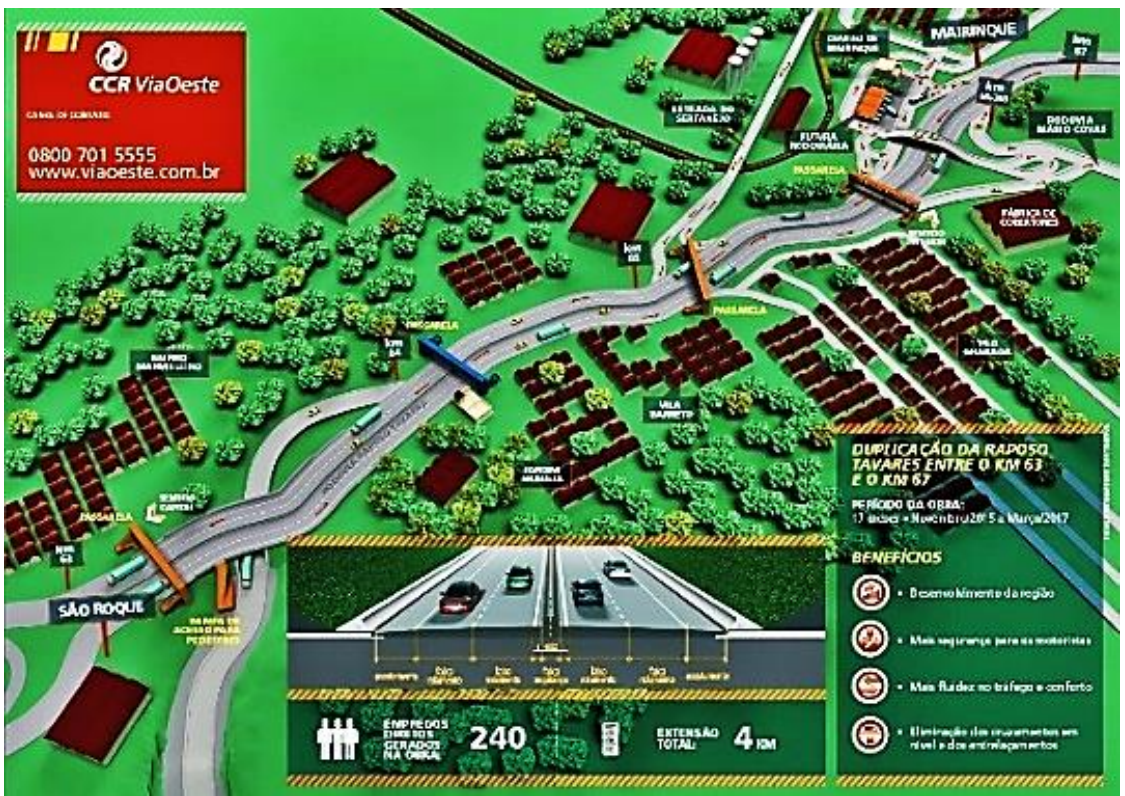

Disponivel em: http://jeonline.com.br/images/ck/images/IMG_8833.JPG.

Figura 67 - Foto do Novo Contorno RRT km 61 RRT São Roque, abril de 2016.

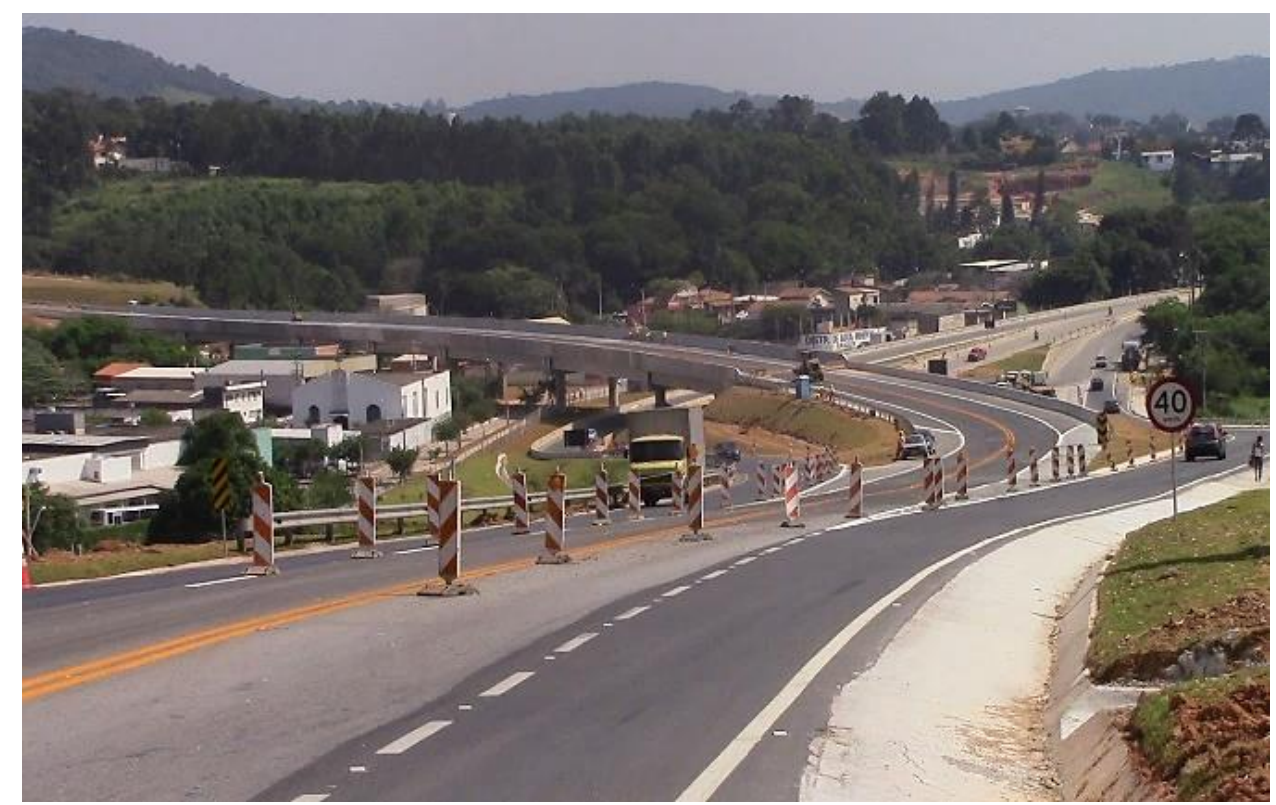

Foto: S. Lanças, 2017.

Desde a implantação da fazenda de São Roque no tempo colonial, passando pela implantação da via férrea e sua estação no trecho, verificou-se que a ocupação urbana ocorreu primeiramente atrelada à estrada São Paulo-Paraná, depois à linha férrea. A topografia do Morro do Cruzeiro, à esquerda da desta, não facilitava a ocupação dessa área, e ainda havia a questão da transposição da linha férrea. A mancha urbana expandiu-se, desta forma, para a direção leste, onde atualmente está o Centro Principal 1 de São Roque, e sua área urbanizada 
aumentou ainda mais após a pavimentação da RRT em 1954. Nas áreas lindeiras da RRT fora do trecho do núcleo central, a ocupação foi de sítios e chácaras produtivas, como pode ser vista nas fotos do trecho de 1962 e 1972 (IGC, 1962 e 1972).

A desapropriação amigável de parte da área rural do lado direito da RRT pelo poder municipal nos anos 60 (lei no. 407 de 20/10/1960 e decreto 158 de 19/03/1963) permitiu à execução de uma avenida marginal de acesso da região da RRT à RCB, o que auxiliou posteriormente na instalação de indústrias na área estabelecida pelo zoneamento municipal, preferencialmente nas áreas lindeiras à RRT. Estas áreas lindeiras foram destinadas à atividade industrial, e proibidas para a ocupação de uso residencial, exceto na região do km 64, para 0 loteamento residencial Vila São Rafael, já iniciado, antes da promulgação da lei do PD de 1972 (lei municipal no. 953/1972).

O zoneamento municipal para este trecho de São Roque foi estabelecido com parâmetros diferenciados como: a) $\mathrm{CP} 1$, com TO $=75 \%, C A=1,0$; TP máx. 100\%) no trecho analisado como Centro Principal 1 (CP1) para o núcleo urbano antigo, com parâmetros de usos variados, permitindo-se atividade residencial, unifamiliar e multi-familiar, comércio, serviços, mas protegendo a população residente, proibindo-se a cadeia pública e outros tipos de usos considerados mais perigosos na área central; b) a área lindeira da RRT no início da década de 70 ainda tinha vários sítios produtivos, mas com a instalação do então novo loteamento Vila São Rafael foi determinado um zoneamento especial, de um centro de serviços 1 (CS1), na confluência da RRT com outra via projetada (VL-9, futura av. marginal do córrego do Marmeleiro e depois Av. Prefeito Bernardino de Lima), que receberia equipamentos de saúde e cultura, para atendimento aos novos habitantes do loteamento Vila São Rafael recém instalado, por estar afastado da área central.

De 1972 a 1999 verificou-se o aumento da ocupação e densidade da ocupação do lado direito da RRT na área central. A produção rural das áreas lindeiras dos km 61 a 64 deu lugar à industrias; o loteamento Vila São Rafael cresceu e aumentou sua área urbanizada; surgiram áreas ocupadas e mesmo na porção sul do Morro do Cruzeiro, teve grande parte da área lindeira de seu acesso ao Jardim Suíça ocupado.

Constatamos que a urbanização ocorrida no trecho analisado após a aprovação da lei 953/1972, referente ao PD de 1972, seguiu em sua maior parte o zoneamento estipulado, pois a urbanização seguiu os parâmetros estabelecidos pelo poder municipal. Apenas um local (Jd. Ester, entre a região central e a área industrial) teve sua área utilizada para fins residenciais ao invés de industrial; mas isto poderia ter sido previsto, pois a área fica próxima à área central, com acesso por ela, e foi ocupada por residências unifamiliares, com baixa densidade. 
O zoneamento do PD 1972, aplicado ao trecho 1, simples em sua lógica de três zonas, atendia aos propósitos mencionados no início de sua lei. No mapa de uso e ocupação do solo para o trecho analisado em 1981 (IGC, 1981) as áreas urbanizadas estão de acordo com as fotos aéreas de 1977, exceto pela incipiente ocupação na porção sul do Morro do Cruzeiro (IGC, 1977) (Fig. 68).

Figura 68 - Mapa do uso do solo do Trecho 1em 1981.

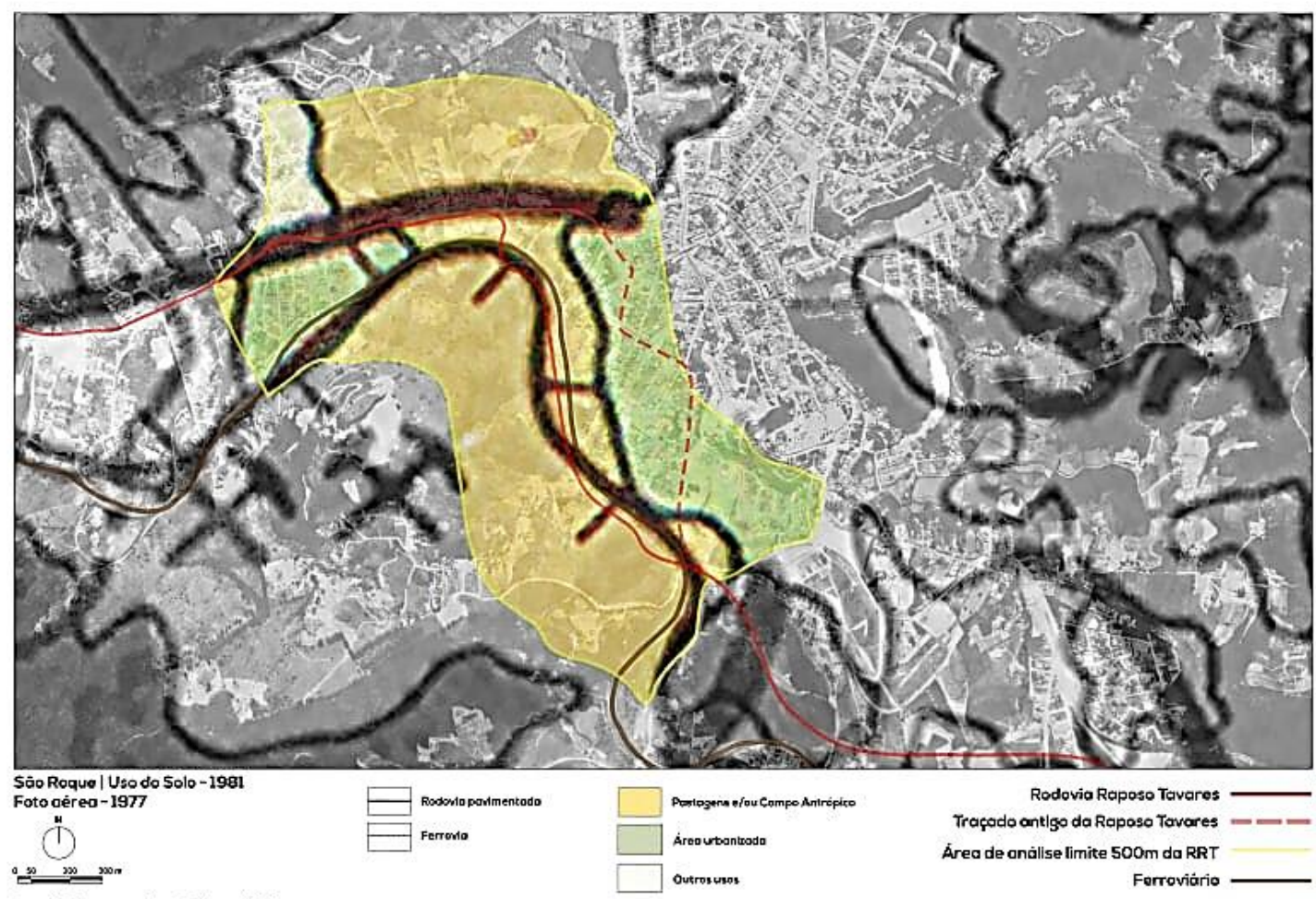

Fonte: IGC, 1981. Retrabalhado por Amanda Dias, março/2018.

O zoneamento determinado pelo PD de 2006 foi estabelecido através de lei complementar (Lei complementar no. 39 e 40/2006). Este PD foi elaborado após o advento do Estatuto da Cidade (2001) e trazia a preocupação com o meio ambiente municipal, e estabeleceu no trecho aqui analisado vários novos tipos de macrozoneamento, para estabelecer uma ocupação mais regrada com parâmetros ambientais e introduziu novas referências para a legislação urbanística em São Roque, cruzando informações sobre o macrozoneamento ambiental com aspirações do município quanto a manutenção de sua atividade turística; e preparando permissão de adensamento e de usos diferentes (não especificados completamente na lei), com previsão de compensação e utilização de áreas verdes de parcelamentos futuros para composição de futuros parques, estabelecendo-os concomitantemente à estrutura viária de 
maior complexidade, que provavelmente deverão ser revisados, visto que o traçado da RRT que passava no núcleo urbano central foi desviado em 2017 para um novo contorno paralelo à linha férrea, fora da área urbana mais densa.

A grande quantidade (mais de vinte) de núcleos de interesse social passíveis de regularização fundiária pela lei complementar no 82 e 84 de 2015 indicam porém, que boa parte da população municipal não tem condições ao solo urbano regularizado. No trecho estudado, porém, havia menção a um núcleo para regularização fundiária (Vila Nova São Roque) atualmente localizado na área industrial do lado direito da RRT entre o km 63 e 64, em um terreno que era uma grande chácara nos anos 70 .

Verificando no mapa de uso e ocupação do solo de São Roque de 2017 (EMPLASA, 2018) notamos que a autorização para as atividades especiais (ZUCAe) nos corredores da Av. do Marmeleiro, foi seguida em todas as quadras menos a primeira do lado esquerdo em direção à RCB, pois hoje tem-se ocupação do tipo residencial vertical, comércio e serviço, o uso em até $60 \mathrm{~m}$ de profundidade da avenida foi estabelecido para predominantemente depósitos e garagens. Nas outras vias regradas pelo mesmo raciocínio de utilização das áreas lindeiras na profundidade de 60 metros para verticalização (ZUCV) isto ainda pouco ocorreu. De fato, a verticalização aliada ao uso residencial, comercial e de serviços ocorreu mais na antiga entrada do município, especificamente quando termina o trecho do antigo traçado da RRT na rua Santa Cruz com este zoneamento, na Rua São Roque e São Joaquim. A explicação seria que estes edifícios se localizam na frente de uma área verde da APP de um córrego que desce do Morro do Cruzeiro, desta forma criando visão e micro-clima agradáveis, além de ser também área de ocupação antiga que foi reformada e verticalizada, com adequação para os usos mais atuais. Nas demais áreas também permaneceu na sua maior parte, residencial de baixa densidade; poucas áreas tem pelo levantamento in loco, uso residencial somado ao comércio e serviços (parte do centro principal 1 mais verticalizado e parte leste da Vila São Rafael). Na zona industrial, ainda há áreas para empreendimentos industriais, depósitos e garagens, pois nem todas as áreas foram ocupadas. Há ainda uma ocupação residencial irregular na área residencial, apontada para regularização fundiária.

Concluímos que a ocupação urbana do trecho 1 São Roque seguiu na quase totalidade da área do trecho estudado o zoneamento do PD de 2006, como pode ser verificado no atual mapa de uso do solo de São Roque (EMPLASA, 2017) (Fig. 69) visto que já foram colocados vários parâmetros de ajustes às tendências de ocupação de então, também de indução à verticalização de determinados corredores viários da área central. Também foi obedecido no trecho estudado, o quesito gabarito de altura, visto que a ocupação é predominantemente de uso 
residencial de baixa e média densidade; de vocação mais industrial e de comércio de grande porte ao longo da RRT após o trecho do centro urbano; e na porção sul onde está o Morro do Cruzeiro, os imóveis seguiram os índices estabelecidos pelo zoneamento municipal de 2006, já com ocupação residencial bem consolidada, embora estando em zona urbana de proteção ambiental (ZUPA). 


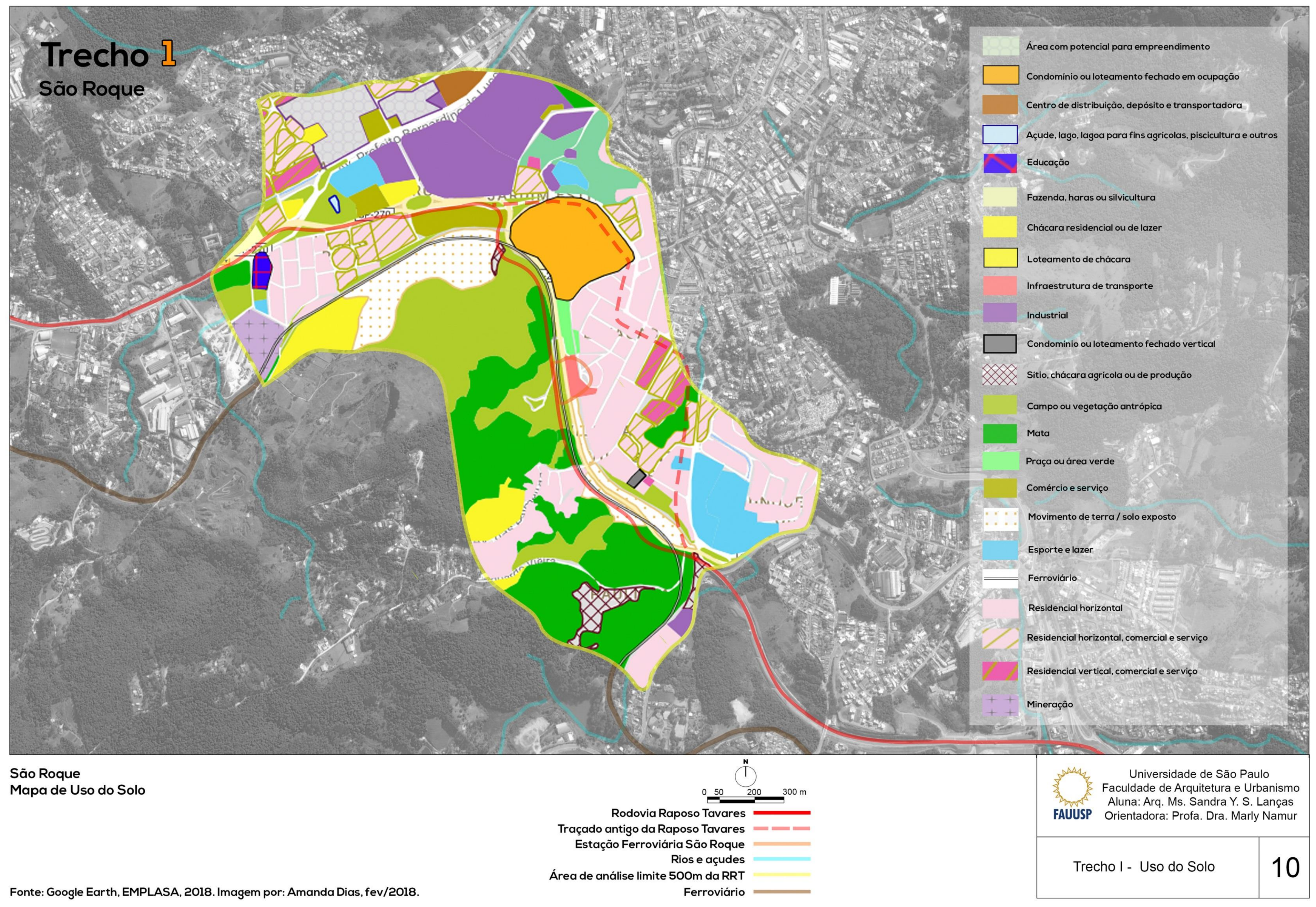


CAP. VI - URBANIZAÇÃO X LEGISLAÇÃO

Zoneamento do Trecho 2 - Alumínio:

RRT do $\mathrm{km} \mathrm{75-79}$ 


\section{CAP. VI - URBANIZAÇÃO X LEGISLAÇÃO Zoneamento do Trecho 2 -}

\section{Alumínio: RRT do km 75-79}

\subsection{Breve histórico do Município de Alumínio, SP}

O Município de Alumínio teve origem no bairro formado pelos trabalhadores próximo à estação ferroviária e da fábrica Companhia Brasileira de Alumínio, (Fig. 70) fundada em 1955. 0 bairro se chamou Alumínio devido ao produto principal da CBA, hoje uma das maiores produtoras de alumínio no mundo. Ele foi distrito do Município de São Roque, depois foi parte do Município de Mairinque de 1980 a 1991, quando foi emancipado pelo então governador Paulo Maluf. Atualmente, alumínio faz divisa à leste com o Município de Mairinque, à oeste com o Município de Sorocaba, ao sul com o Município de Votorantim e a Represa de Itupararanga, principal manancial de recurso hídrico da população de cerca de um milhão de pessoas (Fig. 71).

Figura 70 - Vista da área da CBA em Alumínio, (SP), lado sul da RRT no km 77.

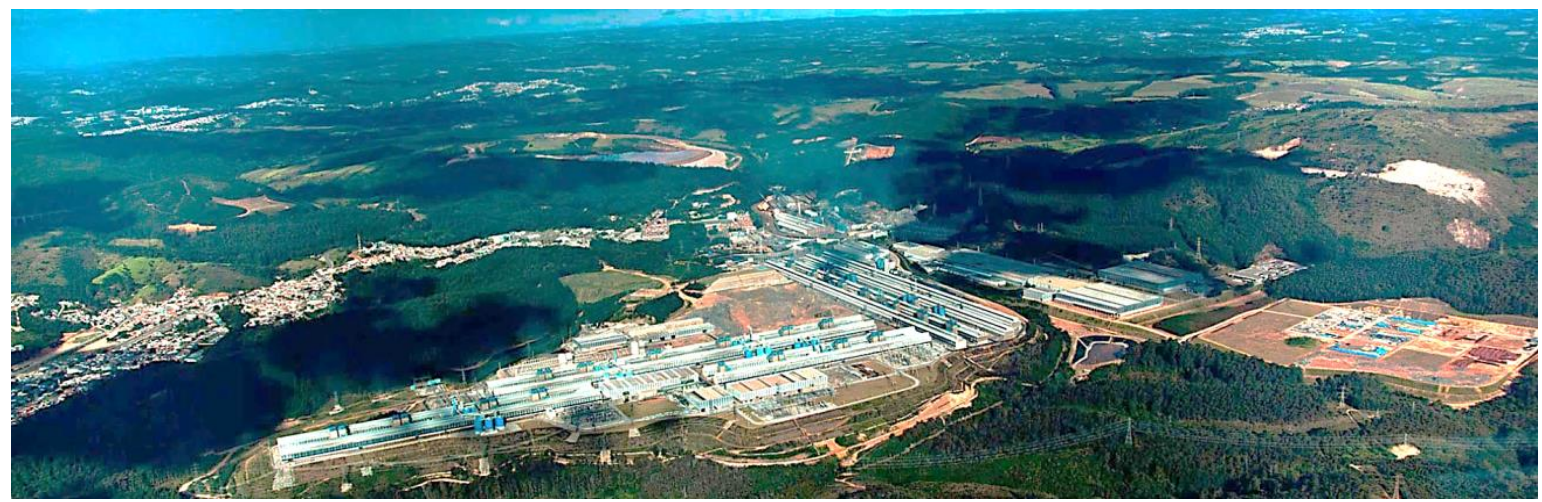

Fonte: CBA, 2018. Disponível em: www.aluminiocba.com.br, acesso em mar/2018. 
Figura 71 - Vista de satélite da área do território municipal de Alumínio, (SP).

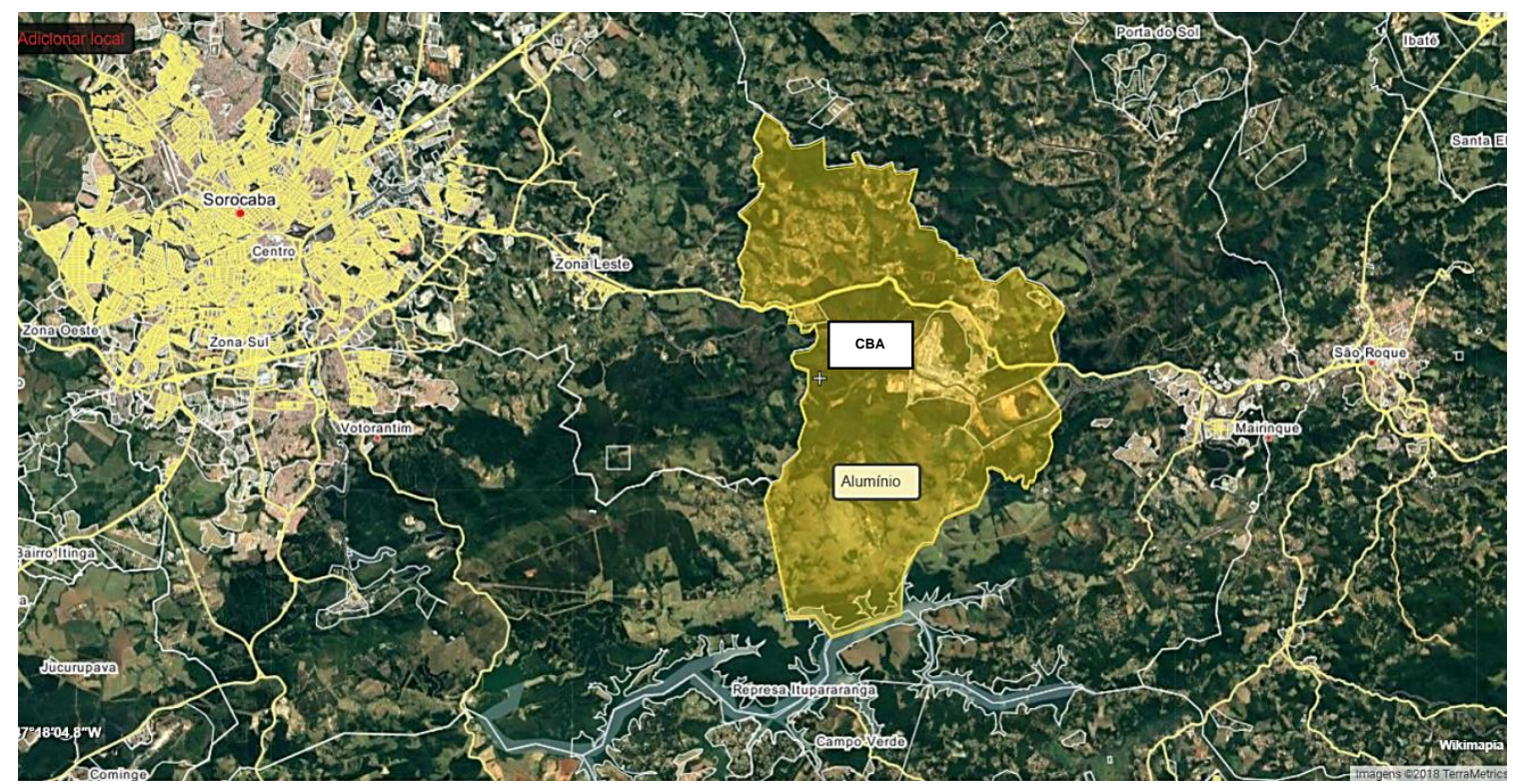

Fonte: Wikimapia/Google Maps, 2018.

Figura 72 - Foto do satélite em direção norte do mesmo local.

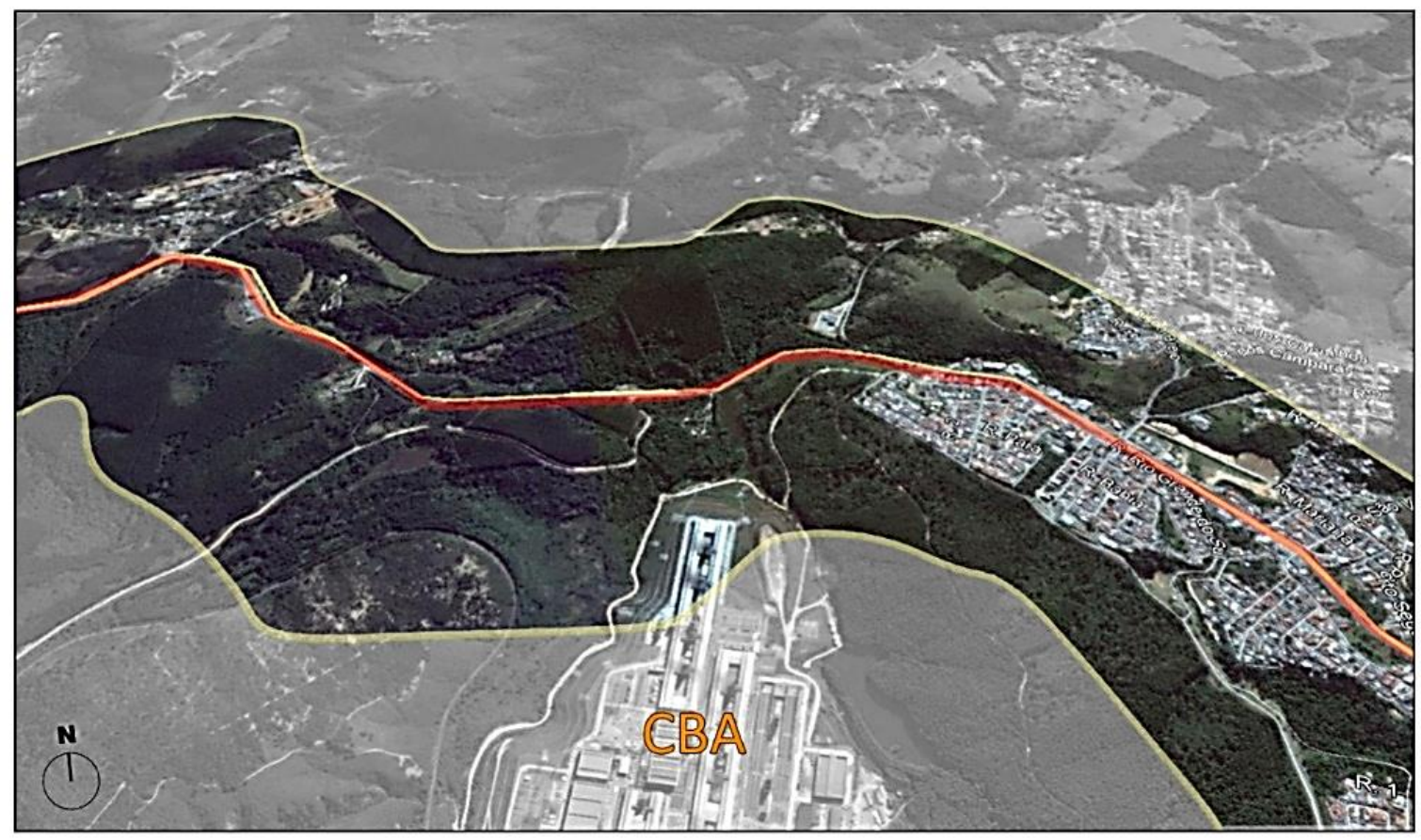

Rodovia Raposo Tavares Área de análise limite $500 \mathrm{~m}$ da RRT

Fonte: Google Maps, 2017. Retrabalhado por Amanda Dias, 2018. 


\subsection{Legislação urbana no Trecho 2 (1942 - 1999)}

Alumínio, a princípio, foi um distrito policial de São Roque, criado pelo Decreto-Lei no. 13.013, de 26/10/1942. Com a instalação da CBA no então território de São Roque, cresceu o bairro em população e Alumínio foi elevado à condição de distrito de Mairinque pela Lei Estadual $n^{0} 2.343$, de 14 de maio de 1980. Anos mais tarde, após plebiscito local, o Município de Alumínio foi criado pela Lei $n^{0} 7.664$ de 30 de dezembro de 1991.

A Legislação urbana de Alumínio, entre os anos de 1972 a 1980, seguiu igual à de São Roque, até passar a ser subordinado ao Municipio de Mairinque. A partir de 1980 até 1991, ano de emancipação municipal de Alumínio de Mairinque, permaneceu a legislação urbana de Mairinque, sendo que a partir de 1992, o novo municipio vai iniciar as tratativas da nova legislação urbana, a começar pela determinação do novo perimetro urbano, pela lei ordinária no. 148 de 06 de outubro de 1994:

\footnotetext{
"A Camara Municipal de Alumínio decreta:

Art. 10: fica definido como urbano, passando a incorporar o perímetro urbano do municipio de Alumínio, cujas linhas perimetriais foram fixadas pela lei municipal no. 428/70, de 22/05/1970, e ampliada pela lei no. 1112/1984 de 11/12/1984 do municipio de Mairinque, a área (...)" (CMA, 1994).
}

A zona urbana de Aluminio foi oficialmente instituída pela lei 374 de 22/12/1997, estabelecendo cinco áreas específicas, sendo a primeira descrita, área "A" a área analisada do trecho 2 neste capítulo. Depois, pela lei no. 477 de 23/07/1999, o parcelamento urbano do solo estabeleceu dois tipos de zoneamento: urbano e rural, e não foi modificado até hoje. Na zona urbana, a área minima do lote foi estabelecida para ser de $125 \mathrm{~m} 2$, com testada minima de $5,0 \mathrm{~m}$ para lotes encravados e 7,0 metros para lotes de esquina. A profundidade minima dos lotes deve ser igual ou superior a 20 metros em lotes encravados e $15 \mathrm{~m}$ de lotes de esquina. Não há menção de TO, CA ou gabaritos de altura, evidenciando a baixa disposição de ordenamento do uso do solo quanto as questões de recuo (insolação, ventilação) e permeabilidade e aproveitamento do solo.

Pela lei ordinária no. 524, de 15/05/2000, os vereadores de Alumínio de então autorizam o poder executivo a celebrar convênio com o governo do ESP, através da Secretaria de Agricultura e Abastecimento de então, objetivando a construção e instalação de pontes metálicas padronizadas em vias públicas na zona rural do município. Esta medida possibilita o atendimento das próximas leis, que vão tratar da expansão do perímetro urbano, a partir de 2007 (leis nos. 1006, de 03/10/2007; Lei Ordinária No 1427, de 02/12/2010; Lei Ordinária № 1431 de 02/12/2010; Lei Ordinária № 1557 de 05/12/2011; Lei Ordinária № 1565 de 13/01/2012; lei ordinária no. 1580, de 10/04/2012; lei ordinária no. 1740 , de 08/08/2014; e lei no. 1907, de 19/04/2017), transformando 
sítios e fazendas em áreas de expansão urbana na última década passada, principalmente para novos loteamentos residenciais.

Também houve desde então maiores destinações de verbas municipais para aplicação em drenagem de estradas municipais e verbas para instalação de equipamentos de lazer em bairros distantes do centro principal, principalmente no bairro Irema (bairro no $\mathrm{km} 79$ do trecho 2), que recebeu na última década muitos habitantes em ocupação irregular em terreno público municipal, junto ao Centro de zoonoses e Centro de Reciclagem de Alumínio (Emenda $N^{0} 3$ ao Projeto de Lei $\mathrm{N}^{0} 48 / 2016$, aditivo aprovado em 18/11/2016), dentre outros aditivos para outros bairros mais distantes do centro.

O Município de Aluminio tem atualmente uma população estimada de 18.321 pessoas (estimativa IBGE, 2017), com densidade de demográfica de 201 pessoas/km2 (2010) e está preparando seu novo plano diretor desde o ano passado, embora, pela Lei do Estatuto (BRASIL, 2001), apenas municipios com mais de 20.000 habitantes sejam obrigados a promulgá-las.

$\mathrm{Na}$ figura a seguir, está o mapa do zoneamento atual de Alumínio para o trecho 2 aqui estudado. Percebe-se que foi deixada grande área para a expansão da área urbana no trecho, mas em pelo menos metade de sua área mantêm-se a característica verde das atividades de produção agrícola.

Figura 73 - Zoneamento atual de Alumínio.

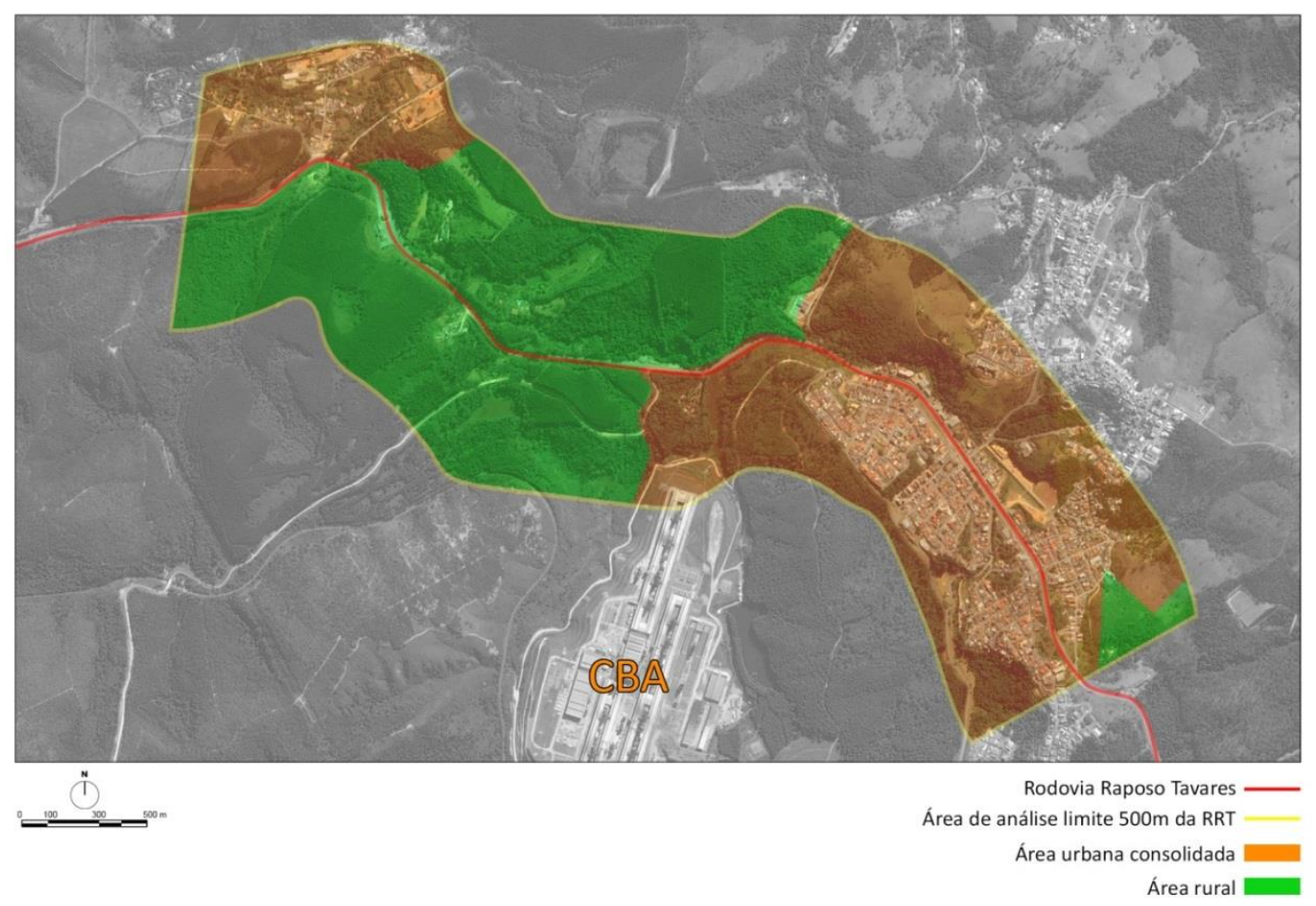

Em laranja, zona urbana consolidada, em verde, área rural. Em destaque, RRT e área lindeira considerada para 0 trecho estudado. Fonte: EMPLASA, 2017, retrabalhado por Amanda Dias, 2018. 


\subsection{Ocupação Urbana x Zoneamento Trecho 2 (1962-2017)}

Embora exista oficialmente como distrito de São Roque desde 1942, o distrito policial só começa a ter maiores volumes de população a partir de 1955, com o início do funcionamento da fábrica de alumínio da CBA, do grupo Votorantim, muito presente na região. Mas era distante do centro principal de São Roque, para se poder fiscalizá-lo; até por que os limites territoriais entre São Roque, Mairinque e Alumínio variaram muito até 1980.

Em 1962 a ocupação urbana nas áreas lindeiras da RRT ainda era incipiente, como pode-se verificar na figura no. 74. A instalação da CBA possibilitou a implantação do loteamento vizinho ao limite das terras da empresa, do lado esquerdo da RRT sentido interior, no início da década de 70. A mancha urbana ultrapassou o lado direito da rodovia e a ocupação irregular começa a acontecer ao final da década de 70 na entrada do núcleo urbano (Fig. 75).

Ao final do séc. XX, a CBA começa a construção da expansão de sua planta industrial: mais fornos em uma extensão de $1,5 \mathrm{~km}$. O tamanho da planta industrial é quase igual ao da mancha urbana do trecho aqui analisado. $O$ adensamento urbano próximo à planta continua, mas em lotes pequenos e de quase todos de auto-construção; mas de acoro com o zoneamento vigente, nos terrenos ingremes proximos à CBA. No $\mathrm{km} 75$, início do trecho 2, de área particular e no $\mathrm{km} 79$, de área pública municipal, começam a serem griladas e invadidas, e formam-se os bairro Irema no $\mathrm{km}$ 79 e ao longo da rua Paulo Dias (lado esquerdo da RRT sentido interior, na entrada do municipio), outro local de ocupação irregular, embora na área urbana.

A maior caracteristica de ocupação da zona urbana é a instalação insdustrial da CBA, não havendo diferenciação de parametros para uma zona industrial na legislação urbana municipal, mas a CBA não está na área de 500m de área estudada no trecho Alumínio, pois sua entrada fica em outra direção da RRT.

A área ocupada pelas residências, comercios e serviços nas margens da RRT neste trecho segue o padrão de zoneamento residencial estabelecido, de pequenos lotes com baixa tipologia, e seguindo de ocupação do morro acima da área lindeira ao trecho RRT, com características de autoconstrução. Há ainda uma pequena área ocupada residencialmente próxima à APP de um córrego do lado esquerdo da RRT, na entrada de Alumínio, descendo proximo à Rua Paulo Dias; quase ao fim da área urbana do lado direito, o corrego se junta ao Rio Pirajibu, passando próximo à Rua Lamartine de Oliveira, (em sua várzea) que foi objeto de tramite na Camara Municipal de Alumínio, que a oficializou.

As cores oficiais do mapa de uso e ocupação do solo do ESP de 1981 (logo após a emancipação de Alumínio) não colaboram muito para a compreensão adequada pois a área 
urbanizada está anotada em verde claro, ao invés de amarelo, na figura no. 76 e em laranja está anotada a área de silvicultura, em quase todo o lado esquerdo da extensão do trecho 2, ainda com pouca área urbanizada no seu lado esquerdo. Do lado direito da RRT ficou então a área mais urbanizada do trecho; e em amarelo está anotado os campos antropicos e pastagens. Ao lado direito, no meio do trecho 2, estavam grandes áreas desmatadas, as capoeiras, anotadas no mapa na cor verde escura. A área do $\mathrm{km} \mathrm{79,} \mathrm{no} \mathrm{mapa} \mathrm{de} \mathrm{uso} \mathrm{do} \mathrm{solo} \mathrm{de} 1981$ estava anotada como silvicultura, pois a área ainda tinha trechos de plantações, embora pela foto aérea de 1962, já estava urbanizada com baixa tipologia desde o início da década de 60.

Figura 74 - Vista aérea do trecho 2, de Alumínio em 1962.

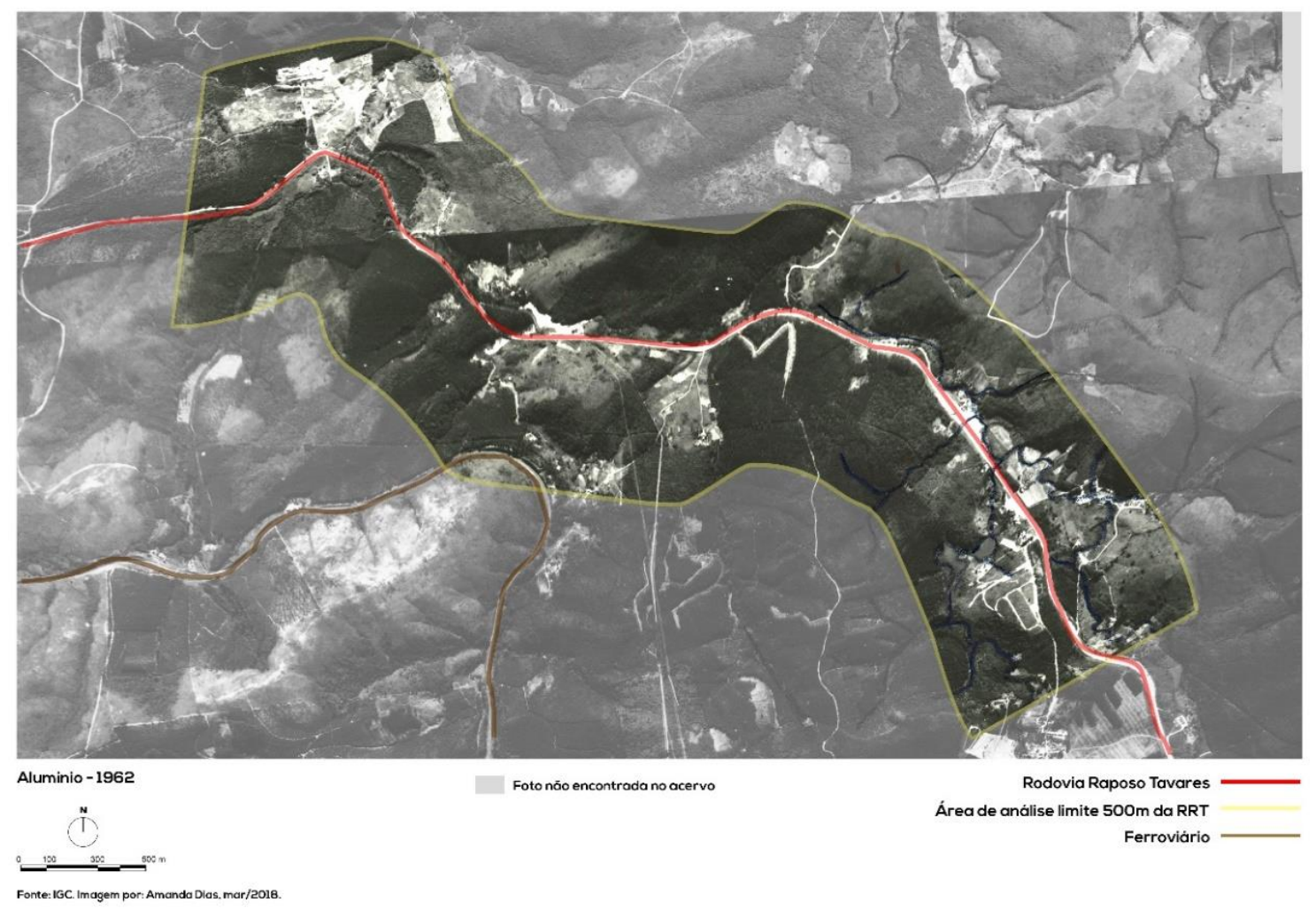

Em destaque, o trecho 2 da RRT. Fonte: IGC, 1962. 
Figura 75 - Vista aérea do trecho 2, de Alumínio em 1978.
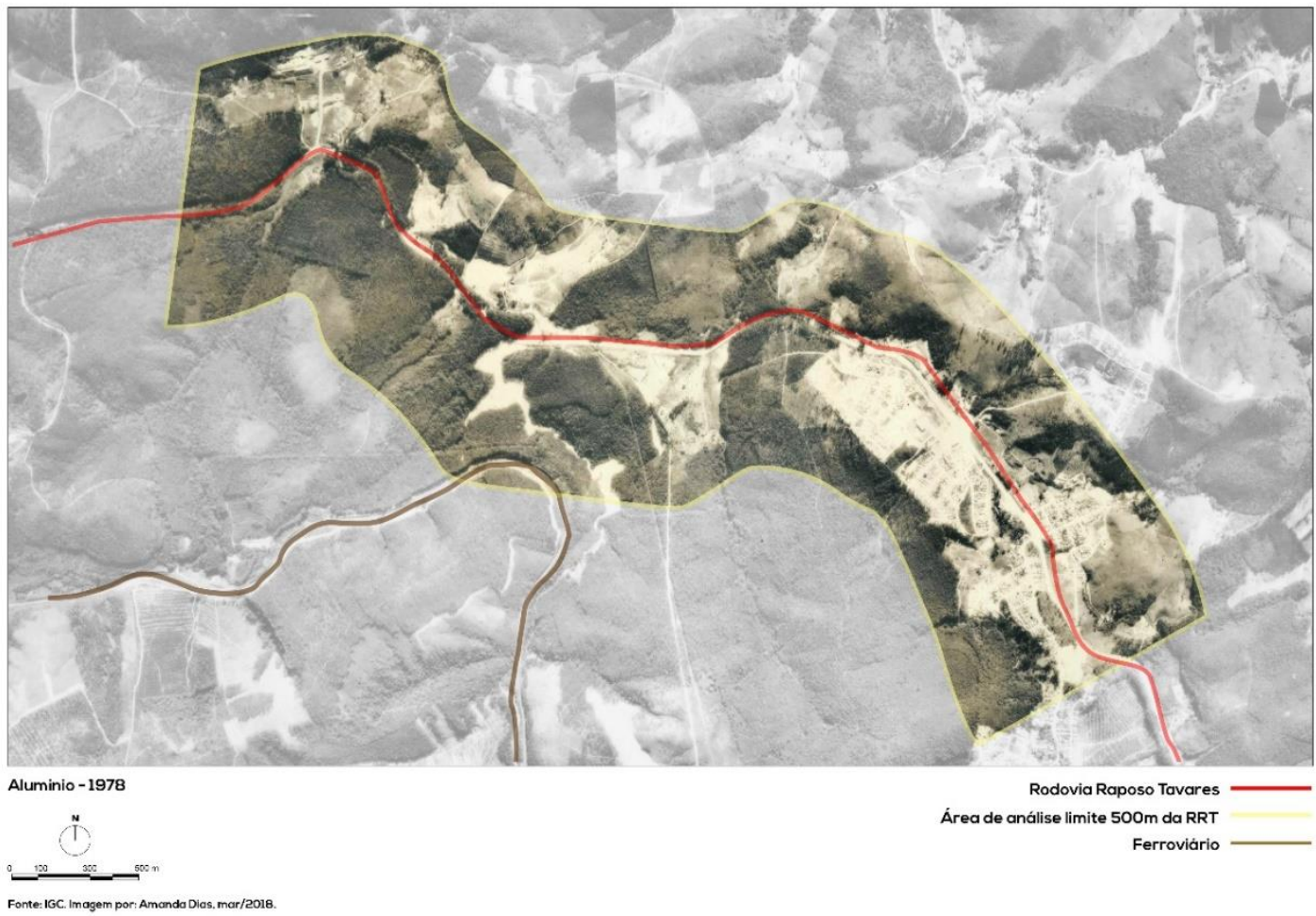

Ferroviário

Em destaque, o trecho 2 da RRT. Fonte: IGC, 1978.

Figura 76 - Uso do Solo no trecho 2, de Alumínio em 1981.

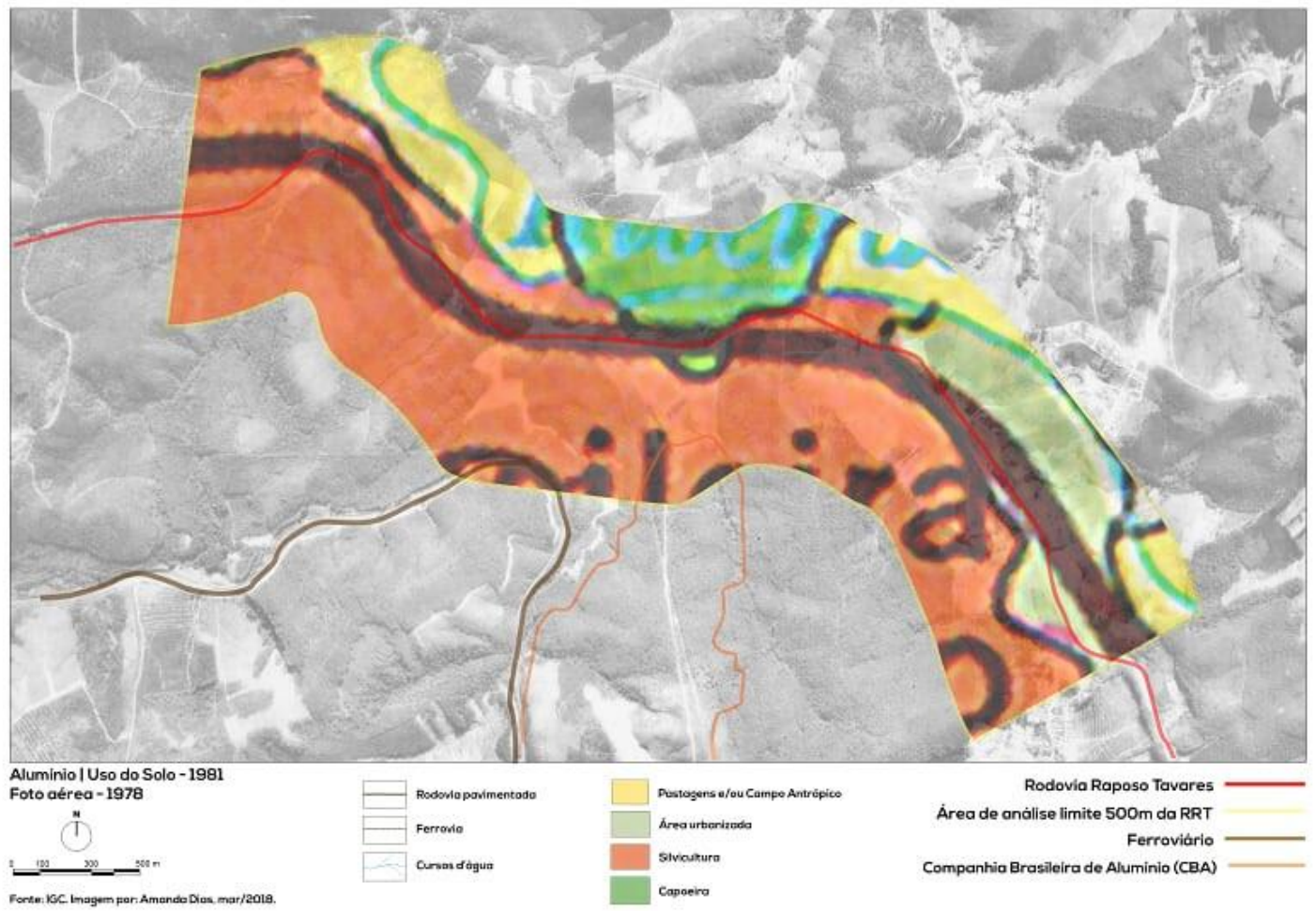

Em destaque, o trecho 2 da RRT. Fonte: IGC, 1981. 
Figura 77 - Vista aérea do trecho 2, de Alumínio em 1999.

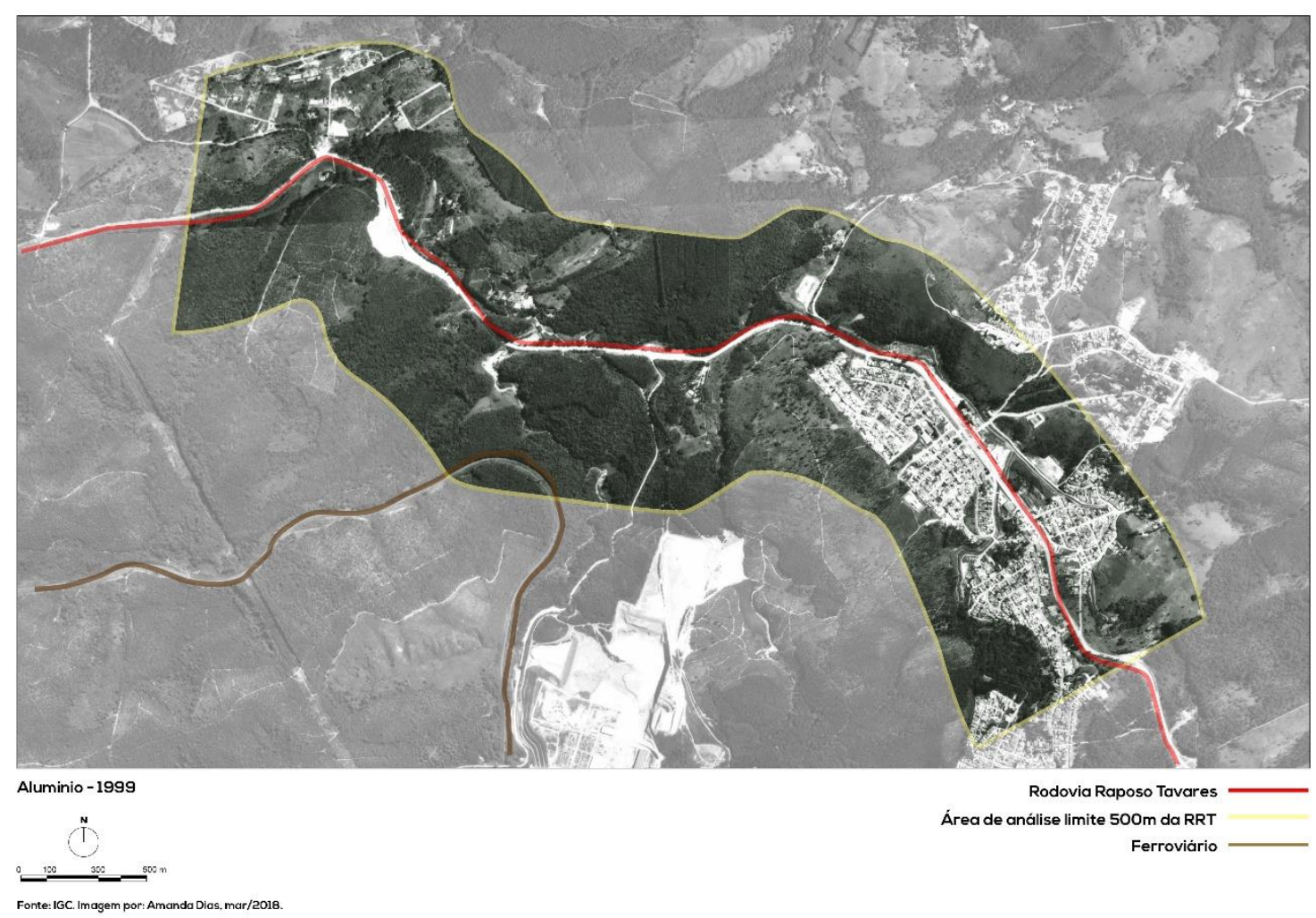

Em destaque, o trecho 2 da RRT. Fonte: IGC, 1999.

Pela foto aérea de 1999, a planta industrial da CBA já teve a expansão de sua área industrial, aumentando muito sua ocupação no solo (até hoje produz quase meio milhão de toneladas de alumínio por mês); e a área urbanizada aumentou muito na porção do lado esquerdo da RRT sentido interior. Esta área topograficamente é de alta declividade, mas o baixo preço da terra possibilitou a ocupação local pela população mais pobre, posto que era distante do centro do municipio (do outro lado da rodovia). O zoneamento é simplesmente dividido em dois tipos: rural e urbano, sendo que o lote mínimo urbano é de $5 \times 25 \mathrm{~m}$; e quando de esquina o mínimo deverá ser de $7 \mathrm{~m} \times 25 \mathrm{~m}$. A tipologia de baixa qualidade e a mancha urbana cruzada pela RRT, sem vistas a um novo contorno da área urbanizada pela rodovia, é até uma surpresa quando comparado o PIB municipal, um dos mais altos da RMS (SEADE, 2015). 
Figura 78 - Vista aérea em direção a oeste do trecho 2 em Alumínio.

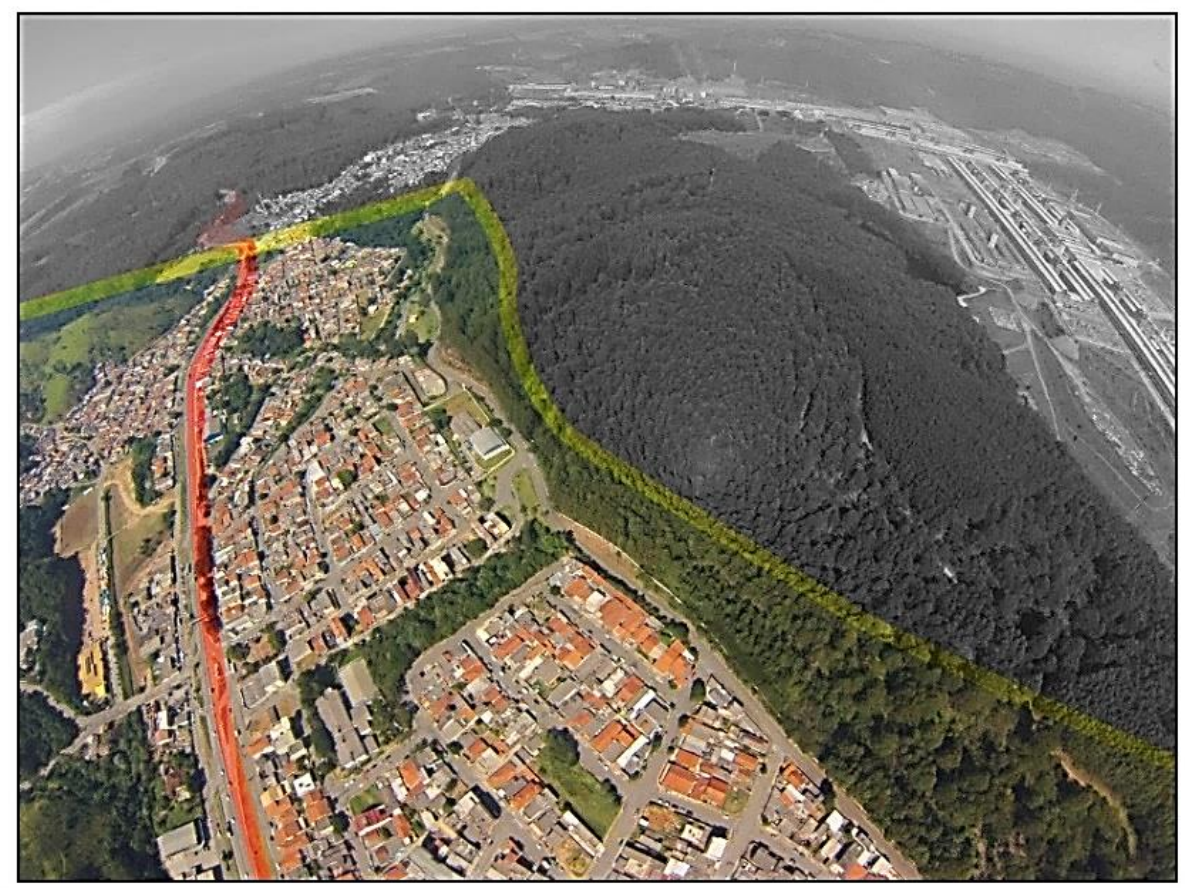

Rodovia Raposo Tavares

Área de análise limite $500 \mathrm{~m}$ da RRT

Imagem por drone: Heiton Gomes. Data: abril/2017. Retrabalhado por Amanda Dias, 2018.

O mapa do zoneamento urbano ainda aponta grande área de expansão prevista na área do trecho estudado, mesmo considerando-se a APP do rio Pirajibu. Mas é limitada pela área privada da CBA do lado esquerdo da RRT (sentido capital-interior). Atualmente, a zona rural de Alumínio acomoda vários tipos de usos do solo mas ainda relacionados à questão do rural: campo ou vegetação antrópica, mata, sítio, chácara ou área de produção agrícola, fazenda, haras ou silvicultura, e chácara residencial de lazer.

Podemos perceber pelas fotos aéreas de 1962 a 2010 que algumas partes das áreas lindeiras foram reflorestadas. Este trecho ainda mantêm muito do aspecto verde, pois apesar da CBA, mais da metade do trecho mantem suas características de produção agrícola. Também percebem-se pelas fotos aéreas e pelos levantamentos feitos in loco que a área urbanizada aumentou em tamanho e densidade, principalmente nas áreas lindeiras no início e fim do trecho estudado ( $k m 75$ e 79). No levantamento do aumento de área urbanizada realizado em 2015, (por fotos do Satélite LandSat 7 e 8, este trecho de Alumínio foi o que mais teve aumento da mancha urbana em números absolutos: 105\%, pela comparação de fotos do satélite de 2002 e 2014.

Com a elaboração e conclusão do novo PD para o Município de Alumínio, provavelmente será criado pelo menos mais uma zona industrial, separadamente da zona urbana, para a melhor 
adequação legal ao uso e ocupação do solo municipal. Também poderão ser estabelecidas áreas de interesse social, para regularização de pelo menos dois núcleos habitacionais já existentes, justamente no início e final do trecho aqui analisado. 0 município certamente deve ter condições para isto enquanto o PIB municipal for o maior de todos os municípios da RMS, com PIB per capita de $\mathrm{R} \$ 100.197,36$ (IBGE, 2015), além de ter a instalação de uma praça de pedágio na RRT, sentido capital.

Concluindo, verificamos que neste trecho, à parte dois pontos de ocupação irregular anterior à lei de 1999 para fins de moradia, na maior parte da área analisada o zoneamento municipal da lei no 477/1999 foi obedecido, com a ressalva da pouca opção de número de zonas (rural e urbana, que inclui a área industrial), como pode-se constatar pela foto aérea de 2010 (Fig. 79) e do mapa de uso e ocupação do solo de 2017 (EMPLASA, 2017) (Mapa 11). 


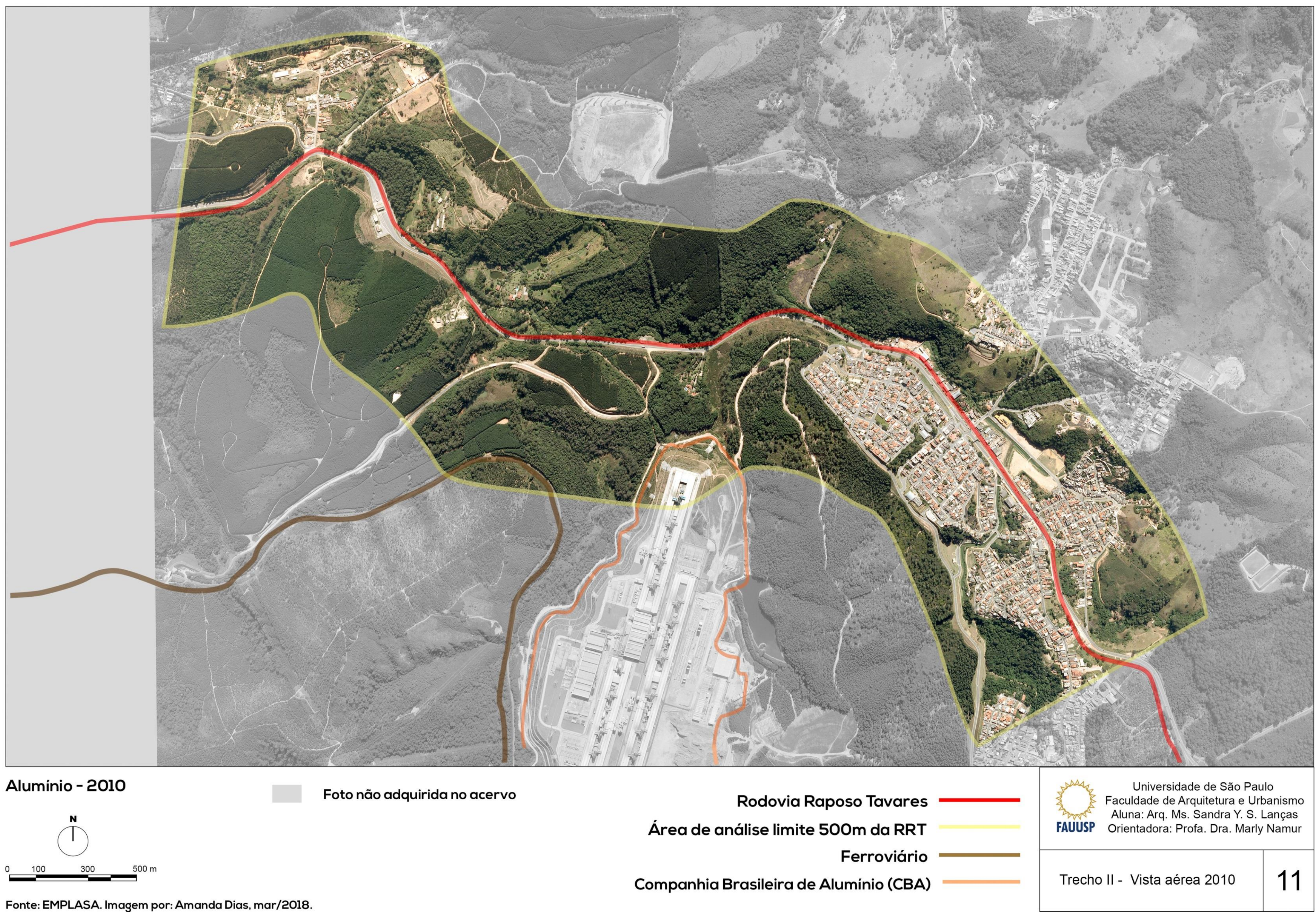




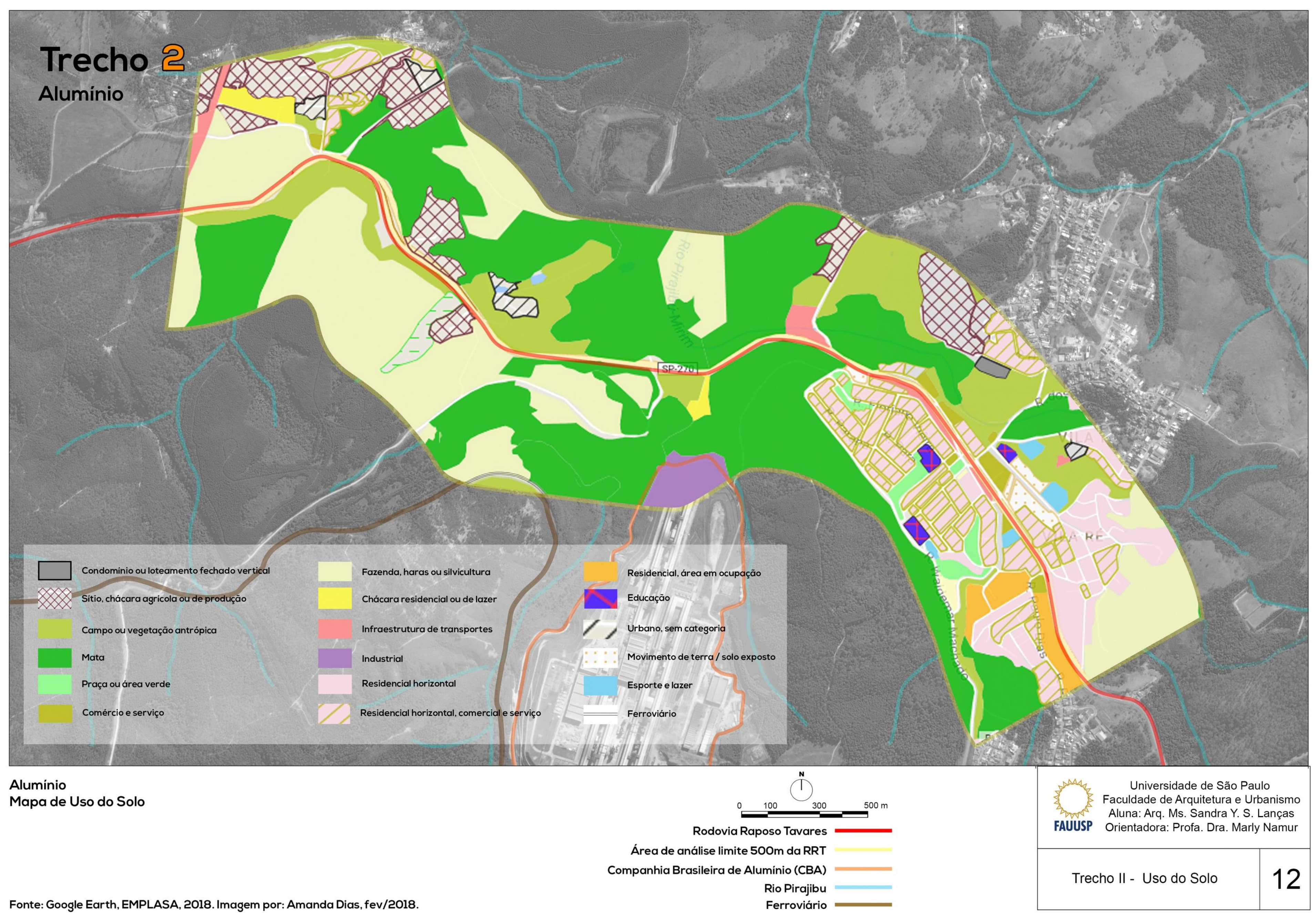




\section{CAP. VII - URBANIZAÇÃO X LEGISLAÇÃO}

\section{Zoneamento do Trecho 3 - Brig. Tobias:}

RRT do km 88-92 


\section{CAP. VII - URBANIZAÇÃO X LEGISLAÇÃO Zoneamento do Trecho 3 - Brig. Tobias: RRT do km 88-92}

O terceiro trecho analisado da RRT adentra o território municipal de Sorocaba, SP, precisamente pelo distrito de Brigadeiro Tobias, um dos distritos da zona leste de Sorocaba, cortado pela Rod. Raposo Tavares entre os km 88 a 92 (Fig. 81).

Figura 81 - Vista aérea de Brigadeiro Tobias em direção a leste da RRT (km 88).

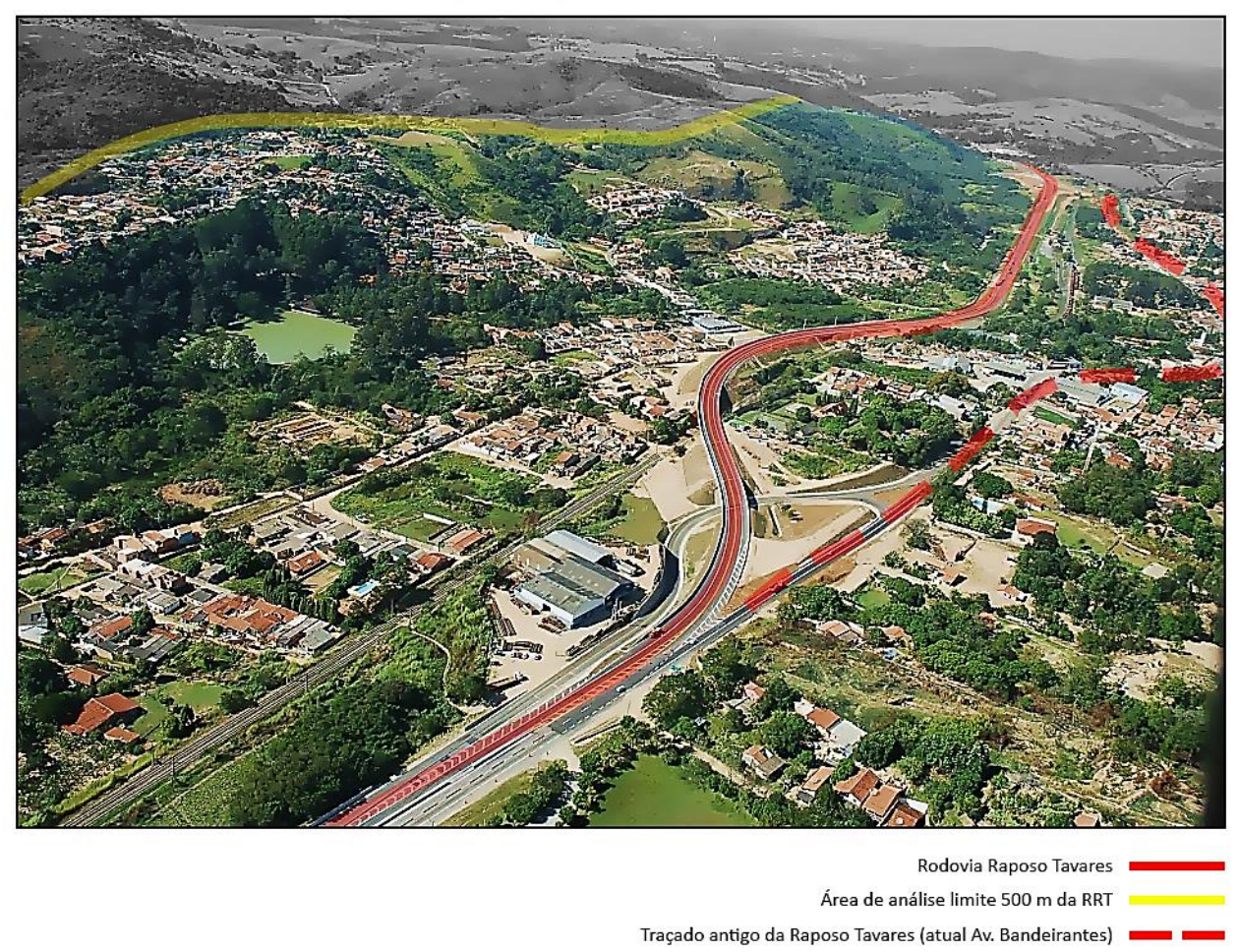

Fonte: CAMPOS; GALVÃO; PRADO; CERRONE; ANDREOLI, 2014. Retrabalhado por Amanda Dias, 2018.

\subsection{Breve histórico do Distrito de Brigadeiro Tobias, Sorocaba, SP}

O distrito é originário da ocupação da área pelo Capitão Antônio Francisco de Aguiar, que no séc. XVIII a utilizava para o plantio de trigo, na Fazenda Passa Três, pois havia água em abundância, devido às nascentes proporcionadas pela topografia local28 (MANFREDINI; GUANDIQUE; ROSA, 2015, p.69).

${ }^{28}$ Lá está também o ponto mais alto da região de Sorocaba, com 1029m (fator de localização na paisagem do séc.

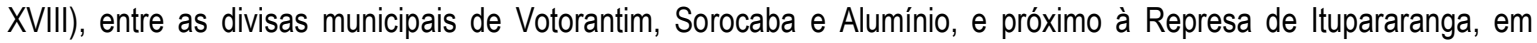
Votorantim, no alto da Serra de São Francisco, construída pela Light \& Co. em 1911 e inaugurada em 1914. Atualmente, é a principal reserva hídrica da população da RMS. 
A ocupação urbana de Brig. Tobias originou-se com a construção, em 1780, da casa sede da fazenda Passa Três. Esta fazenda foi propriedade da família de Raphael Tobias de Aguiar (17941857), o Brigadeiro Tobias ${ }^{29}$, que por sua importância histórica e política foi homenageado, nomeando o local quando este tornou-se distrito pelo Decreto-lei Estadual n. ${ }^{\circ} 6.770$, de 12-10-1934, que criou o distrito de Brigadeiro Tobias e o anexou ao Município de Sorocaba ${ }^{30}$ (IBGE, 2017). Hoje conhecido como o Casarão do Brigadeiro, está a algumas centenas de metros da antiga estação ferroviária Passa-Três (atual Brig. Tobias) e do antigo caminho Via Bandeirantes, que originou a RRT (RIBEIRO, 2006, p. 121), atualmente no trecho km 88 da Rod. Raposo Tavares.

A plantação de trigo da mencionada fazenda não vingou, devido ao clima; também não vingou na região a cultura do café; devido ao tipo de solo (propenso a voçorocas). 0 fato de Sorocaba e região, em relação às outras regiões paulistas com culturas de café e cana-de-açúcar, tido menor desenvolvimento econômico devido ao seu tipo de solo, fez com que se procurassem outras alternativas para as atividades econômicas após o término do ciclo do tropeirismo do séc. XVIII e XIX (com plantações de algodão, industrialização incipiente no início do séc. XIX) (STRAFORINI, 2001; RIBEIRO, 2006).

Devido à guerra da secessão dos EUA, o algodão sorocabano teve breve espaço na economia paulista. A indústria sorocabana era incipiente ao final do séc. $\mathrm{XIX}$, mas havia capital suficiente para a implantação de um ramal ferroviário (antiga Estrada de Ferro Sorocabana) por Matheus Maylaski31 e Roberto Dias Baptista, entre Sorocaba e São Paulo, no período de 1872 a 1875. Em gleba cedida gratuitamente pelos proprietários da então Fazenda Passa-Três, entre 1879 e 1899 foi implantada uma estação da Estrada de Ferro Sorocabana.

Com o advento de sua estação no ramal ferroviário sorocabano, no final do séc. XIX, de localização da Casa-Sede da Fazenda Passa-Três, o local passa a ser a paragem de uma estação ferroviária (antes nomeada Passa-Três, atual Brigadeiro Tobias).

A Estrada de Ferro Sorocabana e a Estrada de Rodagem BR 34 (antes Via Bandeirante, depois São Paulo - Ourinhos), (atual SP 270) cruzavam-se exatamente em Brigadeiro Tobias (Fig. 82).

\footnotetext{
29 Político e militar brasileiro paulista. Conhecido como "Brigadeiro Tobias de Aguiar", foi um dos chefes da Revolução Liberal de 1842, em São Paulo. Fundou a Polícia Militar do Estado de São Paulo, foi o último marido da Marquesa de Santos.

30 In: https://cidades.ibge.gov.br/painel/historico.php?codmun=355220, acesso em nov/2017.

${ }^{31}$ Luiz Matheus Maylasky, Visconde de Sapucaí (1938-1906). Viveu em Sorocaba, e, por volta de 1869, (época da 'febre do ouro branco') a cidade era conhecida como 'A capital do algodão'. Roberto D. Baptista, industrial de Sorocaba e M. Maylaski inauguraram em 24 de maio de 1871 a Companhia da Estrada de Ferro, que se chamaria mais tarde Estrada de Ferro Sorocabana.
} 
Em área considerada rural, a ocupação da gleba no entorno da estação de Brig. Tobias, cresceu nas áreas lindeiras à estrada de rodagem da época, que ligava a população da vila ao centro principal de Sorocaba, e à São Paulo.

Figura 82 - Mapa da região de Sorocaba em 1960.

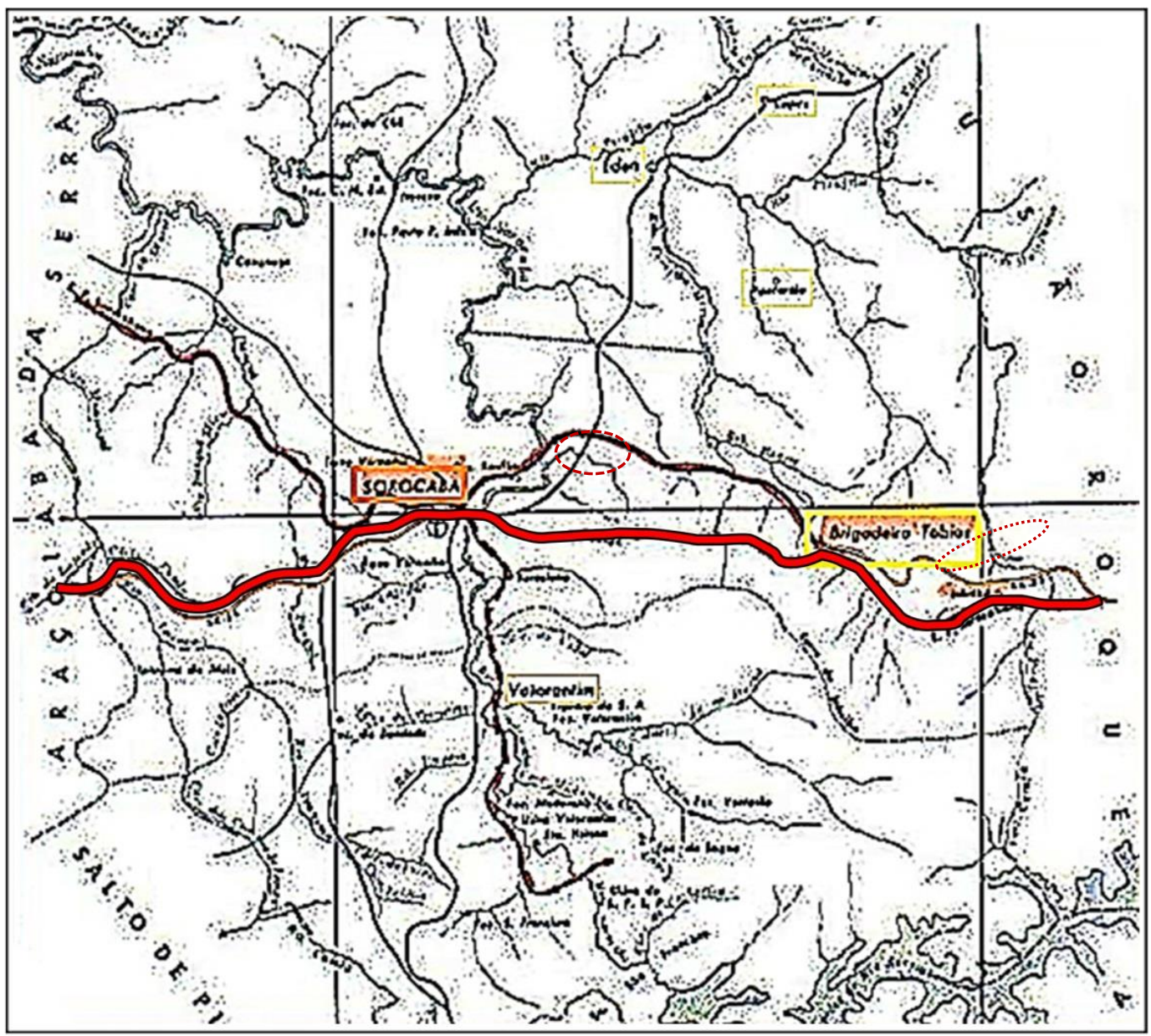

BR 34 - Trajeto original da Rodovia Raposo Tavares

Fonte: Ralph Mennucci Giesbrecht. Disponivel em: http://www.estacoesferroviarias.com.br/s/mapas/sorocaba.jpg, acesso em out/2017. Retrabalhado por Amanda Dias, 2018.

Pelo Decreto-lei n. ${ }^{\circ} 6.770$, de 12-10-1934, o Distrito da Paz de Brigadeiro Tobias ${ }^{32}$ foi criado e anexado ao Município de Sorocaba. Foi instalado também um posto policial, pelo decreto municipal de Sorocaba no. 6.823, de 30 de novembro de 1934, com a jurisdição do novo posto:

"Começam no alto da Bôa Vista (encruzilhada da estrada de rodagem Sorocaba Itu) na estrada da Apparecida, dahi até a Agua de Nhô Tigo descendo por essa até encontrar as divisas de Itu' destas até as divisas da São Roque e destas até as divisas do districto de paz de Votorantim" (ALESP, 1934).

32 In: https://www.al.sp.gov.br/repositorio/legislacao/decreto/1934/decreto-6770-12.10.1934.html, acesso em set/2017. 
Figura 83 - Um dia na história - 06/06/1953: 24 ônibus diários para São Paulo.

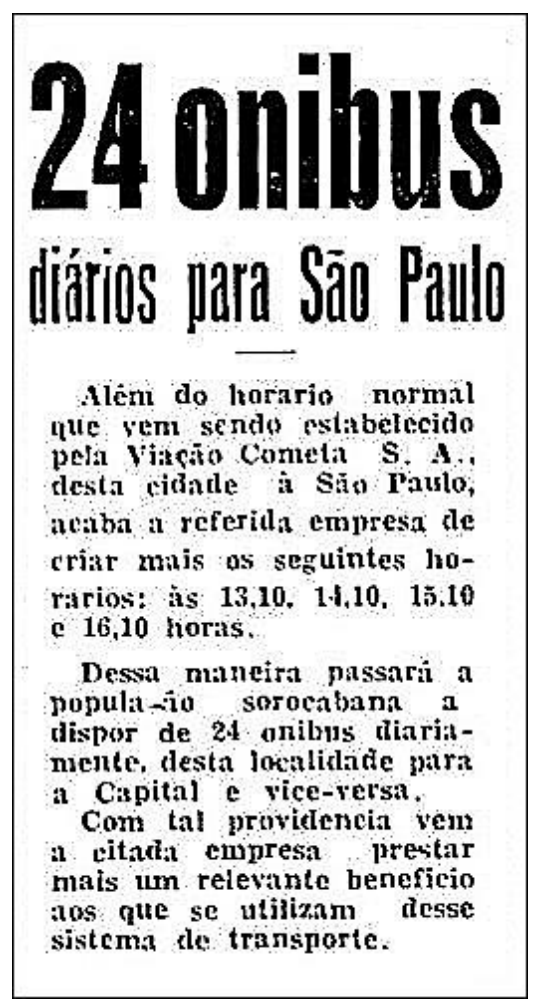

Disponivel em: http://www.jornalcruzeiro.com.br/materia/793491/um-dia-na-historia\#, acesso em 31out2017.

A partir do final do séc. XX, a ferrovia como modal de transporte entra em processo de decadência, e a prevalência é da rodovia e dos veículos automotivos. Em 1993, ocorreu a desativação de serviços para passageiros da ferrovia então chamada de Ferrovia Paulista S.A. (FEPASA) do ramal sorocabano; e algum tempo depois a estação ferroviária de Brigadeiro Tobias foi ocupada por famílias que estão lá até atualmente.

\section{Modificação do traçado da RRT em trecho urbano de Brig. Tobias}

A maioria das decisões políticas acerca das obras públicas não são tomadas apenas devido às demandas técnicas, mas também considerando as demandas da população; dependendo do clamor e do momento político, embora para a resolução de problemas é necessária também a chamada vontade política, suplementada pelos devidos recursos financeiros.

Exemplo disto foi a execução do novo contorno da RRT no trecho urbano de Brig. Tobias: levou cerca de cinquenta anos para ser atendida; da inauguração do asfaltamento do trecho analisado da RRT em 1954 até que o governo estadual paulista iniciasse os projetos do novo contorno e acessos da RRT em Brigadeiro Tobias (2003) (Fig. 84). 
Figura 84 - DER define projeto do contorno de Brigadeiro Tobias na RRT.

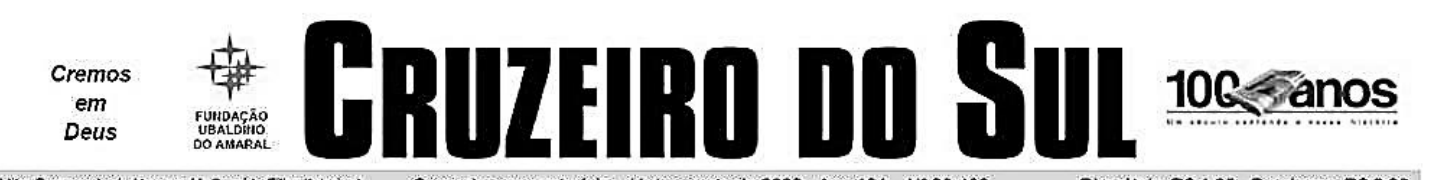

Edilor Responsável - Homero M. Querido Faho (Interino) Sorocaba, segunda-feira, 11 de agosto de 2003 - Ano 101 - № 29.486 Dias úteis: R\$ 1,20 - Domingos: R\$2,30 EnMÇĀO CONCLUIDA ÄS $23 \mathrm{~h} 15$

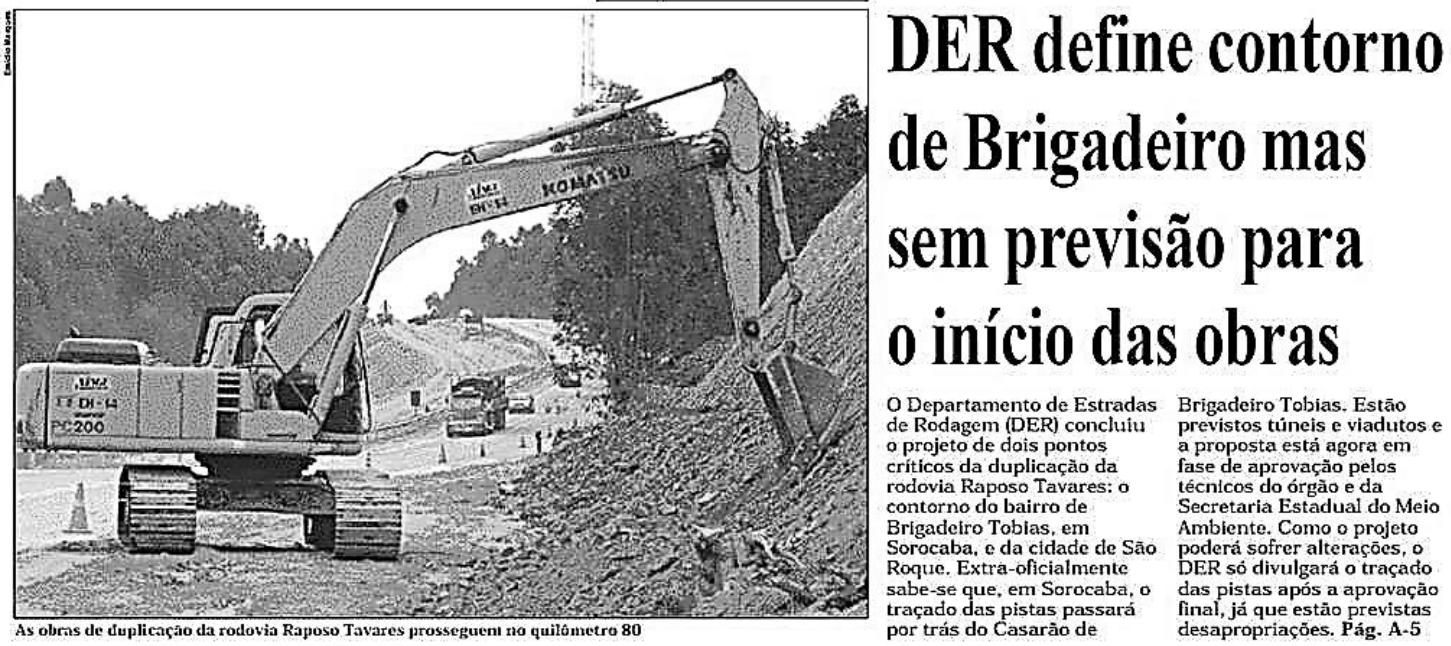

Disponivel em: http://www.jornalcruzeiro.com.br/materia/793491/um-dia-na-historia\#, acesso em 31out2017.

Pelo decreto no. 50.505, de 15 de fevereiro de 2006, o governo do Estado de São Paulo fez as desapropriações necessárias para o novo traçado da RRT no local:

"Declara de utilidade pública, para fins de desapropriação pela Concessionária de Rodovias do Oeste de São Paulo - VIAOESTE S.A., imóveis necessários à implantação do Contorno de Brigadeiro Tobias entre os km87+000m ao km89+750m da Rodovia Raposo Tavares - SP-270, situados no Município e Comarca de Sorocaba no trecho que especifica e dá providências correlatas." (ALESP, 2006).

$\mathrm{Na}$ figura a seguir, o distrito de Brigadeiro Tobias e seus principais caminhos com o novo traçado, inaugurado em 2007: a linha vermelha é a representação da Av. Bandeirantes (antigo traçado da RRT; em amarelo, o novo trajeto da RRT).

No núcleo da elipse em marrom, a localização da Casa de Brigadeiro Tobias, patrimônio histórico que não tem atualmente acessibilidade direta pela RRT, e estando isolada, dificulta-se sua visitação; por conseguinte, a manutenção do casarão, patrimônio público e histórico. 
Figura 85 - Mapa de Brigadeiro Tobias com o novo contorno RRT a partir de 2007; (antigo traçado RRT: av. Bandeirantes), arruamento e principais nascentes e cursos de água.

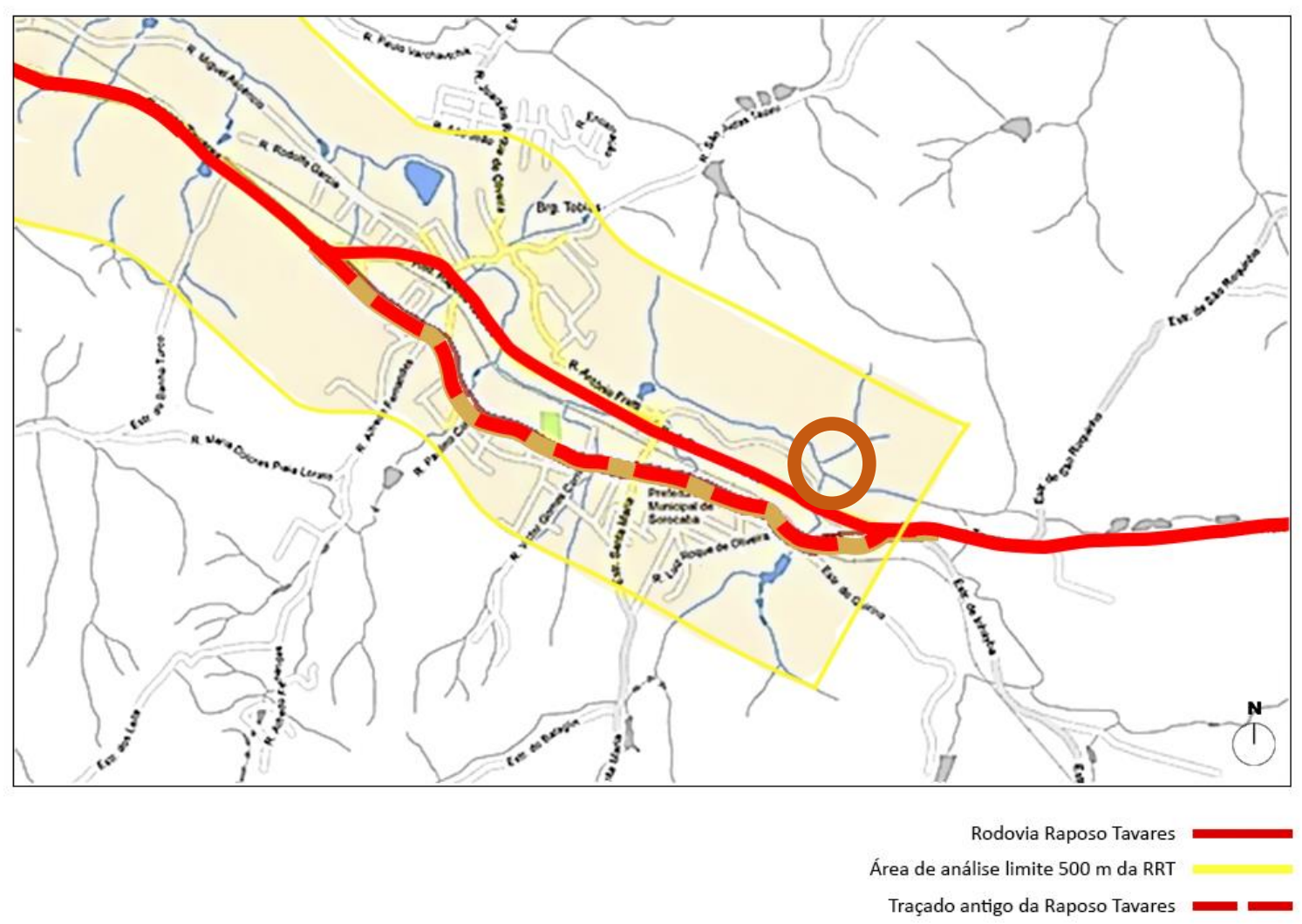

Fonte: Google Maps. Retrabalhado por Amanda Dias, 2018.

\subsection{Legislação urbana no Trecho 3 (1950-2014)}

Para efeito de análise, as primeiras leis consideradas para este trecho são as leis do PD de no. 162/1950, e a lei do PD no. 1438/1966. A lei de zoneamento municipal de Sorocaba no. $1541 / 1968$, correlata às outras duas leis mencionadas, também é analisada pois complementa as leis municipais no. 1437/1966 (lei do Código de Obras) e no. 1438/1966 (Lei do Plano Diretor do Município de Sorocaba, SP) para tentar melhor contextualizar o zoneamento municipal e a ocupação urbana no trecho estudado até 2004, data em que é promulgado um novo plano diretor para o município do trecho em questão.

A Lei municipal no. 162/1950, não estabelecia zoneamento específico para o trecho aqui estudado; os parâmetros válidos seriam os do Zoneamento Rural, conforme estabelecidos na Seção VII, na Zona Rural ou Agrícola (área fora dos perímetros urbanos e suburbanos municipais da época). Por este zoneamento rural, a taxa de ocupação máxima era de 0,60 da área do terreno; a testada mínima do lote seria de quinze metros e a área mínima do lote de quatrocentos metros quadrados; o recuo mínimo da edificação seria de três metros ao máximo de quinze metros do 
logradouro; o afastamento mínimo em relação a cada uma das divisas laterais do lote, não deverá ser inferior a dois metros; os limites das propriedades rurais poderia ser feitos de gradis ou cercas vivas (sem espinhos) se as edificações estivessem afastadas do alinhamento da via, não sendo exigida a construção de passeios públicos na Zona Rural.

Por estas leis, no trecho estudado se um proprietário rural quisesse realizar a construção de via de acesso ou internamente à sua propriedade, conforme o artigo 510 da referida lei, a liberação da licença da obra pelo poder público seria condicionada à execução pelo interessado, sem ônus para a Prefeitura, de todas as obras de terraplanagem: meios fios, pavimentação, pontes, pontilhões, bueiros, galerias, muralhas etc. que fossem necessárias; e sobre a drenagem pluvial, era a juízo da Prefeitura a solicitação da execução do necessário aos proprietários rurais, o que era de bom senso para as contas municipais, não sendo onerada pelo interesse privado; e quanto às habitações do tipo econômico só podiam ser construídas nas zonas suburbanas ou na Zona Rural.

A lei municipal 162/50 denota a preocupação da legislação municipal com relação não ao só do uso do solo para a função agrícola; mas do uso do solo quanto à questão das edificações, uma vez que a zona rural era utilizada para locação de inúmeros usos não possibilitados à área urbana principal (de usos comercial e residencial); permitindo a construção de edifícios destinados as indústrias pesadas, depósitos e inflamáveis e explosivos, comércio, depósitos, hospitais, casas de saúde, estabelecimentos de ensino e esportivo, hangares, estúdios, e similares), e também as habitações construídas de madeira e habitações populares. Estas, inclusive, recebiam planta gratuita fornecida segundo a lei, pelo Diretoria de Obras municipal, com no mínimo de três cômodos (sala de jantar, quarto e cozinha, além das dependências sanitárias), e estabelecia multas de diversos tipos para minimizar a ocupação irregular.

Com o crescimento da população do núcleo urbano no trecho estudado, pela Lei municipal no. 1071, de 26 de março de 1963, foram oficializadas as seguintes vias públicas (ruas) do distrito de Brig. Tobias: 1) José Sarti, 2) Alfredo Fernandes, 3) Avenida Bandeirantes, 4) Antônio Moreira (da Silva); 5) Bernardino de Camargo Reis, 6) Júlio de Mesquita, 7) Marquês de Herval, 8) Mathias de Albuquerque, 9) Padre Paiva, 10) Prof. Pereira de Vasconcellos, 11) Rodolfo Garcia e 12) Rodrigues de Abreu (CMS, 1963). A lei mencionada oficializa a Av. Bandeirantes, no trecho estudado a principal via do núcleo urbano, situado no lado sul da estação ferroviária, e algumas ruas também do lado esquerdo da RRT, com exceção da rua Rodolfo Garcia, que está do lado direito da linha férrea e do córrego que margeia a linha férrea (Fig. 86).

A lei municipal no 1417, de 30/06/1966, embora não fosse uma nova lei de Plano diretor para Sorocaba, aprovou o Código de Arruamento e Loteamento, para ser aplicada junto às próximas mencionadas, determinando o uso de termos relativos a questão do tamanho mínimo de glebas 
(mínimo de 1000m2), lotes urbanos (até 1000m2), lotes industriais (mínimo de 2000m2), nomenclatura dos loteamentos, tamanho de vias, classificações, etc: $\mathrm{Na}$ prática, aprova um disciplinamento para os loteamentos, tanto urbanos quanto industriais, e também especifica os tamanhos dos arruamentos.

Pela primeira vez aparece menção às vias laterais à ferrovia e rodovias de $1^{\text {a }}$ categoria, estipulando largura mínima para estas vias públicas, bem como distância mínima das vias públicas aos cursos d'água principais (Rio Sorocaba e demais rios e córregos municipais, uma novidade para a década de 60, provavelmente devido ao início da popularização do uso de veículos automotivos no Estado de São Paulo e na região de Sorocaba, resultado da interiorização da atividade industrial e desenvolvimento econômico do interior paulista. 
Figura 86 - Mapa de Brigadeiro Tobias e principais ruas em 1963. (Lei municipal no. 1071/63).

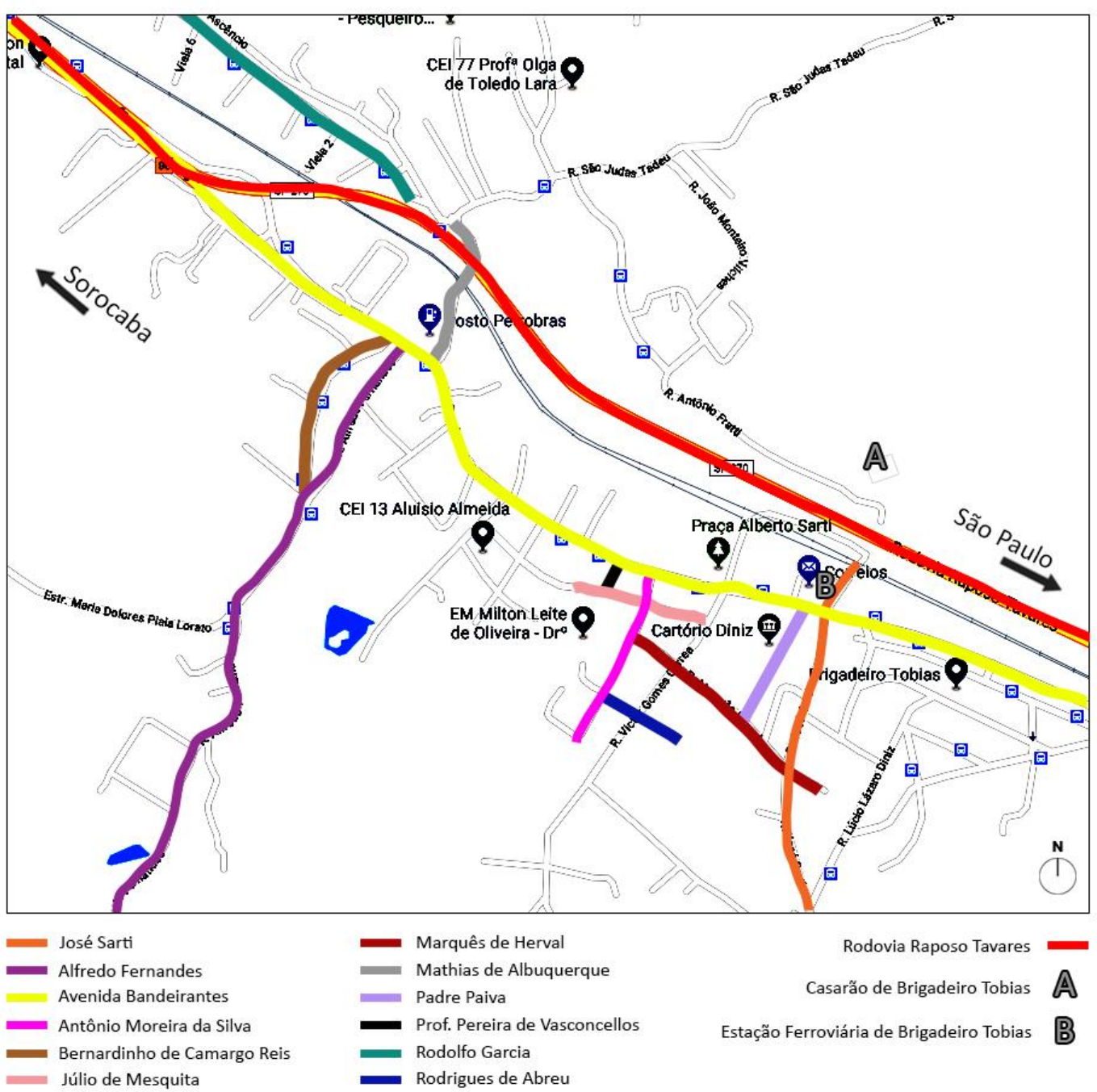

Fonte: CMS, 1963 e Google Maps. Retrabalhado por Amanda Dias, 2018.

A próxima lei referente ao trecho aqui estudado é a Lei municipal no. 1438/66, uma nova lei do Plano Diretor do Município de Sorocaba, lançada concomitantemente ao Código de Obras municipal (Lei 1437/1966), que manteve a divisão do território municipal em dois tipos de áreas: urbana e rural; mas aumentava a área urbana para 6.565.962 hectares, pela expansão do perímetro urbano. $O$ trecho em estudo nesta época está com sua parte do lado sul da RRT fora da zona urbana e suburbana, permanecendo como Zona Rural, seguindo a lei de então. A parte do trecho do lado norte da RRT passa para a zona residencial 3 (ZR3). O trecho do lado sul permanece na Zona rural, fora do perímetro urbano. Entre 1961 e 1966, a administração municipal elaborou ${ }^{33} 01^{\circ}$ Plano Diretor Municipal, instituído pela Lei Municipal $n^{\circ}$ 1.438/66. "Tratava-se naquela oportunidade de fixação de diretrizes gerais para os assuntos relacionados com a ordenação territorial do município,

\footnotetext{
${ }^{33}$ Este plano foi resultado de um plano piloto, apresentado em 06/05/1963, com a participação não identificada de um urbanista, pois não consta o seu nome; mas provavelmente um profissional da Universidade Mackenzie, pelas referencias encontradas.
} 
objetivando especialmente a solução dos problemas urbanos, servindo o Plano Pilôto de base para a execução do Plano Diretor." (SANTORO, P. F.; CYMBALISTA, R.; NAKASHIMA, R., 2009).

As anotações da lei municipal 1438/66 que interessam ao trecho estudado, por esta lei dividia a RRT ao meio em duas partes, que consideraremos ao norte da RRT e lado sul. A seguir algumas anotações desta lei sobre a Zona Rural:

"TAMANHOS MÍNIMOS DE LOTES PARA AS ÁREAS RURAL E URBANA: Lote rural - $2.000 \mathrm{~m}^{2}$ (dois mil metros quadrados). Lote urbano - $250 \mathrm{~m}^{2}$ (duzentos e cinqüenta metros quadrados). Os lotes não poderão ser subdivididos. As demais exigências sôbre loteamento, continuarão a obedecer o disposto na lei n. 1.561-A (Código Sanitário do Estado de São Paulo), e outros dispositivos legais federais, estaduais e municipais, existentes ou que venham regular o assunto no futuro. As zonas só poderão ser utilizadas para o fim a que se destinam de acôrdo com êste relatório. (...)

A estruturação viária regional, compreendendo a estrada do Oeste ${ }^{34}$, que atravessa boa parte do território municipal, o acesso, o nôvo ramal de E.F.S. de ligação Sorocaba-Itu já locado, o Ramal de Brigadeiro Tobias, em locação, a nova estrada de Pôrto Feliz, e a perimetral rodoviária, se realizada integralmente proporcionará excelentes condições de integração das áreas de vocação industrial, dadas as ótimas características físicas e topográficas do terreno. (...)

O Plano Diretor prevê para a implantação industrial na região de Sorocaba, uma faixa ao longo das rodovias e ferrovias programadas de aproximadamente $1 \mathrm{k}$ e $500 \mathrm{~m}$ respectivamente para cada lado. (...)" (CMS, 1966).

Percebe-se por este novo Plano Diretor municipal que a legislação urbana para 0 ordenamento do uso e ocupação do território municipal foi pensada em termos da implantação da futura rod. Castelo Branco, dentro de uma estruturação viária regional, inclusive considerando-se 0 ramal ferroviário de Brigadeiro Tobias dentro do contexto do planejamento urbano de então.

Enquanto a lei aprovada em 1950 ponderava sobre o policiamento quanto às instalações de edificações de usos não conformes para a zona urbana, determinando-as à zona rural, nesta lei inclusive previa-se a utilização da faixa de um quilometro e meio de cada lado, e ao longo das ferrovias e rodovias para favorecer a implantação das esperadas indústrias que viriam devido a nova rodovia Castelo Branco, o que realmente acabou acontecendo para a parte norte do território municipal, (perpassada em boa parte pela então nova rodovia), mas não em quantidade esperada no trecho estudado de Brigadeiro Tobias, embora nele já estivessem instaladas as condições de utilização da estação ferroviária para os grupos de mineração (Grupo Votorantim, Minercal, préexistentes). Também as condições topográficas eram menos favoráveis neste trecho à implantação de novas unidades fabris, que precisariam receber e escoar os insumos e produtos, e as estradas existentes de difícil circulação em tempos chuvosos; as condições eram mais favoráveis nas estradas próximas à Rod. Castelo Branco, localizadas à jusante dos muitos cursos d'água existentes no trecho de Brig. Tobias.

\footnotetext{
${ }^{34}$ N.A. Futura Rod. Castelo Branco (SP 280) inaugurada em 1967.
} 
A grande mudança na nova lei do PD de 1966 é a visão mais abrangente, já considerando 0 desenvolvimento econômico buscado, e a iniciativa da manutenção de áreas verdes para a população, pois este PD inclusive pensa no território municipal a preparação da expansão da área urbanizada, prevê um sistema de espaços livres e implantação de um Horto Florestal, no então limite da área urbanizada das zonas residenciais. Neste sentido, o relatório recomenda 0 aumenta 0 tamanho do lote mínimo estabelecido tanto para a zona rural, que passa de quatrocentos metros quadrados para dois mil metros quadrados; quanto para a zona urbana, que passa de cento e vinte metros quadrados para duzentos e cinquenta metros quadrados. A intervenção deste PD municipal prepara o trecho estudado (e outros espaços rurais a serem loteados) para a transição de zona rural para zona de expansão urbana.

Neste breve resumo do plano diretor municipal de Sorocaba de 1966, nota-se claramente 0 delineamento das políticas públicas urbanas municipais, que afetam a análise do trecho 3 Brig. Tobias da RRT: 1) o aumento de área urbana municipal, em detrimento da rural, e preparando-a para uma zona de expansão urbana; 2) a criação do sistema de zoneamento a partir do centro comercial: zona comercial principal, zonas comerciais 1 a 4; e zonas residenciais de tipos de 1 a 4 , com coeficientes mais permissivos à ZR1; 3) delimitação de áreas mínimas de maior tamanho dos lotes para as áreas rural (lote mínimo de dois mil metros quadrados de área) e urbana (lote mínimo de duzentos e cinquenta metros quadrados); 4) devido à implantação da rodovia Castelo Branco, também se determina uma zona industrial próxima a esta rodovia, na faixa de $2500 \mathrm{~m}$ ao longo dela; 5) $O$ quinto fator a se notar é o zoneamento proposto para as faixas lindeiras à ferrovia e às rodovias: "O Plano Diretor prevê para a implantação industrial na região de Sorocaba, uma faixa ao longo das rodovias e ferrovias programadas de aproximadamente $1 \mathrm{k}$ e $500 \mathrm{~m}$ respectivamente para cada lado" (CMS, Lei 1438/1966).

Complementando as leis do Código do Arruamento e Loteamentos (LEI No 1.417/1966), lei do Código de Obras municipal (lei no. 1437/1966) e a Lei do PD municipal (Lei 1438/1966), a Lei municipal sorocabana no 1.541, de 23 de dezembro de 1968, "dispõe sobre o Código de Zoneamento, regulamentando os usos do solo e de todos os edifícios do Município de Sorocaba". A aplicação destas leis era atribuída ao órgão municipal encarregado do planejamento (CMS, 1968).

Pela primeira vez estabelece-se oficialmente o zoneamento municipal em Sorocaba no sentido stricto da palavra (com relação ao planejamento urbano e regional), ao se pensar um plano integrado de leis (código de arruamento e loteamentos, lei do plano diretor e código de obras e código de zoneamento), para determinar a cada área zoneada do município usos prioritários, permitidos e restrições pertinentes; fruto da preparação do município (iniciado com o grupo de conselheiros) para a nova era industrial e de desenvolvimento econômico que se delineia com a 
abertura e asfaltamento da grande Estrada do Oeste (futura RCB), e o escritório técnico implantado para fazer frente a questão do planejamento do uso e ocupação do solo criado pela já mencionada Lei municipal no. 837/1961 (no Capitulo III - Zoneamento municipal de Sorocaba).

A diferenciação das treze zonas municipais foi complementada pelo estabelecimento dos índices de aproveitamento, taxa de ocupação, coeficiente de aproveitamento bem aos tamanhos mínimos dos lotes em área rural (mínimo de $2.000 \mathrm{~m} 2$ ) e urbana (mínimo de $250 \mathrm{~m} 2$ ), e vários outros itens de planejamento urbano e regional. Conforme delimitação da área urbana na lei 1438/66, e do zoneamento da lei municipal no. 1541/1968, o trecho estudado tinha o zoneamento de Zona Agrícola (ZA):

A Zona Agrícola, onde se encontrava à época a parte sul à RRT do trecho estudado, poderia comportar, como podemos verificar na lei de zoneamento no. 1541/1968, uma extensa gama de atividades, relacionadas à: 1- Agricultura; 2- Pecuária; 3- Florestamento; 4- Pontos de atração turística e de recreio; 5- Patrimonial (próprios públicos); e 6- Industrial.

Esta lei de zoneamento municipal é específica e clara em seu propósito do ordenamento do uso e ocupação do solo municipal, prevendo os vários tipos de instalações que poderiam se estabelecer no município, para orientar a instalação de novas industrias, buscando 0 desenvolvimento econômico esperado pela instalação da RCB, com um detalhamento (segue classificação do IBGE da época) que não existia na lei do PD anterior de 1950, visto que a administração municipal preparou (montou uma comissão para o plano diretor municipal, e estabeleceu um escritório técnico para provê-la de informações, entre 1961 até 1968); um plano de uso e ocupação do território municipal para o advento da RCB, inaugurada em 1967, esperando o sucesso de um segundo período industrial sorocabano (LEI municipal de Sorocaba no. 1438/1966).

As edificações na Zona Agrícola, conforme o artigo 56 da lei 1541/68, deveriam obedecer ao Código de Obras da lei 1437/66; e o artigo 57 da mesma lei 1541/68 estabeleceu o recuo mínimo de frente de quinze metros das edificações na Zona Agrícola, aumentando a indicação do afastamento mínimo da lei anterior, que era de quatro metros em relação ao logradouro, mas desaparecem da nova lei os coeficientes ocupação máxima do terreno, de testada mínima, recuo lateral mínimo, tipo de fechamento do terreno, e a menção à necessidade de atendimento, com recurso próprio do proprietário da gleba, a necessidade de execução de obras de drenagem pluvial se demandada pelo poder público municipal.

O uso agrícola, pecuário, florestamento, pontos de atração turística, e de recreio, patrimonial, e próprios municipais são permitidos no trecho estudado; além destes, também é permitido o uso industrial pelas alterações mencionadas à zona agrícola pela lei 1541/68. 
Verifica-se, portanto que o zoneamento industrial nesta Zona Agrícola, é a mais permissiva possível no tocante às instalações industriais ${ }^{35}$ com "problemas", como por exemplo de possibilidades de ruídos, explosões, incêndios, etc descritos no artigo 58 da referida lei.

E por último, mas não menos importante, esta lei do zoneamento municipal inaugura no município a questão da aprovação "tardia" dos PD de Sorocaba pelos edis municipais no final do mês de dezembro; no caso da lei 1541, foi aprovada em 23 de dezembro de 1968, época em que normalmente ou as pessoas estão mais atarefadas com preparativos natalinos, viagens, etc., e tem pouca atenção às questões urbanas, fatores que permanecem relevantes até os dias de hoje.

O outro PD do Município de Sorocaba, aprovado pela Lei no 1.672/71, de 23/1281971, tem o objetivo de propor um desenvolvimento integrado para o município, nas instâncias do desenvolvimento 1) urbano; 2) social, e 3) econômico; e propõe em seu Artigo 2:

“(...) III - Instituir, em caráter permanente, dinâmico e flexível, o sistema municipal de planejamento integrado, com a criação de um órgão técnico de planejamento integrado do município, podendo, ainda, serem criados grupos de planejamento setorial, junto aos setores funcionais, sujeitos à orientação do órgão de planejamento integrado." (CMS, 1971).

Mas, na sua redação, manteve, as mesmas leis de regulação do uso do solo já mencionadas do período anterior: pelo Art. 3, inc. I, "b" da Lei 1672/71: "O uso do solo e de todos os edifícios do município, continua sendo regido pelas normas estabelecidas pela Lei $n^{0} 1.541$, de 23 de dezembro de 1968, que dispõe sôbre o Código de Zoneamento"; e pela alínea "d": "A ordenação territorial do desenvolvimento do município continua sendo regido pelas normas constantes da Lei $n^{0} 1.438$, de 21 de novembro de 1966, que aprovou o Plano Diretor do Município de Sorocaba , e "g) Continuam vigorando as normas estabelecidas na Lei $n^{0} 1.417$, de 30 de junho de 1966 e que aprovou o Código de Arruamento e Loteamento do Município".

Portanto, legalmente, sobre o zoneamento municipal, prevaleceram à época as leis municipais aprovadas na década de 60 . E elas serão seriamente modificadas para o trecho de Brigadeiro Tobias apenas no início do séc. XXI, como veremos mais à frente. Desta maneira, esta lei: "compatibilizou o adensamento versus a disponibilidade de serviços públicos e equipamentos sociais; e estimulou a concentração de atividades comerciais e de prestação de serviços; às atividades industriais, com propostas de acessibilidade, pela melhoria de acessos ferroviário e rodoviário." (SANTORO; CYMBALISTA; NAKASHIMA, 2009).

Em 1978 o escritório do Arq. Jorge Wilheim elaborou um PD Regional (1978) para a RA de Sorocaba (então com 59 municípios) que orientava a reserva de terras para a indústria

\footnotetext{
35 Já havia no início do século XX várias fábricas de tecelagem e outros gêneros na área urbana; apenas duas grandes fábricas (Votorantim e Santa Rosália) localizavam-se então na área suburbana (CESAR, 1914, p.43).
} 
(refletindo a retomada industrial do município devido à implantação da Rod. Castelo Branco, em 1964), e propunha também a implementação de áreas estritamente industriais ligadas ao transporte rodoviário; as vias marginais ao longo do Rio Sorocaba (só foi implantada mais tarde na marginal do lado esquerdo), e áreas estritamente residenciais, que não foi aprovado como lei municipal, ficando engavetado (PRESTES, 2001, p.263).

Depois, foi iniciada a elaboração de outro PD para adequar a legislação municipal de então à nova Constituição Federal de 1988, que resultou em um projeto de lei entregue à Câmara Municipal em 1991. Mas: "O PL ficou parado até 1995, quando foi feita uma revisão transformando-o no PL no 167/95, que se dedicava principalmente à ampliação dos corredores comerciais e de serviços e da ZR1, conhecido como a "Lei dos Corredores Comerciais" (Lei Municipal $\left.n^{0} 4.874 / 95\right)$ (SANTORO, 2009):

"Por outro lado, a área urbana de Sorocaba aumentou consideravelmente nos últimos 23 anos (entre 1988 e 2011), passando de 4.798,8 ha em 1988 para 12.928,8 ha em 2011 (...) Isso significa que atualmente a área urbana atual de Sorocaba equivale a aproximadamente $29 \%$ da área total do município. É importante destacar que Sorocaba tem uma taxa de crescimento populacional anual de $1,75 \%$. Esse índice é maior que a média do Estado que é de 1,09\% (Seade, 2012). Ainda, segundo a Secretaria do Meio Ambiente de Sorocaba (2010), em 1988 a população era de 344.261 habitantes e atualmente possui 596.060 habitantes." (PDTUM, 2014).

Junto ao então iniciado estudo para o novo plano diretor municipal de 1990 (que foi aprovado somente em 2004, após adequação inclusive ao Estatuto da Cidade, de 2001), o SAEE ${ }^{36}$ em 1994 encomendou um Plano Diretor de Abastecimento de Água do Município de Sorocaba pelo Contrato $N^{0}$ 018/SL/94, para efeito do planejamento estratégico em relação ao abastecimento de água no município com horizonte do ano de 2015.

Sobre a situação de abastecimento hídrico para a população do núcleo urbano naquela época (1995, ao termino do diagnóstico e projetos), havia para Brigadeiro Tobias o Centro de Distribuição no.16 com três áreas de reservação, alimentadas por poços semi-artesianos: 1) Vila Astúrias - 373m3 de água (av. Encarnação x rua Santa Helena, no lado direito da RRT em Brig. Tobias); 2) Vila Conceição - 50m3 (final da rua Olegário Gomes Correa) e 3) Jd. Novo Eldorado 40m3 (rua Miguel Sayego, já na confluência da Av. São Paulo com a variante da Rod. Raposo Tavares e da Rod. Celso Charuri (SP 91/270), interligação da Rod. Castelo Branco com a Rod. Raposo Tavares), no km 92 da RRT.

Pelo aumento da população do censo promovido por uma empresa contratada para determinar um plano diretor de abastecimento de água para Sorocaba percebe-se a crescente ocupação das margens lindeiras da rodovia. No seu diagnóstico já revisado, o PDAA de Sorocaba

\footnotetext{
${ }^{36}$ Autarquia municipal para questões de abastecimento de água e esgoto.
} 
continha as seguintes informações a respeito da ocupação urbana de Brigadeiro Tobias em meados da década de 90:

\begin{abstract}
"ZRM-BT - Zona Residencial Mista de Brigadeiro Tobias: área de uso predominantemente residencial de médio/baixo padrão, com lotes médios de $250 \mathrm{~m} 2$. Apresenta estabelecimentos comerciais destinados ao abastecimento local e extra local, pequenas indústrias e empresas prestadoras de serviços. Possui área total de 237,80 ha e média de 4,21 hab/dom.

ZE-BT - Zona de Expansão do Distrito de Brigadeiro Tobias: compreende a totalidade dos vazios urbanos existentes dentro da zona ZRM-BT; sua ocupação futura deverá obedecer aos padrões existentes nas áreas adjacentes quais sejam: baixo padrão, com lotes médios de cerca de $250 \mathrm{~m} 2$. Possui área total de 199,80 ha e média de 4,23 hab/dom." (SAAE, 2000).
\end{abstract}

Para Sorocaba e seus distritos, "Prevê-se, desta forma, para o horizonte de 2015 o total de 695.340 habitantes na área de projeto ${ }^{37 "}$ (OESP, 2000, p. 2.17). Neste plano de abastecimento hídrico para Sorocaba já estabelecia a importância das nascentes e cursos d'água de Brigadeiro Tobias, e foi baseado também no plano diretor municipal à época em fase de aprovação, que até 1990 visava a ocupação dos vazios urbanos no vale do Rio Sorocaba, próximo à área já urbanizada.

A Lei $n^{0} 7.122$ de 01/06/2004, Lei do Plano Diretor do Município de Sorocaba, SP, decorreu do projeto de lei no. 246/2002, de autoria do poder executivo local de 23-12-1971. Mais de trinta anos se passaram desde 0 início deste projeto de lei, e cerca de quatro décadas desde que 0 anúncio da abertura da Grande Estrada do Oeste (RCB) iniciou o processo de industrialização no interior paulista. A nova lei por muito tempo aguardada, e que incluía diretrizes ambientais e sociais emanadas do Estatuto da Cidade (Lei n o 10.257, de 10 de julho de 2001), instituiu o Plano Diretor de Desenvolvimento Físico Territorial do Município de Sorocaba: "definindo objetivos e diretrizes específicas para alcançar o objetivo geral, que é o pleno desenvolvimento das funções sociais da cidade e da propriedade imobiliária urbana." (CMS, 2004). "As funções sociais do ordenamento do desenvolvimento urbano da cidade" substituem no $2^{\circ}$ artigo "as funções sociais da cidade"; a "propriedade imobiliária urbana" continua sendo representada pelos "agentes econômicos instalados e atuantes no Município".

Pelo PD de 2004, a questão do zoneamento municipal no trecho estudado do (e nas demais áreas do território municipal, mas com ênfase no) distrito de Brigadeiro Tobias, passa pela primeira vez pela questão ambiental; (muito apropriada a este trecho), e enfatizada pelo macrozoneamento ambiental do território municipal, como instrumento fundamental de orientação à ocupação urbana. Por esta lei do plano diretor municipal, a definição das Macrozonas Ambientais ficou assim estabelecida para o trecho estudado no distrito de Brigadeiro Tobias.

\footnotetext{
${ }^{37}$ Para o Município de Sorocaba.
} 
A legislação urbana referente ao macrozoneamento ambiental segue a tendência legal da época de se indicar a prioridade da ocupação antrópica pela base fisiográfica específica do local, uma vez que a legislação ambiental no Brasil, e particularmente, no estado de São Paulo avançou, introduzindo na lei do plano diretor municipal a questão da sustentabilidade ambiental. Nesta lei especificamente, após quase quarenta anos de liberação de uma nova lei municipal sobre este assunto, é de se esperar avanços e adequações legais, principalmente devido ao aumento da população e da proporção da área urbanizada no território municipal.

Para ordenar a ocupação antrópica, é indicado no macrozoneamento ambiental as áreas mais adequadas para a ocupação urbana; e a necessidade de se preservar os mananciais, principalmente por questões estratégicas: a) abastecer a zona industrial e b) abastecer a população da zona norte de Sorocaba (área indicada neste PD de 2004 para a expansão da mancha urbana). A nova lei é um avanço neste tipo de questão (ocupação antrópica observando-se a base fisiográfica e relacionando-as às questões do desenvolvimento econômico industrial e populacional do Município de Sorocaba da época).

Por isto, estão especificamente citadas, por critérios de restrição à ocupação antrópica, e a justificativa da necessidade de menor ocupação no trecho de Brigadeiro Tobias: os motivos para este trecho estar incluído no artigo sexto, na categoria: "Macrozona com Grandes Restrições à Urbanização", pois incluem as: I - Várzeas ou Planícies Aluviais; II - Áreas de Proteção a Mananciais (...) do Tipo 2 que correspondem à porção da bacia do rio Pirajibu, à montante da bacia do Pirajibu-Mirim, considerada de interesse estratégico para futura utilização como manancial de captação de água para Sorocaba, conforme plano estabelecido pelo SAAE em 2000.

\section{A questão da legislação ambiental para o Macrozoneamento de Sorocaba no PD 2004}

Nos EUA, os livros Silent Spring, de Rachel Carson (1962), e Design with Nature (1969), de lan McHarg suscitaram a discussão sobre a importância do Meio Ambiente, e a compreensão pela geração do pós-guerra de que os processos produtivos da revolução industrial, depois de um século de aplicação em uma escala nunca antes vista - resultava em uma imensa intervenção sobre estes, promovendo a idéia de que os recursos naturais tinham finitude dependendo de seu tipo e utilização, causando muitas vezes resultados difíceis de serem mitigados. O Relatório Brundtland ${ }^{38}$ (ONU, 1987) divulgou globalmente o conceito do desenvolvimento sustentável 39 , com foco na crescente necessidade de se levar em conta a finitude de alguns recursos naturais, para que algo possa ser deixado às futuras gerações.

${ }^{38}$ Our Common Future. (ONU, Comissão Mundial sobre o Meio Ambiente e o Desenvolvimento, 1987).

$39 \mathrm{O}$ desenvolvimento que satisfaz as necessidades presentes, sem comprometer a capacidade das gerações futuras de suprir suas próprias necessidades (ONU, 1987). 
No Brasil, muitas das questões da nossa urbanização desde a metade do séc. XX estão ligadas à farta disponibilidade de terras rurais, tornadas urbanas por empreendimentos imobiliários. Além do preço da terra, outro fator de influência é a lei federal de APP's e a questão da beleza cênica de determinada paisagem, que normalmente também é ligada à disponibilidade de água por meio de nascentes, córregos, riachos, ribeirões, lagoas, etc; e mais preponderantemente, do acesso por rodovias, asfaltadas, ou estradas, de terra, cascalhada ou asfaltadas.

No caso do trecho estudado, Almeida cita especificamente em 1972:

\begin{abstract}
"A paisagem do município de Sorocaba continua muito linda no que tem de natural. A sua divisão entre campos de colinas e lombadas suaves e morros abruptos ou serras compridas, os seus horizontes largos cercados pelas serras de São Francisco, Inhaíba e Pirajibu de sudoeste e nordeste e marcados a oeste pelo Araçoiaba solitário nos campos, o seu rio encaichoeirado até a cachoeirinha, alguns capões de matos perdidos na distância, tudo isto é muito belo. De Itanguá em diante, depois das chuvas de verão, por entre o capim verde escuro, nas baixadas, uma lagoa azul e cristalina vos convida a um soneto". (ALMEIDA, A. História de Sorocaba, 1972 p. 4.113, apud MANFREDINI; GUAINDAQUE; ROSA, 2015, negrito nosso).
\end{abstract}

Com a alteração do traçado da RRT e a revisão do Plano Diretor Municipal em 2004, 0 zoneamento, antes agrícola ou rural, diminui no município cerca de quarenta por cento. $O$ distrito de Brigadeiro Tobias, já um núcleo urbano consolidado no início do século $X X$, recebe delimitação urbana e passa a ter três tipos de zoneamento: Zona de conservação ambiental (ZCA), Zona de chácara urbana $(\mathrm{ZCH})$ e zona residencial tipo ZR3. O aumento da ocupação urbana de maior densidade populacional de Brigadeiro Tobias, não era mais esperado pelo PD de abastecimento hídrico do SAAE de 2000, o que era contra-indicado pelo plano diretor de 2004, por este trecho estar em área de alta declividade, e com localização de tantas nascentes e cursos d'água.

Pelo macrozoneamento ambiental do PD 2004, Brigadeiro Tobias localiza-se em uma macrozona de grandes restrições à ocupação, devido a ter várzeas e planícies aluviais e mananciais à montante do Rio Pirajibu-Mirim, e a micro-bacia do Rio Pirajibu, principal afluente da margem do Rio Sorocaba. A partir do PD de Sorocaba 2004, o conceito de uma macrozoneamento ambiental foi aplicado corretamente a um plano diretor municipal. Antes disso, os planos diretores municipais eram sujeitos ao conhecimento e capacidade de persuasão dos indivíduos que tinham acesso à discussão e tomadas de decisão, um círculo de pessoas muito mais restrito do que agora, e de graus de especialização diferentes.

Outro fator positivo do então novo plano diretor foi a contratação de uma empresa especializada, intermediada pelo arquiteto A. C. R. Abibe ${ }^{40}$, sorocabano que fez sua especialização em Planning Studies (Developing Countries) pela University of Edinburgh (1980), na Escócia, terra

\footnotetext{
40 Depois mestrado e doutorado em Estruturas Ambientais Urbanas pela FAU-USP (1995).
} 
natal de lan McHarg e depois seu mestrado e doutorado pela FAU-USP. Abibe trouxe a empresa especializada Ambiente Urbano, para realização do novo PD de Sorocaba. A empresa implantou no novo PD a definição de Macrozonas Ambientais, ranqueada quanto à ocupação urbana pela capacidade das características naturais de suportá-la, o que foi uma medida acertada, pois parte-se de informações especificas da base fisiográfica. Percebe-se pela redação da lei do Macrozoneamento Ambiental do PD de 2004, a especificidade de cada setor de compartimentos estabelecidos, devido à influência da topografia com o vale do Rio Sorocaba, onde a população se instalou inicialmente e configura a parte mais urbanizada do território. Pela lei do macrozoneamento ambiental realizado para todo o Município de Sorocaba, a parte leste, devido à sua topografia e especificidades foi adequadamente protegida, e coerentemente com o PDAA elaborado pelo SAAE em 1994.

Isto está coerentemente de acordo com a base fisiográfica, e as determinações de preservação e conservação da área, suas nascentes e até de seu patrimônio histórico. Portanto na parte leste, (onde está a região analisada do Trecho 3 da RRT), esta região do município recebe um macrozoneamento classificado como Macrozona de Grandes Restrições à urbanização, devido à 'sua topografia, de altitudes mais elevadas (cerca de $1000 \mathrm{~m}$ ), pela quantidade de nascentes e cursos dágua, nas marcações da rede hídrica em formato dendrítico; e era considerada "área de reserva" para fins de planejamento urbano, pois estava previsto, segundo entrevistas feitas ao diretor do SAAE em 2007, Pedro Dal Pian, como uma área que não deveria ser ocupada, por sua fragilidade quanto às nascentes e suscetibilidade à erosão, cujas águas abastecem o Rio Pirajibu (maior afluente do lado direito do Rio Sorocaba).

A seguir, detalhes do trecho estudado no mapa das Macrozonas Ambientais do PD de 2004 de Sorocaba: este trecho estudado está na Macrozona Ambiental de grande restrição à urbanização (tipo I) e contém especificamente: I - Várzeas ou Planícies Aluviais, em amare, no mapa de macrozoneamento ambiental do PD especifico, e a Área de Proteção aos Mananciais do tipo "1a" e "2a" , pois estão relacionados, pelo tipo de relevo, solo e Rio Pirajibu estrategicamente ao abastecimento da região leste do município (em grande parte rural e industrial) e à região norte do município (área de expansão urbana do município, que atualmente é morada de aproximadamente 400.000 pessoas (dados estimativa 2015, segundo IBGE) (Fig. 87 e 88). 
Figura 87 - Mapa de Macrozoneamento Ambiental do PD de 2004, com a localização do trecho 3 de Brigadeiro Tobias.
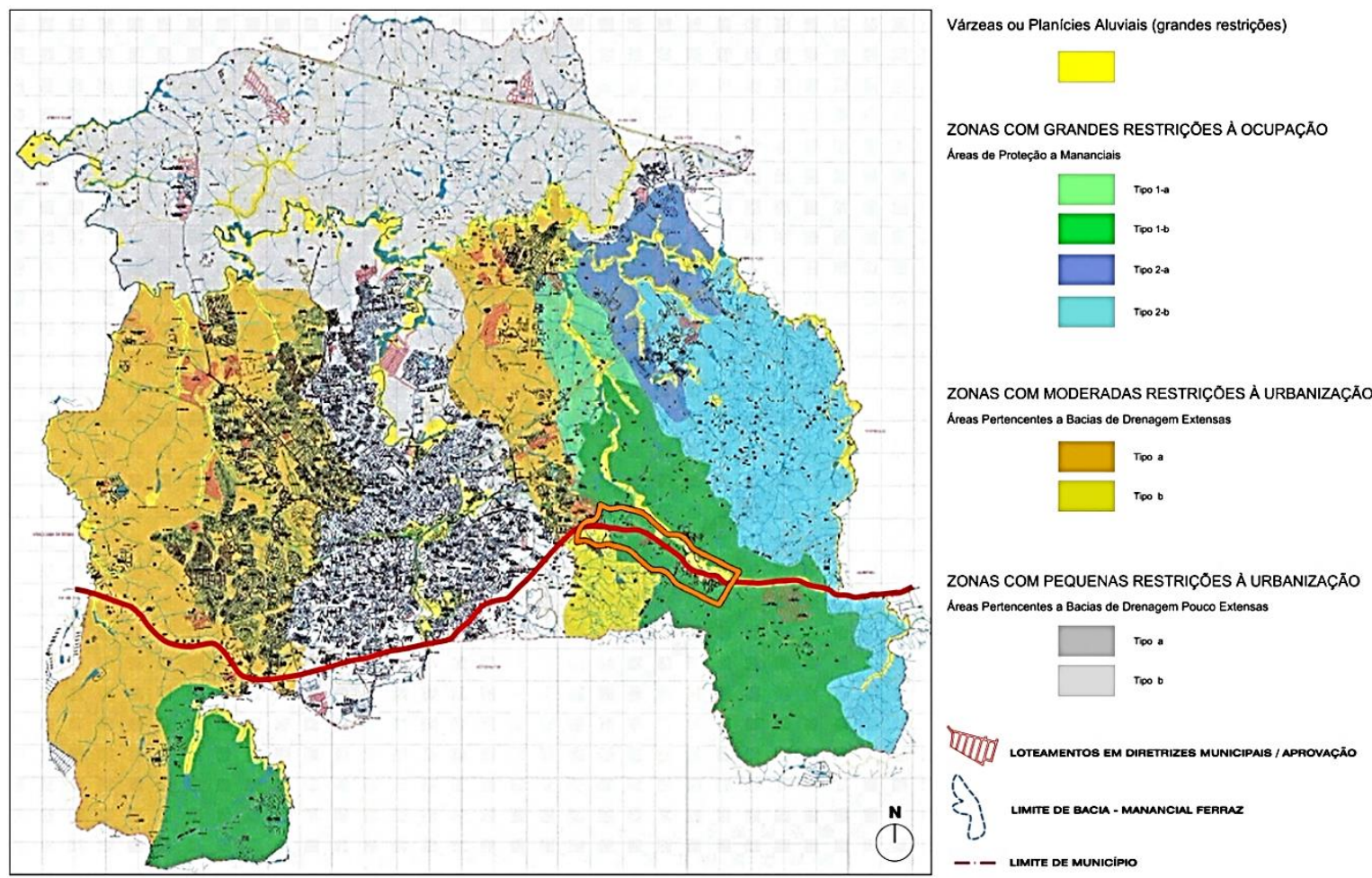

Rodovia Raposo Tavares _-

Trecho 3 - Brigadeiro Tobias

Fonte: PMS, 2017. Retrabalhado por Amanda Dias, 2018.

Figura 88 - Trecho RRT Brig. Tobias, detalhe do Mapa 01 de Macrozoneamento Ambiental do PD de Sorocaba - 2004.

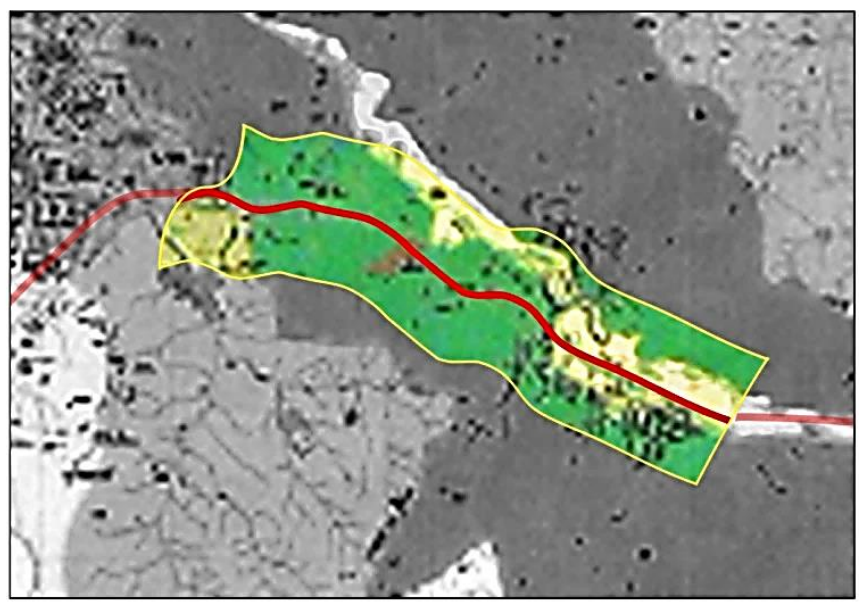

Várzeas ou Planícies Aluviais (grandes restrições)

ZONAS COM GRANDES RESTRIÇÕES À OCUPAÇÃO

Áreas de Proteção a Mananciais

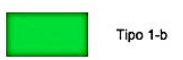

ZONAS COM MODERADAS RESTRIÇÕES À URBANIZAÇÃO

Áreas Pertencentes a Bacias de Drenagem Extensas

$\mathrm{N}^{\mathbf{N}}$

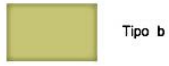

- Rodovia Raposo Tavares

— Área de análise limite 500m da RRT

Fonte: PMS, 2004. Retrabalhado por Amanda Dias, 2018.

No trecho 3 aqui estudados, seguem-se as considerações sobre a Área Rural (artigo 14), a Zona de Conservação Ambiental e Zona de Chácaras Urbanas (Artigo 15) na lei do PD de 2004, que ilustra com o Mapa 02 de Zoneamento Ambiental no trecho. E complementa a lei do zoneamento municipal no PD de 2004 com os seguintes parâmetros (listados a seguir para o trecho 3 estudado). Segue o mapa de zoneamento municipal do PD de 2004 com o trecho 3 (Fig. 89): 
Figura 89 - Mapa de Zoneamento Municipal do PD de 2004.
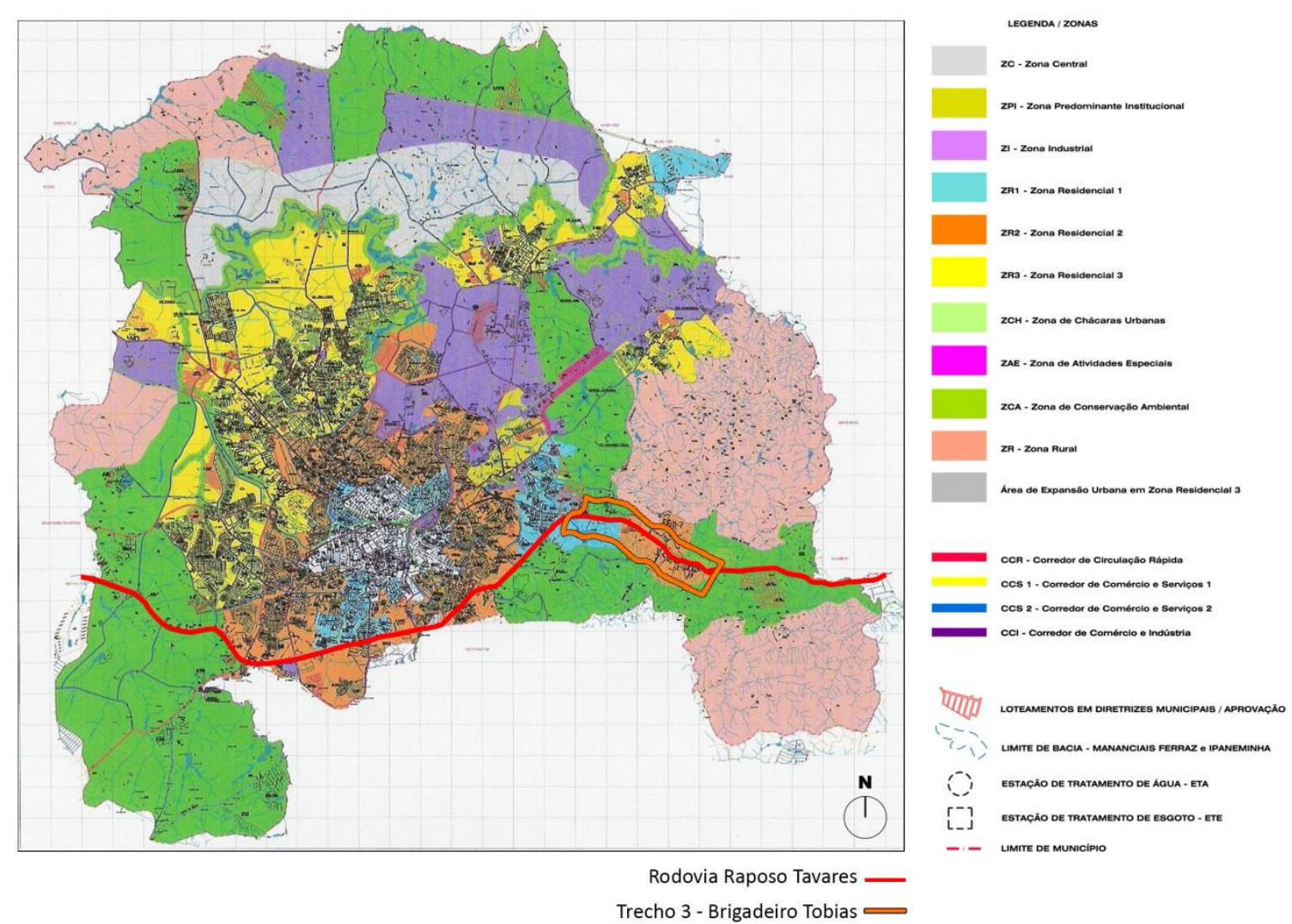

Fonte: PMS, 2017. Retrabalhado por Amanda Dias, 2018.

Figura 90 - Detalhe do trecho 3 no Mapa de Zoneamento Municipal do PD de 2004.
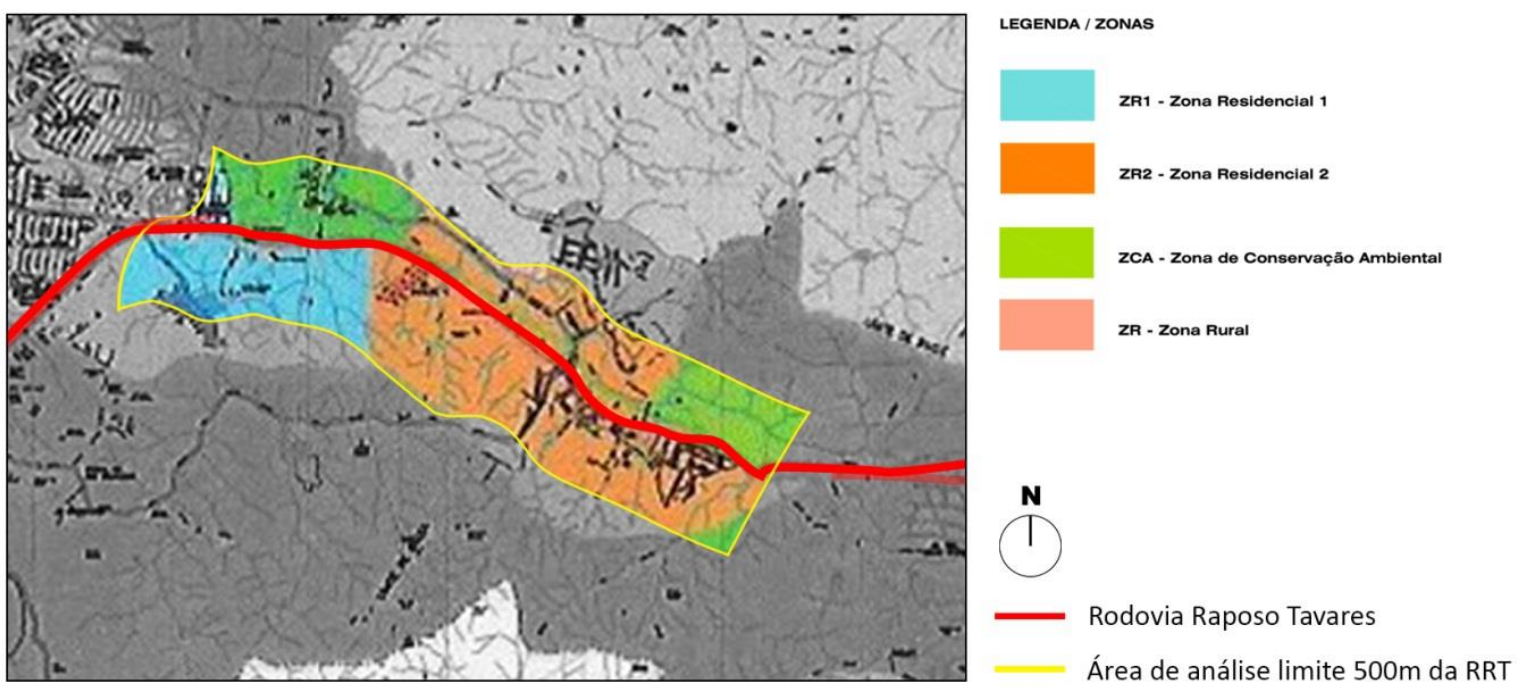

Fonte: PMS, 2017. Retrabalhado por Amanda Dias, 2018.

Segue a tabela de índices relativos ao zoneamento municipal do trecho 3 estudado no PD municipal de Sorocaba 2004: 
Tabela 18 - Tabela de índices relativos ao zoneamento municipal do Trecho 3 no PD de 2004.

\begin{tabular}{|c|c|c|}
\hline \multicolumn{3}{|l|}{ (Indices Trecho 3 - Brig. Tobias) } \\
\hline \multicolumn{3}{|c|}{ Tabela de Zoneamento municipal Anexo Lei 7122/2004 - } \\
\hline Zonas de uso & \multicolumn{2}{|l|}{ Usos admitidos } \\
\hline Área Rural & \multicolumn{2}{|l|}{ |RL, TL; UAl, EU } \\
\hline Zona de Conservação Ambiental - ZCA & \multicolumn{2}{|l|}{ |RL, RG, TL, EU } \\
\hline Zona de Chácaras - ZCH & \multicolumn{2}{|l|}{ |RL, RG, TL, EU } \\
\hline Zona Residencial 3 - ZR3 & \multicolumn{2}{|l|}{ |RL, RG, CSI, TL, EU } \\
\hline Zonas de uso & \multicolumn{2}{|c|}{ | To |Ca |Percentual mínimo de Permeabilidade (\%) } \\
\hline Área Rural & \multicolumn{2}{|c|}{ |Livre |Livre| $\quad 50 \%$} \\
\hline Zona de Conservação Ambiental - ZCA & \multicolumn{2}{|l|}{$|0,10| 0,3 \mid$} \\
\hline Zona de Chácaras - ZCH & $|0,35| 0,6 \mid$ & $50 \%$ \\
\hline \multirow[t]{2}{*}{ Zona Residencial 3 - ZR3 } & \multicolumn{2}{|c|}{$|0,70| 2,0 \mid 10 \% \mathrm{p} /$ terrenos com área inferior a $500,00 \mathrm{~m} 2 \mathrm{e}$} \\
\hline & \multicolumn{2}{|c|}{$20 \% \mathrm{p} /$ terrenos com área superior ou igual a $500,00 \mathrm{~m} 2$} \\
\hline \multicolumn{3}{|c|}{ DIMENSÕES MÍNIMAS DE LOTES POR ZONA DE USO } \\
\hline ZONA DE USO & \multicolumn{2}{|c|}{ | Área Mínima (m2) | Testada mínima (m) } \\
\hline Zona de Conservação Ambiental - ZCA & $10.000,00 \mid$ & 50,00 \\
\hline Zona de Chácaras - ZCH & $1.000,00 \mid$ & 15,00 \\
\hline Zona Residencial 3 - ZR3 & $150,00 \mid$ & 7,00 \\
\hline
\end{tabular}

Fonte: Câmara Municipal de Sorocaba, 2004. Organizado pela autora.

O novo PD de Sorocaba foi adequado pelo legislativo e executivo municipal para atender ao Estatuto da Cidade (2001) e neste sentido, além das questões ambientais, foram também colocados os instrumentos urbanísticos, derivados da lei do Estatuto, que serão colocados a seguir, na medida em que pudessem interessar sua aplicação ao trecho estudado e sua população em Brigadeiro Tobias (Operações Urbanas Consorciadas, Transferência do Direito de Construir, Áreas de Especial Interesse Social para Habitação, Transparência das informações, Direito de Preempção, Habitação de interesse social, Patrimônio cultural edificado e áreas de interesse paisagístico e ambiental.

A zona rural diminuiu neste PD de 2004, e no trecho foram estabelecidas 0 macrozoneamento ambiental de planície aluvial e de áreas com nascentes e corpos de água de bacias estratégicas para o abastecimento hídrico da zona industrial e da zona norte, além do estabelecimento da ZCA (zona de conservação ambiental) e ZCH, zona de chácaras, onde os lotes tem tratamento diferenciado, com a legislação exigindo, conforme a metragem da gleba, e dos lotes, sistema interno aos empreendimentos de tratamento de resíduos. Isto denota tratamento mais adequado e pormenorizado na legislação conforme a base fisiográfica e tentando limitar ao menos na lei, a ocupação nas áreas mais íngremes. Mas não foi inserido no plano diretor nenhuma 
indicação para utilização dos instrumentos urbanísticos (OUC, TDC, direito de preempção, HIS, AEIS), tão necessários à população do trecho de Brigadeiro Tobias.

E infelizmente, mesmo com vários cidadãos morando em áreas de risco, não houve proposição de soluções, como nos programas de remoção de áreas de risco, nem de determinação de perímetros para AEIS e de HIS, ou de programas de melhorias nas habitações, disponibilizados pelos instrumentos notáveis urbanísticos pelo Estatuto das Cidades, nem para a população carente em áreas de risco, nem para o Casarão de Brigadeiro Tobias e seu entorno, área estratégica de abastecimento de água potável para a cidade.

A questão mais antiga e talvez mais fácil de ser resolvida seria pelo instrumento da preservação de patrimônio paisagístico, edificado e área de interesse paisagístico e ambiental, para o Casarão de Brigadeiro Tobias e seu entorno. Pela pesquisa, este item foi só incluído no PD de 2004 porque cidadãos de outro bairro, interessados na preservação ambiental do seu próprio bairro (Jd. Bandeirantes, inclusive mencionado no PD) lutaram para que isto fosse incluído no PD.

O único avanço foi na questão de áreas verdes e espaços livres para lazer, que já existia no meio do núcleo antigo e já era utilizado pela população de Brigadeiro Tobias, como Centro comunitário, com campo de futebol, implantado em área adequada na várzea do rio Pirajibu, ao lado da linha férrea próximo à estação de Brig. Tobias.

Quanto ao sistema municipal de informação, embora colocada na lei do pd e 2004, na prática ainda não está totalmente implantado (em 2018, os mapas do PD de 2004 não estão disponibilizados no sistema online da prefeitura municipal, nem no site da Câmara municipal de Sorocaba).

As informações referentes ao mapa de macrozoneamento ambiental e zoneamento municipal de Sorocaba foram extraídas de MEIRA (2006).

O trecho estudado de Brigadeiro Tobias, por sua localização em terras de alta (40\%) declividade e profusão de nascentes e cursos d'água, foram protegidos, além da lei federal sobre as APP's, a partir de 2004, pelo próprio plano diretor municipal sorocabano, pelo macrozoneamento ambiental, de zona de conservação ambiental e zona de chácaras para as áreas menos íngremes, com menor parcelamento do solo, baixa taxa de ocupação e esperada baixa densidade, denotando uma visão sistêmica abrangente e conjunta entre as administrações municipais anteriores ao PD de 2004 e sua autarquia de abastecimento hídrico para a população municipal (SAAE de Sorocaba), que seguiram para esta região a recomendação do PDAA de 1995.

Também normalmente as terras que contêm olhos d'água, nascentes e riachos, ou outro curso d'água (ainda que intermitentes), tem menor custo de aquisição para empreendimentos imobiliários, porque tem menor disponibilidade de solo edificável por conta das áreas de 
preservação permanente (APP's) associadas a estes cursos de água, pelo Código Florestal pela Lei federal $n^{0} 4.771$, de 15 de setembro de 1965:

"Art. $1^{0} \S 2^{\circ}$ Para os efeitos deste código, entende-se por:

II - Área de Preservação Permanente: Área protegida por Lei, coberta ou não por vegetação nativa, com a função ambiental de preservar: os recursos hídricos, a paisagem, a estabilidade geológica, a biodiversidade, o fluxo gênico de fauna e flora, proteger o solo e assegurar o bem estar das populações humanas. (...)

Art. $2^{\circ}$

a) ao longo dos rios ou de qualquer curso d'água desde o seu nível mais alto em faixa marginal cuja largura mínima seja:

1) de 30 (trinta) metros para os cursos d'água de menos de 10 (dez) metros de largura;

2) de 50 (cinqüenta) metros para os cursos d'água que tenham de 10 (dez) a 50 (cinqüenta) metros de largura;

3) de 100 (cem) metros para os cursos d'água que tenham de 50 (cinqüenta) a 200 (duzentos) metros de largura;

4) de 200 (duzentos) metros para os cursos d'água que tenham de 200 (duzentos) a 600 (seiscentos) metros de largura;

5) de 500 (quinhentos) metros para os cursos d'água que tenham largura superior a 600 (seiscentos) metros;(...)

c) nas nascentes, ainda que intermitentes e nos chamados "olhos d'água", qualquer que seja a sua situação topográfica, num raio mínimo de 50 (cinquenta) metros de largura;(...) Parágrafo único. No caso de áreas urbanas, assim entendidas as compreendidas nos perímetros urbanos definidos por lei municipal, e nas regiões metropolitanas e aglomerações urbanas, em todo o território abrangido, observar-se-á o disposto nos respectivos planos diretores e leis de uso do solo, respeitados os princípios e limites a que se refere este artigo." (BRASIL, 1965).

Tendo a mencionada lei federal, no seu Art. 2, modificado pelai lei $n^{0} 7.803$, de 18 de julho de 1989:

"Art. 22. A União, diretamente, através do órgão executivo específico, ou em convênio com os Estados e Municípios, fiscalizará a aplicação das normas deste Código, podendo, para tanto, criar os serviços indispensáveis.

Parágrafo único. Nas áreas urbanas, a que se refere o parágrafo único do art. $2^{\circ}$. desta Lei, a fiscalização é da competência dos municípios, atuando a União supletivamente." (BRASIL, 1989).

Com este último parágrafo, delega-se a fiscalização da aplicação das normas da lei federal sobre as chamadas APP's ao município, o que no caso do Município de Sorocaba, com mais de 2880 nascentes, a maior parte no trecho estudado, de topografia de alta declividade e em área antes em sua maior parte na zona rural, tarefa de enfrentamento que deve ter disposição política e alocamento de recursos financeiros e humanos; nem sempre prioritários ao município, normalmente com precariedade de fiscalização de terras e obras públicas e privadas.

Seguem-se as considerações para o trecho estudado, para a revisão da Lei 7.122 de 04/6/2004, que instituiu o novo Plano Diretor de Desenvolvimento Físico Territorial do Município de Sorocaba.

No zoneamento municipal, as adequações possibilitaram regularização fundiária pontual, admitidas pelo funcionário da prefeitura municipal de Sorocaba; e as demais glebas passaram a 
$\mathrm{ZCH}$, sendo que a área mais crítica em termos de preservação ambiental recebeu denominação ZCA, com parâmetros mais restritos quanto ao zoneamento e coeficiente de aproveitamento, nas áreas lindeiras à RRT, no trecho do $\mathrm{km} 88$ a 92; pois devido à sua topografia (parte mais alta de Sorocaba, na Serra de São Francisco), a região tem muitas nascentes e cursos d'água que contribuem para o encorpamento do córrego do Pirajibu-Mirim, afluente do lado direito do Rio Sorocaba.

A médio e longo prazo, este patrimônio ambiental e paisagístico da região (não apenas do entorno do Casarão do Brigadeiro Tobias) poderia ser aproveitado de maneira inteligente por suas populações, pois fica em área de acesso facilitado pela RRT. Infelizmente o planejamento urbano e regional somente se preocupou em deixar como zoneamento ZR2 ao invés do pleiteado ZR3 (PD 2014), embora com o mérito de depois ter criado o parque municipal de Brigadeiro Tobias, preservando em lei a mata do entorno do Casarão, que teve sua administração seccionada passando para a Secretaria da Cultura de Sorocaba em 2016. Também o Sindicato Rural de Sorocaba, consultado, se manifestou contrário à qualquer redução da área rural, por conta da perda de áreas verdes e da queda de produção de alimentos. Mas recordou que o município já havia perdido 40\% de sua área de zona rural no PD de 2004, e que se aprovada novamente uma redução da área rural, o município teria ZR menor que o Município de São Paulo, que tinha então 15\% de área rural. 


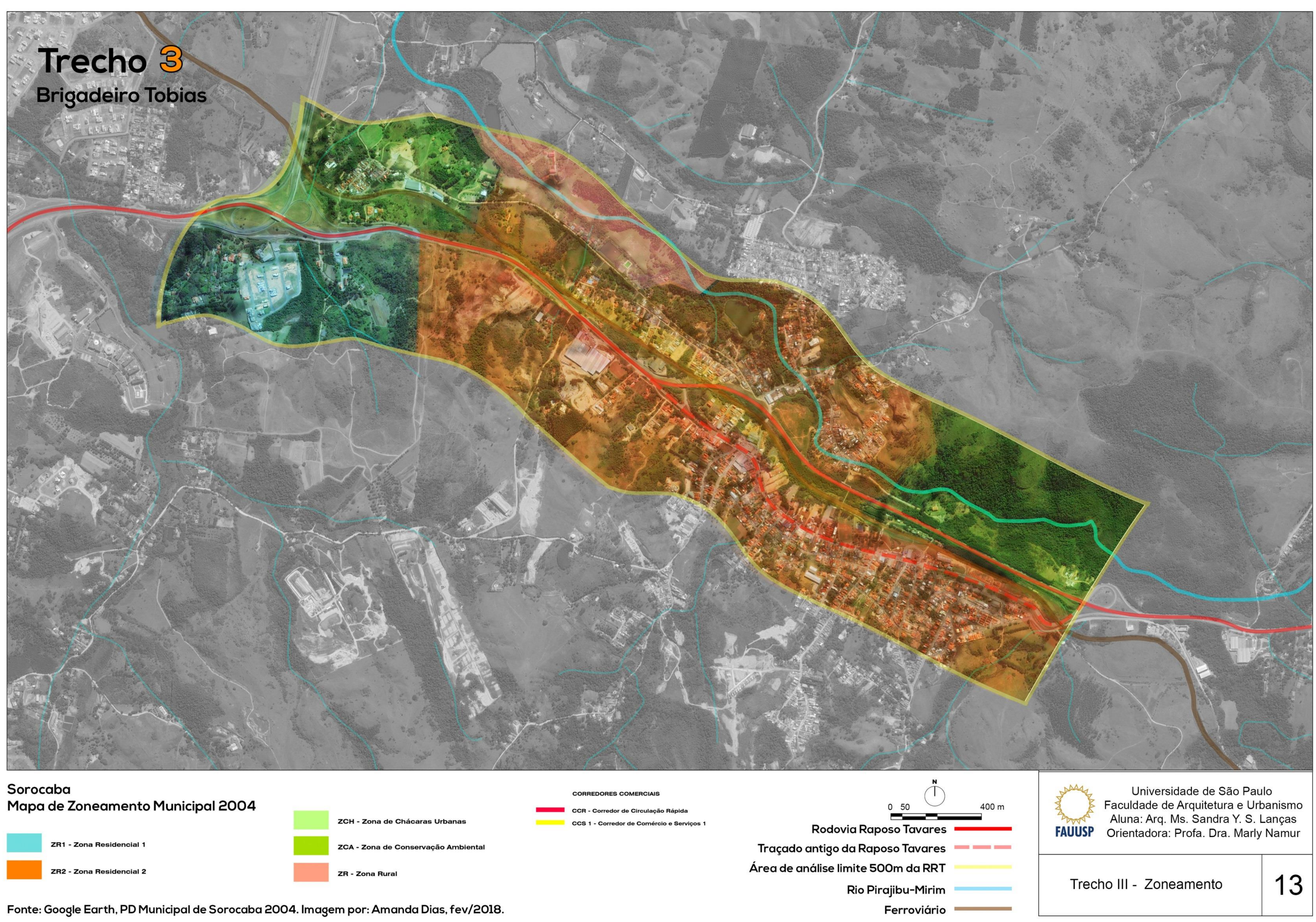


Na tabela a seguir percebe-se a diminuição da área rural imposta pelo PD de 2004, de 222,86 km2 (48,87\% da área total do município) para 80,24km2 (17,60\% da área total do município) e do aumento de $121,44 \mathrm{~km} 2$ de área a ser considerada urbana, um aumento de quase $60 \%$, justificando a opinião do Sindicato Rural sobre as alterações do PD de 2004.

Tabela 19 - Alterações dos perímetros urbanos do Município de Sorocaba no PD de 2004.

\begin{tabular}{|l|c|c|l|c|c|}
\hline \multicolumn{1}{|c|}{ Anterior } & $\mathrm{Km}^{2}$ & $\%$ & \multicolumn{1}{c|}{ Atual [2004] } & $\mathrm{Km}^{2}$ & $\%$ \\
\hline Área rural & 222,86 & 48,87 & Área rural & 80,24 & 17,60 \\
\hline Área urbana & 203,12 & 44,54 & Área urbana & 324,56 & 71,17 \\
\hline Área industrial & 30,02 & 6,58 & Área industrial & 51,20 & 11,23 \\
\hline Área total do municipio & 456,00 & 100,00 & Área total do municipio & 456,00 & 100,00 \\
\hline
\end{tabular}

Fonte: SANTORO; CYMBALISTA; NAKASHIMA, 2009.

Outra entidade consultada sobre o assunto foi o Sinduscon-SP, cujo diretor, Elias Stefan Jr., menciona em entrevista seu ponto de vista:

"(...) a expansão urbana não é negativa, pelo contrário, pois gera empregos e locais para moradias, considerando o déficit habitacional na cidade. "As áreas de APP vão continuar sendo áreas de APP em qualquer região da cidade. A preservação é obrigatória. Nós temos que pensar um pouco mais objetivamente e menos filosoficamente", afirma Stefan, em relação a possíveis impactos ambientais (JCS, 2014).

Do comentário do dirigente da SINDUSCON, pode-se enunciar que realmente a geração de empregos e unidades habitacionais é positiva (desde que sejam ocupados); e que a preservação das APP's é obrigatória desde que mencionada especificamente por lei municipal do PD.

Membros do legislativo também se mobilizaram sobre as alterações do PD e também propuseram outras: sobre este item, o então vereador Carlos Leite (PT) apresentou ao PL178/2014, o projeto de lei da revisão do PD de 2007 e algumas emendas.

Talvez por este trabalho do vereador Carlos Leite (PT), junto a outras razões mais específicas da classe empreendedora, o zoneamento residencial predominante ao final do PD 2014 foi o ZR-2 no trecho estudado, mas quanto à pleiteada vigência do novo PD após apresentação e aprovação dos planos acessórios, a saber: o Plano Diretor de Meio Ambiente, Saneamento, Mobilidade e Transporte Urbano, Resíduos Sólidos e Habitação de Interesse Social, e a proposição de um Corredor de Biodiversidade Norte-Sul, integrando os fragmentos florestais da Represa de Itupararanga até a Flona de Ipanema-Iperó, e as demais demandas listadas pelo edil, talvez por ser de um partido de oposição, nada foi acatado. 
Tabela 20 - Usos permitidos Zonas ZR1 e ZR2 - PD Sorocaba de 2007.

\begin{tabular}{|l|}
\hline \multicolumn{1}{|c|}{ PD 2007: Adequações do Pd de 2004 } \\
\hline \multicolumn{1}{|c|}{ ZONAS DE USO USOS ADMITIDOS } \\
\hline Zona Central - ZC RL, RG, PGTI, GRN, GRD, CSI, TL, UE; \\
Zona Predominantemente Institucional - ZPI RL, RG, PGTI, GRN, GRD, CSI, TL, UE; \\
Zona Residencial 1 - ZR1 RL, RG, UE; \\
Zona Residencial 2 - ZR2 RL, RG, CSI, TL, UE; \\
Zona Residencial 3 - ZR3 RL, RG, CSI, TL, UE; \\
Zona Industrial - ZI PGTP, GRN, GRD, CSI, UAI, UE; \\
Zona de Atividades Especiais - ZAE PGTI, GRN, GRD, CSI, UE; \\
Zona de Chácaras - ZCH RL, RG, TL, UE; \\
Zona de Conservação Ambiental - ZCA RL, RG, TL, UE; \\
Corredor de Comércio e Serviços 1- CCS 1 RL, RG, CSI, TL, UE; \\
Corredor de Comércio e Serviços 2- CCS 2 RL, RG, PGTI, GRD, GRN, CSI, TL, UE; \\
Corredor de Comércio e Indústria - CCI PGTI, PGTP, GRD, GRN, CSI, UE; \\
Corredor de Circulação Rápida - CCR RL, RG, PGTP, PGTI, GRD, GRN, CSI, TL, UE; \\
Área Rural RL, PGTP, PGTI, TL; UAI, UE; AAP \\
\end{tabular}

Fonte: Câmara Municipal de Sorocaba, 2014.

Tabela 21 - Parâmetros de ocupação por zona PD 2007. Sorocaba (tabela parcial).

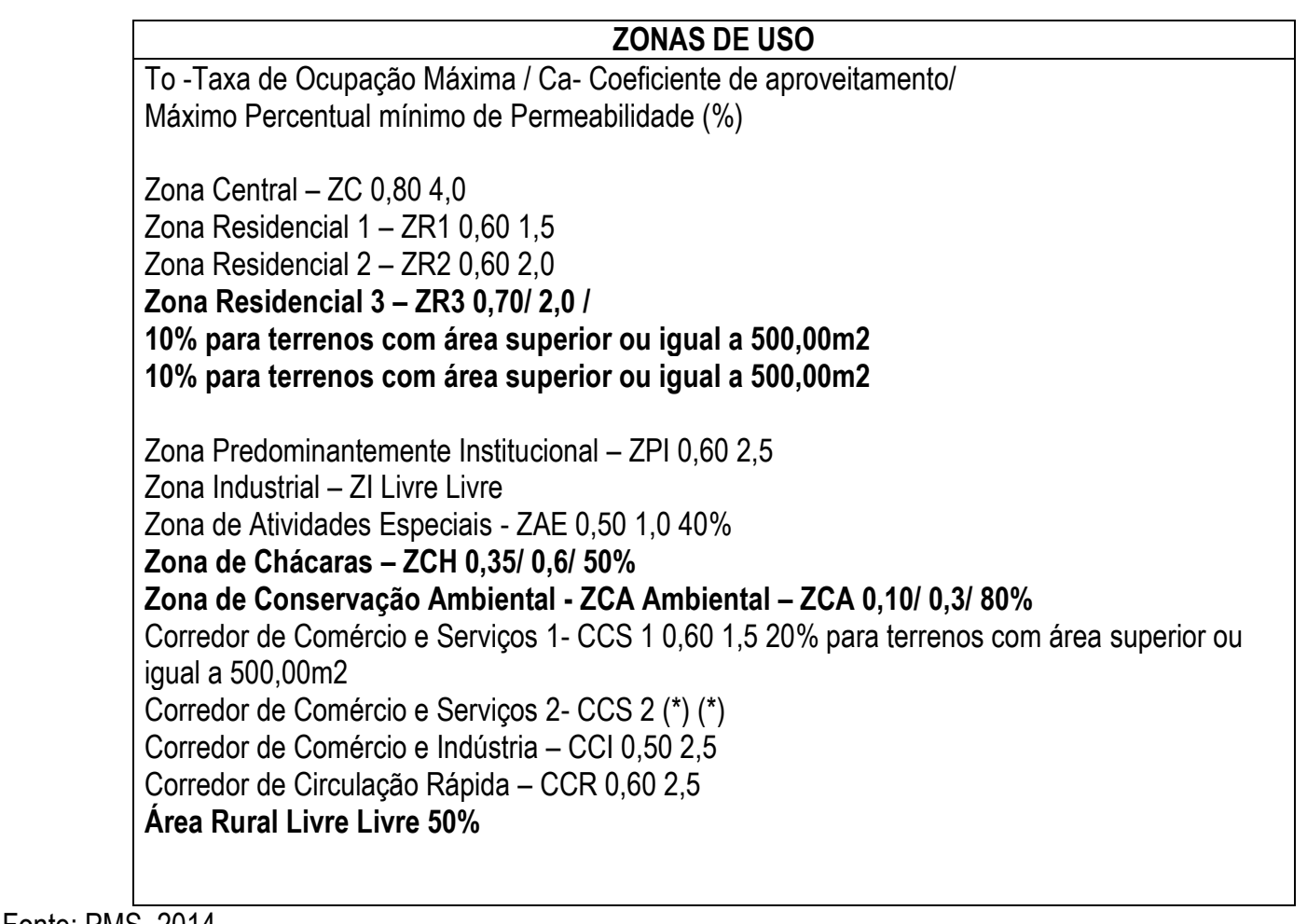

Fonte: PMS, 2014. 
Figura 92 - Macrozoneamento Ambiental, Plano Diretor Ambiental de Sorocaba (2007), detalhe do trecho RRT de Brigadeiro Tobias. À direita:- Macrozoneamento Ambiental, Plano Diretor Desenvolvimento Físico Territorial de Sorocaba (2014), detalhe do trecho RRT de Brigadeiro Tobias.

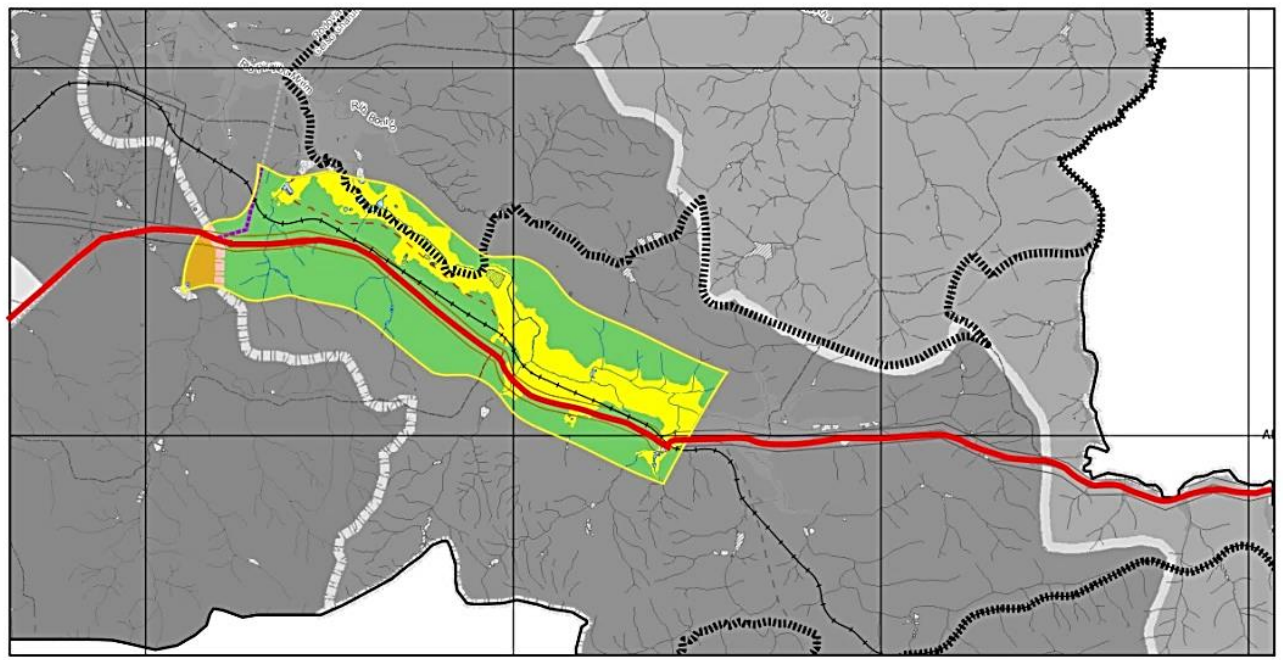

순. Limite de bacia hidrográfica

Convencőes Cartográficas

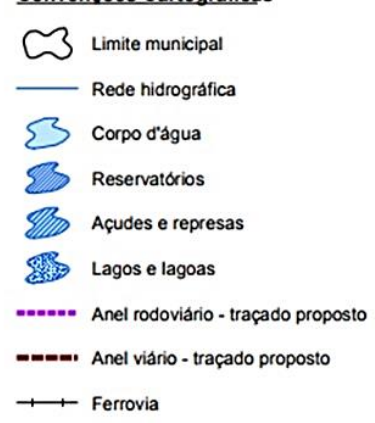

Macrozoneamento Ambiental
MGRO - Macrozonas com Grandos Rostriçoses à Ocupaçáo

Área do Protoçáo a Manancials

MCA-Macrozona de Conservaç̧a Ambiental - varrzeas ou planicies aluviais

- Perimetral - Centro

----- Vias arteriais existentes - padrao 1

----- Vias arteriais existentes - padrao 2

- - - Vias arteriais propostas - padrao 1

- - - Vias arteriais propostas - padrao 2

- Vias coletoras

- Rodovia

Corredores de transporte coletivo
Tipo 18 - base geologica cristalina - bacias que contribuem para captaçoes existentes

Tipo 28 - base geologica cristalina - manancial estratégico

MMRO - Macrozonas com Moderadas Restriços à Ocupaçào

Areas Pertoncentes a Bacias de Dronagem Extensas

Tipo A - base geologica metassedimentar - áreas pertencentes a bacia de drenagem pouco extensas

Áreas pertencentos ao distrito industrial

Tipo 2A- base geologica metassedimentar - áreas pertencentes ao distrito industrial

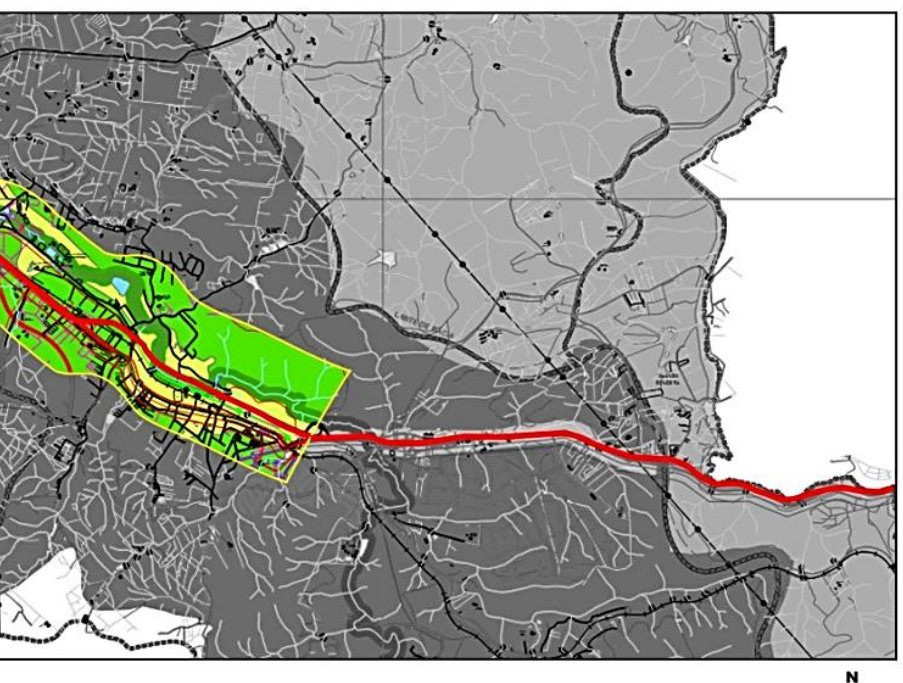

$0^{N}$

Rodovia Raposo Tavares

\section{Zoneamento Municip}

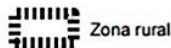

MPRO - Macrozonas com Pequenas Restriç̋os à Ocupaçåo

Áreas Portencentos a Bacias do Drenagem Pouco Extensas

Tipo A - base geologica metassedimentar - área urbana em expansåo

Tipo B - base geologica cristalina - área urbana consolidada

Fonte: SMA Sorocaba, 2007; PMS, 2014. Retrabalhado por Amanda Dias, 2018. 


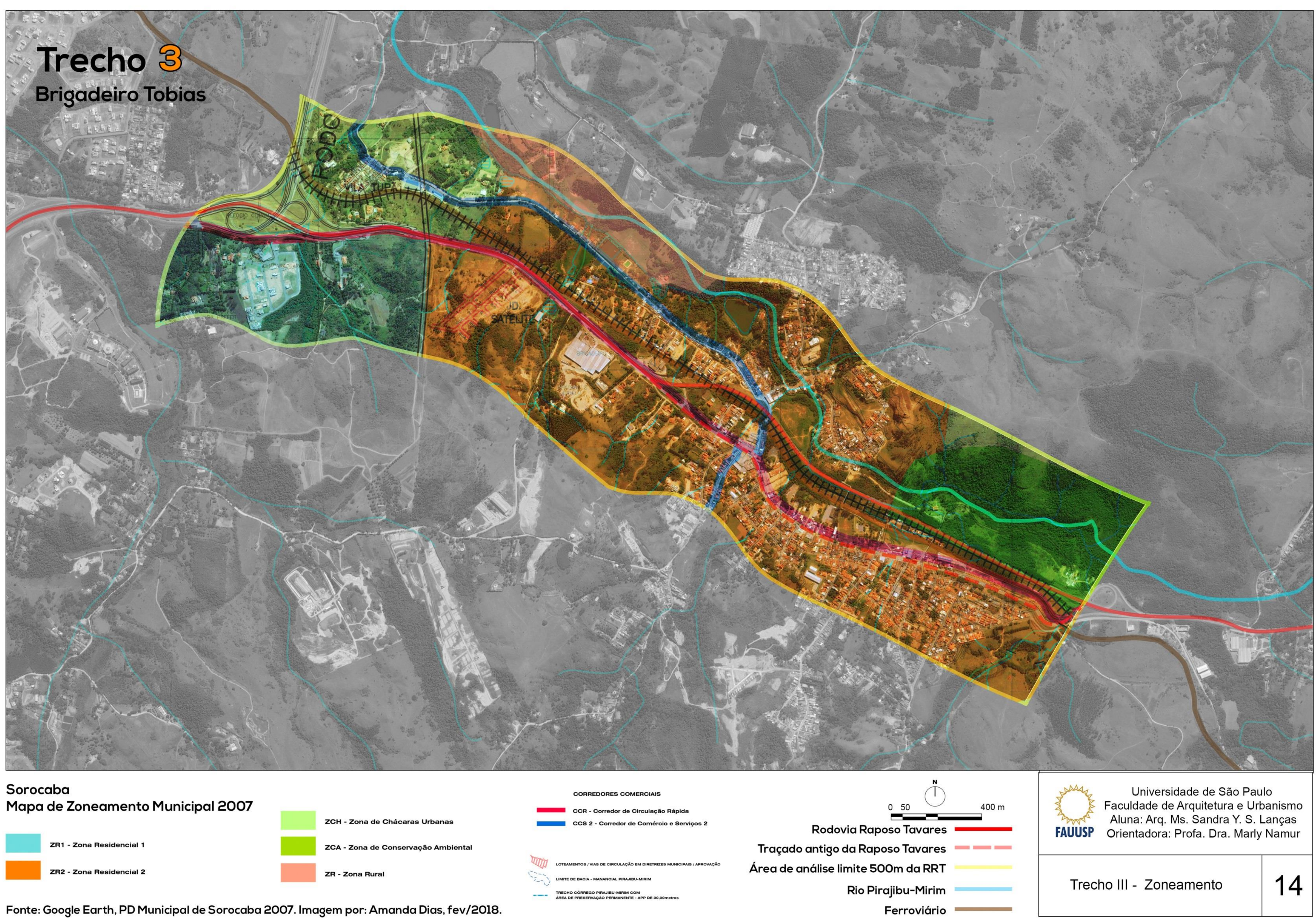


Figura 94 - Á esquerda: Zoneamento Municipal, PD de Sorocaba (2007), detalhe do trecho RRT de BT. À direita - Proposta Zoneamento Municipal, PD de Sorocaba (março/2013), detalhe do trecho RRT de Brigadeiro Tobias.

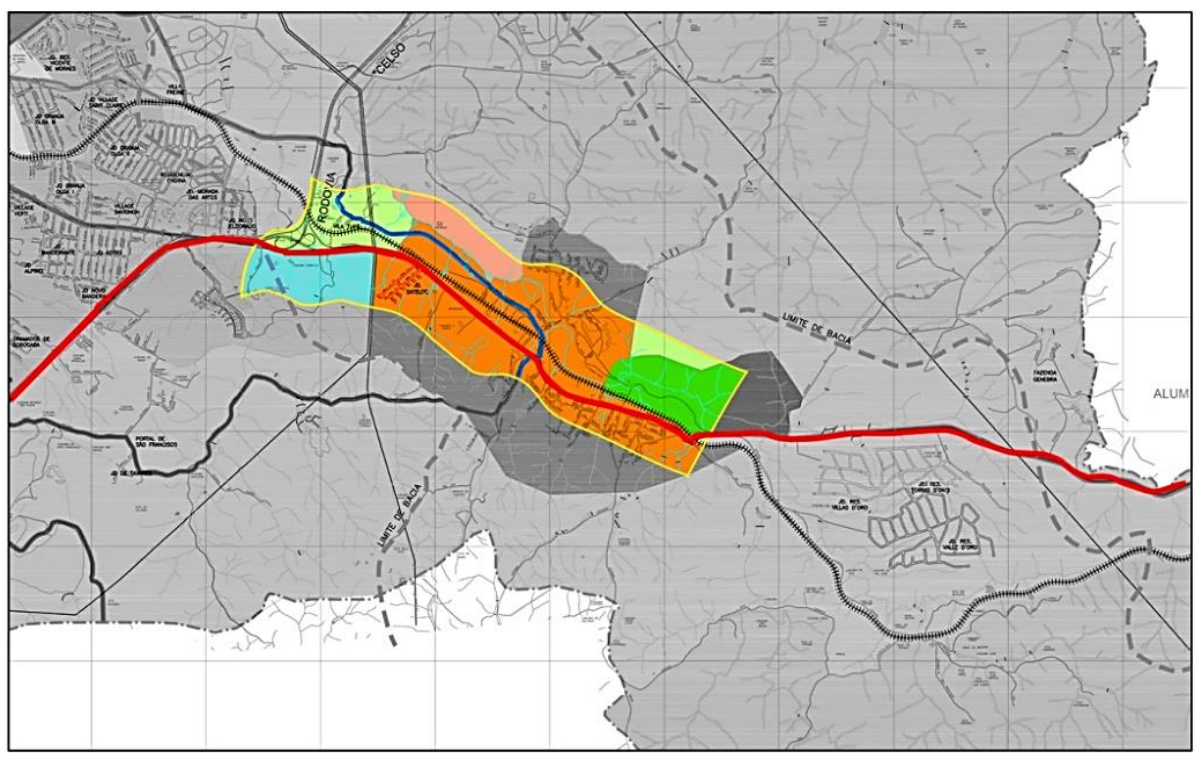

LEGENDA/ZONAS
ZR3 - Zona Residencial 3

ZCH - Zona de Chácaras Urbanas

ZPI - Zona Predominante Institucional

Z1 1 - Zona Industrial

ZI 2 - Zona Industrial 2

ZR1 - Zona Residencial 1

ZR2 - Zona Residencial

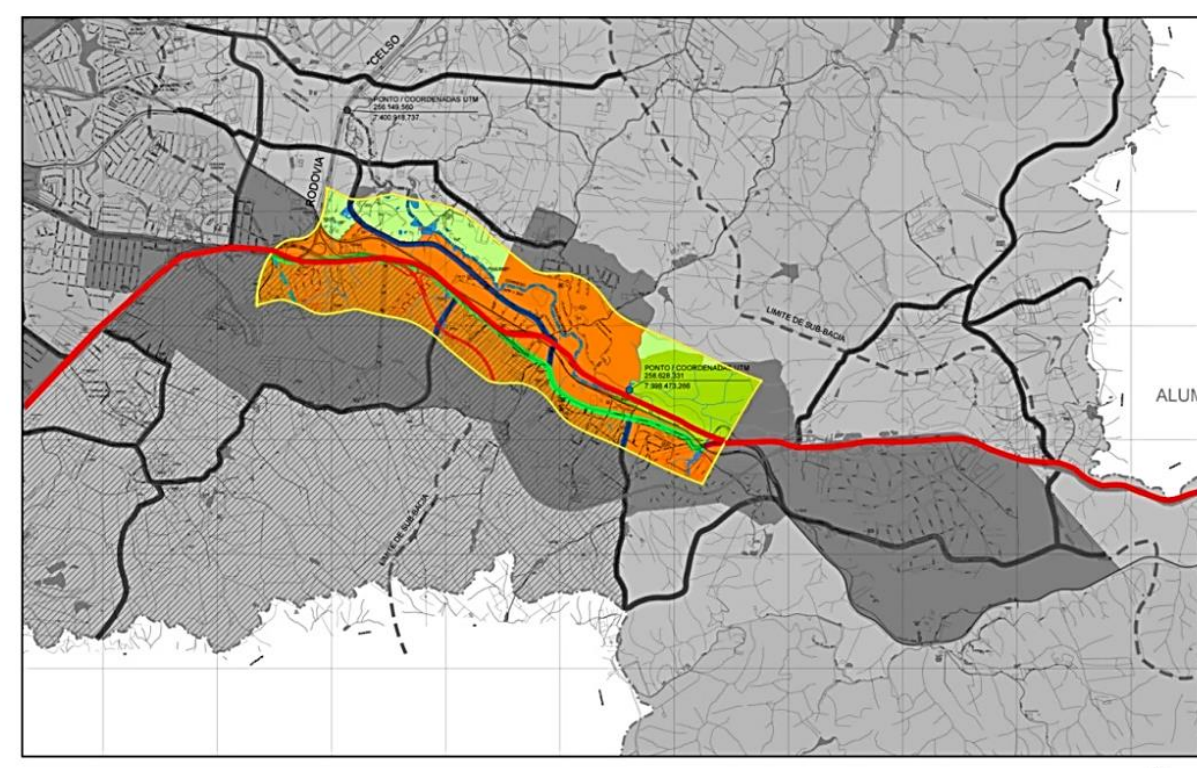

$\overbrace{}^{N}$

Rodovia Raposo Tavares

Área de análise limite 500 m da RRT

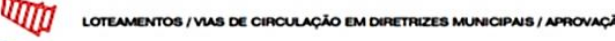

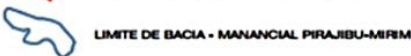

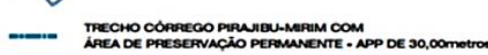

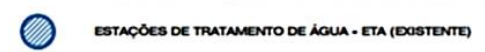

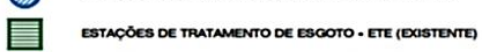

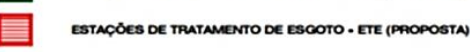

-1.- unve oe munocipio

enprocaputers

\section{CORREDORES COMERCINS}

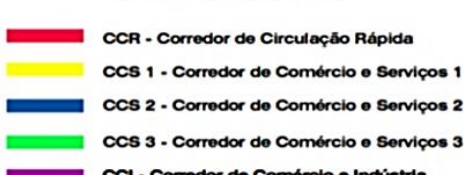

the

Fonte: SAAE, 2013. Disponivel em http://www.saaesorocaba.com.br/downloads/Planta_Plano_Diretor_Zoneamento_Urbano2.pdf, acesso em nov/2017. Retrabalhado por Amanda Dias, 2018. 
Para iniciar a análise das modificações do zoneamento municipal do PD de 2014, neste trecho RRT de Brigadeiro Tobias, devido à área em questão ser importante no quesito ambiental, iniciaremos a análise pelo macrozoneamento ambiental, já como estabelecido no PD de 2014.

No trecho de 500m de ambos os lados da RRT do km 88 ao 92, percebe-se em amarelo, pela legenda MCA (Macrozona de Conservação Ambiental), grande parte a várzea do Rio Pirajibu-Mirim; também o trecho RRT passa sua maior parte dentro da área verde clara (Macrozona do tipo 1B: Base geológica Cristalina - bacias que contribuem para captação existente), onde observa-se muitas nascentes e cursos de água que são contribuientes da microbacia do Rio Pirajibu-Mirim; e limítrofe ao Município de Alumínio, na parte azul clara, a Macrozona do tipo 2B, de base geológica cristalina - manancial estratégico). Todas as três macrozonas mencionadas são do tipo MGRO - Macrozona com Grandes Restrições à Ocupação (mapa 11).

Comparando o zoneamento municipal do PD de 2007, verificamos que o zoneamento segue o limite da bacia hidrográfica para o contorno da zona rural e existe distinção para uma zona de conservação ambiental associada à área de várzea co rio Piraji Mirim, e grande parte da [área de estudo ainda permanece como $\mathrm{ZCH}$, zona de chácaras urbanas, embora seguindo a rodovia, ao se aproximar da confluência da Rod. Celso Charuri e da Av. São Paulo, o zoneamento passa a ser ZR2, onde antes era ZR1, denotando mofidicações co-relacionadas, ao acesso proporcionado pela RRT.

Nas próximas duas figuras, a mesma questão do macrozoneamento municipal pelo plano diretor municipal e pela autarquia Municipal do SAAE: estabelecidas as macro-diretrizes de uso e ocupação do solo pelo PD municipal, a autarquia responsável pelo abastecimento hídrico aplica ao seu mapa de zoneamento municipal as questões mais realistas das várzeas dos cursos dágua, das APP's vigentes, das vias existentes ou a serem abertas, e dos novos empreendimentos imobiliários em estudo ou em vias de aprovação. Percebe-se a diminuição da zona rural, o aumento da área urbanizada, a ocupação agora mais ordenada do território, mesmo sendo este uma zona de conservação ambiental, de chácaras urbanas cujos lotes mínimos passam a $600 \mathrm{~m} 2$ pelo novo PD (era $2000 \mathrm{~m} 2$ ); e de topografia de alta declividade.

Nota-se claramente comparando-se o zoneamento municipal de 2007 e 0 proposto de 2013 a diminuição da zona rural, o aumento da zona residencial tipo 2 e diminuição da Zona de Conservação Ambiental, mesmo estando em área de várzea e anotada no Macrozoneamento Ambiental como macrozona de grandes ocupações à ocupação. Mas o PD de 2014 (mapa 12) conseguiu eliminar a menção à ZCA anteriormente anotada sobre a área de várzea estipulada no macrozoneamento ambiental: no mapa da figura abaixo está o zoneamento municipal no 
trecho RRT de Brigadeiro Tobias ao final de 2014, com a aprovação do novo PD de Sorocaba (Lei Ordinária $n^{0} 11.022$, de 16 de dezembro de 2014):

Figura 95 - Outra proposta (SAAE) de Zoneamento Municipal, PD de Sorocaba (março/2013), detalhe do trecho RRT de Brigadeiro Tobias.
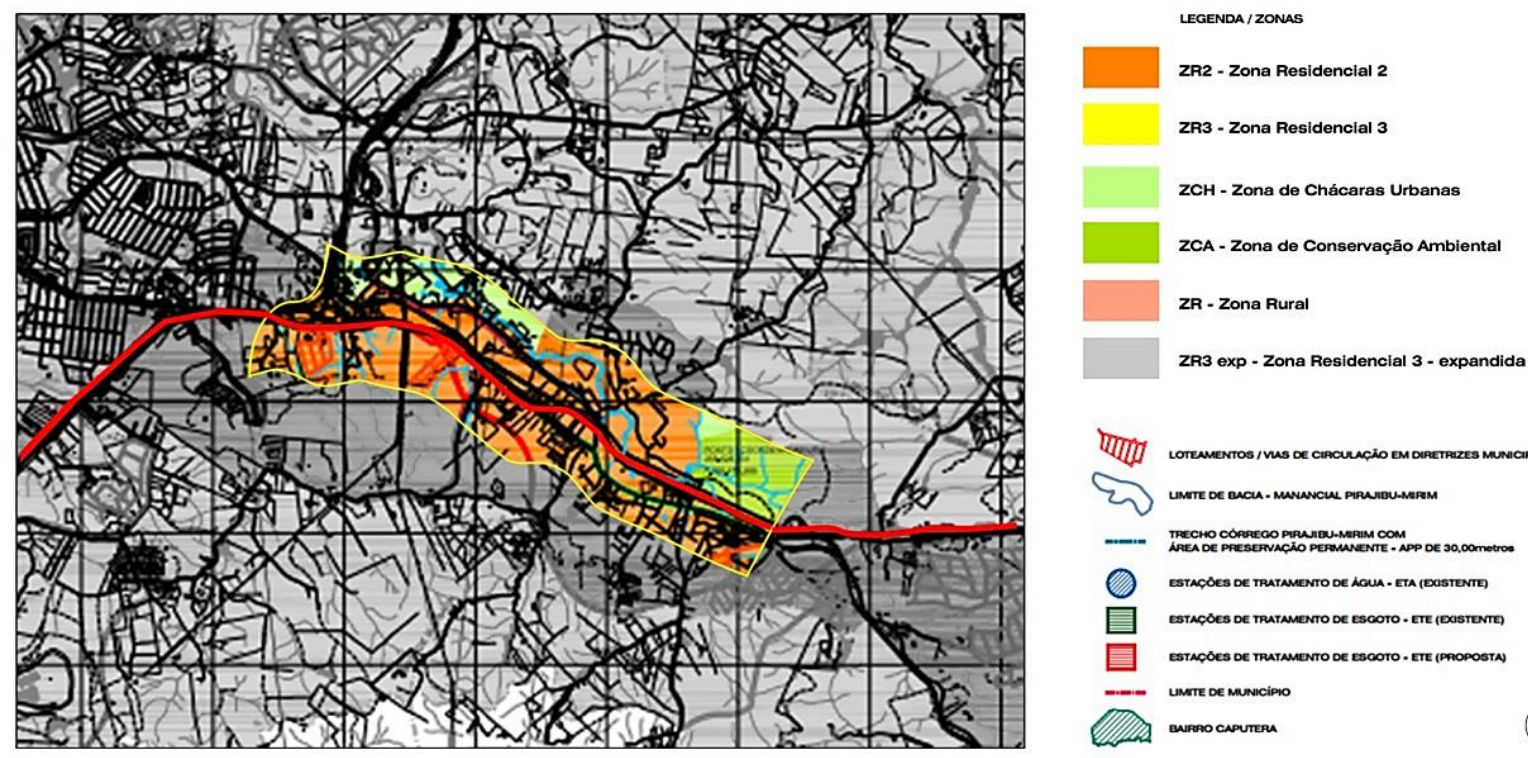

Rodovia Raposo Tavares

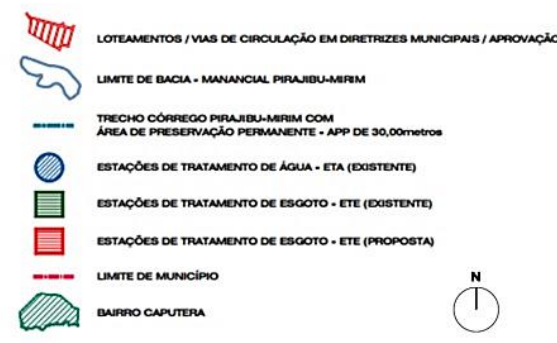

Área de análise limite $500 \mathrm{~m}$ da RRT

Fonte: SAAE, 2013. Disponível em

http://www.saaesorocaba.com.br/downloads/Planta_Plano_Diretor_Zoneamento_Urbano2.pdf, acesso em nov/2017. Retrabalhado por Amanda Dias, 2018. 
Figura 96 - Zoneamento Municipal, PD de Sorocaba (dez/2015), detalhe do trecho RRT de Brigadeiro Tobias.

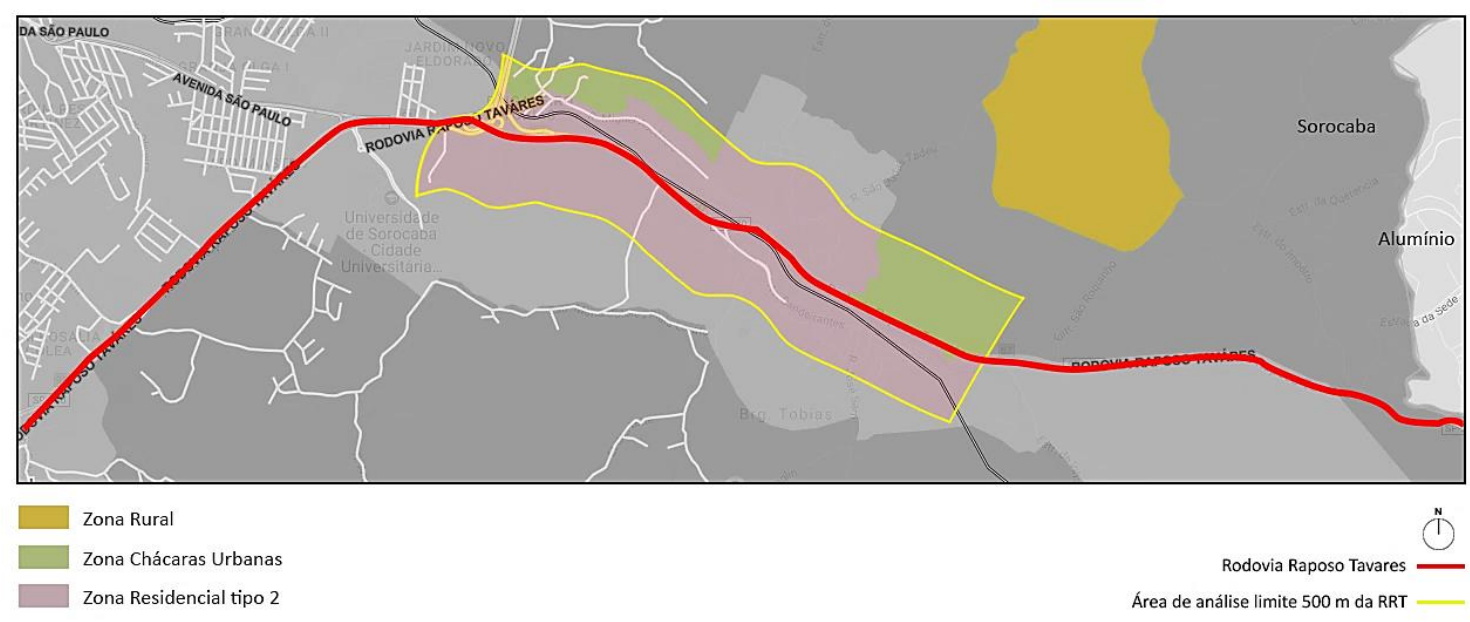

Fonte: EMPLASA, 2017. Retrabalhado por Amanda Dias, 2018.

Na figura acima, a área colorida em mostarda claro corresponde a Zona Rural, praticamente desaparecida do trecho RRT de Brigadeiro Tobias, considerando-se os $500 \mathrm{~m}$ lindeiros às margens da rodovia, corroborando o que já foi mencionado pelo Sindicato Rural de Sorocaba. Para o PD de Sorocaba de 2014: a EMPLASA atualmente considera a ZCH como área de uso sustentável, e ela está colorida em verde claro, que corresponde à zona de chácaras urbanas, com a seguinte legislação TO máximo: 20\%; Ca máximo 0,4, taxa de permeabilidade mínima 20\%, e o PD determina para as ZCH; a EMPLASA, que está atualmente preparando o PDUI da RMS, considera a ZR2 como urbana consolidada. O PD de Sorocaba enuncia sobre a ZR2 a seguinte legislação TO máximo: 60\%; Ca máximo 1,5, taxa de permeabilidade mínima $20 \%$. Sem a localização e registro em coordenadas geográficas legíveis dos filetes de água que brotam da terra, uma nascente pode ser facilmente aterrada e perder-se, embora a legislação ambiental federal as proteja com o raio de cinquenta metros de área de preservação permanente, além das áreas lindeiras aos cursos de água conforme sua largura vai aumentando.

Um parêntese: o município vizinho do lado sul de Sorocaba, Votorantim, (com arrecadação municipal muito menor) mapeou seus cursos d'água e já anotou suas respectivas áreas de proteção permanente (APP) no seu último plano diretor de 2015 (em comparação com o PD do Município de Sorocaba, aprovado em dez/2014): 
Figura 97 - Mapa de zoneamento municipal de Votorantim (lado inferior esquerdo) x o zoneamento municipal de Sorocaba (PD 2014), com anotações de APP',s Projetos MCMV, e loteamentos aprovados e em estudo.
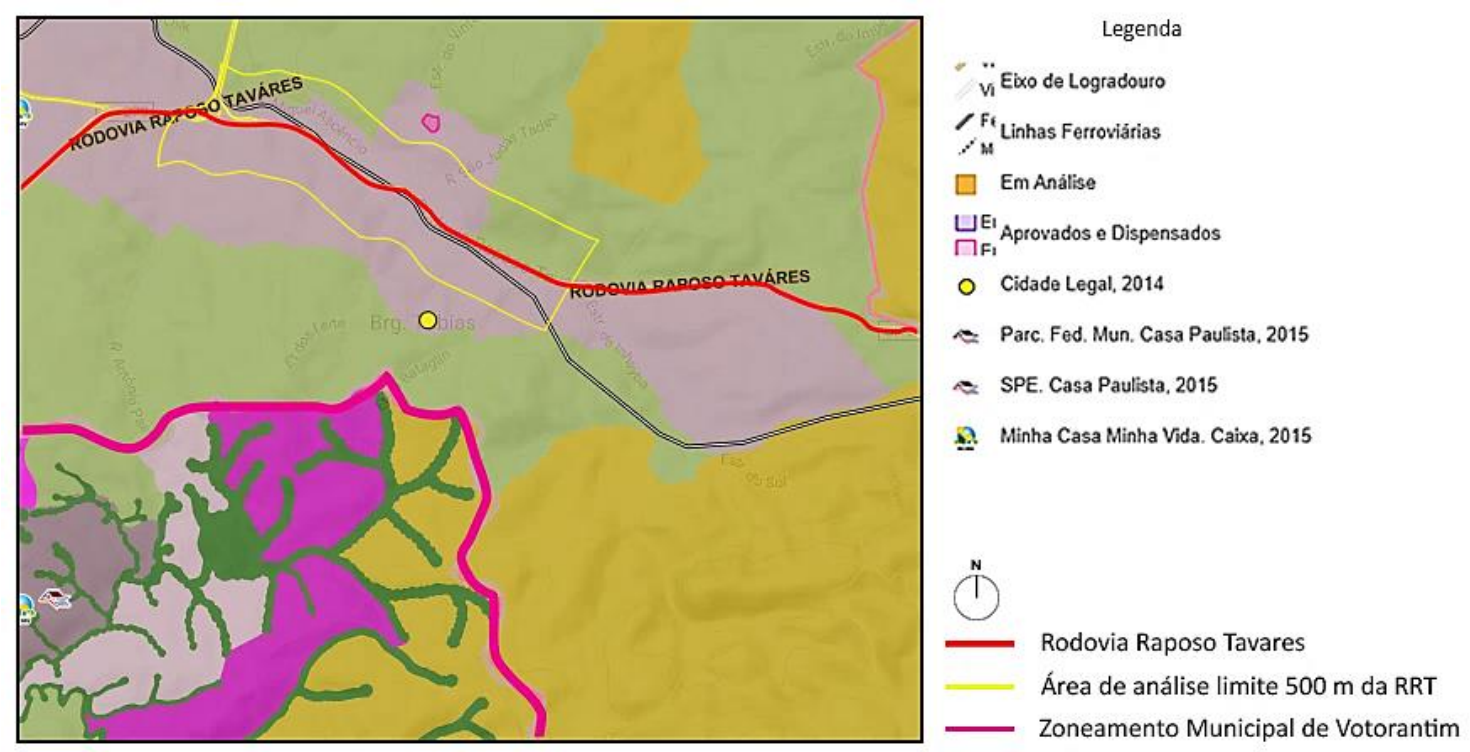

Fonte: EMPLASA, 2017. Retrabalhado por Amanda Dias, 2018.

Em Brigadeiro Tobias, as áreas colinosas e verdes contêm muitas nascentes; mas por ser uma área aonde o acesso à fiscalização é difícil, abrem-se muitas clareiras, e desmatamento acontecem frequentemente (Depoimento de moradora local). Embora muitos cursos de água já fossem conhecidos e mapeados no trecho RRT, desde os tempos de implantação da ferrovia, infelizmente o conhecimento destas nascentes, claro ao se ver o mapa de nascentes e APP's, não foi suficiente para a elaboração de uma política pública que se fizesse presente para uma finalidade de seguimento da própria macro-diretriz ambiental escrita como fundamento de ordenamento territorial do Pd de 2004, gestado após quase quarenta anos do anterior (PD 1966). Pelos macrozoneamentos especificados, pode-se concluir que a área estudada no trecho de Brigadeiro Tobias é importante ambientalmente, e isto deveria estar também correlacionado no zoneamento municipal. Mas, por isso mesmo são áreas propensas a novos parcelamentos, pelo apelo bucólico. A professora Paula Santoro, do Instituto Pólis, ao analisar o PD de Sorocaba de 2004, escreveu:

"Temos como hipótese que as questões levantadas refletem o processo de construção de planos (diretores) em cidades interior do Estado de São Paulo, onde novos parcelamentos do solo sobre áreas rurais dominam o conteúdo; enquanto que instrumentos de indução à utilização de áreas subutilizadas e instrumentos para recuperação da valorização da terra ainda estão longe de serem implementados, que dirá então, de serem auto-aplicáveis." (SANTORO; CYMBALISTA; NAKASHIMA, 2006, negrito nosso). 
Anos mais tarde (2013, por ocasião de discussão da nova proposta de revisão do PD de Sorocaba), o presidente em exercício do Sindicato Rural de Sorocaba, Roberto Marcello Filho, comentaria que a entidade é contrária à qualquer redução da área rural, por conta da perda de áreas verdes e da queda de produção de alimentos. Lamentou a maior perda de zona rural já ocorrera com o Plano Diretor de 2004: "Antes de 2004 nós tínhamos cerca de 40\% do território de Sorocaba como zona rural". Marcello cita que em outras cidades, como Campinas, Bauru e Ribeirão Preto, a área rural atualmente é entre 30\% e 40\% (JCS, 2017).

Após a publicação do PD de 2004, atendendo as reinvindicações de agentes do setor imobiliário do município, que conseguiram mudanças pontuais de zoneamento para a implementação de seus empreendimentos, o PD de Sorocaba foi revisado em 2007. Não houveram, entretanto, modificações estruturais de zoneamento no PD de 2007, que manteve a zona leste de Sorocaba, onde está o trecho de Brigadeiro Tobias estudado. Até então, a penúltima revisão do PD de Sorocaba foi em 2007 (a anterior foi aprovada em 2004), e em 2012 começaram os estudos para uma nova revisão, que pela lei federal do Estatuto das Cidades poderia demorar até dez anos. Inicialmente, a PMS propõe para a revisão a proposta da figura abaixo. Para o trecho de Brigadeiro Tobias, nota-se de pronto a redução da Zona Rural, ZR1, ZCH e ZCA; com o aumento da ZR2 (mapa 15). 


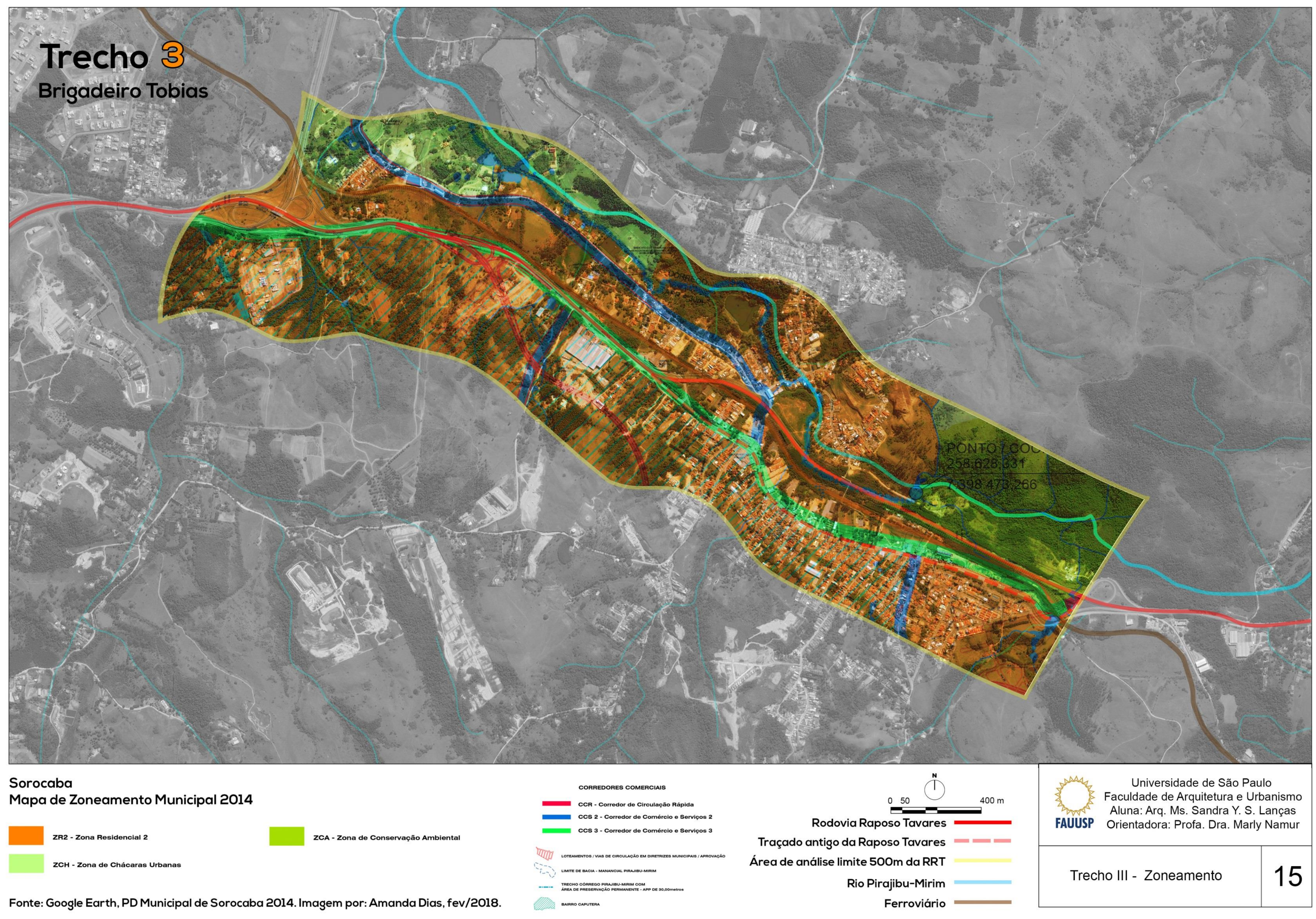


Pela lei no. 11.022/ 2014, revisão do Plano Diretor de Desenvolvimento Físico Territorial do Município de Sorocaba, introduziu-se as seguintes alterações para o trecho:

Tabela 22 - Parâmetros de ocupação do Município de Sorocaba no PD de 2014.

SEÇÃOI

PARAMETROS DE OCUPAÇÃO POR ZONA

Art. 107. Os valores limite para os indices urbanísticos por zona são aqueles indicados no quadro a seguir:

\begin{tabular}{|c|c|c|c|}
\hline ZONAS DE USO & $\begin{array}{l}\text { To } \\
\text { Taxa de } \\
\text { Ocupação } \\
\text { Máxima }\end{array}$ & \begin{tabular}{|l|}
$\mathrm{Ca}$ \\
Coeficiente de \\
aproveitamento \\
Máximo
\end{tabular} & $\begin{array}{l}\text { Pp } \\
\text { Percentual mínimo } \\
\text { de permeabilidade } \\
(\%)\end{array}$ \\
\hline Zona Central- ZC & 0,80 & 4,0 & \multirow{4}{*}{$\begin{array}{l}5 \% \text { para terrenos } \\
\text { com área de até } \\
200 \mathrm{~m} 2 \\
10 \% \text { para terrenos } \\
\text { com área entre } \\
200,01 \mathrm{~m} 2 \text { a } \\
499,9 \mathrm{~m} 2\end{array}$} \\
\hline $\begin{array}{l}\text { Zona Predominantemente Institucional - } \\
\text { ZPI }\end{array}$ & 0,60 & 2,5 & \\
\hline Zona Residencial 1 - ZR1 & 0,60 & 1,5 & \\
\hline Zona Residencial 2-ZR2 & 0,60 & 2,0 & \\
\hline Zona Residencial 3-ZR3 & 0,70 & 2,0 & \multirow{2}{*}{$\begin{array}{l}20 \% \text { para terrenos } \\
\text { com área superior a } \\
500 \mathrm{~m}^{2}\end{array}$} \\
\hline Zona Residencial 3 expandida - ZR3-e & 0,70 & 2,0 & \\
\hline Zona Industrial $1-\mathrm{ZI} 1$ & Livre & Livre & \multirow{2}{*}{$10 \%$} \\
\hline Zona Industrial 2-ZI 2 & Livre & Livre & \\
\hline Zonas de Chácaras - ZCH & 0,35 & 0,6 & $50 \%$ \\
\hline Zona de Conservação Ambiental - ZCA & 0,20 & 0,4 & $20 \%$ \\
\hline $\begin{array}{l}\text { Corredor de Comércio e Serviços } 1 \text { - } \\
\text { CCS1 }\end{array}$ & 0,60 & 1,5 & \multirow{5}{*}{$\begin{array}{l}10 \% \text { para terrenos } \\
\text { com área igual ou } \\
\text { superior a } 500 \mathrm{~m}^{2}\end{array}$} \\
\hline $\begin{array}{l}\text { Corredor de Comércio e Serviços } 2 \text { - } \\
\text { CCS2 }\end{array}$ & 0,60 & 2,0 & \\
\hline $\begin{array}{l}\text { Corredor de Comércio e Serviços } 3 \text { - } \\
\text { CCS3 }\end{array}$ & 0,60 & 3,0 & \\
\hline Corredor de Comércio e Indústria - CCI & 0,50 & 2,0 & \\
\hline Corredor de Circulação Rápida - CCR & 0,60 & 2,0 & \\
\hline Área Rural & Livre & Livre & Livre \\
\hline
\end{tabular}

Fonte: Câmara Municipal de Sorocaba, 2014. 
Tabela 23 - Dimensões mínimas de lotes do Município de Sorocaba no PD de 2014.

\begin{tabular}{|l|l|l|}
\hline DIMENSÕES MÍNIMAS DE LOTES POR ZONA DE USO \\
\hline ZONAS DE USO & $\begin{array}{l}\text { ÁREA } \\
\text { MÍNIMA }\left(\mathrm{m}^{2}\right)\end{array}$ & $\begin{array}{l}\text { TESTADA } \\
\text { MÍNIMA (m) }\end{array}$ \\
\hline Zona Central - ZC & 200,00 & 8,00 \\
\hline Zona Predominantemente Institucional - ZPI & 360,00 & 12,00 \\
\hline Zona Residencial 1 - ZR1 & 360,00 & 10,00 \\
\hline Zona Residencial 2 - ZR2 & 300,00 & 10,00 \\
\hline Zona Residencial 3 - ZR3 & 200,00 & 8,00 \\
\hline Zona Residencial 3 - ZR3 - expandida & 200,00 & 8,00 \\
\hline Zona Industrial 1 -ZI 1 & $1.000,00$ & 15,00 \\
\hline Zona Industrial 2 - ZI 2 & 500,00 & 15,00 \\
\hline Zonas de Chácaras - ZCH & $1.000,00$ & 15,00 \\
\hline Zona de Conservação Ambiental - ZCA & $6.000,00$ & 75,00 \\
\hline Corredor de Comércio e Serviços 1 CCS1 & 300,00 & 10,00 \\
\hline Corredor de Comércio e Serviços 2 - CCS2 & 250,00 & 10,00 \\
\hline Corredor de Comércio e Serviços 3 - CCS3 & 500,00 & 15,00 \\
\hline Corredor de comércio e Indústria - CCI & $3.000,00$ & 30,00 \\
\hline Corredor de Circulação Rápida - CCR & 600,00 & 15,00 \\
\hline
\end{tabular}

Fonte: Câmara Municipal de Sorocaba, 2014.

Pode-se notar, na comparação da elaboração desta última lei do PD de 2014, além do maior detalhamento dos itens, uma flexibilização maior nos índices de TO, CA, e do percentual mínimo de permeabilidade, que no caso da ZCA passa de TO de 0,10; CA 0,3; TP mínima de $80 \%$ para TO de 0,20; CA 0,40 e TP mínima de 20\%. A área do lote na ZCA também diminuiu de $10.000 \mathrm{~m} 2$ para $6.000 \mathrm{~m} 2$, com testada mínima de $75 \mathrm{~m}$ para 50 metros; mas o lote mínimo da ZR3 foi estabelecido em $200 \mathrm{~m} 2$, com testada mínima de 7,00metros, quando antes era de $150 \mathrm{~m} 2 \mathrm{e}$ testada mínima de $8,00 \mathrm{~m}$.

Um artificio colocado nos parágrafos pretendia flexibilizar os lotes mínimos na ZR3, ZCH, mas foram vetados pelo executivo (vetos parciais anotados em vermelho) e motivo de ação de inconstitucionalidade administrativa movida por entidades de associação de bairros (de Brigadeiro Tobias, dentro outros), garantidos pela Promotoria Pública e instancias superiores:

$\S 2^{\circ}$ Nos loteamentos aprovados até a entrada em vigor da Lei Municipal $\mathrm{n}^{\circ} 7.122$, de $1^{\circ}$ de
junho de 2004 localizados na ZR2 e ZR3 ficam permitidos os fracionamentos dos lotes
com área mínima de $125 \mathrm{~m} 2$, com testada mínima de $5,00 \mathrm{~m}$ e profundidade mínima de
$10,00 \mathrm{~m}$.
$\S 3^{\circ}$ Nas Zonas de Chácaras Urbanas - ZCH serão admitidos novos parcelamentos do
solo com lotes de $600 \mathrm{~m} 2$ de área territorial e testada mínima de $15,00 \mathrm{~m}$, desde que 0
empreendimento possua sistema individual para tratamento de esgoto gerado no
mesmo, compreendendo rede coletora, estação de tratamento e rede de descartes de
efluentes, devidamente aprovados pelos órgãos técnicos ambientais, bem como para
sua ocupação seja prevista uma unidade residencial para cada $600 \mathrm{~m} 2$ de fração de área
de lote. (Veto Parcial n ${ }^{\circ} 53 / 2014$ Rejeitado)
$\S 6^{\circ}$ Fica permitida a redução da área mínima dos lotes para $150 \mathrm{~m} 2$ na ZR3 e $250 \mathrm{~m} 2$ na
ZR2, caso o empreendedor opte pela ampliação da área destinada ao lazer de $12 \%$ para
$20 \%$ da gleba do loteamento, área esta que deverá contemplar as áreas verdes e 0 
sistema de lazer. (Veto Parcial $\mathrm{n}^{0}$ 53/2014 Rejeitado) (Parágrafo declarado inconstitucional pela ADIN $n^{0}$ 2138826-16.2016.8.26.0000).

Nota-se por estes vetos e parágrafos declarados inconstitucionais pelo julgamento do ADINs, que a sociedade civil, embora de forma ainda incipiente, passou a entender melhor os mecanismos urbanísticos propostos, tanto pelo executivo quanto pelo legislativo, e suas consequências para a população. Muitos cidadãos da área jurídica também colaboraram para que a lei fosse formulada de forma menos desigual, quando consideradas as forças da indústria civil, empreendedora como sempre, principalmente no período considerado (2005-2014), coincidente com o desenvolvimento econômico brasileiro positivo.

A sociedade civil começou a organizar-se mais com relação às questões de ordenamento do uso e ocupação do solo: além de algumas lideranças da zona leste e oeste do município, surgiu o Instituto Defenda Sorocaba (IDS) que junto a outras entidades (associação de amigos de bairros, universidades, etc.) e começou a questionar a grande flexibilização dos índices de uso e ocupação do solo, comparativamente ao PD de 2004.

$\mathrm{O}$ trecho estudado de Brigadeiro Tobias, embora de maior dificuldade de incorporação, era uma fatia de terra atualmente mais acessível à população pelos automóveis mais populares; tanto pelo Município de Sorocaba, quanto pela população da capital e outras cidades da região.

O zoneamento municipal do distrito de Brigadeiro Tobias, ainda (março/2018) está sob júdice, devido ao ADIN nº 2138826-16.2016.8.26.0000, que julgou inconstitucional vários artigos do PD de 2014, que seriam aplicados à área do trecho de Brigadeiro Tobias. 


\title{
7.3 Ocupação urbana x Zoneamento - Trecho 3 (1962-2017)
}

\begin{abstract}
"The area is beautiful and vulnerable: development is inevitable and must be accommodated. Uncontrolled growth is inevitably destructive; development must conform to regional goals; observance of conservation can avert destruction and ensure enhancement; the area can absorve all prospective growth without despoliation; planned growth is more desirable and as profitable as uncontrolled growth; public and private powers can be joined in partnership in a process to realize a plan." (McHARG, 1982 apud SPIRN, 2000, p.104).
\end{abstract}

Figura 99 - Vista aérea do trecho do entorno do Casarão de Brigadeiro Tobias e trecho RRT, em 2015.

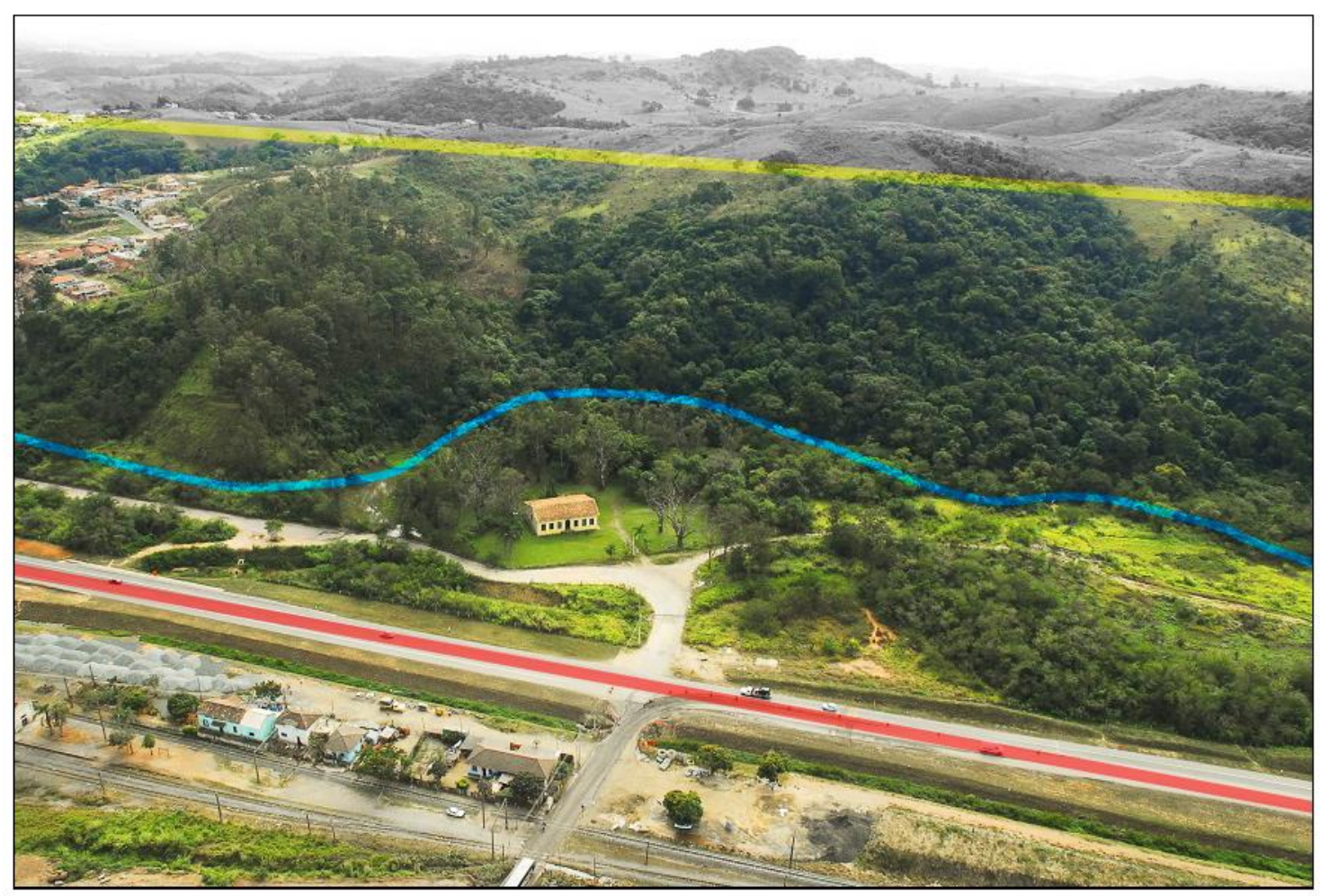

Rodovia Raposo Tavares

Área de análise limite $500 \mathrm{~m}$ da RRT

Rio Pirajibu-Mirim

Fonte: JCS, 2015. Disponível em: http://agencia.sorocaba.sp.gov.br/prefeitura-de-sorocaba-implantara-um-parquenatural-em-brigadeiro-tobias/, acesso em nov/2017. Retrabalhado por Amanda Dias, 2018.

A ocupação urbana do distrito de Brigadeiro Tobias iniciou-se com a instalação da fazenda na época colonial. 0 casarão41 da família do Brig. Tobias (Fig. 99) foi construído por volta de 1780 na sede da fazenda, e está listado como patrimônio histórico tombado pelo CONDEPHAAT42 (PAULA, 1974, p.1515). A edificação, ainda existente, localiza-se em frente às

41 http://cultura.sorocaba.sp.gov.br/casaraobrigadeirotobias/,acesso em nov/2017.

42 "Do Arquivo Histórico Nacional "Washington Luís". Rua da Consolação n.o 1024 - São Paulo - Capital. 1. Fazenda de Brigadeiro Tobias é agora Patrimônio Histórico - "Diário de São Paulo" - 19 de janeiro de 1973. 2. Brasiliana - Casa de fazenda protegida pelo patrimônio. - "Diário de São Paulo" - 20 de Janeiro de 1973." (PAULA, 1974). 
terras com alta declividade e repleta de nascentes e cursos de água, o que também configura a necessidade de maior proteção quanto à preservação e conservação das nascentes e cursos dágua ${ }^{43}$. Esta região sempre foi considerada "reserva" para a boa manutenção do Rio Pirajibu, afluente do lado direito do Rio Sorocaba, que contribuiu com suas águas, junto com outros córregos da área, para o abastecimento de três outros distritos importantes da zona leste de Sorocaba e Itu. Também o ponto mais alto de Sorocaba está em Brigadeiro Tobias, com 1029m, nas cabeceiras do Rio Pirajibu, nos altos da Serra de São Francisco, entre os limites municipais de Votorantim, Sorocaba e Alumínio.

Como na maioria dos municípios brasileiros, a ocupação da terra no trecho foi feita primeiramente pela agricultura, com grande devastação florestal, que reduziu as áreas de matas e capoeiras, cedendo lugar aos campos, pastos e lavouras. Em Sorocaba, em 1940 as matas e capoeiras eram cerca de $6,94 \%$, e os campos e pastos cerca de $47,93 \%$. A área cultivada, cerca de 20,74\%, e as terras inaproveitadas, 24,38\%; e as áreas inaproveitadas eram 0,10\% em 1904, os números demonstrando a enorme diferença ocorrida na primeira metade do séc. XX no município quanto ao uso e ocupação do solo (SANTOS, 1999, p. 95).

A ocupação urbana neste trecho foi limitada pela alta declividade topográfica (até $40 \%$ de inclinação), e o tipo de solo existente nesta região, propenso a voçorocas. A área mais propicia à implantação da estação ferroviária e posteriormente das casas (habitações do tipo popular em sua maioria), era na parte plana próxima à estação, embora também na área de várzea da formação do Rio Pirajibu-Mirim (Fig. 100), entre o chamado Casarão do Brig. Tobias e a estação ferroviária.

\footnotetext{
${ }^{43}$ Estabelecida pela Lei federal $n^{0} 4.771$, de 15 de setembro de 1965.
} 
Figura 100 - Detalhe da Carta Base da Bacia do Ribeirão Pirajibu-Mirim.

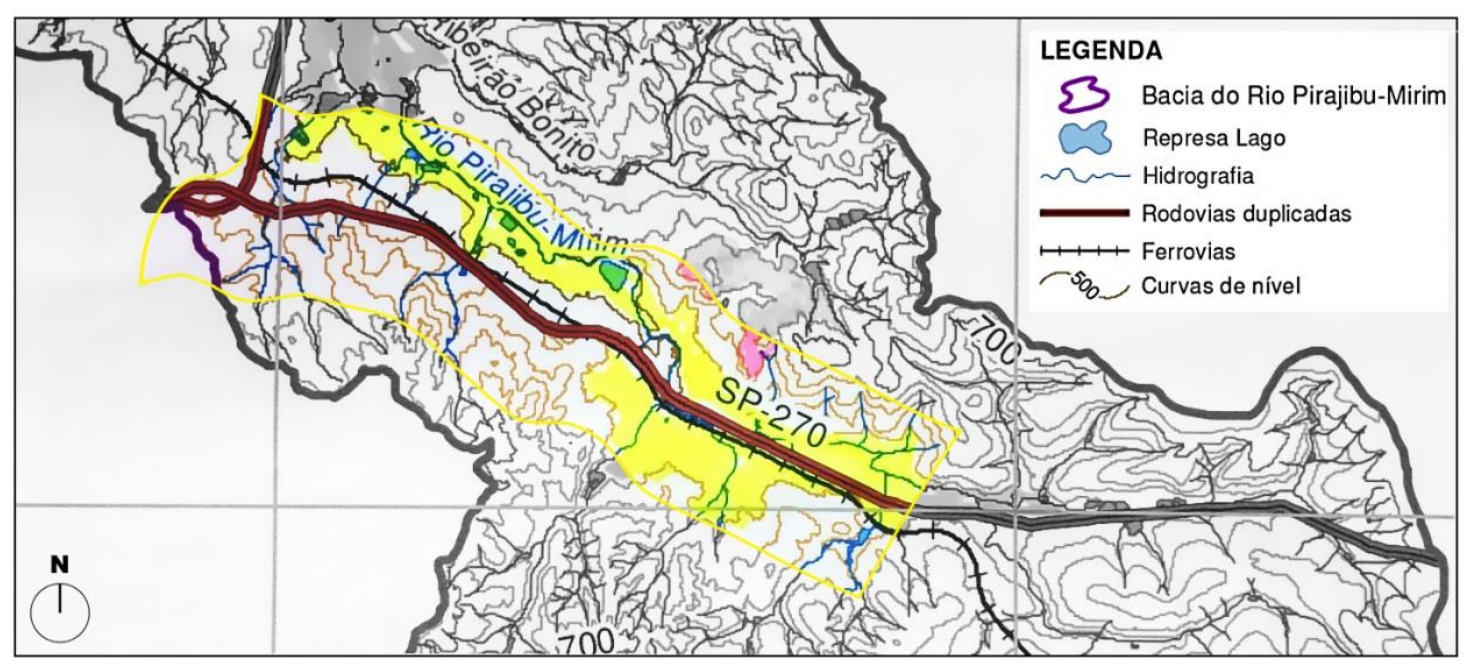

Área de análise limite $500 \mathrm{~m}$ da RRT

Autor: Valteir Marques (2017, p.49). Retrabalhado por Amanda Dias, 2018.

A foto aérea do trecho estudado de Brigadeiro Tobias de 1941 (SANTOS, 1999) evidencia o traçado da RRT à época, e embora em preto e branco, permite verificar que as encostas dos morros lindeiros à RRT no trecho de Brigadeiro Tobias eram bem cultivadas.

Segundo Saint Hilaire: "Nos arredores da cidade cultiva-se a cana-de-açúcar. (...) os algodoeiros vegetam perfeitamente acima das montanhas que se estendem a leste da cidade (...)" (HILAIRE, 1940, trad. P. 251, apud SANTOS, 1999, p. 75).

No trecho aqui estudado, fora da área urbana de Sorocaba (perpassada pela via férrea e a estrada de rodagem à época São Paulo-Curitiba) verificou-se que foram principalmente os imigrantes europeus (principalmente espanhóis), que atraídos pelo baixo preço da terra e acostumados às condições precárias da agricultura de sua terra, que estabeleceram as pequenas propriedades na base de ocupação colonizadora da região, pois "não havia cafezais a substituir, pois eram terras áridas; e os laranjais, mais restritos, se intrometem na paisagem pedregosa do contato da zona cristalina com a depressão permeana" (área do trecho estudado) (SOUZA, 1944, apud SANTOS, 1999, p. 104):

"Convém lembrar o fato de ter sido no distrito de Brigadeiro Tobias, pertencente ao município de Sorocaba, que imigrantes europeus, principalmente espanhóis se estabeleceram e introduziram o cultivo da batata e da cebola. Nas fotos aéreas, tomadas em 1941, pode-se constatar nessa área um aproveitamento agrícola intensivo através da técnica de terraceamento: árvores frutíferas, especialmente laranjais, aparecem circundando as encostas inferiores dos morros, enquanto nas baixadas e nos planos aluviais entre os morros, cultivam-se hortaliças.

A citricultura, introduzida em Brigadeiro Tobias por volta de 1937, estendeu-se até as proximidades de Sorocaba, marcando a paisagem rural. Deve ser ressaltada a localização privilegiada desse distrito atravessado pela rodovia São Paulo-Itu e pela E.F. Sorocabana, que garante transporte fácil e barato entre 0 centro produtor e os consumidores, tanto em direção à capital quanto ao interior." (SANTOS, 1999, p. 101-102) (Fig. 101). 
Figura 101 - Detalhe da foto aérea da RRT no trecho estudado: Arredores de Brigadeiro Tobias (ao sul da estrada de rodagem São Paulo-Curitiba).

Autor: desconhecido. Data: 1949. Fonte: SANTOS, 1999, p. 154.

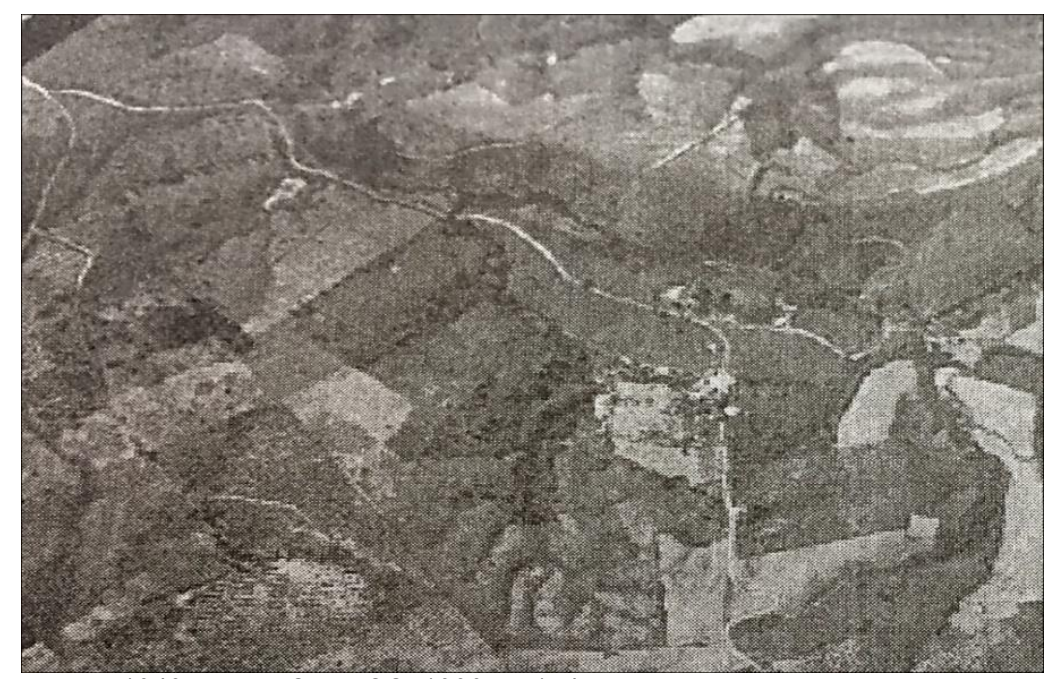

Santos e Ab'Saber, então colegas na FFLCH, fotografaram Brigadeiro Tobias em 1949 para o doutorado da profa. Eulina, (depois profa. Na FFLCH/USP) registrando as imagens de então (Fig. 102 e 103), que nos ajudaram a comparar a ocupação urbana existente em 1950, para analisar em que medida a ocupação urbana de 2005, é decorrente ou não dos zoneamentos municipais estabelecidos pelos Planos diretores municipais de 1950 (lei 162), 1966 (lei 1438) e 1968 (lei 1541).

Pelas imagens, notamos que a tipologia das edificações era de baixo/médio baixo padrão, a maioria de um pavimento; algumas continuam de pé até hoje. $O$ uso predominante no núcleo urbano formado pela Av. Bandeirantes e transversais era uso misto de residencial e comercial, com exceção do Casarão do Brigadeiro, que continuava como atração turística e cultural local. No trecho estudado, entre a linha férrea e a Av. Bandeirantes, provavelmente pela situação de várzea do Rio Pirajibu-Mirim, os terrenos não foram ocupados por casas: são até hoje utilizados como área de recreação da população local: lá funciona até hoje (2017) o centro comunitário esportivo, com campo de futebol de tamanho oficial, que também funciona como área drenante em períodos de chuva.

Após o ciclo do algodão sorocabano, a agricultura intensiva no trecho estudado foi praticada por imigrantes (portugueses, italianos, espanhóis), com plantações de laranjas, cebolas (áreas das encostas, pela técnica de terraceamento) e hortaliças nas áreas aluviais entre os morros existentes no trecho estudado (Fig. 102). 


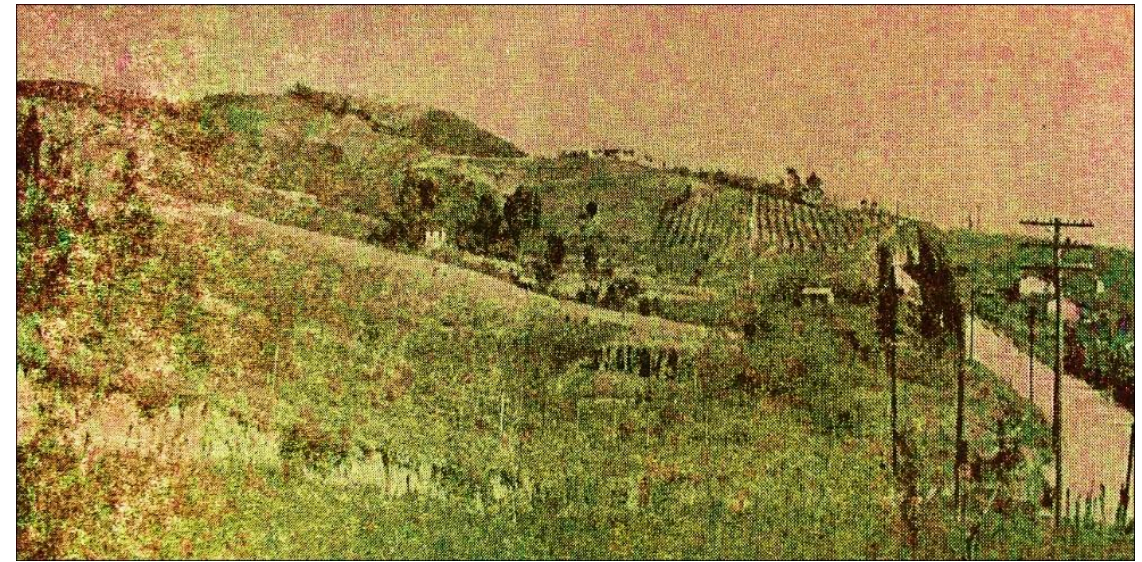

Paisagem agrícola sobre os morros mamelonares e vales largos da área granítica. Sítios e fazendolas com culturas e pomares nas encostas e nos patamares. Pequenos pastos, capoeiras e restos de matas. Habitat disperso. À direita vê-se a rodovia São Paulo Curitiba. Autor: A. N. Ab'Saber, 1949. Fonte: SANTOS, 1999, p. 140.

O distrito de Brig. Tobias ao final da década de 40, nas palavras da profa. Eulina Santos:

"Brigadeiro Tobias é uma verdadeira vila com uma população rural bastante dispersa e muito dependente da cidade de Sorocaba (Foto 56 e 57). Está situada num dos planos aluviais existentes na base da serra de Inhaíba, no contato dos xistos com os granitos. Apesar de se encontrar em sítio semelhante ao dos núcleos industriais, dele difere em seu traçado. É um povoado tipicamente linear entre o leito das estradas de ferro e de rodagem. (...) A zona de Brigadeiro Tobias é indiscutivelmente a de maior importância econômica; destaca-se por sua paisagem agrícola: (...) A policultura se desenvolve, embora de modo descontínuo como mostram as fotos aéreas." (SANTOS, 1999, p. 119) (Fig. 102).

$\mathrm{Na}$ foto a seguir, um retrato da atual Av. Bandeirantes em 1949, onde se vê o casario de tipologia modesta, misto de comercial para a avenida e residencial, mas já eletrificada. Não se nota calçadas, pois não eram exigidas pela legislação urbana de então (Fig. 103). Na foto não aparece a linha férrea, paralela à esquerda da estrada de rodagem de então, antes do asfaltamento e batizado da RRT em 1954. 


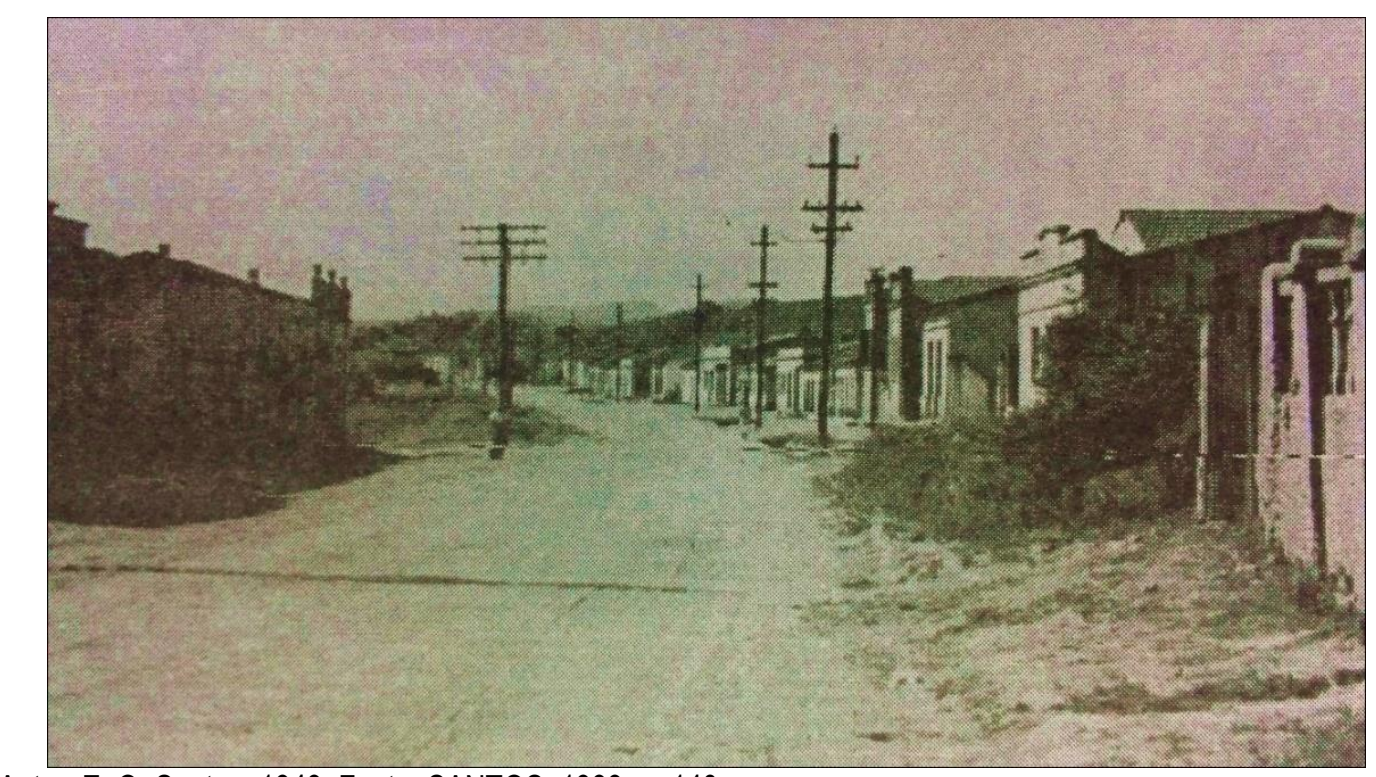

Autor: E. O. Santos, 1949. Fonte: SANTOS, 1999, p. 140.

Para se ter idéia da movimentação da ferrovia à época no trecho estudado, enquanto isto, atrás dos morros da Serra de Inhaíba, localizada atrás e acima de Brigadeiro Tobias, se instalou a Votoran, indústria de cimento do grupo Votorantim, fundada em 1936, e iniciou a exploração de calcáreo na Fazenda Santa Helena, próxima a Represa de Itupararanga (de 1919), produzindo mais de 157 mil toneladas de cimento; outra fábrica da região, propriedade das Indústrias Matarazzo, também produziu cal também utilizando o ramal da EFS transportou mais de 64 mil toneladas de cal virgem, cerca de 2 mil toneladas de cal extinta e quase 4 mil toneladas de pó de calcário em 1947 (SANTOS, 1999, p. 74): "os fornos de cal sorocabanos oferecem metade da produção de todo o Estado de São Paulo, a fábrica de cimento Santa Helena é das primeiras do Brasil, e as oficinas da EFS são as mais perfeitas no gênero da América do Sul" (Jornal o ESP, 28/08/1949).

A indústria na região de Sorocaba acarretou grandes transformações na ocupação do solo e na repartição da população municipal, contribuindo para externalizar as diferentes funcionalidades retratadas nas tipologias das paisagens e das populações do distrito principal de Sorocaba e dos demais. No caso do distrito de Brigadeiro Tobias, sua população era então de 3.229 habitantes, pela estimativa do DEE de 1950, Sorocaba tendo 67.542 habitantes.

Ao asfaltamento da RRT em 1954, o serviço de transporte de passageiros aumentado e contínuo da Viação Cometa, o carregamento e transporte do material a granel pela ferrovia, lembrando também o boom imobiliário de São Paulo (FERREIRA, 1987); em 1964 a inauguração da rod. Castelo Branco (SP 280); e já no início do séc. XXI a construção, pela concessionária 
ViaOeste, dos 6,1 km da Rod. Celso Charuri44 (SP 91), de interligação entre a Rod. José Ermírio de Moraes (acesso à Rod. Castelo Branco) à Rod. Raposo Tavares; o novo contorno da RRT em Brigadeiro Tobias na primeira década deste séc. XXI, e a implantação e concentração de serviços públicos na área urbana, além do asfaltamento das vias do núcleo urbano e as últimas modificações do zoneamento municipal legisladas a partir do PD de 2004 poderão alterar a questão de baixa densidade populacional para aumentá-la, na área do trecho de Brig. Tobias.

A ocupação urbana no trecho, na av. Bandeirantes e suas ruas adjascentes, de tipologia de baixo e baixo/médio padrão, residencial e comercial, com as edificações quase que totalmente de um pavimento, consolidou-se no período de meados da década de 50 a 80, ocupando no trecho estudado a parte do lado esquerdo da Av. Bandeirantes, como era chamado então o trecho utilizado da RRT antes da execução do novo contorno.

$\mathrm{Na} 2^{\mathrm{a}}$. metade do séc. $X X$, concomitantemente ao plano estratégico nacional nos anos 60 à instalação de rodovias para interiorizar o desenvolvimento econômico, Sorocaba concentrou os investimentos industriais da sua região, devido ao acesso às rodovias (RRT e RCB), uma vez que Sorocaba já era então cidade-pólo regional, da RA de Sorocaba, até o final do século XX, com 79 municípios (ZIMMERMANN, 1992; IBGE, 2010): "Nessa etapa, a indústria regional (de Sorocaba) ingressa num novo estágio marcado pela produção de bens intermediários, de capital e de consumo duráveis, em parte fruto da diversificação de grandes grupos locais 45 na exploração mineral da região" (ZIMMERMMANN, 1992, p.151).

O desenvolvimento econômico sorocabano refletiu-se também no aumento da população dos distritos próximos às rodovias mencionadas. Especificamente no trecho estudado, a população urbana do distrito de Brig. Tobias teve acentuada elevação na taxa geométrica de crescimento populacional na década de 60 (9,25\% a.a.); na década de 70 (8,19\%); diminuindo a taxa da década de 80 (4,60\%) (PROESP, 2000, p. 2.9) (tabela 24).

${ }^{44} \mathrm{https}: / / w w w . a l . s p . g o v . b r / n o t i c i a / ? i d=310230$, acesso em nov/2017.

45 Exemplos: Grupo Votorantim, Industrias Matarazzo, etc. 
Tabela 24 - Taxas geométricas de crescimento populacional Município de Sorocaba, SP (1960 - 1991).

Quadro 2.4a - Taxas Geométricas de Crescimento Anual Verificadas

\begin{tabular}{|l|c|c|c|c|c|c|c|c|c|}
\hline \multirow{3}{*}{ DISTRITOS } & \multicolumn{9}{|c|}{ TAXAS GEOMÉTRICAS DE CRESCIMENTO POPULACIONAL } \\
\cline { 2 - 11 } & \multicolumn{3}{|c|}{$1960 / 1970$} & \multicolumn{3}{c|}{$\mathbf{1 9 7 0 / 1 9 8 0}$} & \multicolumn{3}{c|}{ 1980/1991 } \\
\cline { 2 - 11 } & Urbana & Rural & Total & Urbana & Rural & Total & Urbana & Rural & Total \\
\hline Sorocaba & 4,26 & $(8,85)$ & 3,83 & 4,39 & $(5,29)$ & 4,29 & 3,20 & 6,12 & 3,22 \\
\hline Brig. Tobias & 9,25 & $(5,52)$ & 1,60 & 8,19 & 2,58 & 6,64 & 4,60 & 0,74 & 33,85 \\
\hline Cajuru do Sul & 3,14 & 3,81 & 3,67 & 17,99 & & 0,18 & 12,84 & & 12,84 \\
Éden & 17,52 & $(1,39)$ & 5,47 & 13,67 & 2,65 & 10,29 & 8,46 & $(2,53)$ & 6,95 \\
Votorantim & - & - & - & - & - & - & - & - & - \\
\hline TOTAL & 3,57 & $(10,70)$ & 2,42 & 4,60 & $(4,40)$ & 4,39 & 3,45 & 2,39 & 3,44 \\
\hline
\end{tabular}

Fonte: PROESP Enga. S/C. Data: maio/2000. Rev. 1.

Mas a estrada que propiciava o acesso as pessoas às cidades de Sorocaba, São Paulo e outras da região, facilitando a instalação de pequenos comércios, gerando alguns empregos e tributações ${ }^{46}$, também trazia perigos de atropelamentos, devido ao trafego de automóveis cada vez mais rápidos, e caminhões, cada vez mais frequentes e pesados, mas morosos, pelo transporte de carvão e calcário.

Em meados da década de 70 do séc. $X X$, a estação ferroviária de Brig. Tobias, por sua localização na malha ferroviária regional tinha como principal utilização o transporte de a granel de cimento (de Votorantim) e de calcáreo (de Salto de Pirapora)47; e a opção de utilização do trem de passageiros seis vezes ao dia.

Durante a primeira metade do séc. XX, a população rural de Sorocaba caiu de $49,96 \%$ em 1920 para $24,08 \%$ em 1947, enquanto a urbana passou de 50,04\% em 1920 para $75,92 \%$ em 1947 (SANTOS, 1999, p. 105). Entretanto, Santos lembra que esta alta urbanização registrada ainda não representava a realidade de então, pois não levou-se em conta a população urbana das "vilas" (sedes de distritos) nem dos vários povoados dispersos ao longo dos caminhos que cortam a região, caso de Brigadeiro Tobias, que teve alterada profundamente a dinâmica de seu cotidiano rural, quando passou a ser o maior distrito produtor rural de Sorocaba na primeira metade do século XX (registros estabelecem a produção agrícola do distrito, considerado 0 "celeiro" da população da região, principalmente do município, pela facilidade de carga e descarga propiciada pela estação ferroviária e estrada de rodagem (RRT); o que influenciou a ocupação no trecho urbano, e, quando do declínio das áreas cultivadas, (principalmente os laranjais, tomadas pela praga chamada popularmente de "tristeza"), e da queda de exportação decorrente da eclosão da $2^{\mathrm{a}}$ guerra mundial, os sitiantes do trecho voltaram-se para o plantio dos

\footnotetext{
46 N.A.: Algumas terras produtivas do Grupo Votorantim estão próximas do núcleo urbano de Brigadeiro Tobias.

47 O movimento da estação em 1975 (O Estado de S. Paulo, 10/7/1975).
} 
gêneros de primeira necessidade. Com a forte industrialização regional, "a população rural (principalmente Brigadeiro Tobias), foi mão-de-obra barata que abandonou as zonas rurais empobrecidas, atraídas pelas comodidades reais ou aparentes do centro urbano" (SANTOS, 1999, p.106 e 125).

A ocupação urbana aumentou de tamanho ao longo da avenida Bandeirantes, como podemos comparar nas próximas figuras, passando de plantações nas encostas dos morros de 1949 para área urbanizada em 1963 (com cerca de doze ruas oficializadas) do lado esquerdo da Av. Bandeirantes, próximo à estação, deixando a várzea do Ribeirão Pirajibu para o campo de futebol do centro comunitário; apenas uma rua foi oficializada do lado norte da RRT.

$\mathrm{Na}$ foto do satélite de 1984, embora sem grandes definições, dá para perceber que a área urbanizada aumentou linearmente; tanto no núcleo original, próximo à estação ferroviária, quanto no lado norte, próximo ao Casarão do Brigadeiro Tobias; em áreas de cotas mais baixas e elevadas; inclusive nas proximidades do Ribeirão Pirajibu, como em outras áreas urbanas, onde a população mais carente se estabelece próxima aos cursos de água por não ter acesso a rede de saneamento básico na primeira fase de sua instalação. Além da proximidade do Ribeirão Pirajibu, a Rua Rodolfo Garcia, paralela à linha férrea, é oficializada pela lei municipal 1071 de 1963; é palco de mais ocupações, criando vielas, e outro núcleo urbano que dá inicio a outros bairros irregulares: Vila Tupã 1, Vila São João, Vila Astúrias, em cotas mais altas e mais perigosas e propensas a deslizamentos, devido à alta declividade do local.

Observa-se que neste PD de 1966 a diretriz de planejamento urbano e regional que destinava faixa de $1 \mathrm{~km}$ e $500 \mathrm{~m}$ de ambos os lados e ao longo de ferrovias e rodovias já era estrategicamente destinada à atividade industrial, o que não foi seguido no trecho aqui estudado, nem para a faixa lindeira à ferrovia, nem para a faixa lindeira à av. Bandeirantes, antigo traçado da RRT no trecho de Brigadeiro Tobias.

Entre os anos 70 e 80 funcionou ao final do trecho estudado (sentido Sorocaba, do lado norte da RRT), na rua Miguel Ascêncio, no 2000, o Country Club Shangri-lá, que trouxe infraestrutura para o clube, pois tinha salão social, piscinas, restaurante, lanchonete, vestiários, casa de máquinas, etc em uma área de cerca de duzentos mil metros quadrados, que infelizmente a partir da década de 90 não funciona mais. As instalações abandonadas servem de criadouro a insetos, os materiais de construções são retirados, depredados; possivelmente utilizados nas construções das pequenas casas que vão se instalando e formando os novos bairros, sem infraestrutura e sem regularização fundiária.

$\mathrm{Na}$ foto aérea de 2005, pode-se perceber pela mancha do polígono amarelo, executada por Camargo (2015) que a mancha urbana cresceu linearmente ao longo da linha férrea, 
ultrapassou a rodovia e cresceu a oeste e subiu as enconstas dos morros, ocupando principalmente a área próxima à estrada que leva ao outro distrito municipal de Aparecidinha, outro núcleo antigo que também tinha núcleo urbano e ligação, através do antigo caminho hoje chamado de av. 03 de março, ao alto da Boa Vista, onde, a partir dos anos 70, funcionou a Prefeitura Municipal de Sorocaba.

As condições eram precárias, mas com o estabelecimento, por décadas das famílias no local, e a partir da possibilidade e necessidade de regularização fundiária possibilitada pelo Estatuto das Cidades (2001); verificando os técnicos e executores do governo municipal que apenas duas indústrias se instalaram na faixa de 1,5km reservada às indústrias, o próximo plano diretor municipal, vai ser gestado modificando a legislação do zoneamento municipal da área para adequar-se ao Estatuto da Cidade, principalmente quanto à questão ambiental.

Além dessa adequação, a ocupação urbana, em sua maior parte, irregular das populações carentes, também deveria ser analisada para ser saneada através de programas de habitação popular, com realização de planos de habitação de interesse social e indicação de ZEIS, e aplicação de outros instrumentos urbanísticos disponibilizados pela nova legislação urbana federal, a ser aplicada com especificidade municipal, pelo próximo PD municipal de 2004.

A urbanização no trecho estudado, consolidada na década de 50 com a industrialização do distrito próximo de Votorantim e o declínio das plantações de frutas e hortaliças, vai aumentar a ocupação irregular das áreas próximas à linha férrea e ao curso de água; das doze vias públicas regularizadas em meados da década de 60 (lei 1071/63), na década de 80 já podemos ver pelas manchas da foto aérea do satélite Landsat de 30/12/84 que as manchas urbanas já se espalharam em vários núcleos ao longo da via férrea, e subindo as encostas dos morros próximos à estrada de ligação entre Brigadeiro Tobias e Aparecidinha, outro distrito antigo ao norte. $\mathrm{O}$ número de ruas, inclusive já servidas por ônibus circulares já aumentou bastante, em número e em profundidade no território, em relação ao eixo longidutinal da RRT.

É notório o crescimento às margens deste trecho da RRT em Brigadeiro Tobias, que se desenvolve dispersamente, possibilitando novos bairros nos arredores. No mapa de 20140 bairro de Brigadeiro Tobias de Sorocaba atualmente é cercado pelos bairros: Novo Eldorado, Caputera, Tupã I, Tupã II, Mato Dentro, Vila Astúrias, Genebra, Inhaíba, Serrinha. O acesso principal destes bairros é pela RRT. A regularização das áreas urbanizadas se fazia necessária sob o ponto de vista do órgão da prefeitura municipal de Sorocaba, e para empresários do setor imobiliário, a possibilidade de novos negócios pelo sistema MCMV poderia se concretizar com 0 baixo preço das áreas da zona leste do município, de baixa ocupação devido à topografia e à 
restrição legal proporcionada até então pelo zoneamento de Zona rural e de Zona de chácaras urbanas.

A primeira intervenção de políticas públicas que afetou diretamente estre trecho estudado no período de 2000 a 2015 foi a execução da rod. Celso Charuri, interligação realizada como PPP e inaugurada pelo governador Geraldo Alckmin (PSDB) em 28/06/2003 (Fig. 104).

Figura 104 - Detalhe do folheto distribuído pela ViaOeste/GESP no dia da inauguração da rod. Celso Charuri, em 28/06/2003.

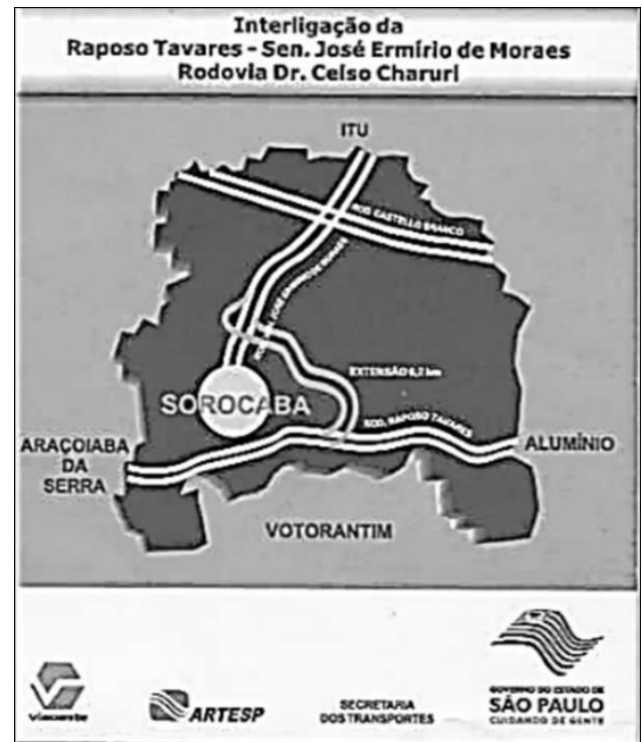

Fonte: Pró-Vida. Disponível em: https://www.provida.net/br/tribute-03/, acesso em nov/2017.

Enquanto o plano diretor municipal de Sorocaba foi sendo elaborado pela prefeitura municipal (PSDB) (1999 a 2004), foi também iniciado em 2003 o projeto do novo contorno da RRT no trecho de Brigadeiro Tobias ( $\mathrm{km} 88$ a 92), demanda da população do bairro atendida e inaugurada em 07/08/2007 pelo então governador José Serra (PSDB), que então discursou:

"É uma obra que (...) Custou 62, quase 63 milhões de reais; não é brincadeira. É uma obra bastante cara, mas vai trazer muitos benefícios aqui para a região. Mais segurança, mais conforto para quem usa a Raposo Tavares vindo de São Paulo, Cotia, Vargem Grande Paulista, Ibiúna, São Roque, Mairinque, quem vem para Sorocaba e vice versa. Vai também desafogar, desviar o tráfego; 0 Vitor ${ }^{48}$ sempre fala, (...) do centro do distrito de Brigadeiro Tobias tirando, transformando Brigadeiro Tobias em um bairro, e não apenas em um ponto de trânsito, de trânsito pesado.

(...) 0 contorno alternativo de Brigadeiro Tobias: 2,5 quilômetros; dois dispositivos de desnível localizados nos quilômetros 87 e 88, onde há duto em cada dispositivo; implantação de um viaduto sobre a via férrea; implantação de um viaduto sobre a via de acesso ao bairro Vila Astúrias; dois viadutos ferroviários para a transposição sobre o viário local da Avenida dos Bandeirantes; dois viadutos ferroviários sobre 0 acesso ao bairro Vila Astúrias; implantação de uma passarela; implantação de um sistema de drenagem; sinalização horizontal e vertical; recuperação asfáltica da Avenida dos Bandeirantes, duplicação da SP-270 em uma extensão de um quilômetro com a implantação de pista nova e recapeamento da existente.

48 Vitor Lippi, prefeito Município de Sorocaba da época. 
Enfim, vocês vêm que é muita coisa; oito viadutos." ${ }^{\text {99 }}$ (GESP, 2007).

Na época da inauguração do novo contorno, o então prefeito de Sorocaba, atualmente deputado federal Vitor Lippi (2015-2018), já havia começado a construir sua base eleitoral em Mairinque, como vereador pelo PDT; colaborou para a emancipação de Alumínio de Mairinque (que já havia de emancipado de São Roque); e também foi vereador no primeiro governo municipal, e chegou a presidente da câmara municipal de Alumínio. Como médico de formação, foi convidado para ser o secretário da saúde no governo Renato Amary (PSDB), e quando este terminou duas legislaturas como prefeito municipal de Sorocaba, Lippi mudou de partido (para o mesmo de Amary, que o fundou em Sorocaba), e elegeu-se prefeito municipal de Sorocaba, exercendo este mandato por duas vezes consecutivas. 0 fato de que o governo municipal (PSDB) à época (2007) ter boa interlocução com o governo estadual (PSDB) certamente colaborou para que o novo contorno da RRT pudesse ser executado, após 50 anos do início do asfaltamento da RRT no trecho em questão (sendo realizado projeto, desapropriações e as obras entre 2003 e 2007); e foram inauguradas antes das eleições municipais de 2008, o que pode ter, junto às outras ações e opções, colaborado significativamente para o resultado positivo ao partido, que manteve o poder municipal até as eleições de 2016 em Sorocaba.

Após tantos anos e PD municipais aprovados, a população de Brigadeiro Tobias, nas áreas ocupadas nas várzeas e encostas dos morros, em situação precária, ainda não tem regularização de suas casas, pois a maioria está estabelecida na faixa de domínio da linha férrea. Nas cotas mais altas, além de colaborar para a dificuldade de acesso, a falta de regularização fundiária complica a busca por recursos financeiros para melhorias de vias e habitações; os vereadores eleitos nos períodos de 2009-2016 não conseguiram a esperada regularização fundiária, e na atual câmara de vereadores não há nenhum eleito especificamente para tratar das questões de regularização ou colocação de um empreendimento HIS no Trecho 3 pela população local.

${ }^{49}$ http://www.saopaulo.sp.gov.br/discursos/inauguracao-contorno-brigadeiro-tobias-e-duplicacao-do-trecho-darodovia-sp-270/, acesso em nov/2017. 
Figura 105 - Vista aérea do Trecho 3, de Brigadeiro Tobias em 1962.

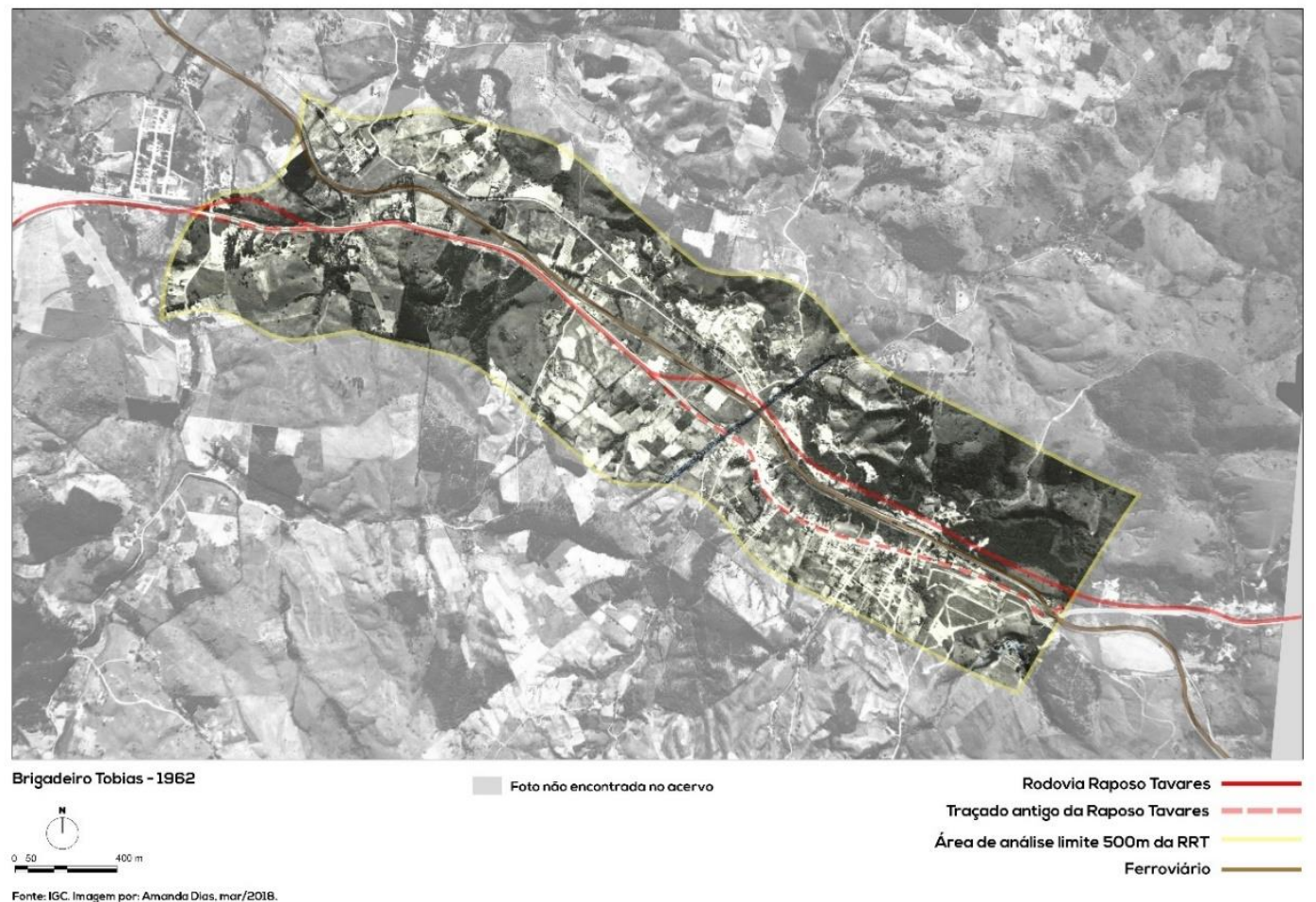

Figura 106 - Vista aérea do Trecho 3, de Brigadeiro Tobias em 1972.

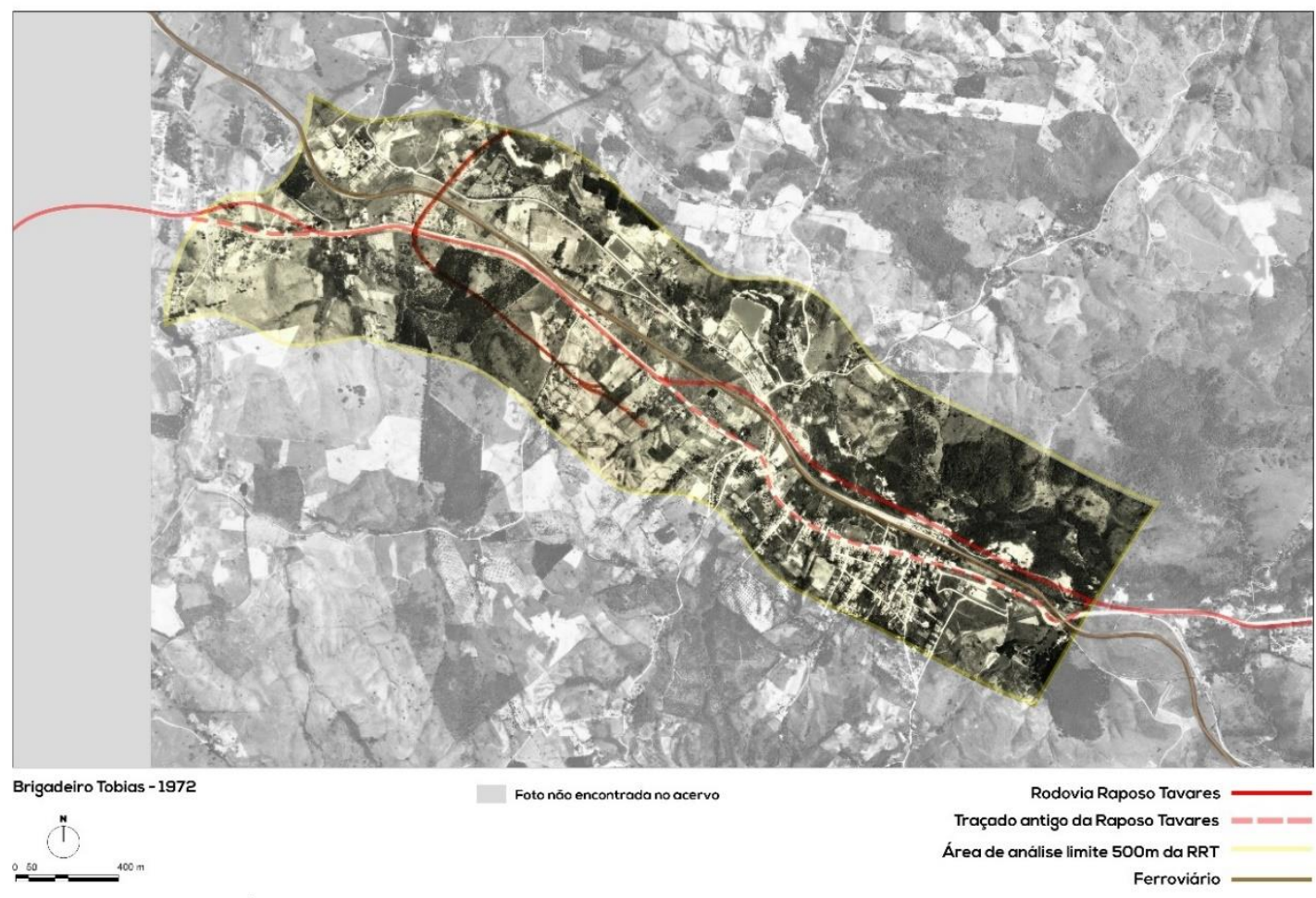


Figura 107 - Vista aérea do Trecho 3, de Brigadeiro Tobias em 1978.

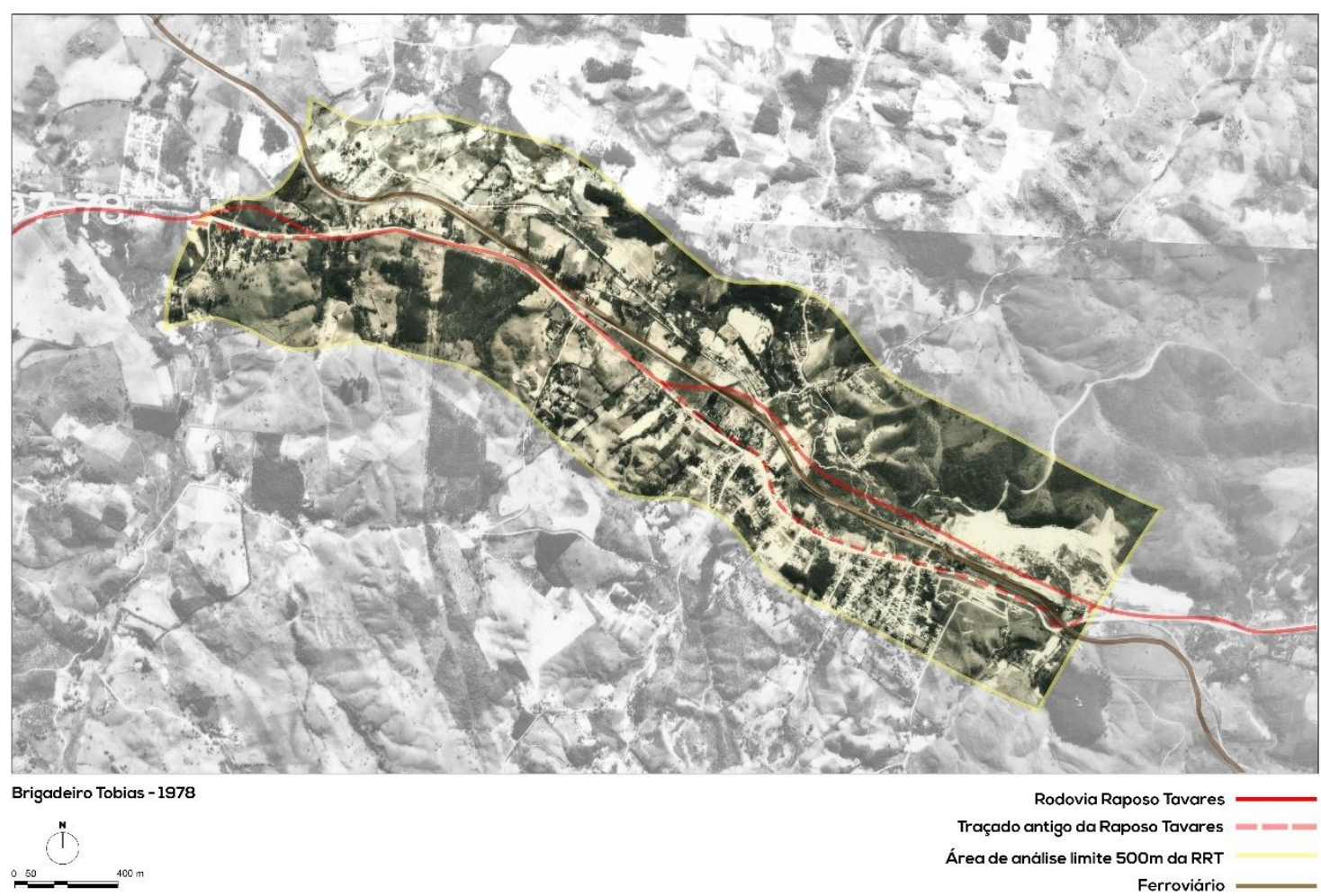

Figura 108 - Mapa do Uso do Solo do Trecho 3, de Brigadeiro Tobias em 1981.

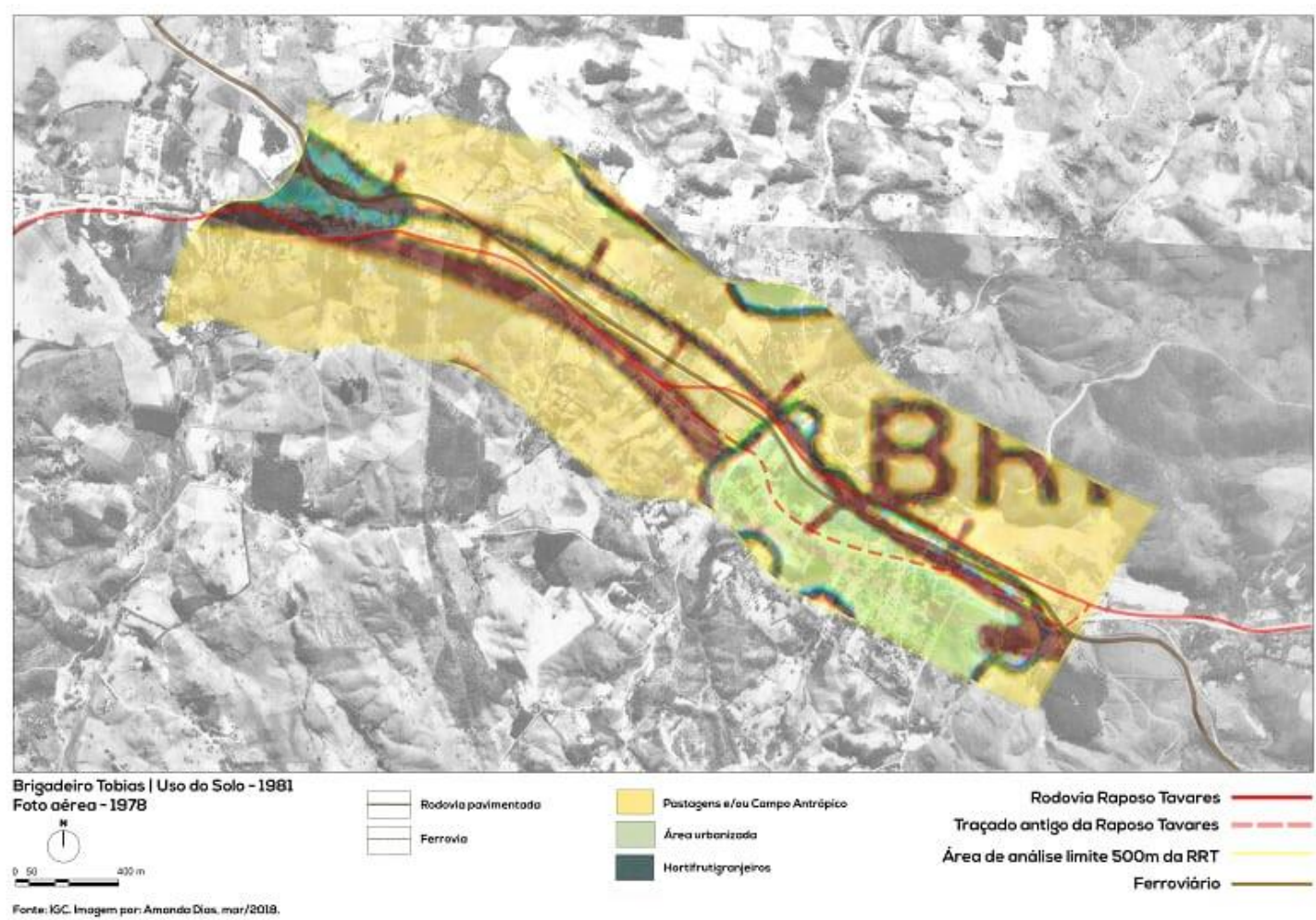




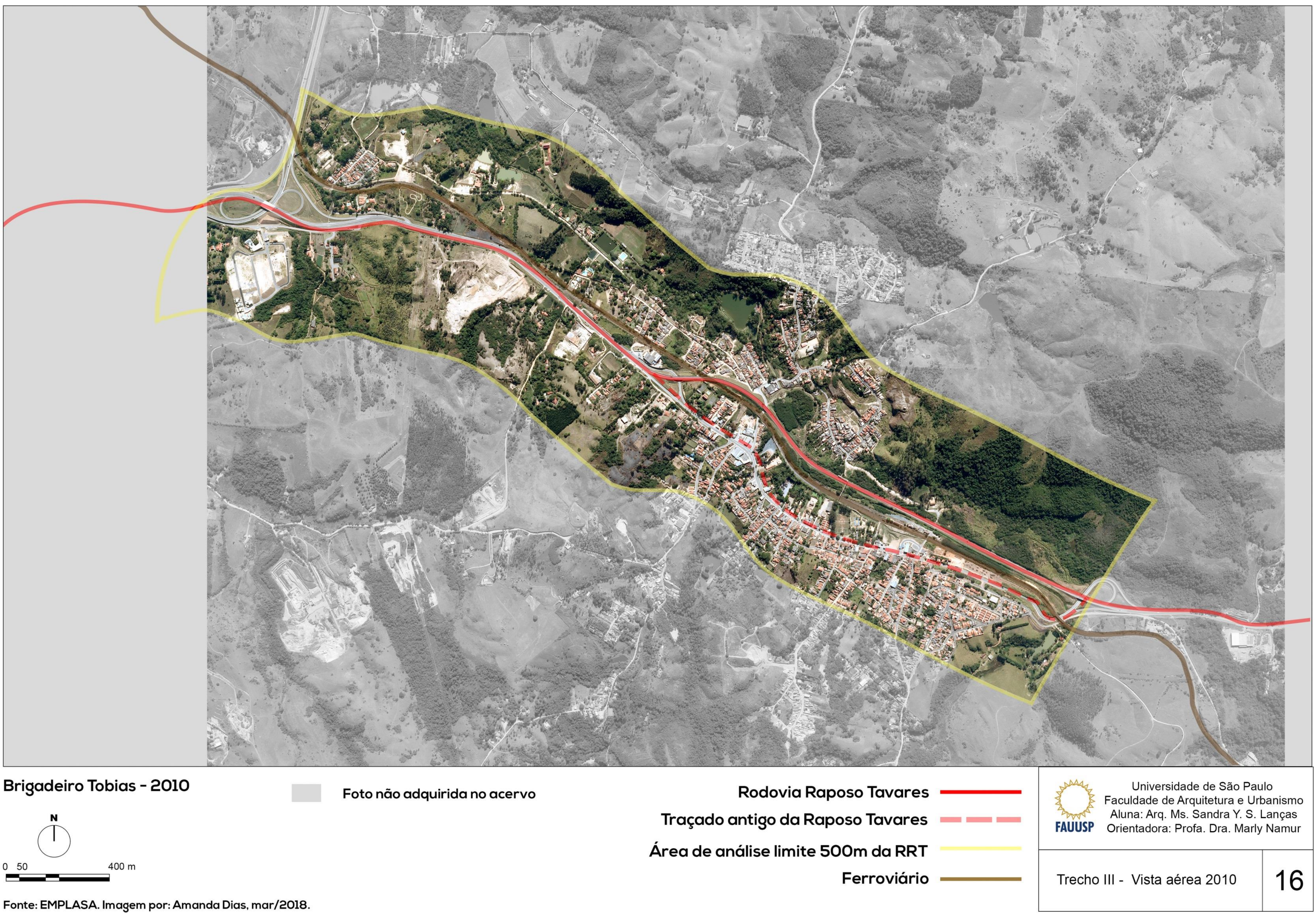


Comparando-se a ocupação urbana de 1950 à de 2005, com as leis de zoneamento propostas para o Distrito de Brigadeiro Tobias neste intervalo de tempo, até a aprovação do novo plano diretor em dezembro de 2004, percebe-se que em realidade estas leis contribuíram grandemente para a ocupação irregular nas áreas do trecho estudado, pois focavam a questão da instalação das indústrias, com a diretriz de ocupação para as áreas lindeiras à linha férrea e a estrada de rodagem na época, aumentando o tamanho do lote mínimo de 400m2 para 2000m2 na zona rural. Embora a questão da instalação de novas indústrias junto ao eixo da rod. Castelo Branco tenha sido bem enfrentada, com a instalação até neste início do século XXI de novas indústrias neste eixo rodoviário, não foi o caso da RRT neste trecho estudado. Examinemos as hipóteses da não ocupação pela indústria, esperada pelas autoridades municipais após a promulgação da primeira lei do PD municipal (no: 162/50):

$\left.1^{\circ}\right)$ Base Fisiográfica: não se levou em conta as características naturais deste trecho da RRT, dadas pela base fisiográfica: a instalação da Casa-sede da Fazenda Passa-Três se deu na localidade de mudança da base cristalina para a sedimentar, (fator que motivou a implantação de várias cidades ao longo da transição geológica do Estado de São Paulo: Sorocaba, Campinas, etc), facilmente percebida pela população nativa e dos governantes portugueses da época colonial, que seguiam a leitura da paisagem para se movimentarem no território; bem como pela linha férrea, que ocupou as várzeas, junto ao caminho possível por entre as serras (de São Francisco e Inhaíba), cheio de morros de alta declividade, nascentes e cursos d'água; não propiciava a facilidade necessária às indústrias de receberem os insumos e enviarem os produtos executados, a não ser pela ferrovia, mais a granel, proporcionada pelas indústrias já instaladas no distrito de Votorantim;

$2^{\circ}$ ) População de baixa renda: desde o início da implantação da fazenda, a ocupação da área próxima à casa sede e da estação ferroviária foi pela população menos favorecida em termos de rendimento: primeiro ali estavam os escravos da fazenda (próxima à casa-sede); depois os imigrantes europeus (que se estabeleceram nas encostas e utilizavam o transporte ferroviário e rodoviário para o escoamento de seus produtos) e depois alguns migrantes paranaenses (BADDINI, 2002) ; antes mesmo da desativação da estação ferroviária em 1993; quando a área mais plana se esgotou (as onze ruas iniciais do núcleo central aprovadas pela lei 1071 de 1963), iniciaram a ocupação do outro lado da RRT, pela rua Rodolfo Garcia, formando vielas que existem até hoje.

Sem enfrentamento da questão de políticas públicas de habitação popular para a área do trecho estudado na década de 60, 70, 80 (anos de aumento da população local, decorrente também da situação de crise econômica da época); a necessidade da habitação popular, ainda 
aumentou para as proximidades do curso de água principal próximo ao início da rua Miguel Ascêncio e depois subiu o morro pela Estrada do Vinte e Cinco, que se conecta com o distrito de Aparecidinha (localizado ao norte), conformando outros novos bairros: Vila Astúrias, São João, Vila Tupã 2, todos com tipologia precária, de ocupação irregular, que sofre com a questão das chuvas (a drenagem pluvial da zona rural sempre foi objeto de preocupação na lei municipal, detalhando-se a necessidade de execução dela sem ser à custa do recurso público);

$3^{\circ}$ ) Aumento do tamanho do lote mínimo de $400 \mathrm{~m} 2$ solicitados pela lei 162 de 1950 para a zona rural de então, tenha sido modificado para $2000 \mathrm{~m} 2$ para que a zona rural pudesse receber, com bom tamanho de lote, as pequenas indústrias ao longo dos trechos municipais da RRT;

$\left.4^{0}\right)$ Tamanho da faixa lindeira proposta $(1,5 \mathrm{~km})$ para uso industrial, para cada lado do eixo longitudinal da linha férrea e da RRT, muitas vezes inviabilizando a ocupação oficial desta faixa como proposta, embora com intenção do município e suas atividades econômicas beneficiarem-se da facilidade de integração à ela. mesmo quando parte do trecho estudado é incorporado para a área urbana, na essência desta lei o que ainda se pretende é a instalação de novas indústrias; (faixa ao longo da atual rodovia Celso Charuri (SP91-270), do lado do distrito de Aparecidinha e Brigadeiro Tobias), mas como a região é cheia de lagos e cursos de água, já havia ocupação por clubes (Country Club Shangri-lá nos anos 70 e 80; Centro do Professorado Paulista, no cruzamento da Av. São Paulo com a variante da RRT, no final do trecho; a futura Universidade de Sorocaba, onde antes era plantação de laranjas; mais tarde, com o aumento do perímetro urbano, o parcelamento de empreendimentos em lotes residenciais;

$5^{\circ}$ ) Inviabilidade de se manter apenas a ocupação e uso do solo pela indústria, não só pela questão da base fisiográfica, e dificuldade de movimentação do território dos caminhões pelas estradas rurais: como o trecho estava localizado em uma das estradas mais antigas do País, já havia ocupação e uso do solo em seus trechos com vários usos definidos, muitas vezes há séculos; e em outras vezes pela questão da propriedade;

$\left.6^{\circ}\right)$ Zoneamento rural ou agrícola, que em 1950 permite a atividade rural, e as habitações populares com lotes mínimos de quatrocentos metros quadrados, e ocupação de sessenta por cento no máximo, não é compatível com este trecho estudado, onde a população é de baixa renda, não há condições da população da vila ter um lote mínimo de 400m2;

$7^{\circ}$ ) Zoneamento ultra-permissivo do PD de 1966 para o trecho estudado, em termos de implementação de industrias não funcionou, pois a priori, poderia ser de vários tipos perigosos, alinhados lado a lado, embora somente com a autorização do setor de planejamento da 
prefeitura municipal de Sorocaba, o que por fim, se aplicado, poderia não garantir a segurança jurídica buscada pelo empresariado industrial;

$8^{\circ}$ ) Zoneamento sem diferenciação para a RRT e RCB: poderia ter sido feito um zoneamento diferente para duas rodovias tão importantes, justamente pelo posicionamento opostos no território e de base fisiográfica diferentes; consideradas apenas como rodovias, não foi levado em consideração como fator de determinação de localização industrial, (fator que 0 empresariado industrial considera primordialmente ao instalar suas fábricas);

Por todos ou individualmente, todos estes itens mencionados acima, o zoneamento municipal das leis de 1950 a 1968 não funcionou para o trecho estudado, pois não levaram em conta o tipo de terreno, sua topografia e cursos d'água gerados; não houve inclusão de políticas públicas para ocupação do território de maneira regular para abrigar de maneira digna a população que necessitava delas; o conjunto habitacional "Habiteto" foi implantado na zona norte de Sorocaba, a dezesseis quilômetros do centro principal, ao final do séc. XX, desprivilegiando a população carente dos antigos distritos municipais, que já tinham núcleos carentes consolidados, mas com ocupação de muita precariedade.

Nesta época, o poder público municipal escolheu retirar a população carente das áreas públicas ocupadas, mais centrais, portanto "mais visíveis" e colocá-las na zona norte da área urbana do município, e determinou isto legalmente no próximo PD municipal de 2004); portanto quando chegou-se ao ano de 2005, verificou-se extensa ocupação irregular do solo, com habitações precárias e ocupações em vilas com 30 anos ou mais de existência; a população e a área ocupada irregularmente aumentou muito em relação à vila de 1950.

A ocupação urbana deste trecho foi realizada sem condições apropriadas primeiramente nas áreas planas próximas à estação ferroviária, ao longo da estrada de rodagem e da linha férrea, de forma linear; depois, subiu os morros mais próximos, mesmo considerando-se a alta declividade, as voçorocas e a falta de infra-estrutura para água potável e esgotamento sanitário. A população local tentou por anos a regularização fundiária, mas até o início do séc. XX não havia sido atendida.

A população de Brigadeiro Tobias que ocupa irregularmente parte do trecho urbano, elegeu em 2009, um vereador (guarda municipal Geraldo Reis) para tentar a regularização fundiária de suas casinhas, estabelecidas ao longo da férrea, Rio Pirajibu e ainda nos morros próximos, pois estavam se estabelecendo há mais de trinta anos. Não conseguiram, e em 2013 elegeram outro vereador, Muri de Brigadeiro, que também não obteve a regularização fundiária pretendida pela população mais carente. 
Figura 110 - Fotos da visita do vereador Geraldo Reis, à vila São João, distrito de Brig. Tobias, ocupação do lado direito da RRT.

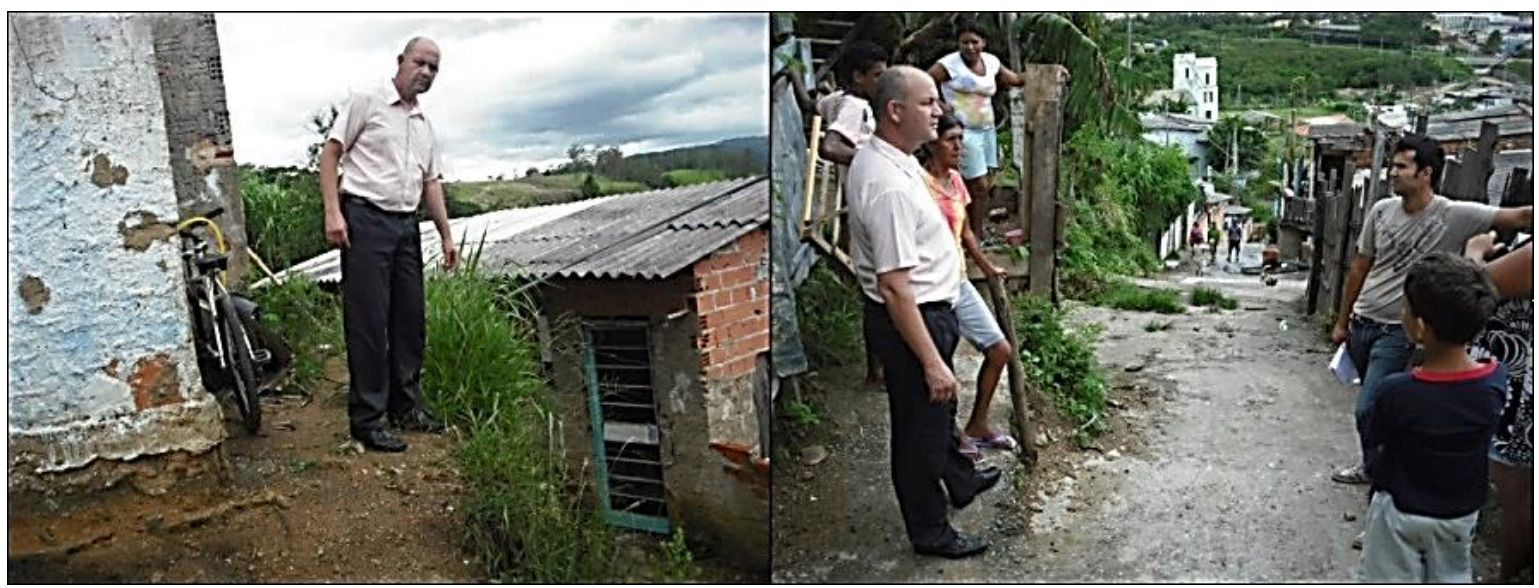

Fonte: blogspot vereador.geraldo.reis. Data: 2011.

Com o PD de 2014, os vetos parciais e o ADIN que garantiram a lei no papel, mas ainda não foi instituído como resolução deste problema jurídico. Como mudou a administração municipal, nas últimas eleições municipais (2016), e a nova administração também teve problemas em sua estabilidade (foi cassada pela Câmara Municipal na metade do ano de 2017 e voltou através do sistema jurídico após 40 dias), foi um ano atípico politicamente que colaborou para a indefinição dos termos dos índices de ocupação do uso e ocupação do solo no trecho de Brigadeiro Tobias.

No campo de proposições ambientais, a proposta da FAU-USP para uma APA de Brigadeiro Tobias (MACEDO, 2009), condição que talvez oferecesse um desenvolvimento mais sustentável para a preservação das nascentes, não vingou. Desde 2013, o poder público propôs a criação do Parque Natural de Brigadeiro Tobias, já decretado por lei municipal em 2015 (Decreto $n^{0}$ 21.618, que o criou oficialmente na condição de Unidade de Conservação e Proteção Integral). Sobre o parque, o então prefeito Antonio C. Pannunzio, em seu segundo mandato como prefeito de Sorocaba (2013-2016) se pronunciou:

"Tal medida essa que vem ao encontro dos interesses da população de Brigadeiro Tobias, que há muito reclamava a adoção dessa medida. (...)

É o que aconteceu com o Parque Natural Municipal de Brigadeiro Tobias. A partir de um processo aberto em meu primeiro ano de governo, ele acaba de se converter numa realidade jurídica com a publicação, no jornal oficial do município, do Decreto $n^{0} 21.618$, que 0 criou oficialmente na condição de Unidade de Conservação e Proteção Integral. Tal medida essa que vem ao encontro dos interesses da população de Brigadeiro Tobias, que há muito reclamava a adoção dessa medida. Com uma área de 117 mil metros quadrados, ele é um fragmento da antiga Fazenda Passa Três, que pertenceu ao Brigadeiro Rafael Tobias de Aguiar.

Com o advento da legislação ambiental alicerçada na Constituição de 1988, criaramse limites rígidos à utilização do seu entorno e favorecendo a sua utilização para fins de preservação de ecossistemas naturais de grande relevância ecológica e beleza cênica; a realização de pesquisas científicas e o desenvolvimento de atividades de 
educação e interpretação ambiental, de recreação em contato com a natureza e de turismo ecológico. (...)

Temos nele múltiplos pontos em que a Mata Atlântica, que é uma floresta úmida típica de encostas, contata-se com o Cerrado e o interpenetra, gerando um tipo de paisagem que em poucos locais do território paulista se pode ver. Essas peculiaridades são pouco conhecidas e, até por isso, insuficientemente valorizadas. O Parque Natural de Brigadeiro Tobias abriga, portanto, dois portais valiosíssimos: 0 ambiental, que permitirá aos sorocabanos, com a orientação técnica necessária, melhor apreciar o nosso patrimônio vegetal e as formas de vida que nele se desenvolvem, e o histórico, que nos remete às nossas origens rurais, hoje em grande parte esquecidas." (Pannunzio, 2015)50.

O único ganho para o trecho nas políticas públicas urbanas foi em termos ambientais, porque foi instituído pelo decreto $n^{0} 21.618$, de 7 de janeiro de 2015, o Parque Natural Municipal de Brigadeiro Tobias, em uma área de 117.067,39 metros quadrados, parte das propostas do Plano Municipal de Conservação e Recuperação da Mata Atlântica, elaborado em 2014 pela Secretaria do Meio Ambiente (Sema), em parceria com universidades da cidade, com o objetivo de proteger os fragmentos ainda existentes em Sorocaba, restaurar as áreas que hoje se encontram degradadas e recuperar as áreas importantes de serem vegetadas. 0 instrumento atende à Lei n ${ }^{0} 11.428$, de 22 de dezembro de 2006 - a chamada Lei da Mata Atlântica.

Atualmente, o distrito de Brigadeiro Tobias apesar de sua distância (c. 16km) ao centro da área central de Sorocaba, tornou-se, por ser trajeto alternativo da capital ao interior do Estado, uma centralidade no território municipal, principalmente para os bairros rurais ao longo da RRT; possuindo prestação de serviços públicos (Casa do Cidadão, Sabe-Tudo), comércio e usos institucionais (Escola Estadual Brigadeiro Tobias), supermercados, postos de gasolina, pequenos comércios e prestações de serviços; na área rural, tem-se sítios, chácaras, pesqueiros, e paulatina ocupação urbana, subindo os morros da região, que tem até $40 \%$ de declividade e solos suscetíveis à erosão (PD Sorocaba, 2004). Do lado oposto da área da Avenida Bandeirantes em Brigadeiro Tobias, tem-se a Vila Astúrias, e a rua Miguel Ascêncio, que passa paralelamente à RRT, onde além de pesqueiros e clube de campo sindicais, tem-se também vielas, com casas colocadas em barrancas, talhados em à picaretas, evidenciando a condição de vulnerabilidade social já detectada pela renda média pesquisada nos setores censitários pelo IBGE. Conforme a Ficha IPVS51 Trecho I (pg. 19 e 20), na confluência das

\footnotetext{
50 In: http://diariodesorocaba.com.br/novo/pagina/2/293, acesso em nov./2017.

51 Índice Paulista de Vulnerabilidade Social, criado pelo governo estadual paulista para exemplificar a vulnerabilidade social de grupos sociais com dados fornecidos pelo IBGE por critérios trabalhados e atualizados pela Fundação Seade que os fornecem ao governo do Est. De São Paulo. Os sete grupos do IPVS resumem as situações de maior ou menor vulnerabilidade às quais a população se encontra exposta, a partir de um gradiente das condições socioeconômicas e do perfil demográfico segundo os grupos de 1 a 7: 0 Grupo 1 (baixíssima vulnerabilidade); Grupo 2 (vulnerabilidade muito baixa); Grupo 3 (vulnerabilidade baixa); Grupo 4 (vulnerabilidade
} 
rodovias Celso Charuri e acompanhando paralelamente à faixa urbana do distrito de Brigadeiro Tobias, tem-se os grupos de IPVS 4 (vulnerabilidade média), interligando as duas áreas de IPVS grupo 3 (vulnerabilidade baixa). Lembrando que os dados são de 2010, e que o rendimento médio mensal das mulheres da faixa de IPVS 1 era de aproximadamente R $\$ 2.800,00$ e do IPVS grupo 4 era de R $\$ 770,00$ (ALESP, 2010). No trecho RRT de Brig. Tobias, percebe-se que próximo à área urbanizada próxima à rodovia o IPVS da população estabelecida é majoritariamente 3 e 4 (Distrito de Brigadeiro Tobias); em direção à Alumínio, não tendo área urbanizada de dimensões significativa, predominam as chácaras urbanas e plantações de eucaliptos, conforme pode ser verificado no local.

Figura 111 - Mapa parcial com os grupos de IPVS por setor censitário do Trecho Brig. Tobias

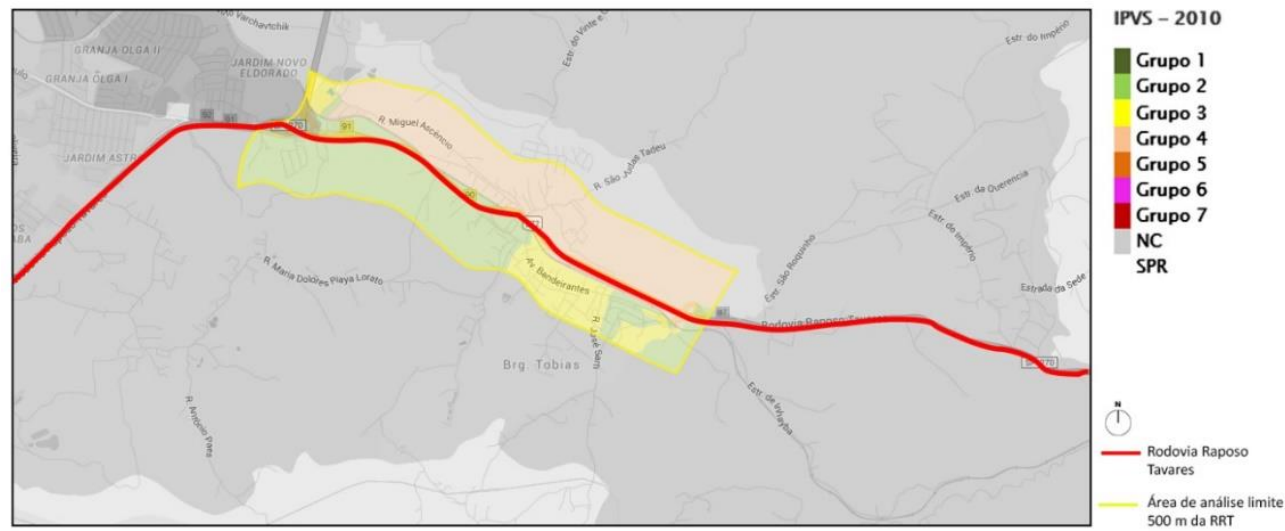

Destaque para a faixa de IPVS 4, paralela à rodovia Raposo Tavares, interligando duas áreas de IPVS grupo 3.) (dados de 2010). Fonte: Assembléia Legislativa do Estado de São Paulo. Acessado em: http://indicesilp.al.sp.gov.br/view/index.php, em janeiro/2016. Retrabalhado por Amanda Dias, 2018.

No km 92, confluência da RRT com o seu antigo trajeto de entrada em Sorocaba (av. São Paulo), e a interligação da RRT com a Rod. Celso Charuri, próxima da Universidade de Sorocaba (Uniso). A paisagem neste trecho tem características rurais e urbanas, e lembra a questão da dicotomia rural-urbana discutida por Caiado e Santos (2003). Não é de se admirar, pois trata-se de antigas propriedades rurais que a partir do final do século XX começam a ser desmembradas para outros fins, atendendo aos interesses de maiores demandas imobiliárias, proporcionadas pela fluidez de um trecho duplicado e inclusive depois interligado à Rodovia Castelo Branco (pela rod. Celso Charuri).

O bairro Jardim Novo Eldorado em Sorocaba, SP, na confluência das rodovias citadas, com grande quantidade de condomínios horizontais, lembra o crescimento de áreas urbanizadas

média - setores urbanos; Grupo 5 (vulnerabilidade alta - setores urbanos; Grupo 6 (vulnerabilidade muito alta aglomerados subnormais); Grupo 7 (vulnerabilidade alta - setores rurais). 
em meio às áreas antes rurais, que ocorreram em Sorocaba e em Brigadeiro Tobias, (pertencente a Sorocaba, SP) que está ao final deste primeiro trecho, está o distrito de Brigadeiro Tobias, que possui elementos históricos importantes da história local e até brasileira, (PRESTES, 2001) e a memória de lugares (BESSE, 2006) pelos que ali passam, pois antigamente a rodovia Raposo Tavares passava no meio da área urbana, desviado quando da duplicação no trecho de Brigadeiro a Sorocaba.

Com utilização regional, neste trecho a RRT é caminho diário de trabalhadores, que vão e voltam das fábricas do distrito industrial, ou à Itu, São Paulo; Campinas, etc; e estudantes, vindos de Ibiúna, São Roque, Mairinque e Alumínio, Itu, Porto Feliz, Votorantim, e de várias outras cidades da RMS, para as universidades e escolas técnicas localizados em Sorocaba, (a maioria por vans e fretados, alugados por suas próprias municipalidades), além da procura por serviços, ligados às áreas de saúde, educação, etc.

Também passa neste trecho da RRT a maioria dos caminhões com cargas, vindos da região de Itapetininga e Piedade (devido à sua produção agrícola), destinadas à RMSP, além do transporte interestadual do sul do país, que desta forma evitam os custosos pedágios da rod. Castelo Branco (SP 280). A ferrovia atualmente já não transporta passageiros; então a concessão estadual permite o funcionamento dos ônibus da Viação Cometa para o transporte da população das mencionadas cidades à capital e vice-versa.

Quanto aos meios de transporte público local, a tabela abaixo denota a oferta de trajetos de circulação municipal ao distrito de Brigadeiro Tobias, muito utilizado inclusive pelos estudantes de Sorocaba e região, da Universidade de Sorocaba (UNISO), localizada no km 92,5, para se deslocarem até a universidade.

Ao lado da Universidade de Sorocaba, no lado esquerdo km 92 da RRT, está o Horto Florestal Municipal, e em frente a este, surgiu um empreendimento imobiliário vendendo lotes de 250 a 500m2 com entrada e saída facilitada para a RRT no $\mathrm{km} \mathrm{95,} \mathrm{refletindo} \mathrm{a} \mathrm{tendência} \mathrm{de}$ ocupação urbana observada de instalação desses empreendimentos, pela facilidade de acesso proporcionada pela RRT.

No mapa de Uso e Ocupação do Solo elaborado pela EMPLASA, com as chamadas Unidades de Informações Territoriais (UIT), verificamos que o uso do solo para o trecho estudado tem como maior característica o residencial, do lado esquerdo da RRT, e do lado direito, ainda existem áreas de interesse ambiental e áreas de uso predominantemente rural. Do lado direito deste trecho, no km 88 da RRT, ainda está ocupado pelos campos e matas, devido à topografia, mas as estradas rurais já ligam os bairros de Brigadeiro Tobias e Aparecidinha, mais ao norte. 
A ocupação urbana está avançando, principalmente do lado esquerdo da RRT neste trecho analisado, lado do núcleo urbano inicial da antiga estação ferroviária, onde predomina a ocupação residencial. Do outro lado, devido a topografia, ainda ela é menor do que do lado direito, fato que deve ser equilibrado com mais ações para a preservação e conservação dos mananciais. Do lado direito, temos a condição de maior vulnerabilidade social, conforme dados dos setores censitários (IBGE, 2016). Este trecho tem como característica ainda a extensão de campos e de matas nas áreas lindeiras, mas após o trecho urbano de Brig. Tobias, predominam as residências de uso misto (residência e comercio e/ou prestação de serviços) na área urbana antiga de Brigadeiro Tobias. Poucas indústrias (máximo de seis) e vários anúncios de novos empreendimentos imobiliário no trecho estudado.

Figura 112 - Localização e Vista aérea do trecho 3 - Brigadeiro Tobias km 88 a 92 RRT.

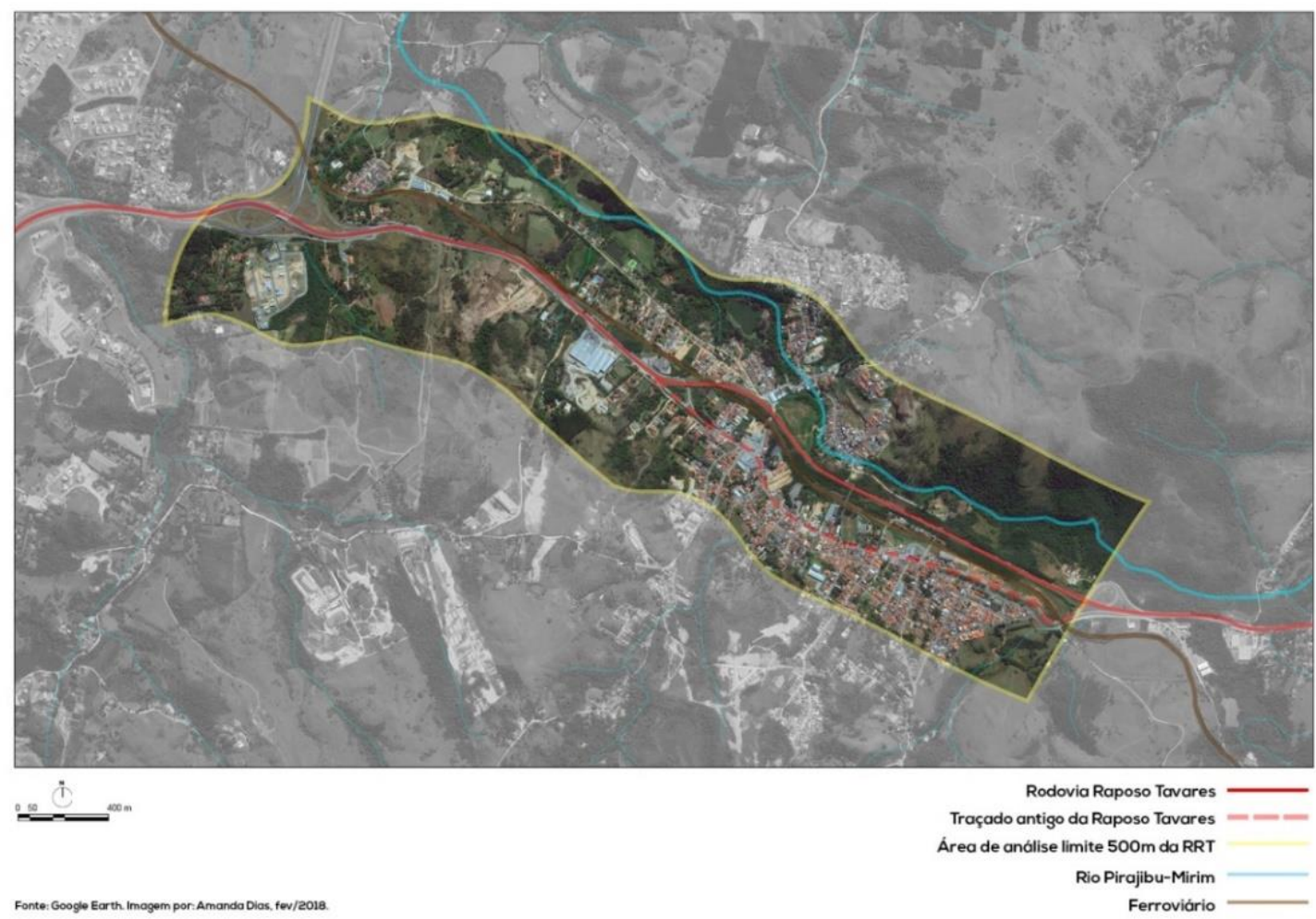


Figura 113 - Foto de entrada de "loteamento fechado" no km 91 da RRT, final do trecho estudado.

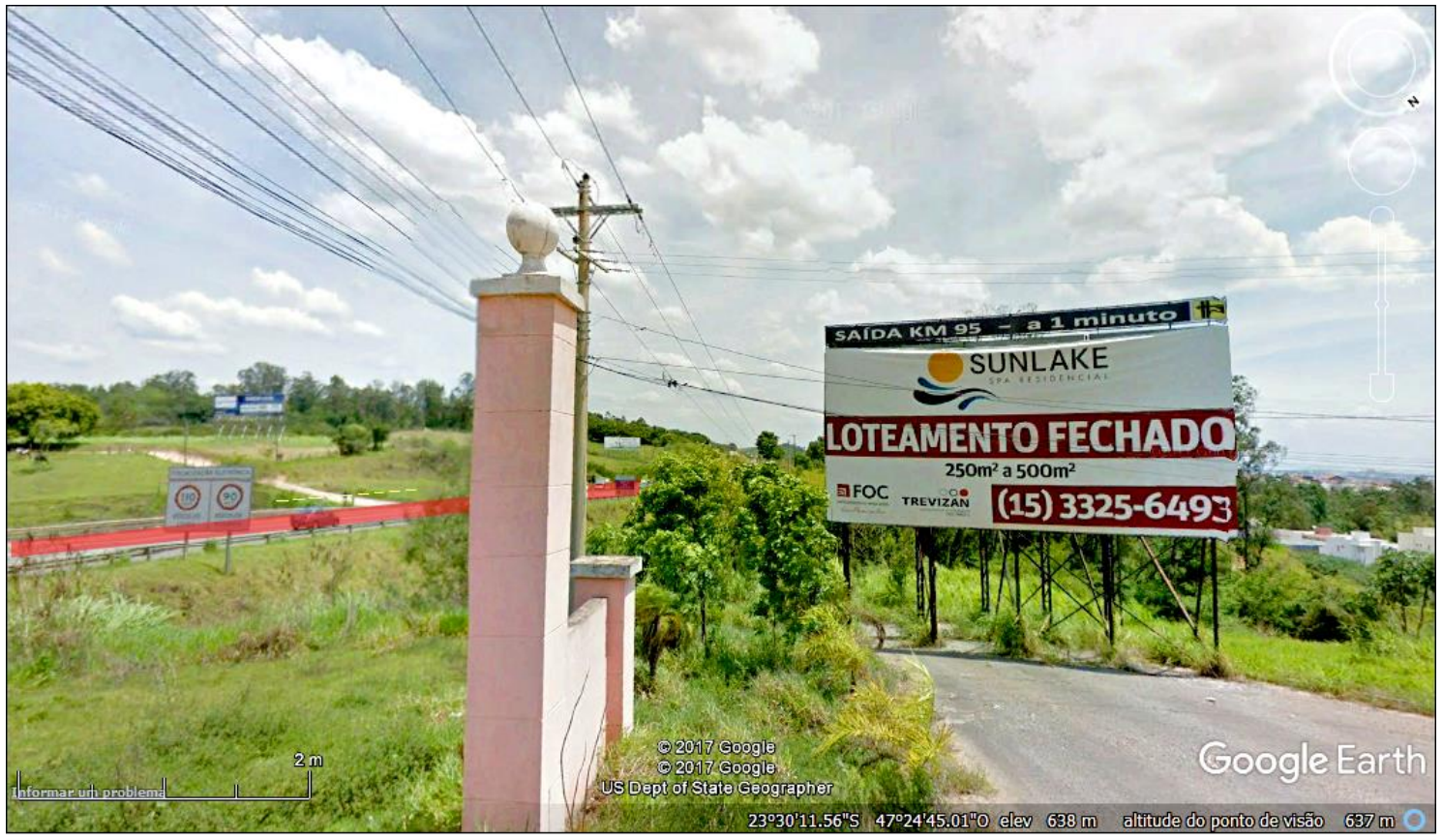

Rodovia Raposo Tavares

Fonte: Google Earth, 2017.

Figura 114 - Anúncio de empreendimento de 18 torres MCMV na Vila Astúrias, Brig. Tobias no canto inferior esquerdo, a RRT.

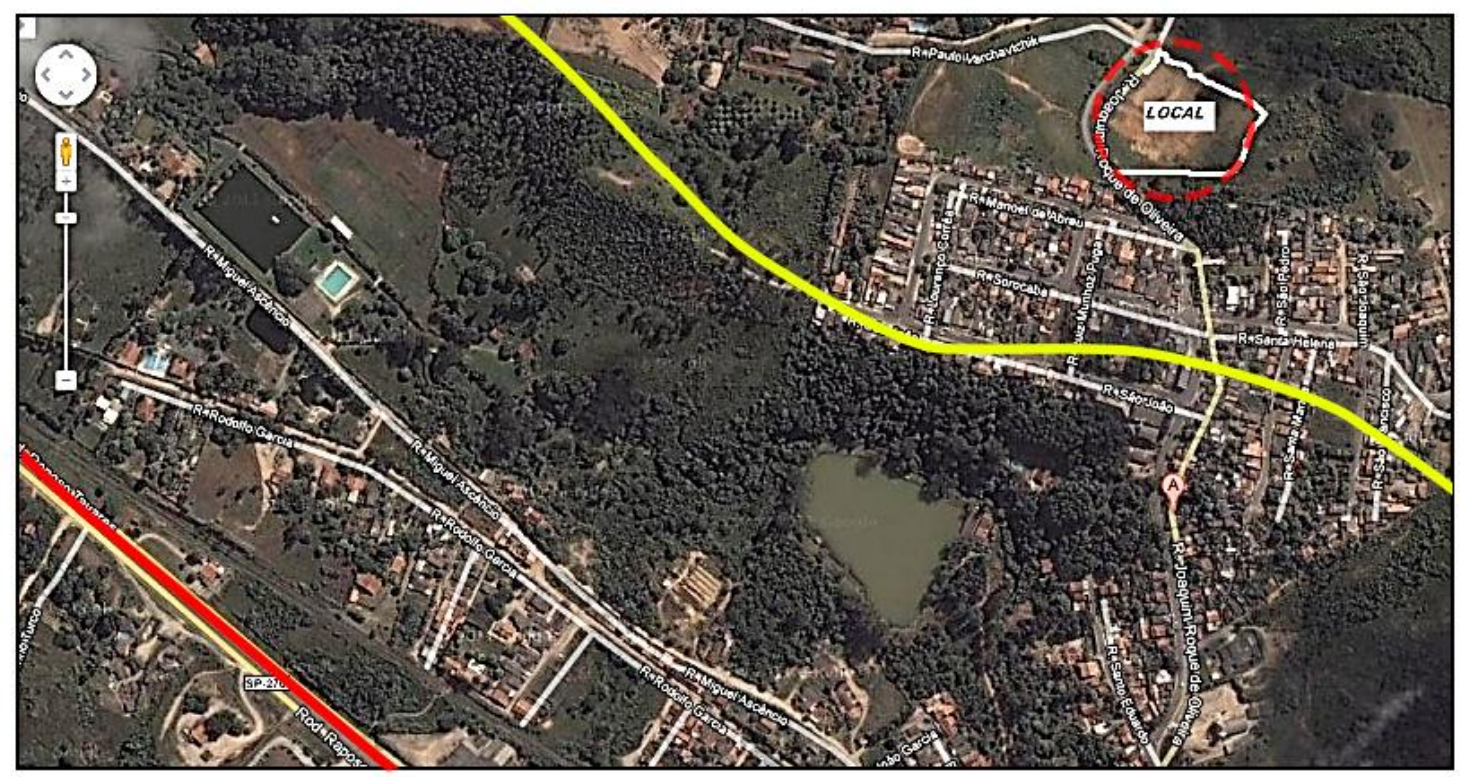

an Área: $23.643,95 \mathrm{~m}^{2}$. Rua Joaquim Roque de Oliveira, Bairro Brigadeiro Tobias - Sorocaba, SP. Pré projeto já com viabilidades aprovadas - 18 torres de 4 pavimentos $p /$ o plano (MCMV) Apartamento $=2$ Dor, útil $=45 \mathrm{~m}^{2}$ a $52 \mathrm{~m}^{2}$

Rodovia Raposo Tavares

Área de análise limite $500 \mathrm{~m}$ da RRT

Fonte: Site imobiliário sorocabano, acesso em outubro de 2017. Retrabalhado por Amanda Dias, 2018.

Concluímos pela foto aérea do trecho de 1962, que o zoneamento agrícola da lei no. 162/50 era seguido na maior parte do trecho 3. A área do núcleo central, ocupada próxima à 
estação ferroviária, já tinha um núcleo urbano que foi consolidado e legalizado pela lei no. 1071/63. Mas o distrito era distante do centro velho de Sorocaba, município sede; e para a zona rural eram deixadas as construções mais pobres, de casas de madeira e pequenas indústrias que poderiam causar incômodos à população da área central, mais nobre então. Portanto, pouco se vistoriava por lá.

Após o plano diretor de 1968, pelas fotos aéreas de 1972, 1978 e 1999 (IGC) e pelo mapa de uso e ocupação do solo do governo do ESP de 1981 percebe-se que o zoneamento agrícola estabelecido pelo PD de 1968 foi seguido em boa parte das áreas lindeiras do trecho de Brigadeiro Tobias, com utilização para a atividade agrícola; mas a partir da década de 60 as áreas começaram a serem ocupadas irregularmente principalmente nas várzeas do Rio PirajibuMirim e mais tarde, na área próxima à linha férrea do lado direito da RRT. Quando estas áreas já estão em sua maioria ocupadas, ainda que precariamente, a população mais carente começa a ocupar os terrenos de cota mais alta, ainda que em condições de risco, pois a declividade destes terrenos é maior do que 40\%; e quando chove, realmente há perigo de deslizamento; nas partes próximas ao Rio Pirajibu-Mirim, alagamentos. Surgem e se consolidam as ocupações da Vila Tupã I e II de grande precariedade em suas ocupações, até piores do que as verificadas em Alumínio.

Portanto, concluímos que o PD de 1968, não foi seguido na maior parte das áreas ocupadas pela população, uma vez que se passaram mais de quarenta anos para a promulgação de um novo plano diretor, em 2004. 
Figura 115 - Vista aérea da ocupação da várzea do Ribeirão Pirajibu, em Brig. Tobias; em segundo plano, o trecho d a RRT.

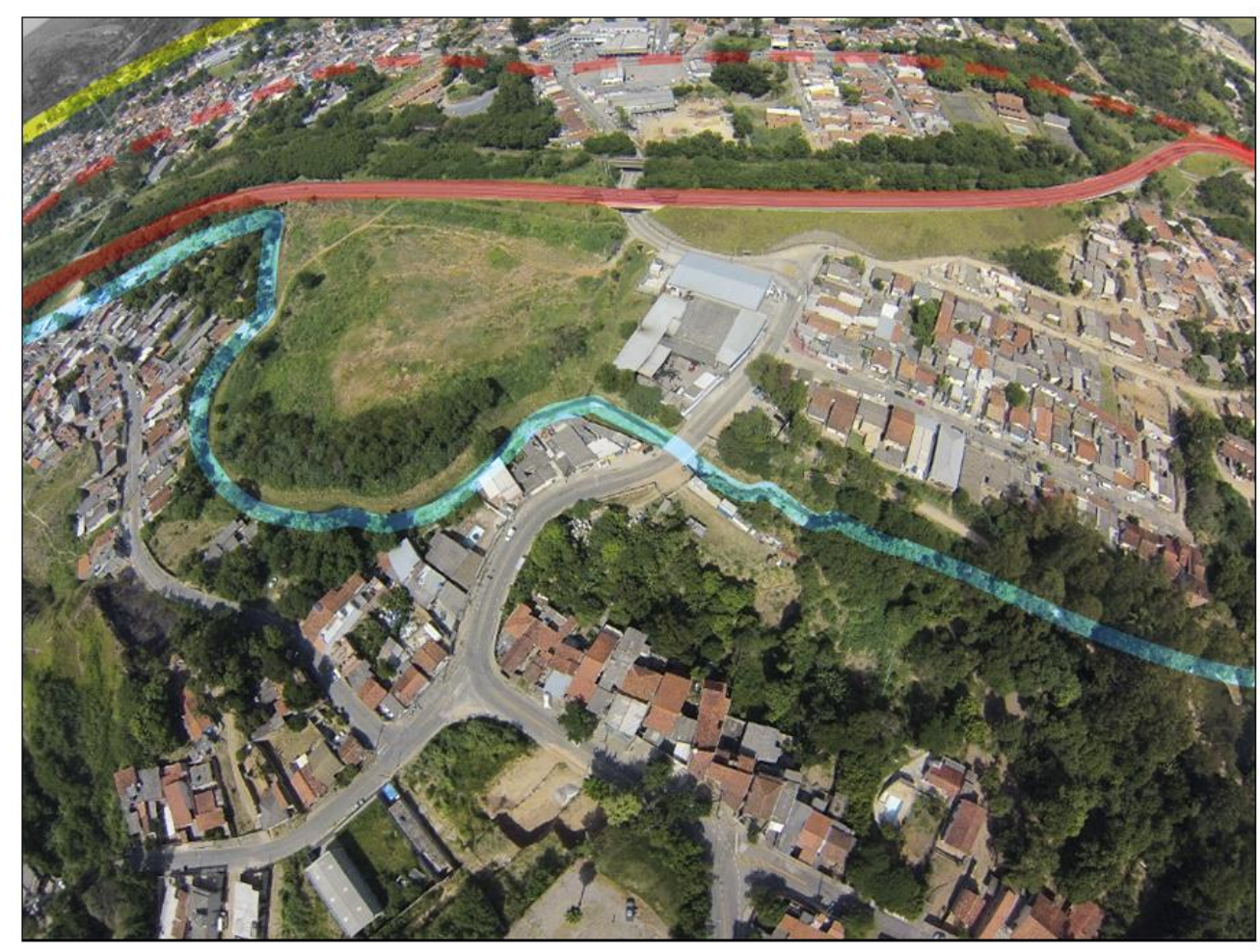

Rodovia Raposo Tavares

Traçado antigo da RRT

Área de análise limite $500 m$ da RRT

Rio Pirajibu-Mirim

Autor: Heiton Gomes. Data: abril/17, por drone. Retrabalhado por Amanda Dias, 2018. 


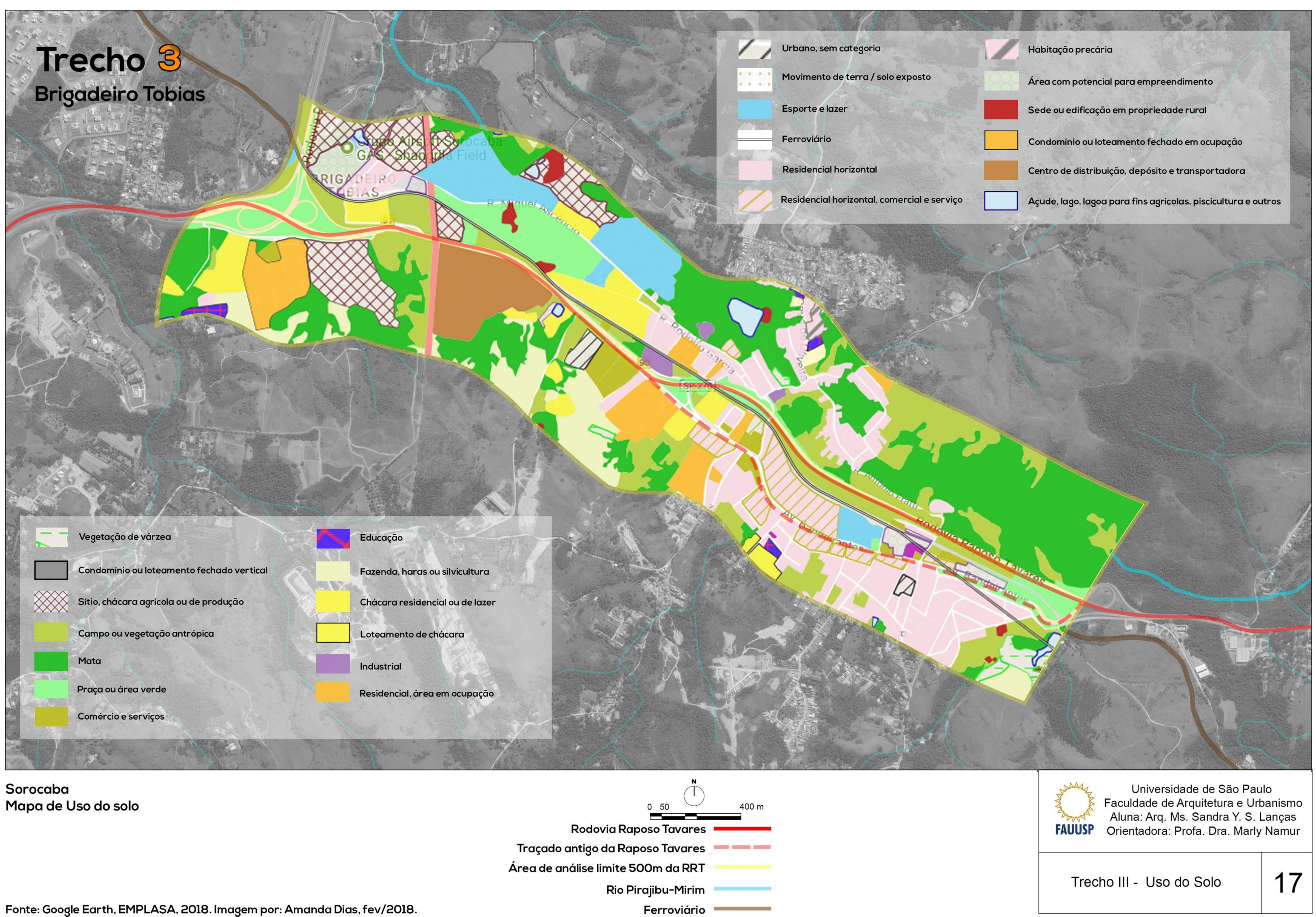




\section{CAP. VIII - URBANIZAÇÃO X LEGISLAÇÃO Zoneamento do Trecho 4 - CAMPOLIM: RRT do $\mathrm{km} 98$ A 102}




\section{CAP. VIII - URBANIZAÇÃO X LEGISLAÇÃO Zoneamento do Trecho 4 - CAMPOLIM: RRT do km 98 A 102}

Pela importância econômica local e regional, e seu desenvolvimento urbano ocorrido principalmente nas duas últimas décadas, este trecho foi escolhido para estudo denominado quatro. 0 trecho inicia-se no $\mathrm{km} 98$ até $0 \mathrm{~km} 102$ da Rod. Raposo Tavares (do Rio Sorocaba ao cruzamento da rodovia com a Av. Armando Pannunzio), e como nos demais trechos, inclui a área distante cerca de 500m de cada lado do eixo central longitudinal da rodovia (Fig. $117 \mathrm{e}$ 118).

Figura 117 - Foto aérea trecho 4 - Campolim.

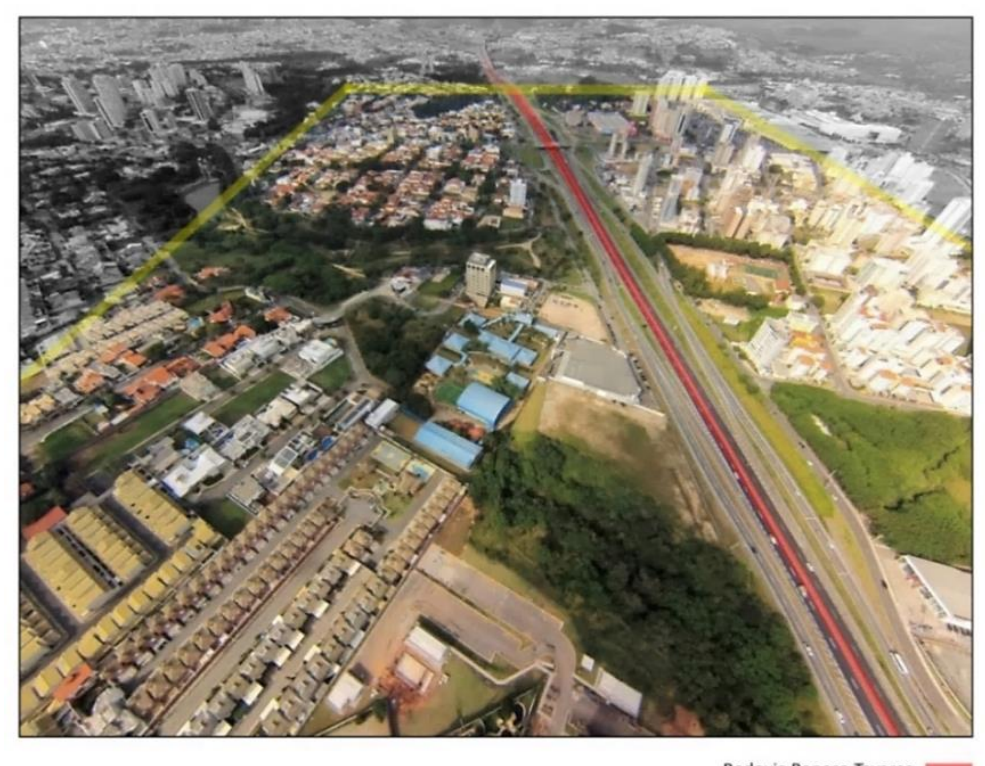

Rodovia Raposo Tavares

Área de análise limite 500m da RRT

Imagem: Heiton Gomes, por drone. Data: maio de 2017. Retrabalhado por Amanda Dias, 2018.

Figura 118 - Tráfego de veículos ficou lento na pista sentido interior.

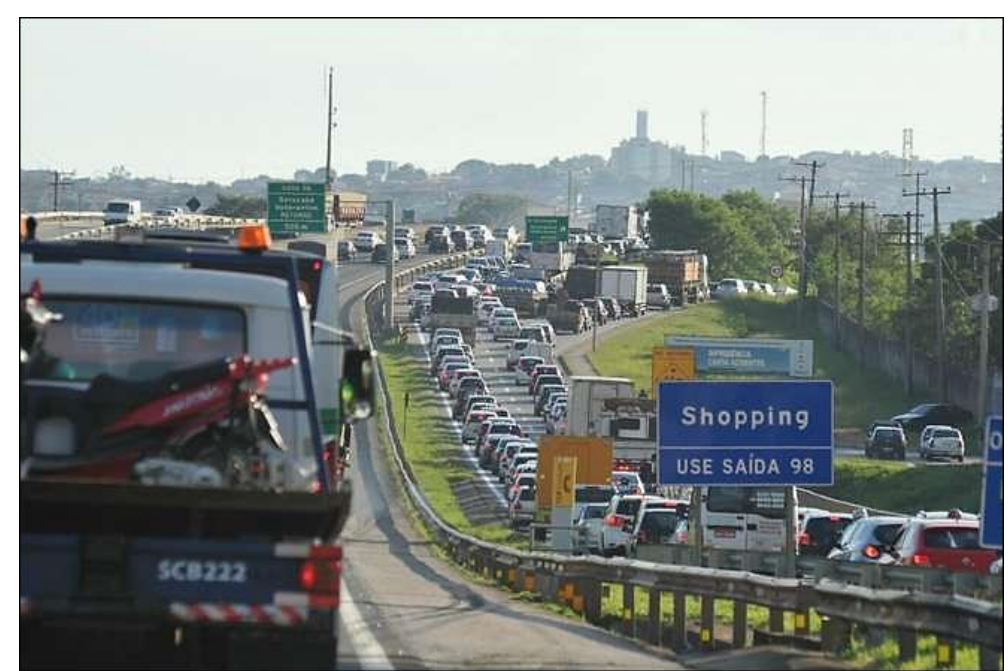

Autor da Foto: PEDRO NEGRÃO, 2017. 


\subsection{Breve histórico do Bairro Parque Campolim, Sorocaba, SP}

Como vários empreendimentos imobiliários do fim do século passado nos municípios do interior paulista, o bairro originou-se de um sítio pertencente a Achilles Campolim, popularmente conhecido por Quiló. As terras eram utilizadas para criação de gado leiteiro e cultivo de gêneros agrícolas para o sustento familiar. O zoneamento municipal da época, pela lei municipal no. 162, de 18 de agosto de 1950, era determinado como zona rural. No meio desta área do trecho 4, passava um caminho52 que ligava o núcleo urbano do centro velho de Sorocaba até a parte alta do município vizinho de Votorantim, e era utilizado para travessia da Via Raposo Tavares, então uma "variante" do caminho principal.

Área agrícola cortada pelo Rio Sorocaba, o trecho 4 recebe nos anos 50 do séc. XX a variante da Raposo Tavares, pois o aumento da população do centro velho, e problemas com caminhões com cargas diversas atravessando e retardando a velocidade do tráfego na área central solicitavam, já nos anos 50 , um caminho alternativo ao trajeto tradicional, adentrando a urbe pela Av. São Paulo, atravessando o centro comercial e saindo pela av. Paraná em direção à Araçoiaba da Serra - então Campo Largo, à oeste.

Com a variante, o transito pesado foi desviado da área urbana e permitiu a ida dos caminhões mais rapidamente para Votorantim, Araçoiaba da Serra, Salto de Pirapora e Piedade, municípios próximos, de economia mais voltada à indústrias têxteis, calcáreo, cimento e produção agrícola, melhorando a velocidade dos automóveis e diminuindo ocorrências na área central, e minorando incômodos relativos à passagens de caminhões carregados.

$\mathrm{Na}$ década de 60 e 70 a região e principalmente Sorocaba teve desenvolvimento econômico positivo, principalmente decorrente da instalação de novos equipamentos educacionais: Faculdade de Medicina (PUC-SP); Faculdade de Tecnologia (Universidade Paulista Júlio Mesquita Filho - UNESP) e escolas técnicas do Centro Paula Souza, qualificando parte da população advinda das áreas rurais para o trabalho no parque industrial, o que fez com que a população crescesse em números absolutos e com isso também a mancha urbana de Sorocaba. De maneira que nos anos 70 houve terreno fértil para a preparação de um novo desenho urbano para as áreas lindeiras à variante da RRT, ainda rural. Nesta época esta área estava zoneada como ZR3, devido à proximidade das indústrias de Votorantim; mas a área do

\footnotetext{
${ }^{52}$ N. A. Este caminho, chamado então de Estrada do Quiló, (atual Av. Antônio Carlos Cômitre) cortava a fazenda do Quiló, apelido de Achilles Campolim. A área foi adquirida em 1917 e era utilizada para a criação de gado leiteiro e 0 cultivo de gêneros agrícolas para o sustento da família (JCS, 2015).
} 
trecho 4 localizava-se na parte alta (Rio Acima), e próxima às chácaras de veraneio da elite local.

A área do trecho 4 permaneceu rural até o final dos anos 70 da séc. $X X$, quando a família Júlio, tradicional no Município de Sorocaba, e detentora de uma pedreira próxima à este trecho da RRT, realizou o projeto e venda de um novo bairro denominado Parque Campolim, nas terras da família Campolim, no sul do município, próximo às terras altas (Rio Acima) do Município de Votorantim.

Figura 119 - Trecho 4 - Estradas e mancha urbana do trecho 4 em 1973, do Rio Sorocaba até confluência da Av. Armando Pannunzio, Bairro Pq. Campolim.

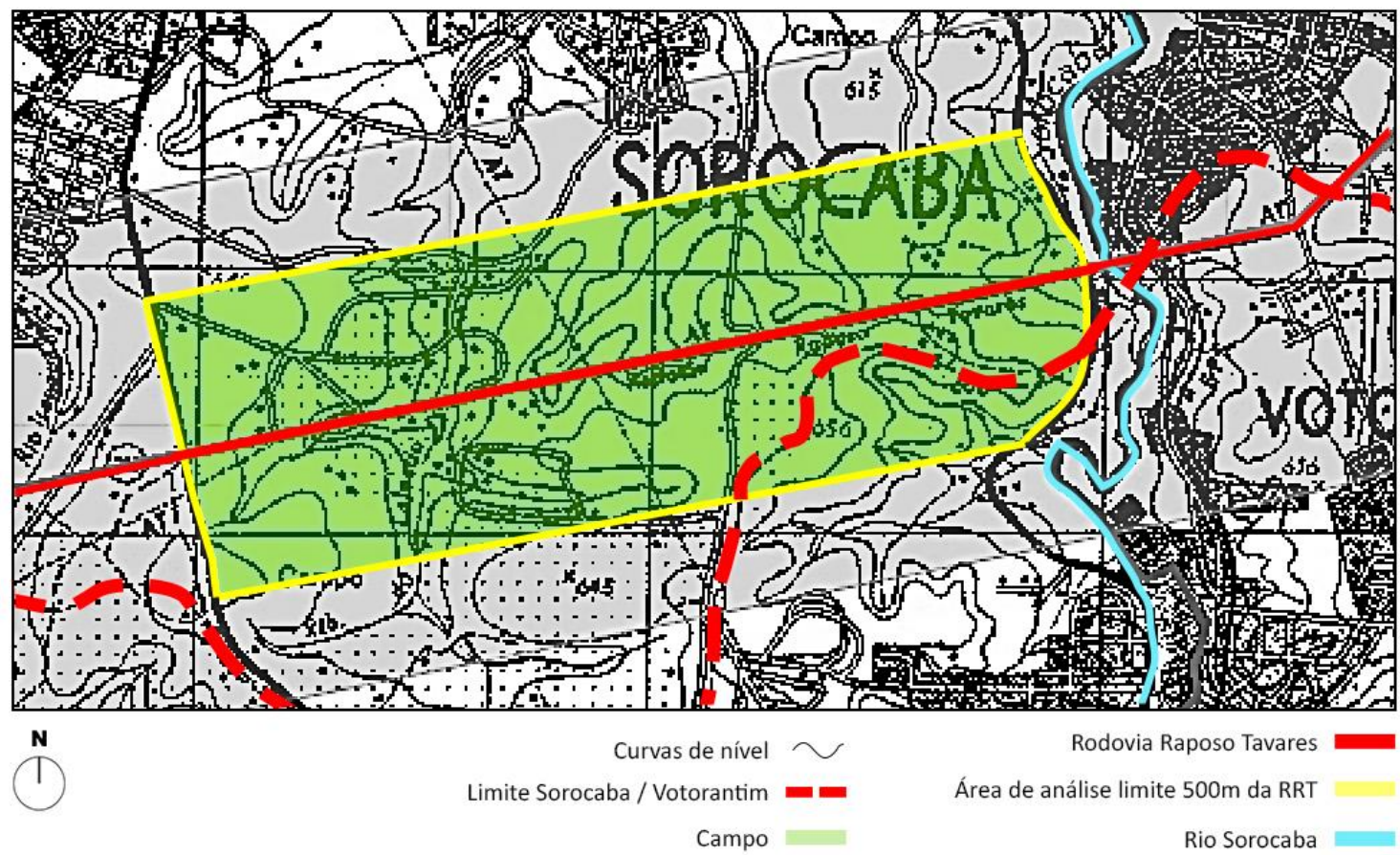

Fonte: IGC, Mapa de Sorocaba (1973). Retrabalhado por Amanda Dias, 2018.

Em meados da década de 70 a família Campolim e a Construtora Júlio e Júlio (empresa local), dotou a área de infra-estrutura para comercialização dos lotes. O loteamento foi liberado por fases, sendo que a primeira ficou pronta em 1981. O empreendimento "Parque Campolim", era próximo e acessível à área central de Sorocaba por uma avenida (Av. Barão de Tatuí) e pelo caminho (Estrada do Quiló) que, passando pelo meio do sítio, ligava então Sorocaba a Votorantim.

O novo bairro teve seu desenho influenciado pelos bairros-jardins de São Paulo, (urbanização desenvolvida nos anos 20 do sec. XX pela Companhia City do Pacaembu e dos Jardins Europa, América, Paulista), imenso sucesso de vendas entre a elite paulistana (ABIKO; 
ALMEIDA; BARREIROS, 1995). Isto possibilitou uma proposta diferente dos loteamentos típicos da Sorocaba de então: o novo desenho urbano tinha vias que terminavam em "cul-de-sac", arborização com mudas de sibipirunas já com altura de 1,5m e lotes de 12×30m, com área média de 360 m2. Além disso, havia áreas de drenagem da água pluvial era interna às quadras, devido à topografia de alta declividade da gleba, e as áreas institucionais e verdes ficaram ao longo das vias de acesso, proporcionando vista de cunho "verde" e agradável a quem passasse pelo bairro, tanto como pedestre como motorista de automóveis, e quando as árvores já estavam com maior porte, a visão realmente chamava atenção, principalmente dos que não eram moradores, pela calma bucólica da paisagem.

Figura 120 - Áreas Verdes e APP's do Campolim.

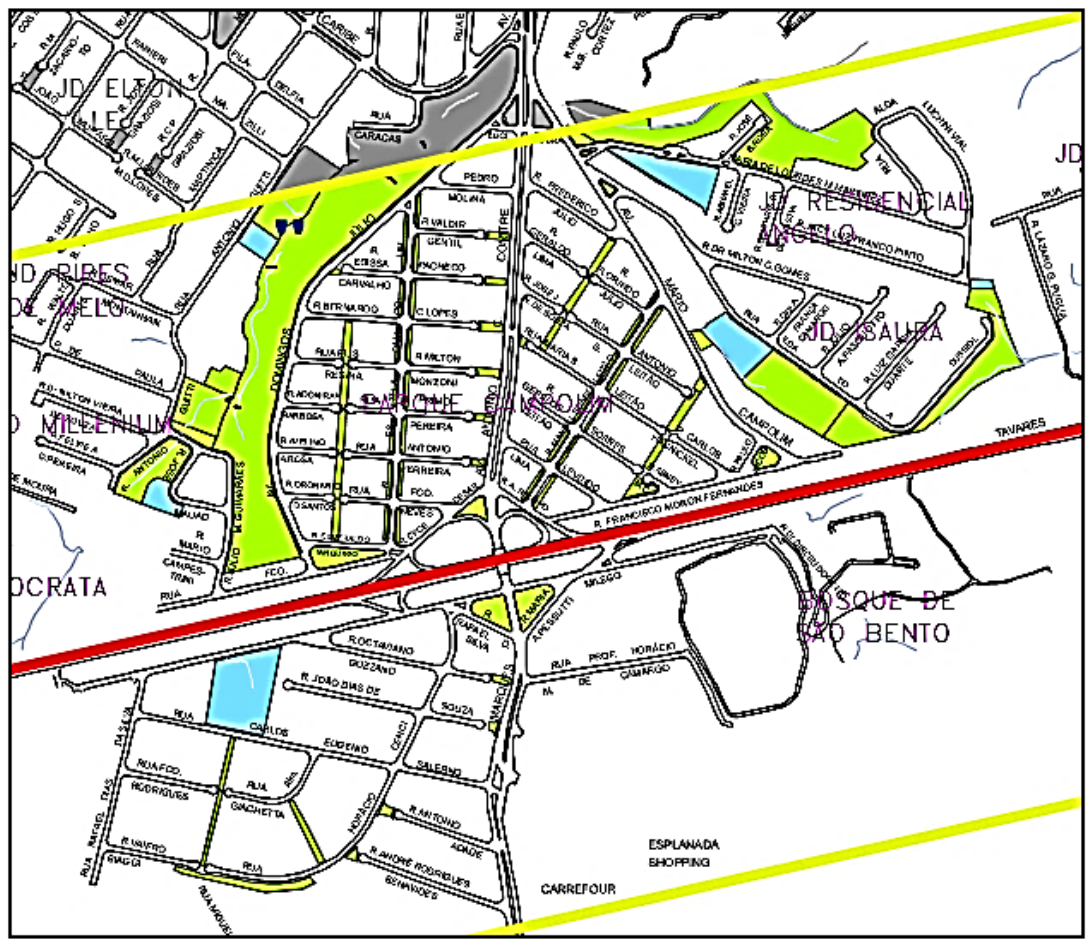

\section{LEGENDA}

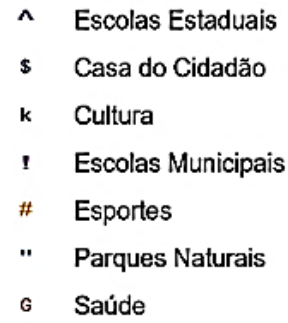

Áreas Públicas

Classificação

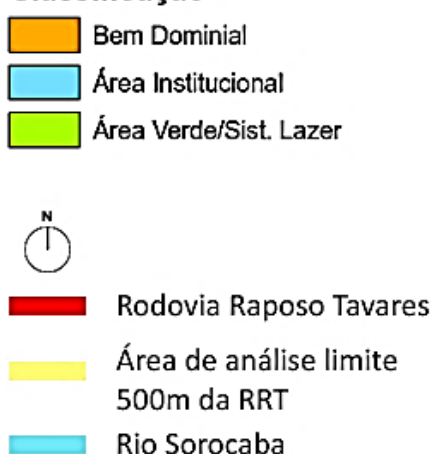

Fonte: Mapa de Próprios da PMS, 2014. Retrabalhado por Amanda Dias, 2018.

A venda dos lotes, destinados à classe média alta, teve lenta velocidade nos primeiros anos, (28 lotes comprados e construídos pela Marinha do Brasil para instalação e residência de oficiais que vieram do Rio de Janeiro trabalhar no projeto Aramar, para enriquecimento de urânio a ser utilizado nos submarinos brasileiros na vizinha FLONA em Iperó); mas foi realmente acelerada após a instalação do hipermercado Carrefour, do outro lado da variante, agora já nomeada oficialmente como RRT. 
O hipermercado de origem francesa reconstruiu o antigo viaduto sobre a RRT, dobrando a sua capacidade de transposição, o que ajudou a alterar, pela função comercial de âmbito regional, a dinâmica urbana da região (esta provida pelo acesso pela RRT às cidades de São Roque, Mairinque, Alumínio, Votorantim, Salto de Pirapora, Piedade, Araçoiaba da Serra, Capela do Alto e até Tatuí, Iperó, Porto Feliz e Itu, dentre as maiores e próximas à Sorocaba).

Também colaborou para isto o fato de que a fase três do empreendimento, com lotes de 17x40m, próximo ao km 100, do outro lado da Rod. Raposo Tavares. Foram dimensionados para serem pequenas chácaras de lazer, acessíveis pela rodovia. Eram similares à destinação da área próxima pertencente ao Município de Votorantim, mas devido a este processo de urbanização, tornaram viáveis a construção de pequenos prédios de 4 pavimentos, o que acelerou ainda mais a ocupação e a valorização do solo urbano nesta área.

A inauguração do Parque Carlos Alberto de Souza, popularmente chamado de Parque Campolim, acelerou a venda dos lotes e valorizou o bairro. Na verdade o parque é uma bacia de contenção em três níveis, implantado no final da década de 90 para amenizar as cheias à jusante do córrego da Água Vermelha, mas seu aspecto terraceado e a agradável paisagem local foi incorporado às práticas de exercício físico e de contemplação da população local. Hoje, em seu entôrno têm-se restaurantes, outros loteamentos e condomínios residenciais, e o corredor comercial da antiga Estrada rural do Quiló transformou-se na av. Antônio Carlos Cômitre, que interliga-se à Av. Izoraída Marques Peres de Votorantim e corresponde ao m2 mais valorizado em termos comerciais.

O bairro Parque Campolim, localizado na zona sul de Sorocaba, SP é atualmente um bairro relevante para o município e sua região (RMS), localizado próximo ao km 100 da Rodovia Raposo Tavares, e ponto da conurbação urbana entre os municípios de Sorocaba e Votorantim, onde localiza-se o Shopping Iguatemi Esplanada, o Iguatemi Business Center, o hipermercado Carrefour, o hipermercado Extra, o hipermercado Tauste e o NovoHotel e o Ibis Hotel. Seguindo pela av. Izoraída M. Peres, adentrando os limites territoriais de Votorantim, têm-se os residenciais fechados do Alphaville 1, 2 e 3; alguns outros loteamentos horizontais mas principalmente os verticais, que agora vem em propostas de 4, 5 torres em empreendimentos do tipo clube completo de amenidades valorizados pela classe média alta (varanda gourmet, salão de festas, quadra de esportes, horta comunitária, jardins bem tratados, APP's, etc).

Todos estes empreendimentos são facilmente acessados pela RRT neste trecho, o que colaborou, junto ao Parque Carlos Alberto de Souza, e o desenho à época novo do bairro para a região, (antes da proposta dos "loteamentos" fechados) para valorizar no sentido imobiliário a área construída a ser vendida futuramente, no entorno do bairro Campolim. 


\subsection{Legislação urbana no Trecho 4 (1950-2014)}

Lembrando que no capítulo IV já foi descrito o zoneamento municipal de Sorocaba até 1950, e o detalhamento da Zona Rural; como a ocupação no trecho 4 era inquestionavelmente rural até meados da década de 70, passaremos a analisar o zoneamento municipal da área do trecho 4 pela Lei no. 1438 do PD de 1966, quando de ZR passa a ser ZR3:

\footnotetext{
"Zoneamento de índices de aproveitamento, índices de ocupação e alturas: Para a Z.R.3 deverá ser redigida lei de teor semelhante à Lei 1147 de 1.10.63, com algumas alterações as quais terão as seguintes redações:

Artigo $1^{\circ}$ - Mantidas no que não contrariem a presente lei, as atuais exigências e restrições do Código de Obras e das Legislação complementar vigente, na zona residencial 3 (Z.R.3) aqui descrita, os edifícios de habitação coletiva (apartamentos), prédios comerciais (escritórios), edifícios mistos (uso comercial e apartamento) bem como aquêles destinados a hotel deverão obedecer às seguintes restrições:

0 coeficiente de aproveitamento do lote não poderá ser superior a: 2 (dois) para habitação coletiva e hotéis; 2 (dois) para prédios comerciais.

0 coeficiente de ocupação do lote não poderá ser superior a: 0,5 para habitação coletiva, edifícios mistos e hotéis; 0,5 para prédios comerciais; loja e sobreloja de prédios comerciais e edifícios mistos poderão apresentar ocupação máxima de $70 \%$ (setenta pôr cento).

Parágrafo único - A zona residencial 3 (Z.R.3) dividida em dois setores e referidas neste artigo fica assim delimitada:

$1^{\circ}$ Setor - Começa na confluência da Av. Bento Mascarenhas e Com. Pereira Inácio, segue pôr esta e toma a rodovia Sorocaba-Votorantim, segue até a Variante Raposo Tavares, segue pôr esta até a Avenida Curitiba (...) até a Av. Comendador Ignácio, 0 ponto de partida" (CMS, 1966).
}

Logo a última lei mencionada é alterada afetando o trecho 4: percebe-se pela lei no. 1541 de 23/12/1968, que para este trecho do km 98 a 102 da rodovia Raposo Tavares, a área é estabelecida como sendo Zona Residencial tipo 1 , no $2^{\circ}$ setor, com os seguintes coeficientes: área mínima do lote: $250 \mathrm{~m} 2$; testada mínima do lote: 10 metros; profundidade mínima do lote 15 metros; afastamento mínimo do alinhamento do lote: $4 \mathrm{~m}$ ou 6 metros quando voltados para vias de $1^{\text {a }}$ categoria; os fundos deveriam ter recuso mínimo de 4 metros. Para as laterais, distância de 1,5 metros e 2 metros para o lote de esquina. A taxa de ocupação máxima dos lotes na ZR1 era de 0,6 para habitação, hotéis, prédios comerciais industriais e surge a alteração de que para edifícios comerciais, lojas e edifícios de uso misto, 0,8. Também é estabelecido o coeficiente máximo de construção, que era de 3,0 para este $2^{\circ}$ setor da ZR1.

Em seguida o zoneamento estabelecido para a área do trecho em estudo, tiveram seus os parâmetros de ZR1 alterados pela lei 1882 de 05/10/1976:

"Artigo 21 - Na Zona Residencial 1 (Z.R.1), as construções e os lotes deverão obedecer os seguintes requisitos, excluindo-se os mercados:

1 - Área mínima do lote. $.250 \mathrm{~m}$;

2; - Testada mínima do lote $10 \mathrm{~m}$

3 - Profundidade mínima do lote $.15 \mathrm{~m}$ 
4 - Afastamento mínimo do corpo da construção principal em relação aos limites dos lotes: a - frente: 4 metros; 6 metros quando voltados para as ruas de $1^{\circ}$ categoria; $b$ - fundos: 4 metros; $c$ - Laterais: $p /$ lote encravado: 1) 1,50 metros para residências individuais; 2) para edifícios comerciais de caráter transitório, mistos, de habitação coletiva e hotéis - afastamento de $\mathrm{H} / 4$ (sendo $\mathrm{H}$ a altura entre o piso do andar térreo e a laje do último pavimento, com um mínimo de $3,5 \mathrm{~m}$ ); $p$ / lote de esquina: Será adotado o afastamento estabelecido para via voltado o prédio para o outro lado o estabelecido para lote encravado.

- Coeficiente máximo de ocupação do lote: a - 30\% da área do terreno para habitações coletivas ( $A$ área de projeção da cobertura da garagem não será computada para efeito do cálculo do coeficiente de ocupação desde que não ultrapasse a $15 \%$ da área do terreno e seja apenas o andar térreo); b - 30\% para prédios comerciais ou de caráter transitório; c - 30\% para loja e sobreloja de edifícios comerciais e mistos; $d$ - 0,6 para residências individuais; 6 - Coeficiente máximo de aproveitamento do lote: a - 3 (três) vezes a área do terreno;

7 - Nos edifícios de habitação coletiva, deverão corresponder a cada unidade habitacional, no mínimo 50 (cinquenta) metros quadrados de terreno. A parte fracionária resultante do cálculo, será arredondada para a unidade e somada à parte inteira. Cada habitação será constituída de, no mínimo, uma sala, um dormitório, cozinha e um banheiro." (CMV, 1976).

Pela lista de alterações da Lei 1541/1968 a seguir, sobre o zoneamento municipal, além das alterações já mencionadas, percebem-se várias alterações, feitas à medida para ajustar a legislação urbana enquanto não se revisa ou prepara-se novo plano diretor municipal, principalmente na década de 90, época de instalação do hipermercado Carrefour, Esplanada shopping center e suas consequências:

- a criação da zona comercial no. Quatro (lei 3287/1990);

- a proibição de instalação de indústria nos Jardins, (lei 3457/1990);

- autorização de construção de apart-hotéis (Lei 4594/1994);

- a criação de corredores comerciais, as zonas comerciais secundarias, a ampliação de zonas comerciais tipo 3 e 4, e a ampliação da ZR 1 - $2^{\circ}$ setor (lei 4874/1995);

- e nova ampliação da zona residencial ZR-1 - $2^{\circ}$ setor, (lei 5911/1999).

Todas estas leis aprovadas refletem as modificações para as áreas comerciais e para as áreas residenciais do tipo 1 , viabilizando proteger da instalação de indústrias as áreas do tipo ZR1; permitindo no trecho 4 a construção de apart-hotéis; e ajustando e regulamentando o uso e ocupação do solo nos corredores comerciais e residenciais do tipo 1.

Note-se que até a implementação da Lei do Estatuto das Cidades, em 2001, não era necessária legalmente a participação da sociedade civil através de audiências públicas no processo de decisões do Plano Diretor municipal. Com a promulgação da Lei número 10.257, de 10 de julho de 2001 pelo Planalto, foram necessárias duas audiências públicas, para aprovação de um novo plano diretor municipal em 2004. Nestas audiências, cerca de 100 pessoas foram ao 
teatro do SESI sito à Rua Gustavo Teixeira, próximo ao centro velho. Em sua maioria, técnicos e representantes do setor imobiliário de Sorocaba.

O plano diretor de Sorocaba foi realizado pela empresa Ambiente Urbano, e promulgada pela Lei no. 7122 de 01/06/2004. A empresa53, especializada em planos diretores municipais, utilizou uma metodologia centrada em diretrizes que culminam na lei do plano diretor e invariavelmente três mapas como produtos: 1) mapa de Macrozoneamento Ambiental, 2) mapa de Zoneamento Municipal e 3) mapa do Sistema Viário municipal. Os usos permitidos na área refletiam a priorização da vocação residencial ZR1 e ZR2; e a Av. A.C. Comitre, como CCS1 (a partir da lei 4874/95), a comercial. Para fins de comparação posterior com a mudança de priorização da vocação estritamente residencial na ZR1 e residencial de casas térreas e prédios de apartamentos na ZR2, anotamos a seguir os parâmetros aprovados pelo PD 2004 (Tab. 25 e 26 e artigos 18 e 19):

Tabela 25 - Usos permitidos Zonas ZR1 e ZR2 - PD Sorocaba de 2004.

\begin{tabular}{|l|l|}
\hline Zona Residencial 1 & ZR1 RL, RG, UE; \\
\hline Zona Residencial 2 & ZR2 RL, RG, CSI, TL, UE; \\
\hline Corredor de Comércio e Serviços 1 & CCS 1 RL, RG, CSI, TL, UE; \\
\hline
\end{tabular}

Fonte: Câmara Municipal de Sorocaba, 2004.

\footnotetext{
${ }^{53}$ que realizou diversos planos diretores para os municípios circunvizinhos (São Roque, Itapetininga, etc.)
} 
Tabela 26 - Parâmetros de ocupação por zona PD 2004 Sorocaba

\begin{tabular}{|c|c|c|c|}
\hline ZONAS DE USO & To & $\mathrm{Ta}$ & $\begin{array}{c}\text { Mínimo de } \\
\text { Permeabilidade(\%) }\end{array}$ \\
\hline Zona Central - ZC & 0,80 & 4,0 & \multirow{6}{*}{$\begin{array}{l}10 \% \text { para terrenos } \\
\text { com área inferior } \\
\text { a } 500,00 \mathrm{~m}^{2} . \\
20 \% \text { para terrenos } \\
\text { com área superior } \\
\text { ou igual a } 500,00 \mathrm{~m}^{2}\end{array}$} \\
\hline Zona Predominantemente Institucional - ZPI & 0,60 & 2,5 & \\
\hline Zona Residencial 1 - ZR1 & 0,60 & $\overline{1,5}$ & \\
\hline Zona Residencial 2 - ZR2 & 0,60 & 2,0 & \\
\hline Zona Residencial 3 - ZR3 & 0,70 & 2,0 & \\
\hline Zona Industrial & Livre & Livre & \\
\hline Zona de Atividades Especiais - ZAE & 0,50 & 1,0 & $40 \%$ \\
\hline Zona de Chácaras - ZCH & 0,35 & 0,6 & $50 \%$ \\
\hline Zona de Conservação Ambiental - ZCA & 0,10 & 0,3 & $80 \%$ \\
\hline Corredor de Comércio e Serviços 1 - CCS1 & 0,50 & $\overline{1,0}$ & \multirow{4}{*}{$\begin{array}{c}10 \% \text { para terrenos } \\
\text { com área inferior a } \\
500,00 \mathrm{~m}^{2} ; \\
20 \% \text { para terrenos } \\
\text { com área superior ou } \\
\text { igual a } 500,00 \mathrm{~m}^{2} ; \\
\end{array}$} \\
\hline Corredor de Comércio e Serviços 2 - CCS2 & $\left({ }^{(*)}\right.$ & $\left({ }^{(*)}\right.$ & \\
\hline Corredor de Comércio e Indústria - CCl & 0,50 & 2,5 & \\
\hline Corredor de Circulação Rápida - CCR & 0,50 & 2,5 & \\
\hline Área Rural & Livre & Livre & $50 \%$ \\
\hline \multicolumn{4}{|c|}{$\begin{array}{l}\text { (†) Nos corredores CCS2, a CA e o TO são os mesmos das zonas por eles atravessadas, sendo aplicável a } \\
\text { fórmula mencionada no Artigo } 83 \text { desta lei. }\end{array}$} \\
\hline
\end{tabular}

Fonte: PMS, 2004.

"Art. 18 - Nas Zonas Residenciais 1 - ZR1, que inclui áreas destinadas à ocupação exclusivamente residencial, em padrões de baixa densidade e baixas taxas de ocupação, as normas de parcelamento, uso e ocupação do solo devem: I Privilegiar o uso residencial em padrões de baixa densidade, sem proibir uso complementar e não incômodo, tal como trabalho de profissional autônomo realizado em sua residência. II - Visando a boa qualidade paisagística e ambiental dos bairros, estimular a formação e manutenção de jardins nos lotes, limitando 0 percentual dos terrenos que pode ser coberto e impermeabilizado.

Art. 19 - Nas Zonas Residenciais 2 - ZR2, que inclui em sua maior parte bairros já consolidados e utilizados predominantemente por uso residencial, as normas de parcelamento, uso e ocupação do solo devem: I - Permitir a implantação de usos não residenciais, desde que não causem incômodos para a população residente, tais como escolas e trabalho de profissional autônomo, bem como comércio, serviços e indústria de pequeno porte; II - Fixar índices urbanísticos que permitam a adoção de padrões variados de edificações, desde casas térreas até prédios de apartamentos. " (CMS,2004).

$\mathrm{Na}$ análise do zoneamento deste plano diretor municipal de 2004, (levando-se em conta 0 PD de Sorocaba somente, pois o trecho escolhido está quase em sua totalidade dentro do território municipal de Sorocaba), pela figura 121, nota-se que a área é predominantemente ZR1, como pode-se observar pelas leis municipais até então aplicáveis a este setor do município, inclusive já com muitas ruas implantadas e outras (arruamento em vermelho) que segundo a 
legenda são de loteamentos aguardando aprovação municipal. Os compradores de imóveis na época 4 então:

“(...) preferem outras áreas nobres e com características bem mais convidativas ao consumidor final. É o caso do Parque Campolim e, nas suas proximidades, do Elton Ville, Jardim Emília e Condomínio Isaura54." (BARRETO, 2007).

O novo Plano Diretor ${ }^{55}$ traz um coeficiente de aproveitamento mais convidativo às construções no Centro antigo do que o coeficiente do bairro Parque Campolim, por exemplo. No primeiro o CA é de 4,0 (quatro vezes a área do terreno) e no segundo, 2,0.

Mesmo assim, diante dos fatores já citados ${ }^{56}$, nota-se que é irrelevante a quantidade de edifícios em construção então no centro velho de Sorocaba. Barreto destaca também a questão da permissividade do Estado na questão da verticalização do bairro:

"(...) no mês de junho de 2004, foi aprovado o novo Plano Diretor da Cidade de Sorocaba. No caso específico do Parque Campolim, no que tange às construções verticais, houve poucas mudanças, sendo que além das nomenclaturas, cabe ressalvar o potencial de aproveitamento, ou seja, a relação direta entre o tamanho do terreno e número de pavimentos que ali podem eventualmente ser construídos.

0 extremo sul do bairro, onde já se havia permissão para construções verticais segundo o Plano Diretor anterior, estava na área denominada de ZR4, ou Zona Residencial 4; hoje ZR2. 0 restante do bairro, anteriormente denominado de ZR1 $3^{\circ}$ Setor, agora está incluso numa área denominada de ZR1, onde a verticalização continua vetada, com exceção da avenida Carlos Cômitre. O coeficiente de aproveitamento para verticalização na av. Carlos Cômitre é de 2,5; na porção sul do bairro, 2,0.

Em função disso, apesar da já destacada e inquestionável importância do Hipermercado Carrefour e Esplanada Shopping Center, para a verticalização da parte sul do Parque Campolim, é importante que se destaque que, sem a permissividade que havia e que há na legislação urbana - obviamente por ação direta do Estado capitalista - para essa verticalização, ela não ocorreria; como não ocorreu no restante do bairro, onde, dos 82 edifícios construídos ou em fase de construção, com mais de 4 pavimentos, somente 7 estão localizados fora desta área" (BARRETO, 2007).

Já pela figura do zoneamento no mesmo trecho na revisão de 2007, há mudança significativa no limite dos municípios de Sorocaba e Votorantim, devido a uma alteração entre 0 traçado que passava entre o hipermercado Carrefour e Esplanada Shopping, o que fez com que o Município de Votorantim ganhasse direito aos impostos retroativamente à implantação dos empreendimentos. (Votorantim zoneava a parte ganha de Sorocaba como ZRL = zona recreativa de lazer 1) (Fig. 122).

Do outro lado oposto da rodovia, mas ainda assim solo sorocabano, o desenho do loteamento na sua fase 3 contemplou lotes maiores, agora já sem o desenho de bairro jardim,

\footnotetext{
${ }^{54}$ Bairro e condomínios próximos ao Parque Campolim. (N.A.)

55 De 2004.

${ }^{56}$ Área com desenho urbano de bairro jardim, a proximidade ao Parque Campolim, e supermercados, centros de compras, escolas de marca, restaurantes, bancos, serviços, etc.
} 
sem os culs-de-sac; mas com lotes maiores, de $17 \times 40 \mathrm{~m}$ de largura, tamanho de lote que propiciou rápida verticalização quando houve iniciou-se a procura de apartamentos para fins residenciais - devido à localização - próximo ao Parque/bairro Campolim, mesmo considerandose que havia uma rodovia estadual dividindo os dois lados do loteamento. A mudança do limite municipal entre os dois municípios significou na prática mais recursos para o vizinho Município de Votorantim, e como consequência modificou a densidade permitida pelo seu zoneamento na área, passando de baixa para média densidade, com lote mínimo de 250 metros quadrados onde antes era zona de chácaras de recreação e lazer, pelo PD de 2009 de Votorantim (PMV, 2009).

Pelo Plano Diretor de 2004 (Lei municipal no. 7122 de 01/06/2004), mantêm-se parte do trecho em ZR1, mas passa a ter parte dela em ZR-2 no trecho após a rodovia (Fig. 122).

O zoneamento foi modificado justamente para se permitir a verticalização, pois verifica-se, pelo levantamento da EMPLASA (2017) que nos prédios implantados na fase 3 do loteamento Campolim está uma das maiores concentrações de alta/média renda do município. Pouco tempo depois, pela revisão do PD de 2007 (Lei municipal no. 8181 de 05/06/2007), no mapa de zoneamento pertinente, uma das modificações no trecho estudado no zoneamento foi a inclusão de uma área ZR2 no bairro do lado de Sorocaba, onde está um edifício de nove andares; pelo zoneamento ZR1 ele não seria permitido antes da revisão, elaborada e aprovada tão poucos anos após a aprovação do PD anterior, de 2004. Também o coeficiente de aproveitamento (CA) foi alterado de 1,5 para 2,5 para ZR1, e a taxa mínima de permeabilidade diminui para terrenos com área igual ou superior a 500 m2, passando de 20\% para 10\% no PD de 2007 (Tabelas 27 e 28).

Tabela 27 - Usos permitidos Zonas ZR1, ZR2 e CS1 - PD Sorocaba de 2007.

\begin{tabular}{|l|l|}
\hline Zona Residencial 1 - ZR1 & RL, RG, UE \\
\hline Zona Residencial 2 - ZR2 & RL, RG, CSI-1, TL, UE \\
\hline Corredor Comercio e Serviço 1 - CS1 & RL, RG, CSI-1, TL, UE \\
\hline
\end{tabular}

Fonte: Câmara Municipal de Sorocaba, 2014.

Tabela 28 - Parâmetros de ocupação por zona PD 2007 Sorocaba (tabela parcial).

\begin{tabular}{|c|c|c|c|}
\hline ZONAS DE USO & TO MAX. & CA Max. & $\begin{array}{l}\text { \% MÍnimo de } \\
\text { permeabilidade }\end{array}$ \\
\hline Zona Residencial 1 - ZR1 & 0,60 & 2,5 & \multirow{2}{*}{$\begin{array}{c}10 \% \text { para terrenos com } \\
\text { área superior ou igual a } \\
500,00 \mathrm{~m} 2\end{array}$} \\
\hline Zona Residencial 2 - ZR2 & 0,60 & 1,5 & \\
\hline Corredor Comercio e Serviço 1 - CS1 & 0,60 & 1,5 & $\begin{array}{l}20 \% \text { para terrenos com } \\
\text { área superior ou igual a } \\
500,00 \mathrm{~m} 2\end{array}$ \\
\hline
\end{tabular}

Fonte: PMS, 2007. 
Pelo PD de 2007, instituindo no trecho estudado modificações da ordem dos parâmetros de lote mínimo que na ZR1 anterior era de 360m2; e mantendo a Taxa de ocupação de máxima de 0,6; mantendo-se o coeficiente de aproveitamento de 2,5 e incluindo 0 limite de três pavimentos e máximo de $750 \mathrm{~m} 2$ de área construída tot. 0 ponto principal é a inclusão, nas características da ZR1, a palavra "predominantemente" residencial, na prática praticamente retirando a característica estritamente residencial e permitindo outros usos:

"Art. 18. Nas Zonas Residenciais 1 - ZR1, que inclui áreas destinadas à ocupação
predominantemente residencial, em padrões de baixa densidade e baixas taxas de
ocupação, as normas de parcelamento, uso e ocupação do solo devem (...)
$\S 1^{0}$ Na Zona Residencial 1 - ZR1, além dos usos RL, RG, UE e de atividades de
profissionais liberais, excetuando-se os loteamentos fechados, são permitidos usos
que não sejam poluentes, perigosos, incômodos ou nocivos à vizinhança e pólos
geradores de tráfego, tais como: escritórios em geral, consultórios e clínicas médicas
e odontológicas, escola de educação infantil que atendam crianças de zero a seis
anos de idade, sociedades ou associações de amigos de bairro, com respectiva
estrutura de apoio interno, tais como área de lazer e de estudo, sala de refeições,
espaço para café e similares, instaladas em imóveis com área construída não
superior a $750 \mathrm{m2"} \mathrm{(NR)} \mathrm{(PMS,} \mathrm{2007).}$

Após a modificação de 2007, no plano diretor municipal, deu-se permissão para construção de quitinetes no trecho em questão, com resultados numerosos no lançamento de empreendimentos imobiliários.

A partir de 2010, incluiu-se os instrumentos notáveis de planejamento urbano: outorga onerosa do direito de construção (lei 9232 de 20/07/2010); do IPTU progressivo para 0 cumprimento da função social da propriedade urbana (lei 10.497 de 10/07/2013). Mas estas leis mencionadas neste paragrafo não tem modificação pertinente no trecho aqui estudado.

A última revisão do PD municipal de Sorocaba foi aprovada pela Lei municipal no. 11.022, de 16/12/2014, e trouxe novos usos permitidos para a ZR1 e a ZR2: I - Uso Residencial $\mathrm{R}$, correspondendo a local de moradia permanente, que incluem: a) $\mathrm{RL}$ - uso residencial em lotes - residências unifamiliares isoladas, geminadas ou agrupadas; prédios de apartamentos, conjuntos residenciais implantados em lotes; habitações coletivas, excluídos hotéis e motéis; $b$ ) RG - uso residencial em glebas - conjuntos residenciais implantados em glebas não previamente parceladas para fins urbanos; c) RT - uso residencial com apoio terapêutico - conjunto residencial com prestação de serviços internos gerais, médicos e terapêuticos; d) RSI - uso residencial com serviços internos ou privativos - conjuntos residenciais com prestação de serviços internos gerais: manutenção e conservação, recreação e lazer, e alimentação para utilização residencial e estabelecimentos tipo comerciais, classificados em CSI-1, Estabelecimentos de comércio, serviços, indústrias e instituições não enquadrados nas 
categorias PGT, GRN ou GRD; e na ZR1: CSI-2: estabelecimentos com usos que não sejam poluentes, perigosos, incômodos ou nocivos à vizinhança, tais como: escritórios em geral, consultórios e clínicas médicas e odontológicas, escola de educação infantil que atendam crianças de zero a seis anos de idade, sociedades ou associações de amigos de bairro, salões de beleza e estética, instaladas em imóveis com área construída não superior a $750 \mathrm{~m}^{2}$; do tipo CSI-3, escritórios de contatos, virtuais e de trabalho pessoal, sem atendimento específico no local e finalmente, UE: (usos especiais) compreendendo estabelecimentos cuja localização é definida em função de condicionantes técnicas estritas, notadamente instalações de sistemas de infraestrutura, tais como reservatórios e estações de tratamento de água, estações de tratamento de esgotos, subestações de energia elétricas, cemitérios de humanos e de animais, bibliotecas, museus de todos os tipos, parques urbanos e unidades de conservação ambiental, como podem ser verificados na Tabela 29:

Tabela 29 - Usos permitidos Zonas ZR1 e ZR2 - PD Sorocaba de 2014.

\begin{tabular}{|l|l|}
\hline ZONAS DE USO & USOS PERMITIDOS \\
\hline Zona Residencial 1 - ZR1 & RL, RG, RT, RSI, CSI-2, CSI-3, U E \\
\hline Zona Residencial 2 - ZR2 & RL, RG, RT, RSI, CSI-1, CSI-2, CS-3, TL, UE \\
\hline $\begin{array}{l}\text { Corredor Comercio e Serviço 1 - } \\
\text { CS1 }\end{array}$ & RL, RG, RT, RSI, CSI-1, CSI-2, CSI-3, TL, U E \\
\hline $\begin{array}{l}\text { Corredor Comercio e Serviço 2 - } \\
\text { CS2 }\end{array}$ & $\begin{array}{l}\text { RL, RG, RT, RSI, PGTI, GRN, GRD, CSI-1, CSI-2, CSI-3, TL, U } \\
\text { E }\end{array}$ \\
\hline $\begin{array}{l}\text { Corredor Comercio e Serviço 2 - } \\
\text { CS3 }\end{array}$ & $\begin{array}{l}\text { RL, RG, RT, RSI, PGTI, GRN, GRD, CSI-1, CSI-2, CSI-3, TL, U } \\
\text { E }\end{array}$ \\
\hline
\end{tabular}

Fonte: Câmara Municipal de Sorocaba, 2014. 
Tabela 30 - Parâmetros de ocupação por zona PD 2014 Sorocaba (tabela parcial).

\begin{tabular}{|c|c|c|c|}
\hline ZONAS DE USO & TO MAX. & CA max. & $\begin{array}{l}\% \text { minimo de } \\
\text { permeabilidade }\end{array}$ \\
\hline Zona Residencial 1 - ZR1 & 0,60 & 1,5 & \multirow{2}{*}{$\begin{array}{c}5 \% \text { para terrenos com } \\
\text { área até } 200 \mathrm{~m} 2,10 \% \\
\text { para terrenos com área } \\
=\text { a } 200,01 \mathrm{~m} 2 \mathrm{a} \\
499,9 \mathrm{~m} 2,20 \% \text { para } \\
\text { terrenos com área } \\
\text { superior a } 500 \mathrm{~m} 2\end{array}$} \\
\hline Zona Residencial 2 - ZR2 & 0,60 & 2 & \\
\hline Corredor Comercio e Serviço 1 - CS1 & 0,60 & 1,5 & \multirow{3}{*}{$\begin{array}{c}10 \% \text { para terrenos com } \\
\text { área superior ou igual a } \\
500,00 \mathrm{~m} 2\end{array}$} \\
\hline Corredor Comercio e Serviço 2 - CS2 & 0,60 & 2,0 & \\
\hline Corredor Comercio e Serviço 2 - CS3 & 0,60 & 3,0 & \\
\hline
\end{tabular}

Fonte: PMS, 2017.

Na prática, após perder o caráter predominantemente residencial da ZR1 no PD de 2007, permite-se os mais abrangentes usos: subestações de energia elétrica, cemitérios de humanos e animais, museus de todos os tipos, etc, no PD de 2014, claramente para se oficializar a gama de usos diversos possíveis na ZR1 e ZR2 após o PD de 2007. Outra modificação verificada no PD de 2014 foi a inclusão de mais corredores do tipo CSI-1, CSI-2 e CSI-3 no trecho aqui estudado, significando na realidade o aumento de usos possíveis e desta forma, do tráfego de automóveis nas vias e a permissão ao aumento de vários tipos de estabelecimentos de comércio e serviços disponibilizados ao longo destas vias.

Os valores-limite para os índices urbanísticos por zona são aqueles indicados na Tabela 30. Se considerarmos a TO máximo de $60 \%$ podemos considerar que é um valor altamente restritivo ao uso do solo, mas se considerarmos o terreno médio do Campolim na fase 1 (360 2 de área média), e aplicarmos os $10 \%$ do taxa de permeabilidade teremos área mínima destinada à permeabilidade de $36 \mathrm{~m} 2$; sendo que os demais $90 \%$ poderiam ser impermeabilizados, é uma tabela de parâmetros que pode gerar dúvidas na sua aplicação quanto a fiscalização de TO.

Tentou-se também permitir, neste PD de 2014, uma série de medidas do tipo modificações indicadas apenas no mapa de zoneamento, e não no texto legal; e outras tantas que depois foram consideradas inconstitucionais, motivando ação direta de inconstitucionalidade 
solicitadas ao MP pela sociedade civil organizada. Exemplo 1: também foi vetado pela ADIN No. 2138826-16.2016.8.26.0000 de 2017 a redução de área mínima dos lotes de 150m2 na ZR3 e 250m2 ZR2, em condição favorável ao empreendedor, pois se pretendia aumentar de 12 para $20 \%$ o tamanho da área destinada ao lazer em glebas de loteamentos residenciais, já considerando as áreas verdes (que normalmente são as áreas de APP's, definidas por lei federal) para o sistema de lazer:

\begin{abstract}
$\S 6^{\circ}$ Fica permitida a redução da área mínima dos lotes para $150 \mathrm{~m} 2 \mathrm{na} Z \mathrm{ZR} 3$ e $250 \mathrm{~m} 2$ na ZR2, caso o empreendedor opte pela ampliação da área destinada ao lazer de 12\% para $20 \%$ da gleba do loteamento, área esta que deverá contemplar as áreas verdes e o sistema de lazer. (Veto Parcial $n^{0}$ 53/2014 Rejeitado) (Parágrafo declarado inconstitucional pela ADIN nº 2138826-16.2016.8.26.0000).
\end{abstract}

E exemplo 2: as atividades e instalações de templos religiosos no trecho 4, independentemente do número de lugares nestes templos:

\footnotetext{
$\S 1^{\circ} \mathrm{Na}$ Zona Residencial 1 - ZR1, e na Zona de Chácaras - ZCH e CCS1 os usos RL, RG, RT e RSI, somente serão admitidos na forma de residências unifamiliares.

$\S 2^{\circ}$ Ficam também permitidas as atividades e instalações de templos religiosos na ZC, ZPI, ZR1, ZR2, ZR3, ZR3-expandida, ZI1, ZI2, ZCH, ZCA o Área Rural, independente do número de lugares que acompanham a lotação desses templos. (Veto Parcial $n^{0}$ 53/2014 Rejeitado) (Parágrafo declarado inconstitucional pela ADIN $n^{0} \underline{2138826-16.2016 .8 .26 .0000)}$.
}

Além de outras mudanças que não são pertinentes a este trecho, o PD de 2014 tem outros dezessete itens que foram vetados e/ou declarados inconstitucionais, conforme relatório do TJSP (ver em anexos). A nova administração municipal (2017-2020) ainda não reformulou 0 plano diretor municipal para esclarecimento de posição quanto aos vetos do Ministério Público; portanto, ainda estão para serem refeitos os parâmetros de uso e ocupação das ZR1 e ZR2. Por questões administrativas e políticas, a nova administração prefere nomear junto com membros da sociedade civil organizada, uma equipe técnica que estabeleça novos parâmetros para serem aplicados ao zoneamento após revisão do texto legal. 


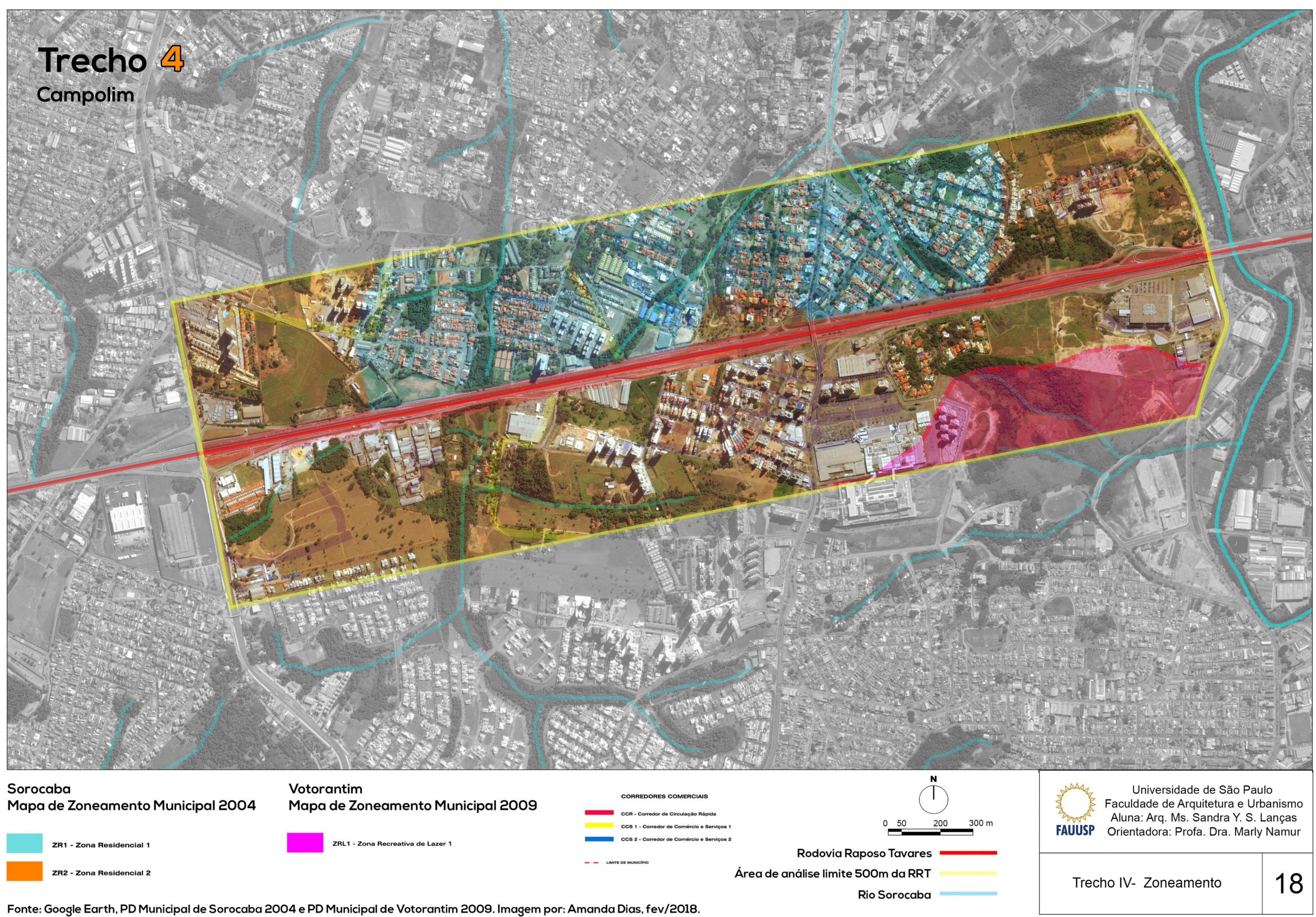




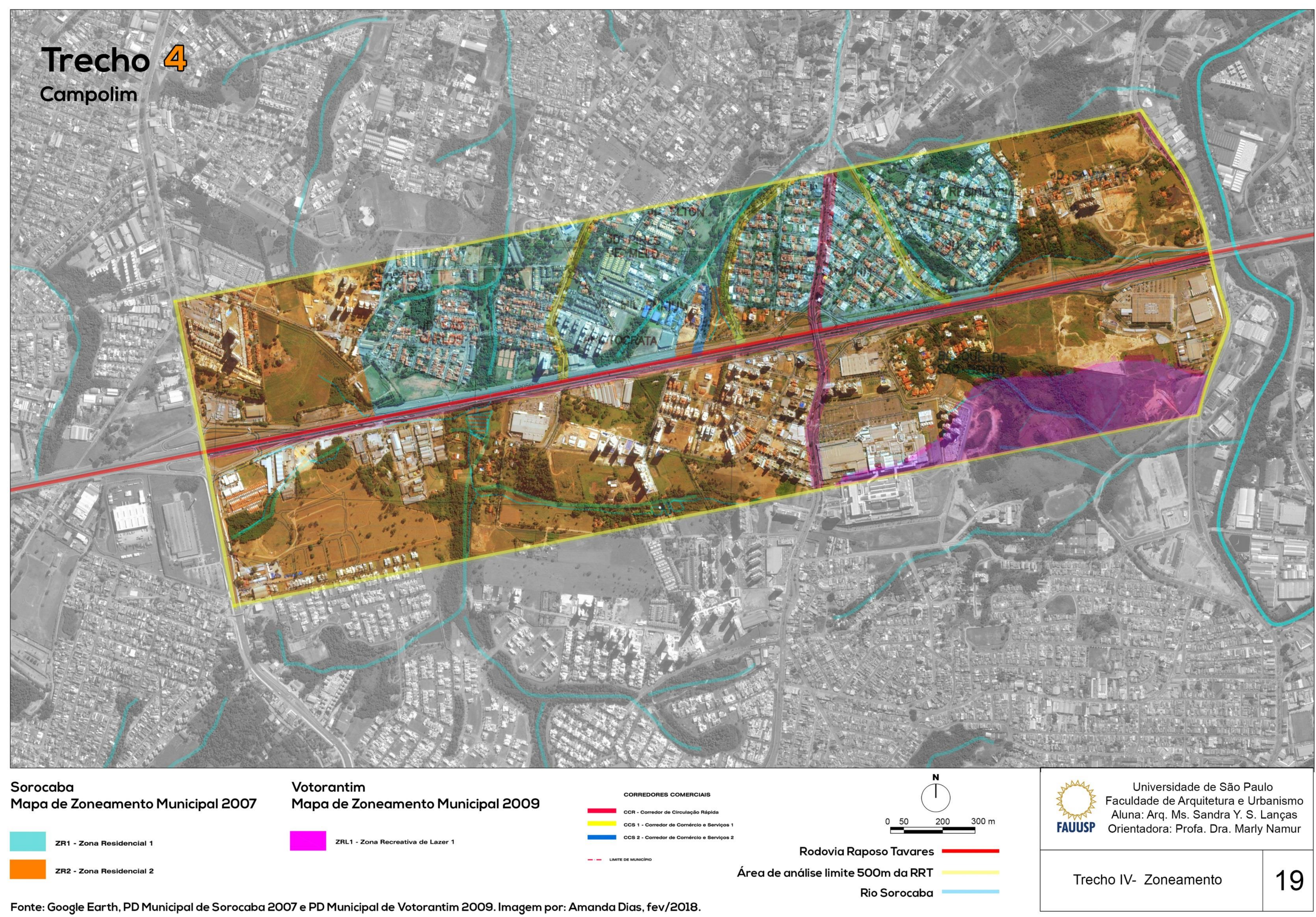




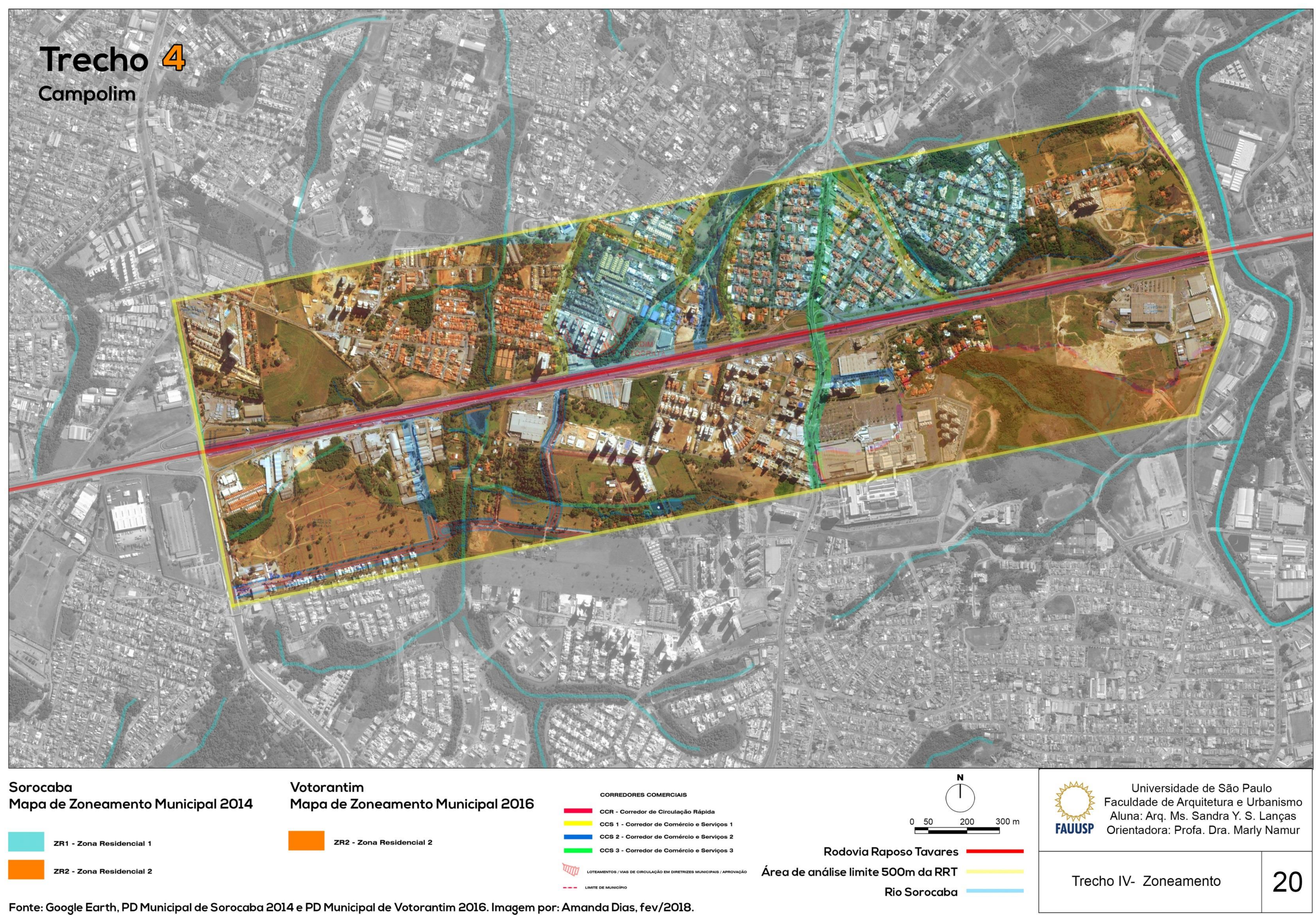




\subsection{Ocupação urbana x Zoneamento Trecho 4 (1962-2017)}

\section{$1^{\circ}$ período: 1962 a 2003}

Desde a instalação em 1914, da zona urbana e não urbana no Município de Sorocaba (MONTEIRO, MATTOS, 2015), o trecho 4 esteve fora da zona urbana. Posteriormente, pela lei municipal no. 162/50, o zoneamento da área neste trecho passou a ser Zona Rural (ZR). Podemos verificar pela foto que o trecho 4 em 1962 (Fig. 137) já era cortado pela variante da RRT na época, e que suas áreas lindeiras eram ocupadas por sítios e chácaras, portanto a ocupação seguiu o zoneamento municipal até então. Uma pequena área ao lado do Rio Sorocaba na porção sul do início do trecho 4, próximo ao km 98, atualmente pertence (após disputa judicial sobre o limite territorial municipal) ao Município de Votorantim. Como este foi distrito de Sorocaba até instalação do município em 27/03/1965, e até hoje a área não tem ocupação urbana (o zoneamento anterior era para chácaras de recreio e hoje é destinado pelo PD de Votorantim de 2015 para fins industriais); e está na área de várzea do Rio Sorocaba, será desconsiderada para fins de análise do zoneamento e urbanização.

Pelo mapa da área em 1973, elaborado pelo IGC, (Fig. 126) pode-se notar que o trecho permaneceu pelo menos uma década ainda com atividade rural, pois havia apenas caminhos sem ocupação urbana significativa. Já pela foto aérea de 1978 (Fig. 127) pode-se perceber os caminhos mais utilizados na época e o início da produção do espaço urbano, permitidos a partir da lei municipal no. 1147/63, quando o zoneamento passa de ZR para ZR3 (zona residencial do tipo 3); permitindo uso rural (com lote mínimo de 2000m2) e também residencial do tipo habitações coletivas (apartamentos), prédios comerciais, edifícios mistos, hotéis, e residenciais unifamiliares, em lotes com áreas mínima de $250 \mathrm{~m} 2$; com TO de $50 \%$ para habitações coletivas e $70 \%$ para residências unifamiliares, e $C A=2,0$ para todos os casos. A lei recomendava a ocupação industrial, para as áreas lindeiras em 1,5 km de profundidade do eixo da RRT, nos seus dois lados. Tal recomendação foi pouco aplicada à área, entretanto, como pode-se notar na figura 128 elaborada com informações da carta de uso e ocupação do solo de 1981, (IGC, 1981), no trecho apenas uma área próxima ao município vizinho de Votorantim foi utilizada para fins industriais. A legislação urbana do trecho 4 ainda foi alterada neste trecho várias vezes: em 1968, pela lei no 1541/68 (Lei do Plano Diretor do Município de Sorocaba), que vai estabelecer setores diferenciados para o zoneamento ZR3; neste trecho ele passa a pertencer ao $1^{\circ}$ setor ZR3 e tem as modificações: TO=30\% máximo para edifícios comerciais e de uso misto; TO=60\% máximo para uso residencial, e $C A=3,0$ máximo, o que já começa a caracterizar o aumento de 
área construída permitida pela legislação urbana. A urbanização da área, incipiente a princípio pela lenta velocidade das vendas dos lotes urbanizados da área, recebe, a partir da metade da década de 70, dois empreendimentos: o Parque Campolim, implantado em 1976, com desenho urbano baseado nos bairros jardins da Cia. City de São Paulo, com lotes de $360 \mathrm{~m} 2$ na fase 1 e 2 (ambos os lados da atual Av. Antonio Carlos Comitre), e de 680m2 na fase 3, do outro lado da RRT; e o Eltonville, de desenho urbano mais tradicional, situado na área mais plana do trecho 4 e lotes maiores (1000 a 1200 m2); onde começam a se instalar os moradores mais abastados da cidade. O Parque Campolim, junto ao desenho urbano diferenciado do bairro homônimo, foi um elemento importante para a valorização imobiliária do entorno, extrapolando sua área de influência direta, chegando a pelo menos $2 \mathrm{~km}$ seu raio de influência direta nas ultimas quatro décadas, pois a ele juntaram-se comércio e serviços que garantiram lançamentos de várias unidades habitacionais nas proximidades, aproveitando-se da oferta de terras ainda não urbanizadas do entorno imediato (Fig. 124).

Figura 124 - Parque Campolim visto em direção à Votorantim.

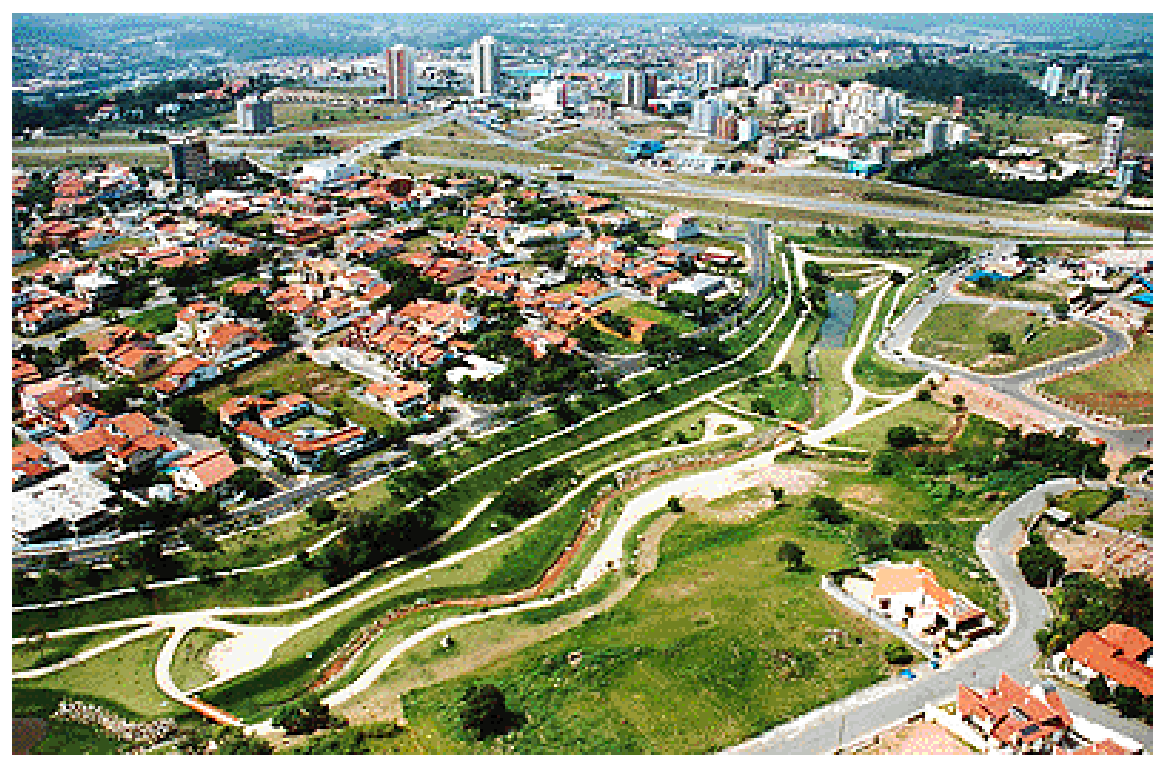

Fonte: PMS, 2006. (Autor: Zaqueu Proença Bueno).

Pelo mapa de uso e ocupação do solo do trecho 4 de 1981, elaborado com dados do IGC (1981), já se percebe as manchas urbanizadas da área residencial, área industrial e de mineração, em meio a pastagens e campos antrópicos (Fig. 128).

Embora pela próxima lei referente à área (lei municipal no. 2821/1988), houvesse a proibição de construção de edificações multi-familiares, no retângulo conformado entre os vértices da Av. Marginal com a RRT, com a Av. Armando Pannunzio (km 102) com a atual av. Arthur Fonseca $x$ a av. Comendador Pereira Inácio, neste caso englobando especificamente os 
dois novos bairros, pouco tempo depois já se autoriza pela lei municipal no 4594/94 a construção de apart-hotéis em praticamente todos os setores do Município de Sorocaba, lembrando que são considerados apart-hotéis pela mencionada lei, as edificações multi-familiares residenciais, com prestação de serviços de hotelaria e a lei 5161/1996 revoga a lei 2821/88.

Percebe-se pela foto do trecho em 1994 quase duas décadas depois, que a mancha urbana se espalhou rapidamente (veja foto de 1978 - fig. 127), conturbando os municípios de Sorocaba e Votorantim, principalmente devido ao hipermercado Carrefour e Esplanada Shopping, estabelecido na divisa dos dois municípios.

Dados oficiais da prefeitura municipal de Votorantim informam que, desde 1996, houve um crescimento populacional de aproximadamente $10 \%$ a cada 4 anos, perfazendo um acréscimo total líquido de cerca de 1.600 pessoas/ano, e atualmente ${ }^{57}$ a densidade populacional de Votorantim é de 1,7 pessoas $/ \mathrm{km}^{2}$ (PMV, 2018). Boa parte deste crescimento refere-se à valorização e construção de empreendimentos imobiliários nas áreas próximas ao antigo Esplanada Shopping, (atual Shopping Iguatemi Esplanada), que recebem adensamento vertical e ocupação de áreas por loteamentos residenciais horizontais.

Outras leis do Município de Sorocaba também alteraram a urbanização pertinente ao trecho aqui analisado: pela lei no. 5261/96 permite-se a construção de edifícios alinhadas nas calçadas desde que tenham até 1,5 vezes a largura da via pública; e a lei no. 5911/99 transforma a área do trecho de ZR3 (1 ${ }^{\circ}$. Setor) para ZR1 ( $2^{\circ}$ setor), ali alocados os bairros Campolim, Eltonville, Jd. Aristocrata e Jd. Pagliato. Mas neste último bairro, a lei 6200/2000 isola a quadra $\mathrm{H}$ para que nela vogue os parâmetros do zoneamento ZR3, ao invés do ZR1 recem-estabelecido.

Pode-se verificar, pela evolução da mancha urbana no trecho, que o maior período de crescimento da mancha urbana no trecho 4 foi na década de 90 , que a partir do empreendimento Parque Campolim, alcançou as duas pontas do trecho: no km 98 da RRT, chegando até a marginal do Rio Sorocaba, e no km 102; até ultrapassando a barreira do corredor comercial da Av. Armando Pannunzio. A urbanização no trecho 4 desta maneira consolida-se na década de 90 e início do séc. XXI (Fig. 129).

Com diferença de três décadas da foto de 1962 para a foto aérea de 1994, nota-se a intensa urbanização e a conurbação efetiva entre os municípios de Sorocaba e Votorantim. Isto foi possibilitado pela legislação urbana provida pelo estado, que prontamente flexibilizava a lei do

\footnotetext{
${ }^{57}$ http://www2.votorantim.sp.gov.br/site/index.php?option=com content\&view=article\&id=6\&ltemid= 19, acesso em março de 2018.
} 
uso e ocupação do solo aos desejos da indústria imobiliária, como notou Wilson Barreto (2007) pesquisador sobre a verticalização (Fig. 130)

Portanto, a urbanização no período de 1962 a 2003, que passou de ZR para ZR3, obedeceu ao zoneamento municipal quanto ao uso do solo; sendo que os lotes tinham muitas vezes, áreas até maiores em alguns novos bairros do que o mínimo de área mínima de 250m2 por lote estabelecido neste período para este trecho; não houve ocupação irregular residencial neste período. 


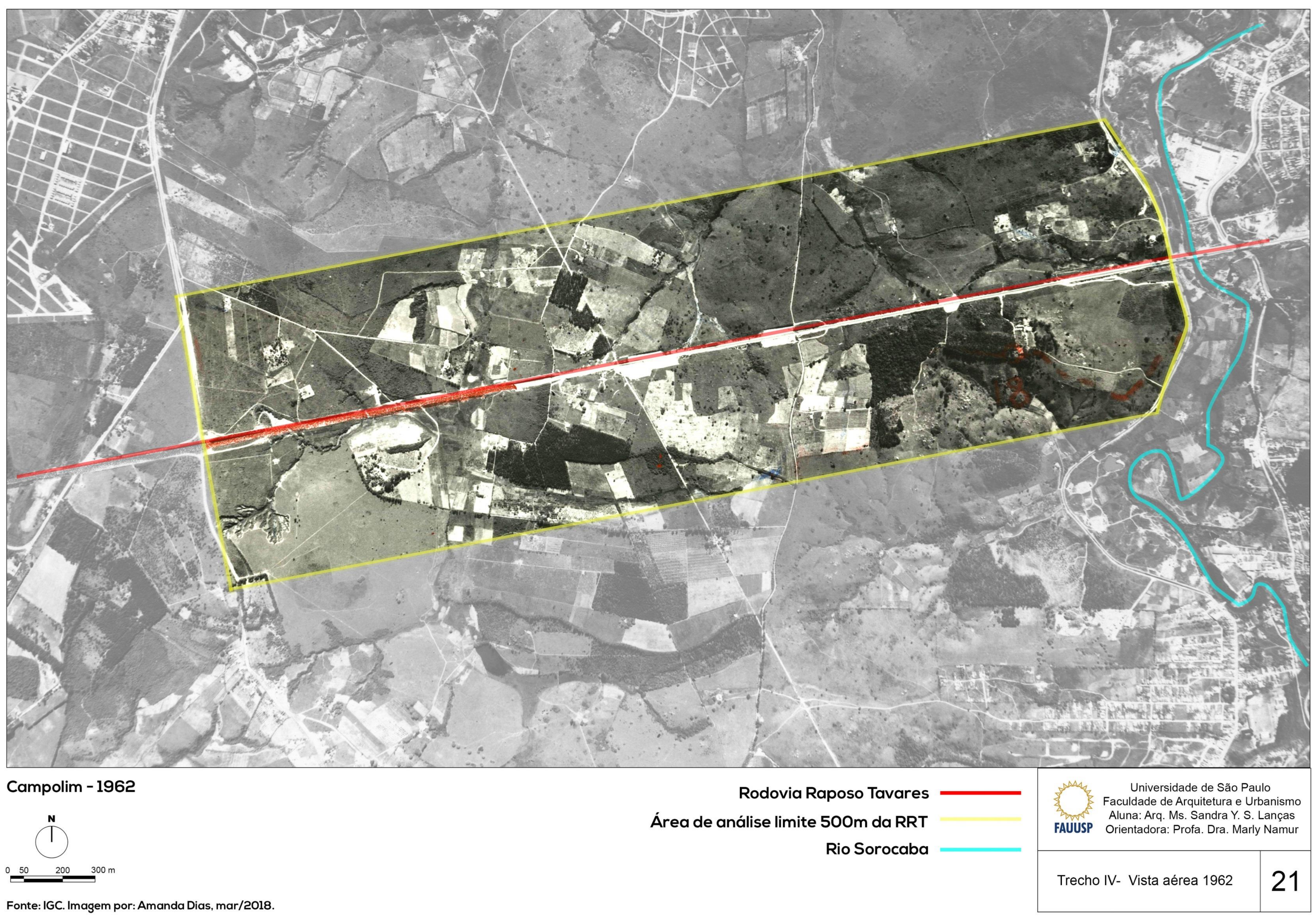


Figura 126 - Trecho 4 - Estradas e mancha urbana do trecho 4 em 1973, do Rio Sorocaba até confluência da Av. Armando Pannunzio, Bairro Pq. Campolim.

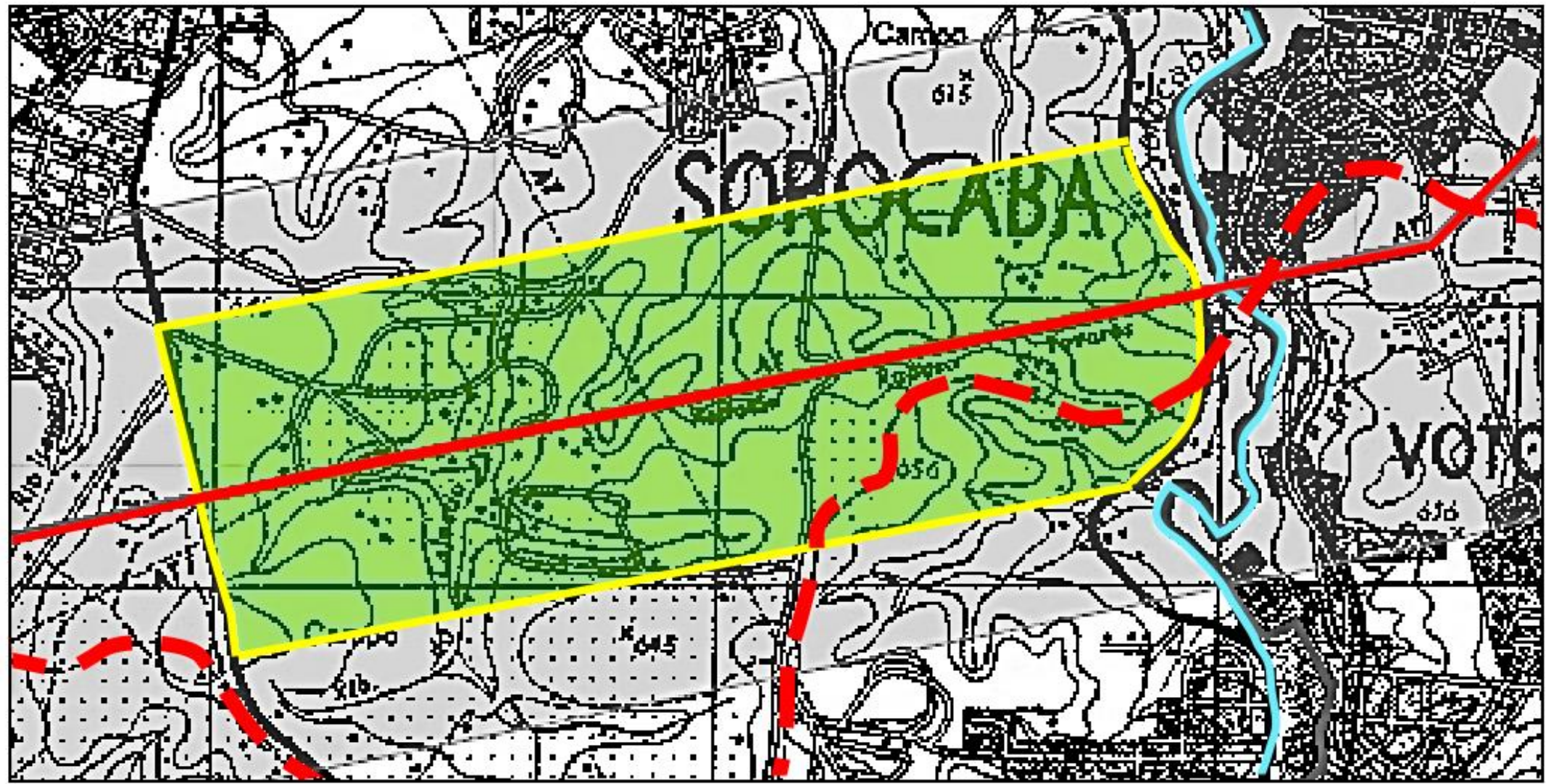

$\mathbf{N}$

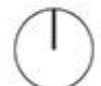

Curvas de nível

Limite Sorocaba / Votorantim $=$

Rodovia Raposo Tavares

Área de análise limite $500 \mathrm{~m}$ da RRT

Rio Sorocaba

Fonte: IGC, Mapa de Sorocaba (1973). Retrabalhado por Amanda Dias, 2018 
Figura 127 - Vista aérea do Trecho 4, Campolim em 1978.

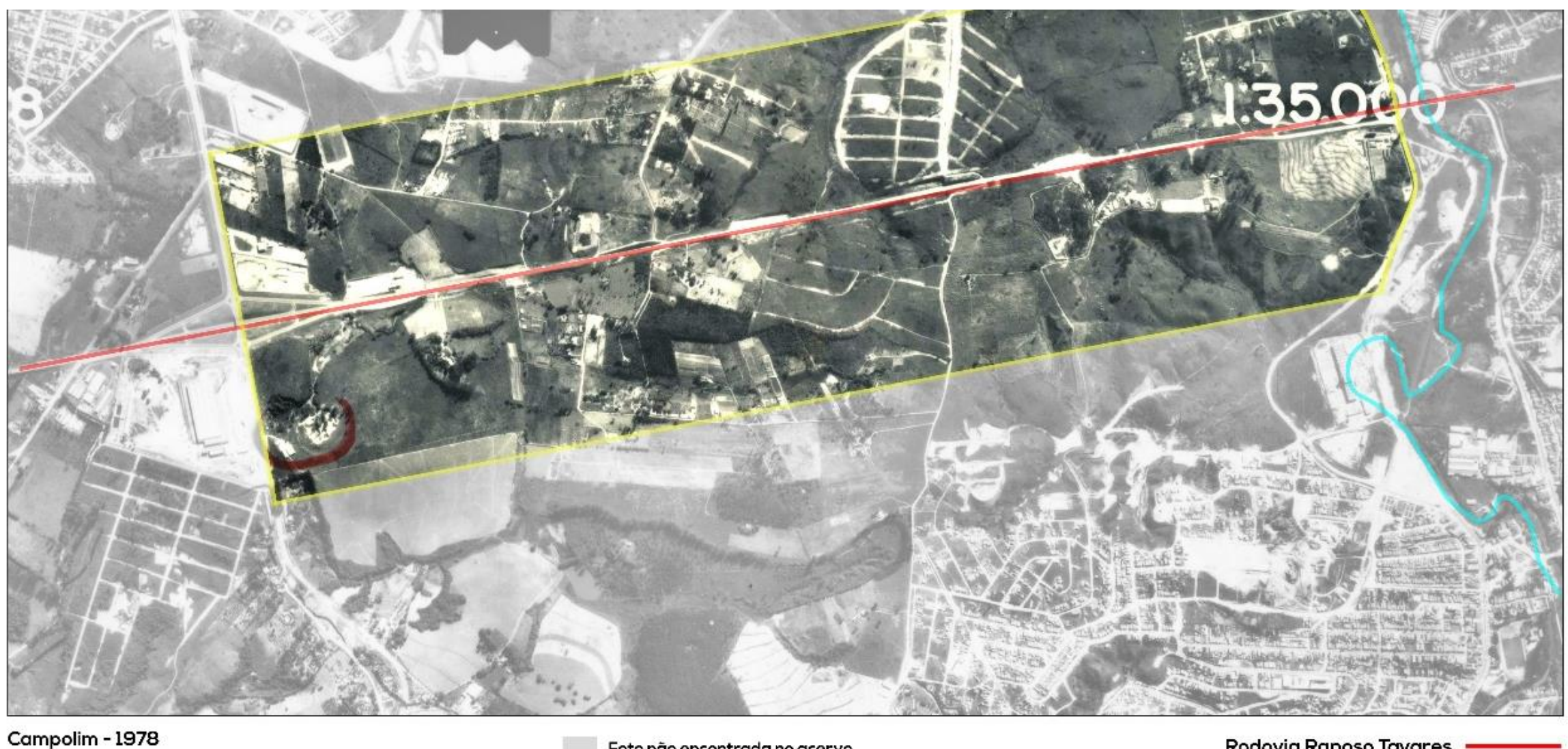

Campolim - 1978 T)

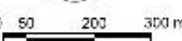

Fonte: IGC. Imagem por: Amanda Dlas, mar/2018.

Fonte: IGC, 1978.
Traçado antigo da Raposo Tavares

Área de análise limite $500 \mathrm{~m}$ da RRT

Rio Sorocabo

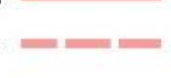
(1) 
Figura 128 - Mapa do Uso do Solo do Trecho 4, Campolim em 1981.

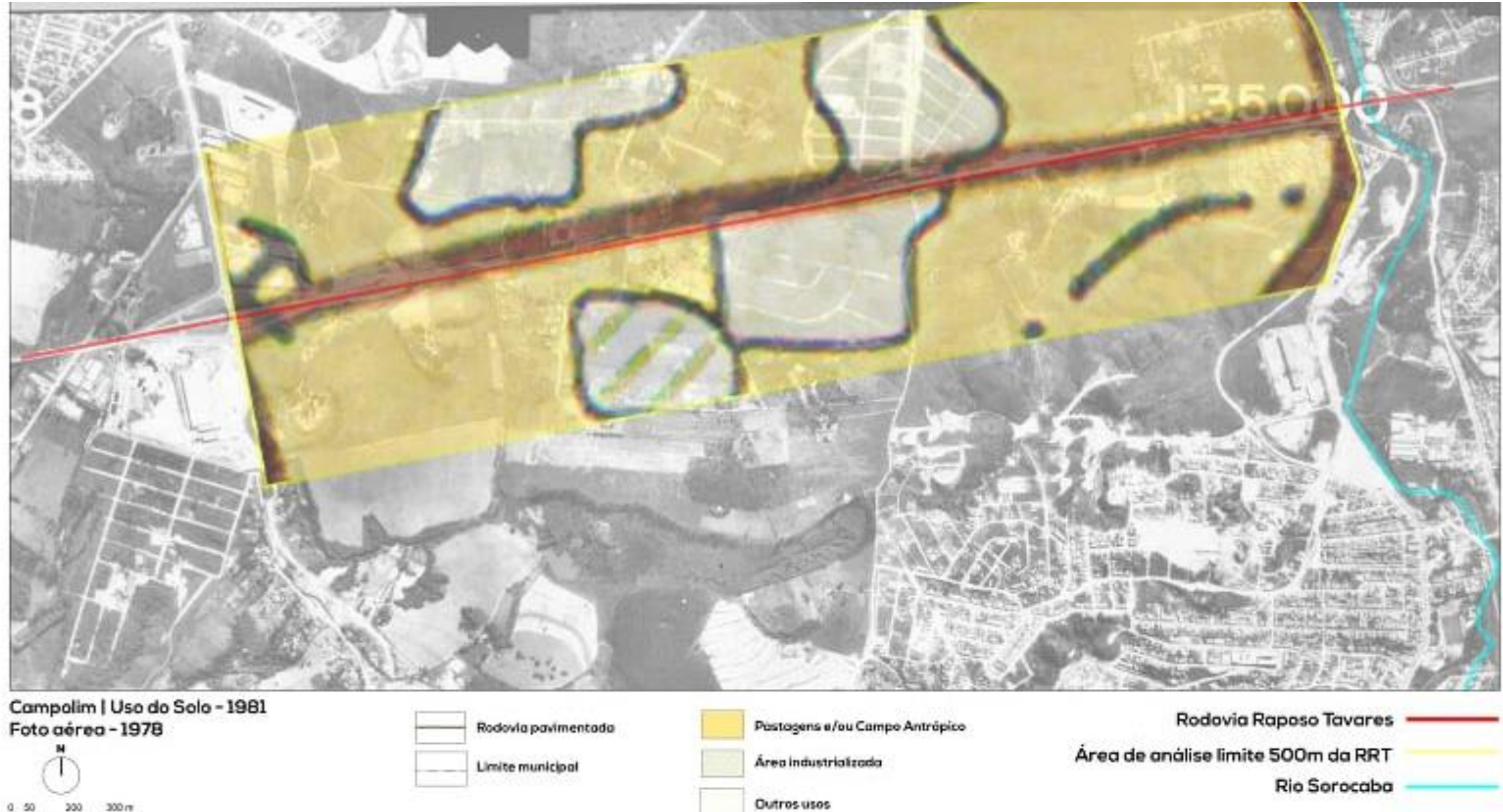

Forte: KSC. Inagem par: Amando Disas mar/2019.

Fonte: IGC, 1981 
Figura 129 - Foto aérea do trecho 4 em 1994.

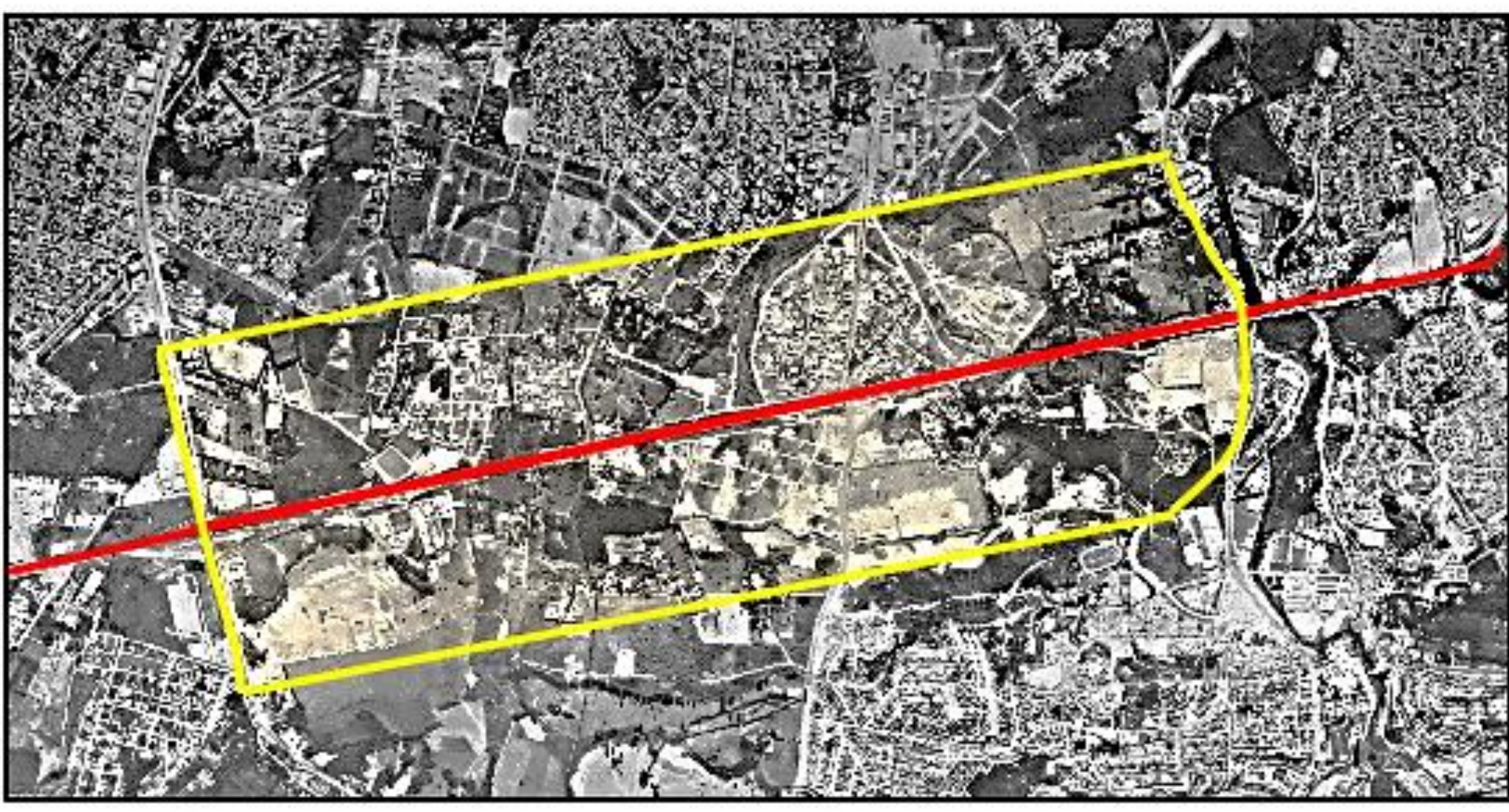

(1)

(T)

Rodovia Raposo Tavares

Área de análise limite 500m da RRT

Fonte: Prefeitura Municipal de Votorantim. Retrabalhado por Amanda Dias, 2018 


\section{$2^{\circ}$ período urbanização 2004 a 2007}

Mesmo o Rio Sorocaba passando no $\mathrm{km} 98$ da RRT (início do trecho aqui analisado), o macrozoneamento ambiental do PD de 2004 estabeleceu este trecho como Macrozona de pequena restrição à ocupação urbana, pois a maior parte do trecho se localiza em cota elevada em relação ao rio e sua várzea. Portanto não havia problemas quanto à urbanização, a priori, do trecho. 0 componente ambiental neste caso, simbolizado pelo Parque Campolim, com suas três bacias de retenção, na verdade contribuiu para a valorização imobiliária do seu entorno, e inclusive para a verticalização do bairro, após a implantação de residências unifamiliares de média e alta renda no entorno imediato do parque, que vinha recebendo desde 1995, ao longo do principal corredor, a Av. A. C. Comitre, a instalação de agências bancárias, comércios, restaurantes, escolas, etc; contribuindo desta maneira ainda mais para a valorização imobiliária do entorno. Com relação ao potencial construtivo, pelo PD de 2004 o CA passou de 2,0 para 2,5 nas áreas lindeiras ao corredor da Av. Antônio Carlos Comitre, fato rapidamente aproveitado pela indústria imobiliária, que construiu prédios de escritórios, consultórios e comércio com mais de 10 andares. No restante da área do trecho 4, correspondente aos bairros iniciais (Parque Campolim, Eltonville, Jd. Pagliato e Jd. Aristocrata), do início da ocupação urbana já com residências unifamiliares consolidadas, a verticalização continuou vetada, com o zoneamento ZR1, limitado a três pavimentos. Em 2007, Barreto observou que "dos 82 edifícios então construídos (no município) ou em fase de construção, com mais de 4 pavimentos, somente 7 estão localizados fora desta área" (BARRETO, 2007). Entre 2002 e 2009, a mancha urbana do Município de Sorocaba cresceu em todas as direções, seguindo seus principais eixos viários, mas principalmente nas direções norte e sul, onde aumentou-se a densidade populacional (MARTINES; TOPPA; OLIVEIRA, 2015) (Fig. 131). A análise do aumento das manchas urbanas no Município de Sorocaba entre 2002 e 2009 indica a expansão da mancha urbana no trecho do lado da RRT de Sorocaba para o outro lado da RRT, correspondendo as proximidades do Shopping Esplanada e do Shopping Panorâmico (Fig. 131), e a partir de 2013, para o lado oeste do trecho 4 analisado, chegando à rod. João Leme dos Santos (SP264), que conecta Sorocaba e Votorantim à Universidade Federal de São Carlos, e aos municípios de Salto de Pirapora, Piedade e São Miguel Arcanjo dentre outros municípios localizados mais ao sul da RMS (Fig. 133). 
Figura 130 - Foto da intensa verticalização na parte sul do Parque Campolim, em sua fase 3, após o viaduto sobre a RRT.

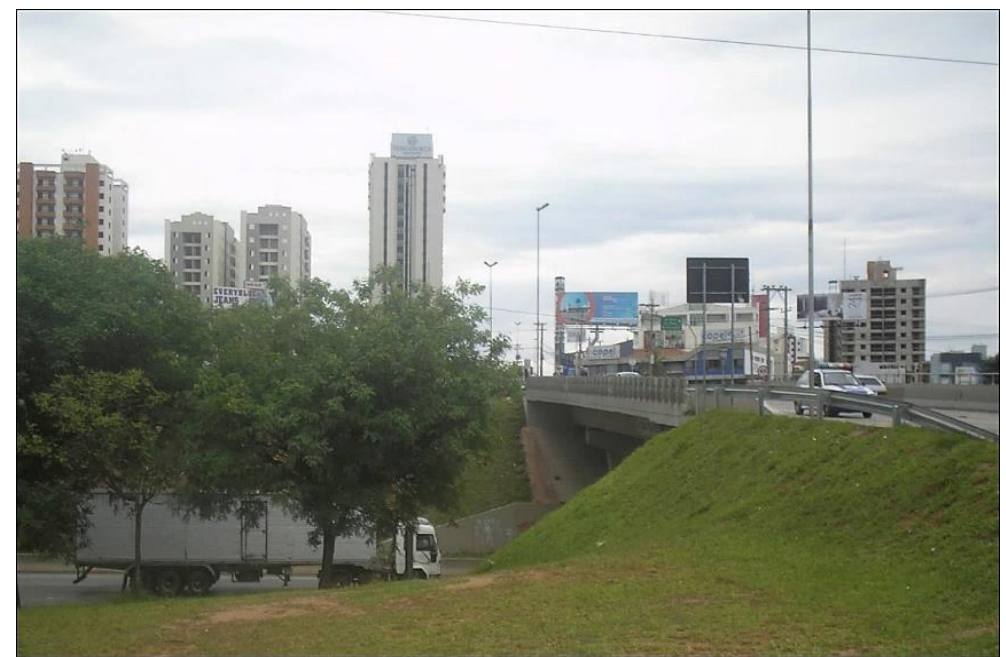

Autor: BARRETO, 2007. Data: novembro/2006.

Figura 131 - Análise espacial da distribuição e expansão das manchas urbanas do Município de Sorocaba.

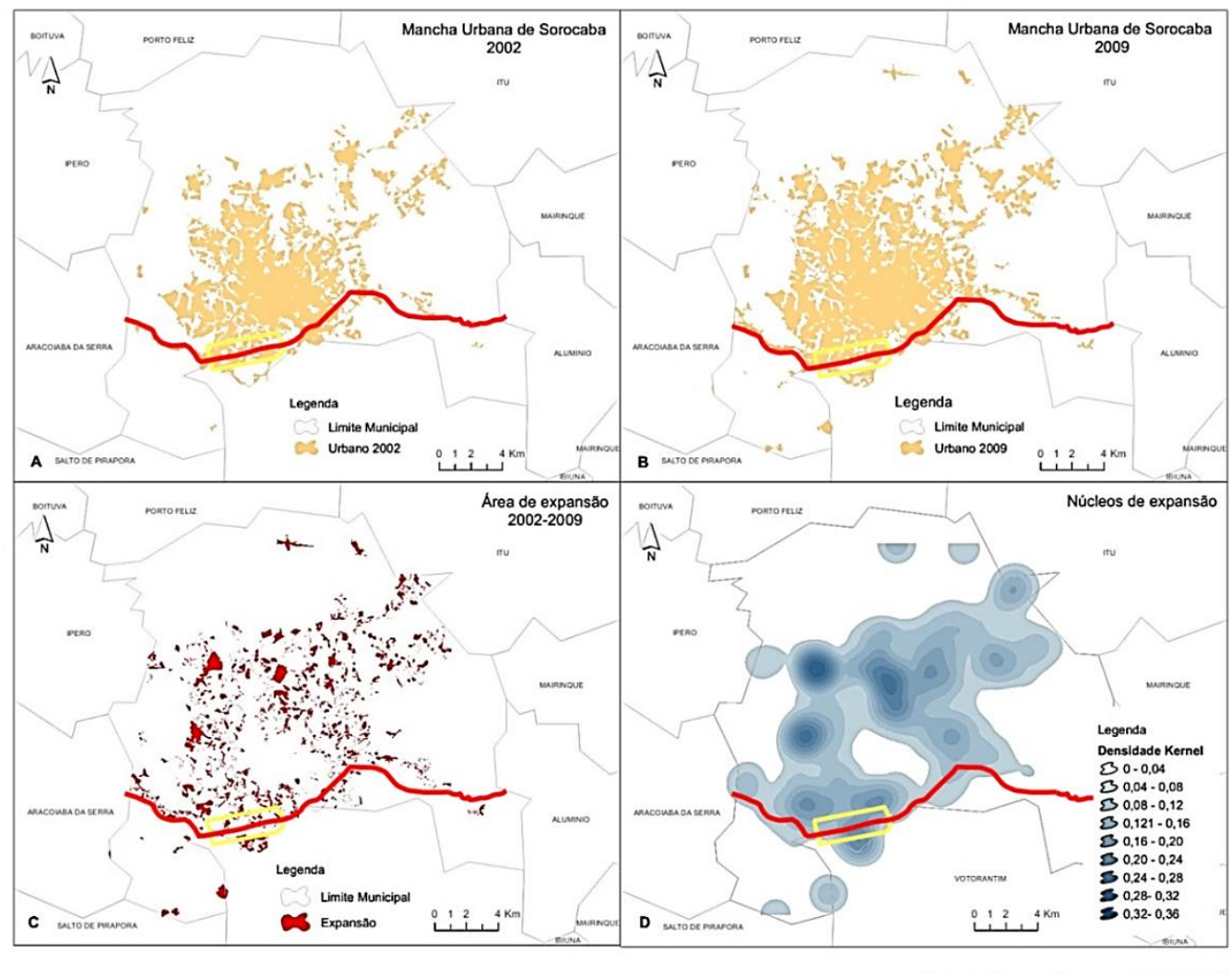

Rodovia Raposo Tavares
Área de análise limite $500 \mathrm{~m}$ da RRT

(A) Distribuição das manchas urbanas para o ano de 2002; (B) Distribuição das manchas urbanas para 0 ano de 2009; (C) Área de expansão urbana para o período 2002 - 2009; (D) Núcleos de expansão urbana. Fonte: MARTINES; TOPPA; OLIVEIRA, 2015. Retrabalhado por Amanda Dias, 2018. 


\section{$3^{0}$ período $2008-2014$}

A análise das alterações do PD de 2007 de Sorocaba indica que este PD de 2007 foi uma revisão do PD de 2004 na redação da lei, mas seus efeitos foram muito mais extensivos e intensificados pela possibilidade descortinada pela modificação e inclusão de algumas palavras; no uso e ocupação do solo permitido a partir do PD de 2007. Por exemplo, no trecho 4 pelo PD de 2007 incluiu-se uma área ZR2 do lado onde o zoneamento era ZR1, para beneficiar um edifício de 9 andares; pelo zoneamento anterior ele não poderia ser aprovado e receber 0 "habite-se" oficial.

Mas uma modificação na lei de 2007 teve profunda modificação no uso e ocupação do solo do bairro do Campolim: trocou-se a palavra "estritamente" por "predominantemente" na redação das características ZR1. Com isto, permitiu-se praticamente a instalação de vários outros tipos de usos além do residencial no bairro Parque Campolim e seu entorno, uma vez que o termo não foi acompanhado de parâmetros mais específicos quanto à atividade residencial $\mathrm{e}$ de profissionais liberais nas edificações de até $750 \mathrm{~m} 2$ de área construída que não estivessem dentro de "loteamentos fechados" (Lei no. 8181/2007, art. 18, parágrafo $1^{\circ}$ ).

A maioria das edificações pré-existentes no bairro à lei de 2007 eram residências unifamiliares; e o PD de 2004 privilegia a função ZR1 inclusive citando seus jardins; a partir de 2007 então há proliferação de pequenos prédios que não tem mais a função predominantemente residencial no bairro Parque Campolim, na área onde não está fechada pelos muros dos "loteamentos fechados". O aumento da oferta de serviços especializados oferecidos nos consultórios e escritórios na região colaborou ainda mais para o aumento da oferta imobiliária de pequenos apartamentos com bom acabamento na região; e rapidamente os empreendedores imobiliários também ofertam imóveis na região próxima, no Município de Votorantim, praticamente conurbado, onde a oferta da extensão de terras, a menor preço, além da menor taxação de impostos em termos monetários do que no Município de Sorocaba favorece a criação de mais loteamentos residenciais horizontais e verticais, com a vantagem de ter acesso a rod. João Leme dos Santos (SP 264) além da RRT. Portanto, o PD de 2007 para o trecho foi importante na medida em que flexibilizou sobremaneira o uso e ocupação do solo do bairro jardim Parque Campolim, passando o zoneamento ZR1 de estritamente residencial para predominantemente residencial, com permissão, a partir de 2010 por lei complementar, para a construção de apartamento do tipo quitinetes. Também não foram utilizados no trecho neste $2^{\circ}$. período nenhum dos instrumentos notáveis de planejamento urbano, embora aprovados no PD de 2007 (outorga onerosa do direito de construção; IPTU progressivo no tempo). Apesar da 
evolução da mancha urbana no trecho 4 do período entre 1970 e 2013 (Fig. 133) alcançar todo 0 trecho compreendido entre o km 98 e 102 da RRT, pela próxima figura podemos verificar, na foto aérea de 2010 da área, que ainda existiam muitas áreas de campos e pastagens que poderiam ser utilizadas para novos empreendimentos imobiliários (Fig. 134).

Figura 132 - Panorama da região do Campolim. À direita, a Av. A.C. Comitre de Sorocaba a Votorantim.

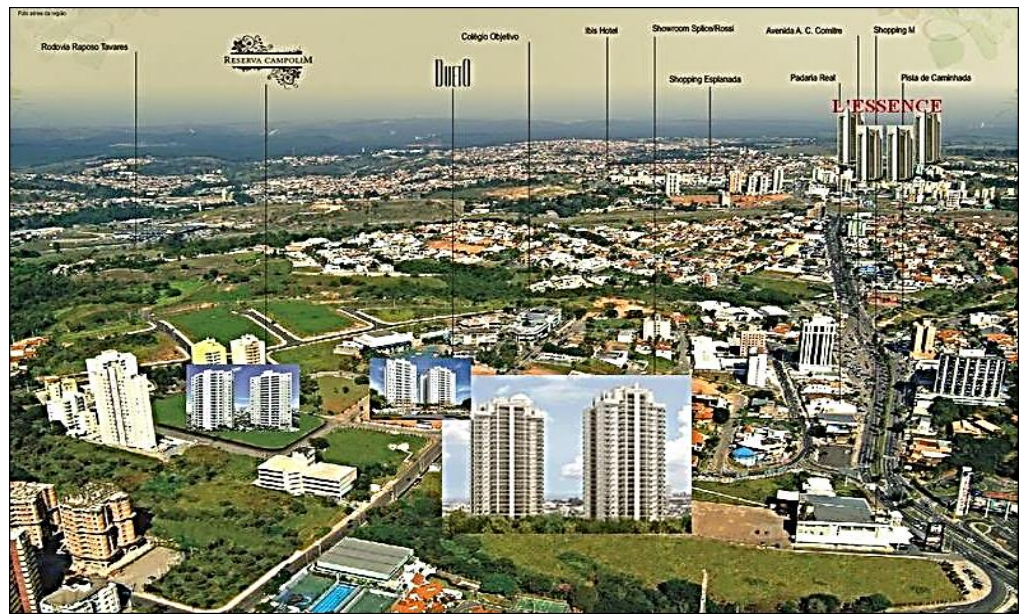

Fonte: Empreendimento L'essence. In: http://www.skyscrapercity.com/showthread.php?t=706958 September 11th, 2008, 07:12 PM.

Figura 133 - Evolução Urbana Sorocaba (1970-2013)

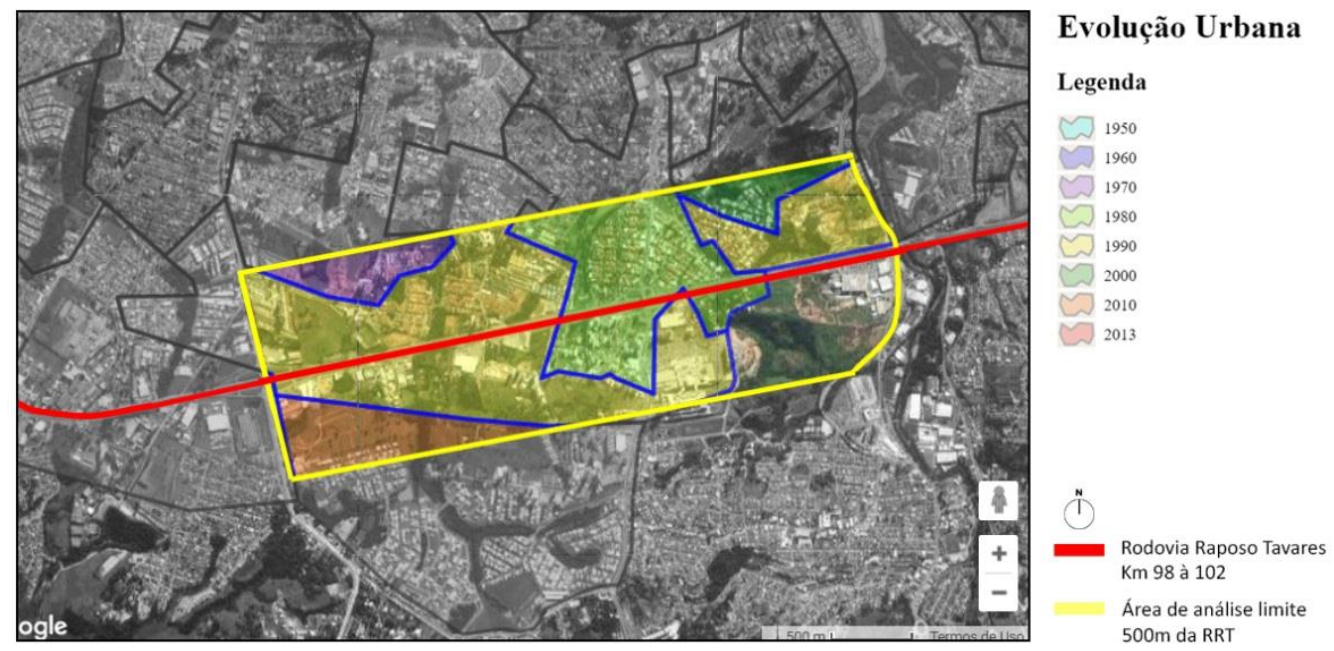

Fonte: http://soromaps.atwebpages.com/Evol_Urb.html. FURLANI, 2017. Retrabalhado por Amanda Dias, 2018. 


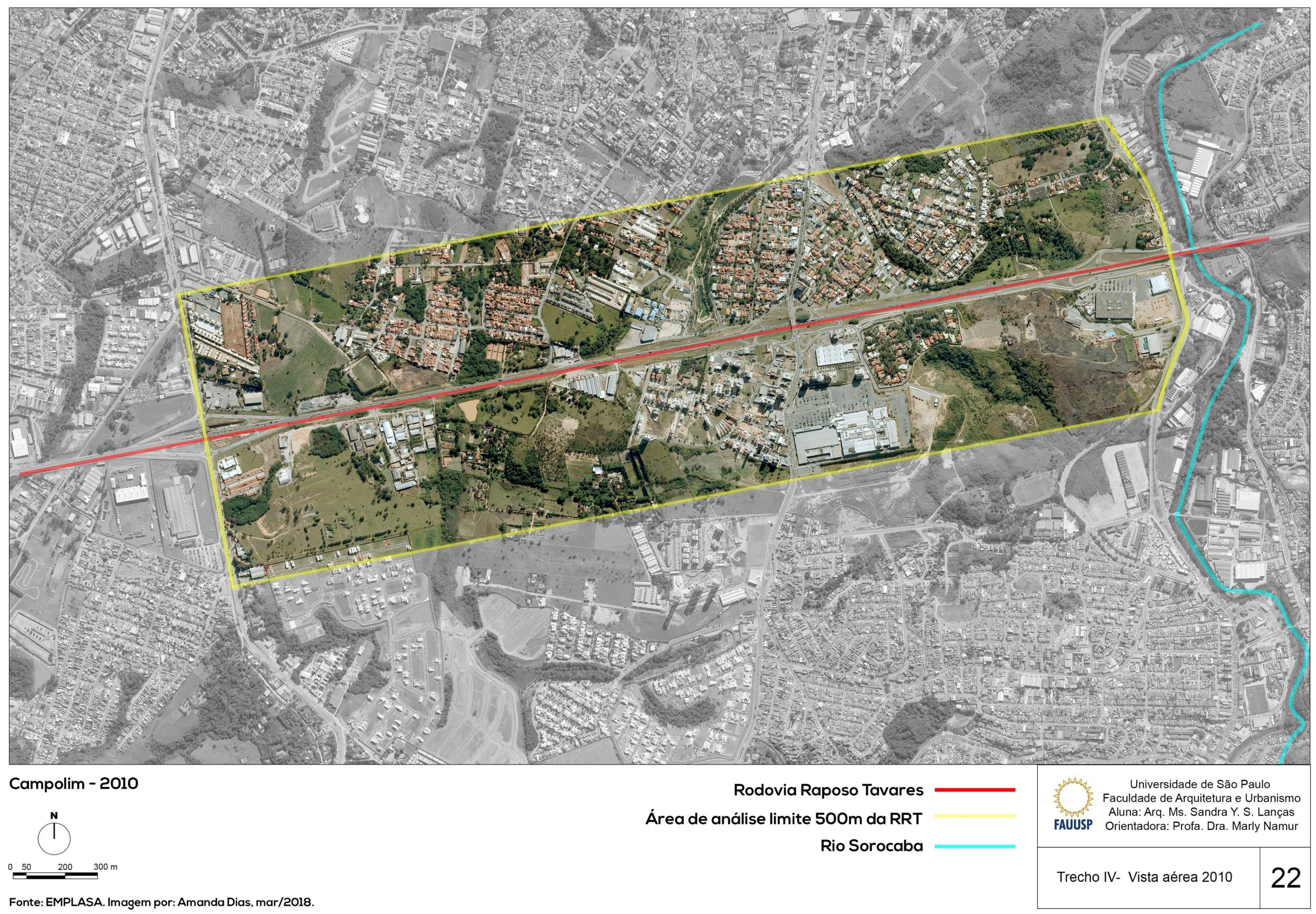


A verticalização proposta pelo empreendimento imobiliário do tipo MCMV também não encontrou legalização no próximo plano diretor de 2014 (PD Sorocaba). Algumas ONG's e profissionais arquitetos e urbanistas começam a notar as mudanças propostas nos coeficientes de TO e CA e buscaram debater melhor a questão do adensamento versus o aumento da frota de veículos automotivos. Os congestionamentos são onerosos, a população agora mais motorizada (dois terços da população sorocabana têm veículo próprio, segundo a URBES), e há demanda pelo plano diretor de mobilidade urbana, que produz uma proposta de um novo terminal intermodal próximo ao km 92 da RRT (PDTUM, URBES, 2016).

Com o movimento pendular aumentando desde 2010 (EMPLASA, 2015) o Sistema Castelo - Raposo Tavares, composto por dois eixos rodoviários muito utilizados no Estado de São Paulo. Para o trecho 3 - Campolim (Verticalização) - do km 92 ao 102 - em estudo, colocase a questão do diagnóstico e prognóstico de carregamentos realizado pelo PDTUM ${ }^{58}$ do Município de Sorocaba, com cenários de curto prazo (2016), médio prazo (2020), e longo prazo (2027), com e sem interferência proposta pelo PDTUM realizado pela Logit59 cujo plano foi aprovado em 2016 pela Câmara Municipal de Sorocaba. O diagnóstico do PDTUM no trecho da RRT tanto para cargas quanto para veículos leves de passageiros indicava:

\begin{abstract}
"As ocupações de regiões cada vez mais afastadas do Centro implicam na necessidade de maior infraestrutura urbana. (...) 0 Eixo Sul não mais se configura como vetor de crescimento porque além de já estar consolidado, apresenta limites de expansão devido à conurbação com o Município de Votorantim." (PMS, 2014, negrito nosso).
\end{abstract}

Contrariando o diagnóstico escrito do PDTUM (elaborado em 2014, aprovado em 2016), com relação ao vetor de crescimento no eixo sul mencionado no texto acima, mesmo com a limitação territorial legal (municípios de Sorocaba e Votorantim), e a conurbação já existente, a expansão urbana ocorreu e ainda ocorre atualmente em termos de verticalização e adensamento, como demonstrada na prática pelo número de lançamentos e instalação de equipamentos no eixo da Rod. Raposo Tavares e Av. Antônio Carlos Cômitre, continuada com 0 nome de Av. Gisele Constantino, a partir do Município de Votorantim.

E inclusive era possivel de se prever devido aos espaços ainda não urbanizados que existiam e ainda existem próximos à RRT neste trecho, ainda no território do Município de Sorocaba (Fig. 135 e 136).

\footnotetext{
58 O PDTUM foi realizado pela Prefeitura de Sorocaba, através da URBES - Trânsito e Transportes durante 0 período de 02 de agosto de 2012 até 10 de abril de 2013. (PMS, 2014).

${ }^{59}$ Empresa de estudos de mobilidade urbana contratada pela PMS para elaboração do PDTUM.
} 
Figura 135 - Panorama do trecho 4 RRT vista ao Sul (em direção a Votorantim), hipermercados, shopping, e verticalização.

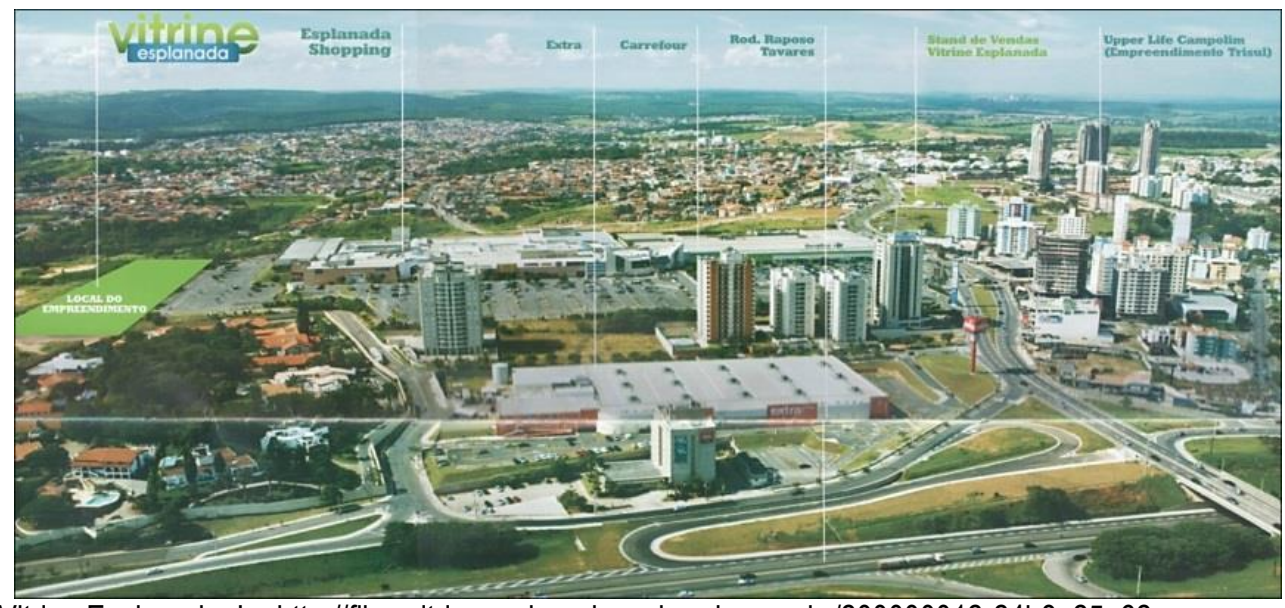

Fonte: Vitrine Esplanada. In: http://files.vitrineesplanada.webnode.com.br/200000012-24b8e25a62public/Localiza\%C3\%A7\%C3\%A30\%20A\%C3\%A9rea.jpg, acesso em julho de 2017.

A área deste trecho 4 é uma das que mais recebem empreendimentos verticalizados no Município de Sorocaba (Fig. 136 e 137). Este fato corrobora os dados já verificados sobre a densidade demográfica e distribuição de densidade de empregos por região (2012-2013) (Fig. 138).

Figura 136 - Foto empreendimento imobiliário.

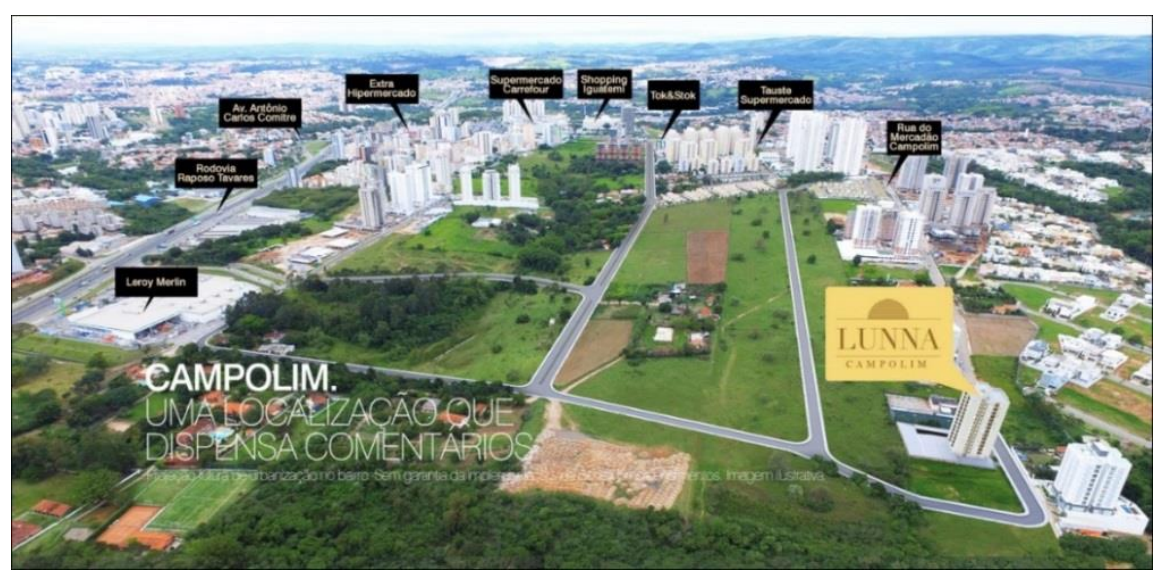

Fonte: Lunna Campolim. In: www.lunnacampolim.com.br, acesso em março de 2018.

Figura 137 - Fotos de empreendimentos imobiliários.

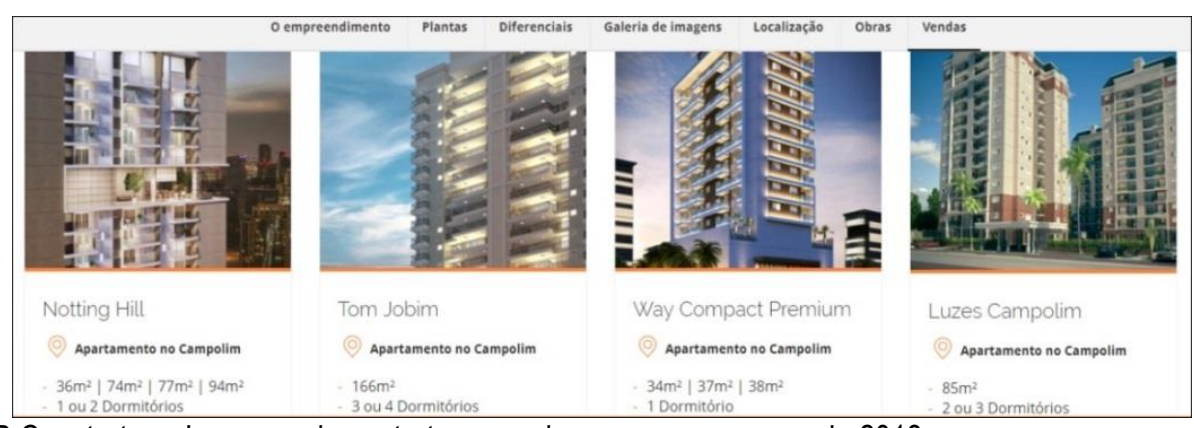

Fonte: CRB Construtora. In: www.crbconstrutora.com.br, acesso em março de 2018. 
Figura 138 - Densidade Demográfica e Distribuição de Densidade de Emprego por Região.

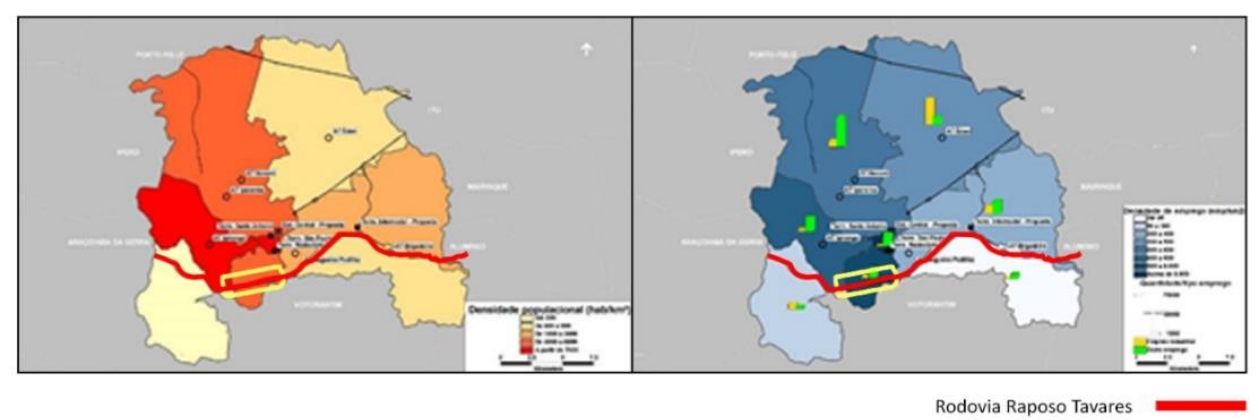

Área de análise limite $500 \mathrm{~m}$ da RRT

Fonte: PDTUM, 2014. Retrabalhado por Amanda Dias, 2018.

Complementando as demais modificações com relação ao corredor principal de comércio e serviços, apesar da intensa urbanização verificada no período, com relação ao uso e ocupação do solo aos a promulgação do PD de 2007, conclui-se que a lei de zoneamento neste quesito foi seguida no trecho até cerca do final do ano de 2012.

No $1^{\circ}$ semestre de 2013 , constatou-se um caso de empreendimento imobiliário no trecho 4 neste período, que gerou polêmica devido à sua não conformidade à lei promulgada: 0 empreendimento denominado PARQUE SALAMANCA60 INCORPORAÇÕES SPE LTDA., processo administrativo do Município de Sorocaba no. 30417/2012, colocado para aprovação municipal na vigência da lei do PD de 2007, em 23/novembro/2012, como Condomínio Residencial Multi-familiar, pretendia se instalar na Av. João Wagner Wey no. 1565, Jardim América, em área de $50.303,50 \mathrm{~m}^{2}$, com área a ser construída de $39.302,01 \mathrm{~m} 2$, distribuídas em 22 torres de inscrita no CNPJ sob no. 19.563.059/0001-16, sendo construída pela empresa MRV ENGENHARIA E PARTICIPAÇÕES S/A, CNPJ 08.343.492/0001-20 nos termos da lei municipal no. 8270/07, e sua regulamentação, e apontados pelo Estudo de Impacto de Vizinhança (EIV), Relatório de Impacto Viário (RIT) e Laudo de caracterização vegetal, recebeu forte oposição da Associação de Moradores dos Bairros Elton Ville, Uirapuru e Adjacências (AMBEU) (CNPJ 06.986.119/0001-61), pois o empreendimento não seguiu os parâmetros dispostos para a ZR-1, que permitia imóveis com área construída de até 750 m2, (PD 2007, Art. 79, parágrafo 1) e máximo de 3 pavimentos (Art. 81, parágrafo $3^{\circ}$.).

60 Contrato social registrado na Junta comercial do ESP em 21/01/2014 sob. No. 3522811908-1, e PRIME CONSTRUÇÕES S/A, CNPJ 00.409.834/0001-55. 
Figura 139 - Publicidade Parque Salamanca - Campolim - Sorocaba.

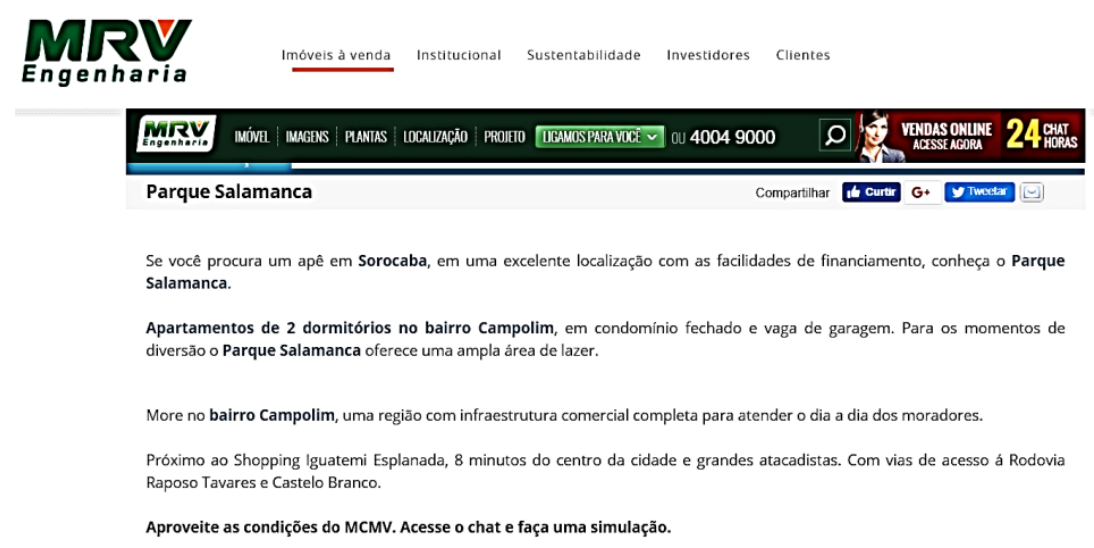

\section{AIRA}

Fonte: http://www.mrv.com.br/imoveis/apartamentos/saopaulo/sorocaba/campolim/parquesalamancal, acesso em março/2018.

Figura 140 - Publicidade Parque Salamanca - Campolim - Sorocaba.

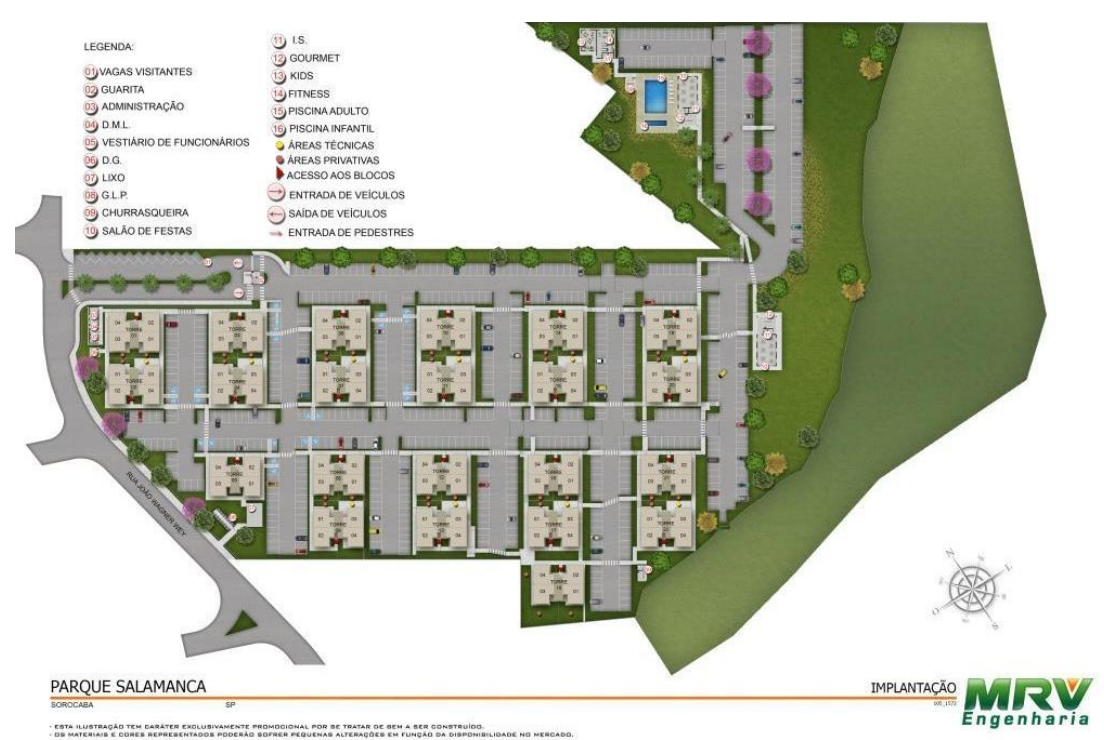

Fonte:http://imoveis.mrv.com.br/upload/imagens/1429/20150303044409 PQ-SALAMANCA PH_IMPLANTACAOFORMATO_2015_02_27.jpg, acesso em março/2018.

O empreendimento, com aprovação municipal, mas desaprovação da associação de moradores dos bairros afetados do entorno (AMBEU), e realmente em desacordo com a lei do PD de 2007, teve iniciada sua construção e em 10/out/2014 firmou com a Prefeitura de Sorocaba, representada pelo então Secretário Municipal de Mobilidade, Desenvolvimento Urbano e Obras, Antônio Benedito Bueno Silveira, e as empresas responsáveis pelo Empreendimento Parque Salamanca, um Termo de Compromisso e Ajustamento de Conduta (TAC) em que esta se comprometeu a empregar e promover de forma compensatória, até 0 limite de $\mathrm{R} \$ 5$ milhões de reais, a execução de parte de obras pertinentes ao viaduto de 
transposição da RRT, entre o km 101 e 102, e suas conexões viárias com a Rua Augusto Lippel (do outro lado da RRT) e a Rua João Wagner Wey (dispositivo então previsto junto Plano diretor de mobilidade urbana e transporte de Sorocaba, aprovado somente em 29/03/2016).

O TAC não havia sido assinado pelo Ministério Público, portanto a AMBEU entrou com ação cautelar no dia 12/fev/2016, com pedido de liminar para que fosse revogado o alvará de construção e determinado o embargo das obras. Foi solicitado também que o grupo responsável fosse impedido de divulgar e comercializar o empreendimento em referência, para que não ocorresse lesão ao consumidor, evitando frustações e expectativas de diversas famílias que adquirissem imóveis do empreendimento em questão, devido às anormalidades à lei vigente. A AMBEU reiterou a solicitação em 22/02/2016, mas a prefeitura já foi citada no dia 06/02/2017, ou seja, um ano após a solicitação legal. N.A.: o novo prefeito não era do mesmo partido (DEM) do prefeito anterior (PSDB). O partido deposto (PSDB) ficou cerca de 20 anos no poder municipal.

O caso foi parar na Corregedoria Geral do Município, e através do ofício no. 04//CGM/2017, de 11/abril/2017, sobre o processo administrativo CGM no. 2014/028.309-4, para averiguação da Divisão de Licenciamento e Controle/ Secretaria da Mobilidade da PM de Sorocaba (DLCON/SEMOB), com o aporte técnico do sr. João Luiz de Souza Areas (arq. e Urbanista, requisitado nos termos do art. 21 do decreto municipal no. 21.565/2014, sendo 0 órgão de instrução a $2^{\mathrm{a}}$ Câmara Correcional. Este processo não se refere apenas a este empreendimento (Parque Salamanca), mas a possíveis irregularidades em autorizações para várias construções, também de outras construtoras, nas imediações da AMBEU: cinco condomínios residências e dois empreendimentos comerciais aprovados nos loteamentos Elton Ville, Jardim são Carlos e imediações. Os estudos técnicos pertinentes foram elaborados pelo CAEx ${ }^{61}$, do Ministério Público de São Paulo, concluídos em 10/02/2017 e juntados aos autos do inquérito civil no. 6351/2014. Especificamente sobre o empreendimento JD Salamanca da MRV, - CAEx assinalou irregularidades no licenciamento empreendimento residencial multifamiliar denominado Parque Salamanca da MRV Engenharia e Participações S/A, com maior importância para:

\footnotetext{
"(a) aplicação dada pela então Secretaria de Mobilidade, Desenvolvimento Urbano e Obras (SEMOB) ao artigo 25, inciso II, da lei municipal no 8181/20017 (plano Diretor de Desenvolvimento Físico Territorial do Município de 2007), que teria desconsiderado o gabarito de altura como um dos índices de ocupação ou como um condicionante para implantação das edificações no lote, isto é, a SEMOB, ao fazer a análise dos parâmetros urbanísticos utilizados pelo empreendimento, não se ateve a avaliação do gabarito de altura, pois considerou que esta grandeza urbanística não faria parte dos índices de ocupação nem das condições de implantação das edificações no lote;
}

\footnotetext{
${ }^{61}$ Centro de apoio operacional à Execução - Ministério Público de São Paulo.
} 
(b) Insuficiência do EIV/RIT, "(...) por não identificar que a região está passando por significativas transformações; não co-localizando outros empreendimentos em lançamento e em construção que, concentrados na região, podem gerar repercussão ou interferência, impactando o sistema viário; a infra-estrutura urbana; o meio ambiente e o meio social" (sic)-fl.319-verso deste processo correcional" (CAEx MP $\mathrm{SP})$.

Desta forma, o corregedor geral do município determinou a imediata remessa destes autos correcionais ao secretário de planejamento e projetos para a adoção de medidas acauteladoras, em 10/04/2017, também baseadas nas leis no. 10.964/2014 e lei municipal no. 11488/2017; e em 10/abril de 2017, o secretario de planejamento e projetos do município determinou a imediata interdição e embargos da continuidade das obras, usando barreiras "New Jersey", referente ao PA 30,417/2012. Neste sentido, houve ocupação irregular de empreendimento residencial no trecho 4 , no caso de pelo menos cinco empreendimentos diferentes; o do Parque Salamanca ainda não resolvido, pois a construtora MRV entrou com liminar em 2a instancia para fazer valer o TAC anteriormente assinado em 2014.

\begin{abstract}
"O desenvolvimento da região ao longo das avenidas centrais do Campolim é recente. O loteamento do bairro começou em 1976 e a comercialização dos lotes teve início em 1981. Atualmente, no corredor da avenida Antônio Carlos Comitre, além do complexo do Shopping Iguatemi Esplanada, destacam-se empreendimentos como 0 hipermercado Carrefour e supermercado Tauste, entre outros. Concessionárias de veículos, clínicas médicas, escolas particulares, lojas de móveis planejados, agências bancárias e prédios com salas comerciais completam a variedade de serviços. Por ali circulam diariamente 31,9 mil carros. (...) A rodovia Raposo Tavares é importante via que facilita 0 acesso desses locais às outras regiões da cidade." (Jornal Cruzeiro do Sul, 25/10/1562).
\end{abstract}

Complementando as demais modificações com relação ao corredor principal de comércio e serviços, apesar da intensa urbanização verificada no período, com relação ao uso e ocupação do solo aos a promulgação do PD de 2007, conclui-se que a lei de zoneamento foi seguida no trecho 4 até cerca do final do ano de 2012.

Em 16/12/2014 foi aprovado novo PD para o Município de Sorocaba, pela lei municipal no. 11.022/14. A ocupação urbana a partir desta legislação urbana não será aqui analisada, devido ao pouco tempo para comparação da mancha urbana e seu uso do solo; mas pelas tabelas 29 e 30 (PD 2014) comparando-as com as do PD de 2007 pode-se verificar a maior flexibilização nos usos admitidos do solo urbano, além da diminuição da exigência quanto aos parâmetros de permeabilidade mínima para os novos empreendimentos imobiliários, a partir de 2015, embora a nomenclatura de ZR1 e ZR2 não tenha sido alterada.

\footnotetext{
62 In: Região vibrante da cidade. Jornal Cruzeiro do Sul. Disponível em: http://www.jornalcruzeiro.com.br/materia/649849/regiao-vibrante-da-cidade, acesso em julho/2017.
} 


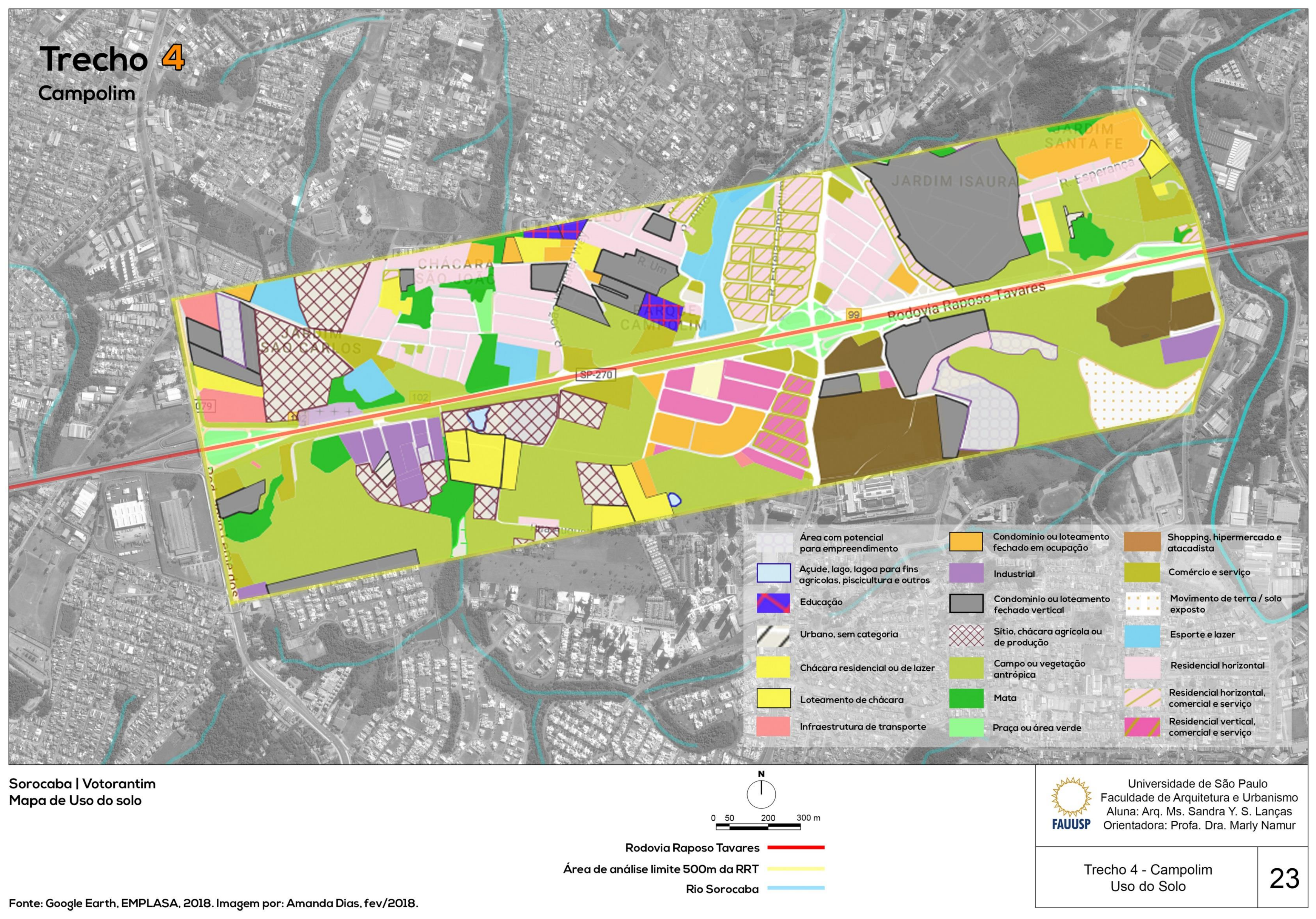




\section{CONCLUSÕES}

“As grandes rodovias permitiram a ampliação do mercado interno. Ao mesmo tempo, levaram à dispersão das indústrias, às grandes migrações da população rural e ao despovoamento dos campos; depois, à dispersão das áreas urbanas e à difusão dos modos de vida metropolitanos."

(REIS, 2006, p. 103). 


\section{CONCLUSÕES}

A urbanização das áreas lindeiras dos trechos da RRT analisados inicia-se com o próprio caminho indígena, que atravessava então o sertão paulista através das serras de São Roque e Inhayba (SANTOS, 1999). Com os caminhos indígenas transformados em estradas, e depois em estradas de rodagem, as comunicações e os transportes venceram as distâncias cada vez mais rapidamente. Com o asfaltamento de algumas destas antigas estradas, até a linha férrea, que transportava grandes cargas para a cafeicultura, foi se transformando em segunda opção em relação às possibilidades do transporte motorizado descortinado pelas novas rodovias, feitos em horários e por veículos totalmente customizados para diversos fins.

Como relata o professor Nestor Reis, as rodovias asfaltadas ampliaram desta maneira mercados, possibilitou a interiorização e desconcentração das indústrias para 0 interior do estado no séc. XX; e mais recentemente possibilitou a dispersão de áreas urbanas e difundiu modos de vida metropolitanos (NESTOR, 2006, p. 103).

Atualmente nesta segunda década no séc. XXI, as rodovias fazem parte da vida diária de mais de 100 mil pessoas na RMS, que se deslocam para estudar, trabalhar, namorar, viajar, visitar pessoas e lugares, comprar, etc. entre várias localidades até em um mesmo dia. A mobilidade disponibilizada pelas rodovias e pelos veículos automotivos às pessoas faz com que as rodovias de alto tráfego sejam importantes para a população que por ali trafegam; e suas áreas lindeiras cada vez mais passíveis da ocupação urbana. 0 uso do solo destas áreas lindeiras da RRT no trecho RMS entre São Roque e Sorocaba, antigamente recomendado à ocupação industrial (mas pouco seguido) dá agora cada vez mais vazão à ocupação residencial verticalizada nos trechos mais populosos, mas mantem a vocação comercial, de lazer e até industrial que cada trecho construiu ao longo de décadas de utilização desde sua criação como estrada de rodagem asfaltada aos moldes americanos.

Sobre os trechos estudados, seguem-se as conclusões finais:

\section{TRECHO 1 - São Roque - RRT km 60 a 64}

O zoneamento municipal foi melhor ordenado a partir do PD de 1972 no trecho RRT, (que ainda passava no centro antigo de São Roque), que determinava um zoneamento no núcleo central de até $100 \%$ no térreo, $75 \%$ nos pavimentos superiores, e CA de 1,0 com permissão para os usos residencial, comercial e de serviços e serviços públicos exceto os considerados mais perigosos, como cadeias e quartéis. Na área fora do núcleo urbano principal, na continuação da 
RRT, foi estipulada para uso industrial, com políticas públicas de planejamento para a desapropriação de certas áreas na intenção de se fazer uma interligação com a Rod. Castelo Branco, mas ao norte. Como já havia um loteamento residencial aprovado no $\mathrm{km} 64$, foi prevista uma zona de serviços públicos para esta comunidade (CS1, com TO = 50\% e CA=1,0).

A urbanização no período de 1972 a 2006, ano do próximo PD, com a exceção de utilização residencial de uma área zoneada para uso industrial próxima ao centro antigo, foi seguida conforme os três tipos de zoneamento proposto para o trecho.

O PD de 2006 de São Roque, analisado para este trecho especificamente, foi elaborado levando-se em conta a vocação turística de São Roque; e o Macrozoneamento Ambiental determinou as zonas urbanas específicas para o trecho, que tem ali o Morro do Cruzeiro, com urbanização incipiente com uma ocupação irregular em sua porção sul, fato que está em conflito com a determinação de criação de uma área especial interesse ambiental do Morro do Cruzeiro, e a formação, através de instrumentos urbanísticos de compensação de outras áreas verdes em outros locais do município para a junção dessas áreas em um Parque municipal, com vistas à proteção ambiental do córrego que passa do morro, atravessa a linha férrea e passa pela porção mais verticalizada do centro velho, que foi valorizada pela vista da APP do córrego.

Outra característica do PD de 2006 é a criação de zoneamento especifico para os corredores de avenidas e rodovias, com a utilização autorizada para usos específicos (depósitos e garagens), nos sessenta metros lindeiros às rodovias de tráfego intenso (no caso a RRT e a RCB); e de verticalização nas principais avenidas do centro principal, liberando TO e CA para os usos residenciais, comércio e serviços, mas limitando o gabarito máximo das edificações, para proteger as visadas dos morros existentes no município, e a atividade turística decorrente da paisagem.

Os zoneamentos da área urbana no PD de 2006 foram estabelecidos por critérios de densidade, para usos mistos, e a manutenção da zona industrial, agora ajustada para a ocupação residencial ocorrida desde 1972, com a novidade da inserção do conceito de maior aproveitamento das áreas lindeiras dos corredores de maior tráfego. Os gabaritos são modificados no mesmo ano de 8 para 9 metros para uso residencial horizontal e de 8 para 12 metros nos demais usos, mas no geral verificando-se a urbanização até 2016 (visitas in loco complementadas com as informações das UIT's da EMPLASA, de outubro de 2014), verifica-se que o zoneamento foi seguido, com exceção de duas áreas de ocupação irregular :a $1^{\mathrm{a}}$ já mencionada na porção sul do Morro do Cruzeiro, próxima ao lado esquerdo da RRT no km 60; e a $2^{\mathrm{a}}$ na área de zoneamento industrial com uma ocupação irregular no lado direito da RRT no km 63. 
No trecho foi encontrado duas áreas de ocupação irregular, mas fora estas áreas, concluímos que o zoneamento estabelecido pelo PD de 2006 foi seguido em termos de uso e ocupação do solo neste trecho 1.

\section{TRECHO 2 - Alumínio - RRT KM 75 A 79}

Antes pertencente aos municípios de São Roque (até 1980) e Mairinque (até 1991).

O zoneamento municipal estabelecido em 1994 e a urbanização verificada através da constatação in loco e do mapa de uso e ocupação do solo deste trecho pela EMPLASA (2016) não revelou incompatibilidade de zoneamento, pois 0 trecho 2 tem desde então dois tipos de zoneamento: a zona rural e a urbana. 0 zoneamento urbano engloba igualmente a área urbanizada propriamente dita com residências de baixa e média tipologias e a área industrial, que não tem zoneamento próprio. A zona rural é ocupada em sua maior porção, por plantações de eucaliptos da Fíbria, empresa multinacional, relacionada ao Grupo Votorantim.

A característica observada foi a questão do PIB per capita do município, a mais elevada da RMS (5,6 SM) (IBGE, 2015) e a localização da praça de pedágio na RRT no sentido Capital. As questões de segurança da travessia no início do trecho estudado e as tipologias de uso residencial, na ocupação do lado esquerdo da RRT no trecho estudado denotam que não se revertem a arrecadação municipal na solução dos problemas de regularização da habitação irregular de baixa tipologia, verificada nesta parte do município. A zona urbana ainda engloba também a área industrial. Um novo PD está sendo elaborado atualmente, embora o município ainda não tenha os 20mil habitantes necessários para a obrigatoriedade da realização do PD, pelo Estatuto da Cidade (BRASIL, 2001).

Também no trecho 2 foi verificado duas áreas de ocupação irregular, do lado esquerdo da $\mathrm{RRT}$, próxima á entrada do município, (km 75) e mais internamente no lado direito da RRT (km 79). A RRT ainda corta o município ao meio.

Apesar destas ocupações, como estão localizadas na zona urbana, também conclui-se que o zoneamento foi seguido neste trecho 2 .

\section{TRECHOS 3 e 4 - Sorocaba, SP:}

Os trechos 3 e 4 estão localizados no Município de Sorocaba, SP. As análises da legislação urbana são comuns até o PD de 1968, quando as variações por trecho se manifestam no zoneamento, que até então era agrícola para ambos os trechos. 


\section{TRECHO 3 - Brigadeiro Tobias - RRT km 88 a 92}

O trecho 3 (Brigadeiro Tobias) foi, como mencionado, área da casa grande da fazenda de uma rica e poderosa família local. A área cedida pelos proprietários da fazenda ao final do séc. XIX para a instalação de uma estação ferroviária era próxima à várzea do Rio Pirajibu e localizava-se justamente na faixa de transição da serra granítica para a depressão periférica. A área foi tornada oficialmente distrito de Sorocaba (1934). Após o asfaltamento e inauguração da RRT em 1954 o tráfego local e a ocupação urbana foram aumentando, e na década de 60 houve reconhecimento da existência do núcleo urbano pelo poder público de 12 vias (lei municipal no 1071/63).

Pelo PD de 1968, o zoneamento era rural e o núcleo urbano obedecia aos parâmetros da ZR3 (destinado a urbanização mais distante do centro antigo, e aos imóveis destinados aos trabalhadores da zona industrial). Estas áreas, neste trecho, entretanto, foram ocupadas principalmente pelos pobres que não encontravam condições de moradia na área urbana, quando migraram do norte do Paraná e do nordeste nas décadas de 70 e 80 para tentar a vida na urbe. Alguns foram para a zona norte de Sorocaba, mas muitos vieram também a se instalar no distrito de Brigadeiro Tobias, pela facilidade de locomoção no território proporcionada pela ferrovia e ônibus (Viação Cometa) para a Capital. A partir daí começaram a ocupar as áreas lindeiras a linha férrea de Brigadeiro Tobias (principalmente as vielas da rua Rodolfo Garcia), na parte plana, próxima à várzea do Ribeirão Pirajibu Mirim. Quando estas áreas ficaram insuficientes, começaram a subir os morros próximos, áreas de risco pela alta declividade e pela possibilidade de escorregamento devido às chuvas que se juntam aos córregos de água, inúmeros devido as nascentes locais.

O zoneamento do trecho 3 (Brigadeiro Tobias) depois foi modificado depois pelo do PD de 2004 (contendo os seguintes zoneamentos: Zona de Conservação Ambiental, Zona de Chácaras Urbanas, Zona Residencial tipo 1, ZR2 e Zona Rural); a ZR, ZCA, ZCH sofreram várias modificações com relação à proteção ambiental das nascentes e cursos d'água; a ZR permaneceu como pequena faixa da área analisada no PD de 2007, terminando por desaparecer no trecho na lei do PD de 2014, assim como a ZR1, que passou a ser ZCH e ZR2. A área determinada de zoneamento como ZCA, de parâmetros mais severos quanto à ocupação urbana na lei do plano diretor teve seus parâmetros alterados de maneira drástica: passou de $80 \%$ de permeabilidade mínima para $20 \%$ de permeabilidade mínima; o que na prática, permite uma ocupação quase que máxima de uma gleba.

Infelizmente mesmo com estas mudanças no zoneamento municipal deste trecho, já aumentando os parâmetros de ocupação e uso do solo, e diminuindo a proteção ambiental com 
a retirada da Zona de Conservação Ambiental do trecho 3; não beneficiou as famílias instaladas há mais de três décadas no local - embora a população do distrito houvesse elegido dois vereadores diferentes por dois mandatos seguidos; embora os edis propusessem e buscassem medidas legais para obtê-la, não houve a regularização fundiária das áreas invadidas, estando estas famílias nas áreas lindeiras à linha férrea do lado direito da RRT sentido interior; pois a maioria das habitações estavam e ainda estão instaladas em vielas nas terras pertencentes à União. Devido à alta declividade do local, muitas vezes fortes chuvas ainda aumentam o risco de alagamentos e até de deslizamentos, causando prejuízos aos habitantes nas áreas de várzea.

Com relação à instalação de conjuntos habitacionais, não há nenhum previsto para esta área no plano diretor municipal de 2014, também nunca houve instalação de nenhuma HIS no trecho de Brigadeiro Tobias. Somente agora uma empresa está tentando colocar um prédio para ser vendido aproveitando subsídios disponíveis pelo programa federal MCMV. Mas sua localização é próxima à uma área de várzea alagadiça. Vale lembrar que o distrito de Brigadeiro Tobias está localizado a cerca de $16 \mathrm{~km}$ do centro antigo de Sorocaba, o que explica 0 alto índice de vulnerabilidade social verificado para grande parte do setor censitário deste distrito. A população de renda mais baixa mora mais longe do centro da metrópole, neste caso não em loteamentos e condomínios fechados. As ocupações como sempre são lindeiras à linha férrea, e nas ruas distantes da rodovia, nas cotas mais altas, mais inacessíveis, ainda sem estruturação urbana, pois pela baixa densidade e alta declividade dificilmente os ônibus podem chegar seguramente.

O zoneamento municipal do trecho do distrito de Brigadeiro Tobias apresenta problemas na sua legislação, o que redundou no ADIN n² 2138826-16.2016.8.26.0000 /-Voto nº 29.805 11 pelo Tribunal de Justiça do Estado de São Paulo. Como se pode verificar pela comparação dos mapas de macrozoneamento ambiental, zoneamentos e propostos e estabelecidos, realmente a lei do PD de 2014 promulgada tinha problemas de constitucionalidade severos, como este relatado no acordão do ADIN em referência:

"Iv. Alterações realizadas diretamente no mapa de zoneamento, por força das
emendas nos 32 e 33 . Alteração de zoneamento, de chácaras urbanas, para zr3.
Inadmissibilidade. Área situada em macrozona com grandes restrições de ocupação
macro zona de grandes restrições à ocupação; proteção de mananciais bacia do
córrego Pirajibu-mirim, que colabora para a captação de água destinada ao
abastecimento: Invasão do poder de direção da cidade do chefe do poder executivo
(artigos 47 , incisos ii, xi e xiv, 180, 181 e 182, da constituição do estado)." (TJESP,
Registro: $2017.0000030545,1 /$ fev/2017).

No trecho 3 está a demonstração da interferência de particulares e de outros interesses não públicos no zoneamento municipal; no acordão listam-se desde modificações diretamente 
nos mapas de zoneamento, bem como outras modificações que demonstram tentativas de modificação dos parâmetros de zoneamento municipal mesmo quando não em benefício público e até sobrepondo-se a questões do abastecimento hídrico da população, questões de mineração, corredores comerciais, etc.

No caso desta lei do PD duas sociedades de amigos de bairro entravam com ações diretas de inconstitucionalidade no Ministério Público e conseguiram vetos importantes que fizeram com que alguns sindicados do setor imobiliário voltassem atrás em alguns empreendimentos, principalmente no trecho 3 , pois tem condições ambientais especiais para terem seus recursos hídricos melhor conservados. Mas até agora não foi estabelecido novos parâmetros e redesenho do zoneamento municipal para este trecho e para o trecho $4 \mathrm{em}$ particular.

\section{TRECHO 4 - Campolim - RRT km 98 a 102}

No trecho 4 está o trecho de áreas lindeiras à RRT que mais se transformou em termos de ocupação urbana desde meados do séc. XX, quando ainda era área rural.

Neste trecho não houve casa grande de fazenda, nem estação ferroviária implantadas, apenas um caminho que ligava o centro velho de Sorocaba às áreas de chácaras de Votorantim, em sua parte alta (Rio Acima), cruzando a variante da RRT criada pela própria cidade na década de 50. O caminho do centro velho ao Rio Acima que passava pela propriedade rural, fora dos limites urbanos de então de Sorocaba, era chamado de Estrada do Quiló foi utilizado como via principal do bairro Parque Campolim, realizado pela incorporação da área rural por uma empresa local, detentora dos direitos da pedreira, que solicitou e conseguiu a transformação do então zoneamento ZR3 para ZR1. Com parâmetros mais restritos no zoneamento do bairro, implantouse nas imediações, nas ainda nas áreas lindeiras da RRT (km 98), no lado direito o Shopping Panorâmico, destinado as populações de Votorantim e Sorocaba, e depois p hipermercado Carrefour e o Shopping Esplanada, no km 100, destinada às classes média e alta de Sorocaba e cidades vizinhas da região, acessível pela RRT; o que valorizou o bairro

A antiga Estrada do Quiló, agora nomeada de Av. Antônio Carlos Comitre, transformouse em via de ligação que ultrapassa a RRT por um viaduto aumentado pelo hipermercado Carrefour no início dos anos 90, criando um corredor viário através do empreendimento Parque Campolim, que segue adentrando o vizinho de Votorantim sob o nome de Av. Izoraida Marques Peres. A av. A.C. Comitre está relacionada no Plano Diretor municipal de Mobilidade Urbana de Sorocaba para receber o ramal do BRT até 2020, após a implementação dos corredores BRT na zona norte (PDTUM, 2016). 
O bairro Parque Campolim foi projetado e instalado na década de 70, por uma empresa que também detêm os direitos de mineração de pedra localmente (Júllio \& Júlio); e incorporava um desenho urbano mais elaborado de bairro jardim com ruas internas terminando em cul-desac, com tamanho de lotes maiores do que o comum na cidade (o tamanho de lotes normalmente eram de 250 e $300 \mathrm{~m} 2$ à época); para o empreendimento foram projetados lotes com cerca de $360 \mathrm{~m} 2$ nas duas primeiras fases (de cada lado da avenida antes da RRT) e 640 m2 na sua terceira fase, (após a transposição da RRT).

Neste trecho do Campolim pelas modificações na legislação do zoneamento municipal desde os anos 70 do séc. XX percebe-se claramente 0 atendimento pelo Estado às demandas do setor imobiliário, quando modifica o zoneamento de ZR3 para ZR1 de depois de ZR1para ZR2 em grande porção das áreas lindeiras analisadas, pois estas foram passíveis de valorização imobiliária pela questão da vizinhança do bairro jardim denominado Parque Campolim. A implantação de um hipermercado nesta área próxima ao viaduto existe e a ampliação deste para atender ao aumento da demanda viária aumentada e os terrenos de maior tamanho do outro lado da RRT (que a principio eram destinados para pequenas chácaras - depois o tamanho do lote permitiu, em um segundo momento, a construção de pequenos edifícios de até quatro pavimentos) - e outras mudanças na legislação do zoneamento municipal colocadas no plano diretor municipal de 2004, atenderam aos interesses imobiliários que puderam, em uma década (o processo de urbanização continua forte ainda agora, pela disponibilidade de áreas lindeiras à RRT para incorporação) aumentar sobremaneira a oferta de imóveis através do programa MCMV vendidos principalmente para a classe média alta de Sorocaba e outros municípios do eixo da RRT.

Ainda assim, após o PD de 2007 ajustar alguns pontos do zoneamento do PD de 2004, 0 mercado imobiliário em Sorocaba e Votorantim, aquecido por vários fatores (dentro do período de mudanças nos zoneamentos dos planos diretores de Sorocaba - 2004 a 2016: maior atividade econômica, demanda reprimida, demanda criada, terras mais baratas do que as da capital São Paulo, liberação de recursos financeiros pelo programa federal MCMV, dentre outros).

"Em resumo, a atividade imobiliária reflete o papel do espaço tanto como fonte de criação quanto de realização da mais valia; é relativamente impérvia aos ciclos de acumulação de capital, exceto no tocante a mudanças em outras formas de investimento (de habitações suburbanas, para edifícios de escritórios e shopping centers na cidade); e representa um processo mais fundamental da criação de riqueza do que entenderam os teóricos da acumulação do capital." (GOTTDIENER, 2010, p. 245). 
Figura 142 - Rodovia Raposo Tavares no ponto em que a mesma "corta" o Campolim.

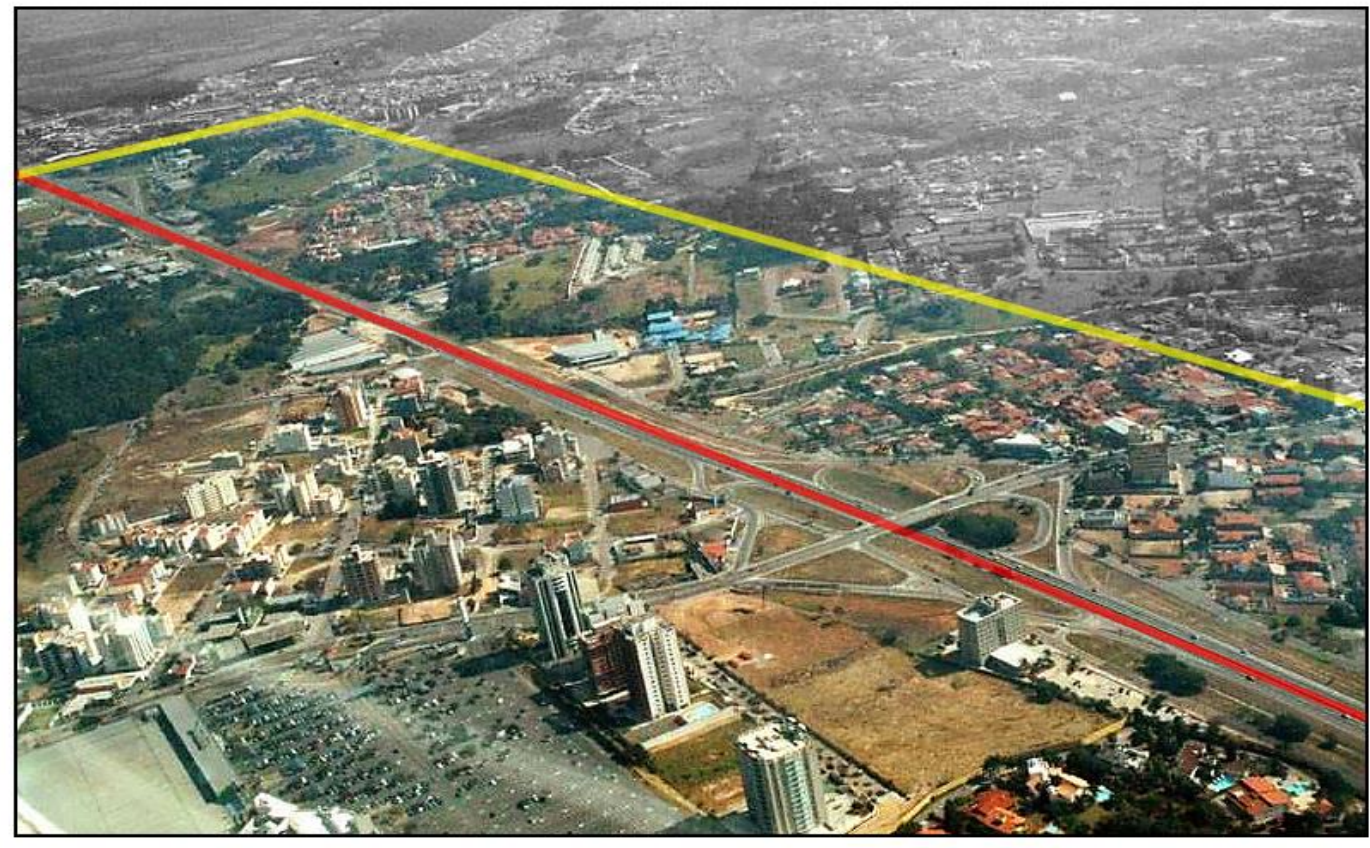

Rodovia Raposo Tavares

Área de análise limite $500 \mathrm{~m}$ da RRT

Do lado inferior esquerdo da foto o ponto mais verticalizado do bairro - a parte sul. Fonte: BARRETO, 2006. Autor: R. VIEIRA, Data: Junho/06. Retrabalhado por Amanda Dias, 2018.

Quanta diferença do antigo mapa de 1973 para a mesma área, se compararmos o mapa de uso e ocupação do solo elaborado pela EMPLASA para a UIT 10 - Campolim, onde antes havia apenas a pastagem de gado leiteiro da fazenda do sr. Achiles Campolim até o fim dos anos 70 no século passado.

Além de vários usos residenciais ZR-1, ZR-2, embora permaneçam ainda algumas áreas de plantações, o aumento do comércio, dos serviços, das residências multi-familiares, etc., com mudanças em praticamente todos os itens de TO e CA nas últimas edições dos PD's dos dois municípios leva a crer que zoneamento das áreas lindeiras às rodovias pode colaborar para 0 carregamento dos veículos e influenciar mais pesadamente que o da mobilidade urbana, demanda da população já atendida em 2015 com a criação das marginais, uma vez que a RRT já havia sido duplicada em 2008.

Devido à crise econômica dos anos 2015 em diante (sinais da melhora econômica ainda são mínimos), os empreendimentos imobiliários destinados à classe da população que compra os empreendimentos na ZR2 - zoneamento da maioria da área do trecho 4, estavam com vendas com baixa velocidade. Mesmo assim, foram inauguradas 6 torres de 20 andares com 4 apartamentos por andar, no terreno que antes era pasto no $\mathrm{km} \mathrm{98}$, lado norte da RRT; do lado 
sul instalou-se, junto ao shopping Panorâmico, Decathlon, Assaí supermercados, Cobasi, e um hotel de 2 estrelas. No km 101, instalou-se do lado sul da RRT a Leroy Merlin, loja de materiais de construção, e no lado oposto, um empreendimento da MRV de 22 torres de 12 andares cada, com 4 apartamentos por andar. Detalhe: pelo zoneamento municipal, poderiam ser erguidos apenas 4 pavimentos; motivo de interpelação jurídica pela Secretaria de Planejamento Municipal em 2017, de outra administração municipal que aquela que aprovou a construção das torres, para uma avenida de 9 metros de largura. Tal empreendimento imobiliário, junta-se a outros também posicionados estrategicamente na área de estudo. É sucesso de vendas, pois muitos querem morar em uma área com equipamentos cobiçados para utilização diária. É pena que outros setores do município não tenham tido este desenho urbano e o investimento imobiliário e público em seus bairros.

E isto prescindindo da instalação do equipamento BRT, previsto pelo PDTUM de 2014 para estar operando em 2020 (com a mudança da administração municipal a parte sul do projeto BRT foi descartada):

"(...) Além do crescimento populacional nos vetores anteriormente expostos e conforme o "Estudo 1 - Cenários de Desenvolvimento Urbano, Econômico e Social" ele também deverá acontecer nas áreas de influência dos corredores de BRT. (...) Justifica-se a melhoria na infraestrutura de Transporte Coletivo onde há maiores densidades populacionais e de emprego, regiões Oeste, Sul, Centro, Norte, Nordeste e Leste. Os principais corredores de BRT e BRS propostos alimentarão essas regiões." (PDTUM, 2014).

Figura 143 - Uso e ocupação do solo no trecho do Campolim em Votorantim.

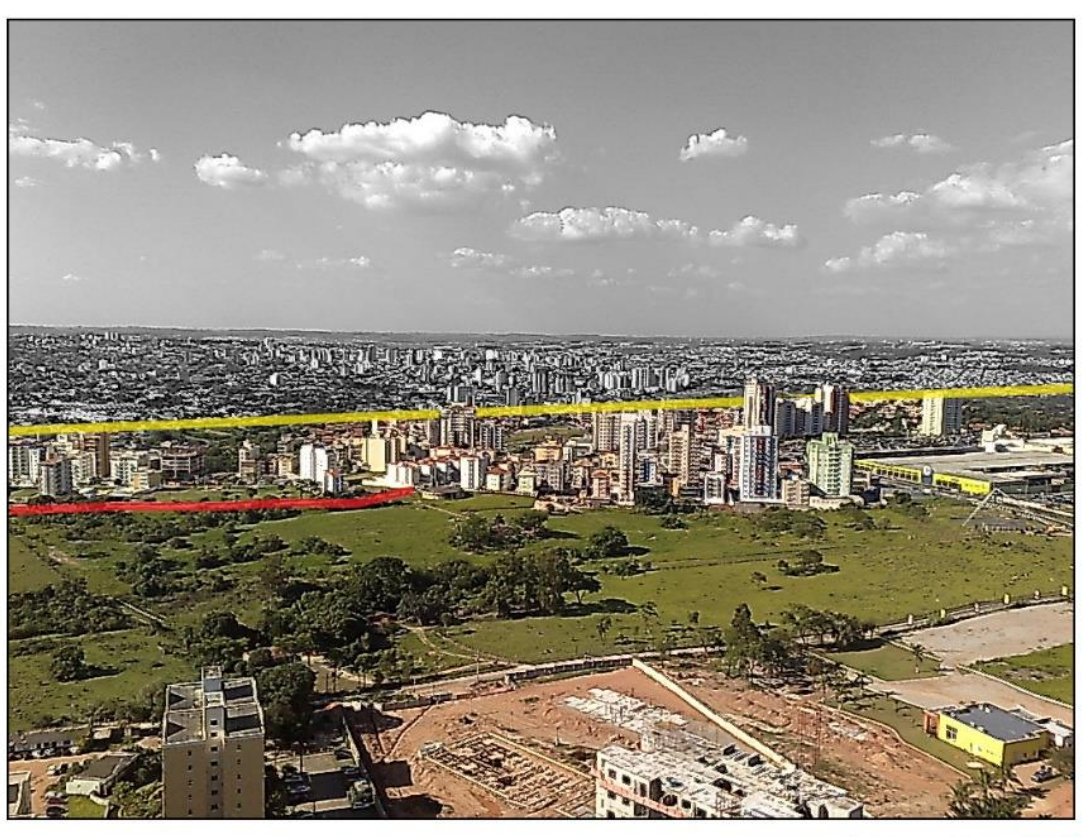

Rodovia Raposo Tavares Área de análise limite $500 \mathrm{~m}$ da RRT

In: http://www.skyscrapercity.com/showthread.php?t=1056513\&page=5, acesso em julho/2015. Retrabalhado por Amanda Dias, 2018. 
Nota da autora: 0 último plano diretor de Sorocaba de 2014 recebeu vetos pela ADIN $\mathrm{n}^{\circ}$ 2138826-16.2016.8.26.0000, estando portanto sob júdice atualmente.

\section{Conclusões sobre o zoneamento das áreas lindeiras de trechos da RRT:}

1. Existe ocupação irregular para fins de moradia, em áreas de risco das áreas lindeiras dos trechos analisados, de auto-construção; e no trecho mais valorizado, e verticalizado, a partir de 2013, existem ocupações irregulares sem estarem em área de risco, por empreendimentos que não são de auto-construção;

2. Na maior parte das áreas lindeiras as rodovias, nas diferentes municipalidades analisadas, a produção do espaço urbano é decorrente do respectivo zoneamento municipal, pois ele é majoritariamente obedecido quanto ao quesito uso do solo permitido;

3. Mas isto é decorrente do fato da legislação urbana ser muito permissiva e flexível quanto aos quesitos de uso e ocupação do solo, pois os parâmetros de ocupação foram continuamente mais permissíveis, ainda que a nomenclatura das zonas na maioria dos casos permanecesse a mesma;

4. As diretrizes de zoneamento municipal para ocupação das áreas lindeiras às rodovias de alto tráfego não levam em conta as necessidades da priorização da ocupação industrial e comercial de grande porte em relação à ocupação habitacional dos tipos unifamiliar e multifamiliar.

As áreas lindeiras à RRT de São Roque a Itapetininga, (no território da RMS) tem áreas de mata, preservação e chácaras de lazer, além de várias outras atividades: industrial, residencial, patrimônio histórico e ambiental, turístico, comercial, serviços, mineração, etc. A ocupação destas áreas terá importância estratégica para o desenvolvimento econômico e material de suas populações, mas o uso deve levar em conta a necessidade de preservação dos recursos naturais, necessários ao abastecimento hídrico da população, bem como às atividades turísticas que já estão sendo e poderão ser desenvolvidas de maneira a melhorar ainda mais as condições existentes destas localidades, como lembrou lan McHarg (1969).

Nos planos metropolitanos, que estão sendo elaborados atualmente para atender, pelos macrozoneamentos metropolitanos, o Estatuto da Metrópole (2015), em conjunto com o PAM (2016), pela EMPLASA, deverá ser levado em conta a ocupação inteligente e sustentável destas áreas lindeiras ao eixo da rodovia raposo Tavares, que atravessa a última área do ESP que ainda não recebeu urbanização maciça e ainda tem áreas verdes e rurais com vocação turística e agrícola, além da urbana:

"Verifica-se, ainda, que parte do território dessa região, inclusive a do vetor de desenvolvimento entre Sorocaba ${ }^{63}$ e São Paulo, é ocupada por áreas de mata,

\footnotetext{
${ }^{63}$ http://agencia.sorocaba.sp.gov.br/wp-content/uploads/2016/01/campolim-011.jpg
} 
preservação e chácaras de lazer, sendo importante a necessidade do planejamento prever uma ocupação que contemple o uso ambiental e turístico com as necessidades do desenvolvimento econômico." (Panorama regional PDUI EMPLASA, 2017).

O mapa de uso do solo da RRT entre São Roque e Sorocaba evidencia as áreas ainda não urbanizadas lindeiras à RRT, que devem ser objetos de planejamento responsável para uma ocupação urbana e/ou rural que seja o resultado deste zoneamento/ macrozoneamento que pode ser elaborado mais responsavelmente e seguido pela sociedade que não deve esperar apenas seguir os parâmetros, mas também cuidar para que eles sejam reflexo de suas aspirações sociais (SOUZA, 2003) (Fig. 144). 


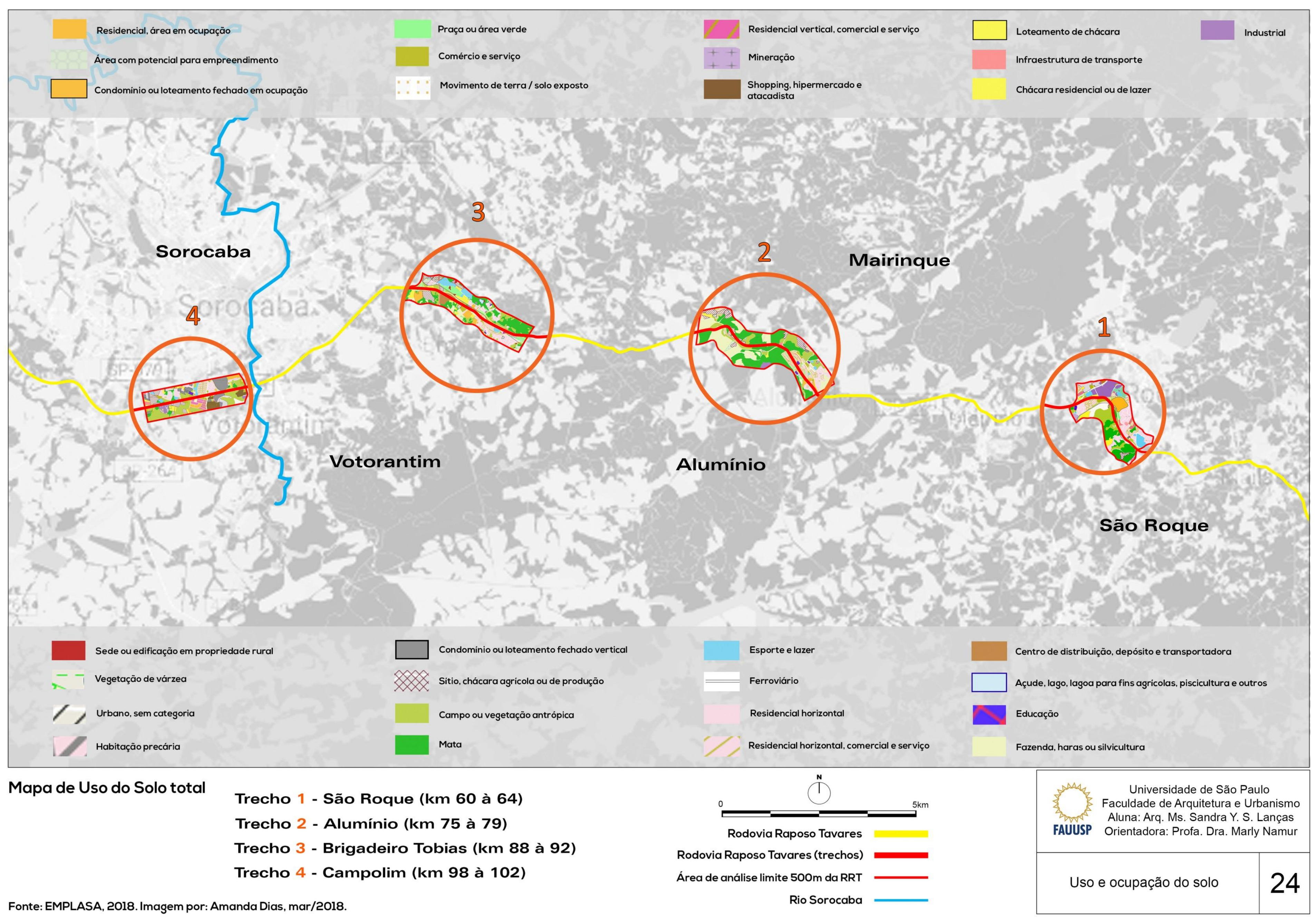




\section{REFERÊNCIAS BIBLIOGRÁFICAS}




\section{REFERÊNCIAS BIBLIOGRÁFICAS}

AB'SABER, A. N. O solo de Piratininga. In: BUENO, E. (Org.). Os nascimentos de São Paulo. São Paulo: Ediouto, 2004.

ABIKO, A. K., ALMEIDA, M. A. P. de, BARREIROS, M. A. F. Urbanismo: História e Desenvolvimento. Escola Politécnica da Universidade de São Paulo, Departamento de Engenharia da Construção Civil. São Paulo, 1995.

ALONSO, W. Location and land use. Cambridge: Harvard University Press. Cambridge, 1964.

ALTHUSSER, Louis. Ideologia e aparelhos ideológicos do Estado. Editorial presença, Lisboa,1980.

ALMEIDA, Aluísio. História de Sorocaba. Pesquisa de Rogick Vieira. Edição da Prefeitura Municipal. Sorocaba, 1972.

ARRIGHI, GIOVANNI. O Longo Século XX. UNESP Editora, 1996.

ARRIGHI, GIOVANNI. Adam Smith em Pequim. Origens e fundamentos do Século XXI. Boitempo Editorial,São Paulo, 2008 Edição original: Adam Smith in Beijing: Lineages of the Twenty-First Century, 2007.

ASHWORT, STEPHEN. Rendas Regulatórias: Usando o sistema de planejamento de uso do solo urbano. Revista Pólis no. 27, 1996 - p. 27

BACELLAR, Carlos de Almeida Prado e BRIOSCHI, Lucila Reis, orgs. Na Estrada do Anhanguera: uma visão regional da história paulista / Carlos de A. P. Barcellar; Lucila R. Brioschi, orgs. São Paulo: Humanidades FFLCH/USP, 1999.

BADDINI. Cássia. Sorocaba no Império: comércio de animais e desenvolvimento urbano. Tese de Doutoramento. Universidade de São Paulo. São Paulo: Ed. Annablume, 2002.

BARRETOS, Benedito Bast. No Tempo dos Bandeirantes. Edições Melhoramentos, 1948.

BARRETO, llson Juliano. A Verticalização e o Bairro: 0 Caso do Parque Campolim - Sorocaba, SP, período de 1990 a 2004. Dissertação de Mestrado. Universidade Estadual de Maringá. Marinagá, 2007.

BASSETT, E. Zoning. New York: National Municipal League. 1922.

BAUMEISTER, R. Stadterweiterungen in Technischer, Baupolizeilicher und Wirthschaftlicher Beziehung. 1876. Berlin: Verlag von Ernst e Horn (in German).

BENEVOLO, L. As Origens da Urbanística Moderna. $2^{\circ}$ ed. Lisboa. Editorial Presença, 1987.

BESSE, Jean Marc. Ver a Terra. Tradução Vladimir Bartalini. São Paulo, Ed. Perpectiva, 2006.

BORJA, J. Ciudadania y espacio público. Barcelona: Centre de Cultura Contemporania, fev. 1998.

BORJA, J. y CASTELLS, M. La gestión de las ciudades en la era de la información. Madrid: Santillana S. A. Taurus, 1997.

BORGES, Marília Vicente. 0 zoneamento na cidade do Rio de Janeiro: gênese, evolução e aplicação. Dissertação de Mestrado - UFRJ. Rio de Janeiro, 2007. Disponível em:

http://www.ippur.ufrj.br/download/pub/MariliaVicenteBorges.pdf

BORBOLETO, L. A., MELO, R. do V., SILVA, A. M. Dinâmica da paisagem no município de Sorocaba SP, situação reportada nos anos de 1988 e 2011: uma abordagem com o uso de geotecnologias. Anais XVI Simpósio Brasileiro de Sensoriamento Remoto - SBSR, Foz do Iguaçu, PR, Brasil, 13 a 18 de abril de 2013, INPE.

BRASIL. Estatuto da Cidade. Lei Federal no. 10.257, de 10/07/2001.

BRASIL. Estatuto da Metrópole. Lei Federal no. 
BRASIL. Regulamenta os arts. 182 e 183 da Constituição Federal, estabelece diretrizes gerais da política urbana e dá outras providências. Lei Federal 10.257, de 10 de junho de 2001.

BRESSER-PEREIRA, “Desenvolvimento e Crise no Brasil”, Ed.34, São Paulo, 5ª Edição, 2003.

BRUNA. G., VARGAS, H.E. Shopping Centers e o Desenho Urbano no Brasil: dois estudos de caso em São Paulo. p.. 91 a 102. In: DEL RIO, V. e SIMBIEDA, W. (orgs.) Desenho Contemporâneo no Brasil. Rio de janeiro: LTC, 2015.

BUGANZA, Cintia Peres. Estudo da Situação pré - metropolitana de Sorocaba: características e perspectivas. Faculdade de Arquitetura e Urbanismo, Universidade de São Paulo, Dissertação de mestrado, USP, São Paulo 2010.

CAIADO, Aurílio Sérgio Costa; SANTOS, Sarah Maria Monteiro dos. Fim da dicotomia rural-urbano? Um olhar sobre os processos sócio-espaciais. São Paulo Perspectiva. [online]. 2003, vol.17, n.3-4, pp. 115-124. ISSN 0102-8839. http://dx.doi.org/10.1590/S0102-88392003000300012 , acesso em 27/03/2014.

CAIADO, Aurílio Sérgio Costa and SANTOS, Sarah Maria Monteiro dos. Fim da dicotomia ruralurbano? Um olhar sobre os processos sócio-espaciais. São Paulo Perspec.[online]. 2003, vol.17, n.34, pp. 115-124. ISSN 0102-8839. http://dx.doi.org/10.1590/S0102-88392003000300012, acesso em 27/03/2014.

CALVINO, Italo. Le città invisibili. Einaudi. 1972

CAMARGO, F. H. S.; LANCAS, S. Y. S. . Estudo Sobre A Transformação Da Paisagem E As Manchas Urbanas Dos Municípios Do Eixo Viário Da Rod. Raposo Tavares, Do Km 45 Ao 92. In: I Maac Mostra De Atividades Acadêmicas, 2015, Sorocaba. I Mostra Acadêmica Pesquisa, Ensino E Extensão, 2015. V. 1.

CAMPOS FILHO, C. M. Cidades brasileiras: seu controle ou o caos. São Paulo: Nobel, 1989.

CAMPOS FILHO, C. M. Reinvente seu Bairro. São Paulo: Editora 34, 2003. CAMPOS, GALVÃO, PRADO, CERRONE \& ANDREOLI, Critérios de Escolha de local de estação intermodal. (pdf). Sorocaba, 2014.

CANO, W. Desequilíbrios regionais e concentração industrial no Brasil. 1930 - 1995. 2a . Edição. Campinas: Instituto de Economia da Unicamp, 1998.

CARLOS, Ana Fani Alessandri. A (re) produção do espaço urbano. São Paulo: Edusp, 1994.

CARLOS, Ana Fani Alessandri. A (Re) Produção do Espaço Urbano / Ana Fani Alessandri Carlos - 1. Ed. 1. Reimpr. São Paulo: Editora da Universidade de São Paulo, 2008.

CARLOS, Ana Fani Alessandri, OLIVEIRA, Ariovaldo Umbelino de. (organizadores) Geografias de São Paulo: a metrópole do século XXI. São Paulo: Contexto, 2004.

CARNOY, Martin. Estado e Teoria política. (equipe de trad. PUCCAMP) $2^{\mathrm{a}}$ ed. Campinas: Papirus, 1988. [pp. 19-62]

CARSON, Rachel. Silent Spring. Ed. Houghton Mifflin. Boston, 1962.

CASTELLS, M. A questão urbana. São Paulo: Paz e Terra, 2000.

CASTELLS, MANUEL. La ciudad inaformacional. Madrid, Alianza Editorial, 1995.

CASTELLS, MANUEL. Para uma Teoria Sociológica do Planejamento Urbano", in Problemas de Investigación en Sociologia Urbana, Siglo XXI Editores, Argentina, pp.195-217, 1971.

CASTELLS, M. e GODARD, F. O advento de Monopoleville: análise das relações entre a empresa, 0 Estado e o Urbanismo. In: FORTES - Marxismo e Urbanismo Capitalista, Livraria Ciências Humanas, São Paulo, 1979. 
CASTRO, J. E. , HELLER, L., MORAIS, M. da P. , (ed.).O Direito à água como política pública na América Latina: uma exploração teórica e empírica. Brasília: IPEA, 2015.

CELLI, Andressa. Evolução Urbana de Sorocaba. São Paulo, Dissertação de Mestrado, Faculdade de Arquitetura e Urbanismo, Universidade de São Paulo, Dissertação de Mestrado em planejamento urbano, São Paulo, 2012.

CERDÀ - La Theorie Genérale de L' Urbanization - Editions du Seul, Paris, 1982. CHAUI, M. O que é Ideologia. Editora Brasiliense, 1980.

CHOAY, F. Urbanismo: Utopia e Realidade. - Editora Perspectiva, São Paulo, 1968.

OFFE, C. Problemas Estruturais do Estado Capitalista. Editora Tempo Brasileiro - Rio de Janeiro, R.J., 1987.

CORREA, R. L. 0 espaço urbano. São Paulo: Editora Ática. 1989

CORREA, Paulo Roberto; PISANI, Maria Augusta Justi. A Estação de Mayrink do arquiteto Victor Dubugras: Resgate de um patrimônio arquitetônico. Arquitextos, São Paulo, ano 10, n. 109.01, Vitruvius, jun. 2009 <http://www.vitruvius.com.br/revistas/read/arquitextos/10.109/44>.

CORRÊA, Roberto Lobato. O Espaço Urbano. São Paulo: Ática, 1995.

CORTESÃO, Jaime. Raposo Tavares e a Formação Territorial no Brasil. Ministério da Educação e Cultura, Serviço de Documentação. Brasil, 1958.

DEAN, W. A Industrialização de São Paulo. São Paulo: DIFEL, 1971.

D'MATIELI, Carlos Augusto e COELHO, Silvia Helena Stecca. "A visão do setor agropecuário sobre a nova proposta de Plano Diretor para Sorocaba". Em: Revista Rumos, uma publicação do vereador Gabriel Bittencourt: Plano Diretor - o crescimento ordenado da cidade. Sorocaba, junho de 2003, pp.1819.

EGLER, Claudio A. G. Subsídios à Caracterização e Tendências da Rede Urbana no Brasil.

Configuração e Dinâmica da Rede Urbana. Petrópolis, 2001.

EMPLASA, Panorama Regional (v.5), 12/junho/2017.

EMPLASA, Processo de Criação da Região Metropolitana. Pdf. São Paulo, Ago/2013.

ESTATUTO DA CIDADE. Lei 10257 de 10 de julho de 2001

FALUDI, ANDREAS. A Reader in Planning Theory. Oxford Pegamon Press, 1a. edição - 1973, 2a. edição, 1974.

FAORO, RAIMUNDO. Desenvolvimento e Crise no Brasil - História, Economia e Política de Getúlio Vargas a Lula. Editora 34, 2003.

FÁVERO, O. A., NUCCI, J. C., DE BIASI, M. Delimitação de Unidades de Paisagem como Subsídio ao Planejamento da Bacia Hidrográfica do Rio Sorocaba/SP. In: Simpósio Brasileiro de 144 PEREIRA, Fernanda C; SILVA, Raquel R.de Souza; VEIGA, Aline C. P. Revista Percurso- NEMO Maringá, v. 3, n. 1 , p. 125-145, 2011, ISSN: 2177-3300 (on-line) Geografia Física Aplicada, 12, 2007, Natal. Anais de Trabalhos Completos. Natal: UFRN, 2007. p. 510-527. 1 CD-ROM.

FÁVERO, O. A.; NUCCI, J. C. e DE BIASI, M. Hemerobia das Unidades de Paisagem da Floresta Nacional de Ipanema, Iperó/SP. In: $4^{\circ}$. CONGRESSO NACIONAL DE UNIDADES DE CONSERVAÇÃO, 2004, Curitiba. Anais, v. 1. Curitiba: Fundação O Boticário de Proteção à Natureza/ Rede Nacional Pró Unidades de Conservação, 2004. p. 550-559.

FAVERO, O. A., Paisagem e sustentabilidade na bacia hidrográfica do Rio Sorocaba (SP). 2007. Tese (Doutorado em Geografia Humana) - Faculdade de Filosofia, Letras e Ciências Humanas, 
Universidade de São Paulo, São Paulo, 2007. Disponível em:

$<$ http://www.teses.usp.br/teses/disponiveis/8/8136/tde-11122007-095647/>. Acesso em: 2016-01-28.

FAVERO, O. A., NUCCI. J. C., De BIASI, M. Avaliação do estado de conservação da natureza nas unidades de paisagem da bacia hidrográfica do Rio Sorocaba (SP) - Contribuições do Planejamento da Paisagem. Revista Unesp.

FELDMAN, Sarah. Planejamento e Zoneamento São Paulo 1947 - 1972. Tese de Doutorado. São Paulo: Universidade de São Paulo, Faculdade de Arquitetura e Urbanismo, 1996.

FERREIRA, C. E. de C., CASTINEIRAS, Luciane Lestido. Transição Demográfica E Demanda Por Moradias: Projeção De Domicílios Do Estado De São Paulo Até 2050. (pdf). SP Demográfico: Resenha de Estatísticas vitais do Estado de São Paulo. Ano 18, no. 1, janeiro de 2018.

FERREIRA, Nádia Somekh. A verticalização de São Paulo. Dissertação (Mestrado em Planejamento urbano e Regional) - Faculdade de Arquitetura e Urbanismo, Universidade de São Paulo, São Paulo, 1987.

FERREIRA, Nádia Somekh. A (des) verticalização de São Paulo. Tese (Doutorado em Planejamento Urbano e Regional) - Faculdade de Arquitetura e Urbanismo, Universidade de São Paulo, São Paulo, 1990.

FIRKOWSKI, Olga Lúcia Castreghini de Freitas. As cidades paranaenses no século XXI. Jornal Folha de Londrina/Folha do Paraná. Paraná, 2000.

FISCHEL, William. Zoning Rules. Hannover, New Hampshire: Lincoln Institute of Land Policy, 2017.

FOUCAULT, Michel. Vigilar y castigar. Madrid, Siglo veintiuno, 1998.

GOTTDIENER, M. A produção social do espaço urbano. 2.ed. São Paulo: Edusp, 2010.

GOTTDIENER, M.; BUDD, L. Key Concepts in Urban Studies. SAGE Publications Ltd. London, 2005.

GOTTDIENER, Mark. Space as a force of production: contribution to the debate on realism, capitalism, and space. International Journal of Urban and Regional Research, v.11, n 3, Sept. 1987.

HALBWACHS, Maurice. Les expropriations et le prix de terrains à Paris, 1860-1900. E. Cornély. Paris, 1909.

HAMPF, Mario Trejos. A cidade dual: sua interpretação no Sul. (pdf). Data: 12/10/2009.

HARVEY, D. A Justiça Social e a Cidade. Editora Hucitec. São Paulo, 1980.

HARVEY, D. A Produção Capitalista do Espaço. São Paulo: Annablume, 2005.

HARVEY, D. Condição Pós-Moderna, uma Pesquisa sobre as Origens da Mudança Cultural. Ed. Loyola, 1993.

HARVEY, DAVID. From Managerialism to Entrepreneurialism: -The Transformation in URBAN GOVERNANCE in Late Capitalism. Oxford, 1989.

HARVEY, David. 0 trabalho, o capital e o conflito de classes em torno do ambiente construído nas sociedades capitalistas avançadas. In: Revista Espaço e Debates no. 6, 1982.

HIRATA, H. K. Desenvolvimento econômico e urbanização: estudo de caso do município de Sorocaba (1960 - 1985). Relatório final de Monografia. Instituto de Economia. Universidade Estadual de Campinas. Campinas, 1988.

HIRT, S. A., Home, Sweet Home: American Residential Zoning in comparative perspective. In: Reading in Planning Theory. Edited by Susan S. Fainstein, James De Filippis. 4th edition. Wiley and Sons: New York, 2016. 
HOYT, Homer. One Hundred Years of Land Values in Chicago. University of Chicago Press. Chicago, 1934.

IANNI, OTÁVIO. O Estado e o Planejamento no Brasil. São Paulo, 1977.

INSTITUTO DE PESQUISAS ECONOMICAS APLICADAS. Relatório brasileiro para o Habitat III / relator: Instituto de Pesquisa Econômica Aplicada. - Brasília: ConCidades, IPEA, 2016.

IPEA/UNICAMP-IE-NESUR/IBGE. Caracterização e tendências da rede urbana do Brasil. Campinas, Unicamp (Coleções Pesquisas, 3), 1999.

INSTITUTO BRASILEIRO DE GEOGRAFIA E ESTATÍSTICA - IBGE. Censos de 2010. Retirado do site www.ibge.gov.br, em fevereiro de 2014.

INSTITUTO GEOGRÁFICO E CARTOGRÁFICO DO ESTADO DE SÃO PAULO - IGC. Mapa

Hipsométrico, 1982. Retirado do site www.igc.sp.gov.br/produtos/mapa_hipsometrico, em agosto de 2015.

INSTITUTO GEOGRÁFICO E CARTOGRÁFICO DO ESTADO DE SÃO PAULO - IGC. Rede Hidrográfica, 1985. Retirado do site http://www.igc.sp.gov.br/produtos/rede_hidrografica, em agosto de 2015.

IPEA/UNICAMP-IE-NESUR/IBGE. Caracterização e tendências da rede urbana do Brasil. Campinas, Unicamp (Coleções Pesquisas, 3), 1999.

IRACHETA, A. X., - "Hacia Una Planeación Urbana Critica" - Ediciones Gernika, México D.F., 1988.

KOOLHAAS, REM. Junkspace. The MIT Press. October, Vol. 100, Obsolescence (Spring, 2002), pp. 175-190.

KOSIK, Karel. A Dialética do Concreto. Rio de Janeiro: Paz e Terra, 1976.

LANÇAS, Sandra Yukari Shirata. Espaços Públicos Abertos e Infra-estrutura Verde para Sorocaba, SP. 2007. Dissertação (Mestrado em Paisagem e Ambiente) - Faculdade de Arquitetura e Urbanismo, Universidade de São Paulo, São Paulo, 2007. DOI: 10.11606/D.16.2007.tde-12112010-102353. Acesso em: 2017-11-29.

LEFEBVRE, H. In: Espaço e Política. Belo Horizonte, Ed. UFMG, 2008, p. 36-57.

LEFEBVRE, Henri. La production de l'espace. Paris. Ed. Anthropos, 1974.

LEFEBVRE, H. O direito à cidade. Trad. de Rubens Eduardo Frias. São Paulo: Centauro, 2001.

LENCIONI, Sandra. A formação de uma megalópole em curso? Rio de janeiro e São Paulo. In: XIII

Seminário Internacional da Red Iberoamericada de Investigadores sobre Globalizacion y Território (RII), VI Taller de Editores RIER. Salvador, setembro de 2014.

LENCIONI, Sandra. A formação de uma Megalópole em curso? Rio de Janeiro e São Paulo. XIII Seminário Internacional da Red Iberoamericana de Investigation sobre Globalization y Território (RII). 01 a 04/set/2014. Salvador, BA, Brasil. Disponivel em:

http://www.rii.sei.ba.gov.br/anais_xiii/gt4/gt4_sandra.pdf, acesso em. 12/01/2016.

LENCIONI, S. Cisão territorial da indústria e integração regional no Estado de São Paulo. In GONÇALVES, M.; BRANDÃO, C.; GALVÃO, A. (orgs.). Regiões e cidades, cidades nas regiões: o desafio urbano-regional. São Paulo: Editora UNESP; ANPUR, 2003.

LENCIONI, Sandra. Da Cidade e sua Região à Cidade-região. In: Panorama da Geografia Brasileira I. São ulo: Annablume, 2006, v.l, p. 65-76.

LENCIONI, S. Reestruturação urbano-industrial no Estado de São Paulo: a região da metrópole desconcentrada. Espaço \& Debates: Revista de Estudos Regionais e Urbanos, 1994, nº 38, p. 54-62. 
LIBAULT, A. "Os quatro Níveis da Pesquisa Geográfica", in Métodos em Questão, 1 IGEOG-USP, São Paulo, 1971.

LIPIETZ, ALAIN - "O Capital e seu Espaço" - Livraria Nobel, 1987.

LOJKINE, Jean. 0 Estado capitalista e a questão urbana. São Paulo: Ed. Martins Fontes, 1981.

LOJKINE,J. - "El Marxismo, El Estado y la Cuestion Urbana" - Siglo Veintiuno Editores, 1979.

LUCCAS, Luis Henrique Haas. Arquitetura das estancias e fazendas do Rio Grande do Sul: distribuição interior e gênese. Arquitextos 3-4. (pdf). (2003).

MACEDO, S., BLANCO, C., GALENDER, F. APPs Urbanas e o Sistema de Espaços Livres de Sorocaba-SP. (pdf) FAUUSP, 2009.

MANFREDINI, Fábio Navarro; GUANDIQUE, Manuel Enrique Gamero; ROSA, André Henrique. A história ambiental de Sorocaba [recurso eletrônico]. - Sorocaba: Universidade Estadual Paulista Câmpus Experimental de Sorocaba, 2015. Disponível em:

http://www.sorocaba.unesp.br/Home/Eventos191/historia-ambiental-editora-ebook.pdf, acesso em nov/17.

MARICATO, E. Metrópole na periferia do capitalismo. São Paulo: Hucitec, 1996.

MARICATO, Ermínia. É a questão urbana, estúpido! In: VAINER, Carlos e outros. (Orgs.) Cidades rebeldes: passe livre e as manifestações que tomaram as ruas do Brasil. São Paulo: Boitempo Editorial; Carta Maior, 2013.

MARQUES, V. V. Fragilidade ambiental associada à conectividade do escoamento superficial indireto na bacia do Rio Pirajibu-Mirim, Sorocaba/SP. Dissertação de Mestrado. Universidade Estadual Paulista (UNESP). Sorocaba, 2017.

MARTINES, Marcos Roberto, TOPPA, Rogério Hartung, OLIVEIRA, Paula Sartori Santiago de. Expansão da mancha urbana de Sorocaba, São Paulo, no período de 2002 a 2009: subsídios ao Plano Diretor por meio de técnicas de Geoprocessamento. Anais XVII Simpósio Brasileiro de Sensoriamento Remoto - SBSR, João Pessoa-PB, Brasil, 25 a 29 de abril de 2015, INPE.

MASSEY, Doreen. Pelo Espaço: uma nova política da espacialidade. Tradução de Hilda Pareto Maciel e Rogério Haesbaert. 3 ed. Rio de Janeiro: Bertrand Brasil, 2012.

MATOS, R. Aglomerações Urbanas, Rede de Cidades e Desconcentração Demográfica no Brasil.

Mc HARG, lan. Design with Nature. New York: The Natural History, Press, 1969, 197p.

MEIRA, Sandro Ivo. Planejamento E Gestão Urbanos Em Sorocaba-SP: Análise Das Políticas

Públicas De Habitação Popular. Dissertação de Mestrado. Universidade Federal do Paraná, Londrina, 2007.

MELVIN, WEBBER. The prospects for policies planning. In: L. J. DUHLI, The Urban Condition, p.320.

MERLEAU-PONTY, Maurice. Fenomenologia da Percepção. São Paulo, Martins Fontes, 1994.

MONBEIG, P. Pioneiros e Fazendeiros de São Paulo. São Paulo: Ed. HUCITEC \& Ed. Polis, 1977.

MONTEIRO, MATTOS, 2015. Cidade dividida: Sorocaba e o zoneamento urbano de 1914. Revista de Direito da Cidade, vol. 07, n 4. Número Especial. ISSN 2317-7721 pp.1791-1824.

MOTTA, Diana Meirelles e AJARA, Cesar. Configuração da Rede Urbana do Brasil. R. paran. Desenv., Curitiba, n. 100, p. 7-25, jan./jun. 2000.

MOURA, Rosa. Arranjos urbano-regionais no Brasil: uma análise com foco em Curitiba. Tese de Doutorado. Universidade Federal do Paraná. Curitiba, 2009.

MOURA, Rosa; HOSHINO, Thiago A.P. Estatuto da metrópole: Enfim, aprovado! Mas o que oferece à metropolização brasileira? Disponível em 
http://www.observatoriodasmetropoles.net/download/estatuto_metropole_artigo_rosa.pdf. Acesso em mar 2018.

MUTH, R.F. Cities and housing. University of Chicago Press. Chicago, 1969.

NAMUR, Marly. A questão da localização no processo de produção pública habitacional da CDHU no espaço urbano. Ambiente Construído. Porto Alegre, v. 4, no. 1, p.55-66, jan/mar/.2004.

NAMUR, Marly. Estado e Empresariado em Curitiba - Formação da CIC (73-80). Tese de doutorado, FAU-USP, São Paulo, 1992.

NIGRIELLO A. \& OLIVEIRA, R. H. Região Metropolitana de São Paulo: delimitação e caracterização de Unidades Territoriais Metropolitanas. São Paulo: Cadernos de Pós Graduação em Arquitetura e Urbanismo. Programa de Pós-Graduação em Arquitetura e Urbanismo - FAU Mackenzie. 2013.

OLIVEIRA, FRANCISCO. A navegação venturosa: ensaios sobre Celso Furtado.

Boitempo Editorial, São Paulo, 2003.

OLIVEIRA, FRANCISCO. O Estado e o Urbano no Brasil. Revista Espaço e Debates 6, São Paulo, 1982.

PADOVANO, Bruno R. (org). NAMUR, Marly (org). SALA, Patrícia B. (org). São Paulo em busca da sustentabilidade. São Paulo, Pini; Edusp, 2012. 349p.

PAULA, Eurípedes de Simões. (Org.) A Cidade e a História vol. III. In: Anais do VII Simpósio dos Professores Universitários de História. São Paulo, Brasil, 1974. Disponível em:

PARNELL, S.; OLDFIELD, S. The Routledge Handbook on Cities of the Global South. New York, 2014.

PEIXOTO, Nelson Brissac. Paisagens Urbanas. São Paulo, Ed. Senac, 1996.

PELLEGRINO, P. R. M. A Paisagem possível. In: Revista Paisagem e Ambiente - Ensaios II.

PELLEGRINO, P. R. M. Pode-se planejar a paisagem? In: Revista Paisagem e Ambiente: ensaios. FAU, 1997. No. 13, p. 159 a 179. - dez. 2000. São Paulo.

PELLEGRINO, P. R. M. Por um design ambiental espaço de aplicação: a região de Sorocaba. In: Revista Paisagem e Ambiente - Ensaios II. Disponível em:

PREFEITURA Municipal de Sorocaba, Plano Diretor de Sorocaba -, LEI № 8.181, DE 05 DE JUNHO DE 2007, (Revisão da Lei 7.122 de 04/6/2004, que instituiu o novo Plano Diretor de Desenvolvimento Físico Territorial do Município de Sorocaba, e dá outras providências). Acessado em: outubro de 2016. www.sorocaba.sp.gov.br/midias/.../478 plano diretor de sorocaba.pdf.

PREFEITURA Municipal de Sorocaba, Plano Diretor de Sorocaba. Lei n ${ }^{\circ} 11.022$, de 16 de dezembro de 2014. Revisão do Plano Diretor de Desenvolvimento Físico Territorial do Município de Sorocaba. Divisão de Controle de Documentos e Atos Oficiais, Sorocaba, SP, 24 abr. 2015. Disponível em: http://www.sorocaba.sp.gov.br/portal/anexos/49/plano-diretor-2014-consolidado.pdf. Acessado em: outubro/2016.

PRESTES, Lucinda Ferreira, Sorocaba, o tempo e o espaço séculos XVIII - XX. Tese de Doutorado apresentada à Faculdade de Arquitetura e Urbanismo de São Paulo. São Paulo: 2001.

PROFETA, R. A. Um Estudo de Caso de Fatores Críticos para a Implementação. Tese de Doutorado. Faculdade de Economia, Administração e Contabilidade. Universidade de São Paulo. São Paulo, 2003.

REIS, Nestor Goulart. Memória do transporte rodoviário: Desenvolvimento das atividades rodoviárias de São Paulo. São Paulo: CPA Consultoria de Projetos e Artes Ltda. [1998], p. 21.

REIS, Nestor Goulart. Notas sobre Urbanização dispersa e novas formas de tecido urbano. LAP Laboratório de Estudos sobre Urbanização, Arquitetura e Preservação, FAPESP. São Paulo: Via das 
Artes, 2006.

REIS FILHO, NESTOR GOULART. Urbanização e Teoria: contribuição ao estudo das perspectivas atuais para o conhecimento dos fenômenos da urbanização. Tese apresentada ao concurso para provimento da Cátedra no. 22 - História da Arquitetura @@, da Faculdade de Arquitetura e Urbanismo da Universidade de São Paulo. São Paulo, Abril de 1967. Edição fac-símile. FAUUSP, 2016.

REIS, Nestor Goulart. TANAKA, Marta Soban. (Coord.) Brasil: Estudos sobre urbanização dispersa. LAP - Laboratório de Estudos sobre Urbanização, Arquitetura e Preservação, FAPESP. São Paulo: 2007.

RIBEIRO, F. C. Das coalizações advocatórias às coalizações defensivas: uma análise da forma de administração condicionada pela dimensão dos municípios. Revista de Estudos Universitários. Sorocaba, SP. V.30, no. 2; dez. 2004, p.63-76.

RIBEIRO, Emerson. Caminhos e descaminhos: a ferrovia e a rodovia no bairro Barcelona em Sorocaba/SP. 2006. Dissertação (Mestrado). Faculdade de Filosofia, Letras e Ciências Humanas. Universidade de São Paulo. São Paulo, 2006.

RODRIGUES, Elcie Helena Costa; BRAMANTE, Antônio Carlos. O Espaço na construção de uma política de lazer - estudando Sorocaba/SP. Revista Brasileira de Ciências do Esporte, Florianópolis, SC, v. 24, n. 3, Jul. 2008. ISSN 2179-3255. Disponível em: $<$ http://oldarchive.rbceonline.org.br/index.php/RBCE/article/view/761/435>. Acesso em: 12 Jan. 2016.

ROSA, Ádima Domingues. O Processo de privatização da FEPASA na década de 90 . Revista de Iniciação Científica da FFC, v. 4, n. 3, 2004. p.105 a 116.

SAINT-HILAIRE, A. Viagem à província de São Paulo. São Paulo: Martins, 1940.

SANTORO, P.; CYMBALISTA, R.; NAKASHIMA, R. Plano Diretor de Sorocaba: um olhar sobre os atores e a auto-aplicabilidade dos instrumentos urbanísticos. In:

http://www.ibdu.org.br/imagens/planodiretordesorocaba.pdf, acesso em outubro/2015.

SANTOS, Milton. A Natureza do Espaço: Técnica e Tempo, Razão e Emoção. $4^{\mathrm{a}}$. Edição, $1^{\text {a }}$. reimpressão. São Paulo: Editora da Universidade de São Paulo, 2004. - (Coleção Milton Santos; 1).

SANTORO, P. F. e CYMBALISTA, R., NAKASHIMA, R. Planos diretores: processos e aprendizados I [organização] Renato Cymbalista, Paula Freire Santoro - São Paulo: Instituto Pólis, 2009. 158p.

SANTOS Jr., Wilson Ribeiro dos. Reconcentração produtiva e estruturação do território: formação do corredor urbano Campinas-Sorocaba. Grupo Temático 5 - Dinâmica da produção e transformação territorial. Eixo Temático - Processos de reestruturação econômica e seu impacto sobre o território. XIII Seminário Internacional da Red Iberoamericana de Investigation sobre Globalization y Território (RII). 01 a 04/set/2014. Salvador, BA, Brasil.

SANTOS, M. A cidade como centro de região: definições e métodos para avaliação da centralidade. Salvador: Livraria Progresso, 1959. In: http://miltonsantos.com.br/site/de-milton-santos/ miltonsantos_1959.pdf, acesso em julho/2013.

SANTOS, Milton. A Natureza do Espaço. Edusp, 4ª Edição - São Paulo - 2004.

SANTOS, M. A Urbanização brasileira. São Paulo: Hucitec, 1993.

SANTOS, M. Espaço e método. São Paulo: Nobel, 1985, 88p.

SANTOS, Milton. Pensando o espaço do homem. $5^{\text {a }}$ Edição - São Paulo - 2004.

SANTOS, M. Técnica, espaço, tempo: globalização e meio técnico-científico informacional. São Paulo: Hucitec, 1996.

SANTOS, E. O. A Industrialização de Sorocaba - bases geográficas. Tese de Doutorado. Faculdade de Filosofia e Ciências Humanas da Universidade de São Paulo. São Paulo, 1999. 184p. 
SÃO PAULO (Estado). Fundação Sistema Estadual de Análise de Dados (Seade). Características gerais do processo de industrialização paulista. São Paulo: SEADE, 1988.

SÃO PAULO (Estado). FUNDAÇÃO SEADE - Migração no Interior do Estado de São Paulo: A Região Administrativa de Sorocaba. In: Informe Demográfico, no. 23, 1990.

SÃO PAULO (Município). EMPLASA - 2nd International Conference and Exhibition on Geospatial Technology and Applications. Rio de Janeiro, s/d.

SÃO PAULO (Estado). Fundação Sistema Estadual de Análise de Dados (Seade). Características gerais do processo de industrialização paulista. São Paulo: SEADE, 1988.

SÃO PAULO (Estado). FUNDAÇÃO SEADE - "Migração no Interior do Estado de São Paulo: A Região Administrativa de Sorocaba", in: Informe Demográfico, no. 23, 1990.

SALES, João Alberto. A pátria paulista. Brasília: Editora Universidade de Brasília, 1983.

SASSEN, Saskia. Cities in a word economy. London, Pine Forge Press, 2000.

SASSEN, Saskia. Ciudades en la economía global: enfoques teóricos y metodológicos. EURE (Santiago), Santiago, v.24, n.71, marzo 1998.

SASSEN, Saskia. El reposicionamento das ciudades y regiones urbanas em uma economia global: ampliando las opciones de políticas e gobernanza. EURE (Santiago), DIC 2007, vol. 33, no. 100m p. 9-34.

SAVIOLI, Mario Luiz. A cidade e a estrada: as transformações urbanas do município de Cotia ao longo da rodovia Raposo Tavares. Pós. Revista do Programa de Pós-Graduação em Arquitetura e Urbanismo da FAUUSP, São Paulo, n. 22, p. 106-121, dec. 2007. ISSN 2317-2762. Disponível em: <http://www.periodicos.usp.br/posfau/article/view/43535/47157>. Acesso em: 10 dec. 2017. doi:http://dx.doi.org/10.11606/issn.2317-2762.v0i22p106-121.

SAVIOLI, Mario Luiz. A cidade e a estrada - Transformações urbanas do município de Cotia ao longo da rodovia Raposo Tavares. 2006. 208p. Tese (Mestrado) - Universidade Presbiteriana Mackenzie, São Paulo, 2006.

SERVIÇO AUTONOMO DE ÁGUA E ESGOTO. Revisão Do Plano Diretor Do Sistema De Abastecimento De Água De Sorocaba. Relatório final volume 1 - Texto. PROESP ENGa. LTDA, Sorocaba, maio/2000.

SCHERER, Rebeca. O Planejamento como Questão. Palestra anexada à memória técnica do seminário: Instrumentos de Gestão Urbana, São Paulo, FUSP-SEMPLA, março de 1996.

SIMMEL, Georg. Filosofia da Paisagem. 1913 - São Paulo, tradução para o português Vladimir Bartalini. 2008.

SMITH, Adam. An Inquiry into the Nature and Causes of the Wealth of Nations. Edited by Sálvio M. Soares. MetaLibri, 2007, v.1.0p.

SINGER. P. Desenvolvimento econômico e evolução urbana. São Paulo: Editora Nacional, 1977,

SMOLKA, M. Estruturas intra-urbanas e segregaçao social no espaço: elementos para uma discussão da cidade na teoria econômica. Série Facsimile, 13. Rio de Janeiro: PNPE/IPEA, 1983.

SMOLKA, M. Estrutura intra-urbana e segregação social no espaço: Elementos para uma discussão das cidades na teoria econômica. Revista Brasileira de Estudos de População, São Paulo, v.9, n.1, jan.jjul. 1992.

SPIRN, Anne Winston. Environmentalism in Landscape Architecture. Edited by Michel Conan. Dumbarton Oaks Research Library and Collection Washington, D.C. Trustee for Harvard University. (Offprint.) Washington, D.C.: 2000. Disponível em:

http://www.annewhistonspirn.com/pdf/environmenalism.pdf, acesso em nov/2017. 
SOMEKH, N. A (des) Verticalização de São Paulo. Tese de doutorado. Universidade de São Paulo, Faculdade de Arquitetura e Urbanismo. São Paulo, 1997.

SOMEKH, N. As regiões metropolitanas no contexto da globalização: uma agenda possível. In: Regiões metropolitanas no Brasil: um paradoxo de desafios e oportunidades / Fernanda Magalhães, editora. Banco Interamericano de Desenvolvimento: Washington D.C., 2010.

SONODA, E. C. Evolução econômica e mudanças na estrutura produtiva da RA de Sorocaba (1980 - 2005). Dissertação de Mestrado. Instituto de Economia. Universidade de Campinas. Campinas, 2006.

SOROCABA. Plano Diretor de Desenvolvimento Físico Territorial de Sorocaba. Lei n ${ }^{0} 7122$ de 02 de junho de 2004.

SOROCABA. Revisão da Lei 7.122 de 04/6/2004, que instituiu o novo Plano Diretor de Desenvolvimento Físico Territorial do Município de Sorocaba, e dá outras providências. Lei $n^{0}$ 8.181 de 05 de junho de 2007.

SONODA, E. C. Evolução econômica e mudanças na estrutura produtiva da RA de Sorocaba (1980 - 2005). Dissertação de Mestrado. Instituto de Economia. Universidade de Campinas. Campinas, 2006.

SOUZA, M.A. Mudar a Cidade - Uma Introdução Crítica ao Planejamento e à Gestão Urbanos. Bertrand, Rio de Janeiro, 2003.

STRAFORINI, R. No Caminho das Tropas. 1a. ed. Sorocaba: TCM Comunicações, 2001. 130p. Texas, 2008.

TOPALOV, C. Ganancias y rentas urbanas: elementos teóricos. Ed. Siglo XXI de España. Madrid, 1984.

TOPALOV, Christian. La Urbanization Capitalista: algunos elementos para su análisis. 1979. Material de uso exclusivo para fins acadêmicos. (pdf).

TOPALOV, C. La Urbanization Capitalista: alguns elementos para su análisis. (em soporte magnético). Universidad de Buenos Aires. Buenos Aires, noviembre de 2006.

TOPALOV,C. Les prometeurs imobiliers. Paris, Mouton, 1974.

VAINER, Carlos. Disseminating 'Best Practices': the coloniality of urban knowledge and citu models. In Parnell, S.; Oldfield, S. The Routledge Handbook on Cities of the Global South. New York, 2014.

VALLADARES, L. e PRETEICELLE, E. - "Reestruturação Urbana, Tendências e Desafios" - Ed. Nobel / IUPERJ, 1990.

VASCONCELLOS, E. A. Transporte Urbano, Espaço e Eqüidade. Análise das políticas públicas. Editora Unidas. São Paulo, 1996.

VEIGA, J. E. - "Desenvolvimento sustentavel. 0 desafio do seculo XXI", Garamond Universitaria, Rio de Janeiro, 2005.

VILLAÇA, F. Espaço Intra-Urbano no Brasil. São Paulo: Stúdio Nobel; FAPESP: Lincoln Institute, 2001. Reimpressão de 2009.

VILLAÇA, F. et ZIONI, S.M. Os Transportes sobre Trilhos na Região Metropolitana de São Paulo: 0

Poder Público Acentuando a Desigualdade. In: Companhia Brasileira de Trens Urbanos, CBTU. $1^{\circ}$

Concurso de Monografias - A Cidade nos Trilhos: transporte metroferroviário, mobilidade e desenvolvimento urbano - monografias premiadas. Rio de Janeiro: CBTU, 2005. pg 223.

WALLERSTEIN, Immanuel. Análisis de Sistemas - Mundo: Una introducción. Siglo Veintiuno Editores.

WILHEIM, J. Cidades: o substantivo e o adjetivo. São Paulo: Editora Perspectiva, 2003. 
WILLIAMS, F. Housing and City Planning. Journal of the American Institute of Architects (January): 2728. 1914.

WINGO, Lowdown. Transportation and urban land. Resources for the Future, Inc. / John Hopkins Press. Baltimore, 1961.

ZIMMERMMANN, Gustavo. A Região Administrativa de Sorocaba. In Cenários e Diagnósticos, A Economia no Brasil e no Mundo. Governo do Estado de São Paulo, Secretaria de Planejamento e Gestão e Fundação SEADE, v.8, 1992 (Coleção São Paulo no Limiar do Século XXI).

Sites consultados:

- $\quad$ Assembleia Legislativa do Estado de São Paulo - ALESP. <http:// www.al.sp.gov.br>

- $\quad$ Câmara Municipal de Alumínio - CMA. <http://www.camaraaluminio.sp.gov.br>

- $\quad$ Câmara Municipal de São Roque - CMSR. <http://www.camarasaoroque.sp.gov.br>

- $\quad$ Câmara Municipal de Sorocaba - CMS.

$<$ http://www.camarasorocaba.sp.gov.br/sitecamara/proposituras/verpropositura?numero_propositura=6200\&tip 0_propositura=1>

- $\quad$ Câmara Municipal de Votorantim - CMV. <http://www.camaravotorantim.sp.gov.br>

- Companhia Paulista de Trens Metropolitanos - CPTM. <http://www.cptm.sp.gov.br>

- $\quad$ Departamento de Estradas de Rodagem - DER. <http://www.der.sp.gov.br>

- $\quad$ Federação das Indústrias do Estado do Rio de Janeiro - FIRJAN. <http://www.firjan.com.br>

- $\quad$ Fundação Escola de Sociologia e Política de São Paulo - FESPSP. <http://www.fespsp.org.br>

- $\quad$ Fundação Sistema Estadual de Análise de Dados - SEADE. <http://www.seade.sp.gov.br>

- Google Imagens. <images.google.com>

- Google Scholar. <https://scholar.google.com.br>

- $\quad$ Governo do Estado de São Paulo - GESP. <http://www.saopaulo.sp.gov.br>

- Instituto Brasileiro de Geografia e Estatística - IBGE. <http://www.ibge.gov.br>

$<$ http://cidades.ibge.gov.br/xtras/temas.php?lang=\&codmun=355220\&idtema=16\&search=||s\%EDntese-dasinforma\%E7\%F5es>

- Jornal Cruzeiro do Sul - JCS. <http://www.site.cruzeironet.com.br>

- $\quad$ New York City Planning - NYCP. <http://www1.nyc.gov/site/planning>

- Plano Diretor de Desenvolvimento Integrado da RMBH - PDDI-RMBH. $<$ http://www.rmbh.org.br/pddi>

- $\quad$ Prefeitura Municipal de São Roque - PMSR. <http://www.saoroque.sp.gov.br>

- $\quad$ Prefeitura Municipal de Sorocaba - PMS. <http://www.sorocaba.sp.gov.br>

- $\quad$ Prefeitura Municipal de Votorantim - PMV. <http://www.votorantim.sp.gov.br>

- $\quad$ Secretaria dos Transportes Metropolitanos - STM. <http://www.stm.sp.gov.br>

- Sobre o bairro Ana Paula Eleutério (Habiteto):

<https://www.youtube.com/watch?v=f69YDgObz_Q> 
ANEXOS 


\section{ANEXOS}

\section{A. Partes das leis consultadas: Leis Sorocaba}

1. a lei no. 1.319 , de 17 de maio de 1965 , é delimitado novo perímetro urbano da sede do município de Sorocaba:

"Artigo $1^{0}$ - A linha perimétrica da Zona Urbana da Séde do Município de Sorocaba, (...), obedecerá à seguinte delimitação:

Começa na Ponte de Madeira, no Rio Sorocaba, na Estrada de Rodagem Sorocaba Pôrto Feliz, seguindo o curso dêste rio até a Ponte do Pinga-Pinga, no final da rua Pedro Alvares Cabral e desta em linha reta até a Estrada da Ronda Grande, seguindo ainda por esta até atingir a confluência da estrada das Pitas, continuando por esta até o Pontilhão existente, e, dêste em linha reta até atingir a variante ${ }^{64} \mathrm{da}$ rodovia "Raposo Tavares", seguindo por esta até o antigo leito da Estrada de Rodagem São Paulo-Paraná, passando em frente ao Lar-Escola Monteiro Lobato até atingir novamente a variante da Raposo Tavares ou Sorocaba-Itapetinga até alcançar a propriedade do sr. Heitor Cury, e desta em linha reta até a rua "Q" (Que) do Parque Manchester e desta, em linha reta, até a rua Vinte e Três (23) da Vila Nova Sorocaba até atingir a Estrada de Sorocaba-Pôrto Feliz, seguindo por esta até a Ponte de Madeira, no Rio Sorocaba, ponto inicial de delimitação." (CMS, 1965)

2. lei no. 9205 , de $28 / 12 / 1965^{65}$, substituindo a lei estadual número 1 de 1947 , altera-se novamente a lei orgânica dos municípios pelo seu artigo 52, sobre as normas urbanísticas, instituindo a necessidade de Plano Diretor:

"Artigo 52 - 0 munícipio elaborará o seu Plano Diretor, considerando integradamente a área urbana, a de expansão urbana e rural, com disposições sôbre o sistema viário urbano e rural, o zoneamento urbano, o loteamento urbano ou para fins urbanos em zona rural, a editificação e os serviços públicos urbanos, e o mais que relacionar com o bem-estar da população local.

$\S 1 .^{\circ}$ - O Estado, quando solicitado, auxiliará a elaboração do Plano diretor com recursos técnicos ou financeiros.

$\S 2 .^{\circ}$ - Nenhum auxílio financeiro ou empréstimo será concedido pelo Estado ao munícipio que não possuir Plano Diretor regularmente aprovado, após 3 (três) anos de vigência desta lei.

Artigo 53 - O município elaborará as normas de edificação, de zoneamento e de loteamento urbano, ou para fins urbanos em zona rural, atendidas as peculiaridades locais e a legislação federal e estadual pertinentes" (PMS, 1965)

3. Lei $n^{0} 1438$ de 21 de novembro de 1966 é aprovado o Plano Diretor do município de Sorocaba, que delimita duas áreas: urbana e rural (para fins de tributação):

"Começa no cruzamento do córrego Taquaraguai com a Rodovia Raposo Tavares, desce pôr êste córrego, atravessa a estrada de rodagem Sorocaba-Itu, sobe pelo primeiro afluente à esquerda, transpõe o divisor de águas, desde o córrego fronteiriço até atingir o rio Sorocaba, (...) desce pôr êste até a sua foz no córrego do Itanguá, sobe em seguida pôr êste córrego até atingir a Rua " "do loteamento denominado Aclimação, segue pôr esta rua até a Rodovia Sorocaba-Itapetinga, segue pôr esta na direção de São Paulo, tomando o desvio à direita e passando em frente ao Instituto Lar Escola Monteiro Lobato, toma a variante da estrada Raposo Tavares, passa pelo cruzamento desta com o rio Sorocaba, toma o divisor de águas à direita do córrego do Vidal, segue pôr êste divisor até atingir novamente a variante da Rodovia Raposo Tavares, segue pôr esta até o ponto de cruzamento do córrego Taquaraguaí com a Rodovia Raposo Tavares, ponto de partida. " (CMS, 1966)

\footnotetext{
${ }^{64}$ A variante é o atual traçado da rodovia Raposo Tavares no trecho estudado, do km 98 a 102.

65 Disponível em: http://www.al.sp.gov.br/repositorio/legislacao/lei/1965/lei-9205-

28.12.1965.html, acesso em julho de 2017.
} 
4. lei no. 1541 , de 23/12/1968:

"1 - ZONAS: a- Zonas Urbanas; b- Zona Rural ; c- Zona de Expansão Urbana

2 - SETORES: numeradas de 1 a 3

$\S 1^{\circ}$ - Zonas Urbanas - São aquelas áreas do solo da séde ou dos distritos, propostas pelo órgão municipal encarregado do planejamento, destinadas às funções característicamente urbanas.

$\S 2^{\circ}$ - Zona Rural - é aquela área do solo proposta pelo órgão municipal encarregado do Planejamento e caracteriza pelas funções rurais como sejam agricultura, pecuária, florestamento e pontos de atração turística e de recreio.

$\S^{\circ}$ - Zona de Expansão Urbana - são aquelas áreas do solo propostas pelo órgão municipal encarregado do Planejamento e que inicialmente possuíam atividades rurais, mas serão gradativamente transformadas em zonas urbanas para atender ao

5. lei no. 1568 de 27/10/1969: natural crescimento urbano do Município". (PMS, 1968)

"Artigo $1^{\circ}$ - A linha perimetral da Zona Urbana da Sede do Município de Sorocaba, na forma da planta anexa, obedecerá à seguinte delimitação: "Começa na "Ponte de Madeira", no Rio Sorocaba, (...) da confluência da Estrada do Bom Jardim com o ramal da Estrada das Pitas segue em linha reta até alcançar a via Raposo Tavares, na confluência da Estrada dos Leites, passando sôbre o leito da Estrada de Ferro Sorocabana (ponto $n^{0} 4$ ); da confluência da Via Raposo Tavares com a Estrada dos Leites segue em linha reta até alcançar a divisa com o Município de Votorantim na junção das Estradas dos Morros com a Travessa dos Morros (ponto $n^{\circ}$ 5); (...) segue pela Estrada da Itavuvu até alcançar o Rio Sorocaba na "Ponte de Madeira", ponto de partida." (PMS, 27/10/1969)

6. “Lei 1882/76.

"Artigo 21 - Na Zona Residencial 1 (Z.R.1), as construções e os lotes deverão obedecer os seguintes requisitos, excluindo-se os mercados:

1 - Área mínima do lote.................................250 m2

2 - Testada mínima do lote...............................10 m

3 - Profundidade mínima do lote.......................... $15 \mathrm{~m}$

4 - Afastamento mínimo do corpo da construção principal em relação aos limites dos lotes:

a - frente: 4 metros, 6 metros quando voltados para as ruas de $1^{\circ}$ categoria.

$b$ - fundos: 4 metros

$c$ - Laterais: $p /$ lote encravado:

1) 1,50 metros para residências individuais;

2) para edifícios comerciais de caráter transitório, mistos, de habitação coletiva e hotéis - afastamento de $\mathrm{H} / 4$ (sendo $\mathrm{H}$ a altura entre o piso do andar térreo e a laje do último pavimento, com um mínimo de 3,5 m).

p/ lote de esquina:

Será adotado o afastamento estabelecido para via voltado o prédio para o outro lado o estabelecido para lote encravado.

5 - Coeficiente máximo de ocupação do lote:

a - 30\% da área do terreno para habitações coletivas ( $A$ área de projeção da cobertura da garagem não será computada para efeito do cálculo do coeficiente de ocupação desde que não ultrapasse a $15 \%$ da área do terreno e seja apenas o andar térreo);

$b$ - 30\% para prédios comerciais ou de caráter transitório;

c - $30 \%$ para loja e sobreloja de edifícios comerciais e mistos;

$d-0,6$ para residências individuais.

6 - Coeficiente máximo de aproveitamento do lote:

a - 3 (três) vezes a área do terreno,

7 - Nos edifícios de habitação coletiva, deverão corresponder a cada unidade habitacional, no mínimo 50 (cinquenta) metros quadrados de terreno. A parte fracionária resultante do cálculo, será arredondada para a unidade e somada à parte inteira. Cada habitação será constituída de, no mínimo, uma sala, um dormitório, coZinha e um banheiro." 
Artigo $1^{\circ}$ - 0 artigo 46 da Lei $n^{\circ} 1.541$, de 23 de dezembro de 1968, fica alterado, passando a ter a seguinte redação:

"Artigo 46 - Na Zona Industrial Urbana (Z.I.U.), definida na planta de zoneamento e no artigo 48, são permitidos os seguintes usos:

1 - Indústrias Complementares, Centrais, Residenciais e Especiais;

2 - Depósitos em Geral;

3 - Oficinas;

4 - Garagens em geral;

5 - Residências individuais e coletivas;

6 - Postos de serviços;

7 - Ambulatórios;

8 - Clubes e Associações esportivas."

\section{Lei 2042/1979:}

(...) Artigo $5^{\circ}$ - Nos arruamentos e loteamentos de interesse social, deverão ser observadas as seguintes características:

I - Vias:

a)declividade máxima de 15\% (quinze por cento) e mínima de 0,5\% (meio por cento);

b) largura mínima total de 10,00 (dez) metros, com o mínimo de 7,00 (sete) metros de faixa carroçável e de 1,50 (um metro e cinquenta centímetros) para cada passeio; c) quando interrompidas, deverão ter praças de retorno que contenham um círculo de 16,00 (dezesseis) metros de diâmetro, no mínimo.

\section{II - Lotes:}

a)- área mínima: 120,00 m2 (cento e vinte metros quadrados);

b)- frente mínima: 6,00 (seis) metros;

c)- recuo de frente mínimo: 4,00 (quatro) metros;

d)- recuo lateral mínimo: 1,50 (um metro e cinquenta centímetros);

e)- recuo de fundo mínimo: 2,00 (dois) metros.

Parágrafo único - Nos lotes de esquina o recuo mínimo para a rua lateral deverá ser de 2,00 (dois) metros.

Artigo $6^{\circ}$ - Além das especificações técnicas contidas no artigo anterior, nos arruamentos e loteamentos de interesse social observar-se-ão as seguintes exigências:

I - Nenhum lote poderá distar mais de 450,00 (quatrocentos e cinquenta) metros, medidos ao longo do eixo da via que Ihe dá acesso, de uma via principal com largura mínima de 12,00 (doze) metros;

II - Nenhuma quadra poderá ter o comprimento superior a 450,00 (quatrocentos e cinquenta) metros, sem que esteja implantada nela via de acesso para veículos e balão de retorno;

III - Nos locais onde a declividade do terreno não permitir a utilização das redes de esgoto e galerias existentes na via fronteiriça, os lotes deverão conter faixa "non aedificandi" nos fundos de no mínimo, 3,00 (três) metros de largura.

9. “Lei 2821/88 (Revogada pela Lei $n^{0}$ 5.161/1996):

Artigo $2^{\circ}$ - Ficam proibidas as construções de edifícios multi-familiares em parte do $1^{\circ}$ Setor da Zona Residencial 3, na região constituída pelo seguinte perímetro: "Inicia-se na Rodovia Raposo Tavares, na confluência com a Avenida Comendador Pereira Ignácio; segue pela Rodovia Raposo Tavares até encontrar a Avenida Dr. Armando Pannunzio; segue por esta até encontrar a linha de alta tensão da Eletricidade São Paulo S/A - Eletropaulo; segue por esta até encontrar a Avenida Comendador Pereira Ignácio; segue por esta até encontrar a Rodovia Raposo Tavares, ponto de partida, fechando-se o perímetro".

\section{0. "LEI No 3.457, de 18 de dezembro de 1990}

Artigo $1^{\circ}$ - Ficam expressamente proibidas as atividades industriais previstas no artigo 35 da Lei $n^{0}$ 1.541/1968, para os loteamentos Jardim do Sol, Jardim das Estrelas e Jardim Ypê;

Artigo $2^{\circ}$ - No Loteamento Jardim Gramados de Sorocaba, Jardim Novo Bandeirantes, Jardim Bandeirantes, Jardim Astro e Jardim Granja Olga, são 
permitidos os seguintes usos:

1 - Residências Individuais

2 - Estabelecimentos de Ensino

3 - Bibliotecas e Museus

4 - Edifícios Públicos

5 - Templos

6 - Associações Esportivas ou Culturais - Clubes

7 - Posto de Serviço

8 - Comércio à Varejo

9 - Mercados

10 - Pequenas Oficinas não incômodas

11 - Casas de Espetáculos e Diversões

12 - Escritórios

13 - Cafés, Bares, Restaurantes e Congêneres

14 - Hotéis

15 - Laboratórios de Análises

16 - Imprensa, Editoras e Instalações de Rádio Difusão e Televisão

17 - Lavanderias

18 - Ambulatórios

19 - Padarias e Confeitarias." (CMS, 1990)

11. "LEI No 4.554, de 03 de junho de 1994: condicionado ao uso do Artigo 15 da Lei no 1.541/1968:

Artigo $1^{\circ}$ - Para usufruir das condições do Artigo 15 da Lei $n^{0} 1.541$, o proprietário do terreno deverá recolher aos cofres públicos a quantia correspondente ao valor determinado pela expressão: $V \quad(C A-4) x \quad 0,75$, em que: $V=$ valor da terra nua no mercado imobiliário, avaliado pelo órgão competente da Prefeitura do Município, na data do pagamento indicado do Artigo $2^{\circ}$. $C A=$ coeficiente de aproveitamento do terreno, até o valor indicado na alínea "a" do Artigo 15 da Lei $n^{\circ}$ 1.541, medido pela relação entre a área total a construir e a do terreno.

\section{LEI N ${ }^{\circ} 4.555$, de 03 de junho de 1994, condiciona o uso do Artigo $7^{\circ}$ da Lei $n^{\circ} 1.541 / 1968$.}

Artigo $1^{\circ}$ - Para usufruir das condições do Artigo $7^{\circ}$ da Lei $n^{\circ} 1.541$, o proprietário do terreno deverá recolher aos cofres públicos a quantia correspondente ao valor determinado pela expressão: $V \quad(C A-5) \times \quad 0,75$, em que:

$V=$ valor da terra nua no mercado imobiliário, avaliado pelo órgão competente da Prefeitura do Município, na data do pagamento indicado do Artigo $2^{\circ}$. $C A=$ coeficiente de aproveitamento do terreno, até o valor indicado na alínea "a" do Artigo $7^{\circ}$ da Lei $n^{0} 1.541$, medido pela relação entre a área total a construir e a do terreno.

Artigo $2^{\circ}$ - 0 recolhimento referido no artigo $1^{\circ}$, deverá ser efetuado em uma das seguintes datas: a) na aprovação do projeto de implantação do edifício no terreno; b)
concessão
do
habite-se
respectivo.

Artigo $3^{\circ}$ - É permitido o recolhimento da quantia estipulada no Artigo $1^{\circ}$, em parcelas proporcionais à duração da construção, desde que tal quantia seja transformada em números de Unidades Fiscais Municipais (UFMS).

13. Lei $n^{\circ} 4.594$, de 2 de setembro de 1994: Dispõe sobre a autorização para a construção de Apart-Hotéis e dá outras providências.

Artigo $1^{\circ}$ - Fica autorizada a construção de Apart-Hotéis nas Zonas, Comercial Principal (ZCP), Comerciais 1,2,3 e 4; Residencial 3 (10, $2^{\circ}$ e $3^{\circ}$ setores); Residencial $4\left(1^{\circ}, 2^{\circ}\right.$ e $3^{\circ}$ setores) e Industrial Urbana (ZIU), definidas na planta de zoneamento criada pela Lei $n^{0} 1.541$, de 23 de dezembro de 1968. Parágrafo único - Ficam excluídas desta Lei as áreas definidas nas Leis $n^{0} 2.811$, de 13 de dezembro de 1988 e 3.202, de 19 de dezembro de 1989. Artigo $2^{\circ}$ - Para efeito do artigo $1^{\circ}$, são considerados Apart-Hotéis, as edificações multi-familiares residenciais, com prestação de serviços de hotelaria. "(CMS, 1994) 
14. LEI No 4.874, de 06 de julho de 1995.

Cria os corredores comerciais, as Zonas Comerciais Secundárias Z.C.5, Z.C.6. e Z.C.7, amplia as Zonas Comerciais 3 e 4 e a Zona Residencial 1 - $2^{\circ}$ setor.

\section{CORREDORES COMERCIAIS}

Artigo $1^{\circ}$ - Ficam criados os Corredores Comerciais nas seguintes vias: Av. Antônio Carlos Cômitre, Av. Washington Luiz, Av. Américo de Carvalho, Av. Pereira da Silva, Av. Roberto Simonsen, Av. General Osório, Av. Ademar de Barros, Av. Armando Salles de Oliveira, Av. Pres. KENNEDY E Av. Bento Mascarenhas Jequitinhonha, Av. Dom Aguirre (trecho compreendido entre a Praça Lions e Av. Roberto Simonsen, Rua Augusto Lippel).

(...) Artigo $3^{\circ}$ - As construções obedecerão os seguintes índices urbanísticos:

a) Taxa de ocupação máxima do lote $-80 \%$

b) Coeficiente de aproveitamento máximo do lote -4

c) Taxa de conforto - $50 \mathrm{m2} /$ unidade habitacional

d) Cada habitação será constituída de no mínimo uma sala-dormitório, uma cozinha, um banheiro e uma área de serviço.

e) Recuos mínimos:

I.- Prédios de até 02 pavimentos:

Frente $-5,00 \mathrm{~m}$.

Laterais - dispensável para o lote encravado e 2,00 m. para lote de esquina.

Fundo - dispensável.

II.- Prédio a partir do $3^{\circ}$ pavimento:

Frente $-5,00 \mathrm{~m}$.

Fundo-2,00 m.

Laterais - H/6 (com um mínimo de 2,00m.) onde houver vão iluminantes e H/12 (com um mínimo de 1,50 m.) onde for parede cega sendo $\mathrm{H}$ a diferença entre o teto do pavimento mais alto e o piso do $3^{\circ}$ pavimento.

Esquina - 2,00 m.

Artigo $4^{\circ}$ - a altura dos edifícios no alinhamento da via pública será de uma vez $e$ meia a largura da Rua, acrescido de seu recuo permitindo-se o escalonamento.

Parágrafo único - Nos lotes de esquina em vias públicas de largura diversas, a altura mínima permitida pela via de maior largura, poderá estender-se unicamente até a profundidade de 30,00 m. a contar de alinhamento, obedecendo daí a redução decorrente a altura permitida na via pública de menor largura.

Artigo $5^{\circ}$ - para prédios comerciais deverá ser reservado uma vaga para veículo a cada $50 \mathrm{~m} 2$ da área construída e para os prédios residenciais uma vaga para cada unidade habitacional.

15. LEI No 5.261 , de 25 de outubro de 1996, altera o Artigo 32 da Lei $n^{\circ} 1.541$, de 23 de dezembro de 1968.

Artigo $1^{\circ}$ - O Artigo 32 da Lei $n^{0} 1.541$, passa a ter a seguinte redação:

"Artigo 32 - A altura dos edifícios no alinhamento da via pública será de 1,5 (uma vez e meia) a largura da rua". "CMS, 1968)

16. "LEI No 5.683, de 26 de maio de 1998: altera o item 7 do Art. 20, da Lei $n^{\circ} 1.541$, de 23 de dezembro de 1968, e dá outras providências.

"Art. $1^{0}$ - 0 item 7 do Art. 20, da Lei $n^{\circ} 1.541$, de 23 de dezembro de 1968, passa a ter a seguinte redação:

"Art. 20 - Na ZONA RESIDENCIAL 1, definida na planta de zoneamento e no Art. 24, são permitidos os seguintes usos:

Nos lotes com frente para as avenidas radiais, são permitidos, além dos acima

citados, os seguintes usos:

7 - Cafés, bares, restaurantes, buffets e congêneres." (CMS, 1968)

17. LEI No 5.911, de 01 de junho de 1999.

Dispõe sobre a ampliação da Zona Residencial 1 - $2^{\circ}$ setor.

Art. $1^{\circ}$ Fica ampliada a Zona Residencial $1-2^{\circ}$ setor, definida no artigo 24 da Lei $n^{\circ} 1.541$, de 23 de dezembro de 1968, alterada pelas Leis $n^{\circ}$ s. 4.874, de 06 de julho 
de 1995; 5.161, de 28 de junho de 1996; 5.676, de 19 de maio de 1998 e 5.795, de 06 de novembro de 1998, passando a vigorar com a seguinte redação:

"Art. 24: Zona Residencial 1 - $2^{\circ}$ setor:

Inicia-se (...) no mesmo alinhamento segue até a Avenida Antônio Carlos Cômitre, segue por esta até o prolongamento da Rua Luiz Pessutti; segue por este prolongamento até a Rua Luiz Pessutti; segue por esta até o final da Rua Romeu Nascimento, segue em linha sinuosa até a Rodovia Raposo Tavares, segue por esta até a Rua João Wagner Wey, segue por esta até o encontro com a Rua Victória Sacker Reze, daí segue até a divisa do loteamento Jardim Pagliato, confrontando com as propriedades do Hospital Ivan Albuquerque, Clube União Recreativo até a propriedade de Ednéia de Carvalho, desse ponto deflete à direita em reta confrontando com a mencionada propriedade, ultrapassando a Rua Lituânia perpendicularmente na distância de trinta metros; deflete à direita seguindo em linha reta paralela a Rua Lituânia até o encontro da Avenida Abraham Lincoln, segue por esta até a Rua Brigadeiro Faria Lima, segue por esta até a Rua José Marchi, segue por esta a até a Rua La Plata, segue por esta até a Avenida Washington Luiz, segue por esta até o córrego, segue por este córrego até o alinhamento final das Ruas Aracaju e Natal, segue por este alinhamento na distância de cento e trinta metros, deflete à direita e segue por sessenta e cinco metros, deflete à esquerda e segue na distância de cinqüenta e três metros e meio, deflete novamente à esquerda e segue até encontrar a Rua Professora Francisca S. de Queiróz, segue por esta até a Rua José A. Lourenço, segue por esta até a Rua Visconde de Cairu, segue por esta até a Rua Barão de Cotegipe, segue por esta até a Rua Duque de Caxias, atingindo o ponto de partida desta descrição."

\section{8. "LEI N 6.200 , de 08 de agosto de 2000.}

Art. $1^{0}$ Fica acrescentado o parágrafo único ao artigo 24 da Lei no 1.541, de 23 de dezembro de 1968, alterada pelas Leis $n^{0} 4.874$, de 06 de julho de 1995; Lei $n^{0}$ 5.161, de 28 de junho de 1996; Lei no 5.676, de 19 de maio de 1998; Lei $n^{\circ}$ 5.795, de 06 de novembro de 1998 e Lei $n^{\circ}$ 5.911, de 01 de junho de 1999, com a seguinte redação:

"Parágrafo único - Na quadra $H$ do Jardim Pagliato serão permitidas construções de edificios residenciais multifamiliares com índices urbanísticos da ZR-3 (Zona Residencial 3)" (CMS, 2000)

A seguir, um quadro resumo das alterações da lei número 1541 de 23/12/1968 até o ano de 2000: 
Figura 145 - Quadro resumo de Leis municipais que alteraram o zoneamento municipal proposto pela Lei 1541/1968.

$$
\mathbf{n}^{*}: 1541 \quad \text { Data : 23/12/1968 }
$$

Ementa : Dispõe sôbre o Código de Zoneamento.

Alterada pela Lei

\begin{tabular}{|c|c|c|}
\hline Lei & Data & Ementa \\
\hline$\underline{6200}$ & $08 / 08 / 2000$ & 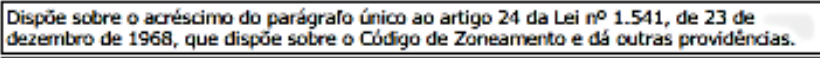 \\
\hline$\underline{5911}$ & $01 / 06 / 1999$ & $\begin{array}{l}\text { Dispóe sobre a ampliaçäo da Zona Residencial } 1 \text { - } 2^{\circ} \text { setor, definida no artigo } 24 \text { da Lei no } \\
\text { 1.541, de } 23 \text { de dezembro de } 1968 \text {, que dispüe sobre o Código de Zonearnento e dá outras } \\
\text { providências. }\end{array}$ \\
\hline$\underline{5683}$ & $26 / 05 / 1998$ & $\begin{array}{l}\begin{array}{l}\text { Altera o item } 7 \text { do Art. } 20 \text {, da Lei } n^{0} 1.541 \text {, de } 23 \text { de dezembro de } 1968 \text {, e dá outras } \\
\text { providểncias. (Dispöe sšbre o Código de Zoneamento) }\end{array} \\
\end{array}$ \\
\hline 5261 & $25 / 10 / 1996$ & Altera o Artigo 32 da Lei $n^{0} 1.541$, de 23 de dezembro de 1968 . (Código de Zoneamento) \\
\hline 4874 & $06 / 07 / 1995$ & $\begin{array}{l}\text { Cria os corredores comerciais, as Zonas Comerciais Secundárias Z.C.5, Z.C.6. e Z.C.7, } \\
\text { amplia as Zonas Comerciais } 3 \text { e } 4 \text { e a Zona Residendial } 1-2^{\circ} \text { setor. }\end{array}$ \\
\hline 4555 & $03 / 06 / 1994$ & Condiciona o uso do Artigo $7^{\circ}$ de Lei no 1541. (Cúdigo de Zoneamento) \\
\hline 4554 & $03 / 06 / 1994$ & Condiciona o uso do Artigo 15 da Lei no 1.541. (Código de Zoneamento) \\
\hline 3519 & $08 / 04 / 1991$ & $\begin{array}{l}\text { Dispóe sobre alteraçáo do artigo } 34 \text {, de Lei no } 1.541 \text {, de } 23 \text { de dezembro de } 1968 \text {, criando } \\
\text { o } 3^{0} \text { Setor da Zona Residencial } 3 \text { (ZR-3) e dá outras providéncias. }\end{array}$ \\
\hline$\underline{3287}$ & $18 / 05 / 1990$ & $\begin{array}{l}\text { Dispỏe sobre alteraçäo do Código de Zoneamento, instituindo a Zona Comercial ro 4, e dá } \\
\text { outras providéndas. }\end{array}$ \\
\hline 1985 & $30 / 10 / 1978$ & $\begin{array}{l}\text { Dispóe sobre permissäo para construçäo de padarias e confeitarias, e dá cutras } \\
\text { providâncias. }\end{array}$ \\
\hline$\underline{1962}$ & $23 / 05 / 1978$ & $\begin{array}{l}\text { Dispöe sobre alteraçäo da redaça do artigo 46, da Lei no 1.541, de } 23 \text { de dezembro de } \\
\text { 1968. (Cudigo de Zoneamenta) }\end{array}$ \\
\hline$\underline{1882}$ & $05 / 10 / 1976$ & $\begin{array}{l}\text { Dispö̉e sobre alteraçües no artigo } 21 \text { da Lei no } 1.541 \text {, de } 23 \text { de dezembro de } 1968 \text {. (Códiga } \\
\text { de Zoneamento) }\end{array}$ \\
\hline
\end{tabular}

Tem matéria versada na Lei

\begin{tabular}{|c|c|c|}
\hline Lei & Data & Ementa \\
\hline$\underline{4594}$ & 02/09/1994 & Dispỏe sobre a autorizaç̄o para a construçقảo de Apart-Hotếs e dá outras providências. \\
\hline$\underline{3457}$ & $18 / 12 / 1990$ & $\begin{array}{l}\text { Dispỏe sobre proibiçao de instalaçües industriais nos Jardins que menciona e define uso } \\
\text { permitido em outros e dá outras providéncias. }\end{array}$ \\
\hline$\underline{3235}$ & $26 / 03 / 1990$ & $\begin{array}{l}\text { Suprime o alargamento para } 25,00 \text { metros da Rua Aparecida, nos termos do parágrafo } \\
\text { únioo, do artigo } 3^{\circ} \text {, da Lei no } 1.438 \text {, de } 21 \text { de Novembro de } 1.966 \text {. } \\
\end{array}$ \\
\hline 2821 & $13 / 09 / 1988$ & Proibe a construçäo de edifícios multifamiliares e dá outras providéncias. \\
\hline$\underline{2102}$ & $01 / 04 / 1981$ & $\begin{array}{l}\text { Altera a redaço dos artigos } 1^{\circ} \text { e } 18 \text { da Lei } n^{\circ} 2.042 \text {, de } 29 \text { de outubro de } 1.979 \text { e dá outra } \\
\text { providância. (amuamento, loteamento e construça de residências de interesse social) }\end{array}$ \\
\hline 2042 & $29 / 10 / 1979$ & Dispöe sobre o arruamento, loteamento e corstruģ̄o de residências de interesse social. \\
\hline$\underline{1717}$ & $12 / 04 / 1973$ & Concede isençäo de tributos à construģöes populares e dá outras providências. \\
\hline
\end{tabular}

Fonte: Camara Municipal de Sorocaba. Acesso em julho/2017.

\section{B. Partes das leis consultadas: Leis São Roque}

"Art. 157 Ficam revogadas as Leis n’s 837 de 30 de dezembro de 1969, 953, de 18 de dezembro de 1972, $\underline{1.002}$, de $1^{\circ}$ de março de 1974, 1.003, de 13 de março de $1974,1.010$, de 04 de junho de 1974, 1.040, de 13 de dezembro de 1974, 1.044, de 24 de dezembro de 1974, 1.047, de 06 de janeiro de 1975, 1.049, de 17 de janeiro de $1975,1.050$, de 17 de janeiro de 1975, 1.055, de 03 de abril de 1975, 1.064, de 17 de junho de 1975, 1.073, de 17 de setembro de 1975, 1.076, de 08 de outubro de $1975, \underline{1.094}$, de 20 de fevereiro de 1976, $\underline{1.109}$, de 08 de julho de 1976, 1.143 , de 18 de maio de 1977, 1.181, de 18 de setembro de 1978, $\underline{1.203}$, de 02 de julho de $1979,1.222$, de 20 de junho de 1980, 1.281, de 13 de abril de 1982, 1.286, de 08 de julho de 1982, 1.306, de 07 de dezembro de 1972, 1.310, de 12 de janeiro de $1983,1.319$, de $1^{0}$ de junho de $1983, \underline{1.329}$, de $1^{\circ}$ de novembro de $1983, \underline{1.357}$, de 12 de abril de 1984, 1.416, de 21 de março de 1985, 1.418, de 21 de março de $1985, \underline{1.461}$, de 3 de dezembro de 1985, 1.468, de 03 de dezembro de 1985, 1.472 , de 09 de dezembro de 1985, 1.514 , de 05 de novembro de 1986, $\underline{1.535}$, de 17 de dezembro de 1986, 1.607, de 21 de abril de 1978,1.718, de 12 de outubro de $1989,1.727$, de 25 de outubro de 1989, 1.812, 5 de junho de 1990, 1.864, de 28 de setembro de 1990, 2.013, de 16 de dezembro de 1991, 2.028, de 27 de março de $1992,2.066$, de 28 de julho de 1992, 2.735, de $1^{\circ}$ de novembro de 2002, Lei complementar $n^{0} \underline{06}$, de 22 de maio de 1997, 13, de 05 de agosto de 1999, 15 de 06 de abril de 2000, 17 , de 13 de junho de 2001." (PMSR, 2006). 


\section{Partes das leis consultadas: Leis Brigadeiro Tobias}

Lei do Plano Diretor de Sorocaba, Lei no. 162/1950, de 18 de agosto de 1950

\section{"TITULO II: ZONEAMENTO}

CAPÍTULO I : SECÇÃO ÚNICA : DIVISÃO E SUB-DIVISÃO DAS ZONAS (...) Artigo $2^{\circ}$ - Para os efeitos do presente CÓDIGO, enquanto outra cousa não se estabelecer, fica o Munícipio de Sorocaba, excluídos os distritos de Salto de Pirapora, Brigadeiro Tobias, Votorantim e Éden, que terão brevemente seu esquema de Zoneamento traçado e aprovado por Lei, dividido nas seguintes zonas:

I - ZONA COMERCIAL PRINCIPAL (Z.C.P.)

II - ZONA COMERCIAL SECUNDARIA (Z.C.S.)

III - $1^{\text {a }}$ ZONA RESIDÊNCIAL (Z.R.1.)

IV - $2^{\mathrm{a}}$ ZONA RESIDÊNCIAL (Z.R.2.)

$V-3^{a}$ ZONA RESIDÊNCIAL (Z.R.3.)

$\mathrm{VI}$ - ZONA INDUSTRIAL (Z.I)

VII - ZONA RURAL OU AGRICOLA (Z.A.) (...) (CMS, 1950)

"SECÇÃO VII: ZONA RURAL

Artigo 10 - A Zona Rural é estabelecida por Lei, e constituída por área fora dos perímetros urbanos e suburbanos. (...)

Artigo 28 - As construções na Zona Rural devem ser destinadas, de um modo geral, a fins agrícolas e a habitação.

$\S$ único - A juízo da Prefeitura, será permitida a construção de edifícios destinados a indústrias pesadas, depósitos e inflamáveis e explosivos, comércio, depósitos, hospitais, casas de saúde, estabelecimentos de ensino e esportivo, hangares, estúdios, e similares.

Artigo 29 - As construções na zona rural não poderão ocupar mais de 60\% (sessenta por cento) da área total do terreno e terão o afastamento mínimo de $10 \mathrm{~m}$ (dez metros) do eixo do logradouro.

$\S 1^{0}$ - Tratando-se de núcleos de população em que exista arruamento regularmente aprovado, o Prefeito poderá fixar por decreto executivo, o recúo mínimo a ser observado em relação ao alinhamento do logradouro, o qual não será, porém, inferior a 3,00 m (três metros), nem superior a $15,00 \mathrm{~m}$ (quinze metros). Pela mesma forma, poderá fixar o Prefeito para êsses núcleos o afastamento mínimo em relação a cada uma das divisas latérais do lote, o qual não será inferior a 2,00 m (dois metros); (...)

Artigo 48 - Na Zona Rural, as obras de pequena importância, assim como acréscimos, reforma, reparos, quando localizados em terrenos não arruados, poderão ser feitas mediante simples comunicação escrita, acompanhada de desenho em três vias, obedecendo, porém os dispositivos dêste Código. (...)

Artigo 105 - Os terrenos construídos, quando a edificação for recuada do alinhamento, serão nêste fechados por gradil ou cêrca viva sem espinhos permanentemente bem tratada e aparada segundo 0 alinhamento do logradouro.(...)

$\S 4^{\circ}-\mathrm{Na}$ Zona rural, o fechamento de terrenos construídos poderá ser feito por qualquer dos meios admitidos para os terrenos não edificados na mesma zona. (...)

Artigo 268 - A construção de casas de madeira somente será permitida na Zona Rural, e, a juízo da Prefeitura, na $3^{\text {a }}$. Zona Residêncial.(...)

Artigo 308 - Ficam isentos dos pagamentos dos emolumentos de acôrdo com a Lei n. 21, de 5 de março de 1948, as casas destinadas para uso próprio e residencial de tôdos aqueles que vivam de salários, ordenados ou vencimentos mensais até Cr $\$ 2.000,00$ (dois mil cruzeiros), desde que construídas em próprios terrenos e 0 interessado não possua outra casa.

Artigo 309 - A casa popular de que trata o artigo anterior só poderá ser construída nos terrenos localizados nas Zonas Residênciais ou na Zona Rural.

$\S 1^{\circ}$ - Em cada lote, que deverá apresentar as condições estabelecidas nêste Código, somente poderá ser construída uma casa, não sendo admitida a existência de mais de uma habitação distinta em uma casa, nem a construção de 
cômodos ou anexos que possam servir de habitação independente, dentro do mesmo lote.

$\S 2^{\circ}$ - Além das disposições do presente Código que Ihes forem aplicáveis, ficam estabelecidas as seguintes condições, especiais para a construção das mesmas casas:

I - observar-se-á o afastamento de 4,00m (quatro metros), pelo menos, entre a construção e 0 alinhamento do logradouro.

II - a construção não poderá ser modificada durante 2 (dois) anos após o despacho da planta;

III - a ventilação e a iluminação dos compartimentos serão feitos por meio de vãos, abrindo diretamente para o espaço livre exterior com dimensões que satisfaçam às determinações dêste Código relativamente ao assunto; IV - os vãos de iluminação e ventilação terão as esquadrias dotadas de venezianas ou dispositivo equivalente, que permita a contínua renovação do ar dos compartimentos;

V - nos vãos de iluminação e ventilação, a distância da padieira ao teto será no máximo igual a sexta parte do pé direito;

VI - obrigatória a instalação de água potável, quando houver no logradouro canalização de distribuição domiciliária;

VII - o esgotamento será regulado pelas disposições dêste Código relativas ao assunto, sendo obrigatória a instalação de fossa e sumidouro quando houver, no logradouro, galeria de esgôtos;

VIII - o escoamento das águas servidas, da infiltração e pluviais, e de efluente das fossas e sumidouros será regulada pelas disposições dêste Código relativas ao assunto.

$\S 3^{0}$ - 0 prazo da licença para construção será de um ano, prorrogável a juízo da Prefeitura.

$\S 4^{\circ}$ - Pelas infrações que se verificarem, serão aplicáveis as multas estabelecidas no presente Código.

Artigo 310 - A Prefeitura Municipal de Sorocaba, pela sua Diretoria de Obras, fará fornecimento gratuito, aos interessados, de plantas padronizadas para construção de casas populares, que deverão ter, no mínimo, três cômodos, ou seja: sala de jantar, quarto e cozinha, além das dependências sanitárias.(...)

Artigo 421 - Além das exigências gerais do Código que lhes forem aplicáveis, as cachoeiras e estábulos deverão preencher as seguintes condições:

(...) III - os estábulos só poderão ser edificados na Zona Rural;(...)

Artigo 486 - Os depósitos para armazenamento de inflamáveis, assim como os depósitos de explosivos e fábricas de pólvora, fósforos, fógos de artifício e semelhantes só poderão existir na Zona Rural e na Zona Industrial. (...)

Artigo 510 - A concessão de licença para a abertura de logradouro, salvo 0 disposto no artigo 513 , será condicionada à execução pelo interessado, sem ônus para a Prefeitura, de tôdas as obras de terraplanagem, meios fios, pavimentação, pontes, pontilhões, boeiros, galerias, muralhas etc. que forem necessárias. (...)

$\S 4^{0}$ - As exigências deste artigo e seus parágrafos são obrigatórias para os logradouros a serem abertos por iniciativa particular em qualquer das zonas do município, exceto estradas e caminhos na zona rural para os quais se exigirão, quanto ao preparo do solo e à pavimentação, obras de terraplenagem em tôda a largura, a compressão e o ensaibamento em uma faixa de 6 (seis) metros, pelo menos, ao longo do eixo e a abertura de valas ou construção de sargetas laterais.

$\S 5^{\circ}$ - mesmo na zona rural, exigir-se-á a construção das pontes, pontilhões, boieiros, muralhas e tôdas as demais obras que, a juízo da Prefeitura, forem necessárias para a consolidação e proteção dos terrenos e para o escoamento das águas superficiais.(...)

Artigo 531 - O loteamento será regulado pelo disposto nos parágrafos seguintes:

$\S 1$ - No loteamento de terreno, resultantes de novos arruamentos de terrenos localizados nos logradouros públicos existente e de áreas ou lotes, que comportem parceladamente, localizados em quadras ou quarteirões existentes (...). Tratando-se de terrenos situados na Zona Rural, êsses mínimos serão de 15,00m (quinze 
metros) para a testada e de $400,00 \mathrm{~m} 2$ (quatrocentos metros quadrados) para a área de cada lote.

Artigo 544 - Os proprietários de terrenos edificados ou não, são obrigados a executar a construção ou reconstrução dos passeios, nos logradouros dotados de guias, em tôdas a extensão das respectivas testadas. (...)

$\S 4^{0}$ - A construção de passeios não é exigivel na Zona Rural. (...)

Artigo 612 - As construções na Zona Rural, terão que obedecer a tôdas as exigências dêste Código, com apresentação de planta com tôdos os detalhes exigidos e aprovação da Prefeitura, ficando, apenas, isentas do pagamento de emolumentos.

Artigo 613 - Antes da construção, o responsável pela obra será obrigado a requerer 0 alinhamento à Diretoria de Obras.

$\S$ único - O infrator das disposições desta Seç̧ão incorrerá na multa de $\mathrm{Cr} \$ 50,00$ (cinqüenta cruzeiros) a $\mathrm{Cr} \$ 1.000,00$ (mil cruzeiros), conforme a gravidade, e será obrigado legalizar a construção dentro do prazo estabelecido pela Diretoria de Obras. (...)

Artigo 622 - Pelas infrações das disposições dêste Código, sem prejuízo de outras providências cabíveis, serão aplicadas multas de acôrdo com o estabelecimento nos diversos parágrafos dêste artigo.(...)

$\S 10$ - Por executar obra sem a necessária licença da Prefeitura, com desrespeito às disposições concernentes ao uso, à taxa de ocupação, ao gabarito, à altura, à localização no lote, à concordância de níveis, ao afastamento do alinhamento ou das divisas laterais ou as dimensões ou condições do lote:

ao proprietário e ao profissional responsável, simultaneamente: a- na zona rural...... Cr\$ 100,00 a $\mathrm{Cr} \$ 200,00$;

$\S 11$ - Por executar obra sem a necessária licença, sem desrespeito a nenhuma das disposições mencionadas no parágrafo anterior, mas em desacôrdo com outras disposições dêste Código;

ao proprietário e ao profissional responsável, simultaneamente: a - na zona rural......... $\mathrm{Cr} \$ 50,00$;

$\S 12$ - Por executar qualquer obra sem licença, não sendo em desacôrdo com êste Código: ao profissional responsável e ao proprietário simultaneamente:a - na zona rural ........ $5 \%$ a $10 \%$. (...)" (CMS, 1950)

19. LEI No 1.417, de 30-junho-1966 - Código de Arruamento e Loteamento do município de Sorocaba, $S P$

\section{"(...) A - Loteamento Urbano:}

(...) Artigo 18 - Os loteamentos e arruamentos para fins residenciais obedecerão a seguinte classificação:

a- Jardim, quando inferior a $500.000 \mathrm{~m} 2$ (quinhentos mil metros quadrados);

b- Parque, quando acima de $500.000 \mathrm{~m} 2$ (quinhentos mil metros quadrados);

c- Bairro, quando a área constituir zona independente da cidade, e que, a critério da

Prefeitura, deva ter essa denominação.

Artigo 19 - Aos loteamentos ou arruamentos é vedado o uso de denominação

idêntica às já existentes.

$B$ - Loteamento Industrial

Artigo 20 - Considera-se loteamento industrial tôda e qualquer divisão de área que se destine à instalação de indústrias, e outros lotes tenham, no mínimo, $2.000 \mathrm{~m} 2$ (dois mil metros quadrados).

(...) Artigo 35 - Junto às estradas de ferro e rodovias de $1^{\text {a }}$ categoria ou especiais (Especificações do Departamento Estadual de Estradas de Rodagem) e ainda junto aos cemitérios, é obrigatória a abertura de vias públicas nos lados, com largura não inferior a $14 \mathrm{~m}$ (catorze metros), exceto quando se tratar de topografia que não o permita, a critério da Prefeitura.

Artigo 36 - Junto as linhas de transmissão de energia elétrica, é obrigatória a abertura de vias públicas em um dos lados, com largura não inferior a $14 \mathrm{~m}$ (catorze metros), exceto quando se tratar de topografia que não o permita, a critério da Prefeitura.

Artigo 37 - As áreas destinadas ao cruzamento de rodovias e passagens de nível sôbre leito de estradas de ferro, exigidas pela Prefeitura, serão 
consideradas como vias de comunicação.

Artigo 38 - Nos arruamentos de terrenos marginais a cursos d'água, será exigida uma faixa longitudinal no sentido do curso d'água, a saber:

I - Nas margens do Rio Sorocaba, $30 \mathrm{~m}$ (trinta metros) de cada lado, a partir da margem do rio retificado;

II- nos demais rios e córregos, $15 \mathrm{~m}$ (quinze metros) de cada lado, a partir da margem do rio ou córrego retificado. (...)

B) Na Zona Rural

Artigo 46 - Os caminhos deverão ter largura não inferior a $14 \mathrm{~m}$ (catorze metros) (v. art. 29, letra e).

Artigo 47 - As declividades dos caminhos oscilarão entre $0,5 \%$ e $12 \%$ (meio e doze por cento), assegurado o escoamento superficial das águas pluviais e a continuidade das águas correntes nas depressões e fundos de vales, por meio de obras convenientes e necessárias.

Artigo 48 - As construções deverão manter um recuo mínimo de $10 \mathrm{~m}$ (dez metros) da margem dos caminhos." (CMS, 1966)

\section{Partes das leis consultadas: Leis Campolim}

\section{Lei no. 1438/1966, de 21-novembro-1966 - Lei do Plano Diretor de Sorocaba, SP}

"VI - Zona residencial 3 - Z.R.3:

Zoneamento de uso - Na Z.R.3 são permitidos os seguintes usos:

1 - Residências individuais e coletivas;

2 - Estabelecimentos de ensino;

3 - Bibliotecas e museus;

4 - Edifícios públicos;

5 - Templos;

6 - Associações esportivas e culturais, clubes;

7 - Comércio a varejo;

8 - Mercados e super-mercados;

9 - Casas de espetáculos e diversões;

10 - Escritórios;

11 - Estabelecimentos Bancários e Financeiros;

12 - Cafés, bares, restaurantes e congêneres;

13 - Hotéis;

14 - Laboratórios de análises;

15 - Imprensa, editoras e instalações de rádio difusão e televisão;

16 - Lavanderias;

17 - Ambulatórios;

18 - Postos de serviços;

19 - Pequenas indústrias não incômodas, nocivas, ou perigosas;

20 - Garagens em geral;

21 - Depósitos em geral destinados a armazenagem de produtos não inflamáveis ou explosivos ou ainda, que possam provocar emanações nocivas;

22 - Padarias e confeitarias;

23 - Oficinas.

Zoneamento de índices de aproveitamento, índices de ocupação e alturas - Para a

Z.R.3 deverá ser redigida lei de teor semelhante à Lei 1147 de 1.10.63, com algumas alterações as quais terão as seguintes redações:

Artigo $1^{\circ}$ - Mantidas no que não contrariem a presente lei, as atuais exigências e restrições do Código de Obras e das Legislação complementar vigente, na zona residencial 3 (Z.R.3) aqui descrita, os edifícios de habitação coletiva (apartamentos), prédios comerciais (escritórios), edifícios mistos (uso comercial e apartamento) bem como aquêles destinados a hotel deverão obedecer às seguintes restrições:

0 coeficiente de aproveitamento do lote não poderá ser superior a:

2 (dois) para habitação coletiva e hotéis;

2 (dois) para prédios comerciais.

O coeficiente de ocupação do lote não poderá ser superior a: 
0,5 para habitação coletiva, edifícios mistos e hotéis;

0,5 para prédios comerciais;

loja e sobreloja de prédios comerciais e edifícios mistos poderão apresentar ocupação máxima de $70 \%$ (setenta pôr cento).

Parágrafo único - A zona residencial 3 (Z.R.3) dividida em dois setores e referidas neste artigo fica assim delimitada:

(...) $3^{\circ}$ Setor - Começa no cruzamento do Córrego Taguaraguai com a Rodovia Raposo Tavares, desce pelo referido córrego, cruza a estrada de rodagem SorocabaItu prosseguindo até aproximadamente $800 \mathrm{~m}$ onde, deflete à esquerda através de seu afluente. Sobe pôr êste até a estrada da Ronda Grande, seguindo pôr esta até a estrada de rodagem Sorocaba-Itu. Segue pôr esta até a confluência com a estrada do distrito de Aparecida, ligando-se daí em linha reta de aproximadamente $1.000 \mathrm{~m}$ à Rodovia Raposo Tavares. Segue pôr esta até o cruzamento com o córrego Taguaraguai, ponto de partida." (CMS, 1966)

\section{(...) "TAMANHOS MÍNIMOS DE LOTES PARA AS ÁREAS RURAL E URBANA:}

Lote rural $-2.000 \mathrm{~m}^{2}$ (dois mil metros quadrados).

Lote urbano - $250 \mathrm{~m}^{2}$ (duzentos e cinqüenta metros quadrados).

Os lotes não poderão ser subdivididos. As demais exigências sôbre loteamento, continuarão a obedecer o disposto na lei n. 1.561-A (Código Sanitário do Estado de São Paulo), e outros dispositivos legais federais, estaduais e municipais, existentes ou que venham regular o assunto no futuro. As zonas só poderão ser utilizadas para o fim a que se destinam de acôrdo com êste relatório. (...)

A estruturação viária regional, compreendendo a estrada do Oeste66, que atravessa boa parte do território municipal, o acesso, o nôvo ramal de E.F.S. de ligação Sorocaba-Itu já locado, o Ramal de Brigadeiro Tobias, em locação, a nova estrada de Pôrto Feliz, e a perimetral rodoviária, se realizada integralmente proporcionará excelentes condições de integração das áreas de vocação industrial, dadas as ótimas características físicas e topográficas do terreno. (...)

O Plano Diretor prevê para a implantação industrial na região de Sorocaba, uma faixa ao longo das rodovias e ferrovias programadas de aproximadamente $1 \mathrm{k}$ e $500 \mathrm{~m}$ respectivamente para cada lado. (...) (CMS, 1966)

"Para fins tributários o território do Município está dividido em zona urbana e zona rural, porém para fins urbanísticos se torna necessário considerar uma terceira zona, intermediária, denominada área de expansão urbana. A área de expansão urbana se destina a receber as novas edificações fora do perímetro urbano, mas resultantes do crescimento normal e previsto na cidade ou vila. Daí porque êste trabalho, embora reconhecendo tratar-se de edificações de zona rural, sujeita-se às exigências urbanísticas da zona urbana, uma vez que irão integrar de futuro a área urbanizada.

Para o caso dos loteamentos, cuja gleba situa-se na zona rural e cuja testada faça frente para os alinhamentos da via perimetral externa, configurada no Plano Diretor (quando esta perimetral funciona como linha limítrofe entre as zonas urbana e rural) aplicam-se as restrições relativas à zona urbana até a profundidade de $150 \mathrm{~m}$ (cento e cinquenta metros) entendendo-se essa profundidade como uma faixa paralela à perimetral." (CMS, 1966)

20. Lei 1541/1968, o trecho estudado tinha o zoneamento de Zona Agrícola (ZA):

"XIl-Zona Agrícola - prefixo Z.A. (...)

Artigo 53 - A Zona Agrícola (Z.A.) terá seu uso do solo determinado pelas seguintes atividades:

1- Agricultura

2- Pecuária

3- Florestamento

4- Pontos de atração turística e de recreio

${ }^{66}$ N.A. Futura Rod. Castelo Branco (SP 280) inaugurada em 1967. 
5- Patrimonial (próprios públicos)

6- Industrial

Artigo 54 - A atividade industrial de que trata o ítem 6 do artigo anterior só poderá estabelecer-se na referida zona mediante apreciação e deliberação prévia por parte do órgão municipal encarregado do Planejamento.

Artigo 55 - Ser permitida, na Zona Agrícola a formação de aglomerações satélites, dotadas de todos os melhoramentos, característicos da Zona Urbana, inclusive Centros Cívicos e Culturais.

Parágrafo único - Para o caso de aglomeração satélite, os interessados ficarão sujeitos a apreciação e deliberação prévia por parte do órgão municipal encarregado do Planejamento.

Artigo 56 - As edificações na Zona Agrícola, inclusive nas aglomerações satélites existentes ou a serem formadas, deverão obedecer totalmente o Código de Obras do Município.

Artigo 57 - As edificações na Zona Agrícola (Z.A.) deverão obedecer um recúo mínimo de frente de $15 \mathrm{~m}$.

Artigo 58 - Fora do perímetro urbano - zona para industrias rurais, serão instaladas as indústrias que apresentam os seguintes problemas:

a- sanitário, segurança, periculosidade, poluição e outros e que não podem ser solucionados por meio de obras ou outros recursos técnicos:

1 - oferecem possibilidade de incêndios

2 - oferecem possibilidade de explosão ou utilizam explosivos;

3 - produzem ruídos

4 - produzem trepidações

5 - produzem fuligem

6 - produzem fumaça

7 - produzem clarão e ofuscamento

8 - produzem calor

9 - produzem radioatividade do ar ou solo

10- produzem odôres fétidos

11- apresentam problemas de poeiras

12- apresentam problemas de insetos

13- lançam resíduos industriais poluídos ou deteriorados

14- determinam outros problemas de ordem sanitária à população da cidade e da região.

b- indústrias extrativas

c- indústrias que necessitam ser instaladas junto aos locais de extração da matéria prima;

d- dispõe de recursos próprios para a completa e perfeita instalação, inclusive residências para o seu pessoal técnico e operário.

e- indústrias cuja instalação é por tempo determinado (indústrias de construção civil).

Parágrafo único - Baseado neste artigo, as indústrias rurais classificam-se nos seguintes tipos:

Número de Ordem DESIGNAÇÕES Classificação I.B.G.E.

1 - Indústrias extrativas de produtos minerais metálicos

2 - Indústrias extrativas de produtos minerais não metálicos

3 - Indústrias de pedras e outros materiais de construção

4 - Indústrias extrativas de combustíveis minerais

5 - Exploração de fontes hidro-minerais 00.5

6 - Indústrias Extrats. e de maceração de plantas fibrosas ............ 01.2

7 - Indústrias extrats. de madeira, lenha, bambús e produtos afins .... 01.1

8 - Indústrias extrats. de sementes oleaginosas 01.4

9 - Indústrias extrats. de borracha, gomas, resinas, cêras e substancias tonantes e tintoriais 01.5

10- Ind. Extrats. de beneficiamento de prod. alimentícios, medicinais e tóxicos 01.6

11- Britamento de pedras e tratamento de saibros e areias para

construção, associados à extração . 10.11

12- Britamento de pedras e tratamento de saibros e areias para construção, não associados à extração 
13- Aparelhamento de pedras e execução de obras de cataria associados à extração 10.13

14- Produção de cal, associada à extração de calcáreo 10.21

15- Produção de cal, não associada à extração de calcáreo

16- Fabricação de tijolos e telhas associada à extração de argilas ... 10.31

17- Produção de cimento 10.51

18- Produção de talco 10.91

19- Produção de gêsso 10.92

20- Imunização de madeira (tratamento destinado a preservar madeiras de deterioração causada por insetos ou umidade) 15.81

21- Preparação de pasta de madeira, fibras ou outros materiais para fabricação de papel e papelão 17.11

22- Secagem, salga e outras preparações de couro e peles 19.01

23- Fabricação de pólvoras, explosivos e detonantes (pólvora negra e sem fumaça, espoletas, estopins, dinamite e fulminantes e semelhantes) 20.21

24- Fabricação de fogos de artificio 20.28

25- Destilação e refinação de petróleo e folhetos betuminosos ........ 20.81

26- Fabricação de adubos e carvão animal 20.91

27- Beneficiamento e moagem de café, mate, cereais e produtos afins e fabricação de farinhas 23

28- Preparação em conserva de frutas, legumes especiarias e condimentos vegetais 23.1

29- Abate de rezes e preparação de carnes para terceiros (Matadouros municipais e particulares que efetuam 0 abate por conta de terceiros) .23.21

30- Abate de rezes em matadouros frigoríficos e preparação, inclusive sub-produtos ....................................... 23.22

31- Abate de rezes em charqueadas e preparação de carnes sêcas e salgadas, inclusive sub-produtos 23.23

32- Abate de suínos e preparação de carne, toucinho, banha,

lingüiças e demais produtos de origem suínas .....

33- Fabricação de banha (não processada em matadouros) 23.26

34- Abate e preparação de carne de aves e de pequenos animais ....... 23.28

35- Pasteurização de leite e fabricação de lacticínios 23,40

36- Fabricação de açúcar de usina (inclusive sub-produtos de cana de açúcar 23.51

37- Fabricação de açúcar instantâneo e de rapadura (inclusive elado).23.53

38- Beneficiamento e purificação de mel de abelha pela centrifugação..23.92

39- Fabricação de aguardente (por processamento de cana de açúcar)....24.31

40- Preparação de fumo (secagem, defumação e outras preparações de fumo em fôlha, rôlo ou corda) 25.01

41- Construção Civil, de duração limitada 30.

42- Serviços Industriais de utilidade pública (energia elétrica, gás de iluminação, águas e esgôtos) 40. (...)

Art. 70 - Pelas infrações das disposições dêste Código, sem prejuízo de outras providências, serão aplicadas as seguintes multas: ao proprietário e ao profissional responsável, simultaneamente:

Parágrafo único - As multas só serão aplicadas após decorridos seis (6) dias úteis contados do recebimento do embargo emitido pela fiscalização, e quando o proprietário ou profissional responsável não tenham período legalizado as infrações dêste Código.

I - Por deixar de cumprir as exigências relativas à índice de ocupação, índice de aproveitamento, afastamentos, recuos, zoneamento de uso, a altura, a localização no lote e a concordância de níveis.

a) Zona Rural..........1/5 do salário mínimo vigente na região. (...)" (CMS, 1968)

21. "Lei dos Corredores Comerciais" (Lei Municipal n 4.874/95) (SANTORO, 2009):

"Por outro lado, a área urbana de Sorocaba aumentou consideravelmente nos últimos 23 anos (entre 1988 e 2011), passando de 4.798,8 ha em 1988 para 
12.928,8 ha em 2011 (...). Isso significa que atualmente a área urbana atual de Sorocaba equivale a aproximadamente $29 \%$ da área total do município. É importante destacar que Sorocaba tem uma taxa de crescimento populacional anual de 1,75\%. Esse índice é maior que a média do Estado que é de 1,09\% (Seade, 2012). Ainda, segundo a Secretaria do Meio Ambiente de Sorocaba (2010), em 1988 a população era de 344.261 habitantes e atualmente possui 596.060 habitantes." (PDTUM, 2014)

22. Lei $n^{0} 7.122$ de 01/06/2004, Lei do Plano Diretor do Município de Sorocaba, SP

Art. $2^{\circ}$ - As principais funções sociais do ordenamento do desenvolvimento urbano de Sorocaba são:

I - Viabilizar a oferta de infra-estrutura e equipamentos coletivos à sua população e aos agentes econômicos instalados e atuantes no Município;

II - Criar condições adequadas à instalação de novos empreendimentos econômicos, garantindo o desenvolvimento do Município enquanto pólo regional de comércio, serviços e produção industrial;

III - Garantir a qualidade ambiental e paisagística, protegendo os recursos naturais. (...) (CMS, 2004)

"CAPITULO II: EXIGÊNCIAS FUNDAMENTAIS DE ORDENAÇÃO DO SOLO,

SEÇÃO I: MACROZONEAMENTO AMBIENTAL

Art. $6^{\circ}$ - Visando o desenvolvimento sustentável de Sorocaba, no território do Município são instituídas três categorias de macrozonas, a saber:

I - Macrozona com Grandes Restrições à Urbanização,

II - Macrozona com Restrições Moderadas à Urbanização; e

III - Macrozona com Pequenas Restrições à Urbanização. (...)

Art. $8^{\circ}$ - São incluídas na categoria "Macrozona com Grandes Restrições à Urbanização":

I - Várzeas ou Planícies Aluviais, marcadas por processos de enchentes sazonais, cujas regras de ocupação devem obedecer às diretrizes que seguem: a) Nos terrenos ainda desocupados a instalação de atividades deve ser restrita a usos compatíveis com baixíssimas taxas de ocupação e impermeabilização e que não impliquem assentamento permanente de, nem tráfego intenso e permanente de veículos, tais como parques, clubes de campo e congêneres; b) Os terrenos que já se apresentam irreversivelmente urbanizados deverão ser contemplados em estudos e projetos específicos de reurbanização, com o objetivo de minimizar a situação de riscos, bem como prejuízos decorrentes das inundações periódicas a que se encontram sujeitos.

II - Áreas de Proteção a Mananciais Tipo 1, que correspondem a bacias que contribuem para captações de água existentes, e Tipo 2 que correspondem à porção da bacia do rio Pirajibu a montante da bacia do Pirajibu-Mirim, considerada de interesse estratégico para futura utilização como manancial de captação de água para Sorocaba, cujas regras de ocupação devem obedecer às seguintes diretrizes: a) Garantir uma densidade de ocupação baixa para a zona como um todo, de modo a limitar a geração de poluição difusa; b) Condicionar a urbanização ao adequado equacionamento da coleta e disposição dos esgotos, através de tratamento individual em caso dos terrenos maiores que $1.000 \mathrm{~m} 2$, ou de sistemas coletivos que exportem os efluentes para fora da bacia de captação, ou cujos efluentes sofram tratamento de nível adequado para o respectivo lançamento nos corpos d'água da bacia sem prejuízo da qualidade da água captada.

Parágrafo Único - Nas Áreas de Proteção a Mananciais, nos compartimentos Tipo "1a" e "2a", que são mais suscetíveis à erosão superficial quando sob processos de urbanização, as regras de ocupação deverão obedecer às seguintes diretrizes: I - Restringir drasticamente a ocupação das várzeas; II Exigir nos empreendimentos urbanos a reserva de espaços para futura construção de reservatórios de contenção; III - Exigir a adoção de medidas de 
prevenção da erosão, tais como recobrimento vegetal de taludes e minimização de terraplanagens. (...)(CMS, 2004)

"Art. 14 - A Área Rural é destinada predominantemente a atividades econômicas não urbanas.

Parágrafo Único - Na Área Rural, admitir-se-ão imóveis e parcelamentos do solo destinados a atividades rurais, bem como estabelecimentos isolados e equipamentos urbanos cuja localização em áreas densamente povoadas seria inadequada. (...)

Art. 15 - Para efeito da ordenação de parcelamento, uso e ocupação do solo, a Área Urbana e de Expansão Urbana do Município de Sorocaba é subdividida em zonas de uso, a saber: (...)

VIII - Zona de Chácaras Urbanas - ZCH;

IX - Zona de Conservação Ambiental - ZCA; (...)

Parágrafo Único - A configuração das zonas mencionadas no "caput" deste artigo está indicada no mapa 02, "Zoneamento Municipal", que é parte integrante desta lei. (...)

Art. 21 - Nas Zonas de Chácaras Urbanas - ZCH, que compreende áreas localizadas nos limites da área urbanizável, sem previsão de atendimento por rede pública de esgotos sendo parte contida a Norte e Noroeste do território municipal, e outra parte contida nas bacias dos córregos Pirajibú-Mirim, Ipanema e Ipaneminha, principais mananciais internos ao Município, as normas de parcelamento, uso e ocupação do solo devem:

I - Limitar a variedade de usos permitidos nos terrenos, bem como a intensidade e extensão da respectiva ocupação, de forma a minimizar os riscos de poluição dos mananciais em cujas bacias estão inseridas;

II - Estimular a formação e manutenção de amplas áreas ajardinadas e arborização intensa, garantindo altas taxas de permeabilidade dos terrenos; III - Exigir que os loteamentos residenciais e demais empreendimentos tenham sistema próprio de coleta e tratamento de esgotos, independente do sistema público. (...)

Art. 24 - As Zonas de Conservação Ambiental - ZCA, são destinadas à implantação exclusiva de usos que garantam a ampla manutenção de superfícies permeáveis recobertas por vegetação tais como parques públicos, sendo admitidos empreendimentos privados semelhantes, tais como clubes recreativos e usos residenciais com baixíssimos índices de ocupação, desde que preservem, em caráter permanente, 0 atributo protegido.

Parágrafo Único - Em Zonas de Conservação Ambiental - ZCA é proibido qualquer loteamento do solo para fins urbanos. (...) (PMS, PD 2004)

"TÍTULO II - ZONEAMENTO, USO, OCUPAÇÃO E PARCELAMENTO DO SOLO CAPÍTULO III - OCUPAÇÃO DOS TERRENOS URBANOS

SEÇÃO PARÂMETROS DE OCUPAÇÃO POR ZONA (...)

III - Nas zonas de uso ZI, ZAE e na Área Rural:

a) Recuo mínimo de frente: $10,00 \mathrm{~m}$, em todos os pavimentos;

b) Recuos mínimos laterais e de fundos: $5,00 \mathrm{~m}$, em todos os pavimentos.

$\S 1^{\circ}$ - No caso de utilização de recuos laterais e de fundo em edificações térreas, adotar-se-ão os valores mínimos estabelecidos no Código Sanitário Estadual;

$\S 2^{\circ}$ - Para as glebas e lotes situados em zonas limítrofes às ZI e ZAE, será obrigatório, apenas junto à divisa de Zona, um recuo de $25,00 \mathrm{~m}$, exclusivamente arborizado.

$\S 3^{\circ}$ - Essa mesma regra de recuos se aplica aos lotes e glebas situados nos limites das Zl e ZAE, lindeiras a outras zonas de uso.

$\S 4^{0}$ - Os recuos mínimos previstos no inciso I, alínea "a", não serão aplicados nas testadas de quadras com mais de $50 \%$ (cinqüenta por cento) já construídos, ou em construção, permanecendo os recuos existentes.

$\S 5^{\circ}$ - Para imóveis com testada igual ou inferior a $7,00 \mathrm{~m}$, fica permitida a instalação de abrigos desmontáveis com largura máxima de $50 \%$ (cinqüenta por cento) da testada do lote, desde que a área remanescente descoberta seja permeável. 
Art. 85 - Para imóveis urbanos limitados ou atravessados por cursos d'água, resultantes de parcelamentos do solo aprovados anteriormente à 1.979, será considerada "non aedificandi" uma faixa com largura de 15,00 metros de cada lado. (...)

\section{CAPÍTULO IV - PARCELAMENTO DO SOLO}

Art. 89 - Nenhum parcelamento do solo para fins urbanos será permitido em terrenos que apresentem uma ou mais das seguintes condições: I - Seja coberto em sua totalidade por vegetação protegida pelo disposto na legislação Federal, Estadual ou Municipal; II - Seja alagadiço;

III - Apresente condições insalubres;

IV - Apresente condições de risco geológico.

Art. 90 - Qualquer gleba objeto de parcelamento para fins urbanos deve ter acesso por via oficial de circulação. SEÇÃO II - LOTEAMENTOS URBANOS E DESMEMBRAMENTOS Art. 91 - Nos loteamentos residenciais, comerciais e industriais, seja qual for a zona de uso em que estiverem localizados, parte da área total da gleba a ser loteada deve ser transferida ao patrimônio público do Município, com a seguinte discriminação: I - $12 \%$ (doze por cento), no mínimo, para espaços livres de uso público;

II - $5 \%$ (cinco por cento), no mínimo, para uso institucional, destinada a equipamentos comunitários, exceto para os loteamentos industriais;

III - Para o sistema viário, a área resultante do traçado e dimensões das vias projetadas, atendendo às diretrizes expedidas pela Prefeitura Municipal de Sorocaba; IV - Faixas de proteção ao longo de corpos d'água, desde o seu nível mais alto em faixa marginal, que poderão ser computadas como espaços livres de uso público, com largura mínima de cada lado de:

a) 60,00 metros, do Rio Sorocaba;

b) 60,00 metros dos córregos Ipaneminha, Ipanema, Pirajibú Mirim e Itanguá;

c) 30,00 metros dos demais córregos;

d) 30,00 metros no entorno das várzeas; banhados; lagos e lagoas.

e) 50,00 metros no entorno das nascentes, (...)

Art. 92 - Nos desmembramentos, quando a gleba a ser desmembrada tiver área superior a $10.000 \mathrm{~m} 2$, deve ser transferida ao patrimônio público do Município uma área correspondente a $12 \%$ (doze por cento), no mínimo, da respectiva área total, a qual será destinada a espaços livres de uso público ou uso institucional. Art. 93 - A área transferida ao patrimônio público do Município, deve ter frente para logradouro público e as exigências quanto à sua conformação e dimensões de sua testada serão estabelecidos pela Prefeitura Municipal de Sorocaba quando da emissão das diretrizes para o desmembramento.

Art. 94 - Nos loteamentos localizados nas bacias dos córregos Ipaneminha, Ipanema, Pirajibu, Pirajibu-Mirim, Itanguá, Matadouro, Lavapés e Água Vermelha, deverá ser exigida, após estudos e se necessário, a doação de área para 0 patrimônio público do Município visando a execução de dispositivos de retenção de águas pluviais no sistema de drenagem do loteamento, que poderão estar localizados nas faixas de proteção a corpos d'água.

Parágrafo Único - A exigência das obras e os parâmetros para a sua execução serão estabelecidos pela Prefeitura Municipal de Sorocaba quando da emissão das diretrizes para o parcelamento.

Art. 100 - Na Área Rural, qualquer parcelamento do solo deverá observar o módulo mínimo rural, definido pelo INCRA.

Art. 101 - Novos loteamentos, residenciais, comerciais e industriais poderão constituir setores fechados ao tráfego geral, com controle de entrada e saída de veículos e pessoas, desde que:

I - Sejam objeto de Estudo de Impacto sobre a Vizinhança - EIV;

II - Tenham a malha viária interna ao setor com acesso controlado composta exclusivamente por vias locais;

III - Mantenham todos os terrenos destinados a uso institucional com acesso por via oficial de circulação sem qualquer tipo de controle;

IV - Seja constituída pessoa jurídica que assuma legalmente a responsabilidade pela manutenção e operação das vias e dos equipamentos e serviços coletivos no interior do setor com acesso controlado. 
V - Atendam as diretrizes emitidas pela Prefeitura Municipal de Sorocaba, as quais deverão:

a) Limitar as dimensões da área controlada, de modo a garantir a livre circulação no interior da área urbana;

b) Exigir, quando considerado necessário, a manutenção de lotes externos ao setor com acesso controlado, de modo a viabilizar a instalação de comércio, serviços e outros equipamentos;

Art. 102 - Para loteamentos residenciais, comerciais e industriais já implantados e não constituídos como setores fechados, o pedido de implantação de controle de entrada e saída de veículos e pessoas deverá ser apresentado à Prefeitura Municipal de Sorocaba acompanhado de projeto técnico, estando sua aprovação condicionada ao atendimento de todos os requisitos previstos no artigo anterior, sem exclusão do Estudo de Impacto de Vizinhança -EIV.

\section{CAPÍTULO V - EDIFICAÇÕES EM GLEBAS}

Art. 103 - Os projetos de empreendimentos que impliquem a implantação de uma ou mais edificações em gleba, em regime de condomínio ou de propriedade indivisa, deverão ser apresentados à Prefeitura Municipal de Sorocaba, na fase de estudo preliminar, para pedido de diretrizes. Art. 104 - Nenhum conjunto de edificações poderá ser construído em glebas que apresentem uma ou mais das seguintes condições:

I - Seja coberto em sua totalidade por vegetação protegida pelo disposto na legislação Federal, Estadual ou Municipal;

II - Seja alagadiço e apresente condições insalubres;

III - Apresente condições de risco geológico.

Art. 105 - Em qualquer empreendimento que implique a implantação de uma ou mais edificações em gleba, em regime de condomínio ou de propriedade indivisa, o Coeficiente de Aproveitamento - (CA) máximo, a Taxa de Ocupação (TO) máxima, vigentes na zona de uso em que se situa o empreendimento, deverão ser corrigidos através de multiplicação pelo fator 0,65 e a Taxa de Permeabilidade mínima será de $25 \%$ (vinte cinco por cento).

Art. 106 - A licença para edificar em gleba com área de $5.000,00 \mathrm{~m} 2$ a $30.000,00$ $\mathrm{m} 2$, uma ou mais edificações em regime de condomínio ou de propriedade indivisa é condicionada à reserva de $12 \%$ (doze por cento) no mínimo, no interior de sua área total, de espaço destinado exclusivamente ao lazer.

Art. 107 - A licença para edificar em gleba, com área superior a $30.000,00 \mathrm{~m} 2$, uma ou mais edificações em regime de condomínio ou de propriedade indivisa, é condicionada à reserva de $12 \%$ (doze por cento), no mínimo no interior de sua área total, de espaço destinado exclusivamente ao lazer, acrescida da transferência ao patrimônio público o município, de $5 \%$ (cinco por cento) no mínimo, de sua área total com frente para logradouro público, destinada à implantação de equipamentos públicos.

\section{“(...) SEÇÃO II - OPERAÇÕES URBANAS CONSORCIADAS}

Art. 32 - A Prefeitura Municipal de Sorocaba poderá instituir e regulamentar, através de lei municipal específica, Operações Urbanas Consorciadas, delimitando as áreas a elas destinadas no interior da Área Urbana.

Parágrafo Único - As Operações Urbanas Consorciadas contarão com a participação de proprietários, moradores, usuários e investidores privados, sendo coordenadas pela Prefeitura Municipal de Sorocaba.

Art. 33 - As Operações Urbanas Consorciadas poderão ser propostas com as seguintes finalidades: I - Intervenção urbanística para melhorias de setores urbanos, podendo abranger, entre outros, programas voltados para espaços de uso público e outros elementos da paisagem urbana, sistemas de transporte público e individual e de circulação de pedestres imóveis de interesse cultural e empreendimentos ou concentrações de empreendimentos - privados, comunitários ou governamentais considerados de interesse público;

II - Proteção de recursos naturais e paisagísticos, tais como matas e outras formas de vegetação significativa, formações especiais do relevo e corpos d'água; 
III - Criação de áreas verdes públicas e unidades de conservação, prioritariamente em áreas de interesse ambiental, tais como Zonas de Conservação Ambiental;

IV - Proteção de imóveis e áreas de interesse cultural, com ações voltadas para a preservação da sua integridade, a adequação do seu entorno e seu melhor aproveitamento social;

V - Regularização de construções e assentamentos existentes em desacordo com a

legislação.

Art. 34 - As Operações Urbanas Consorciadas poderão estabelecer a modificação de índices e normas de parcelamento, uso e ocupação, bem como alterações nas normas edilícias, devidamente avaliadas e considerados os seus impactos ambientais e sobre a vizinhança. Art. 35 - Para orientar e disciplinar cada operação urbana a Prefeitura Municipal de Sorocaba elaborará um plano, que será parte integrante da lei municipal específica, cujo escopo deverá abranger, no mínimo:

I - A exposição dos objetivos a serem alcançados;

II - A delimitação com descrição precisa da área e/ou perímetro objeto da operação;

III - O programa básico de ocupação da área;

IV - Os índices urbanísticos e características de uso e parcelamento do solo estabelecidos especificamente para a área, bem como as condições para sua adoção;

V - As condições para a aplicação da outorga onerosa e/ou da transferência do direito de construir, especialmente no que se refere às contrapartidas;

$\mathrm{VI}$ - A equação financeira da operação, com o estabelecimento dos direitos e obrigações de cada interveniente;

VII - O Estudo de Impacto de Vizinhança da operação urbana, elaborado e analisado na forma definida nesta lei;

VIII - programa de atendimento econômico e social para a população diretamente afetada pela operação;

IX - forma de controle da operação, obrigatoriamente compartilhada com representantes da sociedade civil.

Art. 36 - Ficam definidas como passíveis para Operação Urbana as seguintes áreas: (..) SEÇÃO IV - TRANSFERÊNCIA DO DIREITO DE CONSTRUIR

Art. 38 - A Prefeitura Municipal de Sorocaba poderá, tanto no âmbito dos diferentes tipos de Operações Urbanas Consorciadas previstas nesta lei quanto para fins de preservação dos imóveis tombados pelo Conselho Municipal do Patrimônio Histórico, autorizar o proprietário de imóveis urbanos, situados no interior do perímetro da operação urbana ou tombados, a exercer em outro local, ou alienar mediante escritura pública, integral ou parcialmente, o direito de construir previsto no presente Plano Diretor e na legislação urbanística municipal decorrente. $\S 1^{\circ}-0$ potencial construtivo conferido por lei poderá ser transferido, integral ou parcialmente, para imóveis situados nas zonas urbanas ZC, ZPI, ZR2, ZR3, CCS2, $\mathrm{CCl}$ e CCR, desde que o acréscimo no limite do coeficiente de aproveitamento não supere aos $50 \%$ (cinquenta por cento) do estabelecido e mantendo-se os demais índices urbanísticos e regras de ocupação vigentes, em particular as condições de infra-estrutura do local.

$\S 2^{\circ}$ - Para origem da transferência será dada prioridade a imóveis de valor cultural ou paisagístico e para aqueles localizados em Zona de Conservação Ambiental - ZCA.

SEÇÃO V - ÁREAS DE ESPECIAL INTERESSE SOCIAL PARA HABITAÇÃO

Art. 39 - A Prefeitura Municipal de Sorocaba, nas Áreas Urbanas e de Expansão Urbana, poderá instituir e delimitar, através de lei municipal específica, Áreas de Especial Interesse Social para Habitação, com os seguintes objetivos: I - Promover a regularização fundiária em assentamentos irregulares nos termos da Legislação Federal pertinente;

II - Promover a execução de habitações de baixo custo.

Art. 40 - As propostas de Área de Especial Interesse Social para Habitação serão encaminhadas, analisadas e desenvolvidas pela Prefeitura Municipal de Sorocaba, assessorada consultivamente pelos Conselhos Municipais afins. 
Art. 41 - Para os imóveis situados em Área de Especial Interesse Social para Habitação, a lei poderá prever normas específicas referentes a parcelamento, uso e ocupação do solo e edificações, bem como procedimentos de regularização de construções existentes.

SEÇÃO VII - DIREITO DE PREEMPÇÃO

Art. 48 - Através de lei municipal específica, o Município poderá delimitar áreas, em qualquer local do território municipal, no interior das quais a Prefeitura Municipal de Sorocaba terá preferência para aquisição de imóveis objeto de alienação onerosa entre particulares, por um prazo de até cinco anos, renovável na forma da lei federal n. ${ }^{0} 10.257$ de 10 de Julho de 2.001 e suas eventuais alterações.

Parágrafo Único - 0 direito de preempção poderá ser exercido para fins de regularização fundiária, execução de programas habitacionais de interesse social, implantação de equipamentos urbanos e comunitários, criação de espaços públicos de recreação e lazer, bem como criação de unidades de conservação ambiental e proteção a áreas de interesse cultural ou paisagístico, devendo 0 motivo ser especificado na lei que definirá os perímetros onde 0 direito será exercido.

CAPÍTULO IV - DIRETRIZES PARA PLANOS E PROJETOS SETORIAIS

SEÇÃO I - HABITAÇÃO DE INTERESSE SOCIAL

Art. 49 - A Prefeitura Municipal de Sorocaba deverá apresentar proposta de Plano Municipal de Habitação, compatível com o disposto neste Plano Diretor de Desenvolvimento Físico Territorial, em até 24 meses, contados a partir da data de publicação desta lei.

Parágrafo Único - O Plano Municipal de Habitação, basear-se-á no cadastramento das habitações irregulares, quantificadas e qualificadas segundo 0 tipo de irregularidade existente, bem como no dimensionamento das necessidades habitacionais excluídas do atendimento via mercado formal e deverá contemplar:

I - Proposição de padrões mínimos inovadores para projetos de habitação popular, contemplando empreendimentos de pequeno porte e tipologias adequadas à ocupação de vazios urbanos;

II - Proposição de programas para remoção da população instalada em áreas de risco;

III - Proposição de alternativas de participação popular em programas de regularização e provisão de habitações populares, incluindo treinamento e organização comunitária;

IV - Aparelhamento institucional que viabilize tanto gestões junto a órgãos de outras esferas de governo quanto o gerenciamento direto de projetos pela Prefeitura Municipal de Sorocaba;

V - Definição de perímetros de Áreas de Especial Interesse Social para Habitação e das condições de atuação no interior das mesmas.

SEÇÃO II - PATRIMÔNIO CULTURAL EDIFICADO E ÁREAS DE INTERESSE PAISAGÍSTICO E AMBIENTAL

Art. 50 - A Prefeitura Municipal de Sorocaba deve desenvolver avaliações detalhadas dos imóveis de interesse histórico, arquitetônico, paisagístico e ambiental existentes em Sorocaba resultando em medidas de preservação, a partir de critérios a serem estabelecidos pela Prefeitura Municipal de Sorocaba. Art. 51 - A Prefeitura Municipal de Sorocaba poderá instituir e regulamentar, através de lei municipal específica, Áreas de Especial Interesse Paisagístico e Ambiental, que delimitará seu perímetro e explicitará os atributos a serem preservados e as medidas de proteção a serem adotadas, bem como os agentes responsáveis pelas mesmas.

Art. 52 - Para áreas que incluem edificações ou conjuntos de edificações de preservação histórica ou ambientais poderão ser propostas Operações Urbanas Consorciadas, envolvendo outorga onerosa e transferência do direito de construir. Parágrafo Único - Mediante Operações Urbanas Consorciadas, os imóveis de valor cultural poderão estar sujeitos a condições especiais de uso e ocupação definidas pela Prefeitura Municipal de Sorocaba, desde que garantida a integridade do patrimônio artístico ou histórico e sua fruição por parte da população.

SEÇÃO III- ÁREAS VERDES E ESPAÇOS LIVRES PARA LAZER 
Art. 53 - A política referente a áreas verdes e espaços livres para lazer deve se pautar pelo objetivo geral, que é implantar gradualmente em Sorocaba um sistema de espaços não construídos, composto por grandes parques, praças, pequenos parques vicinais e jardins internos aos empreendimentos.

$\S 1^{0}$ - São diretrizes específicas:

I - Implantar e manter 0 ajardinamento e a arborização urbana, arregimentando a parceria da população através de programas permanentes de manutenção, educação, divulgação e orientação técnica;

II - Implantar novos parques urbanos prioritariamente nas várzeas do rio Sorocaba e de alguns de seus afluentes, em Zonas de Conservação Ambiental, de forma a:

Viabilizar a manutenção da vegetação ciliar e de outros tipos de cobertura vegetal, garantindo a permeabilidade do solo e facilidade de drenagem;

Viabilizar equipamentos de recreação e lazer ao ar livre junto aos bairros onde é previsto crescimento notável da população residente; III - Implantar parques vicinais, inseridos em novos loteamentos urbanos, nas várzeas, de forma a prevenir $\mathrm{o}$ assoreamento dos cursos d'água e conseqüente aumento de ocorrências de inundações, bem como minimizar os prejuízos das cheias;

$\S 2^{\circ}$ - Cabe à Prefeitura Municipal de Sorocaba:

I - Regulamentar e fiscalizar 0 atendimento à exigência de que nos novos loteamentos residenciais, comerciais e industriais e outras modalidades de urbanização de glebas, as áreas a serem transferidas para o Município como espaços livres de uso público tenham localização, dimensões e características topográficas que viabilizem seu efetivo uso enquanto local de lazer e prática de exercícios físicos e sejam objeto de ajardinamento e arborização.

II - Exigir que, quando marginais a cursos d'água, as áreas transferidas para o Município como espaços livres de uso público tenham dimensões adequadas à base geológica e as dimensões das sub-bacias de drenagem onde estiverem situadas, de forma a resultarem tanto mais largas quanto mais vulneráveis à erosão e às cheias forem os terrenos;

III - Exigir dos empreendedores que reservem, junto aos empreendimentos mencionados no inciso I, atendendo a diretrizes e determinações também do Serviço Autônomo de Água e Esgoto - SAAE, áreas para implantação de dispositivos de contenção de águas, bem como ajardinamento e arborização que permitam seu uso como parques públicos vicinais; (...)

CAPITULO VI - DO SISTEMA MUNICIPAL DE INFORMAÇÃO

Art. 71 - 0 Executivo manterá atualizado, permanentemente, o sistema municipal de informações sociais, culturais, econômicas, financeiras, patrimoniais, administrativas, físico-territoriais, inclusive cartográficas e geológicas, ambientais, imobiliárias e outras de relevante interesse para o município, progressivamente geo-referenciadas em meio digital. $\S 1^{\circ}$ - Deve ser assegurada ampla e periódica divulgação dos dados do sistema municipal de informação, por meio de publicação anual na Imprensa Oficial do Município, disponibilizada na página eletrônica da Prefeitura Municipal de Sorocaba, na rede mundial de computadores, internet, bem como seu acesso aos munícipes, por todos os meios possíveis. (...)" (CMS, 2004)

23. ódigo Florestal pela Lei federal $n^{\circ} 4.771$, de 15 de setembro de 1965 :

"Art. $1^{\circ} \S 2^{\circ}$ Para os efeitos deste código, entende-se por:

II - Área de Preservação Permanente: Área protegida por Lei, coberta ou não por vegetação nativa, com a função ambiental de preservar: os recursos hídricos, a paisagem, a estabilidade geológica, a biodiversidade, o fluxo gênico de fauna e flora, proteger $\mathrm{o}$ solo e assegurar o bem estar das populações humanas. (...) Art. $2^{\circ}$.

a) ao longo dos rios ou de qualquer curso d'água desde o seu nível mais alto em faixa marginal cuja largura mínima seja:

1) de 30 (trinta) metros para os cursos d'água de menos de 10 (dez) metros de largura;

2) de 50 (cinqüenta) metros para os cursos d'água que tenham de 10 (dez) a 50 (cinqüenta) metros de largura; 
3) de 100 (cem) metros para os cursos d'água que tenham de 50 (cinqüenta) a 200 (duzentos) metros de largura;

4) de 200 (duzentos) metros para os cursos d'água que tenham de 200 (duzentos) a 600 (seiscentos) metros de largura;

5) de 500 (quinhentos) metros para os cursos d'água que tenham largura superior a 600 (seiscentos) metros;(...)

c) nas nascentes, ainda que intermitentes e nos chamados "olhos d'água", qualquer que seja a sua situação topográfica, num raio mínimo de 50 (cinquenta) metros de largura;(..)

Parágrafo único. No caso de áreas urbanas, assim entendidas as compreendidas nos perímetros urbanos definidos por lei municipal, e nas regiões metropolitanas e aglomerações urbanas, em todo o território abrangido, observar-se-á o disposto nos respectivos planos diretores e leis de uso do solo, respeitados os princípios e limites a que se refere este artigo." (BRASIL, 1965)

28. lei $n^{0} 7.803$, de 18 de julho de 1989 :

"Art. 22. A União, diretamente, através do órgão executivo específico, ou em convênio com os Estados e Municípios, fiscalizará a aplicação das normas deste Código, podendo, para tanto, criar os serviços indispensáveis.

Parágrafo único. Nas áreas urbanas, a que se refere o parágrafo único do art. $2^{\circ}$. desta Lei, a fiscalização é da competência dos municípios, atuando a União supletivamente." (BRASIL, 1989)

"Art. 22. A União, diretamente, através do órgão executivo específico, ou em convênio com os Estados e Municípios, fiscalizará a aplicação das normas deste Código, podendo, para tanto, criar os serviços indispensáveis.

Parágrafo único. Nas áreas urbanas, a que se refere o parágrafo único do art. $2^{\circ}$. desta Lei, a fiscalização é da competência dos municípios, atuando a União supletivamente." (BRASIL, 1989)

29. PL178/2014, o projeto de lei da revisão do PD de 2007, (emenda):

“(...) a que impede a redução da área rural do município, que hoje é de $17,1 \%$ da área total. No sentido de preservar o meio ambiente, o vereador apresentou emenda proibindo o parcelamento do solo para finalidades urbanas em áreas de conservação ambiental".

(...) O parlamentar petista também determina que as regiões de Aparecidinha, Éden, Cajuru e Brigadeiro Tobias não se tornem Zona Residencial 3. Para a mesma região, outra emenda determina que os mapas do PL 178 só passem a dirigir 0 zoneamento da área quando a Estação de Tratamento de Esgoto ABC estiver em pleno funcionamento.

Leite também suprime 0 artigo 140 do PL 178, que garante que os projetos apenas protocolados (e ainda não aprovados) até o início da vigência da revisão do Plano Diretor, sejam apreciados com base no atual texto do Plano, já vigente.

$O$ vereador determina, ainda, que seja criado um corredor de Biodiversidade NorteSul67, integrando os fragmentos florestais da Represa de Itupararanga até a Flona de Ipanema-Iperó. Ainda na linha da preservação ambiental, Leite solicita via emenda que nas áreas lindeiras aos parques municipais com caráter ecológico e ambiental e unidades de conservação, a altura máxima dos prédios seja de 14 metros.

Finalizando, o vereador apresentou a emenda que determina que a revisão do Plano Diretor só passe a ter vigência após a apresentação e aprovação dos planos acessórios, ao menos o de Meio Ambiente, Saneamento, Mobilidade e

${ }^{67}$ (Proposta da Associação de Moradores da Zona Leste, do sr. Claudio Robles e Manoel Borges) 
Transporte Urbano, Resíduos Sólidos e Habitação de Interesse Social. (LEITE, 2014) $)^{68}$

"Art. 14 A Área Rural é destinada predominantemente a atividade econômicas não urbanas. Parágrafo Único - na Zona Rural, admitir-se-ão imóveis e parcelamentos do solo destinados a atividades rurais, bem como estabelecimentos isolados e equipamentos urbanos cuja localizção em área urbana seria inadequada." (PMS, 2014)

\section{"Art. $21 \mathrm{Nas}$ ZCH [...]:}

I - limitar a variedade de usos permitidos nos terrenos, bem como a intensidade e extensão da respectiva ocupação, de forma a minimizar os ricos de poluição dos mananciais em cujas bacias estão inseridas; II - garantir altas taxas de permeabilidade dos terrenos e de índices de áreas vegetadas; III - exigir que sejam instalados nos loteamentos e empreendimentos sistema de coleta e tratamento individual de esgotos, devidamente licenciados junto ao órgãos competentes, observadas as condições geotécnicas do terreno, quando não houver sistema público." (PMS, 2014)

"Art. 19 Nas ZR2, que inclui em sua maior parte bairros já consolidados e utilizados preferencialmente por uso residencial, as normas de parcelamento, uso e ocupação do solo devem: I - estimular o uso residencial de média densidade; II - permitir usos não residenciais, desde que causem poucos incômodos para a população residente; III - fixar índices urbanísticos que permitam a adoção de padrões variados de edificações com soluções térreas ou verticalizadas." (PMS, 2014)

"Art. 19 Nas ZR2, que inclui em sua maior parte bairros já consolidados e utilizados preferencialmente por uso residencial, as normas de parcelamento, uso e ocupação do solo devem: I - estimular o uso residencial de média densidade; II - permitir usos não residenciais, desde que causem poucos incômodos para a população residente; III - fixar índices urbanísticos que permitam a adoção de padrões variados de edificações com soluções térreas ou verticalizadas." (PMS, 2014)

30. Lei $n^{0} 11.022$, de 16 de dezembro de 2014.

Revisão do Plano Diretor de Desenvolvimento Físico Territorial do Município de Sorocaba, introduz as seguintes alterações para o trecho:

\footnotetext{
${ }^{68}$ Disponível em: http://vereadorcarlosleite.com.br/zona-rural-e-preservacao-ambiental-sao-destaquesdentre-as-36-emendas-apresentadas-por-carlos-leite/, acesso em nov/2017.
} 
SEÇÃO I

PARAMETROS DE OCUPAÇÃO POR ZONA

Art. 107. Os valores limite para os indices urbanísticos por zona são aqueles indicados no quadro a seguir:

\begin{tabular}{|c|c|c|c|}
\hline ZONAS DE USO & $\begin{array}{l}\text { To } \\
\text { Taxa de } \\
\text { Ocupação } \\
\text { Máxima }\end{array}$ & \begin{tabular}{l|}
$\mathrm{Ca}$ \\
Coeficiente de \\
aproveitamento \\
Máximo
\end{tabular} & $\begin{array}{l}\text { Pp } \\
\text { Percentual mínimo } \\
\text { de permeabilidade } \\
(\%)\end{array}$ \\
\hline Zona Central- ZC & 0,80 & \begin{tabular}{|l|l}
4,0 \\
\end{tabular} & \multirow{4}{*}{$\begin{array}{l}5 \% \text { para terrenos } \\
\text { com área de até } \\
200 \mathrm{~m} 2 \\
10 \% \text { para terrenos } \\
\text { com área entre } \\
200,01 \mathrm{~m} 2 \text { a } \\
499,9 \mathrm{~m} 2\end{array}$} \\
\hline $\begin{array}{l}\text { Zona Predominantemente Institucional - } \\
\text { ZPI }\end{array}$ & 0,60 & 2,5 & \\
\hline Zona Residencial 1 - ZR1 & 0,60 & 1,5 & \\
\hline Zona Residencial 2-ZR2 & 0,60 & 2,0 & \\
\hline Zona Residencial 3-ZR3 & 0,70 & 2,0 & \multirow{2}{*}{$\begin{array}{l}20 \% \text { para terrenos } \\
\text { com área superior a } \\
500 \mathrm{~m}^{2}\end{array}$} \\
\hline Zona Residencial 3 expandida - ZR3-e & 0,70 & 2,0 & \\
\hline Zona Industrial $1-\mathrm{ZI} 1$ & Livre & Livre & \multirow{2}{*}{$10 \%$} \\
\hline Zona Industrial 2-ZI 2 & Livre & Livre & \\
\hline Zonas de Chácaras - ZCH & 0,35 & 0,6 & $50 \%$ \\
\hline Zona de Conservação Ambiental - ZCA & 0,20 & 0,4 & $20 \%$ \\
\hline $\begin{array}{l}\text { Corredor de Comércio e Serviços } 1 \text { - } \\
\text { CCS1 }\end{array}$ & 0,60 & 1,5 & \multirow{5}{*}{$\begin{array}{l}10 \% \text { para terrenos } \\
\text { com área igual ou } \\
\text { superior a } 500 \mathrm{~m}^{2}\end{array}$} \\
\hline $\begin{array}{l}\text { Corredor de Comércio e Serviços } 2 \text { - } \\
\text { CCS2 }\end{array}$ & 0,60 & 2,0 & \\
\hline $\begin{array}{l}\text { Corredor de Comércio e Serviços } 3 \text { - } \\
\text { CCS3 }\end{array}$ & 0,60 & 3,0 & \\
\hline Corredor de Comércio e Indústria - CCI & 0,50 & 2,0 & \\
\hline Corredor de Circulação Rápida - CCR & 0,60 & 2,0 & \\
\hline Área Rural & Livre & Livre & Livre \\
\hline
\end{tabular}

$1^{0}$ As áreas correspondentes às piscinas descobertas não são computadas no cálculo do Coeficiente de Aproveitamento e da Taxa de Ocupação.

$\S 2^{\circ}$ Em Zona Residencial 1 - ZR1, Zona de Chácaras - ZCH, as edificações destinadas aos usos RL e RG têm sua altura limitada a três pavimentos, exceto imóveis situados nos corredores de comércio e serviços - CCS1, a estes o limite de pavimentos será regido pelos índices de ocupação e aproveitamento.

$\S 3^{\circ} \mathrm{Na}$ Zona Residencial 1 - ZR1, para a edificação de condomínios residenciais, deverá ser observada a Taxa de Conforto - TC, fração mínima de terreno para cada unidade residencial, na proporção de $360 \mathrm{~m} 2$ de terreno para cada unidade.

$\S 4^{0}$ Não serão computados, para efeitos do cálculo de aproveitamento e ocupação dos lotes:

I - para coeficiente de aproveitamento:

a) áreas de construção, quando exclusivo para garagem, atividades sociais, recreativas, caixa de escadas e elevadores, ou com pé direito inferior a 2,30m; $2,30 \mathrm{~m}$;

b) áreas de construção dos pilotis quando livres e sem vedação;

c) áreas de construção para instalações situadas acima do último pavimento;

d) toldos, marquises de cobertura, pérgulas, desde que a somatória do comprimento desses elementos não seja superior a $1 / 3$ da largura da fachada do prédio;

e) abrigos desmontáveis para guarda de autos.

II - para taxa de ocupação:

a) áreas de construção no subsolo, quando de uso exclusivo para garagem, ou com pé direito inferior a $2,30 \mathrm{~m}$;

b) toldos, marquises, coberturas e pérgulas, desde que a somatória do comprimento desses elementos não seja superior a $1 / 3$ da largura da fachada do prédio;

c) abrigos desmontáveis para guarda de autos.

$\S 5^{\circ}$ Para cálculo de área coberta, área construída e recuos, não será feita distinção entre "edificação principal" e "edícula", se esta houver.

$\S 6^{\circ} \mathrm{Na}$ Zona de Conservação Ambiental - ZCA, seus índices urbanísticos se aplicam às áreas remanescentes, excluindo-se as áreas territoriais caracterizadas como de preservação permanente, dos imóveis nela inseridos.

II - nas zonas de uso ZCH e ZCA:

a) recuo mínimo de frente: $5,00 \mathrm{~m}$ em todos os pavimentos; 
b) na ZCA, os recuos mínimos laterais e de fundos: em todos os pavimentos, serão proporcionais à altura da edificação, segundo a fórmula $\mathrm{Rm}$ = h/10+2,00m, onde: "Rm" é o recuo mínimo e " $h$ " é a altura da edificação;

c) na $\mathrm{ZCH}$, os recuos mínimos laterais e de fundos: em todos os pavimentos, serão no mínimo de $2,00 \mathrm{~m}$, excetuando-se os lotes que possuam fundos voltados para vias públicas, que neste caso terão recuo da edificação igual ao recuo da frente;

d) na ZCA, altura máxima da edificação será de sete pavimentos, incluso o pavimento térreo e excluídos os subsolos utilizados como garagem.

III - nas zonas de uso ZI 1 e ZI 2:

a) recuo mínimo de frente: $10,00 \mathrm{~m}$, em todos os pavimentos;

b) recuos mínimos em uma das laterais: $5,00 \mathrm{~m}$, em todos os pavimentos, sendo este obrigatório na lateral da rua, em lotes na esquina.

IV - na Área Rural:

a) recuo mínimo de frente: $20,00 \mathrm{~m}$ do eixo da via, em todos os pavimentos;

b) recuos mínimos laterais e de fundos: $5,00 \mathrm{~m}$, em todos os pavimentos, sendo este obrigatório na lateral da rua, em lotes na esquina.

$\S 1^{\circ}$ Para as glebas e lotes, a serem urbanizadas com uso residencial, situados em zonas limítrofes às ZI 2, será obrigatório, apenas junto à divisa de Zona, um recuo de $15,00 \mathrm{~m}$, formando uma barreira vegetal, constituída de espécies arbóreas.

$\S 2^{\circ}$ Essa regra de recuos, prevista no $\S 1^{\circ}$ deste artigo, se aplica aos lotes e glebas situados na ZI 2, lindeiras a outras zonas de uso.

$\S 3^{\circ}$ Os recuos mínimos previstos no inciso I, alíneas "a" e "c", não serão aplicados nas testadas de quadras com mais de $50 \%$ (cinquenta por cento) já construídos, ou em construção, permanecendo os recuos existentes.

$\S 4^{\circ}$ Para imóveis com testada igual ou inferior a $8,00 \mathrm{~m}$, fica permitida a instalação de abrigos desmontáveis com largura máxima de $50 \%$ (cinqüenta por cento) da testada do lote, desde que a área remanescente descoberta seja permeável.

$\S 5^{\circ}$ É permitida a construção de abrigo de segurança/portaria no recuo de frente dos imóveis, respeitada na construção a relação de largura máxima de $20 \%$ (vinte por cento) da testada do lote e profundidade máxima de $60 \%$ (sessenta por cento) do recuo de frente adotado.

$\S 6^{\circ}$ Os recuos mínimos laterais e de fundo, em todas as alíneas "b" deste artigo, devem ser observados para efeitos urbanísticos, considerando que para ventilação e iluminação os recuos obrigatórios são aqueles estabelecidos em legislação específica, notadamente Código de Obras.

Art. 110. Para imóveis urbanos limitados ou atravessados por cursos d'água, resultantes de parcelamentos do solo aprovados anteriormente a 1979, lei específica definirá as dimensões das faixas de afastamento de cada lado de suas margens.(...)

CAPÍTULO IV - PARCELAMENTO DO SOLO - SEÇÃO I - DISPOSIÇÕES GERAIS

Art. 116. Nenhum parcelamento do solo para fins urbanos será permitido em terrenos que apresentem uma ou mais das seguintes condições:

I - seja coberto em sua totalidade por vegetação protegida pelo disposto na legislação Federal, Estadual ou Municipal;

II - seja alagadiço;

III - apresente condições insalubres, tais como: locais de disposição pretérita de resíduos e áreas contaminadas que apresentem risco à saúde humana;

IV - apresente condições de risco geológico - geotécnico, em conformidade com a Carta de Suscetibilidade e Movimentos Gravitacionais de Massa e Inundações do município de Sorocaba, elaborada em conformidade com a Lei Federal $n^{0}$ 12.608, de 10 de abril de 2012.

Art. 117. Qualquer gleba objeto de parcelamento para fins urbanos deve ter acesso por via oficial de circulação.

SEÇÃO II - LOTEAMENTOS URBANOS E DESMEMBRAMENTOS

Art. 118. Nos loteamentos residenciais, comerciais e industriais, seja qual for à zona de uso em que estiverem localizados, parte da área total da gleba a ser loteada deve ser transferida ao patrimônio público do Município, com a seguinte discriminação:

I - 20\% (vinte por cento), no mínimo, para espaços livres de uso público; 
II - 5\% (cinco por cento), no mínimo, para uso institucional, destinada a equipamentos comunitários, exceto para os loteamentos industriais;

III - para o sistema viário, a área resultante do traçado e dimensões das vias projetadas, atendendo às diretrizes expedidas pela Prefeitura de Sorocaba;

IV - faixas de proteção ao longo de corpos d'água, contados a partir do leito maior sazonal que poderão ser computadas como espaços livres de uso público, com largura mínima de cada lado de:

a) 50,00m, do Rio Sorocaba, no trecho compreendido entre o limite com 0 município e Votorantim até foz do Rio Pirajibu;

b) $150,00 \mathrm{~m}$, do Rio Sorocaba, no trecho compreendido a partir da foz do Rio Pirajibu, excluídas as áreas urbanizadas;

c) $100,00 \mathrm{~m}$, do Rio Pirajibu, Córrego Eufrásio e Ribeirão Tapera Grande, excluídas as áreas urbanizadas;

d) 60,00m, ao longo do Córrego Pirajibu-Mirim, no trecho compreendido entre sua cabeceira até a sua foz com o Rio Pirajibu, exceto no trecho compreendido entre as coordenadas (utm) 258.628,331 e 7.398.473,266 (cruzamento com a rua Maria Augusta Silva) e 256.149,560 e 7.400.918,737 (ponte na rodovia Celso Charuri) excluídas as áreas urbanizadas;

e) 60,00m, ao longo dos Córregos Ipanema/lpaneminha, excluídas as áreas urbanizadas;

f) 30,00m dos demais córregos;

g) 50,00m no entorno das nascentes;

h) lagos e lagoas atenderão ao disposto na Lei Federal $n^{0} 12.651$, de 25 de maio de 2012 e suas alterações.

$\S 1^{\circ}$ Os espaços livres de uso público e os terrenos destinados a equipamentos comunitários devem ter frente para via oficial de circulação em extensão compatível com sua dimensão e condições topográficas que garantam pleno acesso aos mesmos e uso adequado.

$\S 2^{\circ}$ As exigências quanto à conformação dos espaços livres de uso público e dos terrenos destinados a equipamentos comunitários e dimensões de suas respectivas testadas serão estabelecidos pela Prefeitura de Sorocaba quando da emissão das diretrizes para o parcelamento.

$\S 3^{\circ} \mathrm{A}$ critério da Prefeitura de Sorocaba, embasados em parecer técnico, as dimensões mínimas dos espaços livres de uso público e dos terrenos destinados a equipamentos comunitários a serem implantados em empreendimentos habitacionais de interesse social, poderão ser aumentados de acordo com a demanda e demais condicionantes técnicas de cada local.

$\S 4^{\circ}$ Para lotes e áreas urbanizadas as faixas de proteção ao longo dos corpos d'água, devem observar as seguintes distâncias:

a) 4,00m, de cada lado, a contar da face externa da tubulação ou galeria quando já existir esse melhoramento.

b) 6,00m a contar do eixo do córrego não canalizado.

$\S 5^{\circ}$ A critério da Prefeitura de Sorocaba, embasados em parecer técnico, as faixas de proteção exigidas nas alíneas "a" e "b", do $\S 4^{\circ}$, poderão ser alteradas de acordo com as condicionantes técnicas de cada local.

$\S 6^{\circ}$ Deverão ser exigidas faixas com mínimo de $15,00 \mathrm{~m}$ de largura, de cada lado, ao longo das faixas de domínio das rodovias, do anel rodoviário e ferrovias, redes elétricas de alta tensão, oleodutos e gasodutos ou congêneres, de acordo com normas das concessionárias, para vias de circulação.

$7^{\circ}$ Deverão ser exigidas faixas non aedificandi com mínimo de 5,00m de largura, de cada lado, ao longo de cursos d'água canalizados e fechados.

$\S 8^{\circ}$ As faixas de proteção ao longo de corpos de água e as áreas destinadas a espaços livres de uso público, resultantes de loteamento, devem ter frente para a via de circulação.

Art. 119. Para os desmembramentos de glebas em lotes, onde a área resultante dos lotes for superior a $10.000 \mathrm{~m}^{2}$, deve ser transferida ao patrimônio público do Município uma área correspondente a $20 \%$ (vinte por cento), no mínimo, da respectiva área desmembrada, a qual será destinada a espaços livres de uso público ou uso institucional.

$\S 1^{\circ}$ Essa exigência não se aplica à divisão de glebas em glebas e nem glebas em lotes industriais, em Zona Industrial 1 - ZI 1 e Zona Industrial 2 - ZI 2. 
$\S 2^{\circ} \mathrm{A}$ área transferida ao patrimônio público do Município deve ter frente para logradouro público e as exigências quanto à sua conformação e dimensões de sua testada serão estabelecidas pela Prefeitura de Sorocaba quando da emissão das diretrizes para o desmembramento.

$\S 3^{\circ} \mathrm{Na}$ Zona de Conservação Ambiental ao longo do Rio Sorocaba, quando houver parcelamento ou qualquer outro empreendimento imobiliário, deverá ser prevista reserva de área para abertura de rua de $14,00 \mathrm{~m}$ entre a área de preservação permanente e a área remanescente.

Art. 120. Nos futuros loteamentos, localizados nas bacias do Rio Ipanema/lpaneminha, Rio Pirajibu, Córrego Pirajibu-Mirim, Córrego Itanguá, Córrego do Matadouro, Córrego do Lavapés e Córrego da Água Vermelha, será exigida, após estudos e quando necessário, a doação de área para 0 patrimônio público do Município visando à execução de dispositivos de retenção de águas pluviais no sistema de drenagem do loteamento, que poderão estar localizados nas faixas de proteção dos corpos d'água.

Art. 123. As servidões de passagem que porventura gravem glebas a lotear devem ser garantidas pela malha viária do loteamento. de:

Art. 124. São de responsabilidade do loteador, o projeto, a execução e o custeio

I - demarcação das vias, dos terrenos a serem transferidos ao domínio do Município, dos lotes e das áreas não edificáveis;

II - abertura das vias de circulação e respectivas terraplenagem;

III - implantação da rede de captação de águas pluviais e suas conexões com 0 sistema público existente junto ao terreno a parcelar;

IV - implantação de rede de distribuição de energia elétrica e de iluminação pública e suas conexões com a rede de energia existente junto ao terreno a parcelar;

V - pavimentação do leito carroçável das vias internas e aquelas vias lindeiras à área utilizada inclusive seus acessos, devidamente sinalizados;

$\mathrm{VI}$ - implantação da rede de abastecimento de água e de coleta de esgoto, quando for necessário, e suas conexões com a rede pública já instalada;

VII - arborização de calçadas;

VIII - implantação nas vias pavimentadas dos loteamentos de sinalização vertical e horizontal, a partir de projeto previamente aprovado pelo órgão municipal de trânsito;

IX - o projeto de loteamento deve ser precedido de análise técnica favorável da URBES, com indicação de rota de transporte coletivo. As vias da referida rota devem ser pavimentadas segundo recomendações técnicas da Associação Brasileira de Normas Técnicas (ABNT), com a pavimentação dessas vias adequadas ao tráfego pesado.

$\S 1^{\circ}$ Fica permitido ao loteador a venda de lotes do empreendimento imobiliário desde que o mesmo apresente à Prefeitura de Sorocaba a caução em garantia à execução e qualidade das obras e instalações mencionadas nos incisos anteriores, bem como a confirmação do registro imobiliário do referido empreendimento nos termos da Legislação Federal pertinente.

$\S 2^{\circ} \mathrm{A}$ caução mencionada no parágrafo primeiro poderá ser: constituída de lotes oriundos do próprio empreendimento imobiliário; moeda corrente nacional; títulos da dívida pública; garantia hipotecária sobre quaisquer bens imóveis de sua propriedade ou de terceiros, livres e desembaraçados; fiança bancária, ou contrato de seguro de conclusão de obra, devendo atingir o valor correspondente às obras exigidas, neste artigo.

$\S 3^{\circ}$ Para as obras mencionadas no caput do presente artigo, a Prefeitura de Sorocaba fixará o prazo de 24 (vinte e quatro) meses prorrogáveis por igual período a julgamento do poder executivo municipal, bem como normas e especificações técnicas de execução.

$\S 4^{\circ}$ Executadas as obras e instalações previstas neste artigo, o loteador terá a devolução de $50 \%$ (cinquenta por cento) da caução prestada e o respectivo "Termo de Verificação de Obras - TVO". Passados 04 (quatro) anos da data da emissão do "Termo de Verificação de Obras" - TVO, correspondendo esta à garantia de qualidade das obras e instalações, terá o loteador a devolução integral da caução, ou seja, os 50\% (cinqüenta por cento) remanescentes. (Veto Parcial $n^{0} 53 / 2014$ Rejeitado) 
Art. 125. Na área urbana, os lotes resultantes de parcelamento do solo deverão observar as dimensões mínimas para cada zona de uso apresentadas no quadro seguinte:

\begin{tabular}{|l|l|l|}
\hline \multicolumn{3}{|l|}{ DIMENSÕES MÍNIMAS DE LOTES POR ZONA DE USO } \\
\hline ZONAS DE USO & $\begin{array}{l}\text { ÁREA } \\
\text { MíNIMA }\left(\mathrm{m}^{2}\right)\end{array}$ & $\begin{array}{l}\text { TESTADA } \\
\text { MÍNIMA (m) }\end{array}$ \\
\hline Zona Central - ZC & 200,00 & 8,00 \\
\hline Zona Predominantemente Institucional - ZPI & 360,00 & 12,00 \\
\hline Zona Residencial 1 - ZR1 & 360,00 & 10,00 \\
\hline Zona Residencial 2 -ZR2 & 300,00 & 10,00 \\
\hline Zona Residencial 3 - ZR3 & 200,00 & 8,00 \\
\hline Zona Residencial 3 - ZR3 - expandida & 200,00 & 8,00 \\
\hline Zona Industrial 1 -ZI 1 & $1.000,00$ & 15,00 \\
\hline Zona Industrial 2 - ZI 2 & 500,00 & 15,00 \\
\hline Zonas de Chácaras -ZCH & $1.000,00$ & 15,00 \\
\hline Zona de Conservação Ambiental - ZCA & $6.000,00$ & 75,00 \\
\hline Corredor de Comércio e Serviços 1 - CCS1 & 300,00 & 10,00 \\
\hline Corredor de Comércio e Serviços 2 - CCS2 & 250,00 & 10,00 \\
\hline Corredor de Comércio e Serviços 3 - CCS3 & 500,00 & 15,00 \\
\hline Corredor de comércio e Indústria - CCI & $3.000,00$ & 30,00 \\
\hline Corredor de Circulação Rápida - CCR & 600,00 & 15,00 \\
\hline
\end{tabular}

$\S 1^{\circ}$ Nas testadas de quadras que já possuam $50 \%$ (cinquenta por cento) ou mais lotes já fracionados, fica permitido o fracionamento do restante dos lotes nas mesmas condições dos lotes já fracionados.

$\S 2^{\circ}$ Nos loteamentos aprovados até a entrada em vigor da Lei Municipal $n^{\circ}$ 7.122, de $1^{\circ}$ de junho de 2004 localizados na ZR2 e ZR3 ficam permitidos os fracionamentos dos lotes com área mínima de $125 \mathrm{~m} 2$, com testada mínima de $5,00 \mathrm{~m}$ e profundidade mínima de $10,00 \mathrm{~m}$.

$\S 3^{\circ}$ Nas Zonas de Chácaras Urbanas - ZCH serão admitidos novos parcelamentos do solo com lotes de $600 \mathrm{~m} 2$ de área territorial e testada mínima de $15,00 \mathrm{~m}$, desde que o empreendimento possua sistema individual para tratamento de esgoto gerado no mesmo, compreendendo rede coletora, estação de tratamento e rede de descartes de efluentes, devidamente aprovados pelos órgãos técnicos ambientais, bem como para sua ocupação seja prevista uma unidade residencial para cada $600 \mathrm{~m} 2$ de fração de área de lote. (Veto Parcial ${ }^{0}$ 53/2014 Rejeitado)

$\S 4^{\circ}$ Os lotes resultantes de loteamentos aprovados na $\mathrm{ZCH}$, anteriormente a publicação dessa Lei poderão ser reparcelados, observados os índices urbanísticos estabelecidos por esta Lei, para a nova zona de uso onde se insere o referido loteamento desde que atendidos por redes de águas e esgoto.

$\S 5^{\circ}$ Os lotes de esquina, resultantes de parcelamento do solo, com testadas para mais de um corredor ou zona de uso, deverão ter suas dimensões e área territorial, estabelecidas para o lote do corredor com maior dimensão.

$\S 6^{\circ}$ Fica permitida a redução da área mínima dos lotes para $150 \mathrm{~m} 2$ na ZR3 e $250 \mathrm{~m} 2$ na ZR2, caso o empreendedor opte pela ampliação da área destinada ao lazer de $12 \%$ para $20 \%$ da gleba do loteamento, área esta que deverá contemplar as áreas verdes e o sistema de lazer. (Veto Parcial $n^{0}$ 53/2014 Rejeitado) (Parágrafo declarado inconstitucional pela ADIN $n^{0} 2138826-$ 16.2016.8.26.0000)

$\S 7^{\circ} \mathrm{O}$ parcelamento e o reparcelamento nas Zonas de Chácaras Urbanas $\mathrm{ZCH}$ definidos nos $\S \S 3^{\circ}$ e $4^{\circ}$ deste artigo, não será aplicado na área compreendida pelo loteamento do Bairro Caputera, mantendo-se a área mínima de 1.000,00 m2 e testada mínima de 15,00 m.

Art. 126. Na Área Rural, qualquer parcelamento do solo deverá observar 0 módulo mínimo rural, definido pelo INCRA.

Art. 127. Novos loteamentos, residenciais, comerciais e industriais poderão constituir setores fechados ao tráfego geral, com controle de entrada e saída de veículos e pessoas, desde que:

I - sejam objeto de Estudo de Impacto sobre a Vizinhança - EIV;

II - tenham a malha viária interna ao setor com acesso controlado, composta exclusivamente por vias locais;

III - mantenham todos os terrenos destinados a uso institucional com acesso por via oficial de circulação sem qualquer tipo de controle; 
IV - seja constituída pessoa jurídica que assuma legalmente a responsabilidade pela manutenção e operação das vias e dos equipamentos e serviços coletivos no interior do setor com acesso controlado;

$\mathrm{V}$ - atendam as diretrizes emitidas pela Prefeitura de Sorocaba, as quais deverão:

a) limitar as dimensões da área controlada, de modo a garantir a livre circulação no interior da área urbana.

b) exigir, quando considerado necessário, a manutenção de lotes externos ao setor com acesso controlado, de modo a viabilizar a instalação de comércio, serviços e outros equipamentos.

Art. 128. Para loteamentos residenciais, comerciais e industriais já implantados e não constituídos como setores fechados, o pedido de implantação de controle de entrada e saída de veículos e pessoas deverá ser apresentado à Prefeitura de Sorocaba acompanhado de projeto técnico, estando sua aprovação condicionada ao atendimento de todos os requisitos previstos no artigo anterior, sem exclusão do Estudo de Impacto de Vizinhança - EIV.

$(\ldots)$

$\S 1^{\circ}$ Nas testadas de quadras que já possuam $50 \%$ (cinquenta por cento) ou mais lotes já fracionados, fica permitido o fracionamento do restante dos lotes nas mesmas condições dos lotes já fracionados.

$\S 2^{\circ}$ Nos loteamentos aprovados até a entrada em vigor da Lei Municipal $n^{\circ}$ 7.122, de $1^{\circ}$ de junho de 2004 localizados na ZR2 e ZR3 ficam permitidos os fracionamentos dos lotes com área mínima de 125m2, com testada mínima de 5,00m e profundidade mínima de $10,00 \mathrm{~m}$.

$\S 3^{\circ}$ Nas Zonas de Chácaras Urbanas - $\mathrm{ZCH}$ serão admitidos novos parcelamentos do solo com lotes de $600 \mathrm{~m} 2$ de área territorial e testada mínima de $15,00 \mathrm{~m}$, desde que o empreendimento possua sistema individual para tratamento de esgoto gerado no mesmo, compreendendo rede coletora, estação de tratamento e rede de descartes de efluentes, devidamente aprovados pelos órgãos técnicos ambientais, bem como para sua ocupação seja prevista uma unidade residencial para cada $600 \mathrm{~m} 2$ de fração de área de lote. (Veto Parcial $n^{0}$ 53/2014 Rejeitado)

$\S 4^{\circ}$ Os lotes resultantes de loteamentos aprovados na $\mathrm{ZCH}$, anteriormente a publicação dessa Lei poderão ser reparcelados, observados os índices urbanísticos estabelecidos por esta Lei, para a nova zona de uso onde se insere o referido loteamento desde que atendidos por redes de águas e esgoto.

$\S 5^{\circ}$ Os lotes de esquina, resultantes de parcelamento do solo, com testadas para mais de um corredor ou zona de uso, deverão ter suas dimensões e área territorial, estabelecidas para o lote do corredor com maior dimensão.

$\S 6^{\circ}$ Fica permitida a redução da área mínima dos lotes para $150 \mathrm{~m} 2$ na ZR3 e $250 \mathrm{~m} 2$ na ZR2, caso o empreendedor opte pela ampliação da área destinada ao lazer de $12 \%$ para $20 \%$ da gleba do loteamento, área esta que deverá contemplar as áreas verdes e o sistema de lazer. (Veto Parcial $n^{0}$ 53/2014 Rejeitado) (Parágrafo declarado inconstitucional pela ADIN $n^{0}$ 213882616.2016.8.26.0000)

$\S 7^{\circ} 0$ parcelamento e o reparcelamento nas Zonas de Chácaras Urbanas $\mathrm{ZCH}$ definidos nos $\S \S 3^{\circ}$ e $4^{\circ}$ deste artigo, não será aplicado na área compreendida pelo loteamento do Bairro Caputera, mantendo-se a área mínima de $1.000,00 \mathrm{~m} 2$ e testada mínima de $15,00 \mathrm{~m}$.

Art. 126. Na Área Rural, qualquer parcelamento do solo deverá observar o módulo mínimo rural, definido pelo INCRA.

Art. 127. Novos loteamentos, residenciais, comerciais e industriais poderão constituir setores fechados ao tráfego geral, com controle de entrada e saída de veículos e pessoas, desde que:

I - sejam objeto de Estudo de Impacto sobre a Vizinhança - EIV;

II - tenham a malha viária interna ao setor com acesso controlado, composta exclusivamente por vias locais;

III - mantenham todos os terrenos destinados a uso institucional com acesso por via oficial de circulação sem qualquer tipo de controle; 
IV - seja constituída pessoa jurídica que assuma legalmente a responsabilidade pela manutenção e operação das vias e dos equipamentos e serviços coletivos no interior do setor com acesso controlado;

$\mathrm{V}$ - atendam as diretrizes emitidas pela Prefeitura de Sorocaba, as quais deverão:

a) limitar as dimensões da área controlada, de modo a garantir a livre circulação no interior da área urbana.

b) exigir, quando considerado necessário, a manutenção de lotes externos ao setor com acesso controlado, de modo a viabilizar a instalação de comércio, serviços e outros equipamentos.

Art. 128. Para loteamentos residenciais, comerciais e industriais já implantados e não constituídos como setores fechados, o pedido de implantação de controle de entrada e saída de veículos e pessoas deverá ser apresentado à Prefeitura de Sorocaba acompanhado de projeto técnico, estando sua aprovação condicionada ao atendimento de todos os requisitos previstos no artigo anterior, sem exclusão do Estudo de Impacto de Vizinhança - EIV.

(...)

Art. 145. Os casos omissos serão analisados e decididos pela Prefeitura de Sorocaba.

Parágrafo único. Nos casos de divergência entre usos ou índices urbanísticos nas áreas lindeiras a mais de uma zona, a Prefeitura de Sorocaba através da Câmara Técnica de Legislação Urbanística, nomeada por decreto municipal, estabelecerá, para cada situação as diretrizes que deverão ser seguidas pelo empreendedor.

Art. 146. Os Mapas: MP 01 - Macrozoneamento Ambiental - PDA - SEMA, MP 02 - Zoneamento Municipal Proposto e MP 03 - Sistema Viário Principal Proposto, constantes do anexo integram esta Lei. (...)

(CMS, 2014)

\section{E. ADIN PD Sorocaba 2014}

\section{1. $A D I N n^{\circ} 2138826-16.2016 .8 .26 .0000$ /-Voto nº 29.80511 Tribunal de Justiça do Estado de São Paulo:}

(...) O plano diretor elaborado pela Secretaria de Mobilidade, Desenvolvimento Urbano e Obras SEMOB, com a colaboração da CNEC Worley Parsons Engenharia S/A que, mediante contrato, 'disponibilizou uma equipe técnica multidisciplinar, com experiência comprovada na área'. Destacou a participação, também, dos técnicos da Secretaria de Meio Ambiente, Desenvolvimento Econômico, Serviços Públicos, Habitação, Planejamento e Gestão, além de URBES e SAEE, apreciando-se, ainda, as conexões com os Planos de Meio Ambiente, de Saneamento, de Mobilidade e Transporte Urbano, de Habitação e Interesse Social, de Resíduos Sólidos, entre outros. (...)

Disponível em: https://jurisprudencia.s3.amazonaws.com/TJ-SP/attachments/TJSP ADI 21388261620168260000 66228.pdf?Signature=XBq\%2BPStbrWIcb848yamMkFZtosg\%3D\&Expires=1520 382215\&AWSAccessKeyld=AKIAIPM2XEMZACAXCMBA\&response-content-type=application/pdf\&x-amz-metamd5-hash=5ed1208a8764d7faae0663acc67b915c, acesso em 06/03/2018. 


\section{F. Corregedoria Geral do Município}

\section{Prefeitura de}

Ofício $n^{\circ} 044 / C G M / 2017$

Sorocaba, 11 de abril de 2017

Ao ilustríssimo Senhor

Sérgio Antônio Reze

Associaçăo de Moradores dos Bairros Elton Ville, Uirapuru e adjacências

Rua Alvaro Teixeira de Souza, $\mathrm{n}^{\circ} 22$

Centro - Sorocaba - SP

CEP 18035-530 - Sorocaba/SP

Ref.: $\quad$ Processo administrativo CGM n 2014/028.309-4

Anexo: $\quad$ Despacho do Corregedor-Geral (fls. 328/336).

Prezado Senhor,

Em atenção ao despacho proferido pelo Corregedor-Geral do Municipio, nos autos do processo administrativo em epígrafe, venho a presença de Vossa Senhoria, oferecer-lhe à vista o documento supramencionado, para conhecimento.

Atenciosamente,

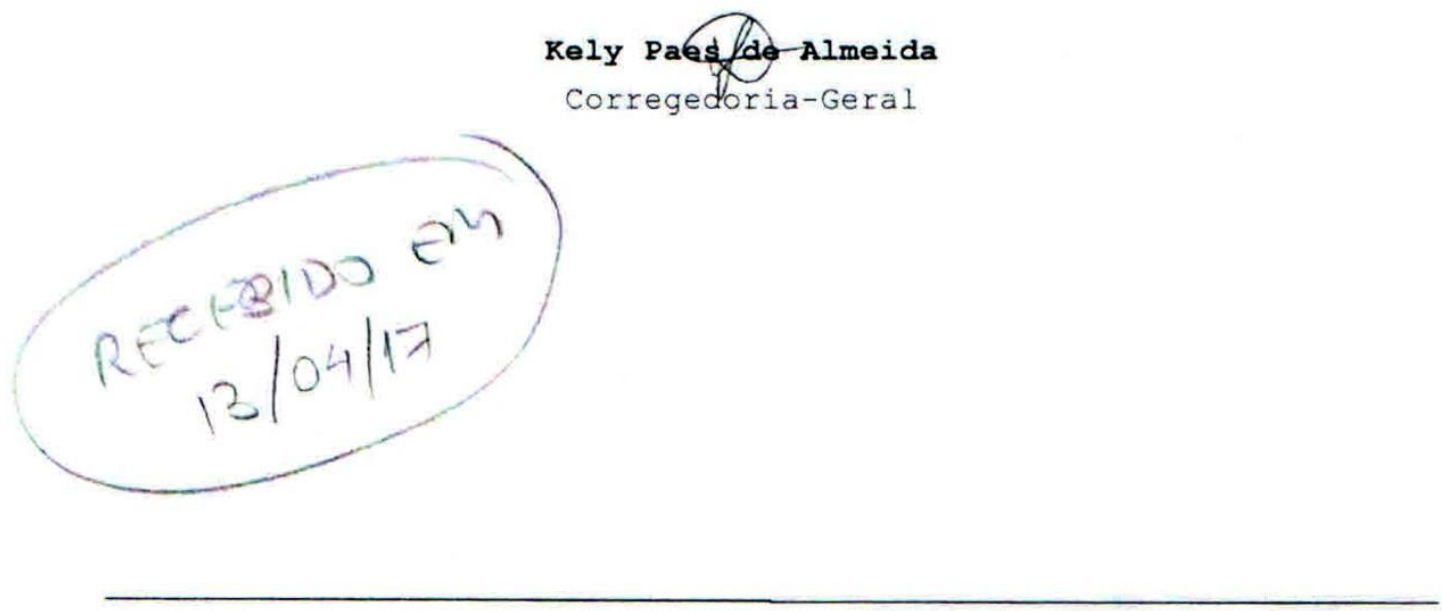

PALÁCIO DOS TROPEIROS $-4^{\circ}$ andar

Av Eng Carlos Reinaido Mendes 3.041 - Aito da Boa Vista - CEP 18013-280 - Sorocaba - SP cano.i1cis 23203177 


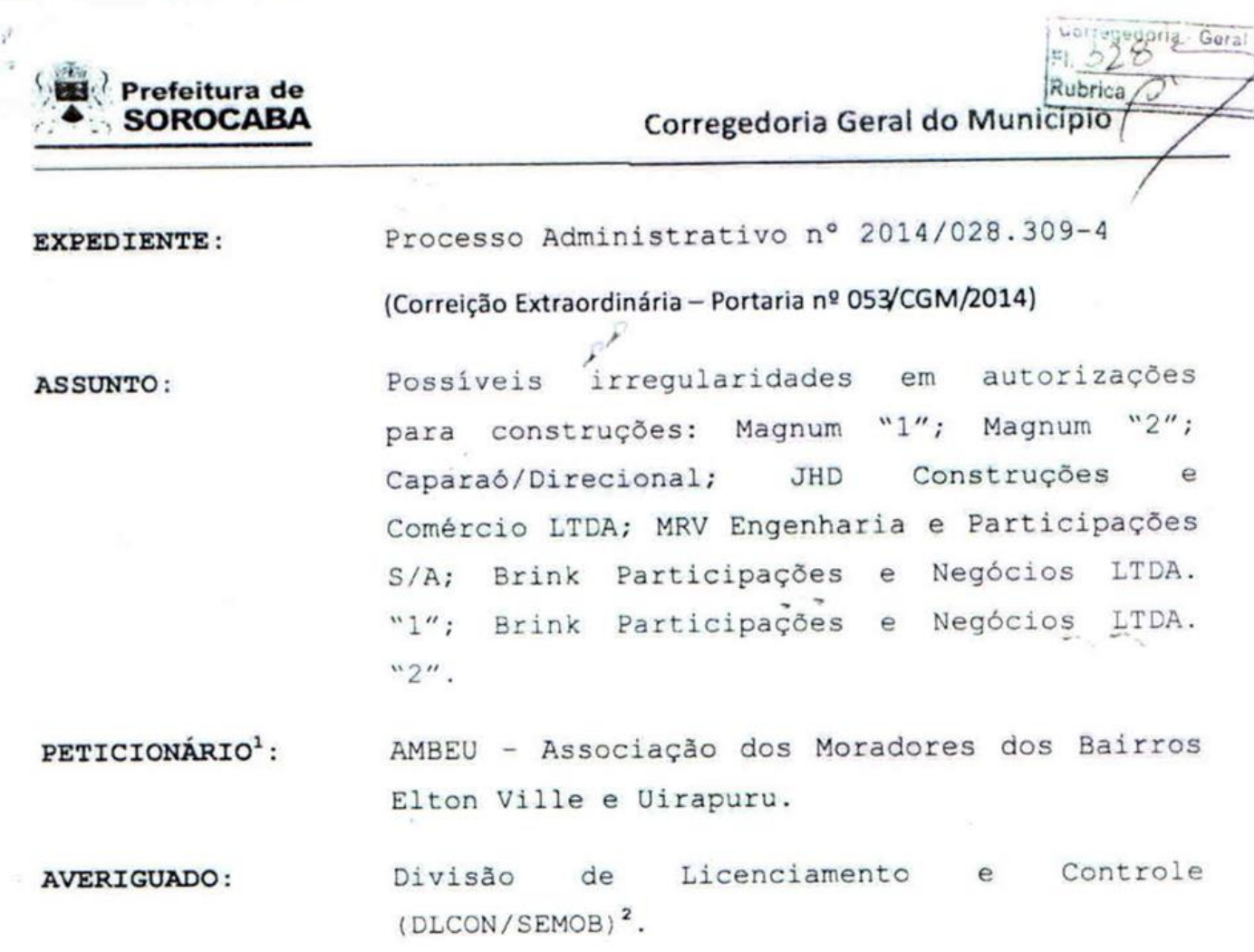

ÓRGÃO DE INSTRUÇÃO: Segunda Câmara Correcional.

APORTE TÉCNICO: JOÃO LUIZ DE SOUZA AREAS (arquiteto e urbanista requisitado nos termos do art. 21 do Decreto municipal $n^{\circ} 21.565$, de 2014).

\section{Despacho do Corregedor-Geral do Municipio}

1. Tratam os autos de denúncia da Associação dos Moradores dos Bairros Elton Ville e Uirapuru (AMBEU) pela qual se alega ter havido procedimento irregular por parte da Divisăo de Licenciamento e controle (DLCON/SEMOB) em processos de aprovaçâo/licenciamento de projetos arquitetônicos e emissão de

1. Lei do Processo Administrativo Municipal (Lei $n=10.964$, de 2014), art. 14, inciso I.

2. As denominações e siglas atribuidas às secretarias e às unidades administrativas, neste ato, são anteriores a reforma administrativa implementadas pela Lei municipal n 11.488, de 2017. 
alvarás de construção, que estariam em conflito com os postulados do Plano Diretor (fls. 7 a 9 ).

2. A petição da AMBEU réfere-se a cinco (5) condomínios residenciais e dois (2) empreendimentos comerciais aprovados nos loteamentos Elton Ville, Jardim São Carlos e imediações, quais sejam:

(a) prédio residencial no cruzamento da Rua Lituânia com a Rua João Wagner Wey - Lotes de 1 a 7 Quadra "C" (Magnum Comercial e Construtora LTDA.);

(b) prédio residencial no cruzamento da Rua Lituânia com a Rua Joåo Wagner Wey - Lotes de 1 a 8 Quadra "A" (Magnum Comercial e Construtora LTDA.) ;

(c) prédio residencial no cruzamento da Rua Lituânia com a Rua Hugo Filho - Lotes de 1 a 17 Quadra "B" (Direcional Engenharia);

(d) Prédio Comercial situado na Rua Lituânia $n^{\circ} 1.101$ (JHD Construções e Comércio LTDA.);

(e) complexo residencial multifamiliar composto de 22 torres localizado no final da Rua João wagner Wey, já próximo alça que dá acesso ao bairro através da Rodovia Raposo Tavares - Parque Salamanca (MRV engenharia e Participaçōes S.A.);

(f) edificio residencial multifamiliar situado na Rua João Wagner Wey (Brink Participaçōes e Negócios LTDA.);

(g) prédios comerciais situados na Rua Antonio Guitti, sede das empresas Brink Participações e Negócios LTDA. e Paifer Investimentos.

3. Os autos foram distribuidos à Segunda Câmara Correcional que, de saída, requereu à DLCON os Processos Administrativos relativos às obras reclamadas, para análise das 
caracteristicas de cada um dos empreendimentos denunciados (despacho ordinatório de fls. 13 a 14).

5. Posteriormente, em, 'relatório preliminar, foram reunidas, metodicamente, ideias relativas a urbanismo, tendo em conta a absoluta necessidade de se pôr em dialogo com conceitos intrinsecos ao Planejamento Urbano, tais como: grandezas urbanisticas (área construída computável, área construída não computável, construída total, afastamentoș/ŗecuos e gabarito de altura máxima); índices urbanisticos (taxa de ogupação, coeficiente de aproveitamento, taxa de permeabilidade e indice de áreas verdes); densidade populacional; outorga onerosa do direito de construir, estudo de impacto de vizinhança (fls. 161 a 184).

6. Naquela circunståncia, havia elementos que necessitam de maiores esclarecimentos para a devida conclusão desse complexo procedimento correcional ${ }^{3}$. Para isso, a então corregedora-geral do Município, Adriana de Oliveira Rosa, requisitou ao secretário Mobilidade, Desenvolvimento Urbano e Obras (SEMOB) o arquiteto e urbanista JOÃO LUIZ DE SOUZA AREAS para dar à Corregedoria-Geral aporte técnico em caráter excepcional, com fundamento no artigo 21 do Decreto Municipal n²1.565/2014 (fls. 194 a 196).

7. Desse modo, à fls. 205 a 233, vieram aos autos a manifestação técnica do arquiteto e urbanista JOÃO LUIZ DE SOUZA AREAS ${ }^{4}$ que teceu, incialmente, CONSIDERAÇÕES GERAIS a respeito (i) das principais diretrizes estabelecidas pelo Plano Diretor de Desenvolvimento Fisicoterritorial (PDDFT) de 2004, revisto em 2007; (ii) da possibilidade de verticalização na regiăo objeto da representação [permissão de verticalização ccsi]; (iii) do

3. O relatório parcial apresentado em $\mathbf{2 4}$ laudas, pela Segunda Câmara Correcional, foi fruto da pesquisa conduzida pelos corregedores Marco Massari e Cibele Goes.

4. Arquiteto e urbanista com 30 anos de serviços públicos prestados ao Município de Sorocaba; foi diretor de Planejamento e Pesquisa Urbana no momento de elaboração do Plano Diretor em 2004. (fonte: http://www.ibdu.org.br/imagens/planodiretordesorocaba.pdf. Disponivel em 25/1/2017). 


correto cotejamento entre indices construtivos e densidade

residencial líquida na localidade dos "empreendimentos Elton

Ville/Pagliato/Uirapuru e adjacêpcias" [índices construtivos vs. adensamento (densidades)]; (iv) dos parâmetros e requisitos da outorga onerosa do direito de construir (OODC), do estudos de impacto de vizinhança (EIV) e do respectivos relatórios de impacto de vizinhança (RIVI), estes como instrumentos de politica urbana.

- assistente técnico, também, debateu especificam̃ente as questões suscitadas pela AMBEU relativamente a cada um dos empreendimentos, concluindo, em suma, pela regularidade da

matéria. Ao final arrematou:

\section{CONSIDERAÇOES FINANS} sào latentes.

A necessidade de aprimoramento da legislaçăo urbanistica e sua efetiva aplicabilidade,

Crescern as responsabilidades à gestào do municipio com a participaçầ cada vez maior dos setores privados e da sociedade civil. Sorocaba há décadas pauta-se pela busca incessante ao aprimoramento no planejamento e ordenamento de seu território, e cada vez mais esse instrumento de açào e gestân se faz presente, em especial nesta atual administraçăo.

Através do PDDFT o que se busca é aproximar a residéncia/moradia ao local de emprego, assim como o estabelecimento de Zonas e Corredores de Uso onde poderăo ser exercidos os instrumentos preconizados pelo Estatuto da Cidade - EC, de modo a proporcionar/incentivar o adensamento com a ocupaçăo maior nas principais vias públicas caracterizadas como comerciais preservando o espaço intrabairro compatibilizando e otimizando com a infraestrutura existente c investida ao longo de décadas pelo poder público.

Consolida-se a estratégia que estabeleceu a criaçào dos "eixos de estruturaçăo moderada para a transformaçầo urbana", ao longo de principais vias dos corredores comerciais onde se propố concentrar o processo de adensamento demográfico e urbano e qualificar o espaço público. $O$ emprego caracterizado como terciário está vinculado à demanda de alta c média renda c, portanto deseja-se com isso que não haja destocamento e grandes viagens para fora dos compartimentos destas localizaçùes.

O que se deseja è promover maiores adensamentos demográficos onde está a oferu de emprego, ou próximo a ela. estimulando $\mathrm{c}$ induzindo a ocupaçăo/adensamento construtivo com aumento do coeficiente de aproveitamento, inclusive através da verticalizaçoo, mediante a concesšo de potencial construtivo com devido controle através dos indices de construçăo similares à Zona de usos lindeira ou, num futuro proximo. através da fraçäo ideal de terreno máxima por unidade, a conhecida taxa de conforto. 
Associar que essa intensificaçào de uso do solo resulta em densidades demograficas elevadas $e$ insustentáveis. é incentivar a dispersło da cidade numa construçăo ideológica que funciona mais como um instrumento de segregaçăo social, impedindo uma moderada compactaçso da cidade que só seria possivel com essa intensificaçâo e a mistura das classes sociais. sendo a verticalizaçào uma forma adequada e equilibrada.

Há que se desmistificar a ideia que a verticalizaçào proporciona negativamente congestionamento de veiculos e tránsito, sendo esse o motivo de resisténcia por parte das chamadas "elites" ao processo de intensificaçăo de uso do solo.

A Prefeitura de Sorocaba ratifica serem os empreendimentos permitidos no local desejado, uma ve $\iota$ que estào amparados na legislaçăo urbanistica anterior ou atual, confirmando os corretos "Alvara de Licença de Construçăo". já expedidos.

Por todo exposto, considera-se não haver fatos ou motivos para o cancelamento on suspensấo de quaisquer atos administrativos que objetivem os licenciamentos dos empreendimentos aqui tratados, manifestando pela sua continuidade até sua conclusăo, remetendo os autos para aos setores competentes da Prefeitura, inclusive para notificação ao empreendedor para os ajustes ante aos procedimentos administrativos e estudos complementares, recomendados.

Por fim, este te o entendimento técnico. o qual encaminho-the a cópia anexo do documento para que conheça e se faça o devido esclarecimento e ciéncia dos fatos $\mathrm{c}$ posicionamentos aqui relatados. colocando-nos à disposiçăo para maiores e melhores informaçðes.

8.

De outro lado, a Segunda Câmara Correcional pronunciouse conclusivamente às fls. 235 a 243.

9. Todavia, por considerar que a compreensão do sentido e

do alcance dos dispositivos do Plano Diretor de Sorocaba não é

tarefa simples, sobretudo, ponderando a tecnicidade da questão

tratada nesta correição, determinei às fls. 278 a 279, a

conversão do ato decisório final em diligência, a fim de que a

Segunda Câmara Correcional pudesse examinar os pareceres técnicos

emitido pelo CAEx (Centro de Apoio Operacional à Execução do

Ministério Público de São Paulo), relativamente a cada um dos

empreendimentos tratados nesta correição.

10. Agora, a Segunda Câmara Correcional trouxe aos autos suas impressões acerca do estudo técnico elaborado pelo CAEx (MP$\mathrm{SP})^{5}$, especificamente a respeito do empreendimento residencial multifamiliar denominado PARQUE SALAMACA da MRV Engenharia e Participações S/A (fls. 288 a 319).

5. O estudo técnico elaborado pelo CAEx havia sido concluido em 10/2/2017, e juntados nos autos do Inquérito Civil ne $6351 / 2014$

PALÁCIO DOS TROPEIROS - Térreo

Av. Eng. Carios Reinaldo Mendes 3.041 - Aito da BOa Vista - CEP 18013.280 - Sorocaba - SP

Fone (15) 3238.2177 
Relatei com breve sintese do necessário. Fundamento.

11. Considerando os apontamentos feitos pela Câmara Correcional (fls. $237 / 239$ e 286/287), tem-se que o CAEx assinalou irregularidades no licenciamento empreendimento residencial multifamiliar denominado PARQUE SALAMACA da MRV Engenharia e Participaçőes S/A, com maior importância para:

(a) aplicação dada pela então Secretaria de Mobilidade, Desenvolvimento Urbano e Obras (SEMOB) ao artigo 25, inciso II, da Lei Municipal $n^{\circ} 8.181 / 2007$ (Plano Diretor de Desenvolvimento Físico e Territorial do Municipio de 2007), que teria desconsiderado o gabarito de altura como um dos indices de ocupação ou como umá condicionante para implantaçăo das edificaçöes no lote, isto é, a SEMOB, ao fazer a análise dos parâmetros urbanísticos utilizados pelo empreendimento, não se ateve à avaliação do gabarito de altura, pois considerou que esta grandeza urbanistica não fazia parte dos indices de ocupação nem das condiçöes de implantação das edificações no lote;

(b) insuficiência do EIV/RIV, "[...] por não identificar que a região está passando por significativas transformações; não co-localizando outros empreendimentos em lançamento e em construção que, concentrados na região podem gerar repercussão ou interferência, impactando o sistema viário; a infraestrutura urbana; o meio ambiente e o meio social" [sic] - fl. 319-verso deste processo correcional.

12. Nesse enredo, em exame prefacial, tenho que a denuncia, relativamente ao empreendimento residencial multifamiliar denominado PARQUE SALAMACA da MRV Engenharia e Participações S/A,

PALÁCIO DOS TROPEIROS - Térreo

Av. Eng Carlos Reinaldo Mendes 3.041 - Alto da Boa Vista - CEP 18013-280 - Sorocaba - SP Fone: (15) 3238.2177 
encontra suporte em elementos capazes de the dar verossimilhança, razão pela qual determino a imediata remessa destes autos correcionais ao Excelentissimo senhor secretário de Planejamento e Projetos (SEPLAN) ${ }^{6}$ para que Eonheça da matéria relativa a sua esfera de sua competência e, desse modo, adote a providencias acauteladoras ${ }^{7}$ que $\circ$ caso reclama.

Após, retornem os autos à Segunda Câmara Correcional
para que promova os atos de seu ofício, especialmente, aqueles
indicados às fls. 286 e 287 .

CGM, 10 de abril de 2017.

\title{
GUSTAVO BARATA
}

Corregedor-Geral do Município

\begin{abstract}
6. Com o advento da Lei municipal no 11.488, de 2017, coube a SEPLAN o planejamento urbanistico do Municipio por meio do Plano Diretor de Desenvolvimento Integrado; o licenciamento e autorizaçăo das construçōes particulares, o uso do solo e seu parcelamento; a orientaçăo e acompanhamento das edificaçס̄es econômicas; projetos e fiscalizaçăo as obras públicas; planejamento e promoçăo das atividades relativas à preservaçăo e ao desenvolvimento urbano e rural; organizaçåo e supervisão do arquivo geral; gestão e integração dos sistemas de informação. Informação disponivel em http://planejamento.sorocaba.sp.gov.br/. Acesso em 10/42017.

7. Lei do Processo Administrativo Municipal (Lei n² 10.964, de 2014), art. 32: "Em caso de risco iminente à saúde ou integridade de pessoas e bens, a Administração Pública poderá motivadamente adotar providências acauteladoras
\end{abstract} sem a prévia manifestaçăo do interessado."

PALACIO DOS TROPEIROS - Térreo

Av. Eng. Carlos Reinaldo Mendes 3.041 - Alto da Boa Vista - CEP 18013-280 - Sorocaba - 5P Fone: (15) 3238.2177 
PA 30417/2012

AO Sr Luiz Alberto Fioravante - SEPLAN

Considerando as possiveis irregularidades em autorizações para construção, conforme parecer técrico da CAEx - Centro de Apoio Operacional à Execução;

Considerando segundo o Ministério Público do Estado de São Paulo, na apuração dos fatos, onde as questôes relacionadas à não exigência ou à insuficiência dos Estudos de Impacto de Vizinhança são comuns a tais empreendimentos dessa região da cidade; $\mathrm{e}$

Considerando que o parecer técnico possibilitou o llustrissimo Dr. \& Gustavo Barata, Corregedor Geral do Municipio, o conhecimento e embasamento legal para fundamentação.

Vista que amparado legalmente, para a imediata interdição e embargos da continuidade das obras.

Segue para determinação.

Sorocaba, 10 de Abril de 2017.

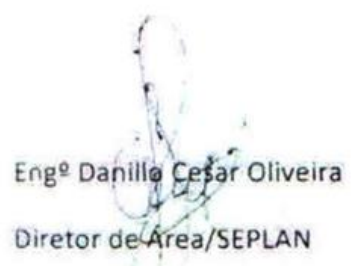


Sorocaba, 10 de abril de 2017

Ao

Eng Danillo C. Oliveira/DLCON

Diretor de Área

Ref. PA $30.417 / 2012$

Considerando que a CAEX Centro de Apoio Operacional à Execução, assinalou irregularidades no licenciamento do empreendimento, como:

1) Não se ateve à avaliação do gabarito de altura;

2) Insuficiência de EIV/RIV

Venho determinar a imediata interdição e embargos da continuidade das obras, usando barreiras "New Jersey".

Cumpra-se.

Luiz-Alberto Fioravante

Secretario de Planejamento e Projetos- SEPLAN

PALÁCIO DOS TROPEIROS $-2^{\circ}$ anđar

Av Eng Carios Reinaldo Mences 3.041 - Alto da Boa Vista - CEP 18013-280 - Sorncaba $\mathrm{SP}$

Fone (15) $3238.2310 /(15) 3238-2312$ 
392

AO CA

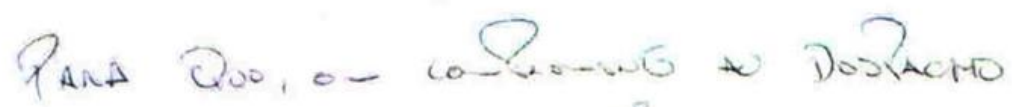

Do fis 328 vives 35 th $^{\circ}$ cintifioue

U Pothanamio do ís og po toor

Da Pecisto

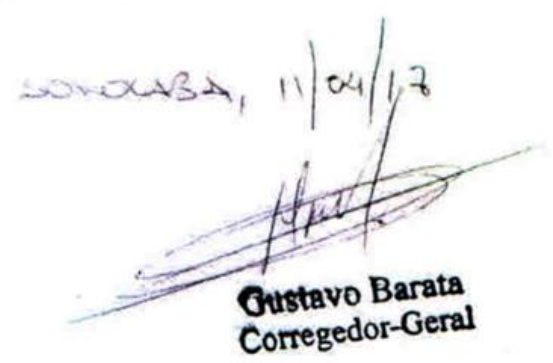

